Universidade de São Paulo

Escola de Comunicações e Artes

Programa de Pós-Graduação

em Artes Visuais
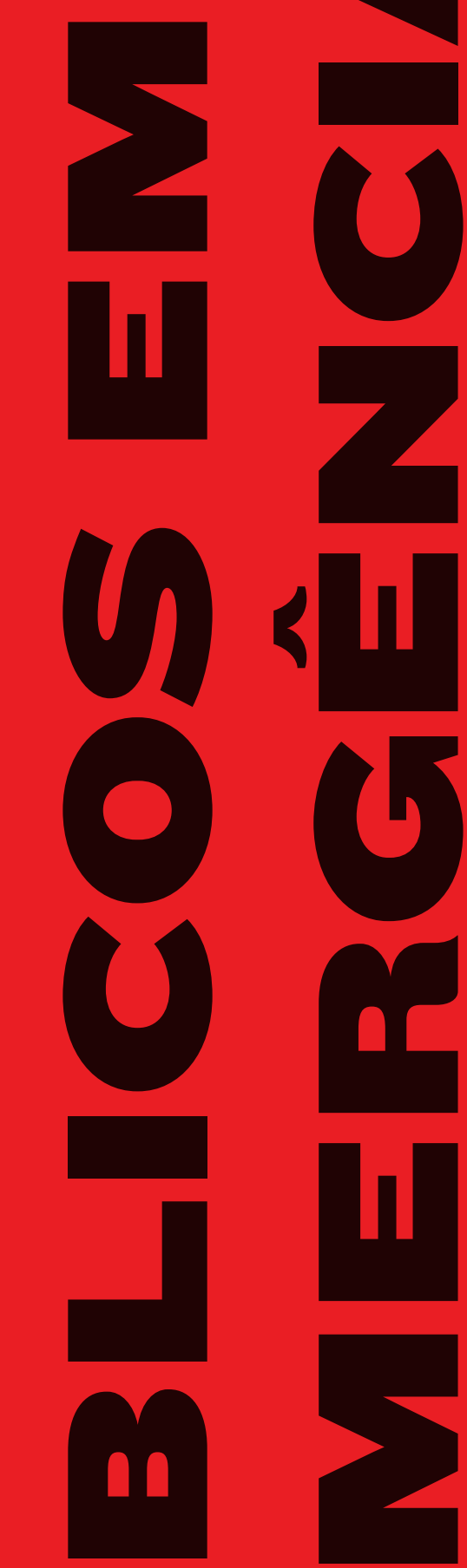

$\Delta$
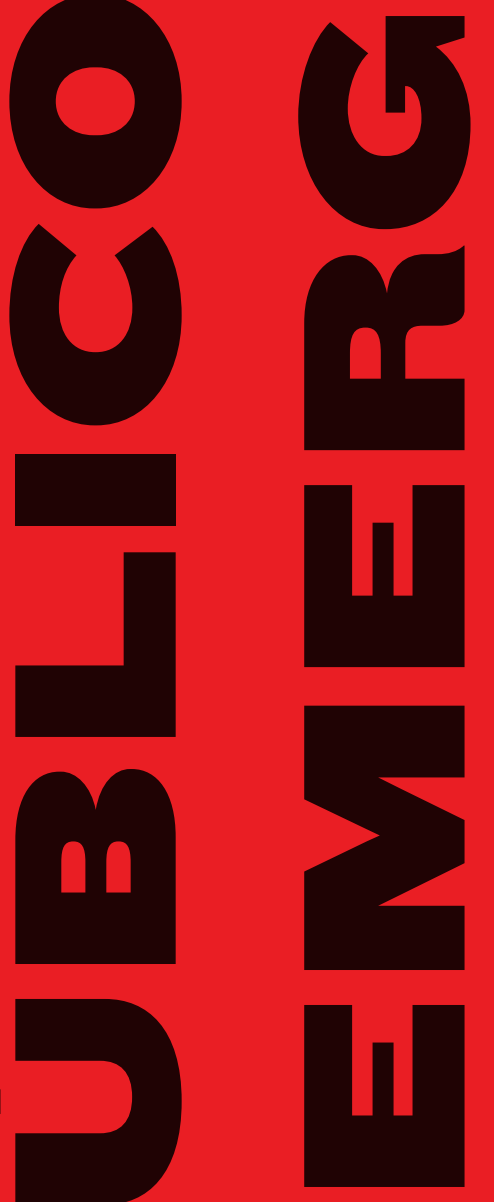

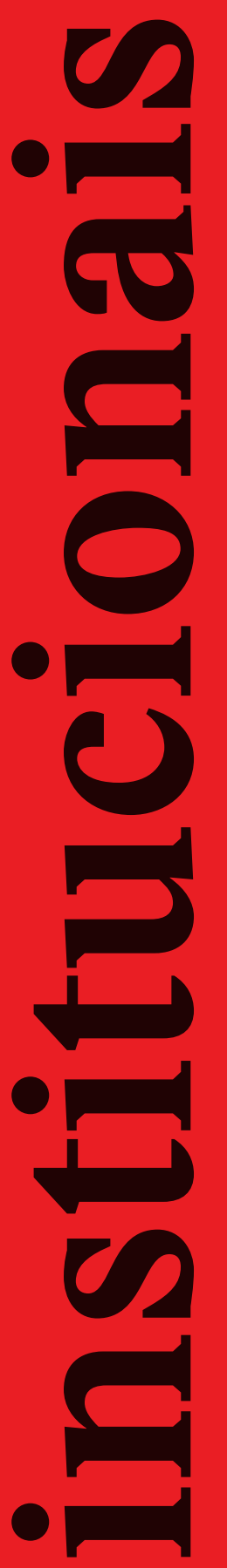

(2)

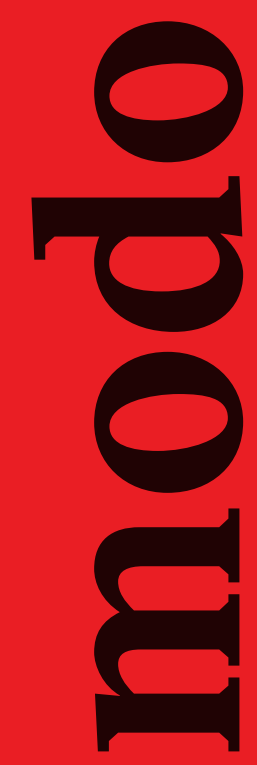

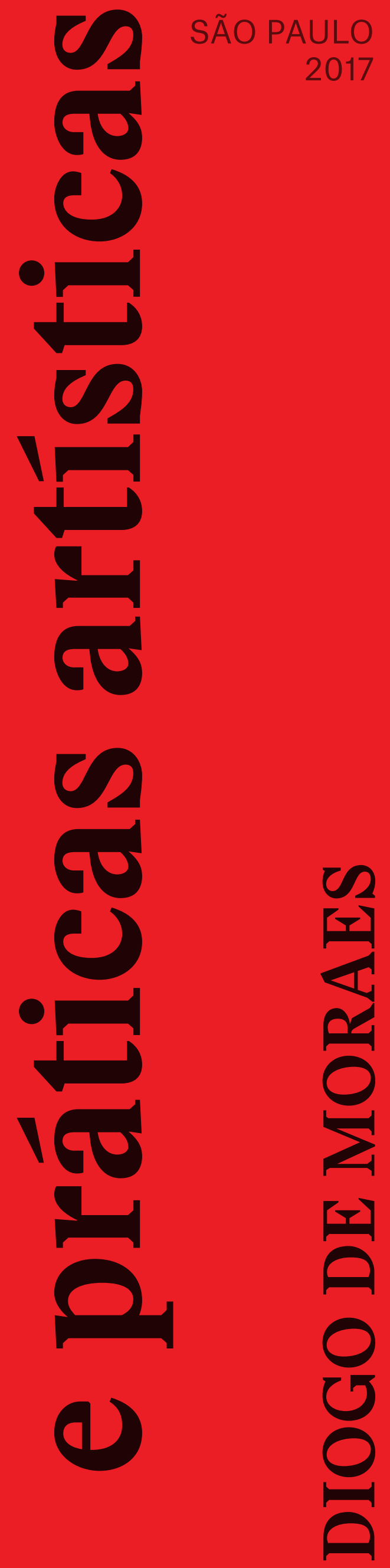




\section{PÚBLICOS EM EMERGÊNCIA modos de usar ofertas institucionais e práticas artísticas}

\section{DIOGO DE MORAES}

Dissertação apresentada ao Programa de Pós-Graduação em Artes Visuais, Área de

Concentração Artes Plásticas, Linha de

Pesquisa Poéticas Visuais, da Escola de

Comunicações e Artes da Universidade

de São Paulo, como exigência parcial para

obtenção do Título de Mestre em Artes, sob

a orientação do Prof. Dr. Martin Grossmann. 
Autorizo a reprodução e divulgação total ou parcial deste trabalho, por qualquer meio convencional ou eletrônico, para fins de estudo e pesquisa, desde que citada a fonte.

-

Catalogação na Publicação

Serviço de Biblioteca e Documentação

Escola de Comunicações e Artes da Universidade de São Paulo

Dados fornecidos pelo autor

Moraes, Diogo de

Públicos em emergência: modos de usar ofertas

institucionais e práticas artísticas / Diogo de Moraes. --

São Paulo: D. . Moraes, 2017.

264 p.: il. + inclui caixa envelope.

Dissertação (Mestrado) - Programa de Pós-Graduação em Artes Visuais - Escola de Comunicações e Artes / Universidade de São Paulo.

Orientador: Martin Grossmann

Bibliografia

1. públicos 2. contrapúblicos 3. mediação cultural 4. arte contemporânea 5. esfera pública I. Grossmann, Martin II. Título. 


\section{PÚBLICOS EM EMERGÊNCIA:}

modos de usar ofertas institucionais e práticas artísticas DIOGO DE MORAES

Dissertação apresentada ao Programa de Pós-Graduação em Artes Visuais da Escola de Comunicações e Artes da Universidade de São Paulo, como exigência parcial para obtenção do Título de Mestre em Artes, sob a orientação do Prof. Dr. Martin Grossmann.

\section{Comissão Examinadora}

São Paulo, 

Para Tati, Kadu e Luiza, pela invenção de possivveis. 



\section{AGRADECIMENTOS}

Agradeço aos meus interlocutores Cayo Honorato, Renata Cervetto, Graziela Kunsch, Jorge Menna Barreto, Fábio Tremonte, Vitor Cesar, Bruno Kurru, Elaine Fontana, Ligia Nobre, José Márcio Barros, Gleyce Kelly Heitor e Leandro Ferro. Ao meu orientador Martin Grossmann. Aos meus pares Valquiria Prates, Lilian L’Abbate Kelian, Sofia Olascoaga, Monica Hoff, Valeria Galarza, Nora Landkammer, Amilcar Packer, Lúcia Maciel Barbosa, Stella Ramos, Tiago Santinho, Flávio Aquistapace, Guilherme Teixeira, Fernando Velazquez, Alberto Tembo, Adalgisa Campos, Pompea Tavares, Guilherme Albani, Thais Olmos, Claudio Bueno, Rafael Campos Rocha, Marta Colabone, Carol Tonetti, Ana Matheus Abbade, Neide Jallageas, Maria Iñigo Clavo, Cibele Lucena, Leandro Muniz, Thia Thiara, Ricardo Basbaum, Ana Roman, Thierry Freitas, Fernando Cohen, Pablo Lafuente, Andrei Thomaz, Mario Ramiro, Alice Shintani, Diana Tubenchlak, Viviane Pinto, Fernando Marineli, João Paulo Guadanucci, Ioná Damiana, Tere Gouvea, Daniel Douek, Helena Bartolomeu, Bira, Sergio Seabra, Roberta Lobo, Debora Bolsoni, Kelly Teixeira, Lais Myrrha, Raphael Escobar, Ethiene Nachtigall, Kelly Sabino, Leonardo Araujo, Mila Chiovatto, Iã Paulo Ribeiro, Thiago Gil, Lucas Oliveira, Guilherme Pacheco, Gilberto Mariotti, Felipe Arruda, Diego de Kerchove, Lúcio Gregori, Daniel Guimarães, Laura Barboza, Oliver Cauê, Luiza Proença, Christiana Moraes, Claudinei Roberto, Ana Paula do Val, Clara Vasconcelos, Grasiele Sousa, Gustavo Torrezan, Marcelo Souza, Thiago Freire e Barbara Rodrigues. À minha companheira Tatiana Almeida. Às crias Kadu e Luiza. Aos meus pais Denise Regina de Moraes e Antonio Cruz da Silva. Aos profissionais envolvidos com a materialização dos volumes resultantes da pesquisa: Frederico Floeter, Érico Melo, Guilherme Martinez, Renan Costa Lima e Ligia Mie Jeon. E, finalmente, aos públicos dos quais me aproximei ao longo da jornada do mestrado. 



\section{RESUMO}

Por meio da combinação entre abordagem teórica e prática artística, a pesquisa coloca em questão o modo como os públicos são compreendidos e geridos no âmbito institucional da arte, particularmente no contexto brasileiro. Para isso, adotamos a mediação cultural como locus de investigação e atuação propício à confrontação de enunciados oriundos dos diferentes agentes envolvidos nesse circuito, desde os gestores, curadores, artistas e educadores até os públicos, cujas discursividades e performatividades correspondem ao foco do nosso interesse. Problematizando as formas abstratas de classificação utilizadas para designar e endereçar os destinatários das ofertas institucionais e das práticas artísticas por elas difundidas, o trabalho se imbui da postulação de um estatuto alternativo para os públicos, entendidos aqui como formações emergentes de sujeitos políticos. Isso implica a articulação de referências e precedentes capazes de contribuir para o processo de constituição de outro regime de interação entre os agentes institucionais e aqueles que seriam os beneficiários de suas proposições de viés educativo. A saber, um regime favorável ao surgimento, ao debate e à repercussão das demandas sociais, políticas e culturais manifestas por esses indivíduos e coletividades. Materializada na dissertação, a face teórica da pesquisa reúne e analisa conceitos, problemáticas e exemplos caros ao exercício crítico em torno da condição de público e das iniciativas institucionais, mediativas e artísticas que se ocupam de diferentes modalidades de interação com suas audiências. Já a sua face artística lança mão de um procedimento documentário, elegendo como recorte um formato de atração, organização e condução de visitantes amplamente usado pelas instituições artísticas para intermediar o seu acesso aos bens artístico-culturais. Trata-se das visitas mediadas com grupos. O Diário do busão: visitas escolares a instituiçôes artísticas funciona como um dispositivo de sondagem e tradução das formas de atuação dos estudantes da rede pública de ensino nos equipamentos de arte concentrados no centro expandido da cidade de São Paulo. Com isso, busca conferir linguagem, visibilidade e circulação às suas respostas a uma ação institucional representativa das políticas de democratização cultural.

\section{PALAVRAS-CHAVE:}

públicos; contrapúblicos; mediação cultural; arte contemporânea; esfera pública. 



\begin{abstract}
Through the combination of theoretical approach and artistic practice, this research questions the way publics are understood and managed within the institutional framework of art, particularly in Brazil's context. To this end, we adopt cultural mediation as a locus of research and action that is conducive to the confrontation of statements from the different agents involved in this circuit, from managers, curators, artists and educators to the publics, whose discursiveness and performativity are the focus of our interest. By problematizing the abstract forms of classification used to designate and address the recipients of the institutional offers and the artistic practices they disseminate, this work is imbued with the postulation of an alternative statute for the publics, here understood as emergent formations of political subjects. This implies the articulation of references and precedents capable of contributing to the process of constitution of another regime of interaction between the institutional agents and those who would be the beneficiaries of their educationally-directed propositions. Namely, a regime favorable to the emergence, the debate and the repercussion of social, political and cultural demands that are manifested by these individuals and collectivities. Materialized in this dissertation, the theoretical face of the research brings together and analyzes concepts, problems and examples dear to the critical exercise around the condition of public and of the institutional, mediatic and artistic initiatives that deal with different modalities of interaction with their audiences. As for its artistic face, it uses a documentary procedure, choosing as approach a format of attraction, organization and conduct of visitors widely used by artistic institutions to mediate their access to artistic and cultural assets - in this case, mediated visits with groups. The Diário do busão: visitas escolares a instituiçôes artísticas [The big bus diary: school visits to art institutions] works as a device for probing and translating the forms of acting of public school students in the art equipments in the expanded center of the city of São Paulo. With this, it seeks to confer language, visibility and circulation to their responses to an institutional action that is representative of the policies of cultural democratization.
\end{abstract}

\title{
KEYWORDS:
}

publics; counterpublics; cultural mediation; contemporary art; public sphere. 


\section{INTRODUÇÃO $\rightarrow 15$}

DO INSTITUCIONAL AO EXTRAINSTITUCIONAL, E VICE-VERSA: MEDIAÇÕES CULTURAIS EM ZIGUE-ZAGUE $\rightarrow 25$

1.1 Instituição artística, processo civilizatório e instrumentalização dos públicos $\rightarrow \mathbf{2 8}$

1.2 Breve histórico do projeto de atualização artística entre nós: a Bienal de São Paulo $\rightarrow 34$

1.3 Público forçado $\mathrm{x}$ contrapúblico $\rightarrow \mathbf{4 2}$

1.4 Democratização cultural como blindagem institucional? $\rightarrow \mathbf{4 5}$

1.5 Mediação extrainstitucional como forma de estar dentro e fora da instituição artística $\rightarrow \mathbf{4 9}$

1.6 Surgimento do museu público $\rightarrow \mathbf{5 8}$

1.7 Museu e controle social: prenúncio do poder brando $\rightarrow \mathbf{5 9}$

1.8 O sujeito no neoliberalismo $\rightarrow \mathbf{6 2}$

1.9 Neoliberalismo como norte institucional $\rightarrow 64$

1.10 Lei de incentivo à cultura no Brasil $\rightarrow 71$

1.11 O financiamento da Bienal de São Paulo e o papel estratégico de seu programa educativo $\rightarrow \mathbf{7 4}$

1.12 Discursos da mediação cultural $\rightarrow 78$

1.13 Limitações funcionais da mediação institucional $\rightarrow \mathbf{8 0}$

1.14 Mediação como colaboração $\rightarrow \mathbf{8 1}$

1.15 Mediação como prática artística, prática artística como mediação $\rightarrow \mathbf{8 4}$

1.16 Dissimulação da ideologia em idealismo $\rightarrow \mathbf{8 6}$

OS PÚBLICOS ENQUANTO FORMAÇÕES EMERGENTES:

AGENTES DESTINATÁRIOS, SUJEITOS POLÍTICOS, INTÉRPRETES ATIVOS $\rightarrow 89$

2.1 Condução dos públicos $\rightarrow 94$

2.2 Modalidades de envolvimento dos públicos com as práticas artísticas $\rightarrow 100$

2.3 (Auto)produção dos públicos $\rightarrow 103$

2.4 A subjetividade e o papel da identificação $\rightarrow \mathbf{1 1 0}$

2.5 Da leitura à escritura $\rightarrow \mathbf{1 1 3}$

2.6 Socialização da produção discursiva e a lógica da emergência $\rightarrow 120$

2.7 Emancipação do espectador $\rightarrow \mathbf{1 2 8}$

2.8 Estética relacional e perspectiva consensual $\rightarrow 135$

2.9 Dimensão relacional da mediação cultural $\rightarrow 144$

2.10 Operações conjunturais $\rightarrow 147$ 
E PRODUÇÃO (DISSENSUAL) DO COMUM:

AGENCIAMENTOS COLETIVOS CATALISADOS POR

PRÁTICAS ARTÍSTICAS E MEDIATIVAS $\rightarrow 151$

3.1 Ser humano em público e o papel dos direitos $\rightarrow 156$

3.2 Arte e mediação no interesse público $\rightarrow 161$

3.3 A colaboração no lugar da participação $\rightarrow 165$

3.4 Um guia para a lógica colaborativa $\rightarrow 167$

3.5 O conceito de esfera pública $\rightarrow 173$

3.6 O caráter tardio da esfera pública na América Latina $\rightarrow \mathbf{1 7 9}$

3.7 Insurgência dos contrapúblicos $\rightarrow 184$

3.8 O que colocar no lugar da esfera pública burguesa? $\rightarrow 188$

3.9 Estúdio como plataforma comunicativa $\rightarrow 194$

3.10 Esfera pública no plural e suas ambivalências $\rightarrow 198$

3.11 A dimensão extrainstitucional de mobilizações da sociedade civil: o movimento dos estudantes secundaristas $\rightarrow 201$

3.12 Aspectos coincidentes entre o "guia”, o "estúdio" e o "espaço-dispositivo" $\rightarrow \mathbf{2 2 0}$

4 DIÁRIO DO BUSÃO: VISITAS ESCOLARES A INSTITUIÇÕES ARTÍSTICAS (MEMORIAL DESCRITIVO E CONCEITUAL) $\rightarrow 223$

4.1 O Diário em termos práticos $\rightarrow \mathbf{2 2 7}$

4.2 O processo de tradução $\rightarrow \mathbf{2 3 0}$

4.3 Por outra forma de documentar a presença dos estudantes nos contextos expositivos $\rightarrow \mathbf{2 3 5}$

4.4 Mediação (documentária) desobrigada da gestão dos públicos $\rightarrow \mathbf{2 4 0}$

4.5 O processo de publicização do Diário $\rightarrow \mathbf{2 4 3}$

4.6 A especificidade da mediação e sua potencialidade de (re)endereçar a instituição a partir dos públicos $\rightarrow \mathbf{2 4 7}$

CONSIDERAÇÕES FINAIS $\rightarrow 251$

REFERÊNCIAS $\rightarrow 255$

ANEXO

Diário do busão: visitas escolares a instituições artísticas $\rightarrow$ Volume à parte 

Ao invés de ação, a sociedade espera de cada um dos

seus membros um certo tipo de comportamento, impondo

inúmeras e variadas regras, todas elas tendentes a "normalizar"

os seus membros, a fazê-los "comportarem-se", a abolir

a ação espontânea ou a reação inusitada.

- HANNAH ARENDT

Ao entrar em uma instituição de arte na cidade de São Paulo, seja um museu, um instituto ou uma fundação, é comum nos depararmos com diversos grupos de visitantes, cada qual reunido em torno de um profissional do seu departamento educativo (ou, em muitos casos, de um estagiário ligado a esse mesmo setor), responsável pela apresentação das exposições em cartaz e pela mediação de suas respectivas obras artísticas e discursos curatoriais. Conduzindo esses públicos mediante determinados protocolos, roteiros, recortes temáticos, formatos de conversa e chaves interpretativas, tais expedientes são manejados pelos mediadores com vistas a subsidiar, em termos pedagógicos e organizacionais, momentos coletivos de fruição que duram, em geral, entre uma e duas horas. Trata-se da "visita mediada" - também chamada de "visita guiada" -, um modelo de mediação institucional amplamente difundido e consolidado.

Num exercício baseado nos fatos, podemos detalhar esse quadro por meio de um percurso imaginário através dos ambientes de uma dessas instituições. Proponho evocarmos mentalmente alguma delas, escolhendo-a entre as que têm em seus departamentos de educação um mecanismo de atração, recepção e monitoramento de visitantes, sem que para isso precisemos nomeá-la - ao menos nesta Introdução -, uma vez que esse perfil reflete a forma de operar de parte significativa dos nossos equipamentos dedicados à difusão da produção artística visual.

Virtualmente situados em um desses equipamentos e dedicando nossa atenção menos às obras artísticas do que às pessoas que por ali circulam, notamos que os grupos conduzidos pelos mediadores diferem entre si segundo marcadores abrangentes, distinguidos por balizas etárias e sociais. Agendadas previamente, suas visitas integram o cardápio de opções pedagógicas pré-definidas e oferecidas pela instituição com o propósito não apenas de mediar em bases educativas o acesso dos públicos às exposições e aos bens artístico-culturais nelas contidos, mas também de organizar e controlar essa aproximação.

Atravessando a porta de entrada do edificio evocado em nosso exercício introdutório, verificamos que o grupo reunido no canto esquerdo do saguão é formado por pessoas idosas, enquanto outro, aninhado no canto oposto desse ambiente, agrega estudantes primários sentados em círculo no chão, durante a etapa de acolhimento. Mais à frente, conforme avançamos em direção ao espaço expositivo, cruzamos com uma turma de universitários que escutam com certa indiferença as palavras da mediadora acerca da mostra que visitarão. Já no interior da exposição, topamos com uma atividade lúdica voltada a algumas famílias ali reunidas. Mais adiante, em 
frente a uma obra tridimensional de grandes dimensões, encontramos outra mediadora tentando injetar ânimo e despertar o interesse de pessoas em situação de vulnerabilidade social. Por fim, caminhando à procura do sanitário, avistamos uma classe de colegiais entrando no ateliê sob as orientações de outro mediador, provavelmente para uma vivência de experimentação plástica. Isso sem falar nos visitantes espontâneos que se distribuem pelos diferentes espaços, alguns deles também acompanhados por mediadores que comentam determinadas obras ao longo do trajeto.

O caráter corriqueiro das cenas descritas sugere a naturalidade e o automatismo com que lidamos, enquanto profissionais da cultura e da educação, com a categorização da presença e a condução das atividades dos visitantes nos contextos artístico-institucionais. Ainda mais elementar e aparentemente neutro, o próprio termo "visitante" denota uma espécie de contrato, indicando se tratar de alguém que não pertence àquele lugar, nele adentrando sob uma série de condições estipuladas pela instituição visitada. Não se estranha - e por esse motivo não se indaga - o fato de os públicos das ofertas promovidas por essas instituições serem classificados por tipologias tão abstratas quanto vagas, tais como "agendado”, “espontâneo", “escolar”, "familiar”, "socialmente vulnerável” etc. Contudo, designações como essas, e as ações mediativas a que se encontram atreladas, correspondem a apenas uma forma - talvez a mais pragmática e eficiente do ponto de vista da gestão - de se conceber o estatuto dos públicos das ofertas institucionais e, por conseguinte, das práticas artísticas por elas difundidas. Forma essa que, além de mediar as experiências de recepção estética em bases pedagógicas, se presta a gerir o modo de estar dos visitantes no ambiente expositivo, considerando-os a partir de identificações que servem principalmente para endereçá-los de maneira planejada e pretensamente previsível.

Articulam-se a essa matriz atributiva outras ferramentas de compreensão e enquadramento dos visitantes, as quais são operadas conforme as características subjacentes aos marcadores genéricos utilizados para identificá-los. Entre as características atribuídas aos públicos, em particular aos não iniciados nas questões e linguagens da arte e na liturgia inerente aos contextos expositivos, destacam-se aquelas que lhes imputam qualidades reversas como a de "inexperientes" ou mesmo de "culturalmente deficitários”. Isso significa que eles são geralmente acolhidos pelas instituições artísticas com base naquilo que lhes falta - e não naquilo que lhes sobeja -, a partir de uma perspectiva concessiva e inclusiva. Para lidar com esse "déficit" de parte significativa dos seus visitantes, as instituições contam com programas educativos vocacionados à aplicação de metodologias imbuídas de lançar pontes por sobre o "abismo da carência de conhecimento em arte”, buscando gerar alguma conexão entre esses públicos e os bens artístico-culturais com os quais eles têm pouca ou nenhuma familiaridade, dada a "incipiência" dos seus estágios de formação cultural. As visitas mediadas e suas diferentes modalidades ("visita palestra", "discussão dirigida", "descoberta orientada”, entre outras) correspondem ao principal instrumento desse empreendimento pedagógico-institucional. 
Em contrapartida, a desnaturalização desse padrão traz consigo a possibilidade de concebermos os públicos a partir de outros critérios e mediante lógicas alternativas de interação e diálogo, favoráveis à produção de deslocamentos e escapes frente aos modos predominantes de designá-los e de gerir suas presenças nos contextos de arte. $\mathrm{O}$ estranhamento a esse formato standard tem como disposição deflagradora, em nosso caso, a abertura e o interesse pela imprevisibilidade incontornável das formas de recepção e atuação desses públicos quando em contato com ofertas institucionais normalizadas. É na temporalidade contingencial dessas situações de encontro (e desencontros), e em resposta ao que se lhes apresenta como exemplares legítimos dos bens artístico-culturais e como instruções da maneira de se comportar diante deles e de fruí-los, que emergem discursividades e performatividades singulares por parte dos públicos, não raro desviantes e desafiadoras dessas mesmas tentativas de condução de suas condutas e percepções.

Esse estranhamento nos impele a reunir e investigar outros precedentes relacionados ao entendimento acerca do estatuto dos públicos e à invenção de novas plataformas de interação e comunicação com e entre eles, decididamente diversas daquelas amiúde utilizadas pelos programas de mediação institucional, sob responsabilidade dos seus departamentos educativos. Experiências nesse sentido podem ser encontradas tanto no campo da própria mediação cultural como no âmbito das artes visuais, ou ainda em projetos que combinam práticas originárias de ambos.

Ao nos dedicarmos à sondagem das responsividades dos destinatários das ofertas institucionais - sobretudo dos públicos escolares, mas não só -, assim como ao levantamento de um conjunto de experimentos alternativos aos modelos hegemônicos de compreensão e interação com os públicos, pretendemos criar condições para que se possam repensar as práticas mediativas nos contextos de arte e, com isso, reimaginar os critérios e propósitos que as orientam, de modo a vislumbrar o seu reposicionamento no escopo das políticas institucionais.

É a partir desse recorte institucional, e nesse lugar de interações e mediações, que a presente pesquisa pretende operar e intervir. Para isso, optamos por realizar um tipo de abordagem que se desenvolve por mais de uma via. Estamos falando da concomitância entre exercícios investigativos de naturezas distintas e que, fazendo uso de linguagens e manobras específicas, buscam gerar passagens entre si e exercer influências recíprocas. Daí que, para nós, a linha de pesquisa em Poéticas Visuais tenha se mostrado adequada a um processo de sondagem, reflexão e criação que conjuga a análise teórica ao ensaio artístico-documental, e vice-versa, ambos em sintonia com potencialidades da mediação cultural que nos parecem articuláveis a premências da contemporaneidade, sobretudo no que diz respeito aos processos de tradução cultural e da produção do comum.

A adoção dessa frente dupla e interdependente baseia-se no entendimento de que as problemáticas com as quais decidimos lidar na jornada do mestrado solicitam, para a sua abordagem ao mesmo tempo crítica e inventiva, instrumentos epistemológicos diversificados. A incorporação de di- 
ferentes modalidades de investigação e produção discursivas ao processo da pesquisa nos permite tratar dessas problemáticas mediante a mobilização de expedientes múltiplos, capazes de atravessá-las a partir de variadas "entradas" e "saídas". Com esses expedientes procuramos não só cartografar criticamente certas ações institucionais de promoção do acesso aos bens artístico-culturais, mas também intervir nesse âmbito através da reunião de precedentes e referências que nos possibilitem formular outras formas de mediação. Nosso ponto de partida é a constatação de que se, por um lado, os mecanismos que oportunizam o acesso o fazem estipulando uma série de condicionantes aos seus beneficiários, por outro, eles são permanentemente investidos por inesperados modos de usar dessas mesmas oportunidades pelos públicos - ainda que esses modos sejam sistematicamente desaparecidos pelo aparelho institucional propositivo.

Na vertente teórica do trabalho que ora apresentamos, nos dedicamos a manejar e confrontar referências oriundas de um arquivo - formado tanto por textos de reconhecida influência como por uma variedade de registros de experiências e situações - que venho constituindo de modo simultâneo e entrelaçado à minha atuação em instituições de arte e cultura na cidade de São Paulo, seja como mediador, artista, pesquisador, gestor ou mesmo público. Esse arquivo resulta de um especial interesse por uma face específica das ofertas institucionais, das ações educativas e das práticas artísticas, a saber, aquela que se refere à sua recepção e seu uso pelos públicos.

A percepção geral em torno dessa face se encontra normalmente associada às premissas que orientam as iniciativas institucionais, os projetos pedagógicos e os experimentos artísticos, como se o envolvimento e a participação dos públicos correspondessem a uma consequência automática dessas proposições, enquanto seu resultado direto. A suspeita em torno de uma lógica que prescreve os papéis a serem desempenhados pelos públicos - muitas vezes sem se indagar sobre a possibilidade de os públicos se desviarem e frustrarem essas mesmas prescrições - nos convoca a "incursionar" pela dimensão responsiva, imprevista e incerta de suas formas de recepção e atuação, em atenção às suas singularidades e possíveis desvirtuamentos. Portanto, o compromisso assumido pelo presente estudo toma distância de metodologias que buscam mobilizar e gerir os públicos, assim como orientar sua percepção, justamente na tentativa de abrir espaço para o seu avesso, mediante a tradução e circulação dos índices das interpretações, usos e apropriações que os públicos já praticam diante desse aparato mobilizador e gestor.

Tratada em bases teóricas no texto da dissertação, essa mesma disponibilidade e atenção adquire corpo poético na vertente artístico-documental da pesquisa, intitulada Diário do busão: visitas escolares a instituiçôes artísticas. Através desse diário, experimentamos a elaboração de enunciados (visuais e textuais) a partir do outro, nesse caso, dos estudantes da rede pública de ensino que participam, em grupo, de visitas agendadas e mediadas a equipamentos de arte concentrados no centro expandido da cidade. Os deslocamentos desses grupos se dão por meio de ônibus 
fretados, cujos traslados de ida e volta chegam a durar, em alguns casos, mais tempo do que o período de permanência na instituição visitada.

Se na vertente artístico-documental produzimos discursos a partir desse outro, no texto da dissertação escrevemos com, por meio ou em contraposição aos autores que lemos e com os quais estabelecemos diálogos. Dito de outro modo, testamos uma forma de fazer pesquisa que, de maneira explícita, se nutre das potencialidades inerentes à condição de público. Isso quer dizer que me vejo ocupando tanto o papel de autor como o de leitor/observador, sem estabelecer uma hierarquia entre eles. Nesse sentido, é como se o meu objeto de estudo pudesse se confundir, em alguma medida, com a minha própria disposição de pesquisador. Em ambos os casos a ênfase recai sobre o ato de nos fazermos público das coisas e, ainda, sobre a possibilidade de produzirmos enunciados, ações e pensamentos a partir dessa condição.

Nessa alternância entre as atividades da leitura/observação e da escrita/desenho, está em jogo a intenção de tomar posição numa certa esfera pública de debate, que envolve agentes interessados e comprometidos com as problemáticas dos públicos e de suas formas de participação e atuação em meio àquilo que lhes é ofertado nos contextos institucionais em termos pedagógicos e artísticos.

Além de contar com as contribuições de autores ligados a diferentes áreas do conhecimento (artes visuais, educação, mediação cultural, filosofia, sociologia, antropologia etc.), nosso texto é perpassado por uma série de micronarrativas referentes às respostas dos públicos às ações institucionais, mediativas e artísticas. Entre essas passagens, estão os episódios contrapúblicos, que venho relatando e publicizando em diferentes meios pari passu à minha trajetória nos equipamentos de arte e cultura. Elas resultam daquilo que postulamos aqui como um estado de atenção e interesse pelas formas de atuação dos públicos nos momentos de interação com as ofertas institucionais. Ao serem articuladas aos capítulos da dissertação, essas narrativas não só adquirem novas camadas, como também agregam elementos factuais e ficcionais às nossas análises.

Subdividido em quatro capítulos, o texto aborda principalmente a instância dos públicos dessas ofertas, bem como a das práticas artísticas por elas distribuídas, a partir da definição de recortes e da utilização de instrumentos que nos permitam colocar essa face da dinâmica artístico-institucional e suas respectivas problemáticas em perspectiva. A nosso ver, a investigação acadêmica representa um "lugar" propício a essa tarefa, uma vez que ela nos proporciona um distanciamento analítico geralmente obliterado pela lógica produtivista do cotidiano de trabalho nas instituições de arte e cultura. Com isso não queremos dizer que a pesquisa se desvincule desse cotidiano. Ao contrário, ela nos permite negociar com ele em outras bases, testando abordagens críticas e manobras inventivas diante de configurações e fatos que facilmente se automatizam no turbilhão de afazeres da rotina institucional, ainda mais quando esse trabalho se encontra pautado por uma agenda exclusivamente propositiva, circunscrita à missão unidirecional de oferecer ao outro aquilo que supostamente lhe falta. 
No primeiro capítulo, procuramos delinear um movimento decididamente oscilante - em zigue-zague - entre os dispositivos institucionais e as disposições extrainstitucionais no que tange às formas de interação com os públicos. Expondo a nossa compreensão do que seja o caráter extrainstitucional de certas formas de mediação, nos ocupamos de imaginar possíveis transições de um registro ao outro, com vistas a apontar para a desejável transformação das instituições de arte em organismos permeáveis às sensibilidades, códigos, repertórios, valores e agendas dos seus públicos (atuais e virtuais). Isso envolve, entre outras coisas, problematizar os princípios norteadores das políticas de democratização cultural, bandeira que tem sido usada para blindar as instituições artísticas frente a antagonismos e dissensos que possam confrontar a sua posição privilegiada de polo difusor da cultura.

Remontando aos primórdios da popularização da prática sociocultural de visitação a ambientes expositivos, por ocasião dos nascentes museus públicos na Europa de fins do século XVIII, nos valemos de análises formuladas no campo dos estudos de museus para articulá-las com reflexões desenvolvidas no âmbito da mediação cultural e traçar um percurso histórico das posições ocupadas pelos públicos nas instituições artísticas. Como veremos, no período de formação e consolidação dos museus públicos está em jogo a produção de um tipo de coesão social pautada pela necessidade dos recém-criados Estados-nação de inculcar no imaginário das populações dos centros urbanos, como parte do processo civilizatório, o sentido de unidade nacional. Já nas décadas mais recentes, marcadas por mudanças provocadas pelo processo de globalização, pelo neoliberalismo de viés transnacional e pela financeirização da cultura, os públicos dos museus, centros culturais e bienais são chamados a desempenhar papéis ligados ao consumo e ao inflacionamento sem precedentes dos números de visitação a exposições identificadas como "blockbusters". Isso condiz a uma forma de instrumentalização da presença dos visitantes nos contextos expositivos, na medida em que a mensuração quantitativa do seu acesso, ao "girar a catraca", serve para auferir o "sucesso" das exposições. A partir do final dos anos 1980 e início dos 90, em diferentes partes do mundo, essa dinâmica passa a ocupar um lugar estratégico nas políticas institucionais de captação de recursos, tornadas dependentes da iniciativa privada e da sua prerrogativa de definir quais projetos financiar com a aplicação de dinheiro público por meio de mecanismos governamentais de dedução fiscal.

O segundo capítulo corresponde à seção da dissertação em que nos dedicamos a refletir sobre as especificidades da condição de público, em particular dos públicos das práticas artísticas, considerando as mediações institucionais e pedagógicas que a elas se interpõem. Amparada por referências oriundas dos campos da filosofia, da semiologia, da crítica e da arte-educação, nossa abordagem procura sustentar e explorar a tensão existente entre aspectos indissociáveis dessa interação: enquanto o sujeito, na condição de público, é enredado em relações de poder e comunicação que vigoram através da sua identificação e categorização por agentes especializados, ele encontra, por outro lado, a possibilidade de 
reagir a esse enredamento instaurando um campo responsivo por meio de indisposições, insolências, provocações e disputas simbólicas. Na temporalidade dessas disputas, em que o exercício de poder é exposto à sua contraface, os públicos (ou contrapúblicos) se apresentam como formações emergentes de sujeitos políticos, reagentes às formas de endereçamento e gestão que buscam objetivá-los e enquadrá-los em determinadas posições. Essa dinâmica antagonista se deixa entrever em ocorrências nas quais o sujeito ousa escapar às cunhagens identitárias e classificatórias que lhe são externamente atribuídas com o propósito de antecipar e conduzir suas condutas. Ao se esquivar dessas cunhagens, ele afirma o direito de ser outra coisa que não aquilo que dele se espera, produzindo linhas de fuga nesse tabuleiro esquadrinhado em função de objetivos iniciáticos e administrativos.

Para testar formas de problematizar e driblar os dispositivos institucionais de endereçamento e gestão dos públicos, assim como de negociar com (ou mesmo subverter) as modalidades de participação concebidas por artistas, curadores e mediadores, nos propomos a investigar os modos de atuação praticados pelos públicos. Tal atuação se dá mediante a conjugação de suas manifestações discursivas e performativas, condizentes à dimensão enunciativa dos momentos de desfrute das oportunidades e bens simbó licos providos pelas instituições de arte. Nessa dinâmica, os públicos se autoproduzem como tal ao dedicar sua atenção e ao interagir com certos discursos e expressividades (e não com outros) a partir de necessidades e vislumbres que lhes dizem respeito diretamente, os quais não podem ser antecipados e tampouco controlados por quem os concebe ou distribui.

A abordagem em torno das características e potencialidades intrínsecas ao ato de se fazer público de algo dá ensejo para trabalharmos, no terceiro capítulo, com um conjunto de noções condizentes a plataformas de aparição dos públicos. Referimo-nos aos conceitos de esfera pública, de arte no interesse público e de mediação como colaboração. Provenientes dos campos da sociologia, das artes visuais e da mediação cultural, respectivamente, esses conceitos nos permitem lidar com o estatuto dos públicos em chave expandida, num registro que excede e complexifica os papéis de visitante, espectador, leitor, ouvinte etc. De modo a ampliar as acepções do que sejam os públicos das ações institucionais e das práticas artísticas, passamos à análise das formas de atuação desses sujeitos considerando-os como membros de comunidades políticas específicas. Tal perspectiva nos leva a reconhecer particularidades relativas às suas procedências, marcadores identitários, sensibilidades, códigos de comunicação, modos de se relacionar socialmente e agendas, que emergem justamente nas situações de interação. Isso significa estabelecer um contraponto à lógica abstrata - de viés administrativo - comumente utilizada pelas instituições de arte para identificar, endereçar e interagir com seus públicos. Ademais, implica enfatizar a diferença frente ao paradigma artístico moderno, que idealiza o público como entidade universal e, portanto, descolada de suas particularidades.

Nesse ponto da pesquisa, buscamos expor a capacidade que certos experimentos artísticos e proposições mediativas têm de catalisar agenciamentos 
coletivos ancorados em distintas problemáticas sociopolíticas, junto a públicos específicos. Comprometidos com a invenção de plataformas comunicativas e processos de tradução cultural, esses experimentos e proposições estariam aptos a instaurar microesferas públicas temporárias, criando alternativas às configurações normativas e excludentes próprias da esfera pública burguesa - dentro da qual o museu figura como uma de suas instituições estratégicas. A desnaturalização e o enfrentamento dessas condicionantes têm na figura do contrapúblico o seu renitente opositor. Suas insurgências diante de configurações sociocomunicativas hegemônicas e discriminatórias fornecem pistas importantes para pensarmos em situações de interação, mediação e tradução favoráveis à transposição das fronteiras entre o domínio privado e a arena pública, justamente onde os interesses e compromissos comuns podem ser repactuados.

A percepção do caráter altamente fragmentado das sociedades contemporâneas perpassa as iniciativas artísticas e mediativas analisadas no referido capítulo. Nelas, as bases para o diálogo entre as comunidades apresentam-se cada vez mais heterogêneas e mutuamente ininteligíveis. Considerando esse aspecto, nos parece necessário chamar atenção para projetos de artistas e mediadores que se ocupam do exercício de tradução dessas bases, a fim de fomentar diálogos e, mais do que isso, contágios entre elas. Sensíveis e abertos às linhas de força mobilizadas por atores sociais historicamente oprimidos e alijados da esfera pública de debate, essas iniciativas se imbuem da invenção de ferramentas e da deflagração de situações mediante as quais se busca produzir novos marcos comuns. Respaldadas pela perspectiva dos direitos humanos e comprometidas com os processos de transformação da realidade social, as manobras empenhadas na criação desses marcos não se furtam de lidar com o dissenso. Longe disso, elas se assentam na constatação de que o encobrimento dos conflitos e antagonismos sociais se presta, sobretudo, à manutenção do estado de coisas. Daí a sua disposição em produzir o comum pela via dissensual.

Enquanto nos três primeiros capítulos nos dedicamos à abordagem teórica de problemáticas pertinentes aos públicos das ações institucionais e das práticas artísticas, na quarta e última seção da dissertação apresentamos o memorial descritivo e conceitual do Diário do busão: visitas escolares a instituições artísticas. Na condição de um ensaio artístico-documental que faz as vezes de um "trabalho de campo", o Diário volta-se ao enfrentamento de questões análogas àquelas trabalhadas no texto da pesquisa, embora utilize para isso expedientes claramente distintos. Ao eleger um segmento do público previamente classificado e extensivamente arregimentado pelas instituições de arte da cidade - os estudantes da rede pública de ensino -, lançamos mão de um procedimento que combina vocabulários artísticos com exercícios documentários caros à mediação e aos seus processos de tradução cultural.

A premissa do Diário é relativamente simples: se, por um lado, essas instituições e seus programas educativos proporcionam aos estudantes oportunidades de acesso aos bens artístico-culturais sob o argumento de que tal 
contato é benéfico aos seus processos de formação, à ampliação dos seus repertórios e ao incremento das suas faculdades perceptivas e críticas, por outro, mostra-se necessário dedicarmos nossa atenção às formas singulares de como esses estudantes se relacionam e respondem a tal oportunidade. Trata-se de um esforço destinado a transpor retóricas afeitas à pressuposição de seus efeitos no outro. Acompanhando presencialmente os estudantes durante os momentos de interação com aquilo que as instituições lhes propiciam, é possível testemunhar o surgimento, por parte deles, de uma miríade de gestos, formulações, indagações e anseios que frequentemente divergem das linhas de abordagem e dos planos da mediação institucional, tensionando-os, embaralhando-os e complexificando-os. Cabe, portanto, trazermos esses desacordos à tona, através da concepção de linguagens e suportes aptos a fazê-los circular para além do local e do tempo pontual de sua ocorrência.

Lançada ao trabalho de investigação e extroversão dos modos singulares de interação dos públicos com aquilo que as instituições de arte têm a lhes oferecer, a presente pesquisa funciona, ela própria, como uma operação de mediação. Contudo, ela procura produzir uma torção no sentido tradicionalmente adotado por essas instituições, e por suas abordagens mediativas, em relação aos públicos. Enquanto estas se apoiam em um conjunto legitimado de bens, saberes e intencionalidades com a finalidade de endereçar seus visitantes, as operações testadas por Públicos em emergência: modos de usar ofertas institucionais e práticas artísticas compilam e conferem visibilidade a formas imprevistas de atuação dos públicos em resposta a esse mesmo endereçamento.

Desautorizadas, anônimas e dispersas, as responsividades desviantes dos públicos são normalmente tidas como "restos" de experiência, como aquilo que não alcança e não se coaduna com as oportunidades facultadas por políticas e programas comprometidos com a democratização do acesso aos bens artístico-culturais. Esses fragmentos residuais servem-nos, por outro lado, para compor uma superficie reflexiva assumidamente fendida, um espelho onde as instituições e nós, seus agentes, possamos nos ver e nos estranhar com as imagens trincadas que o outro nos devolve. 


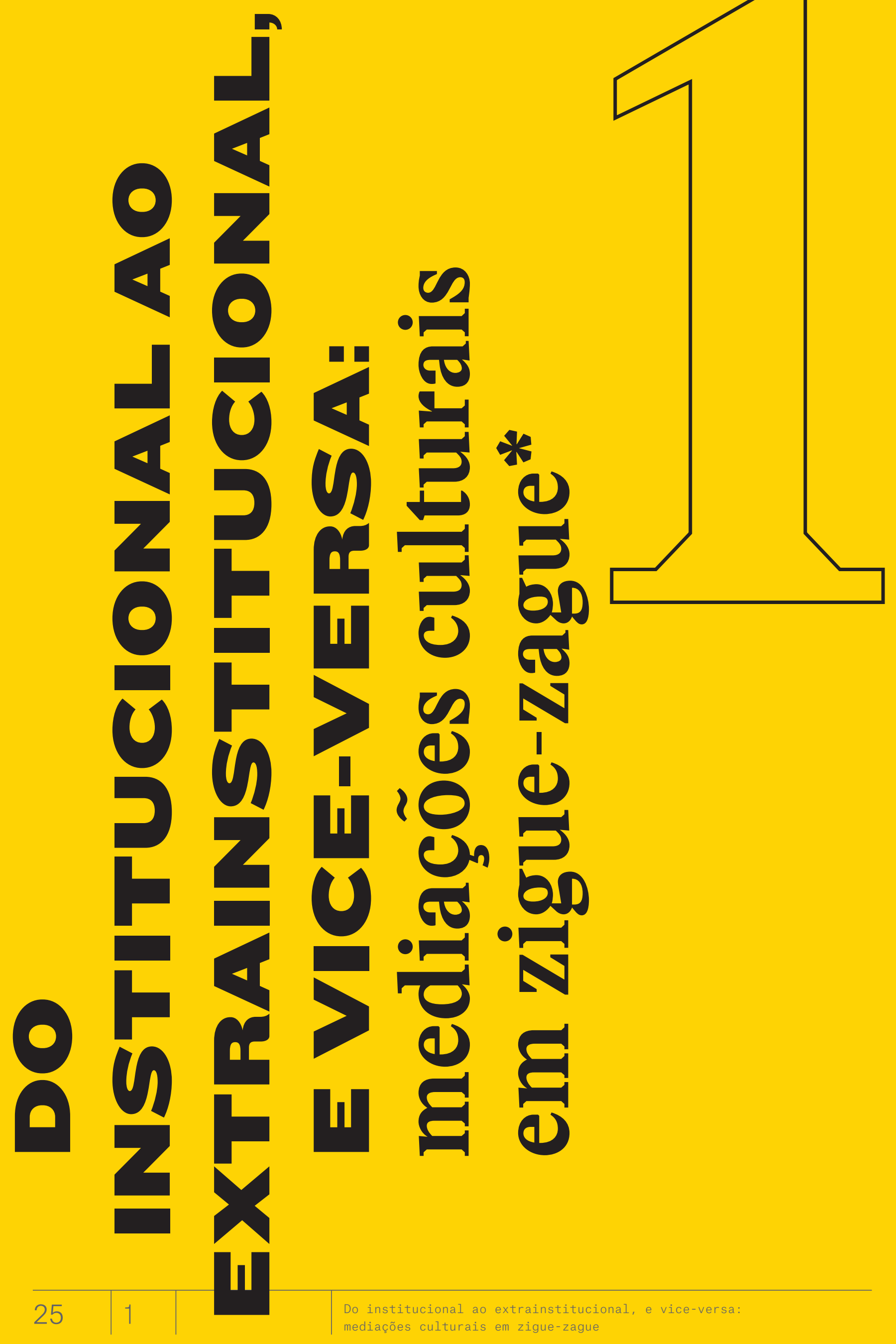


Nós somos a instituição da arte: o objeto de nossas críticas, de nossos ataques, está sempre também dentro de nós.

- ANDREA FRASER

[...] não se trata apenas de mudar as instituições, mas sim

de transformar o modo como instituímos.

- SIMON SHEIKH 
Este capítulo abordará conceitos e discussões provenientes de duas áreas distintas, embora convergentes, do campo das artes visuais, a saber, os estudos de museus e a mediação cultural. Da primeira, serão observados aspectos ligados principalmente à afluência dos públicos às exposições e os códigos comportamentais aí suscitados, incluindo os primórdios dessa prática sociocultural na virada do século XVIII para o XIX na Europa. Da segunda, serão abordadas experiências em mediação e arte, orientadas por situações de interação com públicos. Acredita-se que esse cruzamento permitirá, em alguma medida, problematizar os critérios e diretivas que, de modo hegemônico, têm balizado as políticas de acesso dos públicos aos bens culturais.

Sobre as políticas de acesso e como forma de alicerçar a discussão, serão comentados os princípios que orientam a lógica da democratização cultural, incluindo algumas formas pelas quais se dá na prática a redistribuição das oportunidades culturais. Programas de promoção de acesso aos bens artístico-culturais estão presentes em boa parte do trabalho institucional no campo das artes visuais. É a ação cultural, enquanto área de atuação e saber, que se incumbe, entre outras coisas, das iniciativas dedicadas a aproximar das obras artísticas os públicos alijados do cotidiano de produção e dos contextos de exibição dos bens culturais atestados por instituições de prestígio. Acompanharemos, e indagaremos criticamente, alguns desdobramentos dessa modalidade de atuação surgida na Europa após a Segunda Guerra Mundial como resposta à necessidade de "reconstrução social e educativa da região" (CUNHA, 2003, p. 4).

Quanto à vertente da mediação cultural aqui postulada, estaremos em sintonia com as formulações dos pesquisadores e educadores Cayo Honorato e Carmen Mörsch, para quem a mediação configura uma prática cultural específica, que opera com problemáticas e dispositivos próprios. Desse modo, entende-se não caber a ela a função de distribuir e facilitar sentidos elaborados por outras instâncias do campo da arte - como ocorre na maior parte dos casos, quando observamos que os programas educativos das instituições culturais dedicadas às artes visuais se comprometem com a inclusão de novos públicos ao universo das exposições, estabelecendo conexões entre estes e os conteúdos aí exibidos, mediante processos não formais de ensino-aprendizagem e busca pela ampliação dos repertórios do outro (leia-se do não iniciado).

Em lugar de se comprometer com o binômio inclusão-conexão, a mediação que nos interessa discutir dedica-se à sondagem, ao registro e à análise crítica das aproximações (e disjunções) dos públicos com as produções artísticas difundidas por museus, bienais e demais centros de exposição. Em sentido complementar, tal modalidade de mediação ocupa-se da noção de colaboração, concebendo os processos mediativos não como instâncias acessórias às proposições institucionais, curatoriais e artísticas, a elas acopláveis a posteriori. Ao contrário, afirma-se como dimensão constitutiva dessas mesmas proposições, na medida em que busca criar condições para a colaboração do/com o outro - com suas respectivas demandas, agendas e saberes - durante o momento de concepção e o 
período de duração dos projetos. Será evocada, como exemplo dessa perspectiva, parte do projeto pedagógico da Documenta 12, entendido como importante referência desse tipo de abordagem.

Nota-se, por outro lado, que as políticas institucionais geralmente enquadram a figura do outro como a daquele que, de saída, possuiria uma formação cultural e artística deficitária, no sentido de uma pressuposta carência a ser sanada pelos expedientes da própria instituição artística, como se o que lhe faltasse pudesse ser ali encontrado e incorporado. Enquanto público não iniciado, ele faria parte dessa vaga entidade identificada como público em potencial, alcançável mediante estratégias de categorização e arregimentação, como veremos ao longo do capítulo.

Como maneira de ancorar nosso debate em uma ação institucional significativa, paradigmática dos esforços de renovação e ampliação dos repertórios artísticos dos seus públicos, elegemos percorrer, ainda que de modo não linear e aos saltos, passagens da trajetória da Bienal de São Paulo e a respectiva "história da atualização e da pedagogia da arte moderna e contemporânea entre nós”, proporcionada pela própria instituição (ALAMBERT; CANHÊTE, 2004, p. 11). Esse atravessamento será feito não com o intuito de repor o trabalho educativo desenvolvido pela Bienal em suas mais de seis décadas de existência. Nosso propósito, longe disso, é atentar para determinados fatos e discursos que, ao serem confrontados com as ideias aqui trabalhadas, talvez possam produzir faíscas úteis à nossa tentativa de relativizar alguns dos pilares que sustentam um projeto que, em sua origem nos anos 1950, procurou nutrir-se da "legitimidade que o público pudesse conferir à arte moderna e aos ideais de progresso que lhe correspondiam, conforme um horizonte de expectativas supostamente compartilhado" (HONORATO, 2015b, p. 126). Interessa-nos perscrutar índices de expectativas e reações não coincidentes, por parte dos públicos, com os da instituição e seus agentes. Buscaremos conferir alguma visibilidade e consequência a esses desacordos.

Resta considerar ainda, neste vislumbre de formas de interação e interlocução desviantes dos modelos dominantes praticados nas/pelas instituições de arte junto aos seus públicos, as experiências mediativas que se delineiam no interior do próprio ato artístico. São casos como o do artista Jorge Menna Barreto e seu Café Educativo, em que os processos de mediação compõem o cerne do trabalho artístico, embaralhando instâncias do circuito e, com isso, abrindo outras sensibilidades para o trabalho com os públicos.

\subsection{INSTITUIÇÃO ARTÍSTICA, PROCESSO CIVILIZATÓRIO E INSTRUMENTALIZAÇÃO DOS PÚBLICOS}

Parte-se da ideia de que a instituição artística, com suas respectivas missões e políticas, exerce significativa influência sobre as práticas especializadas que, por sua vez, lhe dão corpo. Dentre elas, destacam-se as atividades artísticas, curatoriais, pedagógicas, comunicacionais e expográficas, por exemplo. São tais práticas que, combinadas a várias outras e desempenhadas em uma 
estrutura funcional hierarquizada, conformam o lugar espacial e discursivo corporificado pela instituição. Importante não perder de vista, também, as contingências e toda sorte de pressões - internas e externas - que interferem nas decisões e ações institucionais, envolvendo aspectos políticos, ideológicos, econômicos e sociais.

Nesse sentido, pode-se inferir que a instituição artística participa de um sistema social, político e econômico complexo, permanecendo diretamente vinculada às suas circunstâncias. Referência nos estudos de museus, Eilean Hooper-Greenhill lembra-nos de que os "museus sempre modificaram a sua forma de trabalhar, e consequentemente aquilo que faziam, de acordo com o contexto, os jogos de poder e os imperativos sociais, econômicos e políticos que o cercavam” (HOOPER-GREENHILL, 1992, p. 1). O que significa destacar, desde já, que tanto a ação institucional como a produção artística e a própria mediação são dimensões integrantes desse tabuleiro loteado por diferentes especialidades e instâncias de poder.

Identificada como um terreno de disputas e conflitos de interesse - distante, portanto, de qualquer neutralidade e objetividade -, a instituição artística corresponde a um organismo (sempre em relação a outros) onde os diferentes anseios, expertises, orientações ideológicas e sensibilidades de seus agentes estão a todo tempo se confrontando e, em alguma medida, se articulando. Simultaneamente, esses agentes buscam se equilibrar frente às contingências do presente e ao cenário político, social, econômico e cultural do qual são parte.

Nessa arena de especialistas e "tomadores de decisão", papéis normalmente pré-determinados e instrumentalizados têm cabido aos públicos a partir do momento histórico em que as portas dos museus lhes foram abertas, entre o final do século XVIII e o início do XIX, na Europa. Ou seja, seus "passaportes de acesso" passam a ser, desde então, marcados por premissas e protocolos esquadrinhados à revelia do que poderiam ser as suas próprias demandas, agendas e desejos individuais e de grupo, já que desde o início o objetivo do "museu para todos" foi o de conformar os públicos, incluindo a classe trabalhadora, às exigências de um processo civilizatório comprometido com os propósitos de coesão social e de unidade dos modernos e recém-criados Estados-nação.

Importa dizer que a ideia de Estado-nação é uma concepção do Iluminismo, que faz do uso sistemático da razão a força motriz da dinâmica de cada Estado nacional e de sua administração, sobretudo no que tange às formas de governar as populações, transformadas em povo, conformando-o a um todo que se pretende unificado e coerente em termos identitários. Portanto, torna-se fundamental fomentar a sensação de pertencimento das pessoas a uma comunidade que compartilhe da mesma língua, cultura e história, ainda que isso seja fruto de uma construção ideológica, normalmente em prejuízo de identidades minoritárias.

1 As referências cujas fontes estão em língua estrangeira têm tradução minha. Essa informação vale para todos os capítulos da dissertação. 
Do ponto de vista das políticas públicas empreendidas pelos Estados-nação com esse objetivo, os esforços concentram-se na consolidação de "comunidades políticas imaginadas", o povo de cada país, mediante a "construção da identidade nacional e da preservação do seu patrimônio cultural”, conforme nos informa o trio de pesquisadores Pablo Ortellado, Luciana Piazzon Barbosa Lima e Valmir de Souza. Eles também pontuam que tais iniciativas estatais concretizam-se por meio da "criação de instituições voltadas à preservação do patrimônio histórico e à construção da memória nacional, a exemplo de museus, arquivos nacionais e órgãos de preservação". Esse aparato institucional proporciona o "estabelecimento de práticas rituais ou simbólicas que buscam inculcar valores e normas de comportamento", ao mesmo tempo que forjam "continuidade com relação a um passado [supostamente] comum" (ORTELLADO; LIMA; SOUZA, 2013, p. 5-6).

Tal natureza do processo civilizatório - que vigorou de modo hegemônico dos primórdios do museu público até pelo menos o período da Segunda Guerra Mundial (1939-45) como um motor atrelado às necessidades de unificação e consolidação da esfera socioidentitária dos Estados nacionais - vai sendo reorientada de acordo com o desenvolvimento do capitalismo e suas novas premências, que na segunda metade do século XX, sobretudo após o fim da Guerra Fria (1945-1991), culminarão na globalização do seu sistema produtivo. É desse contexto que se origina a noção de "fábrica global”, onde se nota "uma transformação quantitativa e qualitativa do capitalismo [para] além de todas as fronteiras" (IANNI, 2001, p. 18). Isso não significa que as políticas estatais ligadas às exigências de coesão do Estado nacional tenham sido abandonadas. Segundo Ortellado, Lima e Souza, elas foram "ressignificadas e permaneceram no rol da atuação do Estado no campo da cultura, evidenciando o caráter cumulativo das políticas de cultura” (2013, p. 6).

Se, por um lado, o capitalismo estimulou a formação do Estado-nação, por outro, ele também o tensiona e o recria ao sabor de suas necessidades de extensão e intensificação, conforme explica Octavio Ianni. O sociólogo comenta que, com o crescimento, a complexificação e a dinamização do livre mercado mundial, a soberania que define a essência do Estado-nação não só é limitada, como "abalada pela base”. O "princípio de maximização da acumulação do capital”, colocado em prática por corporações transnacionais e por organismos multilaterais, faz com que as fronteiras entre os países sejam "contínua ou periodicamente rompidas, refeitas, ultrapassadas ou dissolvidas". Caracterizada pela "desterritorialização das coisas, gentes e ideias”, a dinâmica dos mercados espraia-se não só por todo o globo, mas por todas as instâncias da vida social, englobando as mais diversas instituições, reforçando com isso "os padrões socioculturais e os ideais relativos à racionalização, produtividade, lucratividade, quantidade” (IANNI, 2001, p. 40-49).

Voltando a sublinhar o quão permeáveis são as instituições artísticas àquilo que se dá nos planos econômico, político, social e cultural - e estamos falando agora de uma "sociedade global" -, é evidente que o capitalismo "enquanto modo de produção e processo civilizatório” seguirá influenciando dire- 
tamente as políticas institucionais a partir das prioridades do mercado. Neste momento, tais políticas estariam menos focadas na produção de identidades nacionais unitárias, tanto em virtude do reconhecimento das dimensões multiculturais e multiétnicas que compõem as comunidades nacionais, como também pelo fato de que os países se veem cada vez mais pressionados por injunções de um mercado que "transcende tudo o que é local, nacional e regional” (IANNI, 2001, p. 41, 48). Isso porque ele se "mundializou”, a ponto de ser hiperbolicamente designado como "o mercado de todo o universo" (BRAUDEL apud IANNI, 2001, p. 31).

Necessário pontuar, ainda, que no atual estágio do capitalismo já não são apenas as mercadorias convencionais que circulam pelo mundo. Facilitados pelos avanços da eletrônica e da rede mundial de comunicação (internet), "as informações, os entretenimentos e as ideias [também] são produzidos, comercializados e consumidos como mercadoria” (IANNI, 2001, p. 16). É nesse contexto de diversificação e generalização da produção e hiperconsumo, potencializados pelos processos crescentes de desestatização, desregulação, privatização e abertura dos mercados nacionais para o capital estrangeiro, que a instituição artística irá incorporar ao seu cabedal de políticas e ações os processos de financeirização e espetacularização da cultura.

Não é por acaso, portanto, que a partir dos anos 1980, de acordo com Otília Arantes, passa a reinar "uma grande animação no domínio tradicionalmente austero e introvertido dos museus". Sobretudo nos museus recém-construídos, mas também naqueles que passam por remodelações, consome-se muito mais do que o contato com as obras dos artistas. Além das obras, somos seduzidos pela exuberância do edificio, geralmente assinado por alguma figura do star system da arquitetura internacional. Ao adentrar seus espaços, nossa disponibilidade e atenção são disputadas por toda sorte de serviços e atrações, entre "cafeterias, restaurantes (por vezes entre os melhores da cidade), ateliês, salas de projeção ou de concertos, livrarias etc.”. A diferença entre o museu e o shopping center, segundo a filósofa, já não é mais tão clara. As próprias exposições "apresentam uma inegável dimensão mercantil", sugerindo um modo recreativo de contato com o que é oferecido (ARANTES, 1993, p. 233). A isso se conjuga a transição do modelo de subsídio público das instituições artísticas e suas programações para o registro corporativo de financiamento, que tem como um dos efeitos mais visíveis "a nova ênfase nas exposições blockbuster", organizadas com o objetivo de atrair multidões (WU, 2006, p. 157).

No que se refere à dinâmica de afluência dos públicos às instituições de arte, a entrada dos frequentadores, ao "girar a catraca”, é capitalizada na soma geral das metas de visitação estipuladas pelas instâncias diretivas junto aos parceiros, representando uma das contrapartidas oferecidas pela instituição às corporações que financiam suas exposições - e que delas se beneficiam fazendo marketing com dinheiro público, via isenção fiscal, como detalharemos mais à frente. $\mathrm{O}$ número de pessoas que visita tais exposições passa a funcionar como o critério principal de aferição do sucesso ou fracasso da iniciativa (WU, 2006, p. 157). 
Assim, o público é transformado em "moeda de troca” nas tratativas entre instituição e financiadores. Sua provável (senão provocada) presença enquanto visitante é usada nas mesas de negociação em que se definem as parcerias e as somas a serem aplicadas em cada projeto. Um exemplo eloquente desse tipo de instrumentalização do público empreendida pela instituição artística pode ser encontrado no discurso do ex-presidente da Fundação Bienal de São Paulo, o empresário Luis Terepins (no cargo de 2013 a 2016), que em depoimento a respeito da organização da $31^{\mathrm{a}}$ edição da Bienal², em 2014, dispara:

Nós conversamos muito sobre este processo do Educativo, de poder chegar nesse público ampliado, que eu chamo de público forçado, que são as duzentas/trezentas [sic] mil crianças, os trinta mil educadores e professores que passam por um processo de formação que temos aqui na Bienal. (TEREPINS, 2014, grifo meu.)

A máxima do gestor de uma das mais importantes instituições artísticas brasileiras não surge isoladamente, como deslize de um empresário que se pôs a atuar no campo artístico-cultural. Longe disso, a sentença está respaldada por uma dinâmica institucional consolidada, administrada de maneira alinhada aos preceitos do capitalismo avançado, conforme temos procurado elucidar aqui.

Como forma de colocar esse depoimento em tela, e buscando produzir a exegese que ele nos cobra, seria o caso de reler alguns de seus excertos a partir de uma das lentes de análise fornecidas por Vladimir Safatle em sua coletânea de ensaios intitulada $O$ circuito dos afetos. Nela, o filósofo enfrenta questões sobre como o poder do capital constrói seus corpos políticos e de que modo esses corpos implicam os sujeitos em regimes específicos de afeto e individualização. Num dos ensaios, o autor faz menção ao jovem empresário bem-sucedido Eric Michael, personagem central do romance Cosmópolis de Don DeLillo, para aludir à sua habilidade e prazer em lidar com o dinheiro como "pura abstração”. Essa tendência, conforme se depreende dos comentários de Safatle, representa um sintoma da atual fase do capitalismo financeiro, na qual a riqueza torna-se objeto de si mesma, desdobrando-se numa espécie de tautologia especulativa em que dinheiro compra dinheiro, ad infinitum.

Nesse movimento sistemático de descorporificação das coisas e dos seres - que são transformados em meras cifras -, pratica-se a "redução de todos os corpos à segurança da medida”. Aliás, tal mensuração “se impõe como única experiência de sentido" para os agentes do mercado financeiro, mas não só a eles. Estamos falando de um afeto produzido pelo capitalismo, no qual está baseado o sistema econômico. Ele reflete o "gozo do cálculo" que, ao usar a "equivalência enquanto [forma de] controle”, funciona

2 Disponível em: <http://arte1.band.uol.com.br/bienal-2014/>. Acesso em: 15 jul. 2016. 
como "forma de domínio". Essa lógica - que o depoimento de Terepins parece repercutir - faz com que "todos os corpos [sejam] reduzidos à condição de suportes intercambiáveis de um processo contínuo de circulação fetichista da equivalência” (SAFATLE, 2015, p. 189-191).

Comecemos então pelo trecho em que Terepins enuncia a intenção de "poder chegar nesse público ampliado, que eu chamo de público forçado". Está claro que chegar nesse público ampliado considera apenas as premissas e ações da instituição, no sentido do que ela tem a oferecer ao público escolar. Talvez fosse o caso de nos perguntarmos se os estudantes não teriam nada a oferecer ou a propor à Bienal. Há que se indagar, ainda, sobre a função de tal segmentação abstrata e totalizante dos escolares, que desconsidera quaisquer diferenças entre as escolas, as turmas e cada um dos indivíduos que as integram, com suas distintas experiências, repertórios e desejos. Ela reduz essa multiplicidade a uma tabula rasa, na medida em que a submete a um esquema de superficial equivalência. No caso da expressão público forçado, o que desaparece é a face da relação que poderia dizer respeito ao interesse e à iniciativa (ou mesmo ao desinteresse e a iniciativas em outras direções) dos próprios estudantes e de seus professores em relação à Bienal. Naturaliza-se a ideia de que, não fosse a mobilização institucional de arregimentação de tal público, ele permaneceria alheio ou indiferente ao que se passa no pavilhão por ocasião das mostras que ali ocorrem. Desse modo, é como se a instituição se sentisse autorizada a (ou mesmo responsável por) induzir essa visitação, afastando qualquer dúvida que pudesse surgir sobre o caráter benéfico de sua ação educativa de proporcionar ao outro, enquanto não iniciado, o acesso às práticas artísticas de ponta. Ao sugerir como equivalentes não apenas os perfis dos estudantes, mas também os seus próprios interesses, Terepins lança mão de uma ferramenta de controle. É com ela que o então presidente da Bienal - contando com a expertise e a força-tarefa do departamento educativo - procura submeter os corpos dos estudantes e de seus professores à condição de suportes dos interesses e objetivos da instituição (e dos seus financiadores, diga-se).

Devemos atentar, além disso, para a forma como Terepins quantifica esse público em sua fala. Como ele diz, o público forçado "são as duzentas/trezentas [sic] mil crianças, os trinta mil educadores e professores”. Aqui aparece aquilo que Safatle identifica como um tipo de "redução de todos os corpos à segurança da medida”, ainda que surpreenda a naturalidade com que o gestor oscila entre duzentas e trezentas mil crianças. De uma palavra a outra, o orador acrescenta às suas contas nada menos do que 100 mil pessoas! Seria essa a margem considerada pelo então presidente? Outra possibilidade seria considerar que, em seu discurso, o número adquire de tal maneira um valor em si que pode ser manejado com elasticidade para cima ou para baixo, a depender da circunstância.

Diga-se ainda, a esse respeito, que Terepins teria usado tais números com base nos cômputos das duas edições anteriores da mostra, que antecederam diretamente a sua gestão. Trata-se da 29a (2010) e 30 ${ }^{\mathrm{a}}$ (2012) edições da Bienal, que foram realizadas no momento em que a presidência da Fundação era ocupada pelo também empresário Heitor Martins. Na 29a 
Bienal, o programa educativo chegou a atender 287.261 pessoas, do total de aproximadamente 535 mil visitantes da mostra. Na 30 a , a quantidade de pessoas atendidas diretamente pelo programa educativo foi de 216.257, do total de aproximadamente 517 mil que visitaram a exposição. Notemos, então, que a conta de Terepins - referente às "duzentas/trezentas [sic] mil crianças" - corresponde a algo que rodeia de forma imprecisa as quantidades atingidas nas mostras pregressas. Já a $31^{\text {a }}$ Bienal (2014), objeto do depoimento do então presidente Terepins, alcançaria um público total de visitantes de aproximadamente 472 mil visitantes. Desse universo, 164.242 pessoas foram atendidas em ações promovidas pelo programa educativo ${ }^{3}$. Desses atendimentos via programa educativo, assim como nas duas edições anteriores, a maior parte do público era formada por estudantes recebidos e conduzidos no pavilhão pelos mediadores, através de visitas agendadas.

Em complemento a essa abstração numérica, devemos levar em conta a forma como normalmente as instituições de arte - Bienal inclusa - compreendem e nomeiam o que sejam os públicos de suas exposições e ações de mediação. Em bases apriorísticas, amplas e vagas, essas designações se dão a partir de subdivisões e macroagrupamentos que classificam e organizam os públicos de modo também abstrato, com finalidades meramente funcionais. São exemplos frequentes: público espontâneo, público escolar, público agendado, público especial, público socialmente vulnerável, público da terceira idade, público VIP, público universitário, público familiar, público especializado etc. O "mérito" de Terepins no referido caso foi o de conseguir sintetizar e elevar a um altíssimo grau a lógica de normalização dos públicos, conferindo a ela uma acepção constrangedora - em sentido duplo, tanto por sugerir a coerção do público como por enrubescer os agentes comprometidos com ações educativas nos contextos institucionais ${ }^{4}$.

\subsection{BREVE HISTÓRICO DO PROJETO DE ATUALIZAÇÃO} ARTÍSTICA ENTRE NÓS: A BIENAL DE SÃO PAULO

Intitulada As Bienais de São Paulo: da era do Museu à era dos curadores (1951-2001), a pesquisa de Francisco Alambert e Polyana Canhête nos coloca a par da trajetória desse que para o poeta Décio Pignatari representa "o empreendimento cultural mais ambicioso e representativo - e bem logrado - da América Latina no

3 Fontes: Relatório de gestão e contribuições à sociedade (2010-2011), Fundação Bienal de São Paulo. Disponível em: <http://www.bienal.org.br/publicacao.php?i=2107> Relatório de gestão e contribuições à sociedade (20112012), Fundação Bienal de São Paulo. Disponível em: $<$ http://www.bienal.org.br/publicacao.php?i=2105>; Relatório de gestão e contribuições à sociedade (20132014), Fundação Bienal de São Paulo. Disponível em: <https://issuu.com/bienal/docs/bienal-relatorio_gestao_2013_2014_eaeb546ab363bb>. Acesso em: 6 ago. 2016.

4 Por ocasião da veiculação da entrevista, soube-se que a coordenação do programa educativo da Bienal prontamente procurou Terepins para alertá-lo do tom "inadequado" da expressão público forçado. 
século XX, no âmbito das artes plásticas ou visuais" (PIGNATARI apud ALAMBERT; CANHÊTE, 2004, p. 236). Interessa-nos reunir aqui elementos que denotem os primeiros movimentos dessa instituição no tocante à atualização e à ampliação do repertório estético da comunidade artística e dos públicos locais. Em linhas gerais, os principais debates artísticos daquele momento giravam em torno da oposição entre estéticas figurativas e abstratas, todas elas alinhadas em alguma medida com as preocupaçôes plástico-formais e com a autonomia da arte que marcam o pensamento moderno em arte.

Ao mesmo tempo, não é possível falar dos primórdios da Bienal de São Paulo sem nos referirmos ao período que lhe antecede (e também às fases seguintes a seus primeiros passos), caracterizado pela criação de alguns dos principais museus do país, em particular aqueles que se dedicariam à produção artística moderna. A própria Bienal, como veremos, nasce como uma realização do Museu de Arte Moderna de São Paulo, numa combinação que irá perdurar até a sua sexta edição, em 1961, quando ocorre a controversa separação da Bienal em relação ao Museu. Tal aspecto demonstra quão entrelaçadas (e descontinuadas) são, no caso brasileiro, as trajetórias dos museus (do Museu de Arte Moderna, mas também do Museu de Arte Contemporânea da Universidade de São Paulo) com a da Bienal.

No tocante à atualização dos repertórios artísticos das comunidades locais, figuras importantes como a de Mário Pedrosa "acreditava[m] que o 'fogo divino’ da iniciação aos princípios da sensibilidade moderna poderia surgir da experiência direta com as artes visuais”, sem a necessidade de uma intermediação literária. Havia uma fé que atribuía às "exposições de arte de vanguarda um lugar de esclarecimento e abertura ao novo". Logo, estruturar uma mostra periódica de arte moderna de grande porte seria a oportunidade de "ver esse processo multiplicado". As Bienais representariam, desse modo, a "realização do 'espírito' moderno entre nós, para todos nós (e não apenas para os aficionados ou já iniciados)" (ALAMBERT; CANHÊTE, 2004, p. 22, grifo dos autores).

Sérgio Milliet declara, em 1951, por ocasião da $1^{\text {a }}$ Bienal do Museu de Arte Moderna de São Paulo ${ }^{5}$, que a mostra "assinala a elevação da pequena e provinciana cidade de 30 anos atrás à categoria de Capital artística do país” (MILLIET apud ALAMBERT; CANHÊTE, 2004, p. 11-12). As três décadas anteriores a que o crítico faz menção remontam ao evento que se tornou o emblema da atualização da produção artística no país: a Semana de Arte Moderna de 1922. Sem dúvida, a Bienal tem na Semana uma parcela significativa do lastro artístico-cultural que lhe antecede. Além dela, também foram decisivos para pavimentar o caminho desse gran de evento os grupos vigentes e as respectivas atividades entre os anos 1930-40, como é o caso do Grupo Santa Helena, da Sociedade Pró-Arte Moderna (SPAM) e do Clube dos Artistas Modernos (CAM), bem como

5 Esse era o título usado pelo MAM-SP para designar a sua primeira Bienal Internacional de Arte da América Latina. 
dos Salões de Maio, do $1^{\circ}$ Salão de Arte da Feira Nacional de Indústrias (Rio de Janeiro) e do Clube dos Artistas e Amigos da Arte, conforme levantamento de Alambert e Canhête (2004, p. 24).

No âmbito institucional, na virada das décadas de 1940-50, quem dá as cartas é o capital privado. A esfera cultural no eixo Rio-São Paulo vive "uma nova etapa no processo de formação, transmissão e recepção da arte moderna”. Os pesquisadores designam essa fase da vida cultural brasileira (em que pese sua concentração, nesse momento, no Sudeste) como a “era dos museus". São fundados, nesse período, o Museu de Arte de São Paulo - Masp (1947), o Museu de Arte Moderna de São Paulo - MAM-SP (1948) e o Museu de Arte Moderna do Rio de Janeiro - MAM-RJ (1949) (ALAMBERT; CANHÊTE, 2004, p. 26).

Em especial o MAM-SP e, na sequência, a Bienal têm sua criação atrelada a um componente externo de grande poder de influência. Relatam os pesquisadores que, "durante a Guerra Fria, os Estados Unidos desenvolveram um projeto 'pan-americanista' que tinha na cultura (e nas artes em particular) um de seus braços”. Tal iniciativa era parte de uma política de Estado norte-americana, com propósitos claramente "imperialistas e anticomunistas", num prenúncio das estratégias calcadas no soft power, conceito que comentaremos mais à frente. O magnata Nelson Rockefeller, dono da maior petrolífera do mundo, a Standard Oil, dirigia à época a agência governamental responsável por fomentar os "laços de amizade" entre os EUA e os países da América Latina. Nesse quadro, o industrial ítalo-brasileiro Francisco "Ciccillo" Matarazzo Sobrinho, destacado industrial que já vinha acumulando experiências como colecionador e mecenas das artes, é tido por Rockefeller e pelo MoMA (Museu de Arte Moderna de Nova York) como a figura pública paulistana mais recomendada para assumir a responsabilidade pela fundação de um museu dedicado à arte moderna em São Paulo, que se dá em 1948 (ALAMBERT; CANHÊTE, 2004, p. 28-30).

De outro lado, justiça seja feita, o desejo pela implantação de um museu de arte moderna por estas bandas já vinha sendo alimentado (e ensaiado) desde a primeira metade dos anos 1940. Como nos contam os pesquisadores, em 1944, o próprio Ciccillo havia cogitado a formação de tal museu a partir da doação de sua coleção particular de obras, tendo inclusive organizado reuniões com representantes de diferentes setores da sociedade para discutir a proposta, que não chegou a surtir efeito naquele momento (ALAMBERT; CANHÊTE, 2004, p. 27). A historiadora Regina Teixeira de Barros registra que, em 1946, Milliet vai à imprensa defender a importância e a necessidade da criação imediata do museu. Além disso, ela nos conta que o prefeito da cidade é conclamado por Luís Martins para tal missão, através de uma carta aberta que também circula pela imprensa (BARROS apud ALAMBERT; CANHÊTE, 2004, p. 27). Podemos citar, ainda, "a existência em São Paulo de outras instituições que antecederam o Museu: a Galeria de Arte Moderna de São Paulo e a Fundação de Arte Moderna”. No entanto, uma alavanca não menos decisiva para que o Museu de Arte Moderna saísse definitivamente do papel foi a criação do Museu de Arte de São Paulo, haja vista a dispu- 
ta por reconhecimento social, mais precisamente na high society, entre Ciccillo e Assis Chateaubriand, responsável pela fundação do Masp (ALAMBERT; CANHÊTE, 2004, p. 27). O projeto do MAM-SP, como se pode depreender, oscila entre um feito de interesse público e uma realização ligada à satisfação e à credibilidade pessoais, com a balança pendendo em vários momentos para a segunda, como veremos a seguir.

Cumpre dizer, ainda, que o MAM-SP e, depois, a Bienal surgem tanto do acúmulo de experiências e expectativas em torno da modernidade artística como da confluência de fatores conjunturais de ordem nacional e internacional. A esses fatores se somarão também as "condições internas do momento nacional-desenvolvimentista" do país, que se intensificam com o retorno de Getúlio Vargas à presidência da República, em 1951, ano da $1^{\mathrm{a}}$ Bienal do Museu de Arte Moderna de São Paulo. Os pesquisadores esclarecem que grande parte das políticas de Estado desse período volta-se a "projetos de desenvolvimento [industrial] que visavam criar as condições de substituição de importações”. Nessa mesma linha, a Bienal e as manifestações artísticas por ela representadas passariam a ser consideradas pelo viés da "substituição de importação cultural", na medida em que estimulariam por aqui uma produção artístico-cultural renovada, em bases modernas e progressistas (ALAMBERT; CANHÊTE, 2004, p. 27).

O que se nota, ainda assim, é a importação de modelos. Criada em 1895, a Bienal de Veneza serviu como principal referência para a concepção da Bienal de São Paulo. Ciccillo, seu criador, vai pela primeira vez ao evento veneziano em 1948, ano da fundação do MAM-SP. Dois anos depois, conforme narram os pesquisadores, ele chefia a delegação brasileira que, pela primeira vez, participa da mostra (ALAMBERT; CANHÊTE, 2004, p. 32). O crítico Lourival Gomes Machado, envolvido diretamente com o empreendimento à época, tendo sido diretor artístico do Museu, é claro ao comentar a influência da Bienal de Veneza sobre o evento paulistano: "era inevitável a referência a Veneza; longe de fugir-se dela, procurou-se tê-la como uma lição digna de estudo e, também, como um estímulo encorajador" (MACHADO apud ALAMBERT; CANHÊTE, 2004, p. 32).

No momento em que completa a primeira década de existência, ao mesmo tempo que era reconhecida por haver cumprido "a sua função primeira de $c o$ locar os artistas e o público brasileiros em contato com a arte mais atual, ousada e consequente produzida em todo o mundo", a Bienal havia crescido desmesuradamente: de 23 países representados em sua estreia, em 1951, a 53 na sexta edição, em 1961, a mostra teve seus custos de produção inflacionados enormemente (ALAMBERT; CANHÊTE, 2004, p. 93, grifo meu). A sexta seria, inclusive, a última edição da Bienal organizada pelo MAM-SP, cujo presidente, Ciccillo Matarazzo, vinha planejando "transformar a Bienal de São Paulo em uma Fundação independente do MAM". Entre outros motivos, a separação justificava-se pelo "fato de que o Museu de Arte Moderna passou a ficar em segundo plano em relação à Bienal, que, grande e caríssima, sugava todos os seus recursos, deixando-o incapaz de desenvolver os seus próprios projetos" (ALAM BERT; CANHÊTE, 2004, p. 95). Temos aqui um claro sinal de como a lógica do evento, do brilho passageiro, iria preponderar em detrimento 
de uma ação centrada na continuidade e no adensamento das práticas e do pensamento museológicos.

Em 6 de abril de 1962, a imprensa divulga que o presidente das instituições, Ciccillo

Matarazzo, ficaria no comando apenas da Bienal, relegando o Museu a uma situação de profunda incerteza e fragilidade. Tal situação se tornaria ainda mais delicada após o mecenas ter assinado uma escritura de doação junto à Universidade de São Paulo, cedendo em definitivo à USP sua portentosa coleção de obras, até então sob a guarda do Museu. Além dessas obras, também aquelas que já pertenciam oficialmente ao acervo do MAM foram transferidas para a Universidade ${ }^{6}$. Após polêmicas e processos judiciais, restaria ao MAM, socorrido por alguns de seus sócios, apenas o direito de manter o próprio nome, tornando-se naquele momento um museu sem patrimônio [sic] (ALAMBERT; CANHÊTE, 2004, p. 99-102).

À parte as idas e vindas institucionais e as arbitrariedades que com alguma frequência as pautaram e continuariam a pautar, as quais também dizem respeito aos interesses da nossa pesquisa, importa salientar na gênese de instituições como o Museu de Arte Moderna e a Bienal aquilo que concerne aos propósitos de difusão da arte moderna junto ao público. Ninguém melhor do que o crítico belga Léon Degand para nos esclarecer esse quesito. Degand, que num primeiro momento atuou como consultor de Ciccillo e Yolanda Penteado na formação da coleção de obras do casal, foi o primeiro diretor artístico do recém-criado MAM (ALAMBERT; CANHÊTE, 2004, p. 31-32). Em sua comunicação no World Biennial Forum, em 2015, Honorato comenta passagens dos escritos de Degand acerca do público enquanto elemento central do fenômeno artístico. Dada a perspicácia com que Honorato glosa essas passagens, será útil nos valermos de sua análise para registrar aqui o entendimento e o tom do primeiro diretor artístico do MAM para indicar o estatuto do público da arte moderna, em particular o brasileiro (HONORATO, 2015b, p. 124).

Honorato inicia sua exposição reportando-nos ao texto de Degand intitulado "A importância do público", publicado em 1948. Nele, o crítico belga coloca em questão a desatenção historicamente dispensada aos públicos da arte. Protestando contra esse fato, ele diz que "a obra não é apenas aquilo que o artista pretendeu que ela fosse”. Ela também é, segundo ele, "tudo aquilo que cada um de nós, em obediência aos modismos espirituais da época e do estado de humor pessoal, diminui, acrescenta ou modifica” (DEGAND apud HONORATO, 2015b, p. 124). Entretanto, Honorato nota que Degand, ao longo do seu texto, "mantém criação e fruição como dois mundos paralelos", rigidamente separados, sem que nenhum corte (e passagem) seja produzido entre eles - justamente por onde o público e a exterioridade do mundo poderiam atravessar o "ato criador" do artista, ressignificando-o. De um lado, o crítico parece sugerir que o público desvende "o mais exatamente possível” os senti-

6 O Museu de Arte Contemporânea da Universidade de São Paulo, o MAC-USP, foi concebido a partir dessas transferências, sendo criado em 1963. 
mentos subjacentes ao trabalho do artista; de outro, que esse público responda "da maneira a mais viva", ainda que a sua resposta "não seja conforme as intenções iniciais do autor", para afinal dizer que o importante é a "colaboração de um público". Honorato destaca que, nessa fórmula de colaboração, "não há [um real] ponto de contato entre uma instância e outra”. É como se não houvesse "nenhum tipo de interseção [problemática] entre as 'inovações da arte' e as 'reações contraditórias do público”'. Devemos então nos perguntar: qual é o tipo de colaboração que Degand imagina caber ao público? (HONORATO, 2015b, p. 124). A esse respeito, o crítico será mais explícito no texto "Estarão divorciados a arte e o público?” (s.d.). Ali, Degand reforça que essas esferas sempre estiveram fundamentalmente apartadas, já que, como anota Honorato, reforçando o tom da sentença do crítico, "não se poderia afirmar, a respeito de qualquer época, que o público alguma vez tenha compreendido as 'razões estéticas da arte”" (HONORATO, 2015b, p. 125). É Degand quem diz:

[...] graças à revolução artística que se iniciou durante as primeiras décadas do século XIX [...], percebeu-se, enfim, que o público só se interessava pelas artes plásticas em virtude de um mal-entendido - o de confundir artes plásticas com a encenografia [a representação de personagens e objetos identificáveis, em quadros "vivos" ou cenas dramáticas] - e que a parte especificamente plástica destas artes [o jogo das formas e cores] lhe escapava geralmente. (DEGAND apud HONORATO, 2015b, p. 125.)

Aqui, o crítico fornece sinais de que o processo de colaboração entre público e prática artística talvez não se dê exatamente de modo colaborativo, tendo em vista o desencontro e a assimetria entre práticas que repercutem preocupações e soluções formais (plásticas) e, por outro lado, uma audiência supostamente incapaz de se deter e de fruir as formas em seu valor próprio, distraindo-se com aquilo que menos importaria aos modernos: o tema, ou a dimensão literária da obra. Seguindo a chave proposta por Degand, Honorato avalia que o "eventual interesse [do público] pela arte resulta em última instância de um equívoco”. Daí que a preocupação de Degand com o "divórcio" entre arte e público justifique-se por uma preocupação, a nosso ver, suspeita, haja vista que a "sua tentativa de pôr aqueles dois mundos em contato parece cons truir uma ponte demasiadamente inclinada, que posiciona o público, a quem de resto caberia cruzá-la, como estando sempre aquém da arte” (HONORATO, 2015b, p. 125).

Neste ponto da análise do discurso de Degand, caberia indagarmos sobre o que fazer com o encontro entre as "inovações da arte" e as "reações contraditórias do público". Já sabemos que, na visão do crítico, tais reações acabam sendo rebaixadas à condição de "um mal-entendido" a ser reorientado e, finalmente, sanado. Mas, seguindo a linha de raciocínio de Honorato, "e se tais reações fossem, na verdade, reações inconformes, eventualmente antagônicas, [elas] seriam em todo caso mal-entendidos?”. Ao ser 
recolocada dessa maneira, a questão adquire um tipo de complexidade ausente no posicionamento de Degand, para quem, segundo Honorato, a disponibilidade às idiossincrasias do público simplesmente "prepara a transmissão de uma mensagem específica": a do arsenal estético da arte abstrata, "que solicita um público igualmente abstrato, no sentido de um mero suporte de intenções alheias" (HONORATO, 2015b, p. 125). Logo, é possível insinuar que Degand está menos comprometido com "as diferentes reações do público" - fazendo-se sensível ao que daí poderia advir em termos de oposição e dissenso - do que "interessado na legitimidade que o público pudesse conferir à arte moderna e aos ideais de progresso que lhe correspondiam, conforme um horizonte de expectativas supostamente compartilhado", de acordo com o que adiantamos na introdução do capítulo. Nesse caso, o que teria Degand a dizer a respeito da conduta abaixo relatada? Ela reflete apenas "um mal-entendido"? Ou, ainda, a atitude de um mal entendedor?

Parecia um sujeito matuto. Além da fisionomia, seus modos e trajes denunciavam sua condição de recém-egresso da roça. Um caipira, cochichavam alguns. Caiu de paraquedas naquele que seria um marco das comemorações do IV Centenário de São Paulo: a cerimônia de inauguração da $2^{\circ}$ Bienal do Museu de Arte Moderna de São Paulo. Tinha ido ao Parque Ibirapuera sozinho, sem qualquer objetivo explícito. Ao notar a multidão aglomerada diante de um dos pavilhões - o das Nações - resolveu se aproximar. Supôs que o portão de acesso estivesse prestes a ser aberto, dada a grande quantidade de gente e a inquietação daquele enxame. Sentou-se numa mureta próxima e, pitando seu cigarro, ficou observando e achando graça naquele espetáculo que, sem o saber, o público protagonizava. Dali quinze minutos o portão foi aberto. As pessoas entravam afoitas, aos montes, sequiosas pelo que havia de mais avançado no campo das artes plásticas. $\mathrm{O}$ rapaz permaneceu ali por mais de uma hora, sem esboçar qualquer movimento ou intenção de entrar no pavilhão. Foi quando o motorista do patrono Ciccillo Matarazzo, um nortista generoso, se dirigiu ao anônimo com a proposta: "se quiser entrar eu posso lhe arrumar um convite e um paletó...”. Ao que o rapaz respondeu com insolência: "preferiria não". (MORAES, 2014, p. 246.)

7 Escrito por mim, este relato integra a série intitulada Episódios contrapúblicos. Anotados e trabalhados a partir da observação (direta ou indireta) das atitudes e falas dos públicos frente às ofertas das instituições artísticas, eles adquirem a forma de microcontos que podem circular em diferentes meios e suportes (impresso, digital e oral). 
O episódio acima agrega ao "mal-entendido" - que frequentemente caracteriza, na linha de Degand, as leituras das obras pelo público - a recusa pura e simples. Na perspectiva do progresso, do incremento gradativo do repertório do outro, essa rejeição seria classificada como um estágio ainda anterior ao do "mal-entendido", por revelar falta de sensibilidade para as coisas da arte.

Mas Degand, munido das ferramentas de desenvolvimento do gosto e incorporando o papel de um convicto missionário da estética moderna e dos feitos e conquistas por ela desencadeados mundo afora, tem a solução para todo mal-entendido que possa deturpar a produção moderna em arte:

Existe um meio apenas para acabar com este mal-entendido: ensinar ao público, desde a mais tenra infância, na escola, nas academias de Belas Artes, em toda parte, que em toda obra de arte pertencente às artes plásticas (pintura, gravura, escultura etc.), o importante, em primeiro lugar, é a plástica. (DEGAND apud HONORATO, 2015b, p. 126.)

Retomemos a glosa de Honorato, que nos ajudará inclusive a situar mais precisamente a reação insolente do caipira: para que a centralidade da plástica pudesse ser reconhecida e valorizada pelo público, "era necessário difundir uma subjetividade que fosse a 'expressão de um mundo moderno, urbano e racional", e aqui ele está citando um fragmento do ensaio "Respingos na parada modernista: a invasão fracassada da arte abstrata", de Serge Guilbaut.

O sentido da educação em Degand tem relação direta com um modo de "fabricar e impor o sujeito moderno, e de persuadir o público da importância da arte" (HONORATO, 2015b, p. 126, grifos meus). A crença fervorosa que anima os posicionamentos do crítico leva-o a escrever uma carta a Ciccillo, na qual instiga sua verve liberal e empreendedora nos seguintes termos:

O público não entende nada de arte moderna. Ele deve ser educado mesmo sem ter essa intenção. No presente estado de coisas são os disparadores, ou seja, indivíduos privados audaciosos, que devem educá-los. Sendo assim, seu papel [o de Ciccillo] está bem definido. (DEGAND apud HONORATO, 2015b, p. 126.)

Em outras palavras, o que Degand está propondo é que o público (todo ele, em sentido abstrato) seja submetido a um processo educacional - talvez fosse mais correto identificá-lo como um tipo de instrução - que ocorra à revelia das possíveis demandas dos mais diversos indivíduos e coletividades que integram essa vaga totalidade aludida pelo crítico. Isso denota que eles não teriam condições de, por si sós, reconhecer o verdadeiro valor da arte moderna, concebida como algo de valor universal para Degand. Precisariam, assim, ser conduzidos por mentes esclarecidas e audaciosas. Algo dessa posição de Degand parece ecoar no discurso de Terepins acerca do público forçado. 
O que, a princípio, poderia ser considerado uma ortodoxia datada, restrita ao alto modernismo e seus arroubos, representa um sistema que insiste em perdurar no tempo e nos mais variados contextos, inclusive de forma não consciente, como sugere a pesquisadora e curadora Cristina Freire. Ela descortina o que está em jogo no sistema operacional moderno ao indicar que ele se presta, principalmente, a "administrar comportamentos, educar e 'civilizar' modos, adestrando corpos e, no mesmo movimento desse decoro imposto, despolitizar a apresentação da arte e seu ensino, aliviando-a de crise e conflitos” (FREIRE apud HONORATO, 2015b, p. 125).

À nossa pesquisa compete sondar condutas que reponham, de forma renitente, situações de crise e conflito nos contextos expositivos, desencadeadas muitas vezes pelos "mal-entendidos" e recusas de seus públicos. Interessa-nos contrapor esses índices reagentes às políticas e ações institucionais, com suas diferentes formas de produzir o público, não raro à sua própria revelia.

\subsection{PÚBLICO FORÇADO X CONTRAPÚBLICO}

À noção de público forçado seria oportuno confrontar a ideia de contrapúblico. Submetido a um tipo de gestão que perfila as audiências em função de propósitos muitas vezes estranhos aos desejos e aos repertórios dos indivíduos e coletividades, o contrapúblico irrompe de maneira inesperada e até mesmo improvável nesse cipoal institucional que, em/por princípio, parece ceifar sumariamente a possibilidade de sustentação e autoafirmação de sujeitos políticos enquanto públicos cientes de si.

Ao debruçar-se sobre a lógica globalizante das bienais de arte, o curador e educador Paul O’Neill nos alerta para o caráter ideológico de tais instituições e de suas mostras periódicas, segundo ele responsáveis por reificar as relações sociais entre os públicos e os trabalhos artísticos. O propósito central dessas exposições, segundo o autor, reside no oferecimento de panoramas tematizados e compreensivos da produção artística contemporânea a partir de diferentes arranjos curatoriais. Suas modalidades discursivas seriam de tal maneira predeterminadas e unidirecionais que impediriam a possibilidade de serem questionadas, transformadas e usadas de modo alternativo pelas audiências no decurso de sua concepção e aparição na cena pública, no sentido de uma blindagem diante das contradições e conflitos que poderiam surgir desse contato.

Nessa direção, O’Neill sugere que não apenas os gestores institucionais, mas também os próprios curadores, com algumas exceções, compreendem os públicos como uma espécie de "círculo social unificado e inconteste, deixando de levar em consideração quaisquer noções de diferenciação entre sujeitos e coletividades emergentes ou contrapúblicos". O autor vai mais longe, ao apontar que:

A estrutura institucional por trás das bienais sustenta a ilu-
são de uma inspiração curatorial abrangente, ou mesmo ge-
nial, que seria apresentada aos públicos reais ou imagina-
dos como um fato consumado. Em contraste, o público [...] 
pode ser entendido não apenas como uma entidade concreta a ser desconstruída e pluralizada, mas como capaz de produzir e constituir a si mesma. [Seria o caso de] ver o público como algo em construção [...]. (O’NEILL, 2012, p. 61.)

Esse "ver o público como algo em construção" corresponde ao entendimento de que ele seria, antes de tudo, uma formação emergente constituída temporariamente em torno de discursividades articuláveis aos desejos e agendas de pessoas e grupos que delas se aproximam, dedicando seu tempo e atenção aos enunciados apresentados - com tudo de incerto e contingente que possa configurar essa dinâmica. Logo, estratégias de classificação, arregimentação, organização e condução dos públicos representariam tentativas de gerir algo que, por princípio, não se deixa administrar por expedientes alheios aos desejos e às necessidades de cada um - sendo que intuí-las ou sabê-las compete a cada um de nós, e não a um terceiro supostamente cônscio daquilo que nos falta, antes de nós mesmos e à nossa revelia.

Em $A$ invenção do cotidiano, o historiador Michel de Certeau nos fornece importantes pistas para a investigação das formas de resistência e reação dos públicos frente aos papéis que lhes são frequentemente reservados pela engrenagem institucional. O historiador afirma que as ocasiões mais diretivas e alienantes representam, irônica e inversamente, oportunidades de manobra para aqueles que estariam sob o jugo de forças e discursos alheios. Justamente aí seriam praticadas, de forma insidiosa e desobediente, as táticas e astúcias dos mais fracos (em termos de capital simbólico, por exemplo), mediante gestos oposicionais, desvios semânticos e profanações comportamentais (CERTEAU, 1994).

Identificados aqui como seus praticantes, os contrapúblicos não cessam de reagir com afrontas às ideologias dominantes e seus modos de exercer o poder. Esses segmentos do público, segundo o crítico literário Michael Warner, orientam-se justamente pela "ética do estranhamento", produzindo rasgos nos discursos instituídos (WARNER, 2008, p. 79). Buscando tomar de volta para si o poder de decisão sobre suas escolhas, interesses e formas de conduta, o contrapúblico pode ser identificado como "um grupo dominado [que] aspira a se recriar na condição de público, e ao fazê-lo encontra-se em conflito não só com o grupo social dominante, mas também com as normas que constituem a cultura dominante [...]" (WARNER, 2008, p. 78).

Podemos refletir de maneira contextualizada sobre tal conflito a partir do exemplo da própria Bienal. Quem nos auxilia, nesse sentido, é Pablo Lafuente, um dos integrantes da equipe curatorial da $31^{\mathrm{a}}$ Bienal de São Paulo (2014) ${ }^{8}$. Em seu texto "Arte, educação, classe", o curador relativiza o valor universal da produção artística ao dizer que "a arte contemporânea não pertence à grande parte do público que visita a Bienal, porque é pro-

8 A equipe era formada por: Charles Esche, Galit Eilat, Nuria Enguita Mayo, Pablo Lafuente, Oren Sagiv, Luiza Proença e Benjamin Seroussi. 
duzida por outra classe social que define o que pode ser considerado dentro dessa categoria”. Lafuente está se referindo, principalmente, ao público massivo de estudantes da rede pública de ensino, cujos alunos são "literalmente transportados [à Bienal], com ônibus do Estado e da Prefeitura - para que tacitamente reconheçam essa cultura como uma cultura válida para eles, uma cultura que pode lhes ajudar num processo de emancipação” (LAFUENTE, 2014, p. 275).

Entretanto, esse mesmo lugar que veicula e torna acessíveis exemplares de uma "linguagem [que] se apresenta como uma necessidade ou um beneficio" pode ser pensado, segundo Lafuente, "como um museu de si mesmo (museu sem coleção, mas museu como construção de uma identidade cultural) em que o si mesmo é uma classe alta ou média-alta”. Esse "museu de si mesmo" funciona como um dispositivo de difusão de uma produção cultural a que os estudantes da rede pública geralmente não têm acesso. A instituição trabalha com diferentes estratégias, sobretudo através do seu programa educativo, para "facilitar uma experiência de um produto cultural que não pertence àqueles que o vão experimentar" (LAFUENTE, 2014, p. 275).

O conflito advém, entre outros, do fato de que esse mesmo lugar, enquanto instância de legitimação e extroversão pública das práticas artísticas contemporâneas, se mantém refratário à "cultura que essas classes baixas consideram própria, a cultura que elas produzem”. Essa cultura simplesmente "não é reconhecida como cultura aceitável no contexto da arte contemporânea”, a não ser quando apropriada e reprocessada por agentes reconhecidos pelo circuito artístico. Ali, "o museu do outro não existe”, tendo em vista que a sua cultura "não é útil” sequer "para servir de contraste que ajude a definir o que a cultura contemporânea "propriamente' é” (LAFUENTE, 2014, p. 275).

Ainda que a produção artística contemporânea em geral não opere pela afirmação do "valor da arte em si mesma" - como no caso dos modernos -, e sim pela lógica do uso do objeto ou proposição artística como instrumento de intervenção cultural num dado contexto, o modo segundo o qual ela é exibida e articulada, segundo Lafuente, "libera essa ou aquela obra de arte como possível instrumento para usos além dos definidos em sua origem”. Porém, e é o curador quem o diz, a articulação que tais obras "recebem nas instituições de arte contemporânea e na Bienal mesma não escapa, em linhas gerais, de uma estrutura na qual o controle dos mecanismos e discursos continua nas mãos de uma classe específica” (LAFUENTE, 2014, p. 275).

Nesse arranjo que perpetua relações de poder, “o conflito não tem lugar”. Justamente nesse lugar de assimetrias, de desprezo pela cultura do outro e, portanto, repleto de tensões, o conflito é sistematicamente apaziguado ou desaparecido. Não que ele não aconteça, muito pelo contrário. Ele ocorre a todo tempo nas situações de encontro: "um encontro que pode ser violento, alienador, quando a cultura de um é apresentada ao outro como uma cultura que precisa ser aceitada, adotada, celebrada". Para a instituição, trata-se de exibir "uma cultura de classe, interna, articulada 'sem conflitos", com o objetivo de comunicar "essa cultura a 
outra, em um processo de transmissão que também tenta evitar conflitos". Isso ocorre assim porque, ao vir à tona, o conflito teria o potencial de colocar "em risco o mecanismo de autorreprodução da instituição" no que diz respeito à opinião pública, às suas fontes de financiamento e aos seus frequentadores e entusiastas habituais. Ao adquirir desdobramentos e ganhar repercussão, o conflito poderia "abrir as portas a um questionamento dos processos que definem a instituição como construtora e disseminadora de cultura para o conjunto da sociedade" (LAFUENTE, 2014, p. 275).

Sendo assim, como podemos produzir fissuras através das quais os conflitos protagonizados pelos públicos em relação às instituições artísticas e suas formas trabalhar possam ganhar visibilidade e, desse modo, provocar certos problemas a serem reconhecidos e enfrentados? O que muda aqui, entre outras coisas, é a direção das enunciações. Deslocamo-nos da regra que estipula o endereçamento instituição-público para assumir o seu inverso: público-instituição. Essa nos parece uma forma necessária de se conceber e fazer mediação, amplificando as questões e antagonismos do público, publicizando-os e direcionando-os de volta para a instituição artística.

\subsection{DEMOCRATIZAÇÃO CULTURAL COMO BLINDAGEM INSTITUCIONAL?}

Conforme sugerido, a "instituição como construtora e disseminadora de cultura" vem se mantendo surda e indiferente aos conflitos e aos diferentes modos de antagonismo manifestos pelos públicos. Expressas sob a forma de composiçôes táticas improvisadas, de acordo com o pensamento de Certeau, tais oposições se dão na duração do tempo - no tempo de visitação às exposições, mas também antes e depois dela - e, portanto, não contam com suportes fisicos e a prerrogativa espacial de disseminação de enunciados (artísticos ou não), esses, sim, privilégios da instituição e das práticas especializadas que lhe dão corpo.

Parece-nos que tal surdez estaria ligada a uma espécie de zona de proteção forjada em torno do "inquestionável" papel social (autoarrogado como) benéfico exercido pela instituição em sua missão de distribuir os exemplares da cultura reconhecida como legítima e, assim, garantir a difusão para muitos daquilo que é produzido por poucos, conforme o lema da democratização cultural.

Abriremos agora um parêntese para nos situarmos acerca da natureza e do histórico das políticas de democratização cultural. Como ponto de partida, podemos usar uma chave apresentada pelo pesquisador Newton Cunha no verbete "ação cultural” do Dicionário Sesc: a linguagem da cultura. Aí o autor identifica a "democratização cultural" como um slogan aglutinador das diferentes frentes de intervenção da ação cultural enquanto conjunto de saberes e práticas. Ele nos informa que essa ação buscaria criar alternativas aos "valores conformistas, irracionais [sic] ou de puro entretenimen to que podem ser encontrados, com certa facilidade e apelo, na cultura de massa”. Em outras palavras, Cunha está se referindo ao oferecimento 
de oportunidades que têm por objetivo "integrar indivíduos e grupos de diferentes idades e estratos sociais ao universo artístico-cultural”. Tais oportunidades, segundo o autor, se apresentariam como situações marcadamente distintas "das vivências e do senso comum cotidianos", que estariam povoados por "produtos industriais onipresentes e homogêneos, poderosamente disseminados pelos meios de comunicação”. Ao contrário desses meios e dos produtos por eles veiculados, as situações propiciadas pela ação cultural, desenvolvidas em contextos não escolares baseados nos princípios da educação informal, não formal e permanente, conduziriam "ao enriquecimento intelectual, cognitivo, sensitivo (estético), associativo, social ou mesmo corporal” (CUNHA, 2003, p. 5).

Um aspecto que podemos deduzir da "democratização cultural" e dos meios da ação cultural utilizados para a sua efetivação é que o universo de referências da parcela da população alijada da dinâmica de produção e consumo dos bens culturais reconhecidos como tais é, mais do que frágil, deletério. Nos termos aludidos por Cunha, esse universo é composto por produtos "homogêneos", "de puro entretenimento" e "conformistas", quando não "irracionais”. Desse modo, aqueles que alimentam seus espíritos com o que lhes oferece os meios de massa precisariam ser "salvos" por agentes culturalmente bem formados e bem-intencionados, os quais estariam aptos a introduzir os não iniciados, os aficionados na porcaria toda da "cultura de massa", num patamar superior de bens simbólicos, esses, sim, capazes de enriquecer seus espíritos. Essa equação, porém, faz de algo complexo uma bandeira simplista.

Mas sigamos, concentrando-nos na faceta da ação cultural que diz respeito à promoção do acesso aos bens culturais e buscando traçar um percurso histórico básico, para efeito de localização e cotejo com nosso objeto de investigação. Cunha nos deixa a par de que a expressão "ação cultural" tem sido empregada no contexto brasileiro desde os anos 1970, frequentemente "como sinônimo de animação cultural" (CUNHA, 2003, p. 4). Isso não significa que muitos de seus expedientes já não viessem sendo praticados anteriormente por aqui, como atesta o caso da criação da Bienal e sua preocupação correlata com o incremento e a atualização dos repertórios artísticos dos públicos locais.

Ainda segundo Cunha, as iniciativas da ação cultural podem ser viabilizadas pela atuação de diferentes organizações, incluindo "entidades civis, públicas, privadas ou comunitárias”, cujo ponto em comum tem a ver com a promoção do "acesso da população ou de clientelas específicas aos bens culturais" (CUNHA, 2003, p. 5). No que se refere ao compromisso do Estado com a garantia dos direitos culturais, a França é pioneira ao criar o seu Ministério da Cultura em 1959. Como nos conta Teixeira Coelho, André Malraux, o primeiro a assumir o cargo de ministro, "entendia ser dever do Estado colocar as mais altas criações do espírito humano ao alcance de todos" (COELHO, 2012, p. 11-12).

Quanto às prioridades que embasaram o trabalho do Ministério da Cultura da França em seus primeiros anos de vigência, seu diretor-geral de Artes e Letras, Gaëtan Picon (no cargo de 1959 a 1966), nos fala sobre algumas ênfases da "intervenção do Estado no campo da cultura contemporânea”. Em 
uma conferência de 19 de janeiro de 1960, ano seguinte ao da implantação do Ministério, ele sublinha o viés principal das políticas do órgão: a "difusão cultural”. Dentre as medidas adotadas para a efetivação de tal difusão, destaca-se "a criação de casas de cultura", que representam "a resposta a esse reconhecimento de um estilo contemporâneo [da produção artística nas diversas linguagens] e à vontade de comunicá-lo a todos aqueles que são dignos disso" (PICON, 2012, p. 51-52). Imagina-se que Picon esteja se referindo ao cidadão francês em geral, embora coubesse a pergunta sobre quem seriam os "indignos" dessa comunicação e por que o seriam. Mas é quando ele expõe as convicções compartilhadas pelos agentes do Estado que se evidenciam mais precisamente os propósitos que animam os programas oficiais:

[...] o que é uma beleza que não existe para todos? O que é uma verdade que não existe para todos? O fato de que a cultura só existe para alguns é um escândalo que tem de cessar e que a democracia dedica-se a fazer cessar desde que ela existe. [...] Em suma, nosso dever é acabar com a alienação do indivíduo em relação à cultura do presente e do passado. Transformar em um bem comum um privilégio é o objetivo das casas de cultura; é o objetivo da grande exposição das reservas do Louvre que será vista em maio de 1960; é o objetivo das grandes manifestações teatrais de massa que serão desenvolvidas a partir desse ano. É o objetivo do programa de publicação que está sendo estudado pela Caixa Nacional das Letras e que irá permitir, fora de qualquer subordinação comercial, a reconstituição do patrimônio literário francês. (PICON, 2012, p. 53.)

Tais princípios, com toda a carga unilateral e hierarquizante que os caracteriza, ganham novos matizes conforme o debate sobre a ação cultural e as políticas públicas se adensa, perpassado por visões críticas acerca da centralidade da ideia de difusão dos bens culturais consagrados ou legitimados por circuitos e agentes hegemônicos. Essa variedade de pontos de vista é sistematizada pelo trio Ortellado, Lima e Souza no artigo "O que são as políticas culturais? Uma revisão crítica das modalidades de atuação do Estado no campo da cultura".

De acordo com os autores, o primeiro fórum internacional em torno dessas discussões se dá nas conferências da Unesco ocorridas nos anos 1970. Ali, vão sendo aos poucos discernidas duas vertentes de ação e política culturais claramente distintas: 1) aquelas ligadas às iniciativas de "democratização da cultura" e 2) aquelas atreladas à noção de "democracia cultural”. A primeira refere-se às iniciativas voltadas exclusivamente à ampliação do "acesso às atividades e aos produtos da cultura da elite, com o objetivo e democratizá-lo" (grifo dos autores), que vêm sendo tratadas em bases críticas neste capítulo. A segunda vertente seria discutida em bases mais teóricas do que concretas, dado que à época das conferências existia apenas no campo das ideias e intenções, como ressalta o trio de 
pesquisadores. Ela parte de “uma concepção 'socioantropológica' de cultura”, a partir da qual se buscaria "valorizar e apoiar também as práticas culturais populares (em oposição apenas as da alta cultura e as da cultura de massa promovida pelos meios de comunicação)" (ORTELLADO; LIMA; SOUZA, 2013, p. 2).

Ao fazer essa "distinção conceitual”, a literatura latino-americana dos anos 1980 traz consigo uma reconhecida maturidade, conforme aponta o trio de pesquisadores. O antropólogo Néstor García Canclini é um dos principais representantes dessa geração. Seus escritos sugerem que o modelo de distribuição e popularização da "alta cultura" provocou críticas por refletir uma "concepção elitista do patrimônio simbólico e uma espécie de imposição paternalista do consumo cultural”, de acordo com a leitura dos pesquisadores. Em consequência a críticas dessa natureza concebe-se outra perspectiva: a da "democracia participativa", cujo intuito repousa no incentivo ao "desenvolvimento de todas as culturas, considerando-se os diversos segmentos sociais" (ORTELLADO; LIMA; SOUZA, 2013, p. 3). A base desse outro paradigma é exposta por Canclini: "Como não há uma só cultura legítima, a política cultural não deve dedicar-se a difundir só a hegemônica, mas a promover o desenvolvimento de todas as que sejam representativas dos grupos que compõem uma sociedade" (CANCLINI apud ORTELLADO; LIMA; SOUZA, 2013, p. 3).

Retomando o emblema da democratização cultural pelo viés crítico, o sociólogo Ezequiel Ander-Egg reitera que sua finalidade condiz com a ampliação do acesso aos bens culturais, como já vimos, e destaca o papel central desempenhado por instituições e equipamentos culturais para a sua viabilização. Nesse sentido, ele identifica nas práticas de mediação cultural aí exercidas a predominância dos expedientes que visam garantir o acesso e o consumo de tais bens (ORTELLADO; LIMA; SOUZA, 2013, p. 3).

Esse é um aspecto que nos cobra ponderação. Aqui fechamos o parêntese sobre o histórico do conceito de democratização cultural, para tornar a pensar em uma de suas ancoragens, ou seja, a das práticas da mediação cultural nas instituições artísticas. Na medida em que o trabalho de mediação desenvolvido nessas instituições limita-se a assumir a função de garantir aos públicos não iniciados o acesso aos bens culturais ali exibidos, ele teria muitas de suas outras potencialidades abafadas, senão capturadas pela engrenagem institucional. Ao tomar para si a tarefa principal de incluir novos públicos, a mediação torna-se apenas cúmplice de um programa institucional em nível macro, aderindo e responsabilizando-se por uma política há muito colocada sob suspeita, como vimos. Ao proceder assim, ela tira de foco os conflitos que advêm do contato desses públicos com as ofertas institucionais, pois os indivíduos que integram a vaga e abstrata entidade dos "públicos não iniciados" são tomados pura e simplesmente como sujeitos carentes daquilo que justamente a instituição e a mediação (sua porta voz) têm a lhes oferecer. Honorato define essa fórmula com precisão:

É como se essa mediação soubesse de antemão o que falta ao público, de modo que seu trabalho é providenciar o 
que lhe falta, aquilo de que ela dispõe. Para isso, no entanto, ela precisa confirmar a existência do público como privado de arte, de consciência, de experiência etc. Eis o seu paradoxo: ela vive, por assim dizer, do déficit que imputa ao público. (HONORATO, 2011, p. 345, grifos meus.)

Se esse é o seu foco de atenção, a mediação acaba participando dos esforços de blindagem da instituição artística, que se mantém surda aos antagonismos dos públicos na medida em que segue enraizada no discurso segundo o qual beneficios seriam proporcionados ao outro, enquanto não iniciado, pela transformação do privilégio de uma elite em um bem comum, de todos - e aqui estamos cruzando as ideias notadamente contrárias de Picon e Lafuente.

\subsection{MEDIAÇÃO EXTRAINSTITUCIONAL COMO FORMA DE ESTAR DENTRO E FORA DA INSTITUIÇÃO ARTÍSTICA}

Já está claro a esta altura que a instituição artística e aqui estamos falando não apenas das bienais, mas também dos museus e dos centros de exposição - arroga para si a função de informar os públicos acerca dos objetos de arte merecedores de reconhecimento, valoração, conservação, pesquisa e exibição. Esses objetos são afirmados como representantes materiais de experiências e saberes dignos de serem fruídos e apropriados pelos públicos, iniciados ou não. Como sugere Greenhill, o museu (mas não só ele) oferece o conhecimento como commodity, acreditando na capacidade que esses bens teriam de transformar a percepção e o conhecimento dos públicos, o que reforça a perspectiva unilateral da ação institucional e reitera o que temos visto até aqui sobre a democratização cultural (HOOPER-GREENHILL, 1992, p. 2). É essa perspectiva unilateral da democratização cultural e as premissas que a embasam que tomamos como objeto de nossa crítica.

Andreas Huyssen, por sua vez, nos alerta ser insuficiente o tipo de crítica institucional ocupada exclusivamente do trabalho de desvelar e problematizar os mecanismos que fazem dos museus, bienais e demais espaços de exposição o lugar da "ordem simbólica", a partir de onde são definidos e difundidos os bens culturais. Embora reconheça a pertinência e a necessidade dessa crítica, o filósofo faz uma provocação no sentido de complexificá-la ao dizer que:

A crítica meramente institucional alinhada com os aparatos ideológicos de conhecimento e poder, que operam de cima para baixo, precisa ser complementada por uma perspectiva às avessas, que investigue o desejo do espectador e as inscrições do sujeito, a resposta do público, o interesse dos grupos e a segmentação das esferas públicas sobrepostas, dirigidas a uma grande variedade de museus e exposições. (HUYSSEN, 1994, p. 38, grifos meus.) 
Ainda que Huyssen, como filósofo, não enverede por essa senda, que ele mesmo identifica como "sociológica", ela propicia a sondagem e repercute o que o autor formula como "uma sobra de significados [nos contextos expositivos] que excedem o conjunto das fronteiras ideológicas, abrindo assim um espaço para a reflexão e a memória contra-hegemônica” (HUYSSEN, 1994, p. 37).

A (auto)crítica constante e a atenção às respostas dos públicos apresentam-se como compromissos inescapáveis dos agentes envolvidos com o mecanismo institucional, sobretudo para aqueles que não compactuam e, portanto, dedicam-se a problematizar os preceitos da democratização cultural e a consequente autorreprodução (blindada) das instituições. Como exemplo, Greenhill nos apresenta um panorama relativo aos museus, no final dos anos 1980, cuja balança pende para o lado contrário:

\begin{abstract}
Ainda recentemente, trabalhadores de museus permaneciam desatentos acerca de suas práticas e acríticos quanto aos processos com os quais estão empenhados em seu dia a dia. Dentro das práticas do museu, o criticismo ou a reflexão sobre o trabalho cotidiano têm sido realmente muito fracos. A reflexão crítica, de fato, sofre resistência por parte de alguns curadores que se veem como pessoas práticas que não têm tempo para gastar com essa atividade improdutiva. A maior parte dos trabalhadores dos museus, ainda muito recentemente, procedia sem objetivos claros, sem entender ou estar de acordo com as políticas institucionais [...]. (HOOPER-GREENHILL, 1992, p. 3.)
\end{abstract}

Seguindo as ponderações de Greenhill, essa "desatenção" dos trabalhadores de museus se mostra tanto mais delicada quanto mais as relações de poder aí em ação pautam e orientam as discussões relativas às coleções e exibições, inclusive as decisões sobre a seleção e aquisição de obras, a organização espacial e discursiva das mostras e a delimitação temporal das mesmas. Está em jogo uma posição de poder que autoriza um seleto grupo a determinar o que poderá ser visto, como poderá ser visto e quando será visto. Resta aos públicos que visitam esses locais contemplar os conjuntos de obras organizados em displays calculadamente preenchidos pelas peças, posicionadas de maneira restritiva e protegidas de modo a reforçar sua condição de objetos imaculados. Isso para dizer que, ao fim e ao cabo, "as definições dos significados das coleções são restritas à esfera privada dos agentes do museu”, inclusive nos casos de coleções públicas (HOOPER-GREENHILL, 1992, p. 7).

A crítica a esse modelo de ação passa necessariamente pela evocação da origem colonialista do discurso institucional dos museus. No ensaio "Do eurocentrismo ao policentrismo", os pesquisadores Ella Shohat e Robert Stam fazem uso, pelo viés dos estudos culturais, do sentido atribuído por Michel Foucault à noção de discurso. Segundo a interpretação da dupla, o discurso corresponderia a "um arquivo de imagens e afirmações transindividuais e multiinstitucionais que formam uma lingua- 
gem comum e que permitem representar o conhecimento a respeito de um determinado tema". Nesse sentido, os discursos reivindicam para si o estatuto de "regimes da verdade", privilegiando certas vozes, estéticas e representações em detrimento de outras (SHOHAT; STAM, 2006, p. 44). O museu se valeria, portanto, de um poderoso aparato linguístico e ideológico para compor mapeamentos culturais pretensamente neutros e universais, quando em realidade eles são delineados por indivíduos e grupos hegemônicos em termos sociais, políticos, econômicos, culturais e intelectuais, com pontos de vista e interesses específicos.

Em relação à arte contemporânea, com sua permanente desconstrução dos esquemas mentais que definem as fronteiras da arte, é elucidativo observarmos como muitas vezes os acordos epistemológicos negociados - não raro em circuitos semiprivados - entre os agentes iniciados (artistas, críticos, curadores, historiadores, mediadores, público habitué etc.) em torno da afirmação e reconhecimento dessa ou daquela prática como forma atestada de arte são confrontados pelo público leigo; e o quanto essa reação antagônica revela dos mecanismos de legitimação da arte e de seus exclusivismos.

A socióloga Natalie Heinich, no artigo "A arte contemporânea exposta às rejeições: contribuição a uma sociologia dos valores", dirá que muito dos "mal-entendidos" (lembremos aqui das afirmações de Degand) e "desacordos" entre os leigos e os iniciados no tocante ao estatuto de arte atribuído a certas manifestações deve-se, sobretudo, ao fato de que as referências e valores mobilizados por uns e outros para se reportar e compreender determinada proposição artística diferem radicalmente.

[Se] para os não iniciados o referente espontaneamente solicitado para perceber um objeto sem as características canônicas de uma obra de arte tende a ser o mundo vivido, ao qual se aplicam os valores do mundo ordinário; para os iniciados [...] o único referente realmente pertinente é a história da arte - e uma história da arte muito especializada, que ultrapassa largamente a cultura escolar. (HEINICH, 2011, p. 88-89.)

Logo, podemos dizer que o circuito onde se desdobram a produção, a difusão, a mediação e a fruição da arte contemporânea corresponde a um campo altamente demarcado pelas prerrogativas do saber especializado, que funciona como um bem que autoriza a participação em seus ritos e rumos. Quanto ao espectador não iniciado, ele é desafiado a ler e reconhecer a importância de fraseados artísticos e curatoriais cujo vocabulário e regime de valores são distintos daqueles de que dispõe e sob os quais se relaciona com as coisas da vida cotidiana (e também com a arte). Esse desajuste estrutural pode ser encarado de duas maneiras.

A primeira, mais alinhada com a mediação orientada pelos princípios da democratização cultural, seria tomar o desajuste como ignorância exclusiva do leigo, a ser sanada mediante diferentes ofertas pedagógico-insti- 
tucionais. Essas ofertas supostamente possibilitariam ao público não iniciado se aproximar pouco a pouco do patamar de conhecimento requerido pelo outro (e mais nobre) vocabulário e seu regime de valores. No meio desse longo e incerto caminho, aquilo que o leigo tem a dizer representaria apenas os primeiros ensaios de um inexperiente aprendiz, que sempre terá muito o que aprender antes de emitir juízos realmente dignos de atenção.

Já a segunda articula-se à mediação crítica e ao seu compromisso com as demandas e consequências de uma democracia cultural. Assim, o referido desajuste seria enfrentado pela via do "diferendo", conceito emprestado por Heinich do filósofo Jean-François Lyotard. Nele, a irredutibilidade entre diferentes repertórios e expectativas, em lugar da submissão de um pelo outro, é sustentada de forma não hierárquica. Aí, os dissensos seriam constitutivos das aproximações entre sistemas de compreensão divergentes em sua base. Em outros termos, o diferendo "joga os homens [de ambas as partes] em universos [reciprocamente] desconhecidos de frases". Como os registros a partir dos quais esses personagens argumentam são heterogêneos, tanto os leigos como os iniciados em arte contemporânea "se veem no mais das vezes em situação de diferendo". Ambos se encontram numa encruzilhada cujas vias comunicativas não coincidem - pensemos, a título ilustrativo, no cruzamento de uma estrada de ferro com uma estrada de rodagem -, "de modo que os argumentos de uns careçam, no contexto em questão, de pertinência aos olhos dos outros”. Se o que está em jogo aqui não é o enquadramento de um sistema de compreensão pelo outro, mas o que surge do confronto entre eles, devemos estar dispostos a aceitar e trabalhar a partir do fato de que leigos e especialistas teriam "bem pouca chance não só de chegar a um acordo, como também de se entender” (HEINICH, 2011, p. 88).

Esse desacordo representa uma plataforma de operação para o tipo de mediação que se desloca dos expedientes de acesso e facilitação dos enunciados artísticos, direcionados ao público não iniciado. À espreita e interessada pelo que surge de tal desajuste, a mediação pode desempenhar outro papel. Um papel que produza inversões nas lógicas de endereçamento. Se a regra geral pressupõe que iniciados informam leigos, quem sabe pudéssemos fomentar situações em que leigos informam iniciados. Até porque, como alerta Heinich, "se os leigos têm clara dificuldade para compreender a arte contemporânea, os iniciados não estão mais bem equipados para 'compreender' a incompreensão dos leigos” (HEINICH, 2011, p. 88).

Caberia, portanto, encetar nos contextos expositivos uma prática crítica, pelo viés da mediação, que se proponha a conceber dispositivos de escuta e amplificação das táticas e ruídos produzidos pelos públicos e contrapúblicos em meio à orquestração institucional. Entendemos que desse entroncamento - aquilo que a instituição propaga versus os usos que disso fazem os públicos - poderiam advir reações imprevistas, condutas desviantes e saberes outros, capazes de fornecer artefatos simbólicos para um programa de desconstrução, ou no mínimo de relativização, do discurso institucional hegemônico, pretensamente benéfico para o outro e imbuído da autorreprodução da engrenagem que ele faz funcionar. Daí a 
exigência de uma prática que oscile entre o trabalho com a instituição e a atuação com os públicos, deslocada dos objetivos difusionistas que caracterizam a democratização cultural.

Cunhado por Honorato, o conceito de mediação extrainstitucional corresponde a uma forma de atuação que desafia o mediador a estar, ao mesmo tempo, dentro e fora da instituição e de seus compromissos - ou de não estar nem dentro e nem fora dela, mas numa zona de oscilação -, buscando driblar seus enredamentos e criando situações capazes de problematizar o discurso institucional e a lógica da democratização cultural (HONORATO, 2015a, p. 241-243). Nesse sentido, o mediador se colocaria à espreita tanto das normativas da ação institucional quanto das reações e antagonismos dos públicos e contrapúblicos às ofertas culturais, buscando trazer à tona o que antropólogo Jesús Martín-Barbero denomina "imbricações conflitivas", comumente desaparecidas pelo aparato institucional (MARTÍN-BARBERO apud HONORATO, 2013a, p. 7).

Para melhor enunciar suas intenções e possíveis desdobramentos, devemos nos aprofundar um pouco mais na concepção do extrainstitucional e na sua conjugação com a mediação cultural. Conforme comenta Honorato, embora a mediação institucional venha, pelo menos desde o final dos anos 1990, adotando em suas abordagens a prática do diálogo em lugar da lógica da instrução, nota-se a persistência de "uma unidirecionalidade não necessariamente dialógica”, pois as conversações aí entabuladas teriam como baliza ainda os preceitos da democratização cultural. Ou seja, elas se desenvolvem com base nos objetivos da difusão para muitos daquilo que é produzido por poucos, mantendo inquestionado e intocado o papel da instituição enquanto polo propiciador daquilo que supostamente falta a grande parcela da população: o contato e a familiaridade com o que se produz no campo da arte (HONORATO, 2015a, p. 241).

Já a mediação crítica, deslocando-se dos preceitos da democratização cultural, procuraria fomentar diálogos "com e contra os discursos do museu”, mediante "conversações culturais complexas" que envolvessem os diferentes (e, por vezes, antagônicos) repertórios e valores. Nesse ponto, Honorato está citando o mediador Javier Rodrigo Montero, do coletivo pedagógico Transductores. Em seguida, o autor menciona o sociólogo Jean-Marie Lafortune para sugerir a pertinência de uma médiaction em lugar da médiation corrente, tendo em vista a busca da primeira por "alterar as regras do jogo social”. Como se vê, o que está em pauta é a agenda da democracia cultural, a saber, "uma articulação entre muitos do que também é produzido por muitos” (HONORATO, 2015a, p. 241, grifos meus).

O que tende a vir à tona a partir dessas abordagens mediativas deslocadas das correntes predominantes são discursividades alternativas e condutas desviantes, eventualmente contrapúblicas, que fazem "transbordar um excesso de significado, propriamente político, que as definições institucionais da mediação não podem comportar, ou pior, que elas talvez buscassem deliberadamente eludir”. Como já dito, as instituições artísticas, no mais das vezes, procuram manter-se blindadas em relação àquilo que poderia colocar o seu modus operandi em questão, ou mesmo em xeque. Assim, caberia a pergunta: "que disponibilidade haveria, por parte 
das instituições, em favorecer mediações que buscam alterar as regras do jogo no qual as próprias instituições se sustentam?" (HONORATO, 2015a, p. 241). Qualquer que seja a resposta a essa pergunta, ela deve necessariamente considerar que a mediação institucional comprometida com os expedientes da democratização cultural e, consequentemente, com a autorreprodução da instituição não está apta a (e provavelmente nem se interesse por) produzir essa outra cartografia discursiva. Daí a necessidade de se conceber mediações extrainstitucionais.

Algo que parece óbvio, mas que nos vai cobrando sua urgente desnaturalização, é que o trabalho de mediação em artes visuais "tem existido, invariavelmente, como iniciativa das [próprias] instituições”. Nessa relação siamesa, instituição e mediação acabam por produzir e perpetuar, segundo noção emprestada por Honorato da antropóloga Mary Douglas, "uma delimitação cognitiva" (grifo do autor), que possibilitaria à instituição, amparada pela mediação como sua principal interface de interação com os públicos, ser o que ela é e da forma que ela é, com todo o seu sistema próprio de valores, conhecimentos, códigos e formas de conduzir processos. Isso corresponde a seguir afirmando-se publicamente como "figura estável, idêntica a si mesma” (HONORATO, 2015a, p. 242).

Entretanto, como constata Honorato, devido aos seus esforços de autorreprodução permanente a instituição "desperdiça ou ignora inúmeras oportunidades de aprendizagem" e, diríamos, de transformação pelo outro. Auxiliada por uma mediação ocupada (distraída?) com a difusão de suas commodities, ela se protege daquilo que os públicos teriam a lhe endereçar sob a forma de desacordos, desentendimentos, rejeições, antagonismos, questionamentos e, em última análise, dissensos (HONORATO, 2015a, p. 242).

Daí que iniciativas em mediação frustradoras desse padrão fisiológico se coloquem como inadiáveis. Entendemos ser esse um dos aspectos centrais da mediação extrainstitucional, que trafega por uma via que, em realidade, precisa ser a todo tempo produzida, visto que não conta com o pavimento fornecido pela instituição, com todas as exigências nele implicadas. Honorato formula esse outro modo de operar da mediação em trânsito nos seguintes termos:

[Sua] trajetória de atuação terá estabelecido uma relação peculiar com as próprias instituições. Em relação às instituições, seu posicionamento é decididamente ambíguo, não está fora, nem dentro delas, entende não ser possível ignorá-las, mas não trabalha necessariamente para sua reprodução; por estar na instituição, não exatamente lhe é contrária, mas não confia simplesmente na organização espontânea das demandas externas que poderiam subvertê-la; por estar fora dela, não opera segundo a "lógica conjuntista" da instituição, mas à espreita do que, na ligação de seu posicionamento a um não pensamento, a uma heterogeneidade, fosse capaz de desconcertá-la, de introduzir-lhe "elementos não conjuntizáveis”. (HONORATO, 2015a, p. 242.) 
Portanto, podemos dizer que seu jeito de trafegar desdobra-se em formas específicas e imprevistas de atravessamento das instituições, durante o qual procura produzir entradas e saídas ainda não imaginadas, que possam inclusive surpreender a instituição no sentido de "pegá-la" desprevenida. Desse modo, pratica itinerários ziguezagueantes, "de fora para dentro e vice-versa". A mediação extrainstitucional almeja cavar espaços para o dissenso, compreendido por Honorato, através da lente oferecida pelo filósofo Jacques Rancière, como "um conflito, não entre diferentes ideias ou sentimentos (pessoais), mas entre diferentes regimes (impessoais) de sensorialidade”. Parece-nos que, dessa forma, a instituição poderia ser modificada a ponto de se tornar "um espaço em que, para além dos públicos (educação para todos), também os educadores, artistas, curadores e instituições são aprendizes (educação por todos)"(HONORATO, 2015a, p. 242-243).

Ainda que válida apenas parcialmente, uma imagem útil para pensarmos as possíveis investidas da mediação extrainstitucional seria a do ombudsman no jornalismo. A diferença é que, no jornalismo, esse papel é exercido com o respaldo da empresa de mídia contratante no que tange à estabilidade empregatícia e financeira do profissional, que deve assumir a posição de quem critica o veículo a partir das questões pautadas pelo público e por outros profissionais da área. Ali, ele ocupa um cargo especialmente dedicado à função de receber reclamações, críticas e sugestões daqueles que utilizam os serviços oferecidos pelo veículo. Essas manifestações devem ser por ele trabalhadas e distribuídas às respectivas seções, redações, gerências e afins, a depender do organograma da empresa. Ou seja, o ombudsman é contratado especificamente para garantir que o público possa endereçar suas divergências e protestos àqueles que produzem e disseminam a informação. A ele também cabe produzir, periodicamente, uma espécie de massa crítica acerca do veículo, sempre com base nas reações dos usuários. Faz parte dessa produção crítica a proposição de ajustes e mudanças de procedimento, cabendo ao veículo acatá-las ou não. Em resumo, o ombudsman faz a mediação crítica entre o público e o veículo, cabendo-lhe também comunicar a esse público a avaliação que ele, na condição de ombudsman, faz ao cotejar as críticas do público com as justificativas ou reparações apresentadas pelo veículo.

Já para o mediador em atividade numa instituição artística, cujo estatuto profissional tem se mantido cronicamente precarizado ao longo das últimas décadas, uma empreitada dessa natureza só poderia ser realizada na chave extrainstitucional, por iniciativa pessoal desse mesmo agente (enquanto pessoa fisica). Esse mediador deverá inclusive assumir os riscos de uma atuação não respaldada pela instituição, como se fosse um tipo de ombudsman por sua própria conta e risco. Inclusive porque é impossível prever o quanto a instituição irá aceitar das suas manobras de produção e endereçamento crítico a partir da interlocução com os públicos - ainda que o mediador também possa exercer em alguma medida esse papel em instituições com as quais não tenha vínculo de trabalho, ressignificando a figura do ombudsman na medida em que a multiplica e a ancora em diferentes contextos. Trata-se de testar iniciativas dispersas de agentes extrainstitucionais dispostos a estar não estando completa- 
mente na instituição, num atravessamento ziguezagueante, formulando sua crítica junto aos públicos mediante a invenção de ferramentas operativas, cujos índices resultantes possam ser publicizados. Logo, os riscos são parte do processo, e não contar com o completo respaldo institucional talvez seja na verdade um trunfo, uma garantia de isenção. Quem sabe pudéssemos fazer da histórica fragilidade da profissão do "mediador de exposições" um motivo a mais para agenciamentos menos compromissados com as demandas institucionais de autorreprodução, e mais afeitos a fomentar debates sobre os papéis da própria instituição em relação ao conjunto da sociedade e à complexidade de suas dinâmicas culturais. Quem sabe o que exista aí seja uma brecha no esquema funcional e discursivo da instituição, haja vista que o mediador, esse agente profissionalmente pouco reconhecido e mal remunerado, é justamente aquele que interage diretamente com os públicos das exposições.

Haveria, ainda, outra figura inspiradora do movimento em zigue-zague que estamos postulando neste capítulo. Ela pode ser observada em uma paródia encenada por Andrea Fraser, artista representativa da vertente que se convencionou chamar de "crítica institucional". Encontramos em sua encenação uma contundente problematização dos discursos e protocolos institucionais e da mediação que muitas vezes lhes serve de porta-voz. Em Museum Highlights: A Gallery Talk, a artista personifica uma eloquente e enfática mediadora de exposições, chamada Jane Castleton. A ação, realizada em 1989, se traduz em uma visita guiada ao acervo do Museu de Arte da Filadélfia, envolvendo visitantes que se reúnem ao redor de Castleton acompanhando-a em seu roteiro através das salas de exposição (e também a outros espaços, como a cafeteria e o bebedouro, por exemplo). O público escuta a extensa bricolagem de sentenças e explicações que ela vocaliza, muitas delas extraídas de documentos e comunicações da própria instituição. Entre as muitas assertivas, a mediadora declara que os objetos de arte são menos representações dirigidas às pessoas do que para a construção delas. Nessa mesma direção, afirma que as obras expostas no museu, bem como os enunciados apresentados por ela enquanto mediadora, seriam determinantes na conformação do espaço, da linguagem e da lógica com que os interesses do observador podem ser articulados e subsumidos aos desígnios do museu. Fraser desvela, assim, parte dos esquemas discursivos e valorativos que alicerçam as missões e políticas institucionais (FRASER, 2005, p. 95-114).

Se a opção de Fraser é pela performance paródica, o exemplo a seguir resulta de um exercício documentário dedicado às enunciações do público, neste caso também conduzido por uma mediadora':

9 Uma série composta por sete Episódios contrapúblicos - incluindo este e também o do caipira que se recusa a entrar na $2^{\text {a }}$ Bienal de São Paulo - foi publicada no contexto da $31^{a}$ Bienal de São Paulo, na revista Urbânia, n. 5 (Educação), editada por Graziela Kunsch e Lilian L'Abbate Kelian. 
Foi durante uma visita mediada à mostra $30 x$ Bienal, com um grupo de pré-adolescentes da rede pública do ensino, que estiquei meus ouvidos de visitante bisbilhoteiro e me pus a escutar, a média distância, a conversa entre os estudantes e a educadora da exposição - uma jovem estagiária segundanista de graduação. $\mathrm{O}$ assunto naquele momento era o trabalho do artista Waltercio Caldas. Um dos garotos, sem pedir licença e desviando totalmente o rumo do papo, lançou a seguinte questão: "A Bienal é de quem? Quem banca essa exposição?”. Pega de surpresa, e buscando se situar diante da pergunta, a educadora procurou traduzir para si e para o restante do grupo a indagação do garoto: "Você quer saber de onde vem o dinheiro que paga toda essa estrutura, e a quem pertence a Fundação Bienal?”. Ao que o garoto respondeu de forma decidida: "Isso, isso mesmo!". Foi quando a voz e os gestos da educadora-estagiária começaram a dar sinais de embaraço. Balbuciando, ela tentou responder: "Então... essa é uma boa pergunta... veja bem, a Bienal é uma instituição... humm... que pertence a... bem, está ligada ao... ou melhor... ah, eu não saberia te dizer ao certo... já os seus recursos vêm... humm... precisaria falar com minha supervisão para saber...” Quando então o garoto atalhou: “Então tá, enquanto eu não souber direito como funciona esse lugar, e por quem ele é bancado, eu me recuso a conversar sobre esse tal pêssego em calda”. (MORAES, 2014, p. 245.)

É curioso notar como a inquietação do garoto, surgida de forma inesperada e "solta”, traz à baila aspectos centrais da Fundação Bienal enquanto organização que possui história, patronos e mecanismos de captação de recursos financeiros (em sua maior parte, públicos). Ou seja, para o estudante não bastaria circular por aquele pavilhão tomando-o simplesmente como um suporte neutro e a-histórico, no qual são exibidas as obras dos artistas. De maneira pontual e incisiva, a sua demanda é por enxergar e entender as diferentes camadas da Bienal enquanto um corpo institucional dotado de espessura e elementos factuais e condicionantes que o caracterizam.

"A Bienal é de quem? Quem banca essa exposição?" A pertinência das suas perguntas é tal que elas tocam em algumas das ambiguidades e contradições dessa instituição e de sua história. Sobre de quem seria a Bienal, Alambert e Canhête dirão não ser possível "responder facilmente à questão de quem é o ‘dono' da mostra”. Isso porque “o ‘dono’ foi Ciccillo (seu 'Presidente Perpétuo'), já foram os críticos, o Museu de Arte Moderna, os curadores, a alta burguesia..." (ALAMBERT; CANHÊTE, 2004, p. 235). Hoje talvez pudéssemos dizer que ela está nas mãos das corporações que financiam suas mostras através dos mecanismos de renúncia fiscal; do mercado de arte, com seu circuito de galerias, colecionadores e instituições; além dos seguidos presidentes-empresários à frente da Fundação, dos 
conselheiros, dos curadores. Nesse terreno loteado, é importante manter sempre à vista a pergunta: que papéis ocupam os diferentes públicos que visitam a mostra?

Já no que se refere à questão de quem banca a Bienal, os pesquisadores nos colocam a par de um levantamento realizado pela historiadora Rosa Artigas, o qual demonstra que "nas três primeiras exposições [1951, 1953 e 1955], Ciccillo dividiu os custos com o governo em partes iguais”. Quando saltamos para a sua quinta edição, em 1959, notamos que "o empresário entrava com um terço [do valor], e o governo bancava o resto”. Já a partir da $6^{\text {a }}$ Bienal, em 1961, "o governo arcaria com 4/5 das despesas". Gradativamente, como se vê, a mostra vai tendo o seu financiamento viabilizado por recursos públicos, até tornar-se definitivamente "um evento público, garantido principalmente pelo governo (federal, estadual e municipal)", embora a sua administração permaneça de caráter privado (ALAMBERT; CANHÊTE, 2004, p. 234, grifo dos autores). Atualmente, conforme será detalhado mais adiante, a quase totalidade de seus recursos provém das leis de incentivo à cultura, com dinheiro público originário da dedução de impostos das empresas patrocinadoras.

\subsection{SURGIMENTO DO MUSEU PÚBLICO}

Para evocar os lastros que historicamente pavimentam as atuais políticas das instituições de arte, seria elucidativo traçarmos um breve retrospecto do período em que coleções privadas, originalmente pertencentes às famílias reais e aos membros da aristocracia, são transformadas em patrimônios públicos pelos Estados-nação, em particular Inglaterra e França. Isso ocorre no final do século XVIII e no início do XIX, no bojo da Revolução Francesa e como resultado direto do Século das Luzes, dando origem aos primeiros museus públicos.

Segundo o historiador da arte Donald Preziosi, o museu representa um dos gêneros de maior influência no que ele chama de "ficção moderna", dividindo espaço com outros importantes aparatos ideológicos: ciência, religião, entretenimento e disciplinas do saber acadêmico, todos eles, junto com o museu, integrando os "métodos de produção e factualização do conhecimento". Isso significa dizer que o museu dá corpo e funcionamento a uma poderosa "tecnologia epistemológica", reunindo objetos mediante arranjos capazes de simular relações geográficas, estágios cronológicos e desenvolvimentos evolutivos das formas, matérias e técnicas (PREZIOZI, 1996, p. 407).

Em The Birth of the Museum, o sociólogo e historiador Tony Bennett faz menção às ramificações da episteme iluminista, correspondentes às recém-demarcadas disciplinas do saber: história, história da arte, geologia, arqueologia, biologia, antropologia, entre outras. Faz parte do projeto iluminista uma intensa busca pela comensuração do mundo, transpondo a experiência humana para uma linguagem entendida como parâmetro universal e comum de referência. Os resultados e desenvolvimentos dessa tecnologia do conhecimento desempenharam um papel central na formação dos cidadãos dos Estados-nação europeus, o que posteriormente também ocor- 
reria, ainda que de modo irregular, nas Américas (BENNETT, 2007).

Em concordância com Bennett, Preziosi pondera ainda que a tecnologia do conhecimento abarca, em combinação a outros vetores, um poderoso "sistema de representações" chamado arte, segundo ele uma "invenção" do Iluminismo. $\mathrm{O}$ autor vai mais longe ao afirmar que a "arte é aquilo que a museologia e a museografia praticam", na medida em que organizam e racionalizam o universo da memória social e seus objetos "dentro de um esquema de coordenação e comensuração" onde a arte proveria a lente de observação de todos os tempos, lugares e populações, ajustando-os a uma moldura supostamente neutra, comum e universal. Em última análise, tratar-se-ia do "esperanto" fornecido pela hegemonia ocidental, segundo Preziozi (PREZIOZI, 1996, p. 410-416).

Haveria, então, um método (europeu) de (re)contar e (re)definir a história a partir do estabelecimento de um arcabouço de padrões, regras e critérios de acordo com os quais todos os tempos, lugares e pessoas seriam (re) enquadrados e submetidos a um "mesmo espaço epistemológico", justamente o espaço da arte. É como se o mundo inteiro, com suas mais distintas manifestações culturais, ritualísticas, religiosas, fosse moldado e filtrado por noções de "tradição artística" e "prática estética". Os materiais e índices mapeados por tais noções seriam então traduzidos por um especializado sistema de representações que os tornariam universalmente legíveis (PREZIOZI, 1996, p. 410-416).

Atualmente, no âmbito da museologia crítica, esse e outros aspectos das práticas museológicas têm sido tema de acirrados debates. A historiadora da arte Carol Duncan, por exemplo, propõe uma revisão do caráter pretensamente objetivo e verificável dos conhecimentos representados e gerados pelos museus, em contraposição ao estatuto "supersticioso" e "obscuro" das crenças e rituais religiosos, como se eles fossem sinais de um passado da humanidade já transposto. Problematizando essa dicotomia forjada pelo Iluminismo, Duncan indica que tal "verdade secular" seria usada para prover uma base universal e racional de conhecimento aos objetivos do Estado de integrar as coletividades ao que ela chama de "corpo cívico". O conhecimento secular, portanto, seria capaz de garantir e difundir a "memória cultural oficial da comunidade" (DUNCAN, 1995, p. 8).

Duncan aponta, ainda, que "controlar um museu significa precisamente controlar a representação de uma comunidade e seus mais altos valores e verdades" (DUNCAN, 1995, p. 8). Ou seja, está em jogo o que podemos identificar como processo de fabricação do legítimo, em que o conhecimento aparece isento de particularismos, crenças e interesses de indivíduos e grupos específicos. "Só que não!”, como poderia ter dito o visitante incógnito de algum museu de prestígio.

\subsection{MUSEU E CONTROLE SOCIAL: PRENÚNCIO DO PODER BRANDO}

Corporificação de um sistema de representações dedicado a situar a comunidade em torno de valores e verdades tidos como insuspeitos, o museu assume desde seus primórdios uma posição-chave no processo civilizatório. Isso se dá mediante "lições 
de civismo”, somadas às operações já descritas e materializadas no que Bennett chama de "complexo expositivo":

Tais lições consistiam em demonstrações de poder não pela via do terror - com as pessoas servindo de receptáculos ao poder - e sim em situações em que as pessoas, concebidas como cidadãos nacionalizados, buscavam situar-se no mesmo lado do poder, sendo ao mesmo tempo seu sujeito e seu beneficiário. [...] Essa era a retórica do poder materializado no complexo expositivo - um poder tornado manifesto não por sua habilidade em infligir dor e sofrimento, mas por sua capacidade de organizar e coordenar uma determinada ordem das coisas e, assim, produzir um lugar para as pessoas de acordo com essa mesma ordem. [...] Desse modo, este poder subjuga pela via da lisonja, situando-se no mesmo lado das pessoas ao proporcionar a elas um lugar dentro de suas operações [...]. Este seria, em outras palavras, um poder que mira um efeito retórico através de suas representações de diversidade, em vez de qualquer efeito disciplinar. (BENNETT, 2007, p. 67.)

Organismos de instrução pública e apaziguamento das tensões sociais, os museus passaram a funcionar como hábeis dispositivos do que, dois séculos depois, nos anos 2000, viria a ser chamado de soft power. Cunhado pelo cientista político Joseph Nye, o termo foi originalmente usado no campo das relações internacionais para designar a habilidade dos Estados em influenciar o comportamento e os interesses das pessoas e de outras nações, por meios culturais e ideológicos, criando situações de atração e cooperação mediadas por estratégias indiretas de convencimento. Vale lembrar, nesse sentido, os esforços do magnata Nelson Rockefeller e da agência governamental norte-americana no Brasil, voltados, entre outros objetivos, à implantação do Museu de Arte Moderna e, por consequência, da Bienal de São Paulo.

Lisonja e sedução são, portanto, características constitutivas desse poder brando, como fica evidente no aviso da Pan-American Exposition, de 1901: "Please remember when you get inside the gates you are part of the show" (BENNETT, 2007, p. 68). É nesse jogo inclusivo de supostos beneficios e mobilidades sociais que o poder atua, sendo o complexo expositivo uma de suas plataformas. Bennett nos esclarece a eficácia do museu como ambiente público controlado, onde ao mesmo tempo que os objetos se oferecem à observação dos visitantes, estes também se tornam objetos de observação mútua:

O complexo expositivo [...] aperfeiçoa um sistema de automonitoramento de olhares, em que as posições do sujeito e do objeto podem ser trocadas, e no qual a multidão comunga e se regula através da interiorização da visão ideal e ordenada de si como que observada de um ponto 
de vista do poder controlador - um local de observação acessível a todos. Isso representava, então, a democratização do olho do poder [...] um sistema de observação dentro do qual a posição central estaria disponível ao público a todo o tempo, um modelo de lição de civismo em que a sociedade regulasse a si mesma por meio da auto-observação. (BENNETT, 2007, p. 69, grifos meus.)

Trata-se, sem dúvida, de um desdobramento/sofisticação dos dispositivos panópticos de poder teorizados por Foucault, como as prisões, as escolas, os hospitais psiquiátricos e as fábricas, na medida em que cada sujeito passa a incorporar, nesse estágio avançado, a vigilância como uma atribuição cívica pessoal, desempenhada em situações públicas nas quais a multidão se torna um espetáculo em si, submetida a uma permanente autoinspeção.

A comparação entre os dispositivos de poder hard e soft nos auxilia a problematizar a hegemonia e a conotação benéfica do discurso institucional no campo sociocultural, pois desvela os objetivos subjacentes a suas promessas lisonjeiras. Enquanto os espaços de confinamento compulsório, como as instituições mencionadas acima, estão vinculados à face hard do poder - sem que haja dúvida ou ambiguidade sobre os seus efeitos nesses ambientes -, o museu representa o lado soft desse mesmo poder. No museu, segundo Bennett, o entretenimento substitui a instrução disciplinar, operando pela via da sutileza e dos estímulos. Essa vertente branda do poder pressupõe a atração dos públicos aos museus mediante sua participação voluntária - sem deixar de destacar todo o imenso aparato que possibilita a infusão de valores e necessidades nos diferentes segmentos da população (BENNETT, 2007, p. 87).

O tom leve dessa forma de organização dos corpos no contexto dos museus pode ser percebido já como um índice que prenuncia as formas de operar do capitalismo avançado, principalmente a partir dos anos 1980, quando o neoliberalismo se impõe no cenário internacional. Safatle dirá que ele "não é apenas um modo de regulação dos sistemas de trocas econômicas baseado na maximização da concorrência e do dito livre-mercado". Ele é também, e inclusive, "um regime de gestão social e produção de formas de vida que traz uma corporeidade específica, uma corporeidade neoliberal”. Tanto é assim que Margareth Thatcher, sua mais destacada defensora, afirmará: "A economia é o método. O objeto é modificar o coração e a alma”. Coração e alma, como reforça o filósofo, "são peças na dominação que o poder exerce sobre o corpo" (SAFATLE, 2015, p. 195-196).

No universo do trabalho, por exemplo, a empresa capitalista vai aos poucos alterando suas dinâmicas disciplinares, o que se torna perceptível do final dos anos 1920 em diante, de acordo com Safatle. É nesse sentido que "a brutalidade do modelo taylorista de administração de tempos e movimentos" vai paulatinamente sendo abrandada para dar lugar "a um modelo "humanista”' de gerenciamento. As bases dessa alteração estão assentadas nos elementos "psicológicos de uma engenharia motivacional na qual cooperação, comunicação e reconhecimento se transfor- 
mavam em dispositivos de otimização da produtividade" (grifos meus). Isso tudo num contexto de produção que vai sendo inundado por formas de afeto. Logo, a "humanizada" empresa capitalista favorece "uma mobilização afetiva no interior do mundo do trabalho", resultante da mistura de expedientes do mercado com premências do eu. O filósofo sugere, nessa perspectiva, que quanto mais psicologizadas forem as relações de trabalho, mais bem geridas elas serão. Isso significa que as queixas relacionadas à rigidez e à falta de sentimento no ambiente funcional vão perdendo sentido na exata medida em que o capital vai, de maneira implacável, se apropriando e incorporando às suas operações as demandas do sujeito, tais como a afetividade e a flexibilidade (SAFATLE, 2015, p. 200-201).

\subsection{O SUJEITO NO NEOLIBERALISMO}

Dadas as mudanças promovidas pelo capitalismo ao longo do século XX nas formas de mobilizar o sujeito para a produção material, no sentido de intensificá-la e, ao mesmo tempo, barateá-la, a pergunta colocada por Safatle é: "o que seria então esse novo homem neoliberal?”. Ao tentar respondê-la, o autor chama atenção para um "paradoxo aparente". O suposto contrassenso residiria no seguinte fato, alavancado nos anos 1980: ao mesmo tempo que o neoliberalismo consegue iniciar um processo de erosão das políticas de seguridade social - implementadas pelos Estados de bem-estar social a partir da década de 1970 -, ele é capaz de intensificar os regimes de trabalho e, além disso, reduzir a massa salarial dos trabalhadores. De fato, não parece muito simples entender como esse conjunto de expropriações se fez possível sem que o sistema entrasse em pane. $\mathrm{O}$ autor nos lembra, ainda, que esse processo se deu "a partir do momento em que as sociedades capitalistas não podiam mais constituir sua coesão social e sua adesão psicológica através do recurso aos modelos de internalização psíquica de uma ética do trabalho”, calcada em princípios como a rigidez, o autocontrole, a repressão das pulsões - todos eles tributários da "moralidade própria ao espírito protestante do capitalismo" e de suas "sanções psicológicas". Isso porque as comportas para as urgências e imediatismos do indivíduo já haviam sido abertas pelo "desenvolvimento exponencial da sociedade de consumo e suas exigências de mobilização total dos desejos". Com isso, a "multiplicação da satisfação mercantil”, em lugar de competir para a contenção dos desejos e pulsões do indivíduo, incita-os numa voltagem nunca antes experimentada, tornando cada vez menos vigente o padrão do trabalho disciplinado e abnegado (SAFATLE, 2015, p. 196-197).

Um novo ethos passa a ser requerido no capitalismo avançado. A propósito disso, já não é possível conceber a "disciplina neoliberal” como um "simples conjunto de condições para a internalização de dinâmicas repressivas capazes de determinar sujeitos em individualidades rígidas e funcionalizadas”. Ou seja, ocorre um gradativo abandono de padrões inflexíveis 
de individualização, em beneficio de motivações as mais difusas, ligadas ao domínio do prazer pessoal, antes tidas como alheias ao "universo compulsivo do trabalho alienado", em virtude de sua "improdutividade". Dentre elas, Safatle elenca "o sexo, a experiência amorosa, o fazer estético”, mas podemos pensar também na viagem, na droga, na curtição entre amigos etc. O motivo de toda essa abertura é que o capital e seu modo altamente dinâmico de operar precisa "expropriar todas as motivações que poderiam fornecer espaço para experiências que não se deixam ler a partir da lógica em operação na esfera econômica, eliminando os afetos que essas experiências geram”. Todas essas experiências com alto potencial desviante devem ser incluídas no repertório de possibilidades do sistema neoliberal, de maneira que suas irrupções sejam canalizadas em favor das dinâmicas de hiperprodução mercantil (SAFATLE, 2015, p. 197). Neste ponto, o caráter paradoxal começa a se revelar apenas como algo aparente. Mas há ainda outras ambiguidades a serem apontadas.

Por estranho que possa parecer a uma dinâmica de controle, o arco de reivindicações do sujeito com relação ao livre curso de suas pulsões e desejos passa a ser contemplado e absorvido pela lógica econômica neoliberal. Tais manifestações do eu, e não somente o tempo e a força de trabalho de cada um, tornam-se objeto de expropriação pelo capital. Em vez do seu recalque, o neoliberalismo estimula que pulsão e desejo venham à tona em seu grau mais elevado e que, além disso, sejam socializados. Tal circulação social das pulsões e desejos, e o seu consequente uso como motor produtivo, é identificada pela noção de "mais-gozar" (plus-de-jouir), tomada emprestada de Lacan por Safatle, numa paráfrase do psicanalista francês à "mais-valia” em Marx. A maneira encontrada pelo neoliberalismo para instrumentalizar essas instâncias do sujeito, a princípio avessas aos expedientes da administração, dada a sua "estrutura polimórfica", foi constituir um "dispositivo disciplinar" baseado num "ideal empresarial de si”, e aqui Safatle está fazendo uso das ideias desenvolvidas por Foucault em Nascimento da biopolítica (SAFATLE, 2015, p. 198, 203).

Ao estimular e garantir a internalização desse "ideal empresarial de si", o sistema econômico neoliberal torna-se capaz de desfazer o aparente paradoxo provocado pelo desmonte das políticas de seguridade social, que são substituídas pela intensificação e flexibilização dos regimes de trabalho, pela redução da massa salarial e, finalmente, pelo "risco de insegurança social produzido pela desregulamentação do trabalho". Esse risco, por sua vez, é "suplantado pela promessa de plasticidade absoluta das formas de vida". Confiar nessa flexibilidade irrestrita significa acreditar que já não há fatores externos e burocráticos a moldar, atrapalhar ou impedir o florescimento dos impulsos empreendedores de si. Um dos efeitos disso é o surgimento de uma nova e peculiar forma de gozo: a satisfação subjetiva com a própria capacidade de "intensificação do desempenho e das performances exigida pelo ritmo econômico neoliberal” - sem dúvida uma manobra muito sofisticada do capital (SAFATLE, 2015, p. 199).

Desse modo, a "forma-empresa" torna-se o paradigma da nossa sociedade. Sua ge neralização pelo corpo social e a consequente introjeção por cada um fazem com que o indivíduo se autocompreenda como "empresário de 
si mesmo", sempre assombrado pela iminência do "fracasso de não ser bem-sucedido como sujeito econômico" e, com isso, ver-se excluído do circuito de produção-satisfação. Ele passa, então, a orientar suas ações "a partir da lógica de investimentos e retorno de 'capitais””. Os afetos, nessa linha de produção de si mesmo, são tomados como “objetos de um trabalho sobre si tendo em vista a produção de "inteligência emocional' e otimização de suas competências afetivas”. Já a supervisão de suas atividades produtivas é internalizada pelo indivíduo sob a forma de "um trabalho de vigilância e controle baseado na autoavaliação constante de si", com base em "critérios derivados do mundo da administração de empresas". O "cálculo racional” de cada ação funda-se, aí, na balança de "custos e benefícios”. Em resumo, foi inaugurada "uma nova interface entre governo e indivíduo", por meio da qual se processam "modos de governabilidade muito mais enraizados psiquicamente" (SAFATLE, 2015, p. 199-202).

A governabilidade que se vai tornando intrínseca ao próprio sujeito responde diretamente à exigência de "autovalorização do Capital". Tudo o que circula em suas redes, das coisas mais palpáveis às mais insondáveis, não tem outra função a não ser a produção autorreferente de valor mercantil. Como já foi sugerido, a socialização das demandas pulsionais do sujeito é aí pautada pela "pura medida da intensificação", através de uma dinâmica que atrai e lança "os objetos de desejo em um circuito incessante e superlativo” (SAFATLE, 2015, p. 204). Trata-se de um movimento contínuo no qual gozar é a regra. Dentre os diferentes cenários da vida contemporânea onde o que importa é gozar, sem dúvida os espaços dedicados à arte assumem um papel que não deve ser desprezado, pelo contrário.

\subsection{NEOLIBERALISMO COMO}

\section{NORTE INSTITUCIONAL}

Com o intuito de apontar como os espaços da arte são remodelados em tempos neoliberais - talvez pudéssemos dizer que se trata de uma "reengenharia”, para usar o jargão corporativo -, retomamos algumas noções apresentadas por Arantes em seu texto "Os novos museus". A filósofa comenta que, na virada dos anos 197080, os museus vão sendo "reformulados na medida desse novo contingente de visitantes-consumidores, tanto quanto de uma arte que se quer ela própria cada vez mais na escala das massas”, ajustada às demandas de "consumo de uma sociedade afluente". Para a autora, a ponta de lança desse processo foi o Beaubourg (Centro Nacional de Arte e Cultura Georges Pompidou). Emblema da política cultural francesa comentada acima, o Centro é inaugurado em 1977 como um exemplo paradigmático "das políticas de animação cultural promovidas pelos Estados do capitalismo central”. Como já foi dito, é parte da lógica desse e de outros centros de arte criados a partir de então a encomenda de seus projetos a arquitetos estelares da cena internacional, como é caso de Renzo Piano e Richard Rogers no Pompidou (ARANTES, 1993, p. 240). 
Com seus edificios autorais e espetaculares, tidos como obras de arte em si mesmos, tais centros almejam, segundo Arantes, assumir a condição de "grandes monumentos que sirvam ao mesmo tempo como suporte e lugar de criação da cultura e reanimação da vida pública”. Eles são fruto de políticas culturais que "alegam estar 'animando' o combalido corpo social moderno (ou pós-moderno), graças à indução num público polimorfo de situações de fluidez, comunicação e souplesse [flexibilidade]", denotando um cruzamento com a análise de Safatle sobre o estatuto do sujeito no neoliberalismo (ARANTES, 1993, p. 240, grifos meus).

Outro ponto de interseção com a crítica do filósofo concerne a algo que Arantes identifica como uma guinada no Estado de bem-estar social. Nesse momento, as ações oficiais passam a se concentrar "menos na renovação do aparato de proteção social do que, por exemplo, numa política de reciclagem do Patrimônio, associada à prática de apropriação cultural, centrada na autonomia dos cidadãos" (grifos meus), com tudo o que a lógica da democratização/apropriação cultural tem de problemática, assim como a bandeira da autonomia e do empreendimento de si. Esse desvio de rota nas políticas de seguridade social se processa de modo (dubiamente) amigável, com aparência de concessão benéfica, "como se com as novas responsabilidades econômicas se estivesse devolvendo aos indivíduos a cidadania através de atividades lúdico-culturais patrocinadas pelos grandes centros [de arte]" (ARANTES, 1993, p. 241).

Cética frente a tais propósitos, a filósofa relativiza o caráter público desses espaços de arte, haja vista que a sua "principal performance consiste em encenar a própria ideologia que os anima: são quando muito sucedâneos de uma vida pública inexistente”. Enquanto sofisticados "cenários de uma sociabilidade fictícia", eles tomariam para si a tarefa de garantir a "difusão dessa atmosfera de quermesse eletrônica que envolve a vida pública reduzida em modèle réduit [miniatura]". Fazendo novamente ressoar as observações de Safatle, Arantes dirá que esses museus fomentam em seus públicos "uma atitude crescentemente hedonista", tributária da "sociedade de consumo" (ARANTES, 1993, p. 241, 244). Pode-se interpretar de suas asserções que, sob o signo neoliberal, o museu torna-se o lugar do simulacro, seja de uma sociabilidade pública, seja da própria fruição das obras de arte, na medida em que uma relação contemplativa com elas vai sendo dificultada, senão obliterada por completo.

Se Arantes joga luz sobre um empreendimento paradigmático no qual o Estado é o responsável direto pela definição das diretrizes, pela gestão e realização do investimento financeiro necessário, como no caso da política cultural francesa, nos concentremos agora em sua contraparte inglesa, que num período subsequente tem nas empresas privadas um polo de influência decisivo, graças à transição na direção do financiamento corporativo das instituições públicas de arte. Quem nos auxilia nesse exercício é a pesquisadora Chin-Tao Wu, por meio do seu texto "A absorção da cultura empresarial: instituições artísticas a partir da década de 1980".

Wu destaca que nos anos 1980 ocorre uma mudança profunda nos museus de arte da Inglaterra, precedida pela situação norte-americana e desencadeada pela alteração de suas formas de financiamento. Alinhada aos princí- 
pios neoliberais de diminuição do papel do Estado, enxugamento da máquina pública e rarefação dos investimentos públicos em áreas de interesse social como a cultura, tal mudança se dá a partir do momento em que as galerias públicas inglesas dedicadas às artes visuais se veem "expostas a um clima de crônica incerteza financeira”, em virtude da retirada "do apoio que antes lhes era oferecido pelo governo". Não havia, por outro lado, qualquer dúvida de que o corte dos subsídios governamentais provocaria um deslocamento do financiamento, mas não só dele, para o setor privado - ainda que com dinheiro público, através de concessões tributárias (WU, 2006, p. 175).

A pesquisadora nos ajuda a não perder de vista que as "dificuldades financeiras e a ascensão do patrocínio das artes andam lado a lado”. O financiamento, como é de supor, não anda de viseira e nem sozinho. Ele se confunde com a própria participação nas decisões sobre o que financiar e em que termos financiar, com vistas a uma série de contrapartidas para as corporações. A pesquisadora chama atenção, a esse propósito, para o "erro básico [que é] considerar a presença corporativa dominante nos museus de arte (e no mundo das artes em geral) uma questão apenas financeira”. Muito além do patrocínio, essa predominância do poder econômico no contexto institucional desdobra-se na prerrogativa de influenciar os rumos dessas instituições e de seus programas, a ponto de produzir "um profundo impacto sobre a paisagem cultural das sociedades norte-americana e britânica” (WU, 2006, p. 175). O alerta sobre a natureza desse impacto é dado pelo relatório do Trade Union Congress (Congresso Sindical), citado por Wu: "É importante lembrar que as atividades dos patrocinadores privados das artes, ao contrário das de seu equivalente público, não são sujeitas a nenhum grau de controle democrático" (TRADE UNION CONGRESS apud WU, 2006, p. 179).

No momento em que decisões sobre as políticas institucionais são compartilhadas com o setor privado, suas corporações irão lidar com as artes a partir das prioridades que interessem e respondam às necessidades imediatas das empresas, e não o contrário. Isso se dá sem o crivo de mocrático, que implicaria o debate e o consenso públicos, algo alheio às decisões a portas fechadas dos executivos e acionistas. Trata-se, portanto, de uma prerrogativa problemática concedida às corporações, que interferem nos rumos dos equipamentos artísticos a partir de seus próprios interesses.

Exemplo eloquente disso é o processo da Tate Gallery no final dos anos 1980. Nesse período, desponta na Inglaterra thatcherista o que $\mathrm{Wu}$ denomina como "um novo tipo de diretor de museu". Tal como seus pares norte-americanos, eles são empresários, o que "não quer dizer que sejam necessariamente thatcheristas no sentido político, mas ainda assim estão prontos a vender de forma agressiva a instituição sob sua responsabilidade”. Nicholas Serota, que assume a direção da Tate em 1988, sintetiza essa figura do diretor-empresário de maneira exemplar. Está claro, segundo a abordagem de $\mathrm{Wu}$, que a chegada de Serota à Tate simboliza uma mudança decisiva na cultura gerencial dos equipamentos de arte na Inglaterra. Ele substitui sir Alen Bowness, para quem "pensar que o sistema 
norte-americano é a panaceia” não passava de uma “tolice”. No período próximo à transição na Tate, Bowness vinha se pronunciando publicamente acerca da alteração na estrutura de financiamento institucional: "Acredito no financiamento estatal. Não acredito ser possível - não acredito ser desejável - que as artes sejam deixadas para o setor privado". Alguns o chamavam, por este e por outros posicionamentos, de "uma tia velha” (WU, 2006, p. 159).

Ao substituí-lo no cargo, Serota - que havia sido diretor da Whitechapel Art Gallery de 1976 a 1988 - assume a tarefa de transformar a Tate no "maior parque de diversões da Europa”, de acordo com a definição de Waldemar Januszczak em matéria para o Guardian, em 1988. O diretor era conhecido como um arrojado organizador de exposições, muito bem relacionado com patrocinadores corporativos, junto aos quais havia firmado uma polpuda carteira de parceiros para a Whitechapel. Sua habilidade com a captação de recursos junto à iniciativa privada tornara-se patente, por exemplo, "na negociação da reforma de 2,2 milhões de libras da Whitechapel, em 1985” (WU, 2006, p. 159-160).

A gestão de Serota na Tate é modelar quando se trata de observar os desdobramentos da hegemonia do capital corporativo no âmbito das instituições públicas de arte na Inglaterra. Como exemplo, assim que assume o cargo de diretor dessa instituição, Serota deixa claro o risco que corriam "as atividades primárias de erudição, conservação e educação, bem como as 'exposições acadêmicas”, devido à vulnerabilidade do sistema de subsídios da Tate, sujeito às empresas e, assim, às intempéries do mercado. Sob a sua gestão, a instituição logo irá estruturar um departamento de "desenvolvimento”, responsável pela captação de recursos e formação de redes. É o seu líder, Fay Ballard, quem diz: "A Tate é um animal faminto. Exige alimentação contínua”. É por esse motivo que é montado um arsenal de diferentes canais de captação de recursos, envolvendo o Programa de Doações Caritativas, o Programa de Patrocínio Corporativo, a Seção de Eventos e o Grupo de Amigos da Tate Gallery (WU, 2006, p. 160-161, 175). Ao mesmo tempo, as exposições blockbuster passam a figurar como item essencial na política da instituição, tendo em vista sua alta rentabilidade. Nessa esteira, são montadas grandes mostras, "uma maior do que a outra": John Constable (1991), com a visitação de 169.412 pessoas; Picasso: Sculptor/Painter (1994), com 313.659 visitantes; e a recordista Cézanne (1996), com 408.688 visitantes (WU, 2006, p. 160). A última apresenta um detalhe digno de nota:

[...] a Tate também montou uma grande campanha de merchandising, comercializando de tudo em sua loja, desde vasos, toalhas de chá e CD-ROMs, até echarpes com motivos de Cézanne vendidas a 45 libras, sem esquecer o "Cézannewich" oferecido nas filiais londrinas do Prêt à Manger e um "Cuvée Cézanne at the Tate", um vinho especialmente engarrafado para a ocasião. (WU, 2006, p. 160.)

O que pensa Serota a esse respeito? Perguntado, ele afirma: "Não quero que a Tate se transforme num shopping center. Mas, se as pessoas querem comprar, 
elas têm de ser atendidas”. Mas não são apenas esses produtos que estão à venda na Tate. Seu Programa de Patrocínio Corporativo, inspirado no modelo norte-americano, passaria a oferecer o "aluguel do espaço da galeria para entretenimento corporativo", além de outros beneficios como "visitas particulares para os empregados [das empresas patrocinadoras]”. O interesse das corporações por tal aproximação e por seus respectivos privilégios está diretamente vinculado à "aura de autoridade e aceitabilidade artística na consciência do público" de que goza a Tate (WU, 2006, p. 162). Dada a atmosfera criada para favorecer a relação com a instituição e o uso de suas dependências, "as empresas se sentem seguras na Tate", como registra Antony Thorncroft em artigo para o Financial Times (THORNCROFT apud WU, 2006, p. 162). Nesses casos, as instituições operam como "agências de relações públicas para patrocinadores corporativos”. E isso não é tudo: ao patrocinar e realizar eventos de relacionamento nas instituições artísticas, "as corporações se apresentam como tendo em comum com museus e galerias de arte um sistema humanista de valores", o que lhes possibilita "revestir seus interesses particulares com um verniz moral universal” (WU, 2006, p. 148, 151).

Considerado o panorama em países centrais do sistema produtivo global, cabe agora observarmos de que modo as injunções neoliberais viriam a repercutir na periferia do capitalismo, como no caso do Brasil. Para isso, voltemos ao exemplo da Bienal de São Paulo, atentando para o período em que a Fundação foi presidida por Edemar Cid Ferreira ${ }^{10}$, à época um poderoso banqueiro. Sua gestão tem início em 1993, num período em que a instituição vinha sendo cada vez mais ocupada por homens de negócios, conforme nos contam Alambert e Canhête. Reeleito uma vez, o banqueiro permanece à frente da instituição até 1997 (ALAMBERT; CANHÊTE, 2004, p. 189).

Importante dizer que a década de 1990 marca a entrada de concorrentes internacionais na economia do país, num processo conhecido como abertura de mercado. Tal política foi implementada pelo governo Fernando Collor de Mello, deposto por meio de um processo de impeachment, em 1992, após escândalos de corrupção. No que diz respeito ao campo cultural, acumulam-se significativas perdas, sendo a principal delas a extinção do Ministério da Cultura - MinC por esse mesmo governo, que o transforma em uma Secretaria vinculada à Presidência da República ${ }^{11}$ (ALAMBERT; CANHÊTE, 2004, p. 186).

Num momento em que "o patrimônio público estatal era demonizado e privatizado", a Bienal era compreendida e modelada pela elite financeira, ali representada por Cid Ferreira, como uma empresa privada. Pragmática e privatista, a linha de gestão adotada pelo banqueiro desde que assume a presidência da instituição antecipa "a euforia inicial da 'era FHC”, caracterizada

10 Em dezembro de 2006, após a falência do Banco Santos, Edemar Cid Ferreira foi condenado a 21 anos de prisão, por gestão fraudulenta, lavagem de dinheiro e formação de quadrilha, mas responde em liberdade.

11 O Ministério da Cultura seria recriado em novembro de 1992, no governo Itamar Franco. 
por seu "discurso globalizante e neoliberal". A ambição do banqueiro era profissionalizar a Bienal de acordo com as exigências do mercado, além de destravar qualquer tipo de constrangimento ao livre curso do "mundanismo de ricos e famosos". As mostras se tornaram "um acontecimento social de caráter mais privado do que público”, cotidianamente veiculado por colunas sociais (ALAMBERT; CANHÊTE, 2004, p. 195).

Primeira edição sob a direção do banqueiro, a $22^{\text {a }}$ Bienal (1994) envolveu recursos e números inéditos para o histórico da mostra, custando "cerca de $4,5 \mathrm{mi}$ lhões de dólares”. Desse montante, aproximadamente US\$ 2,7 milhões foram direcionados por "empresas como Coca-Cola, Philip Morris e McCann Erickson”. Sinal da consolidação da lógica do financiamento corporativo, tal patrocínio se beneficiou da política federal de renúncia fiscal. Outra fonte de recursos foi, ainda, a cobrança de ingressos. A previsão era de que a $22^{\mathrm{a}}$ edição rendesse "um lucro", na expressão dos pesquisadores, de cerca de US\$ 1 milhão. Terminada a mostra, o número contabilizado de pagantes foi de cerca de 200 mil pessoas, menos do que os 300 mil estipulados no plano de metas do evento. Ainda assim, tratava-se de um recorde, pois a esse contingente se agregaria a vultuosa soma de 342 mil estudantes, perfazendo um total de 544 mil visitantes. Os pesquisadores pontuam que "nunca os números haviam invadido tanto o discurso sobre a mostra" (ALAMBERT; CANHÊTE, 2004, p. 191-192).

A edição seguinte, de 1996, seria ainda mais ambiciosa em relação às cifras. Com seu orçamento de R\$ 12 milhões ${ }^{12}$, ela foi alardeada pela própria instituição como a mostra mais cara do mundo, ultrapassando nesse quesito a Documenta de Kassel, que "havia custado cerca de 10 milhões de reais (no superfaturado câmbio da época)". O modelo das megaexposições midiáticas tornara-se hegemônico também por aqui. A propósito disso, como nos lembram os pesquisadores, Rio de Janeiro e São Paulo haviam recebido no ano anterior uma grande mostra retrospectiva do escultor francês Auguste Rodin, "conquistando público recorde em filas quase intermináveis”. Afeita a tal estratégia de atração de multidões, a organização da 23a Bienal "contra-atacou com Picasso, trazendo para esta nova edição cerca de trinta quadros, uma escultura e diversos desenhos". Como se vê, os astros modernos eram usados como trunfo eficaz nas mãos de gestores ocupados com a produção de efeitos midiáticos e com a infusão de desejo em uma audiência cortejada de maneira ostensiva pelos meios de comunicação - que operam mediante abordagens publicitárias nas quais os nomes dos artistas e as imagens de suas obras surgem acompanhados por logomarcas e slogans das empresas apoiado-

12 Embora Alambert e Canhête tenham se referido aos custos da edição anterior (1994) em dólares, no caso da $23^{a}$ edição eles apresentam os valores em reais, inclusive por se tratar de um momento em que a moeda brasileira já havia se consolidado. O Plano Real fora lançado em 1994. Levaria algum tempo para que a nova moeda, recém-valorizada, fosse usada como referência em negociações envolvendo agentes estrangeiros, como no caso da $23^{a}$ edição da Bienal. 
ras. Não por acaso, dessa vez a Bienal consegue alcançar a meta almejada de público pagante. Ainda que o número de estudantes e professores tenha sido inferior ao da edição anterior - somando 74.344 visitações -, mais de 300 mil pessoas pagaram para visitar a mostra, gerando lucro de R\$ 1 milhão aos cofres da Fundação. O critério de avaliação estava consolidado: "qualidade" e "sucesso" passam a ser medidos na exata proporção das massas de visitantes que acorrem ao pavilhão (ALAMBERT; CANHÊTE, 2004, p. 196).

Saltando duas décadas, notamos que o discurso do ex-presidente da Fundação Bienal de São Paulo, Luis Terepins, sobre forçar a presença do público escolar na mostra, tem um lastro evidente quanto aos seus propósitos. Ao critério das multidões de visitantes, devemos ainda somar o fato de que, a partir da sua $26^{\mathrm{a}}$ edição, em 2004, o acesso do público à mostra passa a ser gratuito. Em matéria da Folha de S.Paulo ${ }^{13}$, o jornalista e crítico Fabio Cypriano registra que o projeto de gratuidade, implementado na gestão de Manoel Francisco Pires da Costa, fora intitulado como "Movimento Arte Democrática”. Repercutindo uma das ênfases deste capítulo, nota-se que com a gratuidade a bandeira da democratização cultural ganha mais um importante componente. A instituição pode abrir mão da cobrança da entrada justamente porque se torna possível, e crível, convencionar com empresas patrocinadoras o argumento calcado no beneficio social e, assim, o compromisso com a difusão dos bens culturais a toda a população. O que temos diante de nós é um pretenso "discurso perfeito": instituição artística e empresas privadas, de mãos dadas, assumem (muitas vezes no lugar do Estado) a responsabilidade por prover cultura (qual?) às pessoas que, por motivos diversos, padecem da falta de acesso a esse tipo de bem simbólico. Não se pode perder de vista que, subjacente a essa cantilena, processa-se um movimento contínuo de autorreprodução das instituições artísticas e de autopromoção das empresas - com dinheiro público, diga-se.

A propósito dessa irmanação entre as instituições artísticas e as corporações, Hans Haacke, outro artista dedicado à crítica institucional, nos coloca a par do depoimento do presidente da Cartier, Alain-Dominique Perrin. Numa entrevista em meados dos anos 1980, Perrin declara: “o mecenato não é apenas um formidável instrumento de comunicação; muito mais do que isto, ele é um instrumento de sedução da opinião”. Depois, o executivo emenda: o dinheiro investido pela Cartier com iniciativas artístico-culturais visaria a "metas que nada têm a ver com o amor à arte”, sugerindo a vocação pragmática das estratégias de marketing e das relações públicas praticadas por sua empresa nos contextos artísticos ${ }^{14}$ (HAACKE; BOURDIEU, 1995, p. 28). Em alusão aos desdobramentos do sociólogo Paul DiMaggio da teoria bourdiana do capital cultural, Wu comenta que esse mesmo capital "pode ser transformado em capital

13 "26a Bienal terá entrada gratuita". Folha de S.Paulo, 8 de maio de 2004.

14 Em 1984, a empresa inauguraria a Fondation Cartier pour l'art contemporain (Fundação Cartier para a Arte Contemporânea). 
social [...], e que estes [capital cultural e social], por sua vez, podem ser usados para acumular capital econômico". Isso se torna possível graças à "fluidez e [à] flexibilidade do capital privado". Operando com altos níveis de abstração, o capital intercambia com notável facilidade elementos e valores de naturezas as mais distintas (WU, 2006, p. 150).

Eficaz “investimento simbólico”, para usar o termo de Pierre Bourdieu no diálogo com Haacke - registrado na brochura Livre-troca: diálogos entre ciência e arte -, o mecenato da era neoliberal traz consigo ainda outra peculiaridade, conforme nos explica o segundo: "os contribuintes pagam aquilo que as empresas recuperam através de isenções fiscais pelas suas 'doações', e somos nós quem verdadeiramente subvencionamos a propaganda” (HAACKE; BOURDIEU, 1995, p. 28).

Dada a complexidade da questão, urge que a mediação cultural incorpore aos seus debates e ações, de maneira sistemática, aspectos relacionados ao funcionamento do sistema da arte, incluindo suas políticas de financiamento. Essa atenção deve estar conjugada à análise crítica dos papéis, frequentemente instrumentalizados, reservados aos públicos das ofertas institucionais.

\subsection{LEI DE INCENTIVO À CULTURA NO BRASIL}

Cumpre-nos, agora, detalhar a lógica que define a principal lei de incentivo à cultura no Brasil, a Lei Rouanet, criada no início da década de $1990^{15}$. Seu principal mecanismo, ligado ao Incentivo Fiscal (Mecenato), concede beneficios fiscais para investidores que apoiam projetos culturais. Através dele, empresas e pessoas fisicas podem lançar mão da isenção fiscal em até $100 \%$ do valor no Imposto de Renda, ao direcionar os valores correspondentes à sua renúncia tributária para projetos culturais. Apoiando e vinculando-se a iniciativas culturais, elas passam a contar com a oportunidade de investir em sua imagem institucional e em sua marca ${ }^{16}$.

Está claro que em tal modalidade de financiamento não há praticamente dinheiro privado sendo despendido, e sim recursos deduzidos do imposto sobre a renda, que seriam pagos à União. Trocando em miúdos, trata-se de uma outorga federal para o desenvolvimento de estratégias de marketing cultural pelas empresas, pago com dinheiro público, do contribuinte. As empresas não apenas gozam de renúncia fiscal, como também da prerrogativa de escolher qual projeto apoiar. Elas optam comumente por projetos que supram seus interesses diretos, gerem visibilidade e, assim, confirmem-se como investimentos simbólicos certeiros.

15 A primeira lei de incentivo fiscal para a cultura no Brasil, denominada Lei Sarney, é promulgada em 1986, na gestão de Celso Furtado no MinC, durante o governo de José Sarney.

16 Conforme informações apresentadas no site oficial do MinC: <http://www.cultura.gov.br/leis/-/asset_publisher/ $\mathrm{aQ} 20 B v S J 2 \mathrm{nH} 4 /$ content/lei-rouanet/10895>. Acesso em: 25 jul. 2016. 
No texto “Que políticas culturais?”, Lúcia Maciel Barbosa de Oliveira, pesquisadora nas áreas de ação e políticas culturais, pontua que a promulgação da referida lei está diretamente ligada à ausência de investimentos públicos consistentes no setor cultural do país, dados os baixos orçamentos que caracterizam a ainda curta história do MinC, criado em 1985. Ela destaca que a Lei Rouanet, por ocasião de sua criação, assumiu um papel tido como transitório e meramente estimulador, pois se acreditava "que o mercado [cultural] passaria a ser autônomo e suportaria os custos da produção, fato que não se verificou" (OLIVEIRA, 2009).

Oliveira comenta os diferentes matizes entre os governos Fernando Henrique Cardoso (1995-2002) e Luiz Inácio Lula da Silva (2003-2010) em relação às políticas culturais do país. Nesse quesito, a autora chama atenção para "a instabilidade decorrente [do fato] das políticas públicas no Brasil serem políticas de governo e não de Estado, e, portanto, sujeitas às alterações advindas com a posse de cada novo governo" (OLIVEIRA, 2009).

No governo FHC, segundo a autora, a política cultural limita-se às possibilidades geradas pelas leis de incentivo. Para fomentar a agenda neoliberal, o então ministro da Cultura, Francisco Weffort, lança a publicação $\mathrm{A}$ cultura é um bom negócio. Weffort tinha em vista a sensibilização da iniciativa privada, que é conclamada a "investir" em cultura através das leis de incentivo (as aspas são minhas e devem-se ao fato de que, nesses casos, praticamente não há dinheiro das empresas sendo despendido). Em convergência a isso, os artigos da lei são "alterados para aumentar o teto de renúncia e os percentuais de isenção, de forma a tornar mais atrativo o investimento na área”. Chega-se a postular, nessa gestão, que a definição dos rumos da política cultural deveria caber à iniciativa privada (OLIVEIRA, 2009).

No governo Lula, com a nomeação de Gilberto Gil para liderar o MinC, busca-se um maior protagonismo do Estado na definição dos vetores da política cultural do país. A cultura é então afirmada como componente essencial da cidadania. Desse modo, "passa a ser conceituada a partir de uma dimensão antropológica, o que significa compreendê-la como uma dimensão simbólica da existência social brasileira" (OLIVEIRA, 2009, grifo da autora). É esse entendimento que baliza, por exemplo, o Programa Cultura Viva - Arte, Educação e Cidadania, que mapeia e apoia iniciativas culturais já existentes em comunidades em situação de fragilidade material e estrutural.

Outro índice da participação do Estado nos caminhos da cultura se manifesta no próprio escopo das leis de incentivo fiscal, com financiamentos de projetos culturais praticados por empresas estatais, como é o caso da Petrobras, entre outros. No entanto, embora haja uma mudança de perspectiva no que tange ao envolvimento do Estado na gestão da cultura, o governo do PT - incluindo os mandatos subsequentes de Dilma Rousseff ${ }^{17}$ - não

17 O segundo mandato da presidenta, que deveria ter transcorrido de 2015 a 2018, foi interrompido em 2016 por um processo de impeachment cuja legitimidade é questionada por amplas parcelas da população brasileira e da comunidade internacional, sendo identificado como um golpe jurídico, parlamentar e midiático. 
logrou garantir um patamar orçamentário para a cultura que permitisse ao MinC atravessar a faixa da escassez de recursos, o que mantém a política cultural em grande medida dependente das leis de incentivo. Este "estrangulamento do orçamento", para usar um termo de Oliveira, faz com que a Lei Rouanet vá se perpetuando como mecanismo imprescindível de financiamento da cultura no Brasil (OLIVEIRA, 2009).

Há aqui a oportunidade de colocarmos em perspectiva, ainda que de modo esquemático, as formas predominantes de os Estados conceberem suas políticas culturais. Quem nos auxilia nesse exercício é novamente o trio Ortellado, Lima e Souza. Os pesquisadores enfatizam, nesse sentido, as duas forças ideológicas que protagonizam as "disputas políticas contemporâneas" no âmbito oficial da cultura, sendo elas: a liberal e a social-democrata (ORTELLADO; LIMA; SOUZA, 2013, p. 12).

No registro liberal, notadamente atrelado às premissas do neoliberalismo econômico, as políticas culturais são compostas, principalmente, por "mecanismos de mercado para o financiamento das ações culturais”. Como pontua o trio, ele está associado ao modelo norte-americano - embora a análise de Wu em torno da Tate Gallery do fim dos anos 1980 aponte que na Inglaterra essa ideologia também tenha encontrado lugar, ainda que isso não tenha ocorrido em todos os setores, como veremos a seguir. As políticas ligadas a essa matriz assentam-se, em grande medida, nos programas oficiais de renúncia fiscal. Com tudo o que já dissemos a esse respeito, inclusive no tocante à prerrogativa dos entes privados de definir sem restrição quais projetos culturais apoiar, o Estado abdica do papel de financiar diretamente e priorizar ele mesmo os programas e as manifestações culturais, confiando às empresas a decisão sobre o que fomentar e, por outro lado, o que deixar à própria sorte (ORTELLADO; LIMA; SOUZA, 2013, p. 13).

No modelo social-democrata, nota-se que a tônica recai sobre os direitos culturais dos cidadãos. Garanti-los é uma responsabilidade do Estado, mediante a "criação de programas e ações estatais". Haveria, nesse caso, duas ramificações. A primeira origina-se na França, conforme critérios e estratégias já comentados aqui. Apenas para recapitular, lembremos que suas políticas envolvem grandes equipamentos culturais, cujo exemplo mais eloquente é o Centre Pompidou em Paris. Tais instituições, e aqui se incluem também as casas de cultura, são administradas diretamente pelo poder público, concentrando-se na capital. Aí, as decisões "são tomadas por burocratas e gestores vinculados aos órgãos públicos" ligados ao Ministério da Cultura. A segunda ramificação, por sua vez, apresenta ocorrências no contexto inglês. Seu foco reside no "apoio às ações culturais e artísticas da sociedade civil”, geralmente contempladas por meio de editais públicos. Diferentemente do caso francês, baseado em equipamentos físicos, o registro inglês de gestão é "conhecido como [modelo de] administração à distância” (ORTELLADO; LIMA; SOUZA, 2013, p. 13). Ainda assim, há os casos de grandes equipamentos culturais que, como já comentado, têm seus subsídios captados junto às corporações, que exercem significativa influência nos rumos institucionais. 
Ao levar em conta as referidas tipologias, podemos dizer que o caso brasileiro tende nas últimas décadas a se aproximar mais da linha liberal, inclusive em virtude da centralidade assumida pelas leis de incentivo fiscal (e sua perpetuação) nos âmbitos federal, estadual e municipal. Ainda assim, conforme pudemos verificar nas observações de Oliveira, os diferentes governos conferem tons distintos à participação do Estado no financiamento e na elaboração/condução de políticas públicas no campo cultural, indício de que no Brasil tem preponderado a política de governo em detrimento da política de Estado.

A importância de perspectivar tais ideologias e as políticas culturais a elas vinculadas está no fato de que, a nosso ver, nenhuma delas tem logrado estabelecer, salvo algumas exceções, a devida sintonia com as dinâmicas de um presente caracterizado pela "hiperprodução cultural distribuída", para usar um termo de Honorato. A fronteira que divide aqueles que produzem daqueles que consomem os objetos culturais tem se relativizado de maneira inconteste, em função, entre outros fatores, da popularização dos recursos digitais e do amplo acesso às redes de comunicação remota. Logo, a exigência parece ser por iniciativas (em mediação, por exemplo) e políticas culturais capazes de articular entre muitos aquilo que é produzido por muitos.

Apesar disso, devemos reconhecer que programas como o Cultura Viva - Arte, Educação e Cidadania, e os respectivos Pontos de Cultura, representam exemplos de políticas públicas não apenas sensíveis, mas baseadas em tal lógica. Portanto, embora não faça parte do escopo da nossa pesquisa uma análise aprofundada de políticas públicas específicas, e tampouco a postulação de um plano estruturado nesse sentido, revela-se útil aproximarmos nossas análises e proposições acerca da mediação cultural de políticas com as quais nos percebemos mais alinhados em termos conceituais.

\subsection{O FINANCIAMENTO DA BIENAL DE SÃO PAULO E O PAPEL ESTRATÉGICO DE SEU PROGRAMA EDUCATIVO}

Como se pode depreender, foi o uso da Lei Rouanet que garantiu grande parte dos recursos financeiros necessários à viabilização da $31^{\mathrm{a}}$ edição da Bienal de São Paulo, a mesma a que Terepins se refere no vídeo institucional, cujo orçamento total foi de R\$ 24 milhões. Na "Carta do Presidente"18, publicada no site da $31^{\text {a }}$ Bienal, Terepins utiliza outra terminologia para se referir ao $p u ́$ blico escolar. Nesse documento ele faz menção à "ativação de novos públicos”, um eufemismo que, embora menos agressivo do que a expressão público forçado, ainda assim pressupõe os públicos como entidades abstratas e inertes, "ativáveis" pela ação institucional.

Pode-se inferir da leitura da carta que uma das contrapartidas centrais oferecidas pela Bienal aos patrocinadores da mostra referia-se à frequentação ex-

18 Disponível em: <http://www.31bienal.org.br/pt/ about/749>. Acesso em: 16 jul. 2016. 
ponencial de crianças e jovens em fase escolar, arregimentados, organizados e guiados pela equipe do seu amplo programa educativo ${ }^{19}$. Para tais empresas, esse dispositivo arregimentador de visitantes escolares geraria significativos beneficios em pelo menos quatro frentes: 1) associação de suas marcas a um evento cultural que se afirma socialmente comprometido com a educação; 2) exposição de suas marcas aos consumidores de um futuro próximo (e também do presente); 3) obtenção de visibilidade e crédito por meio da ampla cobertura realizada pelos veículos de impressa; e 4) propagação de uma atitude corporativa benevolente, em que os interesses capitalistas vigoram sob o disfarce de ações filantrópicas.

Patrocinador master da Bienal de São Paulo em suas últimas edições, o Banco Itaú vem adotando os financiamentos culturais e sociais como poderosa estratégia de marketing ${ }^{20}$. Como nos conta a crítica de arte Clarissa Diniz, "a marca do Itaú S.A. consolidou-se em 2011 como a mais valiosa do Brasil, num total de 24,3 bilhões de reais, enquanto, no ano de 2010, [o banco] investiu de recursos próprios apenas 59 milhões de reais em cultura, o equivalente a $0,11 \%$ de sua receita líquida naquele ano”. No mesmo ano, o banco direcionou por meio de mecanismos de isenção fiscal R\$ 10,3 bilhões em projetos sociais, incluindo aí a cultura, num total de 19\% de sua receita líquida (DINIZ, 2011, p. 38).

Num país em que a desigualdade social é obscena e onde, apesar das profundas e permanentes crises, as instituições financeiras continuam ampliando o seu porte e suas margens de lucro, o patrocínio das artes apresenta-se como um poderoso artificio de positivação da imagem dos bancos junto à opinião pública. De acordo com Wu, tal patrocínio é "particularmente eficaz para companhias [...] cuja imagem necessite de uma boa burilada”. É o caso das companhias de petróleo, cigarro, armamento e, diríamos, também dos bancos (WU, 2006, p. 152).

Responsável pelo programa educativo da Documenta 12 (2007), Mörsch reforça que o engajamento neoliberal no âmbito da cultura deve ser observado com atenção, inclusive por conta de sua habilidade em apropriar-se de dimensões da subjetividade caras aos processos artísticos e pedagógicos, em favor dos fluxos estimulados pelo sistema financeiro. Nessa seara ambígua - esquadrinhada por Safatle -, virtudes como criatividade, flexibilidade, comunicabilidade, resiliência, sociabilidade e espírito de equipe são apropriadas como requisitos-chave em um ambiente moldado cada vez mais pelas regras do mercado. Mörsch evoca, nesse contexto, a política de governo de Tony Blair - primeiro-ministro da Inglaterra entre 1997 e 2007 - que "(re)descobre a educação cultural como um fator de desenvolvimento econômico e

19 O programa educativo da $31^{\mathrm{a}}$ Bienal de São Paulo (2014), assim como o das $29^{\mathrm{a}}$ e $30^{\mathrm{a}}$ edições da mostra (2010 e 2012), contou com curadoria pedagógica da educadora e artista Stela Barbieri.

20 O Banco Itaú figura como patrocinador master da Bienal desde a $29^{a}$ edição da mostra, em 2010. Nas edições subsequentes $\left(31^{\mathrm{a}}\right.$ e $\left.32^{\mathrm{a}}\right)$, o banco aparece na régua de logos com o status de "correalizador" do evento. 
de favorecimento da coesão social”, fazendo eco à análise de Arantes acerca das políticas culturais francesas na virada dos anos 1970-80 (MÖRSCH, 2009, p. 16).

Adotada pelo governo inglês na segunda metade da década de 1990, essa frente é parte de um conjunto de políticas culturais idealizadas no âmbito do Partido Trabalhista Britânico, cujo slogan afirma: "Trabalho novo, vida nova para a Grã-Bretanha”. Sob esse emblema, o Estado passaria a prover "suporte financeiro substancial para as 'indústrias criativas' e a 'arte socialmente engajada”, o que significa, entre outras coisas, subsidiar programas educativos de grande porte nas instituições de arte, em sintonia com a tendência neoliberal de apropriação "dos efeitos educativos atribuídos à educação em museus” (MÖRSCH, 2009, p. 15-16). Um desses efeitos é o permanente estímulo à criatividade, matéria-prima de grande valor e serventia nos processos de produção pós-industriais.

Não é por acaso, portanto, que desde os anos 1990 os agentes institucionais vêm demonstrando interesse crescente pelos programas educativos, compreendidos como conjuntos de serviços pedagógicos legitimadores da função social dos museus, bienais e demais centros de exposição. Além de fomentar a capacidade criativa de seus públicos, tais programas cumprem ainda outro papel estratégico, visto que ao transformar os públicos atendidos em unidades mensuráveis respaldam as estratégias de captação de recursos financeiros para as ações institucionais.

Alçados à posição de pontas de lança dos esforços institucionais pela captação de recursos financeiros junto às empresas, programas educativos como o da Bienal de São Paulo passam a operar como dispositivos funcionais alinhados aos preceitos das políticas culturais de corte neoliberal inauguradas nos anos 1980. Conforme já comentado aqui, é nessa década que se consolida, em países como Estados Unidos e Inglaterra e, em seguida, no Brasil, a passagem do sistema de financiamento público das instituições artísticas para o financiamento corporativo. Essa transição traz consigo, entre outras mudanças, a ideia de que o sucesso de um empreendimento cultural deve ser medido pela grande quantidade de pessoas que a ele acorre. Nesse aspecto, Wu cita o diretor emérito da National Gallery of Art em Washington, J. Carter Brown:

Inculcou-se na mentalidade corporativa que não vale a pena gastar dinheiro numa exposição a menos que se possa garantir que ela será outro Tut [em referência ao faraó egípcio Tutankhamon, cujo tumulo atraiu multidões de visitantes em exposições nos Estados Unidos e na Inglaterra]. (WU, 2006, p. 157.) 
Nessa direção, o dispositivo arregimentador de visitantes escolares personificado pelo programa educativo da Bienal de São Paulo ${ }^{21}$ fornece as bases necessárias para a concretização da política da instituição e de sua estratégia de captação de recursos, a ponto de configurar um dos tópicos principais da pauta apresentada pela direção da Fundação, encabeçada por Terepins, ao time de curadores da $31^{\mathrm{a}}$ edição da mostra, conforme nos conta Lafuente:

Em abril de 2013 recebemos um convite para organizar a 31 a Bienal de São Paulo. Um convite para fazer uma exposição em uma cidade e um país onde não morávamos, com uma possível audiência de meio milhão de pessoas, quase a metade delas estudantes, visitando em grupo com recursos facilitados por administrações políticas. Era dificil responder a esse convite com um não, mas também era dificil dar um sim que fosse acompanhado de uma compreensão dessa tarefa em toda sua complexidade.

(LAFUENTE, 2014, p. 274, grifo meu.)

O comentário de Lafuente parece revelar um tipo de inversão da relação habitual (também problemática) entre curadorias e ações educativas, visto que os departamentos educativos estão quase sempre "correndo atrás" para compreender e traduzir aquilo que foi definido previamente pelas curadorias em termos conceituais e expositivos. Já no caso relatado, a curadoria parece ter sido convidada pela instituição a dar conta de conceber uma exposição que fosse compatível com a engrenagem construída previamente pelo programa educativo no que diz respeito à atração e ao recebimento de grupos escolares em larga escala. O que não quer dizer que o projeto da $31^{\text {a }}$ Bienal tenha se limitado a esse modus operandi. Inclusive, o time de curadores aqui representado pela figura de Lafuente procurou manter desde o início um distanciamento crítico em relação ao modo de operar do programa educativo, por percebê-lo como agente-cúmplice de uma lógica institucional a ser problematizada:

As instituições [brasileiras] de arte operam com uma ênfase na educação que tem criado grandes aparatos educativos e, ao mesmo tempo, um sistema de geração de públicos, o que resulta em um valor simbólico e um valor econômico para a instituição em particular (por exemplo, a Bienal) e para a instituição 'arte' em geral. No limite, pode-se dizer que a atividade educativa das instituições de arte

21 O porte do programa de atendimento de grupos de estudantes agendados é tamanho que a Bienal vem terceirizando, desde a sua $29^{a}$ edição, a logística de agendamento e recepção desses grupos. A empresa contratada seguidamente para assumir essa frente (inclusive para a $32^{a}$ edição, em 2016) tem o sugestivo nome de Diverte Logística Cultural. 
contemporânea constitui um dos principais mecanismos de autorreprodução das próprias instituições. (LAFUENTE, 2014, p. 275, grifo meu.)

Percepções como essa, capazes de "flagrar" os movimentos institucionais vocacionados à autorreprodução e ao ensimesmamento surdo a outras discursividades e demandas que não as suas próprias e as de seus parceiros financiadores, exigem que a mediação repense criticamente os modos de se relacionar com a instituição de arte. Daí que a ação extrainstitucional pareça necessária, na medida em que estimula a produção de outras entradas e saídas na interação com essa complexa engrenagem, abrindo espaço para agendas e movimentos imprevistos pelo establishment institucional e corporativo.

Até porque a ordem ideológica baseada no cálculo e na instrumentalização do outro nunca perde por esperar. De acordo com Certeau, “contra a expansão de uma força que unifica colonizando e que não reconhece, ao mesmo tempo, seu limite e os outros, deve opor-se uma resistência”. Enquanto a "cultura no singular" (base da democratização cultural) opera pela imposição de um poder, a "cultura no plural" (exigência da democracia cultural) desencadeia uma multiplicidade de formas de combate. Tais confrontos frustram e desconstroem aquilo que seria uma suposta "inércia' das massas em relação à cruzada de uma elite”. Logo, nota-se que a gestão pelo cálculo ignora que "o mensurável encontra em toda parte em suas bordas [um] elemento móvel”. Queira ou não, gerir o outro “deixa [margem para] um enorme 'resto", ou seja, para aquilo que não se pode prever nem controlar. Certeau acredita que com esse "resto" o sujeito dos empreendimentos alheios produza um tipo de cultura que insiste em fazer ecoar, de maneira anônima e clandestina, "rumores nas cabeças de ponte da planificação”. É por esse viés que estamos imaginando a mediação cultural, buscando conceber operatividades moduladas pelo fato de que "as maneiras de utilizar o espaço [e suas ofertas] escapam à planificação” (CERTEAU, 2012, p. 77-78, grifo meu). O que advém desses modos de usar, a nosso ver, deve ser de algum modo reunido e traduzido em suportes que possibilitem a circulação de seus enunciados em outras temporalidades e canais, endereçando e desafiando a instituição.

\subsection{DISCURSOS DA MEDIAÇÃO CULTURAL}

A mediação cultural tem se posicionado de diferentes maneiras em relação às políticas institucionais. Mörsch identifica quatro tipos de discurso atualmente assumidos pela mediação: "afirmativo", "reprodutivo", "desconstrutivo" e "transformativo". Seu escrutínio revela-se útil ao apontar possibilidades tanto de reiteração/comunhão como de estranhamento/desvio da mediação frente às diretivas e pressões a que é geralmente submetida no âmbito institucional (MÖRSCH, 2009, p. 9-12).

Discurso predominante, o "afirmativo" assume a comunicação das missões institucionais como uma constante de suas ações junto aos públicos, informando-os acerca das coleções, pesquisas, modos de conservação e 
exibição, sempre no sentido da promoção do patrimônio cultural. Tal discurso concebe a arte como um domínio especializado e, por esse motivo, destina suas ações à fatia do público iniciado, formada por pessoas familiarizadas com os saberes e códigos da arte e suas exposições. Compõem o arco de suas ações formatos como conferências, visitas orientadas conduzidas por especialistas, programas de filmes e publicações (catálogos, livros etc.) (MÖRSCH, 2009, p. 9).

O segundo discurso, também majoritário, é o "reprodutivo". Entre as diferenças em relação ao afirmativo, está o fato de que se destina aos "públicos de amanhã", aos indivíduos que, por ainda não serem frequentadores das exposições, são a elas introduzidos mediante formas de facilitação do acesso. Grosso modo, corresponde às iniciativas de "formação de públicos", incluindo grupos escolares, famílias, crianças e indivíduos que, por motivos sociais, econômicos ou culturais, estejam distantes do universo dos museus e exposições. Os formatos mais frequentes do discurso "reprodutivo" são as oficinas segmentadas de acordo com características dos públicos, as visitas guiadas às exposições e os programas destinados a pessoas com necessidades especiais, acrescidos por eventos dirigidos a grandes plateias, como jornadas especiais e "viradas culturais" (MÖRSCH, 2009, p. 9-10).

Com incidência bem menor aparece o discurso "desconstrutivo". Ligado à museologia crítica e aos seus desenvolvimentos a partir da década de 1960, sua ênfase recai no exame crítico - junto aos públicos - das dinâmicas dos museus e suas exposições, bem como dos processos educativos aí praticados, geralmente comprometidos com os cânones da arte e com as premissas da instituição que os chancela e difunde. Tal discurso parte do princípio de que museus, bienais e demais centros de exposição correspondem a dispositivos de distinção/exclusão e de construção de verdades. Além disso, apropria-se do potencial desconstrutivo inerente às estratégias artísticas, muitas vezes tomando-as como molas propulsoras de intervenções e performances em contextos expositivos, desencadeados por mediadores e artistas imbuídos do exercício da crítica institucional, envolvendo públicos convidados ou não (a performance de Andrea Fraser Museum Highlights: A Gallery Talk, acima relatada, representa um exemplo disso). Também fazem parte de suas iniciativas projetos com públicos identificados como excluídos ou discriminados pela instituição, além de visitas mediadas com foco na desnaturalização, relativização e crítica dos mecanismos de poder que garantem à instituição o estatuto de difusora privilegiada das manifestações das culturas tidas como legítimas (MÖRSCH, 2009, p. 10).

Ainda mais incomum, o discurso "transformativo" da mediação chama para si o desafio de ampliar e redirecionar o escopo de atuação da instituição artística, buscando apropriar-se dela com vistas a promover mudanças sociais. Interessante notar que essa modalidade de discurso arrisca uma inversão da tão propalada capacidade das instituições e suas exposições de transformar os públicos em termos de sensibilidade e conhecimento. Em vez disso, a instituição passa, ela própria, a ser alvo de processos de transformação, na medida em que é percebida como "orga- 
nização modificável”, para usar um termo de Mörsch. A lógica de fato se inverte, a ponto de a mediação e seus agentes relativizarem o compromisso de introduzir determinados segmentos do público ao mundo da arte - com tudo o que ele tem de autorreferente - para, em lugar disso, produzir na instituição fissuras através das quais ela possa se abrir ao mundo circundante e a seu ambiente social (MÖRSCH, 2009, p. 10-11).

Os discursos desconstrutivo e transformativo, como se pode notar, oferecem as perspectivas mais atinentes aos nossos propósitos. Parece-nos, inclusive, que eles podem ser lidos como complementares. Isso porque a disposição desconstrutiva procura "furar" o verniz institucional, trazendo à tona as suas contradições e hierarquias estruturantes. Desse modo, possibilita uma espécie de desmontagem conceitual das engrenagens enunciativas da instituição e, também, uma série de desvios no tradicional compromisso de introduzir e incluir o outro naquilo que alguns poucos decidiram ser o legítimo. Abre-se caminho, com isso, para o enfrentamento e, quiçá, a transformação dos próprios expedientes institucionais. Trabalhando pela chave negativa, a mediação se distrairia menos com os esforços de facilitação do acesso dos públicos àquilo que está dado por comissões de especialistas, para concentrar-se, junto com os públicos, naquilo que poderia vir a ser postulado coletivamente por qualquer um.

\subsection{LIMITAÇÕES FUNCIONAIS DA MEDIAÇÃO INSTITUCIONAL}

Como se tem buscado evidenciar no presente capítulo, o desenvolvimento de programas educativos em mediação depende, em larga medida, da estrutura funcional e organizacional das instituições artísticas às quais eles respondem e prestam contas. Logo, premissas ligadas ao organograma, à hierarquia, à burocracia e aos compromissos político-institucionais exercem influência direta (e, muitas vezes, pesada) nos planos traçados pelos profissionais envolvidos com tais programas.

Há, geralmente, pouco espaço para a criação de projetos de mediação que consigam contar com níveis efetivos de autonomia face às demandas e premências da instituição como um todo, normalmente relacionadas a:1) atendimento de públicos em larga escala, envolvendo o cumprimento de metas quantitativas; 2) vinculação com as exposições em cartaz, permanecendo sujeitos aos seus períodos de duração; 3) desempenho da posição de "linha de frente" na relação com os públicos, buscando cativar os visitantes para as exposições, garantindo, com isso, uma boa imagem para a instituição junto aos parceiros e à opinião pública; 4) tornar efetiva a tão anunciada função educativa da instituição, por meio de abordagens centradas na ideia de ensino-aprendizagem, na chave não formal; 5) elaboração de estratégias de inclusão e conexão dos públicos com os conteúdos expositivos; e 6) funcionamento como apêndice das curadorias das mostras, à guisa de um serviço de atendimento ao público.

Em tal dinâmica funcional, que setoriza e atribui ao programa educativo a função de um serviço, é comum que as ações estejam desarticuladas (e venham a reboque) das curadorias das mostras, desempenhando papel secun- 
dário e retardatário. A propósito disso, após uma sequência de visitas à 29a edição da Bienal de São Paulo, em 2010, o crítico e curador Simon Sheikh pondera acerca do que ele pôde notar do programa educativo da mostra: "A minha impressão é a de que a mediação é um adendo e não parte do layout curatorial e arquitetônico, da articulação da exposição" (SHEIKH, 2010). Além desse aspecto, Sheikh surpreende-se com as dimensões quantitativas do programa, destacando o número expressivo de mediadores (em sua maioria, estagiários) e a grande quantidade de estudantes atendidos por meio de visitas mediadas. Algumas questões são por ele levantadas em relação a isso:

O que significa então o encontro com a arte? O que significa trazer milhares de crianças em idade escolar para uma hora no Ibirapuera? [...] Qual é a responsabilidade social e o papel que pode ter a Bienal, além da representação das obras apresentadas? Por exemplo, o primeiro encontro que alguém tem com esta Bienal $\left(29^{a}\right)$ é através da barreira de segurança e detectores de metais. O que isso significa, se pensarmos no potencial de liberdade da arte [...]? (SHEIKH, 2010.)

A problematização de Sheikh elenca perguntas às quais um programa educativo não poderia se furtar e deixar de buscar respostas críticas, a não ser que realmente se limite a desempenhar o papel de adendo utilitário dentro da estrutura institucional, abrindo mão de pleitear outro tipo de presença e atuação.

\subsection{MEDIAÇÃO COMO COLABORAÇÃO}

Por outro lado, alusivas aos discursos desconstrutivo e transformativo identificados por Mörsch, haveria outras formas de a mediação se desenvolver, negociando com a instituição artística em bases que problematizem e desloquem suas premissas dominantes. É nessa direção que a educadora e mediadora Nora Landkammer defende uma natureza colaborativa para a mediação. Ela se refere, sobretudo, à possibilidade de atuações conjugadas e dialógicas entre a instituição artística e grupos, organizações e iniciativas do contexto onde ela está inserida, ligados, por exemplo, às práticas ativistas, educacionais, sindicais e sociais. Landkammer sintetiza a ideia de colaboração da seguinte forma:

[Trata-se] de uma relação entre duas ou mais entidades, que define os conteúdos do trabalho conjunto a partir dos interesses dos colaboradores envolvidos, diferentemente do conceito de participação, que supõe um centro, uma estrutura estabelecida, da qual "tomam parte" ou com a qual contribuem os que dela participam. [...] A participação se pensa a partir da instituição, enquanto a colaboração deve ser pensada a partir de pelo menos duas perspectivas. (LANDKAMMER, 2014, p. 25.) 
De saída, nota-se um tipo de atuação desvinculado da pretensa capacidade da instituição artística de transformar o outro a partir de repertórios pré-definidos como legítimos e dignos de apreensão. Essa colaboração se pautaria, de acordo com Landkammer, pela aprendizagem mútua (com a instituição também sendo convidada a aprender com outras entidades e com o outro) e pela construção distribuída do conhecimento - com as diferentes expectativas e agendas que lhe subjazem. A mediação, portanto, se desobrigaria da função prioritária de incluir o outro no mundo da arte, estimulando, em lugar disso, debates e usos (inclusive do mundo da arte e seus artefatos) vinculados às demandas das pessoas e organizações envolvidas nos projetos, sempre por meio da articulação de estruturas existentes, que são ressignificadas a cada nova interação.

Landkammer destaca que, ao serem convidadas a colaborar em determinado projeto, as pessoas não se limitam a representar as entidades ou organizações às quais estão previamente vinculadas, visto que são estimuladas a se colocar como cidadãos comprometidos e interessados no intercâmbio de informações e saberes relativos a determinados aspectos da vida social (LANDKAMMER, 2014, p. 27). Haveria aqui um ponto de contato com a noção do extrainstitucional, ao se pensar atuações que oscilem entre os estatutos da pessoa física e da pessoa jurídica, entre as demandas pessoais e comunitárias e os compromissos institucionais.

Landkammer exemplifica essa lógica colaborativa da mediação referindo-se a um dos projetos integrantes do programa pedagógico da Documenta 12, dirigido por Mörsch. Trata-se do Comitê Assessor, formado por pessoas e organizações de diversos campos sociais e profissionais, todas elas da cidade de Kassel. A moderação das atividades do comitê coube tanto à Documenta, na figura de Wanda Wieczorek, como ao Centro Schlachthof ${ }^{22}$, na figura de Ayse Güleç. A partir dessa vinculação foram convidadas a colaborar pessoas envolvidas com educação formal e não formal, agentes sociais, sindicalistas, urbanistas, ativistas políticos e mulheres engajadas em iniciativas de gênero. Também se envolveram nas atividades artistas que estariam representados na Documenta e os curadores da mostra, Roger Buergel e Ruth Noack (LANDKAMMER, 2014, p. 25-26).

O escopo de atuação do Comitê - que se formou e passou a atuar com um ano e meio de antecedência da inauguração da exposição - correspondeu ao trabalho de relacionar a Documenta com as demandas e conflitos do contexto local para, a partir disso, realizar atividades antes e durante o período da mostra. O cruzamento das problemáticas locais com a Documenta se deu pela apropriação e modulação dos motes indagativos que nortearam a curadoria geral da mostra: "A modernidade é nossa antiguidade?”; “O que é a vida nua?”; e “O que fazer?” (LANDKAMMER, 2014, p. 26).

Observemos alguns exemplos de iniciativas disparadas pelo Comitê. Sabe-se que Kassel foi uma cidade industrial e que o desmantelamento de seu com-

22 Sediada em Kassel, a organização possui larga trajetória nas áreas educacional, social e cultural. 
plexo de indústrias provocou um alto índice de desemprego na região. Como aponta Landkammer, o mote curatorial acerca da modernidade como nossa antiguidade pareceu ter especial relevância nesse contexto, configurando aí uma plataforma discursiva onde

pessoas sem trabalho remunerado estabeleceram um fórum para discutir a crise no universo do trabalho. A articulação com a exposição permitiu abrir um debate que transcendeu o plano da busca de trabalho individual ou o estado do desemprego, para discutir as estruturas de emprego, desemprego e educação na sociedade, mediado pelos principais entendedores dessa matéria, ou seja, as pessoas que naquele momento se encontravam sem emprego remunerado. (LANDKAMMER, 2014, p. 26.)

Outra iniciativa do comitê foi a Tenda da educação, uma espécie de estação onde foram debatidas durante o período da mostra questões relativas ao tipo de educação e à exclusão a que os imigrantes vinham sendo submetidos. Em outra ação, que inclusive ocorreu de forma espontânea e fora do plano do Comitê, foram mapeados espaços públicos não utilizados na cidade, para na sequência serem sinalizados e terem o seu uso estimulado mediante uma série de atividades. Nesse caso, criou-se um interessante embaralhamento entre as atividades que integravam oficialmente a Documenta e as não oficiais, denotando "tipos de redes imprevisíveis e incontroláveis onde se encontra o potencial do modelo de colaboração" (LANDKAMMER, 2014, p. 27).

Entretanto, ao mesmo tempo que tal mobilização coletiva e local se desdobrou em uma série de atividades pautadas pelos interesses dos colaboradores do comitê, ensejando importantes discussões no âmbito da cidade de Kassel, ela também multiplicou a abrangência da Documenta em termos quantitativos, beneficiando a instituição e sua imagem: o número de visitantes locais da Documenta 12 aumentou 50\% em relação às edições anteriores. Apesar disso, os projetos realizados pelo comitê contaram com poucos recursos, o que significa que boa parte dos envolvidos foi pouco, ou nada, remunerado. Sobre esses aspectos, Landkammer pondera:

Dessa maneira se faz visível uma das principais tensões na colaboração entre instituições de arte de grande capital simbólico e iniciativas e organizações menos visíveis. Especialmente em tempos de capitalismo cognitivo/ sociedade do conhecimento, se faz imprecisa a distinção entre uma colaboração com benefícios mútuos e a exploração dos conhecimentos [e da presença] dos públicos envolvidos. (LANDKAMMER, 2014, p. 28.)

Apesar dos deslocamentos possibilitados pela lógica colaborativa no campo da mediação institucional, ainda assim nos deparamos com a instrumenta- 
lização rondando os públicos, nesse caso, públicos-colaboradores. O enfrentamento de tal contradição, segundo Wieczorek, Güleç e Mörsch, pressupõe o compromisso com

um debate transparente e aberto, antes de mergulhar no projeto, sobre os interesses de todas as pessoas implicadas, sobre os possíveis beneficios e sobre o tipo de trabalho que se inicia. Ao mesmo tempo, é necessário garantir um mecanismo de reflexão para voltar ao tema durante o projeto e poder assegurar que os interesses não apenas se enunciem, mas que se realizem realmente durante o processo. Igual grau de transparência é necessário em relação aos recursos materiais disponíveis para um projeto.

(LANDKAMMER, 2014, p. 29.)

O que está em jogo, não só aqui, mas em todas as ofertas institucionais, é a problemática dos públicos enquanto sujeitos cientes da sua posição em relação às situações e aos objetos em pauta. Isso quer dizer que cabe aos agentes vinculados às instituições artísticas a responsabilidade por fazer desse "contrato" algo transparente, de modo que os interesses e agendas em jogo estejam sobre a mesa. Apenas desse modo é possível pensar em colaborações efetivas, nas quais as pessoas se envolvam a partir de uma decisão pessoal e intransferível.

\subsection{MEDIAÇÃO COMO PRÁTICA ARTÍSTICA, PRÁTICAARTÍSTICA COMO MEDIAÇÃO}

Outra forma de a mediação cultural interagir com as políticas institucionais, buscando ressignificá-las, parte do vislumbre de uma "porta de entrada" pela produção artística em si. Ou seja, a partir de trajetórias e proposições de artistas que incorporam, de diferentes maneiras, a mediação com públicos como lógica constitutiva e intrínseca aos seus processos.

Nesses casos, a mediação não é tratada como instância pedagógica justaposta ou acoplada aos trabalhos artísticos posteriormente à sua formalização e extroversão - como meio de aproximar os públicos de suas formas e conteúdos forjados de antemão -, mas, ao contrário, como algo que ocorre por dentro e durante seus desdobramentos no tempo, de modo entranhado, como parte integrante e decisiva dos processos neles implicados. Com isso, aposta-se na possibilidade de produções discursivas compartilhadas e distribuídas com o outro (seja ele iniciado ou não nas linguagens da arte contemporânea), buscando criar dispositivos e condições para a formação de pequenas esferas públicas temporárias.

Dentre os exemplos dessa prática artístico-mediativa, podemos observar uma proposição em curso do artista Jorge Menna Barreto, iniciada em 2008, intitu- 
lada Café Educativo ${ }^{23}$. Aqui o artista percebe o contexto expositivo como um campo repleto de vetores mediativos - um "campo social” na ótica de Simon Sheikh - que abrange desde o edificio e a arquitetura que abriga a exposição até a curadoria, com suas obras, a expografia, as estratégias de comunicação visual, os textos de parede e todo o pessoal dedicado à recepção dos públicos, incluindo os integrantes do programa educativo da instituição. O Café Educativo funcionaria, de acordo com a expressão do artista, como um "nó entre" todos esses vetores, priorizando a relação com os públicos visitantes. Esse nó seria formado pelo

ambiente de um Café em um espaço expositivo, [onde o] atendente é também um educador. [...] [Trata-se de] uma ilha de mediação espontânea, onde se encontram jornais, revistas, materiais relacionados à exposição e também outros. [...] [Ele] é reconfigurado a cada vez que é montado, a partir de uma malha de conversas entre a curadoria, o educativo, a arquitetura (expografia), as obras e $\mathrm{o}$ artista.

(MENNA BARRETO, 2014, p. 218.)

Caberia retomar aqui, a título de cotejo, o comentário de Sheikh acerca do programa educativo da 29a Bienal de São Paulo, que lhe pareceu "um adendo e não parte do layout curatorial e arquitetônico, da articulação da exposição" (SHEIKH, 2010). Na proposição de Menna Barreto, esse layout não apenas recebe e incorpora o ambiente do Café, como também é por ele afetado, na medida em que o ambiente onde os visitantes se dão um tempo para o "cafezinho", inserido justamente no meio do espaço expositivo, funciona como "um dispositivo de desaceleração do tempo do público", criando condições para momentos "de insights, elaborações e metabolizações daquilo que foi visto ou experienciado em uma mostra" (MENNA BARRETO, 2014, p. 219).

Outro cotejo útil seria com a arregimentação dos públicos, visto que o Café Educativo, em lugar disso, busca propiciar "encontros de grupos que se auto-organizam”, como indica Sheikh a respeito da proposição de Menna Barreto. Ainda segundo o crítico, em situações como a do Café as pessoas e grupos "não são obrigados a agir como representantes de uma posição fixa, podendo ser autossustentados; [...] o princípio, portanto, é o da autoeducação". Haveria nisso margem suficiente para iniciativas relacionadas à produção de enunciados e intercâmbios tanto acerca de aspectos da exposição como sobre temas que a extrapolem (SHEIKH, 2010).

23 Entre outros, o Café Educativo já foi montado nos seguintes contextos: projeto Arte e Esfera Pública, no Centro Cultural São Paulo (2008); $32^{\circ}$ Panorama da Arte Brasileira, no MAM-SP (2011); projeto Arte e Gastronomia, no MAM-SP (2012); exposição Campo neutral, no Museu da Gravura da Cidade de Curitiba (2014); exposição Vestígios, no MAM-SP (2014); e em School of Missing Studies, Turning a Blind Eye, na $31^{\mathrm{a}}$ Bienal de São Paulo (2014). 
Sobre a ideia de ressignificação das políticas institucionais, destaca-se o fato de o Café Educativo ter sido adquirido pelo MAM-SP, em 2011, para compor o seu acervo de obras. O processo de aquisição efetivou-se após nove meses de conversas do artista com a curadoria, o programa educativo e os profissionais ligados ao acervo da instituição, no sentido de chegarem a um acordo sobre as condições de incorporação do projeto à coleção, visto que "não existe uma obra material em questão", conforme esclarece o artista (MENNA BARRETO, 2014, p. 218).

Temos, nesse caso, um exemplo de alargamento duplo no escopo institucional: em primeiro lugar, a invenção de uma plataforma alternativa de mediação cultural; em segundo, a necessidade deparada pela instituição no que toca à reelaboração de alguns de seus critérios de aquisição de obras de arte. Importa frisar que, ao produzir essa outra passagem para a mediação (lembremos aqui do movimento em zigue-zague), o artista tem podido experimentar situações de interação com os públicos através de um dispositivo que passa ao largo das demandas institucionais de arregimentação, organização e atendimento de visitantes em larga escala.

\subsection{DISSIMULAÇÃO DA IDEOLOGIA EM IDEALISMO}

Antes de encerrarmos este capítulo, e para reiterar a atenção ao caráter ambíguo dos processos de interação com públicos - em que a instrumentalização do outro parece estar sempre rondando as ações institucionais -, seria útil podermos contar com um crivo de verificação constante da dimensão ideológica presente nas noções e formas de mediação cultural. Acreditamos que as práticas ligadas tanto à mediação institucional e à mediação extrainstitucional como à mediação como colaboração e também à mediação como prática artística poderiam ser constantemente analisadas mediante o uso desse crivo.

A lógica intrínseca a esse crivo será emprestada de uma análise crítica realizada por Diniz acerca das ações artísticas do Grupo GIA ${ }^{24}$, que tem na interação com públicos no espaço urbano o seu principal eixo de atuação. As ponderações de Diniz repercutem as preocupações de Mörsch acerca da ideologia neoliberal e sua capacidade de apropriar-se de aspectos da subjetividade muitas vezes decisivos nos processos artísticos e mediativos, tais como: criatividade, flexibilidade, comunicabilidade, resiliência, sociabilidade e espírito de grupo.

Notam-se pelo menos quatro paralelos entre as intervenções do GIA e as iniciativas predominantes da mediação cultural em contextos institucionais. $\mathrm{O}$ primeiro deles, mais evidente, seria o fato de ambas buscarem fomentar situações coletivas em que as pessoas interajam, refletindo um "dese-

24 O Grupo de Interferência Ambiental (GIA) é um coletivo artístico que, segundo seus integrantes, foge a qualquer tentativa de definição. Sediado em Salvador (BA), é formado por artistas visuais, designers, arte-educadores e músicos, e tem como principal interesse as práticas relacionadas à arte e ao espaço público. Mais informações podem ser encontradas no blog <http://giabahia.blogspot. com.br/p/o-que-e-o-gia.html>. Acesso em: 16 jul. 2016. 
jo de convivência e de promoção de momentos de sociabilidade", nas palavras de Diniz. O segundo paralelo diz respeito a uma espécie de proatividade no sentido de proporcionar ao outro situações "positivas e criativas”. Já o terceiro refere-se à crença no poder que a arte teria de transformar o indivíduo, muitas vezes movida pela fantasia de que "a transformação ampliada do social decorrerá da mudança individual, da conscientização de cada cidadão”. Finalmente, o quarto paralelo estaria ligado a uma combinação entre abnegação, boa vontade e inclinação voluntária, ambas associadas à precariedade das condições materiais e profissionais que comumente caracterizam tanto a atuação de parte significativa dos coletivos artísticos quanto dos mediadores ligados às instituições artísticas (DINIZ, 2011, p. 34-39).

Um exemplo de ação do GIA em que tais valores comparecem é a intervenção Pic-nic (2005), na qual o grupo sugere: "Arranje uma toalha de mesa quadriculada, monte uma cesta de pic-nic com produtos que você conseguir encontrar. Em uma praça do centro de sua cidade, estique a toalha, coloque a cesta no centro e observe as reações" (texto extraído do portfólio do grupo acessível em seu blog).

Diniz chama atenção para o fato de que essa e outras intervenções do GIA operam mediante a "negação das [suas] implicações macropolíticas e sociais", cultivando, em vez disso, um modelo de infiltração no cotidiano da cidade "desobrigado" de um debate efetivamente sistêmico e capaz de confrontar os instituidores - governos e corporações - e suas engrenagens. Inclusive no que se refere às incumbências transferidas ao ter ceiro setor da sociedade, a sociedade civil (incluindo aí artistas e mediadores): a transformação moral dos sujeitos, tendo a cultura e a arte como instrumentos da tarefa de "mudar o indivíduo para depois mudar a sociedade”, com tudo o que essa fórmula tem de problemática.

A essa delegação à arte (e à mediação) de comprometer-se com uma atuação transformadora do indivíduo corresponde diretamente o escapismo dos agentes políticos e econômicos de suas urgentes responsabilidades. Ao transferir compromissos de natureza sociopolítica e socioeconômica, em termos macro, para as esferas individual, subjetiva e moral, tais instituidores não só instrumentalizam o que poderia vir a ser a potência das proposições artísticas e mediativas, como também desviam habilmente o foco daquilo que são as suas irresponsabilidades.

Logo, o engodo estaria justamente em nos imbuirmos da tarefa de buscar transformar o outro por meio dos dispositivos da arte enquanto a transformação da realidade social passa, necessariamente, por intervenções estruturais de ordem econômica, política, social e cultural, que impactariam justamente nos privilégios desses mesmos instituidores em frentes como: radicalização da democracia, redistribuição da renda, revolução do sistema educacional, taxação das grandes riquezas, desprivatização dos espaços públicos, demarcação das terras indígenas, reforma agrária, direito universal a moradia, democracia cultural e descarbonização do planeta, para ficarmos em alguns exemplos-chave. A dinâmica enganosa de transformação moral e pessoal do outro deve ser, portanto, permanentemente problematizada: 
[É necessário] suscitar um olhar para o que há de ideológico nesses trabalhos [do GIA, mas também da mediação institucional]. E para o que há de ideológico, genericamente, no conjunto de experimentos relacionais que, assumindo uma postura moral e proativa diante da realidade, às vezes terminam por, contraditoriamente, dissimular ideologia em idealismo. (DINIZ, 2011, p. 41.)

Teríamos aqui, portanto, um crivo a subsidiar as reflexões nos campos da arte e da mediação, no sentido de nos mantermos à espreita dos processos neoliberais de apropriação e instrumentalização das ações dos artistas e mediadores, tornando claro que as boas intenções e os idealismos nunca bastam por si sós. Aliás, voluntariar-se a "construir um mundo melhor" pode facilmente servir apenas para mantê-lo do jeito como ele está. Logo, caberia à arte e à mediação furtar-se a essa responsabilidade impingida pelas esferas de poder, recusando-se assim a "reificar a ideologia dominante do tipo 'Faça Parte' ou 'Criança Esperança', [para em lugar disso] traçar horizontes para uma subjetividade eminentemente libertária” (DINIZ, 2011, p. 37).

Como procuramos argumentar ao longo do capítulo, frustrar certas expectativas em torno da mediação cultural apresenta-se, inversamente, como sua condição de potência, uma espécie de chave negativa e antídoto contra a sua captura por instâncias de poder contrárias a suas reais possibilidades de intervenção no quadro institucional da arte e, mais amplamente, no campo cultural. 


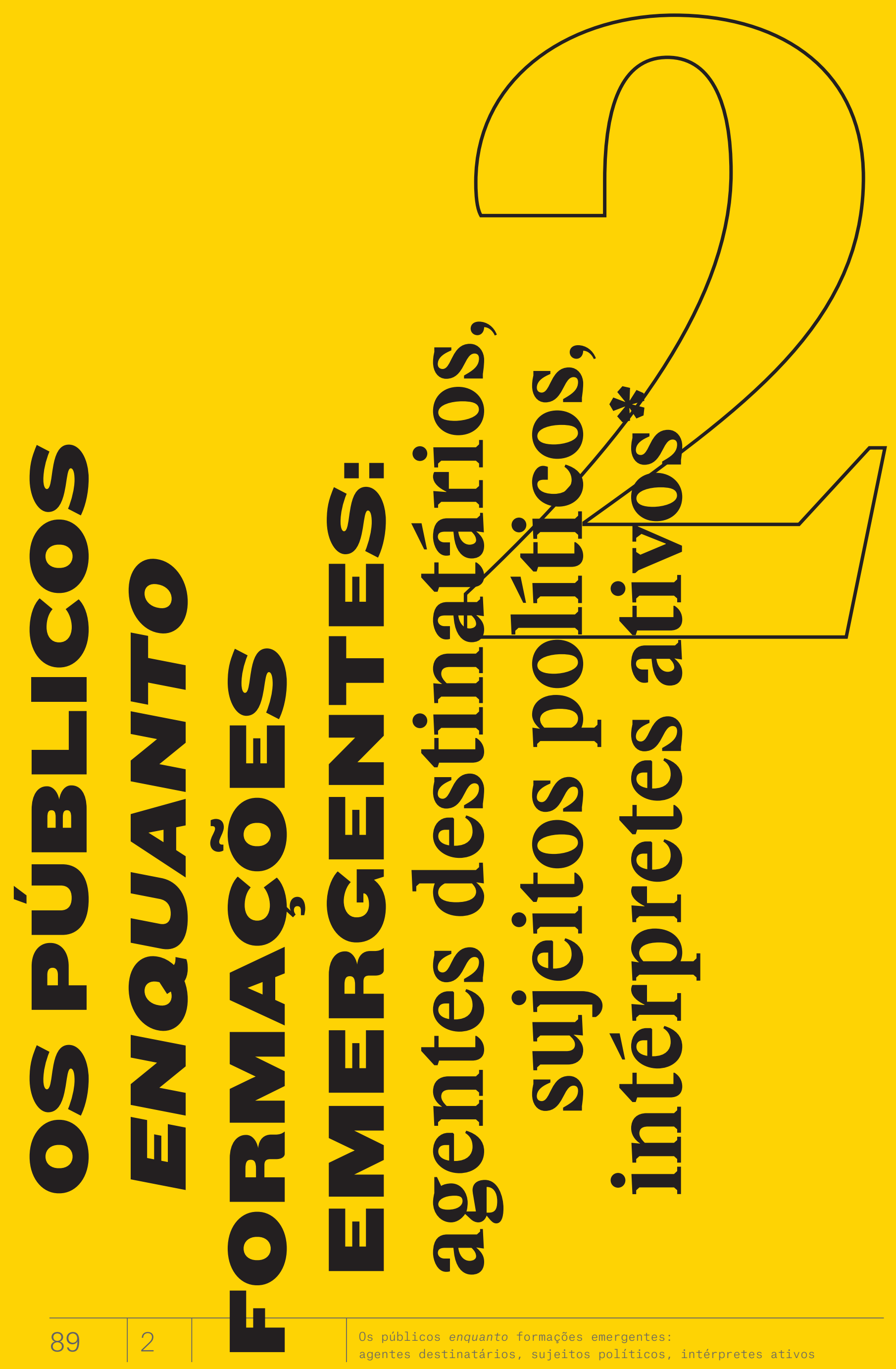


O objeto que eu leio é fundado apenas pela minha intenção de ler.

- ROLAND BARTHES 
O presente capítulo constitui-se como uma espécie de inventário dos regimes de recepção e interação dos públicos com as práticas artísticas representativas do campo das artes visuais, levando em conta as intermediações institucionais aí em jogo. Desse levantamento, busca-se derivar uma análise crítica das diferentes modalidades de endereçamento concebidas por artistas e curadores em relação aos públicos de seus discursos, assim como dos modos dominantes empregados pelas instituições artísticas para se dirigir aos seus "públicos-alvo", sobretudo através de seus programas educativos.

Esse endereçamento é aqui entendido como um duplo movimento de concepção e publicização dos trabalhos artísticos e curatoriais, bem como das ações de promoção artístico-cultural praticadas pelas instituições mediante estratégias de mediação. Partimos da compreensão de que tais endereçamentos imaginam, produzem e procuram conduzir, de diferentes formas, a conduta e a percepção daqueles que venham a se tornar seus públicos. Ao lidar com essa problemática, propomos a formulação de uma chave de leitura não coincidente à lógica hegemônica que, como veremos, concebe esses públicos - em diferentes níveis - como entidades antecipáveis, classificáveis, inexperientes, passivas ou culturalmente deficitárias, todas elas atreladas ao princípio da "objetivação do sujeito”, conforme formulação emprestada do filósofo Michel Foucault (1995, p. 231). Numa perspectiva que se pretende alternativa a esse modelo, os públicos são aqui concebidos como formações emergentes de sujeitos políticos, reativos aos processos de enquadramento e gestão que buscam mobilizá-los e conduzir suas ações e/ou percepções. O que buscamos evidenciar, portanto, não é a atuação de sujeitos supostamente instituintes, mas os embates dos indivíduos e grupos em meio a relações de poder e comunicação que, ao identificá-los e endereçá-los, os tornam sujeitos e alvos de proposições.

Referimo-nos, em particular, aos públicos compreendidos como sujeitos em relação às ações institucionais e às práticas artísticas. A propósito, há em Foucault uma dupla acepção para a condição do sujeito: “[1] sujeito a alguém pelo controle e dependência, e [2] preso à sua própria identidade”. É, sobretudo, à segunda acepção que nos referimos, em atenção a atos desviantes e de resistência que questionam a própria identidade atribuída ao sujeito, por meio de afirmações (discursivas e comportamentais) do direito de ser diferente daquilo que dele se espera (FOUCAULT, 1995, p. 235). Procura-se, portanto, trazer à tona ocorrências em que o sujeito, no papel de público das práticas artísticas e das ofertas institucionais, eventualmente escapa às cunhagens identitárias e às respectivas posições que lhe são atribuídas, produzindo imaginários imprevisíveis, em alguns casos disruptivos e conflitivos.

O exame em torno dessas questões buscará estabelecer, entre outras relações, vínculos com as operações da mediação cultural, entendida como instância de atuação pedagógica situada nas zonas de encontro entre as ofertas artístico-culturais das instituições com foco nas artes visuais e a recepção e interação por parte de seus públicos: visitantes que frequentam programas expositivos e educativos geralmente comprometidos com os princípios da democratização cultural. Nessa interseção, complexificando-a, nota- 
-se que também as práticas artísticas e curatoriais trazem consigo pressuposições e expectativas com relação aos seus modos de apropriação pelos públicos. O que se pretende, então, é problematizar uma "racionalidade específica” - ainda que múltipla em suas formulações e propósitos - que busca antecipar a conduta e a percepção dos públicos, estruturando as formas de identificá-los e endereçá-los, na medida em que predefine seus modos possíveis de interação (FOUCAULT, 1995, p. 233).

A abordagem acerca dessa racionalidade - e ao mesmo tempo em contraposição a ela - será elaborada mediante avizinhamentos e cruzamentos de análises de autores que, a partir de diferentes pontos de vista, refletem sobre as dinâmicas de endereçamento e recepção simbólica. Incluem-se situações que exemplificam a atuação dos públicos, aqui percebidos, entre outras posições, como agentes destinatários, ou seja, personagens sociais que se posicionam em torno de certos discursos a partir de demandas específicas - não antecipáveis e, menos ainda, controláveis por quem os enuncia ou difunde.

Tal análise estrutura-se em dois vetores entrecruzados: a) elaborações teóricas acerca de como os públicos interagem com/e se apropriam das práticas e discursos artísticos e institucionais; b) ocorrências que dão a ver como emergem respostas dos públicos a tais práticas e discursos; chamando atenção, inclusive, para a omissão dessas ocorrências por certos autores e agentes que, embora comprometidos com a esfera da recepção artística, deixam de registrar, evidenciar e discutir as reações dos públicos em sua singularidade, concretude e imprevisibilidade, negando-lhes os desdobramentos (não raro problemáticos e conflitivos) que poderiam produzir nos âmbitos artístico e institucional.

Ensejando dobras reflexivas, os textos aqui em tela funcionam como discursividades geradoras do seu próprio público, proporcionando subsídios a um exercício teórico vinculado aos anseios e às urgências daquele que os lê e que, ao mesmo tempo, busca acrescentar contribuições à referida discussão. Prova disso é o fato de que eu venha me dedicando a eles, fazendo-me público dos seus enunciados e ideias, de modo a tomar parte nos seus processos de circulação e reportar-me a eles para desenvolver a presente análise. Desse modo, é possível afirmar que, não apenas este capítulo, mas a dissertação como um todo resulta do trabalho de um agente destinatário que, aqui, mobiliza-se para assumir, de forma dinâmica e alternada, o papel ora de leitor ora de enunciador. Consequentemente, um leitor-enunciador que, além de retomar conceitos desenvolvidos pelos autores escolhidos e comentados, vai criando outros, incluindo este que serve para designar a posição do "agente destinatário”. Ou seja, daquele que, enquanto agente, se faz destinatário de discursos que lhe atraem e interessam.

Dito isso, serão aqui comentadas e cotejadas as análises de Michel de Certeau ( $A$ invenção do cotidiano - 1. Artes do fazer), Marcel Duchamp ("O ato criador”), Simon Sheikh ("Sobre a produção de públicos ou arte e política em um mundo fragmentado”), Michael Warner (Públicos e contrapúblicos), Jacques Rancière ( $O$ espectador emancipado), Julio Plaza ("Arte e interatividade: autor-obra-recepção”), Cayo Honorato (“Arte para o público: 
comédia ou tragédia da mediação"; "Educação perguntadora”; "Mediação na arte contemporânea: posições entre sistemas de valores adversos"; e "Dos 'públicos no plural' a uma pluralidade das concepções de públicos”), Nicolas Bourriaud (Estética relacional), Denise Grinspum ("Mediação em museus e em exposições: espaços de aprendizagem sobre arte e seu sistema”), Giorgio Agamben (Profanações), Roland Barthes (O rumor da língua), Walter Benjamin (“O autor como produtor”), Claire Bishop ("Antagonismo e estética relacional”) e Néstor García Canclini (A sociedade sem relato). É possível afirmar que esse conjunto de textos, em relação a tantos outros, conforma uma esfera pública de debate em torno das formas de recepção e interação dos públicos com as práticas artísticas e com as ofertas institucionais, a partir da qual a presente reflexão busca tomar posição. Ou seja, trata-se de uma comunidade dinâmica de enunciadores e leitores, que vão se alternando entre esses papéis, e cuja existência no tempo depende de atenção, leitura e enunciação. Aqui estamos.

Devemos destacar, ainda, que a pensabilidade desse campo de problemas estará perpassada pela crítica de Foucault presente no texto "O sujeito e o poder", com foco no exercício do poder e, por conseguinte, na constituição do próprio sujeito. Interessa-nos aquilo que o pensador designa como uma "nova economia das relações de poder", ancorada na empiria dos acontecimentos e em aspectos do presente imediato. Nesse registro, caberá investigar os modos como o poder é exercido em contextos e temporalidades específicos, identificando, por outro lado, as formas de resistência manifestas pelo sujeito - entendido como entidade em permanente tensão e conflito com os enquadramentos identitários e comportamentais a ele atribuídos por diferentes instâncias de poder. Com isso, tende a evidenciar-se todo um campo de forças, provocações e disputas em constante vigência (FOUCAULT, 1995, p. 234, 242).

Trata-se, portanto, de analisar as relações de poder, assim como as relações de comunicação a elas associadas, e não um poder absoluto, já que essas relações são parte constitutiva e inescapável do nexo social. Isso pressupõe a constatação de que "viver em sociedade é, de qualquer maneira, viver de modo que seja possível a alguns agirem sobre a ação dos outros" (FOUCAULT, 1995, p. 242, 245-246). Partindo desse dado, é possível considerar os atos de resistência ou desvio como elementos capazes de revelar diferentes formas de exercício do poder, na medida em que essa mesma relação abre "um campo de respostas, reações, efeitos, invenções possíveis”, que por sua vez reendereçam e confrontam os agentes que exercem tal poder, desfazendo sua pretensa naturalidade (FOUCAULT, 1995, p. 243). Foucault chega a dizer que tais reações do sujeito funcionam como "um catalisador químico", por meio do qual são desnudadas as relações de poder implicadas nas interações sociais. Essa face responsiva representa o foco principal da nossa reflexão. Procuraremos sondá-la justamente nas ocasiões em que os públicos se relacionam com iniciativas artísticas e institucionais. Em outros termos, pretendemos "analisar as relações de poder através do antagonismo" colocado em prática pelos públicos (FOUCAULT, 1995, p. 234). 
Deste ponto em diante, o leitor encontrará uma sequência de marcos conceituais interligados a partir de uma abordagem que procura produzir convergências e paralelos, mas também confrontos e descontinuidades entre as análises dos autores mencionados, e entre elas e outros registros provindos dos campos social, artístico e institucional.

\subsection{CONDUC̣̃̃O DOS PÚBLICOS}

Associada às iniciativas pedagógicas desenvolvidas pelos núcleos educativos de instituições artísticas como museus, bienais e centros culturais, a mediação de exposições a cargo de tais núcleos desenvolve-se em geral a partir (e em função) dos objetos semânticos integrantes dos contextos expositivos: não apenas os trabalhos de arte, mas também os discursos curatoriais e as políticas institucionais que articulam e colocam os trabalhos dos artistas na cena pública. Nesse caso, cabe observar que a mediação envolve, no mínimo, cinco instâncias que se inter-relacionam: os trabalhos de arte, os discursos curatoriais, as políticas institucionais, os públicos e os próprios agentes da mediação, com estes últimos geralmente assumindo o papel de estimular e subsidiar - mediante o uso de uma gama de instrumentos e metodologias - a fruição de objetos e experiências de caráter artístico pelos visitantes.

Entretanto, nessa composição encontra-se normalmente pressuposta uma série de compromissos e expectativas pedagógico-institucionais, associados a critérios como: a democratização dos bens culturais; a noção de arte para o público; a segmentação dos públicos mediante critérios abstratos e generalizantes; e a recepção artística modulada e conduzida por narrativas e modelos hegemônicos. Num excerto já destacado no capítulo anterior, Honorato sintetiza esse conjunto de pressuposições:

É como se essa mediação soubesse de antemão o que falta ao público, de modo que seu trabalho é providenciar o que lhe falta, aquilo de que ela dispõe. Para isso, no entanto, ela precisa confirmar a existência do público como privado de arte, de consciência, de experiência etc. Eis o seu paradoxo: ela vive, por assim dizer, do déficit que imputa ao público. (HONORATO, 2011, p. 345, grifos meus.)

Quanto à designação de certos públicos como entidades deficitárias, trata-se de uma estratégia de gestão que os perfila de acordo com as políticas e ofertas institucionais. Centradas naquilo que são as commodities da instituição, ou seja, o arsenal de conhecimentos em arte - assim como seus mecanismos de legitimação - que ela tem a oferecer aos públicos, essas ofertas (desde as exposições até os programas educativos) são apresentadas como capazes de dirimir, pouco a pouco, essa condição de falta e de pouca familiaridade com as questões da arte, principalmente da arte contemporânea, que identificaria parte de seus visitantes. Tal lógica pode ser notada no discurso da arte-educadora Denise Grinspum: 
[...] poderíamos entender a aprendizagem sobre o sistema da arte como um processo com meios próprios de existência [...], que se dá na experiência de visitação assídua em que, progressivamente, [os públicos] conhecem os mecanismos que outorgam aos objetos ou ações o status de "ser arte". (GRINSPUM, 2014, p. 279-280.)

Depreende-se do comentário de Grinspum que o que está em jogo é a oportunidade de aprendizagem e reconhecimento, pelos públicos, daquilo que artistas, curadores, mediadores e instituições designam como arte. Para alcançar o entendimento dos critérios desse sistema de valoração e legitimação se faz necessário que pessoas comumente alijadas dos contextos artístico-institucionais se reconheçam como retardatárias ou alheias em relação às questões da arte contemporânea, devendo “correr atrás” para sanar o tempo perdido e o alheamento acerca dessas problemáticas, sendo para isso auxiliadas/orientadas pelos agentes da mediação institucional. Ou seja, para poder participar da esfera da arte, antes de tudo elas teriam de reconhecer seu próprio "déficit". Nesse quesito, retomemos a definição de sujeito em Foucault, como aquele que se encontra "preso à sua própria identidade”, acrescentando que tal operação se efetiva na medida em que uma identidade atribuída por terceiros é incorporada pela “consciência ou autoconhecimento" desse mesmo sujeito (FOUCAULT, 1995, p. 235).

Em evidente sintonia com o pensamento de Foucault, o filósofo e educador Jorge Larrosa dirá que "é no momento em que se objetivam certos aspectos do humano que se torna possível a manipulação técnica institucionalizada dos indivíduos” (LARROSA, 2002, p. 52, grifo meu). Ao subsumir os indivíduos à posição de "deficitários" e, portanto, alheios ao sistema de valores e critérios da arte contemporânea, os agentes institucionais autorizam-se a gerir e a suprir, do modo que entendem ser o mais adequado, essa falta que definiria o outro, o não iniciado, nas linguagens e problemáticas das artes visuais.

No discurso corrente da mediação institucional, principalmente na vertente da educação para o patrimônio, outro aspecto que se tem naturalizado é um tipo de "atendimento organizado a segmentos específicos de público, classificados como escolas, famílias, idosos, ou mesmo grupos espontâneos” (GRINSPUM, 2014, p. 273-274). Tais segmentos figuram como públicos-alvo das ações institucionais. É a partir desse mecanismo classificatório, apriorístico e abstrato que os programas educativos se estruturam e desenvolvem suas diferentes frentes de atração e atendimento de visitantes.

Portanto, o que temos é uma classificação em nível duplo: não bastando identificar aqueles que careceriam de familiaridade com as questões e linguagens da arte, haveria, ainda, a necessidade de elencá-los e agrupá-los a partir de aspectos (genericamente) comuns, como o fato de pertencerem a determinada faixa etária ou de provirem dos contextos escolar ou familiar, por exemplo. Grinspum dirá, nesse sentido, que tais públicos "busca[m] visitas monitoradas nos museus, geralmente porque sen- 
te[m] necessidade de mediação para melhor compreender as exposições" (GRINSPUM, 2000, p. 47).

Assumindo-se como um serviço de atendimento ao público, a mediação institucional faz da referida segmentação uma ferramenta hábil em "conduzir condutas" (FOUCAULT, 1995, p. 244). Ao categorizar o indivíduo, "marca-o com sua própria individualidade”. É isso que permite manter o outro, o não iniciado, preso à identidade do leigo. Operando desse modo, a mediação, ainda que talvez não se dê conta, "impõe-lhe uma lei de verdade", uma injunção voltada à iniciação do sujeito no promissor mundo da arte. Institui-se aí um tipo de relação entre os indivíduos e entre grupos no qual "alguns exercem um poder sobre os outros" (FOUCAULT, 1995, p. 240). Estamos falando de um exercício diretamente ligado "ao saber, à competência e à qualificação”, o que implica ações respaldadas pelos "privilégios do saber" (FOUCAULT, 1995, p. 235).

É como se essa prerrogativa conferisse a determinados indivíduos e grupos a credencial para agir não exatamente sobre os outros, mas sobre suas ações e condutas. Nesse sentido, Foucault dirá que "o termo 'conduta' [...] talvez seja um daqueles que melhor permite atingir aquilo que há de específico nas relações de poder. A 'conduta' é, ao mesmo tempo, o ato de 'conduzir' os outros [...] e a maneira de se comportar num campo mais ou menos aberto de possibilidades" (FOUCAULT, 1995, p. 243244). Isso quer dizer que tal noção abarca tanto os movimentos daqueles que exercem o poder como as reações e respostas daqueles que são a ele submetidos.

Nessa mesma linha de raciocínio, Larrosa pontua que "o poder é uma ação sobre ações possíveis” (LARROSA, 2002, p. 78). Daí que, atenta aos variados (e abstratos) perfis de visitantes, assim como aos diferentes riscos que possam representar aos bens em exibição, a mediação chame para si a função de a eles informar "como se comportar no cenário museal, onde se impõem atitudes como ‘não correr e não comer' nas salas de exposições e "não tocar nas obras"' (GRINSPUM, 2014, p. 274, grifo meu).

Em complemento e ainda conforme Grinspum, a mediação institucional ocupa-se do desenvolvimento de tipologias de "visitas monitoradas" destinadas a segmentos específicos de público, priorizando entre os "métodos de interpretação" aqueles "que propiciam melhor aprendizagem e aproveitamento". São eles: "visita-palestra”, “discussão dirigida” e "descoberta orientada". Note-se que em cada um dos casos a premissa da conduta da vivência e da percepção se faz presente na própria nomenclatura, por meio dos termos "palestra", “dirigida” e "orientada". Na primeira modalidade, a ênfase da abordagem reside na explanação do mediador, que se move de maneira dinâmica entre as obras "para prender mais a atenção dos visitantes”, sempre estimulando "o grupo a se manter unido”. A segunda estaria pautada no diálogo entre visitantes e mediador, que por sua vez "deve dirigir suas questões [ao grupo] e controlar a discussão para não se perder dos seus objetivos” - definidos de antemão pelo mediador e, frequentemente, à revelia de questões emergentes e desviantes que possam surgir no tempo da visita. Já na terceira, o mediador "oferece atividades estruturadas permitindo que os visitantes 
determinem o roteiro de visitação". Cabe ao mediador apresentar "uma 'questão problema' no início da visita”. Ainda que aqui os visitantes dediquem sua atenção àquilo que lhes interessa em particular, o mediador "tem o controle do grupo", fornecendo informações e "monitorando o progresso do grupo” (GRINSPUM, 2000, p. 48-49).

Tutelando seus públicos, a mediação institucional reforçará o seu compromisso com o "visitante inexperiente" (GRINSPUM, 2014, p. 278). Ela sabe tanto do déficit do seu capital cultural como da virtual inadequação do seu comportamento, alheio aos códigos de conduta exigidos nos ambientes de fruição artístico-cultural. Sabe, além disso, que "quanto mais [frequentes] forem as vivências de se ver arte [...] mais condições terá o visitante de desenvolver suas habilidades e aprender conteúdos por intermédio da apreciação estética”. Tais conteúdos referem-se, segundo Grinspum, a tudo aquilo que o visitante deve aprender para atingir objetivos postulados pelos agentes da mediação, envolvendo aspectos cognitivos, motores, afetivos, de relação interpessoal e de inserção social (GRINSPUM, 2014, p. 274-275). É com base nisso que boa parte dos programas educativos institucionais se coloca à disposição dos visitantes, frequentemente dirigindo-lhes convites ou mesmo viabilizando seus traslados de ônibus fretado, como é o caso das visitas de grupos de estudantes da rede pública de ensino a esses espaços ${ }^{1}$.

Observadas tais características, cumpre pontuar que a mediação institucional tem seu trabalho orientado por uma perspectiva positiva, que se crê benéfica ao outro. O que ela oferece é a oportunidade de esse sujeito desenvolver-se, na exata medida em que o circunscreve à posição de "inexperiente”, um eufemismo para a condição de não sabedor, ignorante. Ou seja, identifica o sujeito pelo que lhe falta - e não pelo contrário -, para simultaneamente lhe apresentar as chances de sair, aos poucos, desse estágio de déficit. Nessa atitude concessiva da mediação, o sujeito é ligado a si mesmo pelos agentes sabedores de sua carência, de tal maneira que a atribuição identitária permita que ele seja submetido aos desígnios de um corpo de especialistas que o sujeitam enquanto supõem educá-lo. É essa equação que, por outro lado, tende a eclipsar saberes outros, comportamentos alternativos e agendas não coincidentes com os desígnios institucionais e artísticos.

Resta observar, ainda, que não apenas a mediação institucional se ocupa da condução de condutas. O trabalho de arte em si e as propostas curatoriais, ao procurar desencadear diferentes processos comunicativos, imaginam sua recepção pelo público, pressupondo determinadas formas de interação e fruição, o que implica na busca pela condução da percepção e, em alguma medida, dos modos de agir do seu fruidor. Nesse aspecto, é

\footnotetext{
Trata-se de uma política institucional consolidada, em que as instituições culturais estabelecem parcerias com secretarias estaduais e municipais de Educação, com vistas a garantir recursos necessários para que as escolas contratem o serviço de ônibus fretado. Em alguns casos, as próprias instituições oferecem gratuitamente o serviço de ônibus para as escolas.
} 
famosa a narrativa de Tom Wolfe, expoente do new journalism, acerca da sua experiência como espectador em uma grande quantidade de mostras representativas do Alto Modernismo norte-americano. Reproduzimos abaixo um excerto de The Painted Word (1975):

[...] Em todos esses anos estive, como muitas outras pessoas, diante de milhares e milhares - só Deus saberia dizer quanto - de Pollocks, Newmans, Nolands, de Koonings, Rothkos, Rauschenbergs, Judds, Johns, Olitskis, Louises, Stills, Franz Klines, Frankenthalers, Kellys e Frank Stellas... ora como um vesgo, ora com a órbita do olho bem aberta, ora recuando, ora me aproximando, mas sempre à espera... esperando que meu olhar entrasse no foco, de modo que eu pudesse alcançar a recompensa visual por todo aquele esforço que se pressupunha só pelo simples fato de eu estar ali, diante daquelas pinturas todas. Todos (tout le monde) sabiam como se portar ali, à espera de algo que irradiasse, naquele instante, diretamente das pinturas expostas na sala, posicionadas em suas paredes brancas e invariavelmente puras. Essa era a minha cruzada óptica [...]. (WOLFE apud WERBER, 2016, p. 13, grifos meus.)

No relato de sua saga, Wolfe evidencia, em tom de descrença, aspectos de sua conduta enquanto espectador-peregrino de uma série interminável de pinturas cuja força deveria irradiar de suas relações plásticas internas. Todos esses aspectos estão pautados pelas premissas estéticas dos artistas, pelas narrativas curatoriais, pelas configurações expográficas e pelos discursos hegemônicos da crítica de arte, notadamente a crítica de viés formalista que privilegia as obras em sua visualidade pura. Como se pode notar pela descrição, os critérios e valores postulados por cada uma dessas instâncias influenciam diretamente o modo de agir do espectador no ambiente expositivo, na medida em que se apresentam como condições imprescindíveis para o alcance da "recompensa visual" supostamente proporcionada por uma relação "adequada" com as pinturas.

Foucault dirá que a produção e a circulação simbólicas, ao deflagrar processos comunicativos, podem ter por consequência "efeitos de poder". Para o filósofo, "comunicar é sempre uma certa forma de agir sobre o outro" (grifo meu). Contudo, ele também alerta para a necessidade de distinguirmos as relações de poder das relações de comunicação, tendo em vista que a lógica do poder não condiz, necessariamente, a uma dimensão intrínseca da linguagem, mas resulta de imbricações nas quais determinadas formas de poder e certos modos de comunicação se apoiam reciprocamente, "servindo-se mutuamente de instrumento". A propósito disso, nota-se que as relações de poder são exercidas, em grande parte, mediante a produção e a circulação de signos. Ademais, as interrelações entre comunicação e poder ocorrem das mais variadas maneiras e em diferentes contextos (FOUCAULT, 1995, p. 240-241). Interessa-nos 
perscrutá-las nas situações de endereçamento e recepção de práticas artísticas intermediadas pela ação institucional.

Para isso, tomaremos como referência inicial a linguagem escrita, mais especificamente a escrita literária. Ainda que essa linguagem aponte para especificidades que não coincidem completamente com as das proposições em artes visuais, acreditamos que a lógica que lhe subjaz também diga respeito, em alguma medida, aos processos de endereçamento dos públicos experimentados no campo das artes visuais.

Em um texto publicado em 1970 no jornal Le Figaro Littéraire, intitulado "Escrever a leitura”, o semiólogo Roland Barthes faz uma série de ressalvas à centralidade historicamente conferida ao autor dos textos literários. Em contrapartida, isso acaba por relegar as formas de apropriação e simbolização praticadas pelo leitor a uma posição periférica, ou de mera reprodução dos significados tecidos por aquele que escreve. Nessa linha, "o autor é considerado o proprietário eterno de sua obra, e nós, seus leitores, simples usufrutuários". Isso se deve ao "privilégio exorbitante concedido ao lugar de onde partiu a obra” (BARTHES, 2004, p. 27). Tal prerrogativa interessa, inclusive, à crítica especializada, que toma para si a eminente tarefa de "descobrir o Autor (ou as suas hipóstases: a sociedade, a história, a psique, a liberdade) sob a obra” (BARTHES, 2004, p. 63).

Essa ênfase na origem e, portanto, naquele que enuncia, parece reforçar a prerrogativa da ação de uns, na condição de autores, sobre o imaginário de outros, enquanto leitores. De acordo com Barthes, essa é uma constante que vigora há séculos, naturalizando-se. Nela, o autor tem pleno direito sobre o leitor que ele endereça, "constrange-o determinado sentido da obra”, não por acaso "o sentido certo, o verdadeiro" (BARTHES, 2004, p. 27, grifo meu).

Através dessa equação, condiciona-se o que o leitor deve entender àquilo que o autor quis dizer. Entretanto, e aqui tal relação mostra-se dialética, existiria um paralelo entre o sujeito que resiste ao exercício do poder e o leitor que desvirtua as coordenadas postuladas pelo autor, no interior de uma relação de comunicação conflituosa ou desviante. Inclusive porque, de saída, "a lógica da leitura é diferente das regras da composição [autoral]". Enquanto a composição escrita canaliza e acaba por "constranger o leitor a um sentido", a leitura "dispersa, dissemina" esse e outros tantos sentidos imprevistos, inclusive ausentes do texto (BARTHES, 2004, p. 28). Desse modo, podemos depreender que haveria um desacordo fundamental entre os expedientes da escrita e da leitura; consequentemente, entre as intenções da proposição e as operações de apropriação de seus enunciados.

Ainda assim, conforme outra análise do semiólogo presente em "Da leitura”, não se deve perder de vista que a "leitura ocorre no interior de uma estrutura". Ou seja, ela participa, na condição de prática interpretativa e produtora de novos significados, de uma estrutura simbólica organizada inicialmente pelo autor. Para acontecer, a leitura depende e faz uso dessa estrutura. É-lhe, em alguma medida, "submissa", ao mesmo tempo que a "perverte" - daí o funcionamento dialético da operação. Desse modo, o ato da leitura provocaria no organismo do texto uma "hemorragia per- 
manente [justamente] por que a estrutura [...] desmoronaria, abrir-se-ia, perder-se-ia" (grifo do autor). Em suma, "a leitura seria o lugar onde a estrutura se descontrola” (BARTHES, 2004, p. 42).

Por outro lado, Barthes pontua que, embora o "império do Autor" fosse algo "ainda muito poderoso" (o autor escreve isso no final dos anos 1960), certos escritores dedicam-se ao trabalho de abalar essa autoridade. É o caso do poeta Stéphane Mallarmé (1842-1898), que coloca "a própria linguagem no lugar daquele que era até então considerado seu proprietário”, ou seja, o autor compreendido como núcleo subjetivo irradiador de sentidos. Subvertendo tal conformação, o poeta em questão busca fazer a própria linguagem falar, e não mais o autor, escrevendo "através de uma impessoalidade prévia”. Essa e outras experiências imbuídas da destituição do autor do seu lugar de autoridade são comentadas pelo semiólogo no seu famoso ensaio "A morte do autor", no qual ele formula que é justamente dessa morte que depende, em contrapartida, “o nascimento do leitor" (BARTHES, 2004, p. 59-64).

Contudo, ainda que os criadores possam conceber suas obras mediante critérios e opções linguísticas capazes de relativizar a autoridade do autor, há que se atentar para suas abordagens e formas de difusão pelas instituições (escola, família, biblioteca, museu etc.) e seus agentes especializados, que assumem posições intermediárias na relação entre os públicos e as obras artísticas.

Cumpre observarmos essa questão no terreno das artes visuais, em particular nos modos como os objetos artísticos são apresentados nos contextos expositivos, onde seu uso e apropriação são orientados por intenções, compromissos e expedientes específicos. O curador Pablo Lafuente comenta que tal orientação se faz presente "no jeito como os elementos estão articulados". É esse arranjo discursivo e espacial que estabelece os parâmetros de como um trabalho de arte pode funcionar (ou não) como instrumento para usos que transcendam aqueles que foram definidos em sua origem. Entretanto, "a articulação que eles recebem nas instituições de arte contemporânea [...] não escapa, em linhas gerais, de uma estrutura na qual o controle dos mecanismos e os discursos continua nas mãos de uma classe específica”, formada por especialistas autorizados para tal (LAFUENTE, 2015, p. 275).

Portanto, ainda que os artistas experimentem formas de desconstrução da própria autoridade em termos semânticos e comunicativos, suas criações integram um circuito mais complexo, no qual a hegemonia do conhecimento, o poder de influência e a divisão hierárquica muitas vezes se mantêm operantes.

\subsection{MODALIDADES DE ENVOLVIMENTO DOS PÚBLICOS COM AS PRÁTICAS ARTÍSTICAS}

Seguindo com as especificidades das práticas artísticas no campo da visualidade, cumpre agora nos reportarmos a uma análise em torno das respectivas modalidades de envolvimento dos públicos, as quais são ressignificadas - ao menos do ponto de vista das intenções que orientam as proposições artísticas - conforme 
se processam as transições de linguagem, forma e estrutura experimentadas pelos artistas. Está em jogo, portanto, algo que vai além dos sentidos denotados pelas obras, envolvendo, sobretudo, as diferentes formas de relação dos públicos com tais proposições. Como se poderá notar, quando analisados pelo viés da historiografia da arte, os públicos são comumente diferenciados de maneira ampla e genérica, como se representassem desdobramentos diretos e automáticos das criações e proposições dos artistas, mediante categorias como espectadores, participantes e interatores. Soma-se a isso o fato de que tais acepções são frequentemente tomadas em sentindo linear e progressivo - quando não substitutivo.

Num texto do início dos anos 2000 sobre a dimensão interativa nas artes visuais, o professor e artista Julio Plaza traça uma linha histórica dos processos recentes de inclusão do espectador no escopo das práticas artísticas. Segundo o autor, a partir dos anos 1950-60 pode-se verificar "um deslocamento das funções instauradoras (a poética do artista) para as funções da sensibilidade receptora (estética)"(PLAZA, 2003, p. 9). Guardadas as diferenças, pode-se notar nessa mudança de ênfase - do ato criador do artista para as formas de apropriação do público - um paralelo com o nascimento do leitor anunciado por Barthes.

Elencando tendências artísticas interessadas na participação do espectador no acontecimento dos trabalhos de arte, ou mesmo na sua consecução, Plaza delineia um itinerário em que vai enumerando e comentando suas dinâmicas distintas: 1) "participação passiva”, que envolveria contemplação, percepção, imaginação, evocação; 2) “participação ativa”, traduzida em exploração, manipulação do objeto artístico, intervenção, modificação da obra pelo espectador tornado participante; e 3) "interatividade", que corresponderia à relação recíproca entre o usuário-interator e um sistema inteligente (PLAZA, 2003, p. 10-17).

O ponto comum a essas diferentes dinâmicas, segundo Plaza, refere-se à experimentação de novas formas de comunicação, a partir da busca por dinâmicas alternativas à unilateralidade das "mídias de massa". Logo, o espectador seria chamado a se envolver nos processos de efetivação da obra de arte, nesse caso, mais voltada à sua contínua ocorrência e atualização do que à sua finalidade como produto, desencadeando a reorientação dos processos criativos e, consequentemente, dos estatutos do autor, da obra e do espectador. Tais reorientações seriam refletidas em diferentes níveis de abertura da obra à intervenção deste último (PLAZA, 2003, p. 11).

No que Plaza denomina como "abertura de primeiro grau" (participação passiva) a obra de arte em geral se apresentaria como um signo polissêmico e fundamentalmente ambíguo, permitindo que uma ampla gama de significados seja vislumbrada pelo espectador-leitor a partir de um único significante. É nesse âmbito que Umberto Eco (Obra aberta) e Haroldo de Campos ( $A$ arte no horizonte do provável) são evocados como pensadores do caráter (re)criativo da recepção estética (PLAZA, 2003, p. 10-13).

Já na "abertura de segundo grau" (participação ativa) predominariam a dimensão ambiental da obra e a participação direta do espectador. Nesses ambientes, complementados pela presença e atuação do espectador-partici- 
pante, ocorre o desaparecimento do objeto artístico enquanto tal, dando lugar à situação perceptivo-sensorial como ato de recriação permanente. Aqui, o espectador-participante é chamado a envolver-se com seu corpo, de tal modo que seus demais sentidos, além da visão, passam a ser convocados. Haveria aqui um tipo de alternativa criada pelos artistas em relação à hegemonia da visão, característica de boa parte da produção moderna nas artes visuais, como no caso do Alto Modernismo norte-americano. Destacam-se nesse conjunto os ambientes e penetráveis de Hélio Oiticica e Jesús Rafael Soto, além dos objetos relacionais de Lygia Clark, nos quais o espectador se tornaria um agente da constituição da experiência artística. Ainda nesse contexto de abertura à participação ativa do espectador, embora em outras bases, o happening surgiria como forma de incorporação do imprevisível e do acaso, por meio da proposição de eventos abertos, sem a delimitação de começo, meio e fim. Allan Kaprow, John Cage e o Grupo Fluxus são alguns dos representantes desse tipo de experiência (PLAZA, 2003, p. 14-15).

A interatividade é associada por Plaza à "abertura de terceiro grau". Haveria aqui uma determinante relação da arte com as novas tecnologias e mídias digitais, cujas configurações computacionais e telecomunicacionais permitem o desenvolvimento de interfaces entre o espectador-interator e sistemas inteligentes. Articulado às possibilidades de interação multissensorial e de exploração de novos espaços-tempo, nesse segmento são investigadas novas realidades de ordem perceptiva nas relações entre o virtual e o atual. Os artistas Edmond Couchot e Fred Forest, embora concebendo seus experimentos a partir de registros distintos, cada qual a seu modo, estão de acordo com o fato de que em tais processos a obra deixa de ser fruto apenas do gesto do artista, visto que seria produzida no decorrer de uma interação em tempo real - propiciada e traduzida por plataformas tecnológicas apropriadas - na qual o espectador-interator, entendido como "agente inteligente", adquire a possibilidade de agir sobre a obra e modificá-la, de "aumentá-la" inclusive, tornando-se uma espécie de coautor (PLAZA, 2003, p. 16-20).

Ainda que tal sistematização das modalidades de envolvimento dos públicos com as proposições artísticas mostre-se útil da perspectiva da produção, ela nos parece insuficiente do ponto de vista da sua recepção e das formas emergentes de apropriação pelos públicos. Ao priorizar de maneira exclusiva as premissas dos artistas - mesmo que (ou inclusive porque) busquem estimular o engajamento dos públicos -, ela não se atém às discussões acerca: 1) da vocação dessas práticas no que diz respeito à antecipação e ao direcionamento das condutas daqueles que com elas se envolvem e 2) das singularidades potencialmente emergidas desse envolvimento, e que não raro desviam-se das pressuposições e expectativas dos próprios artistas em relação às suas proposições.

Como exemplo de singularidades que possam vir a emergir das relações dos públicos com as práticas artísticas, valeria imaginarmos situações pontuais de descoincidência entre as pressuposições dos artistas e as formas de interação dos públicos: a) um “espectador” que se proponha a dançar diante da monumental pintura One: Number 31, de Jackson Pollock; b) 
um "participante" que, por algum motivo desconhecido, se abstenha de entrar no ambiente $A$ casa é o corpo: penetração, ovulação, germinação, expulsão, de Lygia Clark, dedicando-se, em vez disso, a mirar obsessivamente o semblante daqueles que acabam de vivenciar a experiência; ou c) um "interator" de Dentes-de-leão, de Edmond Couchot, que, em vez de assoprar o microfone que funciona como interface para dispersar as sementes representadas na tela, opte por nele pronunciar palavras de ordem contra a instituição bancária promotora da exposição.

Há casos, inclusive, em que os próprios artistas colocam em xeque as pressuposições em torno do envolvimento dos públicos com as proposições artísticas, ironizando-as. Esse é o caso de Espelho com luz (1974), de Waltercio Caldas. Nessa obra, o artista emoldura um espelho comum medindo $1 \times$ 1 metro, instalando em seu canto inferior direito um mecanismo que inclui um botão e uma minúscula lâmpada vermelha, posicionados um acima do outro. Aos espectadores-participantes habituados com a "arte participativa" dos anos 1960/70 Caldas propunha uma forma de participação mínima e, em certa medida, irrisória: a) olhar-se no espelho, b) apertar o botão e, então, c) perceber a lâmpada vermelha acender. Segundo o historiador e crítico Tadeu Chiarelli, com tal gesto o artista se ocupava de provocar a "frustração do espectador "participativo", haja vista a automaticidade insípida implicada no esforço [sic] e na retribuição por apertar o botão (CHIARELLI, 1999, p. 27).

Interessa-nos, por outro lado, produzir visibilidade e conferir consequência às respostas imprevistas dos públicos às proposições artísticas, inclusive a experimentos metacríticos como o de Caldas. Algumas dessas respostas, como temos buscado evidenciar, frustram com frequência os desígnios dos artistas, dos curadores e dos mediadores, assim como as expectativas subjacentes às próprias ofertas institucionais.

\section{3 (AUTO)PRODUÇÃO DOS PÚBLICOS}

Como já dito, importa-nos refletir acerca dos públicos e suas formas de interação com as práticas artísticas e ofertas institucionais a partir de uma perspectiva que se desloque de concepções baseadas na mobilização do outro e de suas ações por ferramentas de antecipação e/ou condução de condutas. Entendemos que as abordagens prioritariamente ocupadas com os critérios e o modus operandi das proposições artísticas, pedagógicas ou institucionais frequentemente desconsideram e, assim, desaparecem com índices imprevistos, não raro desviantes, que a face responsiva inerente a esses mesmos processos - correspondente à atuação dos públicos - não cessa de produzir.

O desinteresse e a consequente desatenção àquilo que emerge durante as situações de interação dos públicos com tais proposições estão ligados, entre outras coisas, à atribuição sistemática de cunhagens identitárias e posições fixas ao outro, como se elas fossem capazes de estabelecer uma espécie de contrato estável entre quem propõe e quem vivencia uma experiência artística, circunscrevendo o escopo de envolvimento dos públicos e suas virtualidades em bases pré-determinadas. Entre essas 
atribuições figuram caracterizações como: público-alvo, visitante inexperiente, carente cultural, não iniciado, leigo, deficitário, escolar, mas também espectador, participante, interator etc. Buscamos desviar-nos dessa perspectiva, a fim de "promover novas formas de subjetividade", o que implica a suspensão desse tipo de individualização estanque dos públicos (FOUCAULT, 1995, p. 239). No lugar de tais caracterizações, que muitas vezes imputam déficit de repertório e/ou falta de iniciativa e mobilidade ao outro, investimos em designações decididamente ambíguas, que buscam refletir em sua forma as manobras ensaiadas pelo sujeito em relação às discursividades que se lhe apresentam e das quais ele se torna, ou não, um público. Estamos falando das posições indicadas no título deste capítulo: agente destinatário, intérprete ativo e sujeito político.

Conceber outro estatuto para os públicos nos possibilitaria, por exemplo, relativizar afirmações - justificadas pelos preceitos da democratização cultural que disseminam a ideia do acesso aos espaços de exposição como uma "preciosa oportunidade de se entrar em contato com obras de arte originais e aprender a vê-las" (GRINSPUM, 2014, p. 274, grifos meus). Colocar esse tipo de asserção sob suspeita permite, em contrapartida, reconhecer e tornar visíveis sinais daquilo que Honorato identifica como "arte pelo público", em contraposição à noção corrente de "arte para o público". Como exemplo, ele chama atenção para ocorrências protagonizadas pelo personagem principal do filme Juventude em marcha (2006), dirigido pelo cineasta Pedro Costa. A figura em questão é a de um senhor chamado Ventura, ex-pedreiro de origem cabo-verdiana, invalidado por um acidente de trabalho:

Expulso de casa pela mulher na primeira cena, o vemos de lugar a lugar em Lisboa, visitando pessoas que, por uma decisão do roteiro, são tidas como seus filhos. Ventura é na verdade uma personagem real e o que vemos é o próprio "ator" representando uma versão de sua história [...]. Em um desses encontros, Ventura e Bete, "pai" e "filha" se entretêm a ver, nas paredes manchadas do barraco condenado em que ela mora, como bons discípulos de Da Vinci, “[...] figuras estranhas [...] semelhantes às que entram na composição dos quadros”. Em outro, enquanto espera, no museu da Fundação Calouste Gulbenkian, o "filho" vigilante que aí trabalha, Ventura se distrai olhando para o teto, aparentemente desinteressado dos Rubens e Van Dyck à sua frente, ao mesmo tempo intruso e proprietário desse espaço, que de fato ele ajudou a construir. (HONORATO, 2011, p. 347-348.)

Em ocorrências como essa podemos notar descontinuidades produzidas no interior dos preceitos da difusão e da mediação institucionais. Entre elas, estaria a capacidade comum a qualquer pessoa de selecionar e ler/fruir expressividades dispersas no mundo ao redor, incluindo tanto objetos artísticos como não artísticos. Com relação a isso, Barthes comenta que o verbo 
ler "pode ser saturado, catalisado, com mil objetos diretos: leio textos, imagens, cidades, rostos, gestos, cenas etc.” Logo, cabe problematizar o fato de alguém, ou um grupo, pressupor aquilo que o outro necessite (ou não) ler/fruir, e a maneira como isso deva ocorrer, na medida em que "o objeto que eu leio é fundado apenas pela minha intenção de ler" (BARTHES, 2004, p. 32). Objeto que, aliás, relaciona-se direta e intimamente com meus desejos, incluindo os mais insondáveis e inomináveis.

Tais descontinuidades produzem desvios na pressuposição de terceiros acerca do que o sujeito deva ler/fruir. Barthes associa tal pressuposição ao que ele chama de "recalques de leitura" (grifo do autor). Tal recalque resulta de toda sorte de injunções, incluídas as das diferentes instituições e seus mediadores, "que fazem da leitura um dever em que o ato de ler é determinado por uma lei" (grifo do autor). Essa lei define os objetos aos quais devemos devotar nossa atenção e esforço, como partícipes de um "ritual de iniciação" - lembremo-nos do termo "não iniciado" como uma forma recorrente de identificação do outro (BARTHES, 2004, p. 34). Negligenciar esses objetos representaria uma heresia, uma forma de profanação. Parece-nos, contudo, haver potência (e não simplesmente ignorância ou necessidade de iniciação) na recusa em ler/fruir certos objetos eleitos por agentes credenciados e, portanto, "aptos" a dizer que necessitamos fazê-lo, postulando inclusive a forma como devemos fazê-lo, de modo que possamos aprender a lê-los.

Precedentes como os de Ventura, comentados sob um viés específico por Honorato, apontam para outras dimensões do gesto de se fazer público de algo, esquivando-se muitas vezes de repertórios simbólicos e comportamentais usados como ferramentas de condução da percepção e da conduta por agentes autorizados pelas prerrogativas do saber. Despistando tais coordenadas, o sujeito "desativa os dispositivos do poder" que operam mediante os estigmas que lhe são pespegados através da senha público deficitário - nem sempre verbalizada dessa forma, como já dito (AGAMBEN, 2007, p. 68). Até porque, de acordo com Barthes, "a liberdade de leitura [...] é também a liberdade de não ler” (BARTHES, 2004, p. 35). Em seu desprezo pelas pinturas de Rubens e Van Dyck, Ventura parece de alguma forma atualizar esse lema.

Em casos como esse, os públicos podem ser percebidos como esquivos às iniciativas que procuram individualizá-los e geri-los. Desinteressados de certos objetos, em beneficio e atenção a outros, eles demonstram, entre outras coisas, que "toda leitura é penetrada de Desejo (ou de Repulsa)". O reconhecimento desse aspecto-chave exige, por outro lado, compreender que nas situações de fruição e leitura "o Desejo não pode ser destacado, por mais que isso custe às instituiçôes, de sua própria negatividade pulsional” (BARTHES, 2004, p. 33, 35, grifo meu). Somos levados então a relativizar a própria hegemonia da instituição e de seus agentes sobre a definição do que faltaria ao outro no quesito referências culturais.

Olhando por esse lado, torna-se possível inclusive concebermos o esgarçamento das premissas e políticas institucionais, tornando-as mais porosas. E, portanto, atravessadas por aquilo que os públicos - e suas respectivas demandas - também têm a ensinar à instituição e aos agentes nela im- 
plicados, incluindo artistas, curadores e mediadores. Uma dessas contribuições está relacionada à sua (auto)produção como público, com tudo o que há de contingencial, emergente e incerto nesse processo.

De acordo com o crítico literário Michael Warner, longe de personificar entidades classificáveis e capturáveis mediante qualquer tipo de decreto ou expediente de gestão, os públicos são imaginados e produzidos pelos próprios objetos e suas discursividades, num processo que ocorre na duração do tempo de sua exposição e/ou circulação. Tais discursividades podem se dar, entre outras, sob a forma de obras visuais, textos, programas de TV, trilhas sonoras, filmes, encenações teatrais ou peças publicitárias. Constituindo objetos semânticos, elas são capazes de formar em torno de si comunidades anônimas, temporárias, heterogêneas e dinâmicas, irredutíveis às estratégias de antecipação, arregimentação e administração por quem as concebe ou veicula.

Segundo Warner, a razão de ser dos públicos depende da "relação com textos e com a sua circulação, como é o caso do público deste artigo" - o dele, mas também o da presente dissertação (WARNER, 2008, p. 10). Trata-se, desse modo, de conceber os públicos como públicos discursivos, vigentes na duração temporária da relação com determinado objeto semântico.

O autor afirma, em sentido ainda mais elementar, que "o simples fato de prestar atenção pode ser o suficiente para que alguém seja membro de um público". Logo, o público "se cria a si mesmo", justamente por sua capacidade de proceder por escolha e edição (WARNER, 2008, p. 18). Ao fazê-las, posiciona-se diante daquilo que lhe interessa em termos discursivos, daquilo que possa se articular aos seus desejos e buscas, já que, segundo Barthes, "o que pode nos reter por um instante [diante de um texto] é a marca de desejo" (BARTHES, 2004, p. 34). Surge aqui uma espécie de enigma de resistência, um trunfo nas mãos do sujeito diante das tentativas de captura da sua atenção por formas discursivas e estratégias de gestão alheias às suas premências e desejos de simbolização.

Nesse sentido, evidencia-se o fato de que o público não corresponde a uma entidade única, fixa ou dada, mas a formações contingenciais e emergentes, constituídas temporariamente (no tempo da atenção e da vigência do interesse e disponibilidade) em torno das mais diversas discursividades - como sugere $o$ leitor Simon Sheikh num texto em que comenta as ponderações de Warner, articulando-as às suas preocupações nos campos da curadoria e da crítica. Assim, os públicos assumem dimensão plural enquanto coletividades múltiplas e coexistentes, integrantes (logo, fomentadoras) de esferas públicas fragmentárias e temporárias. Já não se trata, portanto, de um espaço público em sentido totalizante (SHEIKH, 2009, p. 74, 80). Nessa direção, Warner afirma que "poderia existir um número infinito de públicos dentro da [abstrata] totalidade social" (WARNER, 2008, p. 13).

A condição de emergência implica numa atuação de caráter marcadamente político, haja vista que os sujeitos se fazem destinatários de textos específicos (programas de TV, jornais, músicas, vídeos de internet, filmes, livros, blogs, obras de arte etc.), dispondo-se junto deles como um público, constituindo sua subjetividade e sua posição política na relação com 
determinados enunciados. Nessa linha, Warner pondera que "um público se organiza com independência das instituições estatais, das leis, dos marcos formais da cidadania ou das instituições pré-existentes", o que nos auxilia na desconstrução de discursos institucionais comprometidos exclusivamente com a iniciação do outro no universo dos bens culturais reconhecidos como legítimos. Ademais, o autor contrapõe a (auto)produção dinâmica e temporária de um público à ideia generalizante de que existiria $o$ público, essa entidade abstrata frequentemente fatiada e classificada pelas instituições de arte com a finalidade de ser endereçada e atendida por seus diferentes programas (WARNER, 2008, p. 14-15). Acrescente-se, portanto, que tal lógica de (auto)produção representa um contraponto às categorias genéricas que subdividem os diferentes perfis de públicos com o intuito de melhor geri-los.

É possível ponderar, além disso, que fazer-se público de determinados enunciados também significa poder ocupar lugares táticos de disputa narrativa, o que reforça a sua dimensão política. Corresponde, nessa direção, a posicionar-se como sujeito político em "pontos cegos" das relações de poder e de comunicação, onde esse sujeito, na condição de público (abrangendo as posições de leitor, espectador, consumidor etc.), experimenta alguma liberdade para se apropriar e manejar os sistemas simbólicos em jogo do modo que lhe parecer mais pertinente (e justo), ao mesmo tempo que se desloca das identificações que lhe são unidirecionalmente atribuídas. Algo disso pode ser percebido num registro em vídeo que viralizou recentemente nas redes sociais da internet, e que apresenta um diálogo entre uma garota de aproximadamente dez anos de idade e um adulto que a entrevista na seção de um magazine onde se expõem camisetas infantis estampadas, dividas por gênero:

Adulto: Daisy, o que você achou das roupas

em oferta hoje?

Daisy: Bem, as roupas das meninas dizem [em suas

estampas]: "Ei”, “Linda”, "Encantada”. [Enquanto] as dos

meninos [dizem]: "Aventuras te esperam”, "Pense fora da

caixa", "Herói”.

Adulto: E o que você acha disso?

Daisy: Isso não é justo, porque todo mundo pensa

que as meninas devem ser bonitinhas e os meninos

devem ser corajosos.

Adulto: E qual a sua opinião?

Daisy: Acho que isso está errado. Por que as roupas de meninos e meninas devem ser separadas? Todos nós somos tão bons quanto qualquer um. [Veja esta estampa masculina]: "Pense fora da caixa". O que isso significa? Isso significa: "aventure-se!”, "ninguém pode te parar!", "siga seus sonhos!”. Mas [em relação às estampas femininas], "Ei", o que isso quer dizer? Eu não sei. Talvez inspire você a dizer: "eil" e...

Adulto: Você não acha inspirador? 
Daisy: Eu não acho. Que parte do "Ei” é inspiradora?

Não entendo isso. Veja, os meninos têm "Pense fora da caixa”, que significa: "arrisque”, "vá atrás de seus so-

nhos”... essas coisas. Já “Ei”... sério, o que isso significa?

Como isso inspira você? ${ }^{2}$

Nota-se nos comentários críticos da garota em torno dos enunciados estampados nas camisetas à venda algo que coincide com o que Sheikh observa em relação aos trabalhos de arte (o que também é válido para as ações mediativas e institucionais). Trata-se do olhar e da capacidade interpretativa dos públicos, que não estariam vinculados apenas aos aspectos formais e temáticos das obras - ou à natureza das ofertas institucionais e das oportunidades pedagógicas -, mas também às condições sociais do sujeito, no que diz respeito, por exemplo, a sua idade, classe social, referências culturais, origem étnica, gênero, posicionamento político, situação psíquica, contingências pessoal e social etc. Em sentido mais abrangente, liga-se a "suas experiências e intenções" (SHEIKH, 2009, p. 76).

Honorato, por sua vez, nos reporta a um caso que não apenas exemplifica tal constatação, como a radicaliza. Nele, as experiências e anseios do indivíduo revelam-se de maneira astuciosa, desencadeando uma surpreendente negociação simbólico-existencial com aquilo que se lhe apresenta como ação representativa da mediação institucional e das políticas de democratização dos bens culturais.

O ocorrido em questão deu-se a partir de um projeto realizado pelo Museu do Louvre em parceria com uma penitenciária parisiense, a Prison de la Santé, situada a poucos quilômetros de distância do museu. O projeto previa a realização de uma exposição nas dependências do presídio, mais precisamente em seu pátio central, com reproduções de obras-primas pertencentes ao acervo do museu. Entre os aspectos centrais do projeto estava o fato de que a exposição seria organizada e montada nas paredes do pátio pelos próprios detentos.

A proposição do Museu facultava a tal grupo, conforme observa Honorato, "meios autoexpressivos, experiências de sociabilidade, ou mesmo momentos de evasão simbólica”, assim como lhes concedia a oportunidade de se aproximar (ainda que por meio de reproduções) de algumas das mais significativas obras da História da Arte ocidental. Um dos detentos, ao ser consultado, apresentou aos proponentes a seguinte condição para se envolver com o projeto: a de que pudesse usar parte do tempo de elaboração da exposição para plantar seus tomates no canteiro do pátio plantio que vinha sendo a ele impedido pela administração do presídio (HONORATO, 2013b, p. 5).

É possível notar nessa ocorrência o anúncio de um anseio que, paradoxalmente, vislumbra a possibilidade de sua consumação em uma ocasião a princípio

2 Disponível em:

<https://www.facebook.com/psicologiaparaeducadores/ videos/615007155335924/?pnref=story $>$.

Acesso em: 7 out. 2016. 
incompatível com as prioridades do sujeito desejante, não fosse o fato de ela ter sido apresentada por agentes - integrantes da equipe do $\mathrm{Mu}-$ seu - munidos de credibilidade (e, portanto, de poder de barganha) e, ainda, prever justamente a ocupação do pátio do presídio. O detento em questão toma essa oferta institucional como uma ocasião oportuna, uma brecha para viabilizar aquilo que desejava poder fazer - plantar seus tomates -, transpondo o impedimento estabelecido pela administração prisional a esse respeito.

Praticando o que Certeau identifica como táticas atreladas aos diferentes modos de usar aquilo que nos é ofertado ou, em certos casos, imposto, ele faria do convite do Louvre uma alavanca para a realização daquilo que não estava previsto no escopo do projeto (CERTEAU, 1994). Ao fazê-lo, dá a ver o já mencionado campo de forças e respostas ensejado pelas ofertas institucionais e práticas artísticas, bem como pelas relações de poder e comunicação nelas implicadas. Pode-se dizer que o detento endereçado pelo Museu, afirmando-se como sujeito político, ciente de sua dupla posição de presidiário e participante de um projeto promovido pelo Louvre, busca fazer do projeto institucional uma plataforma de negociação, buscando viabilizar aquilo que confere algum sentido à sua experiência cotidiana.

O que aí se flagra é a emergência de um público que produz deslocamentos nos planos de um projeto institucional, na medida em que nele introduz outra agenda. Trata-se de uma situação emblemática do aparecimento de singularidades nas relações entre a arte e seus públicos, ou entre os programas institucionais e seus destinatários. Essas singularidades resultam numa diversidade incontrolável de apropriações e desvios que, por outro lado, são frequentemente desaparecidas pelos discursos institucionais e, também, pela historiografia da arte - majoritariamente focada nas premissas e nas produções dos artistas, bem como nas decisões daqueles que organizam as exposições. As narrativas contemporâneas acerca da sua recepção ficam, por sua vez, restritas a um círculo de agentes especializados, simbolizado pela figura do crítico de arte, que assume a posição de um intérprete privilegiado e autorizado. Já a imensurável e incontrolável rede anônima da recepção, povoada pela turba não especializada e anônima, fica relegada ao vão da invisibilidade, ou à opacidade de versões generalizantes que a classificam de acordo com as modalidades apriorísticas de interação com a arte.

Conceber narrativas que ensaiem refletir as formas singulares e anônimas de recepção das práticas artísticas pelos públicos implica lançar mão de um viés epistemológico menos ligado à esfera da proposição do que às instâncias da apropriação e do uso. Seu foco, portanto, está menos na propriedade dos discursos, atribuída aos seus enunciadores, do que nos modos como os públicos neles se "hospedam" temporariamente. 


\subsection{A SUBJETIVIDADE E O PAPEL DA IDENTIFICAÇÃO}

Em virtude do nosso interesse pela análise de casos singulares que emergem dessa face insuficientemente comentada e, portanto, praticamente invisível do circuito artístico-institucional, faz-se necessário abordarmos aspectos inerentes aos modos de operação da subjetividade, pensando-a em referência aos públicos das ofertas institucionais e das práticas artísticas. Em seu artigo "Antagonismo e estética relacional", a crítica e historiadora da arte Claire Bishop baseia-se na teoria da subjetividade dos filósofos políticos Ernesto Laclau e Chantal Mouffe para dizer que "a subjetividade não é transparente, racional e pura presença, mas [...] irremediavelmente descentrada e incompleta”. À primeira vista, essa condição parece denotar um desajuste inconciliável entre, de um lado, a capacidade de agenciamento do sujeito político e, de outro, o descentramento estrutural do indivíduo.

Enquanto o descentramento corresponde à ausência de um "sujeito unificado", o agenciamento parece sugerir um "sujeito completamente presente", supostamente autônomo e politicamente autodeterminado. No entanto, como já vimos em Foucault, a própria acepção de "sujeito" implica levar em consideração a sua sujeição (e resistência) a diferentes formas de exercício do poder, afastando-a das fantasias de um indivíduo instituinte, constituído exclusivamente por suas próprias vontades e por aquilo que sua consciência está apta a vislumbrar. Laclau, por sua vez, dirá que o desajuste, ou o conflito, entre sujeito descentrado (cujo ápice seria a psicose) e sujeito unificado (pretensamente absoluto) é, de saída, falso. A partir da perspectiva psicanalítica de Lacan, a teoria de Laclau propõe que o sujeito tem, nas palavras de Bishop, "uma identidade estrutural falha e, portanto, dependente de identificação para seguir em frente" (BISHOP, 2011, p. 121, grifo meu). Essa noção de identificação interessa sobremaneira à nossa reflexão, na medida em que repercute o movimento de escolha e atenção dos públicos em torno de discursividades que possam se articular aos seus desejos, inclusive àqueles que porventura sejam intuídos e alimentados no tempo de duração dessas (não raro surpreendentes) relações de identificação. Tal dinâmica revela quão fundamentalmente incompleto é o sujeito, fato que o mobiliza permanentemente no sentido de lançar-se a processos de identificação e de encarnar o papel de público das mais diversas discursividades, podendo incluir as práticas artísticas. Tais discursividades não são simplesmente incorporadas a subjetividades formadas, prontas, mas a constituem contingencialmente como tal. Além do processo de identificação, há ainda uma figura mítica que pode nos auxiliar nas ponderações sobre o estatuto da subjetividade e o respectivo papel da identificação. Trata-se de Genius e sua abordagem por Giorgio Agamben. O filósofo nos conta que esse era o nome atribuído ao deus que, para os latinos, acompanhava toda pessoa desde o momento de nascimento até a morte. Genius representava "a divinização da pessoa" e, desse modo, o princípio maior a orientar sua vida. Pré-individual, essa entidade tornava-se, paradoxalmente, o que havia de "mais íntimo e próprio" a cada pessoa, que era, portanto, encorajada a condescender 
com Genius, a ponto de "abandonar-se a ele". Interessa-nos, em particular, o fato de que, com Genius, "o homem não é apenas Eu e consciência individual", convivendo durante toda a vida "com um elemento impessoal e pré-individual” (AGAMBEN, 2007, p. 15-16).

Nessa perspectiva, o homem é tido como um ser cuja existência se compõe de duas instâncias que interagem dialeticamente: 1) "uma parte (ainda) não identificada e [já] vivida" e 2) "uma parte já marcada pela sorte e pela experiência individual”. Mantendo-se não identificada, a primeira instância não se refere a um passado estratificado, com lembranças codificadas (por exemplo, a queda dos dentes de leite, o primeiro dia de aula no colégio primário, o falecimento de um ente querido, o grêmio estudantil, os encontros amorosos da juventude etc.), mas a algo que, embora inacessível à memória e à consciência, "está presente até agora, em nós e conosco e junto de nós, no bem e no mal, inseparável”. É justamente essa "presença inaproximável”, essa constância insondável, que impede "que nos fechemos em uma identidade substancial" ou, retomando Laclau, absoluta. Mais ainda, é ela que nos desidentifica de nós mesmos, obstruindo o "Eu de bastar-se a si mesmo", como um monólito (AGAMBEN, 2007, p. 16-17).

Animando essa instância ao mesmo tempo íntima e desconhecida de nós mesmos, que, além da dimensão psíquica, envolve nosso organismo fisiológico, Genius presentifica-se "lá onde o mais próprio é o mais estranho e impessoal, o mais próximo é o mais remoto e indomável”. Agamben chega a dizer que, caso ousássemos não nos entregar a Genius, buscando inutilmente fincar pé no Eu e na consciência, "nunca poderíamos sequer urinar". Logo, ser habitado por Genius corresponde a "viver na intimidade de um ser estranho", topando (inclusive porque o contrário seria humanamente impossível) manter-se permanentemente ligado "a uma zona de não conhecimento" que nos impele tanto quanto os agenciamentos da consciência (AGAMBEN, 2007, p. 17).

O sujeito e sua subjetividade conformariam, portanto, "um campo de tensões, cujos polos antitéticos são Genius e Eu”. Esse campo é permanentemente cruzado por forças que, a todo tempo, se conjugam e se opõem. Um desses vetores "vai do individual na direção do impessoal", enquanto o outro "vai do impessoal para o individual". Tais forças, ainda que possam conviver, entrecruzar-se e separar-se, não podem "nem se emancipar integralmente uma da outra, nem se identificar perfeitamente" (AGAMBEN, 2007, p. 18). Ou seja, a subjetividade, além de estruturalmente falha e incompleta, é formada por traços identitários e impessoais que se mantêm em permanente interação.

A presença do elemento impessoal em cada um de nós, além de concorrer para a despossessão do Eu, parece preservar uma imaturidade fundamental, "infinitamente adolescente", que vibra na iminência dos ensejos de identificação - aqui Agamben e Laclau se mostram claramente convergentes. Esse "púbere" perpetuamente indefinido anima e impulsiona cada um de nós na direção do outro e, sem dúvida, na direção de objetos e discursividades produzidos pelo outro, com os quais podemos nos surpreender e nos identificar, mas também nos estranhar. Fora de nós, 
"procuramos apenas a emoção, que em nós continuou incompreensível, esperando que, por milagre, no espelho do outro [e dos objetos], esclareça-se e se elucide". Isso corresponde à busca, para além de nós, daquilo que possa constituir nossa parte desconhecida, impessoal. Daquilo que, ainda que nos provoque ímpetos de identificação, continuará não nos pertencendo como algo próprio (AGAMBEN, 2007, p. 19-21).

Cabe tratarmos, ademais, do papel específico desempenhado pelo desejo nos processos de identificação vivenciados pelo sujeito. Barthes dirá que "o Desejo não pode nomear-se, nem mesmo (ao contrário da Demanda) dizer-se" (BARTHES, 2004, p. 36). Agamben, por sua vez, anota que, embora o ato de desejar seja a "coisa mais simples e humana que há", os desejos se mantêm renitentemente "inconfessáveis” para nós, sendo no mais das vezes dificil "trazê-los à palavra”. É essa dificuldade crônica que, segundo o filósofo, faz com que os escondamos numa espécie de “cripta, onde permanecem embalsamados, à espera”. Sabemos, aliás, do frêmito inerente aos instantes imediatamente anteriores ou durante o transcurso dos encontros com o outro e com certos objetos semânticos. O filósofo postula, a propósito da "cripta” onde teríamos alocado nossos desejos, que nela há "apenas imagens", como "[n]um livro de figuras para crianças que ainda não sabem ler”. Note-se que a metáfora em si é apresentada sob a forma de um objeto de fruição. Ao cabo, o "corpo dos desejos" de um sujeito torna-se, ele mesmo, "uma imagem". Logo, o "desejo inconfessado somos nós mesmos”, que seguimos simultaneamente presos à cripta e desejosos de nela poder acolher projeções e afetações que se articulem com (e ressignifiquem) as imagens que aí foram sendo acumuladas (AGAMBEN, 2007, p. 49).

A esse respeito, Barthes contrapõe à "lógica da razão", calcada na decifração dos objetos e seus enunciados, a "lógica do símbolo", que, ao contrário da primeira, não é dedutiva e orientada pelo encadeamento de signos e ideias, mas "associativa” por excelência. Com isso, ela articula ao objeto de leitura e fruição "outras ideias, outras imagens, outras significações" (grifos do autor). Portanto, para o sujeito leitor/fruidor não se trata de decodificar os enunciados presentes em dado objeto, tendo em vista que, em lugar disso, "ele sobrecodifica; não decifra, produz, amontoa linguagens, deixa-se infinita e incansavelmente atravessar por elas: ele é essa travessia” (BARTHES, 2004, p. 28-41, grifo do autor).

Registremos neste ponto, com base em Agamben e Barthes (e num paralelo com Foucault), que o sujeito - assim como o público - não é uma entidade que precede os encontros com o outro e com os objetos (tampouco que antecede os exercícios de poder a que é submetido). Ele é uma instância que se constitui e atualiza permanentemente durante tais interações e suas contingências, seja como "cripta" atravessada pelo que vem de fora ou como "imagem" de uma travessia infindável (ou ainda como alguém que resiste e reage àquilo que busca conduzir suas condutas). Já não se concebe o sujeito como "o sujeito pensante da filosofia idealista”, mas sim, com base na episteme psicanalítica, como ser "despojado de toda unidade, perdido no duplo desconhecimento do seu inconsciente e da sua ideologia”, assentado apenas em uma imponderável "sucessão de linguagens" (BARTHES, 2004, p. 41). 
Com base nisso, somos levados a considerar os momentos de aproximação dos públicos com as proposições artísticas, curatoriais e mediativas como situações abertas às mais variadas (e imprevistas) formas de identificação, estranhamento e resposta, que em certos casos desencadeiam antagonismos, como veremos a seguir.

\subsection{DA LEITURA À ESCRITURA}

Pensar a esfera da recepção artística nesse registro significa, necessariamente, borrar as fronteiras e problematizar as hierarquias entre as intencionalidades daqueles que escrevem/ propõem e as atividades daqueles que leem/fruem. Com relação à prática da leitura, Barthes alude ao "texto que escrevemos em nossa cabeça quando a levantamos [da página]”, o que ocorreria durante nossas frequentes interrupções na leitura, provocadas não por desinteresse "mas, ao contrário, por afluxo de ideias, excitações, associações”. Segundo ele, esse texto produzido mentalmente no ato mesmo da leitura deveria ser designado por "uma só palavra": "texto-leitura" (BARTHES, 2004, p. 26-27, grifo do autor).

Contudo, além do texto que escrevemos mentalmente enquanto lemos, haveria também ensejos para desdobramentos da escrita em sentido literal, mediante a adoção dos mais distintos suportes e gêneros. Nesses casos, “a leitura é condutora do Desejo de escrever”. Desejo esse que liga a leitura a uma forma de produção simbólico-material: "não mais de imagens interiores, de projeções, de fantasias, mas, literalmente, de trabalho" (grifo do autor). Nesse caso, a leitura funciona como motor para outras escrituras, as quais não mantêm necessariamente compromisso de continuidade e endosso em relação ao texto lido, operando em certos casos de modo disruptivo. Aqui, "o produto (consumido) é devolvido em produção” (BARTHES, 2004, p. 39-40). Anote-se, de passagem, que a presente dissertação procura operar nessa mesma chave.

Parece-nos plausível usar essa mesma lógica na discussão das formas de recepção e interação dos públicos com as práticas representativas das artes visuais. Tomaremos como exemplo de produção disruptiva - a partir de um discurso dado - um controverso episódio ocorrido no contexto da $28^{\mathrm{a}}$ edição da Bienal de São Paulo (2008), intitulada Em vivo contato. Nessa ocasião, um grupo de quarenta pichadores, alguns deles ligados ao grupo Susto" ${ }^{3}$, invadiu o pavilhão expositivo, pichando paredes, corrimãos e colunas do segundo andar do edificio, mantido vazio pela curadoria da mostra sob a designação de "Planta Livre".

3 Nem todos os pichadores eram integrantes do referido grupo, visto que a chamada feita dias antes fora aberta aos pichadores que quisessem se incorporar à intervenção na Bienal.

4 Conceito emprestado do arquiteto Le Corbusier, usado originalmente para indicar um dos cinco princípios da arquitetura moderna: graças ao uso dos pilotis e do concreto armado, as então novas edificações puderam liberar a função de sustentação das paredes, propiciando andares inteiros livres de divisões, chamados de "plantas livres". 
Nossa abordagem em torno dessa ocorrência procura pensá-la em articulação às problemáticas e perspectivas discutidas na presente pesquisa, com o intuito de sondar suas consequências no contexto artístico-institucional. Para isso, servimo-nos da postulação de Barthes, segundo a qual "ao ler, nós também imprimimos certa postura ao texto, e é por isso que ele é vivo" (BARTHES, 2004, p. 29, grifos meus). No caso em questão, o ato de leitura atenta de modo enviesado e provocativo para o statement curatorial da Bienal Em vivo contato, assinado por Ivo Mesquita e Ana Paula Cohen, enquanto o correlato ato de escrita desdobra-se sob a forma de inscrições performativas e gráficas produzidas pelos pichadores no interior do prédio, mas também na própria concepção de "Planta Livre" proposta pela curadoria.

Originalmente, a proposição dos curadores para a $28^{\mathrm{a}}$ Bienal ambicionava criar uma "plataforma para observação e reflexão sobre o sistema e sobre a cultura das bienais no circuito internacional". Nesse sentido, Mesquita e Cohen conceberam-na como "um estudo de caso". Reduzindo consideravelmente o número de $\operatorname{artistas~}^{5}$ e diversificando a natureza das atividades no pavilhão ${ }^{6}$, eles se propunham a redirecionar o "modelo de mostras sazonais, atendendo às demandas das práticas artísticas, do debate político-cultural”’ (MESQUITA; COHEN, 2008b, p. 17-19). Mais (ou menos) do que uma bienal tratava-se de produzir uma metabienal, um evento que buscasse produzir uma dobra crítica sobre si.

Logo, o envolvimento dos frequentadores nessa pretensa esfera pública - compreendida pelos curadores como um "espaço social temporário" - pressupunha sua familiaridade com tais questões, bem como o interesse por debatê-las. Neste ponto, cumpre assinalarmos consonâncias com as afirmações de Grinspum, que concebe "o sistema de arte como um processo com meios próprios de existência”, embora o faça sem problematizar o hermetismo e o isolamento não raro gerados pela inclinação autocentrada do circuito das artes visuais. Desse modo, se apresentariam duas possibilidades dominantes de envolvimento dos públicos com a $28^{a}$ Bienal: 1) já gozando de familiaridade com as problemáticas internas ao circuito e ao seu vocabulário específico, dispor-se a debatê-las, ou 2) participar de tal fórum especializado na condição de curioso e/ou aprendiz, buscando se inteirar das questões, jargões e agendas em jogo nessa arena restrita.

Dentre as problemáticas e agendas pautadas pela curadoria, destacavam-se as preocupações com a própria vocação da Bienal, que talvez devesse "se trans-

5 Importante pontuar que, por ocasião da $28^{a}$ Bienal de São Paulo, a Fundação Bienal passava por uma grave crise financeira e de gestão. O que, em alguma medida, exigia da curadoria um tipo de solução economicamente viável para que o evento pudesse acontecer.

6 Além da Planta Livre, a $28^{\mathrm{a}}$ Bienal contaria com as seguintes plataformas: Praça; Video Lounge; Plano de Leituras (Exposição, Biblioteca e Conferências); Publicações; e Serviços Educativos [sic].

7 Embora aqui coubesse indagar: quais práticas artísticas? E que vieses do debate político-cultural? 
formar ou substituir-se dentro de uma cidade com seis museus de arte, assim como uma série de centros culturais ativos", fato que haveria tornado a Bienal "redundante em seu contexto local". Além desse aspecto, a curadoria chamava atenção para a existência de uma enorme quantidade de bienais ao redor do mundo, as quais se baseariam em um modelo desgastado e amplamente instrumentalizado por elites econômicas e políticas nos diversos contextos onde ocorrem. Com isso, em lugar de conceber a mostra como plataforma de exibição de uma grande quantidade de trabalhos alinhavados por determinado mote curatorial, os curadores optariam por fazer da $28^{\mathrm{a}}$ edição do evento uma espécie de "pausa para um processo de autorreflexão e crítica", com o intuito de repensar "sua agenda e sua função" (MESQUITA, 2008).

O principal emblema desse "ato de suspensão" propugnado pela curadoria se traduzia exatamente no segundo andar do pavilhão, mantido vazio durante o período da mostra ${ }^{8}$ (MESQUITA, 2008). Tida por alguns como "mão pesada”, pois excessivamente determinante da configuração da mostra e do pouco espaço destinado aos trabalhos artísticos propriamente ditos, a curadoria via sua própria iniciativa em relação ao vazio como "um gesto radical”, favorável à instauração de uma "análise sobre o modelo das bienais e seu papel no mundo contemporâneo”. Fazendo repercutir o vazio-pleno presente na poética de Lygia Clark ${ }^{9}$, o vazio proposto pela curadoria pretendia funcionar como "fonte geradora, [...] território do devir, com múltiplas possibilidades e caminhos” (MESQUITA, 2008). A aposta se dava pela criação de "condições para a busca de outros sentidos, de novos conteúdos” (MESQUITA; COHEN, 2008b, p. 21-23).

Durante o período em que a Bienal Em vivo contato esteve em cartaz, se tornaria patente, contudo, que o espaço aberto pelos curadores e pela instituição para as "coisas em potência", para o "devir", para as "múltiplas possibilidades e caminhos" e, com isso, para a "busca por outros sentidos e conteúdos”, não era um espaço tão aberto assim. O grau de abertura ficaria condicionado às expectativas da curadoria e da instituição em torno do que pudesse dali emergir em sentido convergente com os desígnios do projeto. Ou então limitada a gestos aceitáveis, até mesmo desejáveis, na medida em que denotassem usos propícios do espaço pelo público, como "colar stickers, fazer barcos de papel, ou tocar música no segundo andar do pavilhão” (MESQUITA; COHEN, 2008a).

9 Abordado por Suely Rolnik no artigo "Molda-se uma alma contemporânea: o vazio-pleno de Lygia Clark" (1999), um manuscrito da artista, inédito e sem data, traz a seguinte acepção: “[...] É preciso se [sic] morrer mesmo integralmente e deixar o novo nascer com todas as implicações terríveis do 'sentimento de perda' da falta de equilíbrio interior, do afastamento da realidade já adquirida; é o vazio vivido como tal, até o momento dele se transformar no vazio pleno, cheio de uma nova significação". 
Entretanto, como anota um grupo independente de teóricos, artistas e ativistas ${ }^{10}$, num texto de repúdio à prisão da pichadora Caroline Pivetta ${ }^{11}$ por ocasião da intervenção, a discussão proposta pela curadoria em torno do modelo "bienal" ficaria circunscrita a "um círculo pequeno de experts" - digamos, uma esfera menos pública do que semiprivada, formada por pares pertencentes a uma elite da comunidade artística. Em contraponto, parece-nos necessário demandar e fomentar o reconhecimento de uma terceira forma de envolvimento dos públicos com o evento em questão, que não se enquadra nem na posição do habitué familiarizado com os códigos e temas ali em pauta, tampouco no papel do curioso ou aprendiz interessado em se aproximar desse universo de questões. A partir da formulação presente no texto do referido grupo independente, falamos de um "interesse leigo em torno das possibilidades criativas de ocupação de um espaço privilegiado” (MESQUITA et al., 2008, grifo meu). Nota-se que a posição do "leigo" aparece aqui com o sinal invertido: no lugar do déficit, sublinha-se a potência e a capacidade de deflagrar respostas imprevistas, problemáticas e disruptivas. Em vez da convergência com os desígnios curatoriais e institucionais, o "interesse leigo" pelo vazio teria provocado

possibilidades que a Bienal não soube aproveitar, nem podia perceber, porque se fundavam em tensões totalmente estranhas à compreensão possível no âmbito institucional, referindo-se às latências do ambiente em que este se insere, sem dar-se conta. (MESQUITA et al., 2008.)

Tais possibilidades se relacionavam a outros desejos, na medida em que apontavam para outras problemáticas e outras agendas, num movimento desautorizado e simultâneo de apropriação e desvio da oferta institucional e da pauta curatorial. Desse modo, encetava no interior da Bienal, de modo decididamente turbulento, uma reivindicação acerca do reconhecimento de uma prática periférica, estigmatizada e criminalizada: o "pixo".

Mas não percamos de vista o fato de que a ação dos pichadores se deu, sobretudo, a partir da identificação de seus autores com o vazio-pleno ensejado pela

10 Grupo formado por André Mesquita, Artur Matuck, Cristiane Arenas, Euler Sandeville, Flavia Vivacqua, Gavin Adams, George Sander e Henrique Parra.

11 Caroline Pivetta da Mota, à época com 24 anos de idade, permaneceria presa por mais de cinquenta dias na Penitenciária Feminina de Santana, em São Paulo, sem julgamento, sob a acusação de infração à Lei de Crimes Ambientais (Lei $n^{\circ}$ 9.605), em virtude de o Pavilhão da Bienal ser um edifício tombado como monumento histórico estadual. A detenção resultava não apenas do ato da pichação, mas também de uma (perversa) filigrana jurídica relacionada ao fato de a jovem não ter conseguido comprovar residência fixa e ocupação legal. Pivetta preencheria seus autos de prisão com a assinatura "Caroline Sustos". Além dela, também seria preso o taxista Rafael Vieira Camargo Martins, de 27 anos, que respondeu ao processo em liberdade alegando ter apenas seguido $o$ ato como espectador. 
"Planta Livre", tomada como oportuna plataforma de visibilidade e reivindicação. Caroline Pivetta teria dito durante uma entrevista concedida no período em que esteve presa: "Todo mundo tem um vazio dentro de si” (Folha de S.Paulo, 5 dez. 2008, p. C7). E, em outro depoimento: "Eu me identifico com o vazio. Sentia falta de alguma coisa na minha vida, fazia coisas e nada cobria aquilo. Sentia um buraco. Comecei a pichar, foi tapando aos poucos..." (Folha de S.Paulo, 15 dez. 2008, p. A2, grifo meu).

Com isso, é plausível afirmar que a pichadora do Susto"s se fez público - numa combinação entre agente destinatária e sujeito político - dos enunciados veiculados pela $28^{\mathrm{a}}$ Bienal, em particular do vetor discursivo baseado no conceito-chave do vazio. Fazendo-se público, ela também imprimia uma postura transgressora (além dos sinais gráficos da pichação propriamente dita) ao texto curatorial. Não nos parece insignificante, ao contrário, o fato de que esse ato emergente e desviante dos propósitos curatoriais tenha sido levado a efeito, entre outros, por integrantes de um grupo cuja insígnia é Susto"s. Também não devemos deixar escapar outro detalhe: esses e outros comentários de Pivetta, capazes de nos colocar a par das motivações subjacentes à intervenção, só foram registrados e divulgados por que a pichadora acabou sendo presa. Eis o paradoxo.

Ainda conforme o grupo de teóricos, artistas e ativistas independentes, os pichadores teriam experimentado "um percurso imprevisível para a curadoria", surpreendendo e desafiando-a na medida em que a afrontavam com uma conduta nada polida e, portanto, "inadequada" para um espaço público pretensamente civilizado e democrático (MESQUITA et al., 2008). A aversão dos curadores ao tipo de intervenção praticada pelos pichadores transparece em seus comentários publicados na imprensa: "Quarenta jovens invadem o pavilhão da Bienal como um arrastão, derrubando tudo, agredindo pessoas fisicamente"; "mais um gesto peculiar deste grupo destrutivo" ${ }^{2}$; "vandalismo agressivo e autoritário"; "usa a pichação como meio para apagar e danificar o trabalho de outros artistas [sic]" (Folha de S.Paulo, 18 dez. 2008, p. E6).

À acusação da curadoria de que os pichadores pretendiam pichar as obras expostas no terceiro andar do pavilhão, Pivetta responderia com a seguinte afirmação: "A gente não queria estragar as obras, mesmo porque não tinha obra [no segundo piso]. A obra, ali, nós que íamos fazer" (Folha de S.Paulo, 5 dez. 2008, p. C7). Produzindo esse desvio no discurso oficial da mostra, Pivetta ainda diria: "Estava me manifestando contra [sic] os desfavorecidos, os que não têm acesso àquela coisa toda”. Ou seja, tratava-se de um tipo de envolvimento com a mostra vocacionado a "tornar pública a existência de outras realidades”, outras urgências, deslocadas das protagonizados por pichadores meses antes do ocorrido na Bienal. O primeiro refere-se à pichação da fachada do Centro Universitário Belas Artes e de grande parte das obras dos alunos expostas na galeria da instituição. $\mathrm{O}$ segundo diz respeito à invasão da Galeria Choque Cultural, quando pichadores danificaram cerca de vinte obras expostas no local. 
preocupações que teriam balizado o projeto dos curadores (MESQUITA et al., 2008, grifo meu).

Nesse sentido, o jornalista Fernando de Barros e Silva apresenta uma leitura do episódio no qual comenta o quão ambígua é a identificação afirmada por Pivetta em relação ao vazio, sugerindo a preponderância da sua contraface antagonista:

Entre o vazio existencial da jovem [do grupo] Susto"s e o vazio conceitual da Bienal há menos identificação do que antagonismo: a fúria da primeira é um impulso desesperado de vida que traz à luz o espírito burocrático e mortificante da segunda. (Folha de S.Paulo, 15 dez. 2008, p. A2, grifo meu.)

Ao friccionar o statement curatorial e a oferta institucional, a "fúria" manifesta por Pivetta e seus colegas pichadores concorre para a implementação temporária de uma esfera de fato pública, porque também contrapública, formada por posições plurais, divergentes e inconciliáveis. A esse respeito a crítica de arte Rosalyn Deutsche dirá que a constituição da esfera pública em sentido democrático só pode se dar na medida em que suas exclusões naturalizadas são trazidas à tona (DEUTSCHE, 2008, p. 24). Esse é o caso do embate dos pichadores com a Bienal e seus agentes, por meio do qual se exacerba a condição marginal dos primeiros. Lembremo-nos do que diz Foucault com respeito à capacidade que as reações e respostas dos sujeitos têm de revelar relações de poder. Tanto essas relações como as exclusões estruturais encontram-se frequentemente enrustidas sob o manto da normalidade e da civilidade.

Desafiadas, as relações de poder e as exclusões naturalizadas se veem implicadas num campo de contestação e antagonismo: um espaço social em vivo contato, aberto a contradições e, por conseguinte, a demandas que não se conformam umas às outras. No avesso dos argumentos de Mesquita e Cohen em torno do que eles identificam como "destrutivo" e "autoritário" no gesto dos pichadores, Deutsche afirma: "conflito, divisão e instabilidade [...] não destroem a esfera pública; são condições para sua existência”(DEUTSCHE, 2008, p. 25). Logo, evidencia-se que também a ideia dos curadores acerca do que seja um "espaço social temporário" é rasurada pelos pichadores, que entram numa disputa por seu significado.

Devemos frisar que essa outra acepção de "espaço social” pleiteada pela ação dos pichadores não pode ser completamente antecipada por aqueles que a anunciam em primeira instância, na condição de propositores de um evento, como no caso da Bienal de São Paulo. Sua dimensão efetivamente pública depende também do protagonismo do outro em face de um dado arranjo discursivo, espacial e temporal. Esse outro traz consigo agendas, linguagens e códigos de conduta específicos, muitas vezes descoincidentes e incompatíveis com os daqueles que tomam a iniciativa (com respaldo das instituições) de formar esse tipo de plataforma de interação, dispondo de um importante conjunto de capitais (simbólico, social e material) para concebê-la em uma escala significativa e contando com amplo reconhecimento e publicidade. 
Laclau e Mouffe afirmam, a esse respeito, que a "presença do 'Outro' faz com que eu não seja eu mesmo completamente" (LACLAU; MOUFFE apud BISHOP, 2011, p. 122). Transpondo essa constatação para o contexto da $28^{\text {a }}$ Bienal, podemos supor que a presença e a agência do outro - nesse caso, os pichadores - convocariam a comunidade artística, animada pela chamada dos curadores, a se observar em um espelho trincado (ou pichado), no qual, citando Bishop, "a presença do que não sou eu torna minha identidade precária e vulnerável, e a ameaça do que o outro representa transforma o próprio senso de mim mesmo em algo questionável” (BISHOP, 2011, p. 122, grifo da autora). Os pichadores lançavam-se, portanto, em uma empreitada pretensiosa, corrompendo em alguma medida a autoimagem prestigiosa e estável dos curadores e de seus pares da comunidade artística.

Ciosos dos propósitos originais do seu projeto e convictos da pertinência das questões elencadas previamente para a discussão, os curadores, ao mesmo tempo que refutavam o gesto dos pichadores, perdiam uma oportunidade ímpar (da ordem do singular) de topar o atravessamento produzido por essa ação alternativa e claramente antagonista. Mas não no sentido de capitalizá-la, agregando valor a si, e sim de aceitar a interpelação e a afronta do outro, que faz com que eu não seja eu mesmo completamente, suspeitando da validade e consistência dos meus propósitos e, assim, abrindo-me para a dinâmica democrática calcada no exercício da alteridade, com tudo o que ela tem de instável e vital. Inclusive porque a arena democrática, de acordo com Bishop, "não é aquela em que todo o antagonismo desaparece, mas aquela em que novas fronteiras políticas são constantemente traçadas e colocadas em debate” (BISHOP, 2011, p. 121).

O esgarçamento e a redefinição permanente dessas fronteiras, num processo em que as exclusões naturalizadas são enfrentadas e reveladas, só podem se dar a partir de interações sociais "em que as relações de conflito são sustentadas e não apagadas". Por outro lado, nos casos em que o antagonismo é expurgado o que resta é "apenas um consenso imposto por uma ordem autoritária”, ainda que essa imposição geralmente seja relativa e escorregadia, haja vista as obstinadas e intransigentes provocações dos sujeitos políticos postulantes de reconhecimento e liberdade, que não cessam de confrontar essa mesma ordem (BISHOP, 2011, p. 121).

É por esse motivo que Foucault considera mais pertinente identificar tais insurgências não exatamente com a noção de "antagonismo", mas com a ideia de "agonismo". O último termo denota uma lógica de interação social "que é, ao mesmo tempo, de incitação recíproca e de luta”, deixando claro que os endereçamentos e provocações não partem apenas de um dos lados, enquadrando o outro por completo. Ao contrário, "trata-se [...] menos de uma oposição de termos que se bloqueiam mutuamente do que de uma provocação permanente” (FOUCAULT, 1995, p. 244-245). Obliterar tal relação conflituosa, independentemente do lado de onde isso possa partir, corresponde a agir de modo autoritário.

Desse ponto de vista, a prisão de Caroline Pivetta e o fato de os curadores Ivo Mesquita e Ana Paula Cohen terem se eximido de contrapor-se à medida 
judicial, abdicando de lançar-se em defesa da sua liberdade ${ }^{13}$, representam sinais eloquentes de uma postura autoritária - inversamente reputada pelos mesmos curadores aos pichadores - que obstruiu a continuidade da contenda simbólica. Talvez esse tenha sido um dos principais efeitos do gesto dos pichadores e de seus posteriores desdobramentos jurídicos e midiáticos: o caráter supostamente autoritário da ação dos pichadores teria se descolado da iniciativa e da figura dos jovens para cair no colo dos curadores.

\subsection{SOCIALIZAÇÃO DA PRODUÇÃO DISCURSIVA E A LÓGICA DA EMERGÊNCIA}

Parece-nos elucidativo cotejar a perspectiva curatorial acima comentada com as preocupações de um coletivo de agentes artísticos, o Group Material ${ }^{14}$, que se predispõe a conjugar práticas artísticas, curatoriais, ativistas, educacionais e editoriais, com base em "uma visão mais inclusiva e democrática da arte"15. Atuando nos anos 1980 em Nova York, o coletivo apresenta-se, à época, como um "grupo independente que se propõe organizar, exibir e promover uma arte orientada para a mudança social” (GROUP MATERIAL, 1996a, p. 894). Desse modo, instalam o que se tornaria um misto de ponto de encontro com a vizinhança e galeria de arte num imóvel situado na área hispânica do lado leste de Manhattan, após longo período de levantamento de fundos para a locação e a administração do imóvel.

De modo notadamente distinto dos curadores da $28^{\mathrm{a}}$ Bienal de São Paulo - desejosos de discutir com seus pares determinadas problemáticas internas ao circuito das artes visuais -, os integrantes do Group Material, imbuídos de um "ativismo cultural mais amplo", buscavam se aproximar e interagir com "um abrangente público "não artístico”, a fim de discutir "questões sociais específicas" com pessoas dos mais diferentes perfis e procedências (GROUP MATERIAL, 1996a, 1996b, p. 894-895). Privilegiando problemáticas de natureza sociopolítica, o grupo experimentaria uma variedade de formas de transformação de exposições de arte em "fóruns para a participação", conforme comentado por Graziela Kunsch em seu Projeto Mutirão (KUNSCH, 2008, p. 19).

Em Democracy (1988-89), trabalho subsidiado pela Dia Art Fundation, o grupo identificaria quatro áreas em que a crise da democracia se tornava explícita

13 Ainda que considerasse a pena pesada, Mesquita se furtaria de tomar qualquer atitude em sentido contrário: “Eu não sei o que a curadoria tem a ver com isso [...]. A curadoria não pode fazer nada. A curadoria é um serviço terceirizado, que a Bienal contrata para fazer um projeto" (Folha de S.Paulo, 13 dez. 2008, E4). Disponivel em: <http://www1.folha.uol.com.br/fsp/ilustrad/ fq1312200810.htm>. Acesso em: 16 jun. 2016.

14 Entre suas diferentes formações, incluem-se os nomes de Doug Ashford, Julie Ault, Felix Gonzalez-Torres, Mundy McLaughlin, Tim Rollins, Patrick Brennan, Beth Jaker, Marybeth Nelson e Peter Szypula.

15 Cabe mencionar o crescente interesse dos atuais estudos curatoriais pelo legado do Group Material. 
no panorama norte-americano: educação, eleições políticas, participação cultural e aids. Para cada um desses tópicos, o grupo organizou colaborativamente uma discussão no formato de mesa-redonda, uma instalação e encontros denominados town meetings. Para as mesas-redondas foram convidados especialistas em cada um dos tópicos para ajudar o grupo a elaborar as instalações, enquanto os town meetings eram abertos à participação de qualquer pessoa que quisesse debater os temas a partir da sua própria experiência. No cartaz-convite para um desses encontros o grupo dizia: "Por favor, venha preparado para falar sobre estes assuntos. O town meeting sobre educação e democracia será gravado, transcrito e incorporado a uma publicação organizada pelo Group Material para a Dia Art Foundation” (KUNSCH, 2008, p. 19-21).

Pode-se notar, em tal projeto, a afirmação de um duplo propósito. Primeiramente, a tentativa de deflagrar esferas públicas temporárias de participação e discussão. Por meio de tais situações, busca-se formular de maneira distribuída e publicizável concepções críticas acerca de problemáticas concernentes ao conjunto da sociedade, mediante a participação do outro, de modo a socializar a produção discursiva. Nesse quesito, importa pontuar que, em lugar de ser compreendido como público não iniciado nas questões da arte e do seu circuito, o outro é aqui tido como cidadão habilitado a se posicionar diante de temas pungentes de uma realidade sociopolítica que lhe diz respeito. Logo, o convite à participação não deveria ficar restrito aos pares da comunidade artística.

No entanto, dentre aqueles que viriam a aderir ao convite do grupo, fazendo-se público do projeto Democracy, houve quem chamasse atenção, por exemplo, para a ínfima representatividade dos diferentes segmentos da população em tais encontros. Este foi o caso de Geno Rodriguez, diretor do Alternative Museum, participante do town meeting dedicado ao tema da educação:

Estou tentando imaginar como nós poderemos falar sobre a educação americana hoje, quando a audiência não parece refletir o espectro total dos americanos. Quero dizer, não vejo muitos negros, não vejo hispânicos ou asiáticos, e aqueles que vejo são na maioria artistas ou pessoas com conhecimento em arte, frequentemente isolados das preocupações de sua própria comunidade. Acho que a primeira coisa que devemos fazer - antes de discutir sobre educação - é refletir dentro de nós mesmos por que não conseguimos fazer essa ponte cultural ser funcional. Ninguém está realmente tentando fazer com que as pessoas cruzem a ponte. [...] Este diálogo, no qual estamos supostamente buscando soluções para as pessoas, tem um lado farsesco. (RODRIGUEZ apud KUNSCH, 2008, p. 22.)

O que o participante parece salientar é o risco de que, ao estimular a produção de uma esfera pública de debate acerca de um tema tão abrangente e central, como é o caso das interseções entre educação e democracia, se 
suponha falar em nome da coletividade. Contudo, apenas uma pequena parcela desta - nesse caso, a própria comunidade artística - sente-se realmente estimulada a aceitar o convite feito pelo grupo.

Sua crítica vai além, ao afirmar que tais pessoas (ele incluído) encontram-se muitas vezes afastadas "das preocupações de sua própria comunidade”, em sentido local e extra-artístico. O importante aqui, além da problematização em si e do que ela significa, é notar que a abertura para uma situação dialógica (textualmente documentada, o que a torna acessível em outras temporalidades e contextos) favorece e sustenta a emergência de uma voz dissonante, que coloca em questão a própria efetividade da iniciativa do grupo em questão.

Apesar disso, Kunsch acredita que a autocrítica diante do problema da representatividade já estaria presente nas proposições do Group Material, na medida em que buscam o "alargamento da arte e [portanto] do público da arte”. Daí o foco nos aspectos da vida social, que dizem respeito aos cidadãos em geral, e a lógica participativa que dá o tom dos encontros (KUNSCH, 2008, p. 22). Porém, não é possível considerar a disponibilidade dos diferentes públicos como um resultado automático das proposições dos artistas, garantido apenas por elas. Ou seja, a intencionalidade e a proposição artísticas correspondem apenas a uma das faces de um processo mais complexo, que depende, por outro lado, do interesse e da iniciativa dos públicos em se vincular temporariamente a elas.

Isso quer dizer que as esferas efetivamente públicas, enquanto formações plurais e abertas a posições distintas, se constituem de modo contingencial e temporário, a partir de uma dinâmica emergente que não pode ser completamente antecipada por quem busca instaurá-las. Ou seja, elas estão sempre condicionadas à imprevisibilidade da parte que cabe ao outro, na condição de um público, no sentido de seu interesse e disposição por vincular-se ou não a determinadas situações dialógicas, ou mesmo atravessá-las sem chegar a constituir vínculo. No caso de haver essa disposição, há que se considerar, ainda, a frequente reivindicação do outro por agendas, repertórios, códigos e formatos em desacordo com o que apresentam o programa inicial e as expectativas subjacentes a ele. Um exemplo claro disso é a intervenção protagonizada pelos pichadores na $28^{\text {a }}$ Bienal de São Paulo.

Em direção análoga, observemos outro caso em que a emergência de um público se manifesta de modo divergente, produzindo descontinuidade em uma dada proposição. O que no projeto do Group Material aparece como chamada pública para a discussão de aspectos relativos à democracia no âmbito de uma exposição de arte, no caso dos processos desenvolvidos pelo artista Ricardo Basbaum surge como agenciamento e estímulo à produção discursiva pelo outro - entendido como colaborador. Com isso, o artista experimenta um deslocamento na noção de "arte para o público", repropondo-a através da lógica da "arte pelo público", já mencionada por nós em referência a outra situação. Em seu projeto intitulado Você gostaria de participar de uma experiência artística?, Basbaum lança mão de um dispositivo artístico-relacional que funciona como plataforma a partir da qual o outro é convidado a participar como pro- 
dutor de discursividades, que podem ser gráficas, fotográficas, textuais, projetivas, videográficas e performáticas, ou mesmo híbridas.

Assim como nas propostas do Group Material, embora com outros critérios e propósitos, há por parte do artista a preocupação de que tais discursividades sejam não apenas produzidas de forma distribuída, mas também publicizadas. No caso de Você gostaria de participar de uma experiência artística?, as operações de registro e publicização são feitas pelo próprio colaborador do projeto, sendo hospedadas no sítio virtual ${ }^{16}$ dis- $^{-}$ ponibilizado pelo artista, correspondendo a uma parte integrante da "experiência artística" anunciada por Basbaum no título de sua proposição-convite. Inclusive, a própria definição do que seja "artístico" é compartilhada entre o artista e cada público do projeto, na medida em que cabe ao último realizar algo que considere artístico com a peça emprestada por Basbaum.

Com início em 1994, o projeto se mantém ativo no presente. Trata-se de um trabalho em curso. Em termos práticos, ele prevê a disponibilização de um objeto de proporções médias, em metal esmaltado, aos públicos que se dispõem a envolver-se com a experiência. Ao receber o objeto, o público torna-se colaborador do projeto, tendo diante de si um horizonte aberto de uso e, a partir disso, de produção simbólico-discursiva. As únicas prescrições do artista indicam que esse uso seja documentado e publicizado, e que a peça seja devolvida, de modo que possa seguir circulando mediante novos empréstimos ${ }^{17}$.

Desse modo, Basbaum parece promover uma radicalização da proposta de Barthes acerca da destituição da autoridade do autor. Abdicando do papel de criador privilegiado de enunciados artísticos, o artista opta por compartir os processos de criação com os públicos que colaboram com seu projeto, o que se processa pela disponibilização/apropriação de um objeto disparador.

Importante índice de uma prática autoral distribuída, nesse caso, é o fato de o objeto deflagrador da experiência aparecer sempre associado à sigla NBP, relativa à noção de Novas Bases para a Personalidade. Os usos desse dispositivo pelos colaboradores do projeto podem ser entendidos, conforme propõe o artista no próprio título do trabalho, como produções distribuídas de caráter artístico, que deixam, assim, de ser uma prerrogativa exclusiva do artista, inclusive no que se refere àquilo que o trabalho veicula enquanto repertório gerado e acumulado por uma comunidade formada em torno do projeto.

É necessário destacar, ainda, que o artista se ocupa da preparação da plataforma de ocorrência e evidenciação pública de sua proposição, mantendo-se atuante e fomentando permanentemente os processos de interlocução com diferentes públicos. Tais públicos-colaboradores vão sendo (auto)produzidos, para retomar as ideias de Warner, pelas situações e discursivi- 
dades apresentadas por Basbaum e em relação a elas, as quais envolvem desde a disponibilização do objeto, até a operacionalização do sítio virtual onde seus usos são apresentados, mas também uma série de outros eventos, como exposições, oficinas, performances e encontros.

Assim como nos parece importante chamar atenção para esse modo distribuído de se conceber os trabalhos de arte, interessa-nos trazer à tona formas imprevistas e disruptivas de sua apropriação pelos públicos, com destaque para o caráter fundamentalmente agonista das esferas públicas ensejadas por essas mesmas proposições. Nota-se, no exemplo a seguir, um tipo de apropriação e resposta que procura subverter as regras do jogo sugerido por Basbaum. Trata-se da participação do grupo Vaca Amarela ${ }^{18}$ no projeto em questão, no ano 2004.

Ao receber o objeto de metal esmaltado, o grupo decidiu dar a ele um destino alheio aos propósitos originais do projeto, doando-o para o Museu de Arte de Santa Catarina - Masc ${ }^{19}$. Praticando esse gesto, seus integrantes visavam provocar um “curto-circuito" na proposição de Basbaum, na medida em que interrompiam o movimento de circulação do objeto, que ficaria, a partir de então, "trancado" no Museu ${ }^{20}$. Ao tomar conhecimento da iniciativa do grupo, Basbaum foi até a cidade de Florianópolis com o intuito de reaver o objeto junto ao Museu, além de buscar dialogar presencialmente com os integrantes do Vaca Amarela, que, por sua vez, se abstiveram de encontrá-lo.

Ainda que pudéssemos nos dedicar a discutir as implicações desse gesto - como, por exemplo, a crítica do grupo ao fato de os créditos artísticos do projeto, embora resultantes do trabalho coletivo, permanecerem associados, em última instância, à figura de Basbaum -, o que interessa destacar são as formas de apropriação das proposições e discursos artísticos. Invertendo a direção do convite, o Vaca Amarela convoca Basbaum a se tornar público da ação provocativa do grupo. $\mathrm{O}$ artista, por sua vez, afirmará não ver sentido algum em deixar o NBP parado em um museu, de acordo com o registro textual realizado por Kunsch a partir de um evento público protagonizado por Basbaum, tempos depois ${ }^{21}$. Além disso, e aqui se revela um interessante desacordo semântico entre as intenções do grupo e a forma como o artista as compreende, Basbaum dirá que não entende essa ação como uma provocação ao seu projeto, mas como uma provocação ao incipiente circuito institucional e museológico de Santa Catarina. Ou seja, para cada enunciado - seja do artista, seja do grupo - surgem, como respostas, interpretações não

18 À época, formado por uma turma de alunos da Universidade do Estado de Santa Catarina. Vários deles são hoje artistas com produção regular no circuito das artes visuais.

19 O documento que atesta o recebimento do objeto, pelo museu, pode ser consultado em: <http://www.nbp.pro. br/blog.php?experiencia=7>. Acesso em: 10 mai. 2017.

20 Tal propósito me foi relatado, pessoalmente, por um dos integrantes do grupo, alguns anos após o ocorrido.

21 O relato crítico completo pode ser acessado em: <http://www.forumpermanente.org/event_pres/mesas/ basbaum/r-x-eu>. Acesso em: 15 fev. 2017. 
coincidentes e notadamente desencontradas, marcadas por uma perspectiva dissensual.

Registremos, ainda, que tanto o projeto de Basbaum como o fórum articulado pelo Group Material têm como lastro histórico e conceitual as ideias desenvolvidas pelo filósofo Walter Benjamin, na década de 1930, acerca do "autor como produtor". Assim como Barthes, Benjamin elabora sua análise a partir do campo literário. Desse modo, ele chama atenção para os modos como os experimentos literários operam no interior das relações sociais de produção de uma determinada época e contexto. No caso enfocado pelo filósofo, isso ocorre numa perspectiva de ampliação do escopo daquilo que se identifica por "técnica literária". Sua argumentação acerca de tal problemática toma como referência as iniciativas do escritor soviético Sergei Tretyakov (1892-1937). Produzindo sua obra em meio a condições sociais e literárias específicas, e aqui estamos falando do período pós-revolucionário na União Soviética, o autor em questão encarnaria o papel de um escritor "operativo", imbuído da busca por socializar a produção discursiva (BENJAMIN, 1994, p. 122-123). Embora modulado em bases e conjunturas bastante distintas, esse traço também pode ser notado nos processos desencadeados pelos integrantes do Group Material e por Basbaum.

A conjuntura histórica de atuação do escritor operativo analisado por Benjamin condiz à "época da coletivização total da agricultura” na União Soviética (BENJAMIN, 1994, p. 123). No final dos anos 1920, quando os escritores eram conclamados a acorrer aos colcozes ${ }^{22}$, Tretyakov permanece por duas longas temporadas na comuna Farol Comunista, onde se engajaria em uma pluralidade de práticas que combinavam cultivo agrícola e produção discursiva, entre as quais é possível listar:

convocação de comícios populares, coleta de fundos para a aquisição de tratores, tentativas de convencer camponeses individuais a aderirem aos colcozes, inspeção de salas de leitura, criação de jornais murais e direção do jornal do colcoz, reportagens em jornais de Moscou, introdução de rádios e de cinemas itinerantes etc. (BENJAMIN, 1994, p. 123.)

Benjamin associa esse amplo leque de atividades assumidas pelo escritor à necessidade de se "repensar a ideia de formas ou gêneros literários", na medida em que estes são diretamente afetados pelos fatos técnicos e sociopolíticos de seu tempo histórico. Tais fatos impeliriam o escritor a se reconhecer "no centro de um grande processo de fusão de formas literárias", cujo principal emblema seria o jornal. Desse modo, o filósofo afirma que a definição do autor como produtor "precisa recorrer ao exemplo da imprensa”, haja vista que o jornal seria a plataforma discursiva onde se ope-

22 Propriedade rural coletiva em que os camponeses cultivavam a terra em comum e davam uma parte do que produziam ao Estado. 
ra uma promissora "confusão literária” (BENJAMIN, 1994, p. 123-125).

Nesse contexto, o jornal representaria o veículo onde a "impaciência do leitor" se manifesta mais intensamente. Tal impaciência exigiria, por sua vez, um tipo de "alimentação diária”, demandando dos editores a ampliação e diversificação contínuas das seções do jornal, a fim de que o periódico conseguisse responder às sempre crescentes "perguntas, opiniões e protestos" dos leitores (BENJAMIN, 1994, p. 124). O que, formalmente, se daria através da seção de "cartas dos leitores", mas não apenas. Segundo o filósofo, essa dinâmica geraria um movimento simultâneo de retroalimentação e embaralhamento de papéis: "Com a assimilação indiscriminada dos fatos cresce também a assimilação indiscriminada dos leitores, que se veem instantaneamente elevados à categoria de $c^{-}$ laboradores [do jornal]" (BENJAMIN, 1994, p. 124, grifo meu).

Desse modo, a pauta do periódico se tornaria o resultado de uma diversidade de exigências provindas do conjunto da sociedade (ou, mais precisamente, de seus segmentos letrados e socialmente influentes), e não apenas das redações e gabinetes. Se, por um lado, essa abertura às urgências dos leitores tende a forçar o "declínio da dimensão literária na imprensa burguesa”, por outro, ela aponta para a possibilidade de sua "renovação na imprensa soviética". Essa possibilidade estaria atrelada a dois fatores interdependentes: 1) ao mesmo tempo que a permanente ampliação dos fatos tematizados pelo jornal concorre para a perda da profundidade literária das abordagens, 2) ocorre uma gradativa relativização da "distinção convencional entre autor e público”, preservada de maneira artificial pela imprensa burguesa. Ou seja, à vulgarização da pauta jornalística corresponderia uma inescapável revisão do estatuto do leitor do jornal, que em certo sentido adentra as redações como alguém apto a prescrever e, também, escrever a respeito de assuntos de interesse comum, ainda que cada vez mais segmentados. A divisão moderna do trabalho, com seu caráter fortemente especializado, concederá a certos atores sociais, com base "no cargo em que exerce[m] suas funções" no mercado de trabalho, a possibilidade de se fazerem autores. Com respeito a isso, Benjamin dirá que "o próprio mundo do trabalho toma a palavra" (BENJAMIN, 1994, p. 124, grifo meu).

Paradoxalmente, ao passo que o processo produtivo se especializa cada vez mais, a função autor se abre, no caso da imprensa, para um contingente cuja formação passa ao largo das especificidades da "profissão literária". A formação literária deixa, portanto, de representar um pré-requisito indispensável à escrita em âmbito público na medida em que o jornal passa a absorver novos autores de "formação politécnica", que acabam dando a entender que a atividade da escrita é um "direito de todos”. São esses autores politécnicos quem, graças a sua contínua participação na pauta noticiosa, difundem o lema da "literalização das condições de vida”. São eles, por fim, quem narram, a partir das idiossincrasias de seus campos de atuação profissional, fatos capilarmente distribuídos pelos diversos estratos da vida social (BENJAMIN, 1994, p. 125).

Essa ampliação do arco dos agentes que passam a chamar também para si o fazer literário cotidiano desencadearia não apenas o embaralhamento dos gêneros literários, mas também e principalmente o questionamento da 
“própria distinção entre autor e leitor” (BENJAMIN, 1994, p. 125).

Tretyakov é identificado por Benjamin como um intelectual que compreendeu essa transição como poucos, equiparando-o nesse quesito a Bertolt Brecht e sua forma de fazer teatro, assunto que comentaremos mais adiante. A atuação do escritor soviético se tornaria modelar, aos olhos do filósofo alemão, pela "função organizadora" de seus agenciamentos, os quais visariam aprofundar e politizar a abertura do aparelho discursivo, em particular o jornal, ao exercício da escrita por aquele que, além de leitor, passa a assumir a posição de colaborador no processo da produção jornalística (BENJAMIN, 1994, p. 131-132).

No entanto, pensadores contemporâneos como Claire Bishop e Jacques Rancière, cada qual a seu modo, colocam esse modelo pragmático-epistemológico entre parênteses, chamando atenção para os problemas e insuficiências de uma perspectiva que aposta na capacidade que teriam determinados agenciamentos de "conduz [ir] consumidores à esfera da produção” (BENJAMIN, 1994, p. 132, grifo meu). Nossa abordagem também procura problematizar esse tipo de asserção, buscando demonstrar que a atuação dos públicos não condiz, necessariamente, a um desdobramento automático e convergente às proposições de agentes operativos. Como temos procurado chamar atenção, as respostas dos públicos às ofertas e proposições frequentemente não coincidem com os propósitos postulados por aqueles que os endereçam e os convocam a agir, o que acaba por abrir todo um campo para modos de uso imprevistos, desviantes e, em certos casos, antagônicos.

Bishop situa as hipóteses de Benjamin ligando-as a uma vertente intelectual (artistas inclusos) que já se teria configurado como uma tradição moderna, assentada na ideia do "trabalho de arte como um disparador potencial para a participação”. Tal vertente seria formada por expoentes como Brecht, Barthes, Eco, Joseph Beuys, grupo Fluxus e, mais recentemente, Nicolas Bourriaud e os artistas enfocados sob o enquadramento da estética relacional. De diferentes modos, todos eles compartilhariam do “desejo de ativação do observador” (BISHOP, 2011, p. 117). Tal premissa é parcialmente sistematizada por Plaza em sua narrativa historiográfica, já comentada no presente capítulo.

Quanto ao leitor-colaborador de Benjamin, Bishop ressalva que, embora o jornal se abra aos pontos de vista e discursividades dos leitores, ele o faz de modo controlado e parcial, haja vista o papel estratégico e hierárquico exercido pelo editor na seleção e manejo daquilo que provém dessa instância. (Ocorre-nos aqui certa coincidência com a "Planta Livre" da $28^{a}$ Bienal de São Paulo e a respectiva posição dos curadores.) Ademais, a autora destaca que "a seção de cartas não passa de uma entre o amontoado de páginas autorais [presentes no jornal]”, ainda que aqui ela se esqueça de mencionar os autores politécnicos e sua inserção nas demais seções do jornal (BISHOP, 2011, p. 130).

Rancière, por sua vez, lança suspeita sobre o próprio princípio que orienta agenciamentos imbuídos de mobilizar o público, incitando-o a assumir uma posição ativa nos processos artísticos, como veremos a seguir. 


\subsection{EMANCIPAÇÃO DO ESPECTADOR}

Até aqui, pudemos observar dois vetores representativos dos modos de antecipação e/ou condução de condutas dos públicos das práticas artísticas. $\mathrm{O}$ primeiro se estrutura com base no visitante inexperiente tutelado pelos agentes da mediação institucional, enquanto o segundo, subjacente às proposições dos artistas, concebe os públicos numa lógica de transição que vai do espectador, passando pelo participante e interator, até chegar ao colaborador.

Produzindo um deslocamento nesse conjunto de acepções que postulam os papéis desempenhados pelos públicos como desdobramentos diretos das proposições dos agentes do circuito artístico - sobretudo na perspectiva de sua mobilização e ativação -, o filósofo Jacques Rancière postula a "emancipação do espectador". Suas ponderações resultam da suspeita em torno de uma premissa altamente influente no campo artístico em geral (não apenas nas artes visuais) a partir do século XX: a crença de que "o espectador deve ser retirado da posição de observador" (RANCIÈRE, 2012, p. 10).

Em sua crítica a essa crença, Rancière parte do princípio da "igualdade das inteligências", tomando-a como base para estabelecer os pontos de contato entre a "emancipação intelectual" e a problemática do espectador na atualidade. Embora sua crítica tome como referência as artes do espetáculo, caracterizadas pela presença de "corpos em ação diante de um público reunido", em particular o teatro, suas reflexões se mostram úteis para pensarmos as práticas artísticas ligadas ao campo da visualidade e, ainda, para indagarmos as abordagens propugnadas pela mediação cultural, sobretudo em sua vertente institucional (RANCIÈRE, 2012, p. 8).

Nesse tocante, o autor revisita criticamente a ideia de que "é um mal ser espectador", máxima assentada num tipo de oposição arraigada entre o fato conhecer e o ato de olhar, com a famigerada desvantagem para o segundo. Além disso, olhar seria a contraparte inferior do agir. Daí as buscas por outro teatro, "um teatro sem espectadores", em que eles abandonassem o jogo de sedução das imagens - logo, sua condição de voyeurs - para se tornarem participantes ativos (RANCIÈRE, 2012, p. 8-9).

Rancière está se referindo, a título de exemplo, ao teatro épico de Bertolt Brecht e ao teatro da crueldade de Antonin Artaud. A diferença é que, no caso do primeiro, o teatro torna-se "uma assembleia na qual as pessoas do povo tomam consciência de sua situação e discutem seus interesses” (grifo meu); enquanto no segundo trata-se de um "ritual purificador em que uma coletividade se apossa de suas próprias energias”. De maneiras distintas, procura-se mobilizar o outro, tirá-lo do pretenso estado de inércia que estigmatizaria a condição de espectador (RANCIÈRE, 2012, p. 10-11).

"Experimentador" e "inquiridor": esses seriam os estatutos a serem incorporados pelos espectadores ao se depararem, no caso do teatro da crueldade de Artaud, com "um espetáculo estranho, inabitual, um enigma cujo sentido ele precise buscar”. Ou então, no caso do teatro épico de Brecht, com um espetáculo baseado num "dilema exemplar, semelhante aos propostos às pessoas empenhadas nas decisões da ação”. Portanto, caberia ao espectador incauto transformar-se, o quanto antes, no seu contrário, 
tomando parte "[n]o corpo ativo de um povo a pôr em ação o seu princípio vital” (RANCIÈRE, 2012, p. 10-11).

Para favorecer a ascensão do espectador a esse corpo ativo, Brecht se concentraria, segundo Benjamin, nos aspectos essenciais da linguagem teatral, combatendo quaisquer recursos e manobras ilusionistas que pudessem seduzi-lo e distraí-lo das urgências da realidade. A respeito dessa opção estética do encenador, o filósofo afirma que a "ilusão é inutilizável para um teatro que se propõe tratar os elementos da realidade no sentido de um ordenamento experimental”. Em lugar da ilusão, Brecht apostaria no "procedimento da montagem", tratando das condições da realidade mediante a interrupção sistemática das ações dos atores, com a finalidade de produzir fraturas simbólicas nos contextos abordados. Assombrado, o espectador seria impelido a se reconhecer em tais condições, mais desveladas do que reproduzidas pelo elenco. A sequência de interrupções [sic] teria a capacidade de suspender cada um dos acontecimentos. Mais que isso, ela "obriga o espectador a tomar uma posição quanto à ação", no sentido de poder agir sobre as "situações em que vive” (BENJAMIN, 1994, p. 133-134, grifo meu). Nota-se, aqui, uma disposição de conduzir o espectador a uma condição de consciência e a um estado de prontidão que lhe faltaria em alguma medida.

Como se vê, o desígnio brechtiano não seria o de proporcionar ao espectador um espetáculo teatral, e sim um aparelho capaz de incitá-lo a estranhar suas próprias condições de vida, conscientizando-se da necessidade de agir para modificá-las. Nesse caso, a mídia "espetáculo" - condizente a um terceiro elemento entre seus realizadores e a plateia - estaria paradoxalmente orientada para a sua própria supressão, na medida em que o aparelho colocado em seu lugar propõe ao público abandonar a posição de espectador, daquele que assiste e se deixa envolver pelas representações ilusionistas. Elimina-se, com isso, a espessura própria da peça artística, que a um só tempo aproximaria e distanciaria criadores e fruidores.

Nesse quesito, Rancière identifica um paralelo com as relações pedagógicas, em que "o papel atribuído ao mestre é o de eliminar a distância entre o seu saber e a ignorância do ignorante”. No entanto, a operação de redução de distância entre saber e ignorar só pode se sustentar por meio da sua perpétua recolocação: "o ignorante não é apenas aquele que ainda ignora o que o mestre sabe; é aquele que não sabe o que ignora, nem como o saber”. Por isso, depende e continuará a depender do seu mestre, que lhe dirá, em parcelas intermináveis, o que ele deve aprender e como deve fazê-lo. É isso que o autor denuncia como sendo um processo de "embrutecimento" do outro, tornado objeto da instrução alheia (RANCIÈRE, 2012, p. 13).

Tal lógica repercute, em alguma medida, em proposições artísticas que tomam para si a tarefa de mobilizar seus públicos - sabendo em que direção e de que modo fazê-lo -, como se lhes faltasse iniciativa de mobilizar-se por si em relação a premências de naturezas diversas, desde as problemáticas mais concretas da realidade social até os seus anseios mais íntimos. 
No afã por alçar o espectador a uma posição ativa, artistas muitas vezes procuram provocá- $\mathrm{lo}^{23} \mathrm{com}$ o intuito de fazê-lo cônscio da sua capacidade de agir. Intitulado Ações ativadoras, o caso narrado a seguir integra a minha coleção de episódios contrapúblicos. Seria útil observá-lo à luz das problematizações de Rancière:

Em sua $18^{\circ}$ edição, o Festival Videobrasil: Panoramas do Sul agregou à exposição os chamados Programas Públicos. Entre outras frentes, os programas incluíam ações ativadoras realizadas no ambiente da exposição. Neste contexto foi concebida a ação intitulada Público, pela artista Carolina Mendonça, uma performance desempenhada em diferentes momentos da exposição por atores contratados e dirigidos pela artista. Em linhas gerais, a ação traduzia-se na abordagem feita pelos atores - que em princípio se portavam como público da exposição - junto aos visitantes desavisados da ocorrência daquela performance, que os tinha como destinatários. Ao aproximar-se discretamente de um ou mais visitantes, $o$ ator vocalizava a sentença: "é uma visão comum hoje, que no momento em que nós nos percebemos em público, senão antes disso, uma vez que somos seres sociais desde o início, nós nos transformamos em performers performando nós mesmos diante de outros". Imbuído desse script, um dos atores mirou no fundo da sala expositiva, próximo às pinturas da artista Ana Prata, um trio de freiras. Ficou excitadíssimo com a oportunidade que tinha a apenas vinte passos de onde se encontrava. Não fazia a menor ideia de por que uma das freiras, a mais velha, permanecia diante do retrato d'O russo há mais de dez minutos. Não tinha como saber que a freira associara a feição pintada do russo com a do padre Fernando Bastos de Ávila (falecido em 2010) e que, por isso, orava em silêncio e em pé diante da pintura, sem qualquer afetação litúrgica. Quando o ator se aproximou dela e desatou a dizer em voz alta a frase "é uma visão comum hoje"..., foi prontamente interrompido pelas outras duas freiras, que lhe deram um pito: "psiu! não lhe ensinaram que exposição é lugar de silêncio?!”. (MORAES, 2015, p. 247.)

Na situação acima relatada, chama atenção o quanto a agenda colocada em curso pela espectadora diante da obra - nesse caso, a oração desencadeada pela analogia que fizera - escapa ao ator comprometido com o gesto de

23 A esse respeito, menciono de passagem uma experiência pessoal, vivida na condição de espectador do espetáculo Os sertões (A luta), montando em 2006 pelo Teat(r)o Oficina Uzyna Uzona, quando um dos atores desferiu um forte tapa no meu rosto durante a peça. 
“ativação" da visitante, a ponto de sua intervenção resultar inconveniente, terminando por ser repreendida. É notável como o uso do retrato praticado pela freira não apenas "sobrecodifica" a pintura, conforme a noção de Barthes, como o faz de modo silencioso e secreto e, portanto, inacessível ao ator que a ela dirige a palavra. Além disso, a existência de "performers performando diante de outros" talvez não fosse exatamente uma novidade para as freiras de hábito.

Nas antípodas das bem-intencionadas iniciativas de artistas, mediadores e mestres preocupados em retirar o outro de um pretenso estado passivo e/ou do que seria o reduto da ignorância acerca de suas próprias condições e dos saberes que "realmente importam”, Rancière alerta para o fato de que "não há ignorante que já não saiba um monte de coisas, que não as tenha aprendido sozinho, olhando e ouvindo o que há ao seu redor". Afirmando a "igualdade das inteligências", qualquer pessoa seria capaz de aprender e mobilizar-se por si própria, do mesmo modo que aprendeu a falar a língua materna, observando e cotejando as coisas entre si, aquilo que ela já sabe com aquilo que desconhece, transitando dos desejos aos ensaios de consumação. Compete a cada um de nós - ignorantes, espectadores, leitores e, em última instância, públicos - nos aventurarmos pela "floresta de signos" (discursividades) e pela multiplicidade de contingências que nos cercam e atravessam, desenhando aí nossas trajetórias ou, de acordo com Rancière, "poetizando" a partir dos elementos com os quais nos deparamos (RANCIÈRE, 2012, p. 13-14).

A distância - seja entre artistas e espectadores, seja entre mestres e ignorantes - não deve ser entendida, segundo o autor, como um mal a ser abolido ou uma extensão a ser perpetuamente encurtada e reproduzida, tendo em vista que ela é condição imprescindível da própria comunicação. Essa distância - ou o construto linguístico que a produz - corresponde jus tamente àquilo que pode ser lido e interpretado por qualquer um. "Os animais humanos são animais distantes que se comunicam através da floresta de signos”. Eliminar essa distância, ou seja, suprimir a possibilidade de leitura das coisas, substituindo-a pela incitação direta, corresponderia à supressão da própria interlocução em bases igualitárias, concorrendo para o "embrutecimento" do outro, no sentido da superposição da sapiência e operatividade de uns sobre a suposta ignorância e inércia de outros (RANCIÈRE, 2012, p. 15).

Essa mesma distância é assinalada pelo artista Marcel Duchamp no texto-base de sua conferência intitulada "O ato criador". Ao mesmo tempo que gera distância (como um terceiro elemento) entre o artista e o espectador, a obra pressupõe a produção de elos entre "os dois polos da criação artística: de um lado o artista, de outro, o público”. Enquanto objeto polissêmico, a obra deflagraria um tipo de "fenômeno que conduz o público a reagir [a ela] criticamente”. A questão central de sua abordagem corresponde a indagar como ocorre essa reação (DUCHAMP, 1975, p. 71-72).

Desse modo, ele identifica os trabalhos desenvolvidos pelos artistas, independentemente do seu grau de reconhecimento e inserção social, como "arte em estado bruto”. Esse estado estaria ligado a um processo no qual “o 
artista passa da intenção à realização, através de uma cadeia de reações totalmente subjetivas". Trata-se de uma batalha travada no campo do imaginário, envolvendo "uma série de esforços, sofrimentos, satisfações, recusas, decisões que também não podem e não devem ser totalmente conscientes” (DUCHAMP, 1975, p. 73). Resultaria dessa luta um descompasso inescapável entre o que o artista imaginou produzir como obra e o que, de fato, ele pôde concretizar como tal. Ou seja, "uma diferença entre a intenção e a sua realização”. A isso Duchamp atribui o nome de "coeficiente artístico". É justamente com esse coeficiente que o público vai lidar em sua experiência de fruição e leitura da obra, e não diretamente com aquilo que o artista teria desejado expressar em estado puro, ou, em outras palavras, com o propósito original (em sentido primordial) do seu gesto criativo (DUCHAMP, 1975, p. 73).

Portanto, é possível afirmar que toda e qualquer obra que adentre a cena pública o faz trazendo consigo uma espécie de inacabamento fundamental, ou, nos termos de Duchamp, “um estado bruto que precisa ser 'refinado' pelo público como o açúcar [é] extraído do melado” (DUCHAMP, 1975, p. 73 74). O que implica dizer que o ato criador não é praticado exclusivamente pelo artista. É o público, enquanto intérprete ativo, quem fará o movimento de transição, produzindo a ligação entre a obra e o âmbito público, na medida em que a interpreta e atribui significados às suas qualidades intrínsecas e extrínsecas, acrescentando sua contribuição ao ato criador e, com isso, tomando parte no processo de circulação da obra.

Logo, a oposição assimétrica entre olhar e agir, criticada por Rancière, mostra-se mais uma vez destituída de fundamento. O filósofo desdobra sua crítica ao associar a desconstrução desse binarismo à emancipação do espectador, tendo em vista que, ao se fazer público de uma expressão artística, ele já é um agente:

Ele observa, seleciona, compara, interpreta. Relaciona o que vê com muitas outras coisas que viu em outras cenas, em outros tipos de lugares. Compõe seu próprio poema com os elementos do poema que tem diante de si. [...] Os espectadores veem, sentem e compreendem alguma coisa à medida que compõem o seu próprio poema, como o fazem, à sua maneira, atores ou dramaturgos, diretores, dançarinos ou performers. (RANCIÈRE, 2012, p. 17.)

Manifesta-se nesse ato o que o autor designa como "poder de tradução". Ao cultivá-lo, o espectador afirmaria a sua semelhança a qualquer outra pessoa, inclusive ao artista cuja obra ele traduz à sua maneira, mediante uma "aventura intelectual" que não caberia a mais ninguém senão a ele a próprio, na medida em que sua experiência não reproduz nenhuma outra, tampouco é mobilizada pela vontade de outrem. Rancière dirá que a tradução "é a capacidade dos anônimos, a capacidade que torna cada um igual a qualquer outro" (RANCIÈRE, 2012, p. 20-21). Diríamos, além disso, que a tradução condiz à capacidade de qualquer um de se fazer intérprete daquilo a que se dedica na condição de público. 
É nessa capacidade de estabelecer relações e disjunções que se manifestaria, de acordo com o filósofo, a dimensão emancipatória da recepção. Parte de seu caráter político reside no fato de ensejar e fomentar uma "comunidade de narradores e tradutores", uma coletividade pautada pelo desmanche das assimetrias entre quem enuncia e quem escuta, dado que a audiência elabora "sua própria tradução para apropriar-se da 'história' e fazer dela a sua própria história” (RANCIÈRE, 2012, p. 25).

Ainda na trilha do pensamento de Rancière, acompanhando a transição do autor para o domínio das artes visuais, observemos por um instante a posição que o filósofo postula para o espectador na relação com a modalidade artística caracterizada, em consonância com o esquema de Plaza, pelo "menor" grau de interação: o quadro de cavalete. Remontando à virada do século XVIII para o XIX, quando na esteira do Iluminismo são criados os primeiros museus públicos na Europa, o filósofo aí identifica o advento de um novo "regime estético". Nele, as tradicionais formas de identificação da arte se alteram radicalmente (RANCIĖRE, 2005c). Como já comentado no capítulo anterior, o Iluminismo faria da arte uma espécie de linguagem universal, um esperanto a traduzir e equiparar as mais diversas manifestações culturais e gêneros artísticos, colocando-os num solo comum, o da autonomia da arte. Rancière destaca o que, para ele, são as potencialidades desse novo paradigma no tocante à recepção artística.

Tal regime teria inaugurado a "igualdade das obras de arte”. A partir de então, deixa de fazer sentido valorá-las "segundo as regras de sua produção ou a hierarquia de sua destinação". No caso do quadro de cavalete, nem a sua natureza enquanto pintura e nem os seus gêneros (cena religiosa, histórica, alegórica, paisagem, retrato, natureza-morta etc.) se sobrepujam às demais modalidades artísticas ou entre si, haja vista que as obras em exibição nos museus teriam se tornado "habitantes iguais de um novo tipo de sensorium comum”. Representando “os mistérios da fé, os grandes feitos dos príncipes e heróis, um albergue de aldeia holandesa, um pequeno mendigo espanhol ou uma tenda francesa de frutas ou de peixes", os quadros expostos nas galerias dos museus públicos se exibiriam de modo indiferente à apreciação de qualquer um, independente do seu status social. Para o filósofo, essa indiferença na identificação dos exemplares da arte, articulado ao acesso irrestrito da população citadina aos contextos expositivos, geraria uma "forma singular de liberdade e igualdade", na medida em que produziria um "senso comum" (RANCIÈRE, 2005c).

Esse senso comum é o domínio da "neutralização da oposição entre a atividade e a passividade”, propiciada por uma lógica de visibilidade dos objetos artísticos que "confunde materialmente a distribuição dos lugares e das funções”. Diante de objetos artísticos radicalmente indiferenciados em suas formas de exibição e apreciação, posto que extraídos de seus contextos de origem e deslocados de seus destinatários originais, os papéis sociais dos espectadores seriam, do mesmo modo, embaralhados, a ponto de a divisão entre os homens do lazer (liberados para pensar e agir) e os homens da labuta (presos à passividade do trabalho reprodutor) ser relativizada diante de um conjunto de quadros de cavalete. Esse regime 
estético coloca em jogo uma "política da arte" capaz de ensejar o seguinte paralelo: da "liberdade de indiferença" inerente à exposição das obras no contexto museológico seria possível depreender a indiscernibilidade "de uma atividade e de uma passividade" (RANCIÈRE, 2005c).

Se tomarmos seus critérios como plausíveis, o regime estético em questão denota quão problemático pode ser o ponto de partida de práticas artísticas que se imbuem de transformar seus públicos em agentes atuantes e cônscios de uma determinada realidade, crendo promover a passagem "de uma passividade a uma atividade" ou, ainda, "de uma ignorância a um saber". Inclusive porque a obstinação por tornar o outro ativo negligencia o fato de que todos nós precisamos aprender a cultivar certa passividade, haja vista que "a quem é ativo com suas mãos pede-se, em geral, que seja passivo quanto ao resto", o que significa subestimar e obliterar suas capacidades contemplativas, passivas. Quanto à ignorância, é frequente que se desconsidere a polissemia do termo: "desconhecer" e "desprezar" andam juntos no fato de se ignorar algo. Logo, ignorar pode ser tão importante quanto conhecer, pois "ignorar também quer dizer não mais reconhecer a regra do jogo, não mais aderir à configuração de um mundo”, enquanto, por outro lado, “conhecer também quer dizer reconhecer e consentir”. Por tais motivos, Rancière afirma que uma arte efetivamente crítica é aquela capaz de produzir alguma indistinção e/ou equivalência entre sabedoria e ignorância, entre atividade e passividade (RANCIÈRE, 2005c).

Para ele, em lugar de gerar ativação e conhecimento canalizados para a ação política, caberia à arte produzir "ficções e dissensos" a partir de agenciamentos abertos a diferentes sensibilidades. Ensaiando recortes específicos no "espaço sensível comum”, a arte teria a capacidade de deflagrar situações de "redistribuição das relações entre o ativo e o passivo, o singular e o comum, a aparência e a realidade”. Destarte, ela produziria "não para a ação política, mas no seio de sua própria política” (grifo do autor), rearranjando e confundindo posições, categorias e percepções. Ao mesmo tempo que essa experiência comum é reconfigurada, "novos dissensos artísticos” seriam suscitados (RANCIÈRE, 2005c).

Em contrapartida, o filósofo reconhece que no panorama contemporâneo da produção artística há "toda uma corrente que propõe uma arte diretamente política", cujas experiências abdicam de "obras feitas para serem contempladas”. Em lugar de objetos a serem fruídos pelo espectador, elas frequentemente optam por "modificações do meio ambiente" ou mesmo por "situações apropriadas ao engajamento de novas formas de relações sociais” (RANCIÈRE, 2005c). Esta última modalidade estaria associada à estética relacional, bastante influente a partir dos anos 1990, ainda que retome uma série de aspectos das proposições artísticas dos anos 1960.

Além de Rancière, também Bishop se ocupa de apontar contradições nas iniciativas atreladas à estética relacional, cujo ideólogo e defensor mais destacado é o curador e crítico Nicolas Bourriaud. A sequência do capítulo procurará abordar algumas especificidades dessa vertente da produção artística contemporânea, atentando também para as críticas a ela dirigidas, inclusive porque ligadas às preocupações da presente pesquisa 
no tocante às formas emergentes de atuação dos públicos. Mas, antes de passarmos a esse tópico, registremos previamente a ressalva de Rancière ao empreendimento relacional.

Ela se refere ao que o autor identifica como uma disposição característica da contemporaneidade em geral e da comunidade artística em particular, que tende a minar o próprio processo político vislumbrado pelas experiências relacionais. Trata-se da tendência consensual, que ao esquivar-se das tensões e antagonismos constitutivos das relações sociopolíticas acaba por "excluir aquilo que é o próprio cerne da política: o dissenso". Para Rancière, apenas a perspectiva dissensual poderia dar vazão aos conflitos e sustentar seus efeitos, que não se limitam ao choque de interesses e valores de grupos distintos, envolvendo principalmente a "possibilidade de [se] opor um mundo comum a um outro". Operar pelo dissenso corresponderia a se abrir àquilo que surge do enfrentamento de modos de sentir e simbolizar muitas vezes inconciliáveis entre si, numa arena efetivamente pública porque plural. Já o consenso "tende a transformar todo conflito político em problema que compete a um saber de especialista ou a uma técnica de governo”, no sentido de delegar sua gestão, resolução ou repressão a terceiros - no caso dos pichadores da "Bienal do Vazio”, à polícia. O consenso seria hábil em transferir responsabilidades. Desse modo, desperdiçaria e debilitaria a "invenção política" potencialmente gerada justamente a partir dos desacordos. Esse "déficit da política” exigiria, por outro lado, a contínua produção de próteses substitutivas, vocacionadas a remediar relações sociais enrijecidas, desarticuladas e instrumentalizadas pelas onipresentes dinâmicas de mercado no capitalismo avançado. É aí que, segundo o filósofo, atuaria a estética relacional. Não podemos perder de vista, portanto, que tal "substituição corre o risco de operar-se dentro das categorias do consenso", tomando para si a tarefa de suturar fissuras desagregadoras do laço social, ao invés de sustentá-las e radicalizá-las, conferindo-lhes consequência política. Preocupada em "preencher as lacunas do vínculo social", a estética relacional concorreria para a "redução da política ao serviço social" (RANCIÈRE, 2005c). Observemos agora a argumentação de Bourriaud, confrontando-a com a de outros analistas.

\subsection{ESTÉTICA RELACIONAL E PERSPECTIVA CONSENSUAL}

Bourriaud associa a tendência relacional presente nas proposições de uma constelação de artistas programaticamente elencados à categoria de "experimentações sociais". Para essa modalidade de ação, cujo aspecto comum de seus exemplares residiria na disposição de agir no âmbito das interações humanas em determinados contextos, o autor cunha o já bastante difundido, e não menos questionado, emblema da "estética relacional" (BOURRIAUD, 2006, p. 8, 13).

Dedicando-se à análise dos trabalhos de artistas como Rirkrit Tiravanija, Liam Gillick, Maurizio Cattelan, Pierre Huyghe, Dominique Gonzalez-Foerster e Felix Gonzalez-Torres, entre outros, Bourriaud destaca a "intersubjetividade" e a "elaboração coletiva de sentidos" como os principais ei- 
xos de proposições apresentadas como "duração por experimentar, enquanto uma abertura possível em direção a um intercâmbio ilimitado" (BOURRIAUD, 2006, p. 14). Logo, aos públicos endereçados por essas proposições já não seriam apresentados objetos estéticos e autônomos destinados à contemplação, e sim ocasiões favoráveis à convivência e à interação, geralmente a partir do pertencimento de seus participantes a comunidades específicas, com vistas à geração de formas de participação não convencionais.

O trabalho de arte, nesse caso, funcionaria como um dispositivo apto a atuar no que Bourriaud identifica como "interstícios sociais". Infiltrando-se nas bre chas de uma trama social normatizada pelos desígnios de um mercado onipresente, as iniciativas desses artistas buscariam ensejar "comunidades de intercâmbio que escapam ao quadro econômico capitalista [...], um espaço para relações humanas que sugere possibilidades de intercâmbio distintas das vigentes em tal sistema” (BOURRIAUD, 2006, p. 15-16). Estaria em jogo, portanto, a tentativa de reinvenção de intercâmbios sociais no mais das vezes limitados pelas relações instrumentais que caracterizam as trocas comerciais. Menos entusiasmada, Bishop comenta a esse respeito que os experimentos relacionais pretendem formular um tipo de "resposta direta à mudança de uma economia baseada em bens para uma economia de serviços”, mais flexível e altamente capilarizada no tecido social (BISHOP, 2011, p. 112).

A autora também chama atenção para o fato de que a estética relacional reflete certas premissas caras a modalidades artísticas vigentes a partir da década de 1960, como a performance e o happening, envolvendo, por exemplo, o contato direto do artista com o público, a ênfase nas urgências do presente e a lógica do faça-você-mesmo (do-it-yourself), tendo como horizonte a invenção de "mundos possíveis". Contudo, Bourriaud se esforça para identificar critérios que diferenciam as práticas relacionais das experiências legadas dos anos 1960, embora procure reforçar que elas não seriam menos politizadas do que suas predecessoras (BISHOP, 2011, p. 111).

A principal diferença entre as gerações corresponderia ao tipo de postura diante das perspectivas de transformação sociopolítica. Se para artistas como Joseph Beuys, Allan Kaprow, Vito Acconci, Yoko Ono, Georges Maciunas, entre tantos outros, a dimensão utópica teria servido como alavanca de suas ações, para os artistas comprometidos com a promoção de experiências relacionais tratar-se-ia de "encontrar soluções provisórias aqui e agora”, conforme pontua Bishop. Nesse sentido, a autora pontua que, em lugar de afrontar e buscar transformar a realidade social mediante perspectivas estruturais e estruturantes, os artistas eleitos por Bourriaud se dedicariam a conceber maneiras de "habitar melhor o mundo". Ao abrir mão da dimensão utópica e de seus vislumbres do porvir, a arte de viés relacional se contentaria com “"microutopias' funcionais no presente”, esforçando-se por criar "relações possíveis" no imediatismo do agora (BISHOP, 2011, p. 112).

Um dos trabalhos evocados por Bourriaud nessa direção tem por título Turkish Jokes [Piadas turcas] (1994). Concebido pelo artista dinamarquês Jens Haa- 
ning, o trabalho envolveu o estímulo à formação, no tempo de sua duração, de agrupamentos temporários em torno a um alto-falante instalado numa praça pública do centro da cidade de Oslo ${ }^{24}$. Gravadas e veiculadas no idioma turco, as historietas bem-humoradas eram destinadas às pessoas de um segmento social específico: os imigrantes turcos que vivem ou frequentam a região central da cidade. Segundo o crítico, as pequenas aglomerações de ouvintes e as risadas coletivas que aí se manifestavam seriam capazes de relativizar sua condição de estrangeiros à margem, na medida em que alguns de seus códigos culturais, articulados e evidenciados no ambiente público, perfaziam um lugar reconhecível e partilhável (BOURRIAUD, 2006, p. 17). Pela ótica do crítico, a proposição de Haaning identifica e se imiscui em um interstício social. A partir dele, $o$ artista experimenta a transposição, para um espaço público de razoável visibilidade, de um tipo de sociabilidade praticado entre pessoas pertencentes a um grupo étnico-social marginalizado.

Por outro lado, parece-nos problemático o fato de a descrição de Bourriaud não se ocupar - não apenas nesse, mas em praticamente todos os exemplos comentados em seu livro - das formas emergentes de apropriação e uso da proposição artística pelo público ao qual ela se endereça, limitando-se a nos reportar pura e simplesmente às "aglomerações" e "risadas" das pessoas. Além disso, parece não fazer parte dos interesses e preocupações do crítico a sondagem dos possíveis desdobramentos do trabalho na comunidade turca e, mais que isso, em sua interação com as demais comunidades urbanas.

Negligenciando as formas singulares e imprevistas de apropriação pelos públicos, sua análise não se ocupa de investigar como de fato se deram os usos do trabalho, tanto pelo público priorizado pelo artista como por outros munícipes que devem ter se deparado com o alto-falante e com seus ouvintes mais assíduos. Em seu relato, breve e otimista, a "conta fecha” sem qualquer imprevisto ou mesmo novas questões que pudessem dali ter surgido - de tal modo que os efeitos do trabalho parecem já dados, cabendo ao público definido de antemão apenas desempenhá-los, ratificando-os.

Indagando a efetividade política das proposições relacionais e o modo como elas são analisadas por Bourriaud, Bishop aponta que "a qualidade das relações em 'estética relacional' nunca é examinada ou colocada em questão” (grifo da autora). Nesse sentido, ela suspeita da crença do crítico baseada na ideia de que bastaria a um trabalho artístico favorecer o diálogo para que suas consequências fossem "automaticamente presu-

24 Estranha-se o fato de Bourriaud mencionar como lugar de ocorrência desse trabalho, no livro Estética relacional, uma praça pública de Copenhague (Dinamarca), pois em outras fontes, inclusive em um material de registro coproduzido pela Danish Contemporay Art Foundation Copenhagen com o artista, a cidade mencionada como local de realização é Oslo (Noruega). Essa referência pode ser encontrada em: <http://www.jenshaaning.com/HAANING_LO-RES. pdf>. Acesso em: 15 fev. 2017. Em 1996, o artista desenvolveria um trabalho similar, mas com a comunidade árabe de Copenhague, intitulado Arabic Jokes. 
midas [como] democráticas e, portanto, benéficas”. Como temos buscado demonstrar até aqui, tanto o beneficio como a dimensão pública de uma iniciativa artística não podem ser derivados apenas da matriz propositora de determinada ação, tendo em vista justamente o seu caráter contingencial e relacional [sic]. Ademais, se a arte de corte relacional compromete-se com a promoção de relações entre pessoas e grupos, não há como nos furtarmos à análise dos "tipos de relações [que] estão sendo produzidas, para quem e por quê" (BISHOP, 2011, p. 120).

O desinteresse de Bourriaud pela qualidade dessas proposições, e por tudo aquilo que delas possa emergir de maneira não programada, se assentaria, a nosso ver: 1) em sua crença na positividade intrínseca aos intentos artísticos vocacionados a modelizar formas de interação social e 2) na sua distância acrítica em relação ao enraizamento dessas mesmas iniciativas em estruturas sociais demarcadas por hierarquias e convenções, as quais condicionam essas mesmas iniciativas, ainda que o crítico talvez não queira se dar conta. Nesse sentido, Canclini afirma que a arte de viés relacional se dedicaria a "relações e alianças conjunturais, nunca estruturais, fugindo dos conflitos". Buscando deflagrar situações "construtivas e criativas" imbuídas de remediar o desgastado vínculo social, ela evitaria o dissenso, virando as costas para o fato de que "o antagonismo é um componente ineludível quando os trabalhos falam de relações” (CANCLINI, 2011, p. 133-134).

Reticente aos argumentos de Bourriaud e à seleção de trabalhos de natureza relacional propalada pelo crítico, Canclini se reporta a Rancière e a seu modo de articular estética e política, considerando que estaria fundado "em uma teoria social mais consistente". Cotejando as perspectivas dos referidos autores, o antropólogo constata a vigência de dois modos básicos e distintos de se conceber a política. Um deles, concernente à visão de Bourriaud, apostaria na "construção de consensos”. Enquanto o outro, refletindo a concepção de Rancière, se abriria aos "desacordos". Ocupada em produzir situações favoráveis às relações interpessoais, a perspectiva consensual de Bourriaud "tende a esquecer os desacordos". Talvez por isso a narrativa do crítico se mostre tão hábil em desaparecer com as emergentes (e potencialmente desviantes) formas de apropriação e o uso das situações relacionais pelos públicos, pois tal diversidade poderia desvirtuar e comprometer o propósito último desse tipo de intento, isto é: oportunizar momentos de convivência supostamente capazes de reparar as fraturas do corpo social, ao passo que procura "restabelecer ou reinventar laços" (CANCLINI, 2011, p. 136-137).

Essa maneira de lidar com problemáticas sociopolíticas, em particular aquelas que dizem respeito aos intercâmbios sociais, resultaria num tipo de abordagem apenas otimista e superficial de contradições de ordem estrutural. A esse modelo subjaz uma concepção do “comum” e, por conseguinte, uma expectativa em torno da produção compartilhada de sentido para a experiência social que parece desconsiderar a existência de "divisões do sensível a partir das quais se organizam determinadas hierarquias”. O que significa, portanto, que a própria ideia do comum deva ser vista com alguma desconfiança, pois sobre ela pesa a 
acusação de que estaria cindida entre usos compartilhados e exclusivos/excludentes (CANCLINI, 2011, p. 136).

Por outro lado, não é o caso de dizer que a estética relacional ignora o fato de que "este solo aparentemente comum está fraturado" (CANCLINI, 2011, p. 136). Ao contrário, muitas de suas experiências partem exatamente dessa constatação. Porém, o que nos parece necessário problematizar é aquilo que os artistas e o crítico "oficial" dessa vertente fazem com ela, geralmente lidando com tal condição em chave conciliatória e, desse modo, pouco afeita aos antagonismos.

Já para Rancière, as articulações entre estética e política pressupõem a explicitação dos antagonismos. Logo, elas só podem ocorrer efetivamente sob a condição de tornar patentes os conflitos e dissensos geralmente invisibilizados, ainda que operantes, "reconfigurando a divisão do sensível" na medida em que permite que venham à tona não apenas outros modos de sentir e estar no mundo, mas também os seus confrontos com sensibilidades e perspectivas hegemônicas (CANCLINI, 2011, p. 136). A premissa conciliatória, por seu turno, tende a encobri-los, ocupada que está com a recomposição dos laços sociais.

Ao evitar os antagonismos, a estética relacional nega a possibilidade de emergência da contraface das hierarquias e exercícios de poder intrínsecos ao jogo social: formas de atuação dos públicos entendidos como sujeitos políticos portadores de outras sensibilidades e, ato contínuo, capazes de instaurar outras agendas no interior das situações propostas pelos artistas, curadores e instituições. Em sentido análogo e de acordo com as palavras de Canclini, Rancière postula "uma política [da arte] que introduza sujeitos e objetos novos, faça visível o oculto e escute os silenciados" (CANCLINI, 2011, p. 136).

Em lugar de uma arte vocacionada a "remendar o vínculo social” através de situações favoráveis a uma sociabilidade conciliatória, Rancière defende formas contemporâneas de produção artística que se proponham a redesenhar as próprias regras de distribuição do sensível. Inclusive porque as simulações de consenso presentes nas experiências relacionais se baseariam nas regras dadas de sua distribuição. Portanto, ao invés de fomentar laços sociais que manteriam intactas as regras estruturais de distribuição do sensível, caberia à arte - e à política que lhe é inerente - produzir "uma diferença no sensível, um desacordo sobre os dados mesmos da situação, sobre os objetos e sujeitos incluídos na comunidade e sobre os modos de sua inclusão” (RANCIÈRE apud CANCLINI, 2011, p. 137). Essa antítese pode ser notada na comparação entre as proposições de Rirkrit Tiravanija e de Santiago Sierra, a partir da análise de Bishop.

Os trabalhos de ambos apresentam como aspecto comum o fato de produzirem relações literais entre o artista e o público participante. No entanto, a obra de Sierra é sintomaticamente ignorada por Bourriaud em seu "manual” da estética relacional. Bishop credita tal omissão ao tipo de relação postulada pelas ações do artista espanhol, que, embora também assuma o diálogo e a negociação como parte do seu trabalho, o faz de forma a provocar e sustentar "sensações de mal-estar e desconforto em vez de pertencimento". Decididamente afastado da perspectiva consensual e 
conciliatória, Sierra concebe suas proposições como conjunturas atravessadas por injunções de poder, constrangimentos e antagonismos. Mais especificamente, isso se dá mediante a "introdução de colaboradores [provindos] de realidades econômicas distintas, que, por sua vez, servem para desafiar a percepção da arte contemporânea como um domínio que engloba outras estruturas sociais e políticas”. Tal introdução geralmente configura situações bastante controversas, dado o caráter anódino dos gestos nelas implicados. Elas envolvem, por exemplo, pessoas pagas pelo artista para se deixar tatuar, para trabalhar continuamente por 360 horas, para se masturbar ou para carregar blocos de concreto de um lado a outro de um recinto (BISHOP, 2011, p. 125). Tais exemplos indicam quanto o artista está decidido a radicalizar e expor o exercício do poder de uns sobre os outros, ou da ação de uns sobre a ação de outros, escancarando as regras de distribuição dos papéis sociais e de seus respectivos regimes de sensibilidade.

A propósito dessa opção de Sierra por escalar indivíduos estranhos ao circuito artístico para compor suas ações, pagando-os para desempenhar funções aviltantes, seria elucidativo observar como Tiravanija, por sua vez, imagina os participantes de suas proposições. Adotando a comida e o ato de cozinhar como os meios principais para o estabelecimento de relações de convívio com e entre o público, o artista utiliza com frequência, de acordo com Bishop, a expressão "muita gente” nas listas de materiais necessários para a realização dos seus trabalhos. Contudo, essa gama aparentemente vasta de pessoas não chega a extravasar o círculo restrito de "uma comunidade cujos membros identificam-se uns com os outros porque têm algo em comum", a saber, o interesse por arte e pela frequentação assídua de galerias, bienais, museus etc. Aqui, "muita gente" conforma uma esfera que não se sustenta, de fato, como pública, pois é majoritariamente formada por indivíduos que se reconhecem como membros de uma mesma comunidade, "um grupo privado em que uns se identificam com os outros". Enquanto Sierra conta com quem é estrangeiro ao circuito da arte (e a tantas outras redes investidas de capital social e cultural), inclusive reproduzindo as formas de exploração que ele mesmo, como artista, sofre por parte dos galeristas e marchands, Tiravanija interage com seus pares do círculo artístico, supondo que o contexto expositivo pudesse se tornar automaticamente um espaço aberto e democrático graças ao seu uso como lugar de uma sociabilidade despojada. Bishop afirma que, ao fiar-se nessa "microutopia", o artista "abre mão da ideia de transformação da cultura pública” em sentido estrutural (BISHOP, 2011, p. 114, 124). Observemos o caso de Untitled (Still) [Sem título (Ainda)], exposição individual de Tiravanija realizada na 303 Gallery, em 1992, em Nova York. Ali, como nos conta Bishop, o artista

tirou tudo que encontrou no escritório e no depósito da galeria e colocou na sala principal do espaço expositivo, incluindo o galerista, que foi obrigado a trabalhar em público, em meio ao cheiro de comida e acompanhado por comensais. No depósito, ele organizou o que foi descrito 
por um crítico como uma "cozinha de refugiados improvisada” com pratos de papel, garfos e facas de plástico, fogareiros, utensílios de cozinha, duas mesas portáteis e alguns banquinhos dobráveis. Na galeria ele preparou legumes com curry para os visitantes e os detritos, utensílios e embalagens de comida tornaram-se a exposição de arte enquanto o artista não estava lá. (BISHOP, 2011, p. 113.)

Nota-se que o artista se ocupa de intervir na lógica de operação interna à galeria de arte, deslocando e alterando as funções de seus espaços, ao mesmo tempo que faz dos atos de cozinhar e de socializar os aspectos centrais de uma performance sediada num local tradicionalmente dedicado a exibir e comercializar objetos de arte. Mas tal subversão não chega a abrir espaço para o envolvimento de públicos e problemáticas estranhos ao ambiente especializado e restritivo da arte, ao contrário. A inquietação de Bishop por investigar quão realmente abertas e democráticas seriam as experiências artísticas relacionais fez com que a autora vasculhasse publicações de arte em busca de relatos capazes de evidenciar as formas de apropriação e uso desse trabalho em particular pelo público.

O que Bishop encontra são índices que nos fazem relativizar a certeza de Bourriaud de que as relações propiciadas pela estética relacional seriam intrinsecamente democráticas. Isso porque as comunidades ensejadas por trabalhos como Untitled (Still) são formadas por indivíduos que, como já dito, "identificam-se uns com os outros porque têm algo em comum", o que, por um lado, favorece o diálogo, mas, por outro, afasta as fricções e antagonismos, que poderiam se dar justamente pela confrontação de diferentes regimes de sensibilidade e, portanto, de subjetividades que não se identificam umas com as outras. O caráter ensimesmado e privado da comunidade fomentada pela proposição de Tiravanija pode ser atestado pelo relato do crítico Jerry Saltz, publicado na revista Art in America, a respeito da sua experiência com o trabalho:

Na 303 Gallery eu geralmente me sentava com alguém ou era acompanhado por algum desconhecido, e era ótimo. A galeria virou um lugar para compartilhar, um lugar alegre para conversar com sinceridade. Tive maravilhosas rodadas de refeições com galeristas. Uma vez, Paula Cooper e eu comemos juntos e ela recontou um pedaço longo e complicado de uma fofoca profissional. Outro dia, Lisa Spellman relatou em detalhes hilariantes a história de uma intriga sobre um colega galerista que tentava, sem sucesso, roubar um de seus artistas. Mais ou menos uma semana depois, David Zwirner me acompanhou. Encontrei-o por acaso na rua e ele disse: "nada está dando certo hoje, vamos ao Rirkrit [Tiravanija]”. Nós fomos e falamos sobre a falta de emoção no mundo da arte nova-iorquino Outra vez, fui acompanhado por Gavin Brown, o artista e galerista... que falou do colapso do SoHo - só para consi- 
derá-lo bem-vindo e dizer que já era hora porque as galerias andavam mostrando muita arte medíocre. Em outro momento, uma mulher não identificada me acompanhou e um clima de paquera curiosa pairava no ar. E teve ainda uma outra vez [que] conversei com um jovem artista que morava no Brooklyn e tinha tido verdadeiros insights sobre as mostras que tinha acabado de ver. (SALTZ apud BISHOP, 2011, p. 122.)

O relato acima dá a ver quanto as relações geradas pelo trabalho de Tiravanija tendem a permanecer circunscritas a uma comunidade particular e, consequentemente, a uma subjetividade específica, reunida por interesses coincidentes. Bishop aponta que, na medida em que é praticado por pessoas que pensam e sentem de maneira análoga, o tipo de contato e comunicação aí colocado em jogo "não consegue se aproximar dos aspectos políticos da comunicação”, que pressupõem subjetividades distintas e relações dissensuais (BISHOP, 2011, p. 123).

É como contraponto a esse tipo de proposição que Bishop se reporta ao trabalho de Sierra. Para ela, as ações desse artista se baseiam em relações estruturalmente mais complexas e problematizadoras do que as iniciativas relacionais. Diferentemente de Tiravanija, que em geral organiza suas proposições em torno da comida gratuita compartilhada, Sierra enfatiza o expediente da remuneração ao pagar pessoas dispostas a desempenhar funções no mínimo controversas, previamente definidas por ele. Seus trabalhos outorgam muito menos liberdade e deleite aos participantes diretos, gerando situações constrangedoras em muitos casos. Mas talvez seja exatamente nessa recusa de encenar a liberdade e o gozo da sociabilidade, tão marcante nas proposições relacionais, que resida a possibilidade de colocar entre parênteses certos dispositivos econômicos e sociopolíticos que orientam e limitam a vida social. Como lembra Bishop: "Sierra sabe que nada é de graça: tudo e todos têm seu preço" (BISHOP, 2011, p. 125). Ciente do peso desse ditame, o artista o levará a consequências drásticas.

Bishop identifica diferenças marcantes entre os dois artistas também com respeito aos modos de lidar com contextos específicos. Enquanto para Tiravanija a abordagem contextual se circunscreve à realização de deslocamentos em ambientes expositivos geralmente isolados do seu entorno e, portanto, distanciados das questões extramuros locais, Sierra se dedica a criar, em cada um de seus projetos, "uma espécie de realismo etnográfico em que o resultado ou desdobramento de sua ação forma um indicador da realidade econômica e social do lugar em que trabalha”. Exemplo disso é o trabalho por ele desenvolvido para a $49^{\mathrm{a}}$ Bienal de Veneza (2001), intitulado Persons Paid to Have Their Hair Dyed Blond [Pessoas pagas para tingir o cabelo de loiro] (BISHOP, 2011, p. 125, 127).

Para o referido trabalho, Sierra arregimentou cerca de 130 vendedores ambulantes que viviam do comércio ilegal de produtos falsificados e contrabandeados nas cercanias de espaços e eventos de grande apelo turístico da cidade, como é o caso da Bienal. Dentre os ambulantes pagos para ter o 
cabelo descolorido, estavam imigrantes do Senegal, China e Bangladesh, além de migrantes do Sul da Itália. Cada um deles recebeu algo em torno de sessenta dólares para se submeter ao tingimento aludido no título do trabalho (BISHOP, 2011, p. 127).

A exemplo de seus demais trabalhos, aqui Sierra opta por lidar com um grupo social marginalizado, completamente alijado do que se passa no interior dos pavilhões da Bienal. Ao se aproximar desse segmento, alterando o visual de seus membros de modo a "aproximá-lo" caricaturalmente de um suposto padrão europeu (cabelos claros), o artista produz uma intervenção temporária num quadro social excludente e naturalizado, jogando luz sobre a presença dos vendedores ambulantes na cidade e no entorno da própria Bienal. Além de exibir o vídeo de registro do processo de tingimento do cabelo dos participantes, Sierra cedeu o espaço expositivo destinado ao seu trabalho à atividade comercial desses trabalhadores, abrindo uma brecha através da qual diferentes subjetividades e práticas se confrontaram, gerando estranhamentos mútuos. Tanto os frequentadores da mostra como os ambulantes tiveram suas expectativas e comportamentos afetados por esse tipo inesperado de encontro, conforme nos conta Bishop:

Em vez de chamarem a atenção dos passantes de forma agressiva como faziam nas ruas, os vendedores estavam acanhados. Isso fez com que meu próprio encontro com eles fosse desarmante, de forma que apenas posteriormente revelaria minha própria ansiedade sobre sentir-me "incluída" na Bienal. Era mesmo certeza que [não] eram atores? Teriam se enfurnado lá de brincadeira? Colocando em primeiro plano o momento de não identificação mútua, a ação de Sierra quebrou o senso de identidade do público de arte, que se baseia precisamente nas tácitas exclusões raciais e de classe [...]. (BISHOP, 2011, p. 127, grifo meu.)

Como temos procurado argumentar, a dimensão pública de um espaço relacional ensejado por determinada proposição artística depende, necessariamente, do encontro entre diferentes subjetividades, regimes de sensibilidade e agendas, mediante a abertura para o estranhamento e os antagonismos que lhe são inerentes. No caso de Sierra, inclusive, "é importante que o trabalho [...] não tenha atingido uma reconciliação harmoniosa entre os dois sistemas, mas tenha sustentado a tensão entre eles" (BISHOP, 2011, p. 127). Não nos parece possível, portanto, conceber as relações democráticas a partir de uma perspectiva segmentada e conciliatória, como parece apostar o ideólogo da estética relacional, Nicolas Bourriaud.

A contribuição da experiência de Sierra para a nossa reflexão reside justamente em sua disposição de instaurar e sustentar situações coletivas baseadas nas contradições e nos conflitos inerentes às relações sociais e profissionais no capitalismo avançado, desincumbindo-se de forjar qualquer solução conciliatória. Operando assim, o artista cria importantes precedentes para pensarmos o espaço público em termos dissensuais, como algo estruturalmente fraturado. 


\subsection{DIMENSÃO RELACIONAL DA MEDIAÇÃO CULTURAL}

Apesar das críticas à estética relacional e ao modo como seus experimentos concebem as interações sociais, devemos reconhecer que ela apresenta algumas interseções com a mediação cultural, incluindo as problemáticas da recepção artística e das formas de atuação dos públicos no contexto das artes visuais. Algo que parece indicar esse cruzamento é a constatação de Bourriaud de que "a arte contemporânea modeliza mais do que representa; em lugar de inspirar-se na trama social, introduz-se nela”. A mediação cultural, ainda que não se confunda com a prática artística, se conecta diretamente a essa lógica de invenção e modelização de práticas sociais. Nesse ponto, os escopos da arte e da mediação parecem coincidir em alguma medida:

Atividade humana baseada no comércio, a arte le a mediação] é a um só tempo objeto e sujeito de uma ética: tanto mais porque, ao contrário de outras atividades, não tem outra função senão expor-se a este comércio. A arte [e a mediação] é um estado de encontro. (BOURRIAUD, 2006, p. 17.)

Por "comércio" podemos compreender as vivências sociais de interação afetiva e intercâmbio simbólico. Por meio delas, indivíduos e grupos se endereçam mutuamente a partir de distintos regimes de sensibilidade, subjetividades e registros culturais, formando tramas heterogêneas e, não raro, conflitivas de comportamentos, enunciações e valores.

Por outro lado, o crítico assinala que a dimensão relacional sempre esteve presente no campo da produção artística. Portanto, toda e qualquer obra poderia ser tratada nessas bases, enquanto um lugar de "negociação entre numerosos remetentes e destinatários” (BOURRIAUD, 2006, p. 29). Logo, usando o seu próprio argumento, cabe suspeitarmos dos vínculos distintivos destacados por Bourriaud entre os artistas de sua lista em Estética relacional, como se a vigência da relacionalidade na arte fosse privilégio de um seleto grupo de artistas cuja notória inserção institucional se dá nos contextos europeu e norte-americano, assim como nas bienais globalizadas.

Em lugar de corresponder a um aspecto diferencial do trabalho desse ou daquele artista, a condição relacional estaria atrelada ao caráter fundamentalmente dialógico dos objetos e proposições artísticos, como já notado por Duchamp em suas ponderações a respeito da decisiva participação do espectador no ato criador. De acordo com Bishop, "Bourriaud se equivoca na interpretação desses argumentos, aplicando-os a um tipo específico de trabalho (aqueles que requerem interação literal) e, portanto, redireciona seu argumento de volta para a intencionalidade artística e não para as questões da recepção” (BISHOP, 2011, p. 118). Dito isso, talvez possamos nos autorizar a "destituir" Bourriaud da posição de embaixador oficial da dimensão relacional da arte, dissociando-a de certos critérios adotados pelo crítico e pelos artistas por ele promovidos. 
Em contrapartida, ao mesmo tempo que se presta à validação do conceito-trunfo "estética relacional”, a teorização de Bourriaud acaba por lançar luz sobre aspectos menos comentados nas abordagens coligidas até aqui acerca das problemáticas da recepção no campo das artes visuais. É o que ela faz, por exemplo, ao notar um aspecto distintivo das artes visuais quando comparadas

à televisão e à literatura, que remetem a um espaço de consumo privado, e também ao teatro e ao cinema, que reúnem pequenas coletividades frente a imagens unívocas: não se comenta o que se vê, o tempo de discussão é posterior à fruição. Numa exposição, ao contrário, ainda que se trate de formas [geralmente] inertes, a possibilidade de uma discussão imediata surge nos dois sentidos: percebo, comento e me movo em um único e mesmo espaço. A arte é o lugar de produção de uma sociabilidade específica [...]. (BOURRIAUD, 2006, p. 15, grifo meu.)

Essa forma de sociabilidade propiciada pelo ambiente expositivo em geral e pelas obras e proposições artísticas em particular condiz a um tipo de esfera (potencialmente) pública temporária e fragmentária. Dinâmica e parcial, essa esfera seria formada justamente no/pelo encontro entre os públicos e as produções artísticas veiculadas pelos museus, centros culturais, galerias e bienais, bem como entre os públicos e os agentes institucionais, com destaque para os profissionais da mediação. É nesse espaço relacional por excelência, demarcado pelo exercício do poder, que atua a modalidade de mediação cultural aqui discutida.

Conforme a perspectiva foucaultiana acerca da contraface responsiva inerente ao exercício do poder de uns sobre os outros, haveria um potencial disruptivo nesses espaços-tempo de interação, consideradas as perspectivas dialógicas e conflitivas por eles abertas, em que as apropriações e formulações praticadas pelos públicos se dão de modo imprevisível e emergente. Segundo Bourriaud, o intercâmbio desencadeado pela arte "se resume em um binômio: alguém mostra algo a alguém que, por sua vez, o devolve à sua maneira” (BOURRIAUD, 2006, p. 25).

Além de se dedicar a perscrutar as formas singulares de apropriação e uso experimentadas pelos públicos das ofertas institucionais e das práticas artísticas, caberia às abordagens de uma mediação crítica uma "disponibilidade para efetivamente discutir e expor as [suas] consequências”, sustentando os dissensos e antagonismos aí implicados: potenciais desacordos e afrontas frente aos discursos artísticos e institucionais, incluindo os da própria mediação (HONORATO, 2015c, p. 685).

Entretanto, como Honorato identifica nas premissas e modos de atuação do programa educativo da Fundação Bienal de São Paulo em anos recentes ${ }^{25}$

25 O período em questão vai do ano de 2010 a 2015, e corresponde à vigência do programa educativo em caráter contínuo na instituição, sob a curadoria de Stela Barbieri. 
- trata-se de um exemplo específico, embora paradigmático da situação brasileira no campo da mediação institucional -, a disponibilidade diante do que surge a partir das ofertas institucionais no tocante a sua apropriação pelos públicos, em lugar de se efetivar e se dedicar às suas consequências, vem se afirmando de maneira ambígua.

Apesar de o Educativo Bienal se comprometer não com uma perspectiva unidirecional e meramente instrutiva, mas com situações de diálogo, seus critérios e ações parecem indicar, de acordo com Honorato, uma "certa delimitação" desses espaços de intercâmbio, o que lhe confere um caráter ambíguo (grifo do autor). Ao mesmo tempo que estimula a manifestação das vozes dos visitantes, acaba por enquadrá-las e dissipá-las, visto que se exime de identificar seus lastros e de lhes conferir desdobramentos. Isso pode ser lido como um tipo de arapuca diplomática, que fomenta interlocuções com "os públicos mais variados, ou a variedade de suas questões e de suas referências, somente na medida em que [estes] podem ser subsumidos à arte, ou àquilo que seria prerrogativa da instituição oferecer” (HONORATO, 2015c, p. 685). Podemos entrever nessa equação uma perspectiva análoga à da educação para o patrimônio, já comentada aqui.

Há aí uma dubiedade que nos cobra um tipo de crítica capaz de "furar" as camadas de verniz do discurso institucional, normalmente anunciado em favor do que, do ponto de vista dos agentes institucionais, constituiriam as necessidades de seus públicos quanto às possibilidades de seu desenvolvimento artístico-cultural, educacional e, em última instância, como cidadão. Malgrado as declarações institucionais - da Fundação Bienal, mas também de tantas outras - em torno de tais compromissos, "é também nesse sentido que muitos educativos, embora se façam em nome dos públicos, têm desaparecido com os públicos” (HONORATO, 2015c, p. 686).

Dito isso, acompanhar Bourriaud em seu interesse por práticas artísticas vocacionadas a romper com "as regras relativas à gestão dos públicos” (BOURRIAUD, 2006, p. 69), transpondo tal potencialidade para o âmbito da mediação cultural, demandaria o abandono dos enquadramentos prévios do que possam vir a ser as posições, atitudes e respostas desses públicos diante das ofertas artístico-culturais apresentadas pelas instituições. Caso contrário, e aí tanto a teoria bourriaudiana como as premissas da mediação institucional são colocadas na berlinda, se estaria operando com "a pressuposição de seus efeitos, de maneira exclusivamente positiva”, o que renderia créditos apenas àqueles que anunciam a abertura para a participação e o diálogo, em detrimento de suas imprevisíveis (e potencialmente problemáticas) apropriações pelos públicos. Tal suspensão poderia funcionar como um tipo de antídoto a iniciativas curatoriais, artísticas e mediativas que, com alguma frequência, não logram ultrapassar a condição de "informes publicitários" no que se refere às formas de participação do público (HONORATO, 2015c, p. 685).

Portanto, ainda segundo Honorato, no lugar do "entusiasmo com possibilidades futuras (consensuais)” de envolvimento dos públicos com as práticas artísticas, coloca-se a urgência de uma disposição para o "enfrentamento de questões emergentes (conflitivas)" apresentadas por esses mesmos públicos na interação em tempo real com tais práticas (grifos meus). A autopro- 
moção dos artistas, curadores e mediadores deve, assim, ser abandonada em favor da permanente autocrítica (HONORATO, 2015c, p. 685-86).

\subsection{OPERAÇÕES CONJUNTURAIS}

A nosso ver, a emergência de questões trazidas à tona pelos públicos nos momentos de interação com as ofertas institucionais e práticas artísticas poderia ser articulada a projetos em mediação dedicados não a cercar e gerir o espaço de recepção de tais práticas, circunscrevendo-o para melhor administrar os públicos - com suas enunciações e modos de agir -, mas a narrar e fazer circular em outras esferas e temporalidades os índices das apropriações, reações, leituras, usos, poetizações ou negações daí surgidos, “tornando-os politizáveis” (CERTEAU, 1994, p. 268).

Em $A$ invenção do cotidiano, Certeau nos fornece um conjunto útil de lentes para a percepção dos modos de operação dos públicos endereçados por discursos hegemônicos - de naturezas política, científica ou cultural. Tais sujeitos são por ele identificados como "praticantes de astúcias". Os repertórios culturais desses públicos, afirma o autor, "se elabora[m] nos termos de relações conflituais e competitivas entre mais fortes e mais fracos". Ele pondera, ainda, que essas disputas ocorrem "no coração das praças-fortes da economia contemporânea” (CERTEAU, 1994, p. 86-87). Não há dúvida, nesse caso, quanto ao influente papel exercido pelas instituições artísticas em tal arena.

Se, por um lado, as práticas astuciosas dos públicos abundam em tais "praças" normatizadas, por outro, os mecanismos de funcionamento de tais plataformas, bem como as ferramentas de gestão utilizadas por seus agentes, são hábeis em fazê-las passar despercebidas, ou mesmo concorrer para o seu desaparecimento mediante um arsenal de regras, repressões e penalizações. Segundo Certeau, o que os públicos anônimos fazem nesses contextos é cultivar, obstinada e intransigentemente, a "arte do desvio" (CERTEAU, 1994, p. 90). Portanto, teríamos aqui mais uma oportunidade de nos deslocarmos da noção da arte para o público para a lógica da arte pelo público, na medida em que espectadores e consumidores anônimos

traçam trajetórias indeterminadas, aparentemente desprovidas de sentido porque não são coerentes com o espaço construído, escrito e pré-fabricado onde se movimentam. [Suas trajetórias] são frases imprevisíveis num lugar ordenado pelas técnicas organizadoras de sistemas. Embora tenham como material os vocabulários das línguas recebidas (o vocabulário da TV, o do jornal, o do supermercado ou das disposições urbanísticas [ou mesmo dos contextos expositivos]), embora fiquem enquadradas por sintaxes prescritas (modos temporais dos horários, organizações paradigmáticas dos lugares etc.), essas trilhas continuam heterogêneas aos sistemas onde se infiltram e onde esboçam as astúcias de interesses e de desejos diferentes. (CERTEAU, 1994, p. 97, grifos do autor.) 
Ao mesmo tempo que buscam regular a volubilidade dessa turba inominável de sujeitos astutos e insidiosos, as redes institucionais são lenta e permanentemente deslocadas e erodidas por ela (CERTEAU, 1994, p. 97-98). Por outro lado, isso incitará novos processos de captura das diferenças e os consequentes reforço e ampliação do alcance dessas mesmas redes de controle, conforme a análise foucaultiana do poder nos alerta ${ }^{26}$.

Nesse aspecto, valeria voltar a Foucault, quando ele diz que "enquanto o sujeito humano é colocado em relações de produção e de significação, é igualmente colocado em relações de poder”. Esmiuçando tal constatação, ele ressalva que não devemos, por exemplo, aguardar pelo surgimento de novos campos de concentração para neles identificar as relações de poder (FOUCAULT, 1995, p. 232-233). Inclusive porque num campo de concentração, em virtude das condições violentas de absoluto cerceamento da liberdade e da iminência do aniquilamento, já não é de relação de poder que se trata, mas de opressão e dominação implacáveis, desprovidas de margens de manobra e negociação. Ao contrário, com as hegemonias e assimetrias que lhe caracterizam, as relações de poder implicam dinâmicas muito mais matizadas e variadas e também o exercício de resistências, lutas, liberdades e descontinuidades.

Nesse sentido, Foucault agrega um importante elemento ao nosso intento acerca das formas de interação com as ofertas institucionais, dos modos de recepção das práticas artísticas e do caráter emergente dos públicos, ao indicar que o compromisso da crítica, no que tange à compreensão de como se dão as relações de poder, seria o de "investigar as formas de resistência e as tentativas de dissociar estas relações", combinando-o com um programa de sondagem e desnaturalização dos regimes de verdade vigentes. É o caso das premissas que embasam o trabalho da mediação institucional, que refletem os compromissos da democratização dos bens culturais. As resistências às ações regidas por tais princípios corresponderiam a "lutas imediatas", nas quais são criticadas as estratégias de poder "que lhes são mais próximas", exatamente aquelas que se exercem "sobre os indivíduos". Logo, não visam o "inimigo-mor", e sim o "inimigo imediato". Assumem-se, desse modo, como "lutas anárquicas" (FOUCAULT, 1995, p. 234).

Neste ponto, nota-se um cruzamento da perspectiva foucaultiana em torno do poder, e das formas de resistir a ele, com as análises de Certeau, na medida em que o segundo se dedica a montar um quadro dinâmico das táticas de resistência das pessoas anônimas diante daquilo a que são submetidas no plano da produção simbólica e cultural. Daí a ênfase às práticas do homem comum, alojadas no tempo singular das ocasiões que se lhe apresentam, a partir de "movimentos sub-reptícios" e de iniciativas de

26 A título de exemplo, na sequência da invasão dos pichadores à $28^{\mathrm{a}}$ Bienal de São Paulo, a Fundação Bienal adotou um esquema de segurança com detectores de metal posicionados na entrada do pavilhão, aos quais todos os visitantes tinham de se submeter para poder acessar a mostra. Esse esquema se estenderia da $28^{a}$ à $31^{\circ}$ edição. Apenas na $32^{\text {a }}$ Bienal (2016) o uso do dispositivo foi interrompido. 
"fazer com" aquilo que lhe é proposto ou, em certos casos, imposto ${ }^{27}$ (CERTEAU, 1994, p. 98-99).

Comentando esse modo de operar, Certeau destaca as diferenças entre tática e estratégia. Ao contrário da estratégia, geralmente traçada com distanciamento e antecedência, a partir de engrenagens estruturadas e guarnecidas em termos espaciais, a tática presentifica-se como pura ação no tempo, caracterizada "pela ausência de um [lugar] próprio". Destituída de autonomia e morada própria, ela "não tem por lugar senão o [lugar] do outro". É como uma inquilina. Assim, acaba por "jogar com o terreno que lhe é imposto", organizado pela lei de uma força externa. A tática movimenta-se, portanto, no terreno do "inimigo", no espaço por ele controlado. "É a arte do fraco" (CERTEAU, 1994, p. 100-101). O exemplo abaixo não poderia ser mais revelador dessa renitente astúcia:

[...] o espetacular sucesso da colonização espanhola no seio das etnias indígenas foi alterado pelo uso que dela se fazia: mesmo subjugados, ou até consentindo, muitas vezes esses indígenas usavam as leis, as práticas ou as representações que lhes eram impostas pela força ou pela sedução, para outros fins que não os dos conquistadores. Faziam com elas outras coisas: subvertiam-nas a partir de dentro - não rejeitando-as ou transformando-as (isto acontecia também), mas por cem maneiras de empregá-las a serviço de regras, costumes ou convicções estranhas à colonização da qual não podiam fugir. Eles metaforizavam a ordem dominante: faziam-na funcionar em outro registro. Permaneciam outros, no interior do sistema que assimilavam e que os assimilava exteriormente. Modificavam-no sem deixá-lo. Procedimentos de consumo, conservavam a sua diferença no próprio espaço organizado pelo ocupante. (CERTEAU, 1994, p. 94-95, grifos meus.)

Valeria utilizar essa mesma perspectiva para observar o que fazem das ofertas artístico-culturais os públicos endereçados pelas instituições. Seguindo a linha traçada por Certeau (e também por Barthes), o consumo cultural poderia ser analisado pelo viés de uma produção outra, praticada pelos públicos em lugares (discursivos) que não lhes pertencem e de cujas decisões eles não participam. Quase invisível, tal produção "não se faz notar por produtos próprios", e sim "por uma arte de utilizar aqueles que lhe são impostos” (CERTEAU, 1994, p. 94).

27 Recordemos a designação mencionada no capítulo anterior: "público forçado". Verbalizada pelo ex-presidente da Fundação Bienal de São Paulo, Luis Terepins, essa expressão vinha sendo usada por ele para se referir aos visitantes escolares arregimentados pelo programa educativo da instituição para visitar a mostra mediante o formato das "visitas agendadas". 
Residiria nisto uma das potencialidades da mediação cultural de viés crítico: atuar como prática documentária, engendrando linguagens e suportes capazes de traduzir e fazer circular as discursividades dos públicos em contextos e temporalidades que extrapolem o instante de interação com os objetos e proposições presentes em uma exposição, por exemplo. Certeau identifica esse modo de produção praticado pelos públicos como um "saber-fazer" no mais das vezes desvinculado de uma linguagem estruturada, constituído por “operatividades múltiplas, mas selvagens", afastadas das leis do discurso e de seu poder de influência (CERTEAU, 1994, p. 131, 136-137).

Como referência de tradução - pelos expedientes da linguagem - dessas operatividades, o autor evoca uma vertente do campo literário: o romance. $\mathrm{Na}$ seara ficcional, que lhe serve de terreno fértil, se introduzem as "maneiras de fazer” de personagens ordinários, cujas práticas encontrariam aí um "novo espaço de representação". Elas condizem a "virtuosidades cotidianas", ou mesmo a restos da experiência humana não cultivados pela linguagem - com os quais, segundo o autor, a ciência não sabe o que fazer. A partir desse residual das práticas cotidianas, a produção ficcional forja "narratividades", dando a ler/ver "as maneiras de fazer sob a forma de relatos” (CERTEAU, 1994, p. 131, 142).

No entanto, longe de funcionar como um aparato de seleção e distanciamento analítico, que toma as práticas ordinárias como objetos de verificação e explicação, a composição de narrativas a partir das operatividades dos púbicos representa, em si mesma, "uma maneira de fazer textual, com seus procedimentos e táticas próprios". Mais do que narrar um "golpe”, essa composição de viés documentário o faz. Logo, não quer exprimir uma prática, mas empreendê-la como tal (CERTEAU, 1994, p. 152-153).

Resta dizer, por fim, que tais narrativas se forjam e se apresentam, elas mesmas, de maneira astuciosa. Delas surge a possibilidade de conferir lastro e consequência às respostas dos públicos diante daquilo que as instituições artísticas e seus programas (expositivos e educativos) lhes apresentam como oportunidades de participação no âmbito artístico-cultural. Na medida em que endereçam outros agentes - os próprios agentes institucionais: gestores, curadores, mediadores e também artistas --, essas narrativas operam em colaboração com os públicos, buscando produzir efeitos para além do seu perímetro inicial de atuação, de modo a transbordar as delimitações instrumentais a que geralmente estão circunscritas as ações da mediação institucional e, consequentemente, as formas de atuação emergentes dos seus públicos. 


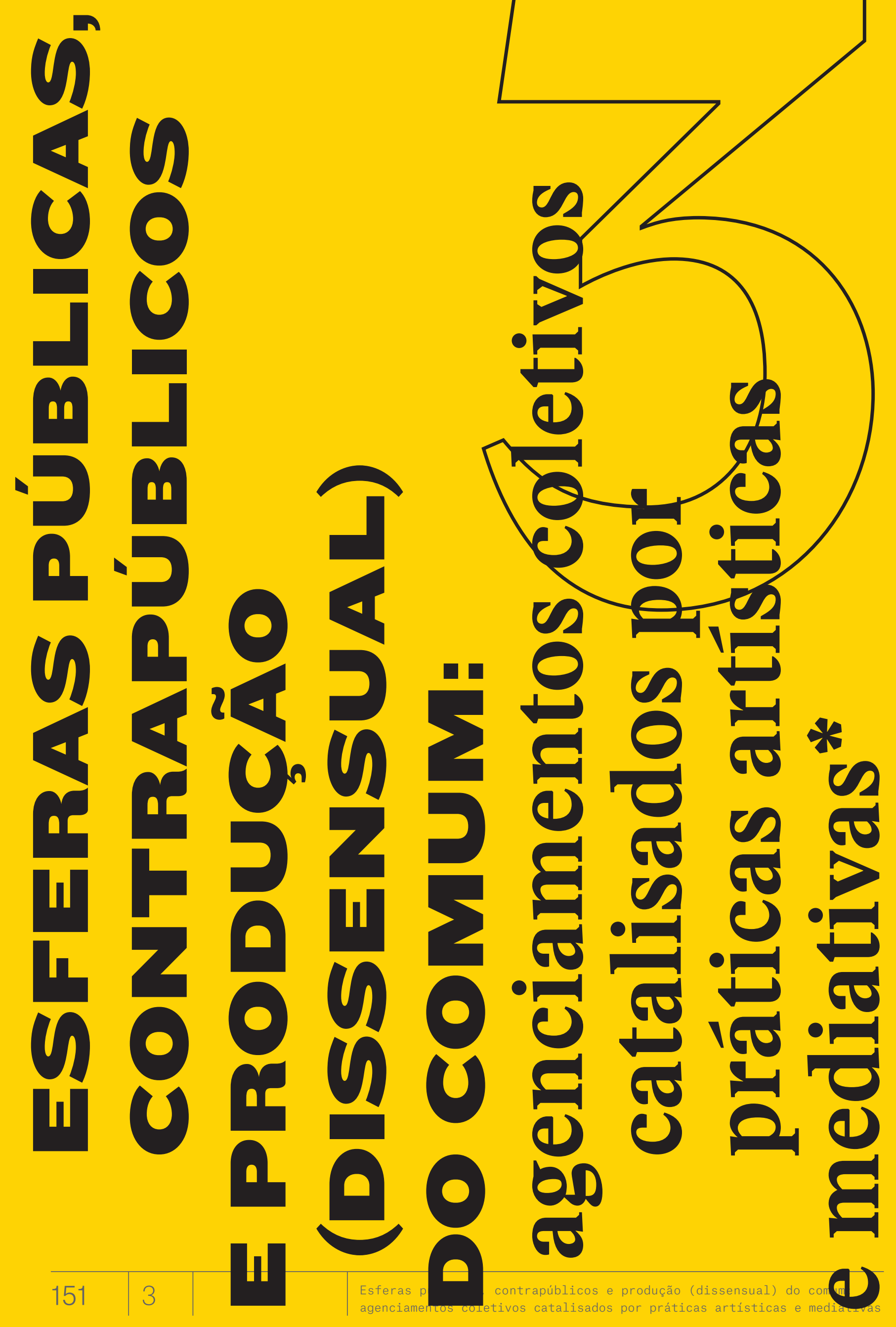


A pluralidade humana, condição básica da ação e do discurso, tem o duplo aspecto de igualdade e diferença. Se não fossem iguais, os homens seriam incapazes de compreender-se entre si [...]. Se não fossem diferentes, se cada ser humano não diferisse de todos os que existiram, existem ou virão a existir, os homens não precisariam do discurso ou da ação para se fazerem entender. Com simples sinais e sons poderiam comunicar suas necessidades imediatas e idênticas.

\section{- HANNAH ARENDT}

A partir da interação, aqueles que não têm lugar algum na comunidade política fazem a aparição. No ato de declarar direitos novos, específicos, eles repetem a demanda democrática original por liberdade e igualdade.

\section{- ROSALYN DEUTSCHE}


No presente capítulo, pretendemos articular um conjunto de referências ligadas à dimensão pública e sociopolítica de determinadas experiências desenvolvidas nos terrenos da arte e da mediação cultural. Para tal, buscamos aproximar e confrontar formulações provindas do universo teórico com práticas experimentadas nos referidos campos da criação e da tradução culturais, procurando tecer uma trama conceitual a partir do cruzamento de variadas linhas de compreensão e uso das noções de esfera pública, arte pública, participação, colaboração e produção do comum.

Interessa-nos investigar certas concepções e experiências relacionadas a diferentes agenciamentos coletivos, com vistas a reunir referências que nos possibilitem problematizar o modelo histórico-social da esfera pública burguesa e seu caráter normativo e excludente. Franqueada a uma subjetividade específica e baseada numa lógica totalizante, na qual as situações comunicativas são praticadas por proprietários privados que participam do debate público mediante o uso supostamente imparcial e objetivo da argumentação crítico-racional acerca de temas (anunciados como) de interesse comum, essa modalidade de esfera pública é analisada pelo sociólogo Jürgen Habermas em Mudança estrutural da esfera pública. Verificar as principais características desse modelo à luz de concepções e experiências que o contradigam e o desafiem nos possibilitará colocar o conceito de esfera pública em perspectiva, permitindo-nos postular outro estatuto para ele. É, sobretudo, do exercício de vislumbrar bases alternativas para a noção de esfera pública que nos ocupamos aqui.

Abordar a esfera pública em suas diferentes ocorrências históricas pressupõe mencionar, além da sua vigência no contexto das revoluções burguesas, seus primórdios na cidade-estado grega, no âmbito da pólis. O surgimento de tal configuração citadina inaugura uma situação social inédita no contexto nascente da civilização ocidental, que proporciona um tipo de existência dupla a uma parte restrita de seus habitantes: à vida privada e doméstica do homem passa a ser incorporada uma segunda dimensão, correspondente à sua vida política exercida em público. O cidadão da pólis passa, então, a fazer parte de duas esferas distintas de existência, transitando "entre aquilo que lhe é próprio e o que é comum" (ARENDT, 2007, p. 33, grifos meus). Ou seja, ele transpõe cotidianamente o seu círculo familiar - orientado para a sobrevivência e a provisão das necessidades básicas - e adentra a arena onde o que está em jogo são as preocupações mais elevadas da vida da comunidade, debatidas por cidadãos que desfrutam da prerrogativa de um lar próprio, servido por suas mulheres, escravos e demais entes. Assim, como a condição de cidadão era facultada apenas a uma pequena minoria masculina possuidora de bens e servos, a experiência de tal duplicidade e a respectiva atuação em público se mantinham inacessíveis à maior parte da população, mantida na obscuridade do lar por todo o período da vida.

Portanto, ao mesmo tempo que buscamos detalhar os aspectos limitadores da esfera pública histórica, optamos por lidar com uma ideia ampliada e deliberadamente difusa dessa dimensão pública da vida, enquanto espaço de aparição do sujeito, em consonância com as reflexões da filósofa Han- 
nah Arendt em $A$ condição humana. Ainda que originalmente inspirada na restritiva $p$ ólis grega, essa acepção pode ser retomada contemporaneamente, com base nos princípios dos direitos humanos, em sua literalidade e abrangência, sugerindo que a esfera pública - localizada e parcial que seja - condiz ao "espaço no qual eu apareço aos outros e os outros a mim", à revelia de privilégios sociais, econômicos e de gênero; de hegemonias epistemológicas e comunicativas; e dos locais onde isso venha a ocorrer. Logo, o que se postula é a incorporação de tal dimensão, o estar em público, a toda e qualquer pessoa (ARENDT, 2007, p. 211). É nessa perspectiva que a crítica de arte Rosalyn Deutsche destaca a centralidade conferida por Arendt à aparição do sujeito em público. De acordo com Deutsche, a aparição vincularia oportunamente a esfera pública ao campo da visão, ao domínio da visualidade, denotando com isso um papel tático potencialmente assumido pelas artes visuais no tocante a possíveis contribuições para a visibilização de grupos e agendas minoritários e, consequentemente, para o "aprofundamento e expansão da democracia” (DEUTSCHE, 2009, p. 175). O ponto de contato entre a aparição do sujeito e as práticas artísticas que operam com a visualidade adquire posição chave em nossa linha de argumentação, pois partimos justamente da ideia de que certas proposições artísticas e mediativas no campo das artes visuais seriam capazes de deflagrar, elas próprias, esferas públicas ancoradas em problemáticas e públicos específicos.

Em meio à profusão de vertentes constitutivas do cenário contemporâneo das artes visuais, a "arte pública" figura entre aquelas que se ocupam das interações e negociações sociais, bem como da produção de novos marcos comuns por meio do diálogo e da colaboração com/entre diferentes públicos. Em virtude da abrangência e da variedade inerentes a esse segmento das artes visuais, procuraremos especificar a qual ramificação da arte pública nos referimos, a fim de evidenciar, inclusive, aquilo que entendemos ser a dimensão pública de uma proposição artística. Mais ainda, visamos expor a aptidão desse tipo de experiência para constituir espaços temporários de visibilização pública de problemáticas e grupos historicamente privados de reconhecimento e do acesso aos seus direitos. Portanto, relegados ao lado sombrio - não público - da realidade social. É à "arte no interesse público" que nos referimos. Suas especificidades serão derivadas de uma síntese apresentada pelos artistas Vitor Cesar e Graziela Kunsch no texto que conceitua o projeto Arte e esfera pública.

Por esse viés específico da arte pública, nos propomos a observar experimentos realizados nos âmbitos da arte e da mediação cultural - considerando também as suas articulações - que se distinguem pelo compromisso com a formação de esferas públicas temporárias. Como veremos ao longo do capítulo, tais iniciativas não apenas confrontam o sentido restritivo das incidências históricas da esfera pública, como também problematizam a ideia de participação na arte, haja vista o seu caráter apriorístico e centralizado. Como alternativa, Landkammer postula a colaboração como outra forma de agenciamento coletivo. Descentralizadora e horizontalizante, ela favoreceria a emergência de agrupamentos aglutinados em torno da reivindicação de direitos sociais, catalisando um 
tipo de atuação pública voltado ao reconhecimento das suas demandas pelo conjunto da sociedade.

Outra baliza importante para nossa análise do modo de funcionamento da esfera pública é representada pelos contrapúblicos. Como detalharemos, seus imaginários e ações disruptivos concorrem para o esgarçamento das convenções que normatizam arenas e agendas tidas como legitimamente públicas, forçando a permanente ampliação da compreensão e do escopo do que venha a ser o interesse e o espaço comuns. Há por parte desses personagens sociais, frequentemente marginalizados, a exigência de que questões predominantemente tidas como privadas ou apenas idiossincráticas sejam reconhecidas como problemáticas de natureza comum, capazes de pautar debates que repercutam para além de seus círculos originários - normalmente invisibilizados pelos dispositivos do publicismo hegemônico.

Ademais, os contrapúblicos apontam para modos de experiência e comunicação alternativos, senão antagônicos, aos expedientes do pensamento crítico-racional masculinista, próprios à dinâmica de funcionamento da esfera pública burguesa. Nossa referência nesse quesito será o texto Públicos e contrapúblicos, do crítico literário Michael Warner, em particular a sua investigação em torno do jornal inglês The Spectator. A esse periódico em circulação no início do século XVIII, aurora da esfera pública burguesa, se contrapôs um grupo de mulheres autodesignado Garotas Brincalhonas, que contra ele se insurgiu com base em seus hábitos de convivência e interesses, os quais se mostrariam inconciliáveis com aqueles defendidos e difundidos reiteradamente pelo editorial do jornal quanto ao seu status público.

Se, por um lado, os contrapúblicos afirmam-se em oposição a conformações públicas seletivas e excludentes, por outro, há práticas artísticas e mediativas dedicadas a conceber ferramentas e plataformas catalisadoras de agenciamentos coletivos que envolvam indivíduos e grupos cujo reconhecimento público (de si e de suas agendas) e acesso aos direitos civis vêm sendo histórica e sistematicamente negados.

Aplicada originalmente nos campos da química e da física, a acepção literal de catálise condiz a um fenômeno causador do aumento na velocidade das reações químicas, o que se deve à inserção de determinada substância (que assume função catalisadora) em um dado conjunto de partículas. Interessa-nos, sobretudo, o sentido figurado desse termo, que conota açôes voltadas ao estímulo e à dinamização de situaçôes alinhadas a certos propósitos. Logo, ao utilizar a noção de catálise, buscamos refletir sobre os diferentes modos de fomentar a formação de esferas públicas temporárias e parciais, mediante a organização e a consequente potencialização de movimentos gerados por agentes que, de maneira colaborativa, mobilizam-se em torno de problemáticas sociopolíticas específicas ou, em outras palavras, de reivindicações por visibilidade e direitos.

Certas proposições artísticas e mediativas assumem para si a função de deflagrar a aglutinação de sujeitos que se comprometem com a vigência de esferas de agenciamento sociopolítico que duram no tempo. Além disso, faz parte dessas proposições a elaboração de ferramentas comunicativas 
capazes de propiciar a transposição dos limites dos círculos onde ocorrem as interações entre os sujeitos, produzindo novos endereçamentos e, consequentemente, públicos para os seus enunciados. Postulamos que essas operações trazem consigo o potencial de criar novos marcos fundados em demandas historicamente negligenciadas. Isso implicaria, em contrapartida, conceber a produção do comum em bases dissensuais, uma vez que ela pressupõe insurgências frente a desigualdades e exclusões tácita e tradicionalmente aceitas, desnaturalizando-as à medida que as confrontam. Produzir o comum nesses termos requer a disposição para lidar com embates voltados ao alargamento e à repactuação permanente do que venha a ser considerado de interesse público.

Como poderemos verificar nos exemplos aqui coligidos, ao anúncio e à reivindicação de direitos específicos subjaz um direito ainda mais elementar, comum à condição humana nos termos arendtianos: estar entre as pessoas, agir em público. De acordo com Deutsche, essa dimensão fundamental da vida humana se refere ao "direito de aparecer como sujeito enunciador na esfera pública”. É o fato de demandá-lo que o torna possível, consumável, fazendo com que esferas públicas sejam instauradas em sentido plural, ao passo que uma miríade de espaços de aparição se constituem e se afirmam justamente "quando grupos sociais declaram o direito de aparecer” em público (DEUTSCHE, 2009, p. 176).

\subsection{SER HUMANO EM PÚBLICO E O PAPEL DOS DIREITOS}

O princípio democrático inerente à "proliferação de novas práticas políticas inspiradas pela ideia dos direitos” serve-nos de base para conceber o estatuto da esfera pública em chave expandida, enquanto conjunto inumerável de formações de caráter contingencial e emergente (DEUTSCHE, 2008, p. 6). Arendt é a autora à qual nos reportamos para refletir sobre esse espaço de interação e comunicação que se dá entre as pessoas que compartilham do ambiente público, nele figurando e atuando (ARENDT, 2007, p. 211).

A fim de definir a natureza daquilo que se processa nesse espaço - que, diga-se, não se limita à sua dimensão físico-espacial -, a filósofa distingue duas acepções complementares para o termo "público". A primeira diz respeito a tudo aquilo que, vindo a público, pode ser acessado por outras pessoas, adquirindo visibilidade. Para que isso ocorra é necessário levar em conta a aparência das coisas, sua forma exterior de manifestação. É ela que, segundo Arendt, confere existência àquilo que, a partir de então, passa a ser "visto e ouvido pelos outros e por nós mesmos" e constitui a realidade mesma. Este seria, então, o efeito da "aparição pública”: fazer com que pessoas e coisas se tornem parte integrante da realidade comum. Do contrário, permanecem confinadas a uma zona "incerta e obscura" de invisibilidade, dela escapando somente na medida em que possam ser "desprivatizadas e desindividualizadas" e, assim, transfiguradas no sentido de alcançar a condição pública (ARENDT, 2007, p. 59-60).

$\mathrm{O}$ ato de falar publicamente sobre as coisas vivenciadas em privado já seria ele mesmo, segundo Arendt, uma iniciativa capaz de provocar tal transfiguração, visto que a alocução corresponde a uma forma, entre outras, de 
manifestação. E, mais ainda, de transposição das vivências "para uma esfera na qual assumirão uma espécie de realidade que [...] elas jamais poderiam ter tido antes", caso permanecessem circunscritas ao plano da experiência íntima ou privada. Contudo, embora faça menção ao ato de fala em geral, a autora enfatiza a capacidade que a tradução artística, em particular a "narração de histórias", teria de potencializar o processo de publicização da experiência do próprio indivíduo ou de terceiros. Arendt dá a entender que a síntese e a organização formal propiciadas pela linguagem contribuem decisivamente para a aparição e a circulação públicas dos enunciados resultantes das vivências de cada um de nós e também dos outros. Esse é um aspecto de suma importância para a abordagem que ensaiamos no presente capítulo em torno dos agenciamentos coletivos catalisados por práticas artísticas e mediativas, visto que denota a função tática das linguagens da arte no processo de aparição pública das trajetórias, discursividades e anseios de indivíduos e coletividades minoritários.

Nessa perspectiva, Arendt sentencia que "a presença de outros que veem o que vemos e ouvem o que ouvimos garante-nos a realidade do mundo e de nós mesmos”, o que nos leva a considerar que o contato que estabelecemos com a realidade social não é apenas mediado pela aparência, como também se encontra fundado nela. É a aparência pública que nos possibilita repactuar parâmetros comuns, aos quais nos reportamos para constatar a natureza necessariamente compartilhada (e negociada) da realidade. A esfera pública surge, então, como o lugar por excelência das aparições, a plataforma "na qual as coisas possam emergir da treva da existência resguardada”, afrontando e alargando permanentemente a realidade, sobretudo quando sujeitos e comunidades minoritários logram que seus enunciados e demandas adquiram publicidade e sejam, em diferentes graus, reconhecidos pelo conjunto da sociedade como preocupações e interesses concernentes a todos (ARENDT, 2007, p. 6061). É desse processo que falamos quando aludimos à ideia da produção do comum em bases dissensuais.

A segunda acepção de "público" em Arendt desdobra-se dessa transposição do sujeito do âmbito privado ao domínio público. Ela aponta para "o próprio mundo", no sentido daquilo que "é comum a todos nós e diferente do lugar que nos cabe dentro dele” (grifo meu). Trata-se, portanto, daquilo que transcende a condição e a posição de cada um, na medida em que compete e afeta a todos. A dimensão pública envolve, portanto, interações e intercâmbios praticados "entre os que, juntos, habitam o mundo", a todo tempo convencionando e divergindo (e vice-versa) acerca do que nele cabe ou não (ARENDT, 2007, p. 62).

Ainda em referência a essas interações e intercâmbios, Arendt constata que a convivência mundana exige a interposição de uma diversidade de coisas (palavras, imagens, objetos, construtos expressivos, performances etc.) que funcionariam, a um só tempo, como elos e divisores entre aqueles que "habitam [o mundo] em comum", ao permitirem tanto a relação como a separação entre as pessoas, de modo a evitar a colisão entre elas (ARENDT, 2007, p. 62). Logo, estar e agir no espaço público requer 
de cada um de nós o uso de artifícios - em termos de traduções linguísticas em sentido amplo - capazes de conferir visibilidade e legibilidade àquilo que buscamos expressar e, em diferentes medidas, postular como relevante para o comum da sociedade, excedendo as experiências individuais e também os círculos sociais aos quais estamos imediatamente ligados.

É nesse âmbito que se dá a incessante negociação - não raro resultante de lutas históricas e disputas narrativas - em torno daquilo que deve ou não ganhar espaço na cena pública e, por conseguinte, na realidade comum. Arendt comenta, nesse sentido, que o "mundo público" tolera apenas "o que é tido como relevante, digno de ser visto ou ouvido", ao passo que "o irrelevante se torna automaticamente assunto privado" (ARENDT, 2007, p. 61). Caberia então nos perguntarmos: quem define o que é relevante, merecedor de atenção pública, e o que é irrelevante, fadado a permanecer na sombra da esfera privada? É aqui que as hegemonias de certos grupos sociais (assentadas em prerrogativas de classe, gênero, raça, formação etc.) exercem influência direta no processo de reconhecimento do que venha a integrar a dimensão pública inerente aos interesses comuns.

A contenda por reconhecimento encontra espaço no processo democrático, que, por sua vez, respalda o surgimento e a multiplicação de movimentos sociais e práticas políticas encorajados pela perspectiva dos direitos, o que envolve inclusive a demanda por direitos novos, que sequer constam dos dispositivos legais. Deutsche comenta que, além da demanda fundamental por atuar publicamente, grupos e movimentos baseados na busca pela garantia de direitos mobilizam-se para "conseguir reconhecimento para as particularidades coletivas marginalizadas". Como exemplo, a autora faz menção a iniciativas "em favor do direito de gays e lésbicas a uma cultura sexual pública” (DEUTSCHE, 2008, p. 6). Essa é uma referência útil para refletirmos acerca da disputa pela admissão pública de orientações e condutas tidas, tradicionalmente, como pertencentes ao domínio privado, justamente por se desviarem das normas sexuais e sociais definidas pela hegemonia hétero. Como veremos mais adiante no caso das Garotas Brincalhonas analisado por Warner, as dificuldades encontradas pelas comunidades gays no tocante à aceitação pública de suas culturas comportamentais devem-se, entre outros fatores, à adoção por seus membros de formas de conduta "excessivamente” corporalizadas e sexualizadas. Por outro lado, o espaço público heteronormativo, baseado no uso distanciado da argumentação racional, exigiria dos cidadãos um tipo de comportamento impessoal, sóbrio e objetivo, supostamente mais adequado à formulação e ao trato dos interesses comuns.

Contudo, como ressalva Deutsche, o espaço público democrático também é o domínio onde as certezas, os padrões e os fundamentos da vida social tendem a desaparecer. A autora credita tal tendência às revoluções políticas burguesas - paradoxalmente as mesmas que ensejaram o florescimento da esfera pública crítico-racional de cunho masculinista e restritivo. Ocorridos entre o período que vai de 1640 a 1850, sobretudo 
na Inglaterra e na França, os movimentos revolucionários burgueses ${ }^{1}$ provocaram um abalo irreversível da sociedade aristocrática, que deu lugar à sociedade liberal capitalista, guiada pela produção mercantil. Além da centralidade conferida ao mercado, as revoluções burguesas desencadearam uma profunda mutação no plano dos direitos do homem. Alexis de Tocqueville, pensador político em atividade no século XIX, designa essa mutação como "a invenção democrática”. Tal invenção resultou na Declaração dos Direitos do Homem, de 1789, que imputa o poder soberano "ao povo", desbancando a autoridade e a concentração do poder na figura do Rei. Daí que à invenção democrática venha se somar a reinvenção do espaço público, um espaço onde o sentido e a unidade sociais, já não mais sob os auspícios dos monarcas, são a todo tempo disputados e negociados pelos cidadãos republicanos - com todas as desigualdades e assimetrias que caracterizam o corpo social ${ }^{2}$ (DEUTSCHE, 2008, p. 7-8).

Destituído de um fundamento absoluto, o espaço social passa a representar um domínio incerto, aberto em suas possibilidades e riscos. É aí que se processa, segundo Deutsche, o "debate sobre o que é legítimo e o que é ilegítimo”, baseado nas exigências em torno dos direitos democráticos - lógica exemplarmente condensada por Arendt na máxima do "direito a ter direitos”. São eles que, ao serem reivindicados pelos diferentes atores sociais - em condições notadamente desiguais -, transformam o espaço público na arena de "institucionalização do conflito", onde se luta pela desnaturalização dos privilégios e das exclusões e pelo reconhecimento de demandas emergentes de grupos historicamente invisibilizados e, portanto, alijados do espaço público de debate (DEUTSCHE, 2008, p. 8-9).

Para Deutsche, o conflito e a instabilidade, em lugar de destruir a esfera pública, "são condições para sua existência" (DEUTSCHE apud BISHOP, 2011, p. 121). Os antagonismos aí em jogo, como sugerido acima, permitem que exclusões e opressões sejam desveladas e enfrentadas, abrindo espaço

1 Os principais marcos das revoluções burguesas são a Revolução Inglesa (1640-88), a Revolução Francesa (1789-1848) e a Revolução Americana (1765-1783).

2 Uma prova eloquente dessa desigualdade pode ser encontrada no caso de Olympe de Gouges, pioneira do feminismo na França e autora do panfleto intitulado "Declaração dos direitos da mulher". Referência direta à Declaração dos Direitos do Homem, que pouco dizia sobre os direitos da mulher, o panfleto conclamava: "Ó mulheres! Mulheres, quando deixareis vós de ser cegas?". Entre as principais bandeiras defendidas por Olympe em seu ativismo, destacam-se a emancipação das mulheres, a instituição do divórcio e o fim da escravatura. Líder de um grupo de teatro formado apenas por mulheres, ela procurava transpor suas ideias sobre direitos para as peças que escrevia, além de produzir cartazes que mandava colar pela cidade. Vistas por Robespierre como uma afronta aos valores republicanos, suas ideias e iniciativas a levariam à condenação e, sem direito a um advogado, à execução na guilhotina, em 3 de novembro de 1793 (Luiza Villaméa. "A pioneira do feminismo que foi parar na guiIhotina". Brasileiros, 25 out. 2016. Disponivel em: <http:// brasileiros.com.br/2016/10/pioneira-feminismo-que-foi-parar-na-guilhotina>. Acesso em: 17 abr. 2017). 
para pleitos mais francos pelo acesso dos mais diversos segmentos da população à condição cidadã - a qual, em contrapartida, também vai sendo permanentemente alargada e ressignificada por aqueles que, ao pleiteá-la, o fazem com base em valores e anseios diversos.

Se, por um lado, isso viabiliza o processo de construção da sociedade democrática, por outro, a coloca em permanente risco, conforme sugerem Mouffe e Laclau. Tal seria o paradoxo inerente à sociedade democrática, do qual ela não pode escapar: na medida em que a demanda por direitos e a vigência dos antagonismos franqueiam a luta por justiça social, elas acabam por levar ao limite a possibilidade mesma de a sociedade vir a se constituir como um organismo coeso. Esse dilema é traduzido nos seguintes termos por Mouffe: "Como condições de possibilidade para a existência de uma democracia pluralista, conflitos e antagonismos constituem ao mesmo tempo a condição de impossibilidade de sua realização final” (MOUFFE apud BISHOP, 2011, p. 122). Daí que a discussão em torno da produção do comum deva considerar os esforços consensuais e dissensuais como igualmente necessários.

Dispomos, portanto, da compreensão do caráter fundamentalmente indefinido e ambivalente do espaço social democrático, aberto a iniciativas e contestações em defesa da pluralidade, mas que, por esse mesmo motivo, não deve se limitar à condição de um ambiente onde as diferenças e particularidades apenas coexistam de modo indiferente e insensível entre si, o que inviabilizaria a repactuação de interesses e preocupações comuns ou, em última instância, a constituição do próprio laço social. Isso nos solicita, portanto, um tipo de abordagem da esfera pública que, ao compreender a importância do dissenso, busque sustentá-lo naquilo que venha a ser o seu potencial de produzir novos marcos comuns. Ou seja, ações e discursos que, ao reivindicar para si visibilidade e relevância, possam se constituir como balizas capazes de afetar e pautar o debate público, postulando o reconhecimento e a influência mútua entre indivíduos, comunidades e culturas.

O que buscamos sustentar é que, entre outras formas discursivas capazes de formalizar aparências e marcos comuns, há práticas desenvolvidas nos âmbitos das artes visuais e da mediação cultural que, ao colaborar com públicos (indivíduos e comunidades) específicos, logram produzir importantes precedentes para o processo democrático de alargamento do espaço e do interesse públicos e, por conseguinte, da própria realidade social. Isso se daria graças à conjugação de esforços voltados à formação de esferas públicas parciais e temporárias, ancoradas em determinadas problemáticas sociopolíticas, cujos desdobramentos são traduzidos e publicizados em diferentes mídias e contextos, beneficiando-se de formas de circulação e legitimação propiciadas por plataformas institucionais. 


\subsection{ARTE E MEDIAÇÃO NO INTERESSE PÚBLICO}

As experiências em arte e mediação ${ }^{3}$ que, nos parece, refletem de diferentes modos os aspectos acima mencionados são aquelas que se dedicam a fomentar dinâmicas de interação social, intercâmbio simbólico e circulação de repertórios mediante a formação de agrupamentos em torno de problemáticas sociopolíticas e práticas culturais concernentes aos seus membros. Nesses casos, a diferença, o conflito e a busca pela produção de marcos comuns são entendidos como aspectos indissociáveis de proposições vocacionadas a deflagrar esferas públicas temporárias e localizadas, em geral propícias à demarcação e ao enfrentamento de quadros sociais de discriminação e exclusão.

Na contemporaneidade, o campo da arte tem sido povoado por diversas experiências dessa natureza. Uma das vertentes da arte pública, em particular aquela que conjuga investigações contextuais e situações colaborativas, nos serve como referência para pensar a catalisação de esferas públicas por meio de iniciativas artísticas e mediativas. Com base nas ideias da crítica de arte Miwon Kwon em torno das práticas site-specific, os artistas Vitor Cesar e Graziela Kusch - num projeto concebido para funcionar, ele mesmo, como uma esfera pública ${ }^{4}$ - lançam mão do conceito de arte pública a partir da modulação "arte no interesse público" (CESAR; KUNSCH, 2008). Importa pontuar que, entre as acepções de arte pública comentadas a seguir, ela é a menos difundida nos compêndios da história da arte.

Discriminando suas linhas gerais, Cesar e Kunsch estilizam três modulações para a arte pública: 1) "arte no espaço público", que corresponde às obras concebidas para serem exibidas fora do museu, conservando o estilo pessoal do artista; nesse caso, o estatuto público da obra se deve apenas ao fato de ela encontrar-se instalada em locais públicos de livre acesso; 2) "arte como espaço público", envolvendo projetos de intervenção e renovação urbana, a partir de construtos arquitetônicos, escultóricos, paisagísticos e de mobiliário na cidade; aqui, a dimensão pública do trabalho está atrelada à sua vocação "aplicada", aberta ao uso pela população; e 3) "arte no interesse público", em que artistas - e também mediadores - atuam

3 Como anota Honorato no texto editorial da revista Periódico Permanente \#6 (Mediação cultural), que tivemos a oportunidade de editar juntos, a mediação é concebida pela antropologia urbana, em particular por Gilberto Velho e Karina Kuschnir, como um tipo de trajetória experimentada por diferentes agentes que transitam por/ entre diferentes universos culturais. Dentre estes agentes, os artistas e os mediadores assumem papel de destaque.

4 Trata-se do projeto Arte e esfera pública (2008). Realizado no Centro Cultural São Paulo, na Casa da Cidade e no Jamac - Jardim Miriam Arte Clube, o projeto agregou artistas, instituições e projetos independentes com o intuito de debater o estatuto da arte e do circuito artístico pela ótica da esfera pública, indagando de que formas a esfera pública artística pode se relacionar com outras esferas da sociedade. Além das sedes mencionadas, o projeto esteve hospedado no portal Fórum Permanente durante o período de sua realização. 
com públicos específicos, de modo colaborativo, a partir de aspectos relevantes da vida daqueles que se dispõem a tomar posição em processos que, com frequência, adquirem a forma e a dinâmica de esferas públicas temporárias (CESAR; KUNSCH, 2008).

Coincidente com o foco da nossa abordagem, a terceira modulação da arte pública põe em xeque a concepção moderna do público da arte, que compreende a instância da recepção como uma dimensão genérica e universal, indistintamente designada pela noção de audiência. No caso da "arte no interesse público”, essa ideia abstrata dá lugar a públicos entendidos em bases heterogêneas, enquanto formações contingenciais de sujeitos políticos que se tornam públicos e, em alguns casos, colaboradores de determinadas práticas artísticas e mediativas a partir de agendas sociopolíticas e culturais específicas. Aqui, o processo artístico se efetiva de tal modo, em articulação com práticas da mediação cultural, que os sujeitos "por vezes são tomados como públicos, outras vezes como parceiros” (BARROS, 2013, p. 14).

Ao interagir com seus públicos em termos discursivos, por meio da interlocução e da colaboração a partir de determinadas problemáticas e repertórios, os projetos artísticos representativos de tal vertente procuram constituir esferas temporárias de envolvimento e interesse comuns, lidando com a noção de espaço público em sentido ampliado. Com ênfase na dimensão comunicacional, essas esferas colaborativas extrapolam a constante fisico-espacial característica dos exemplares “clássicos” da arte pública

Tais projetos se baseiam na constatação de que existem múltiplos espaços discursivos de interesse público, no que se refere a suas problemáticas, subjetividades, culturas e linguagens. Não se restringindo a aspectos territoriais, esses espaços comunicacionais convivem entre si, sobrepõem-se, entram em conflito e, em certos casos, propiciam a produção de novos marcos comuns. Os processos da arte e da mediação são aí compreendidos, portanto, como potenciais catalisadores de agenciamentos coletivos capazes de se configurar como espaços públicos plurais ancorados em premências sociopolíticas e práticas culturais não hegemônicas. A partir desses espaços, sujeitos apresentam-se em público, colocando em pauta demandas e anseios emergentes, com a expectativa do seu reconhecimento pelos demais círculos sociais.

Nesse quesito, a "arte no interesse público" se relaciona diretamente com a analogia destacada por Deutsche, já comentada, entre a aparição do sujeito em público - vista por Arendt como crucial à condição humana e cidadã - e o campo das artes visuais, que, segundo a crítica, traz em si o potencial de favorecer a visibilização de sujeitos e agendas minoritários, Richard Serra, na qual o artista instala uma escultura linear monumental, em posição diagonal, na Federal Plaza de Nova York, alterando radicalmente a disposição espacial do logradouro e o trânsito das pessoas nessa área da cidade. Após uma batalha judicial desencadeada pela "obstrução" que a obra teria provocado na praça, a escultura foi removida pelo poder público em 1989. 
contribuindo para a radicalização do processo democrático. O que se almeja, portanto, são espaços de aparição que, valendo-se de vocabulários artísticos e de plataformas institucionais, ganham traduções e suportes propícios à circulação e à repercussão do que aí se processa, desde publicações, instalações, fotografias e filmes até performances, intervenções e eventos públicos.

Além dos expedientes da arte, o estímulo à formação desses espaços de aparição é lastreado por procedimentos caros à mediação cultural, vista a sua acepção como um "conjunto de ações que se realiza na esfera pública e se configura como conexões entre ações sociais e representações" - podendo estas últimas ser entendidas como traduções culturais. $\mathrm{O}$ autor que compreende a mediação em tal registro é o antropólogo José Márcio Barros, para quem o seu conjunto de abordagens "envolve atores, práticas, objetos e contextos" articulados com o intuito de promover "um circuito de produção e circulação de sentidos”. Dessa forma, as práticas mediativas alavancam processos fundamentalmente dialógicos e relacionais, nos quais se processariam intercâmbios e invenções simbólico-sociais. As dinâmicas interpessoais aí se desenvolvem como numa rede semântica apta a promover a "circulação de sentidos nos diferentes sistemas culturais, operando um percurso [de mão dupla] entre a esfera pública e o espaço singular e individual dos sujeitos”. Isso porque, assim como as práticas artísticas, a mediação cultural seria capaz de produzir "a tão necessária transição do sensível ao inteligível” (BARROS, 2013, p. 1014). Ou também, nos termos arendtianos, a transposição daquilo que se vivencia em privado para aquilo que se veicula no âmbito público.

Em complemento, devemos apontar que, entre o âmbito público em sentido lato e a dimensão individual do sujeito, a mediação instaura espaços coletivos cuja duração depende do tempo dedicado pelos envolvidos aos intercâmbios simbólicos experimentados nessa formação que, por si mesma, adquire um sentido público. É aí que, segundo Barros, "se tenta organizar e tornar públicos significados", sempre de modo "aberto, dinâmico e, potencialmente, produtor de descontinuidades" na realidade - dentre elas, destacamos o esgarçamento e a ampliação do que possa ser considerado de interesse comum (BARROS, 2013, p. 10). A esse respeito, Sheikh comenta que a ideia de "público" passa a abranger quaisquer "espaços organizadores de experiências coletivas", o que nos solicita reconhecer a emergência e a multiplicidade de esferas públicas que se autoproduzem à revelia de condicionantes e normativas externas (SHEIKH, 2008, p. 130). Entretanto, a nosso ver, o seu caráter efetivamente público depende de uma diversidade real no modo como tais coletividades e espaços venham a se constituir e a interagir com outros círculos sociais.

Tais espaços de intercâmbio devem comprometer-se, para usar novamente uma acepção defendida pelo antropólogo, com o "exercício dos direitos culturais” (BARROS, 2013, p. 13). Aí se processam relações entre sujeitos que, experimentando um estado de colaboração, assumiriam de forma alternada as posições tanto de enunciadores como de ouvintes, daqueles que afetam e são afetados, convivendo temporariamente numa rede 
discursiva de caráter experimental. Nessa direção, Barros chama atenção para a dimensão sociopolítica da mediação, na medida em que os intercâmbios simbólicos e a decorrente elaboração compartilhada de sentidos "oportuniza [m] o trânsito, tão fundamental para a constituição do espaço social, entre o eu e o outro; entre o conhecido e o desconhecido; entre as semelhanças e as diferenças" (BARROS, 2013, p. 14).

Logo, às práticas mediativas competiria fomentar e sustentar a natureza ambivalente das aproximações de indivíduos, grupos e instituições entre si e com os diferentes repertórios culturais e demandas sociopolíticas colocados em jogo a cada situação ou projeto. Se, por um lado, tais práticas seriam capazes de "reduzir a distância entre sujeitos e [entre estes e os] objetos de sentido, tornando, assim, a vida coletiva inteligível e possível”, por outro, elas devem reconhecer as tensões provocadas por diferenças e assimetrias, não se furtando de lidar com elas (BARROS, 2013, p. 14).

Essa seria uma condição fundamental para pensarmos o trabalho em mediação numa perspectiva transcultural, em que os exercícios de tradução de uma cultura em relação a outras contribuam para o desafio de se "decifrar o significado do que une a todos, na medida em que também as ultrapassa”. Nessas bases, o diálogo transcultural estimularia a disposição de reconhecer aquilo que atravessa todas as culturas e que, no limite, acaba por excedê-las, sugerindo o vislumbre do que venha a ser comum entre os humanos, justamente por meio da atenção às suas diferenças (BARROS, 2013, p. 15). Estamos falando, portanto, de um movimento dialético, no qual as dimensões do "comum" e do "diferente" operam de maneira indissociável e interdependente.

Sobre as diferenças, Arendt defende que a ação e o discurso em público permitem que as pessoas possam distinguir-se, "ao invés de permanecerem apenas diferentes”, encapsuladas em suas particularidades identitárias (ARENDT, 2007, p. 189). Trata-se, portanto, de uma distinção calcada na afirmação de singularidades que se manifestam publicamente entre indivíduos e grupos, em lugar de se cristalizarem de modo substancial em reservado. Deutsche, por seu turno, constata que o campo social resulta exatamente das "relações entre elementos que não têm identidades essenciais", e vai mais além ao afirmar que a própria constituição da identidade depende da "relação com um 'outro' e, em consequência disso, não pode ser plena por si mesma” (DEUTSCHE, 2008, p. 8). Isso equivale a dizer que as singularidades são capazes de se afirmar como tais apenas na medida em que se abrem à relacionalidade e aos seus consequentes contágios.

Vindo a público, as singularidades denotam a alteridade - enquanto qualidade de ser distinto - como um aspecto inerente à condição humana, nos unindo enquanto nos distingue. Com isso, o espaço onde se manifesta a "pluralidade de seres singulares” poderia ser lido não como um terreno loteado

6 Com respeito a isso, deixamos aqui registrada a máxima da dupla Mouffe e Laclau: "A presença do outro me impede de ser totalmente eu mesmo" (MOUFFE; LACLAU apud BISHOP, 2011, p. 122). 
por diferenças particulares e incomunicáveis, mas, ao contrário, como um tabuleiro social onde aqueles que se declaram distintos interagem entre si, reconhecendo que o comum reside justamente naquilo que, reciprocamente, nos distingue (ARENDT, 2007, p. 189). Como temos procurado argumentar, há práticas artísticas e mediativas que, em virtude de sua disposição de produzir traduções culturais, ocupam-se de dinamizar e potencializar os movimentos experimentados no referido tabuleiro, correspondente ao próprio campo social.

Resta dizer ainda, retomando as ideias de Barros, que a mediação de viés transcultural não nos convoca apenas "para a interpretação de uma cultura pela outra, mas também para que se perceba o processo de fertilização de uma pela outra” (BARROS, 2013, p. 15), o que pressupõe iniciativas voltadas ao reconhecimento e à influência entre os diversos registros culturais, em sentido mútuo. Essa, sem dúvida, seria uma condição imprescindível para a experiência transcultural, na medida em que ela solicita a transposição dos marcos identitários em favor da necessária busca pela identificação do comum - justamente através da distinção inerente à pluralidade, conforme a concepção arendtiana.

Segundo a linha de raciocínio de Honorato, esse tipo de movimento da mediação apresenta-se como resposta propositiva a um cenário sociocultural sensivelmente fragmentado, característico das nossas sociedades complexas, onde as bases para o diálogo entre as culturas - e entre as subjetividades manifestas pelos praticantes de tais culturas - mostram-se cada vez mais heterogêneas e reciprocamente ininteligíveis (HONORATO; MORAES, 2016). Logo, caberia à mediação e à arte comprometidas com o interesse público o exercício sistemático de tradução dessas bases, com vistas a produzir vasos comunicantes e, mais ainda, contágios entre elas. O locus para a realização de experiências dessa natureza não poderia deixar de ser, evidentemente, a esfera pública.

Contudo, como detalharemos mais adiante, o conceito tradicional e totalizante de esfera pública - baseado em prerrogativas sociais e epistemológicas que normatizam e restringem o acesso a ela - revela-se pouco útil à premente necessidade de se promover a interação entre diferentes atores socioculturais e de suas respectivas linguagens e agendas. Por esse motivo, ensaiamos aqui outro estatuto para essa plataforma social, compreendendo-a em chave plural e expandida, sob a lógica de inumeráveis esferas públicas parciais e temporárias. Entre outros aspectos, a colaboração apresenta-se como uma dinâmica propícia a tal propósito.

\subsection{A COLABORAÇÃO NO LUGAR DA PARTICIPAÇÃO}

Em seu artigo "Educación en museos y centros de arte como práctica colaborativa”, Landkammer postula a colaboração como a experimentação de diferentes formatos de interação e de proposição distribuída entre agentes institucionais e não institucionais, baseada na lógica da corresponsabilidade pelo que venha a ser o escopo de um projeto. As plataformas de ação, nesses casos, não se restringem ao âmbito artístico, constituindo-se também a partir de práticas de organização social e ativista. 
Baseadas nos modos de fazer do tipo de mediação cultural que nos interessa, experiências dessa natureza tendem a contribuir de modo significativo para a deflagração de agenciamentos coletivos imbuídos da reivindicação de direitos civis de comunidades minoritárias, assim como da tradução e publicização de suas práticas culturais e enunciados políticos. Ao defendermos a pertinência de tal propósito, parece-nos fundamental atentar para formas de articulação e ação que busquem se constituir de maneira descentralizada, ensejando situações em que pessoas, organizações e instituições trabalhem juntas, a partir de pautas desenhadas de maneira horizontal, com margem suficiente para a emergência de questões e iniciativas que não poderiam ser formuladas a partir de uma única instância.

É nessa perspectiva que o conceito de colaboração, aqui comentado a partir das reflexões de Landkammer, apresenta-se como uma importante ferramenta voltada à produção do que entendemos como marcos comuns. Em linhas gerais, ele designa a relação e a atuação em conjunto entre dois ou mais agentes, sejam eles indivíduos, coletivos, organizações ou instituições, aos quais caberia definir as ênfases de determinado projeto a partir da articulação dos interesses, repertórios e agendas dos colaboradores envolvidos. Importa enfatizar que a colaboração difere substancialmente da participação, visto que a segunda "supõe um centro, uma estrutura estabelecida, da qual tomam parte ou com a qual contribuem os que participam” (LANDKAMMER, 2014, p. 25, grifos meus).

Reforçando essa diferença, a também educadora Gabriele Stöger afirma que "a participação se pensa a partir do lado dos donos, que querem compartilhar, sem ceder o direito de disposição sobre o bem completamente” (STÖGER apud LANDKAMMER, 2014, p. 25). Nos contextos institucionais dedicados às artes visuais, a participação tem sido majoritariamente concebida a partir da própria instituição, calcada em suas políticas e ofertas, atreladas principalmente à lógica da democratização dos bens culturais. A colaboração, por sua vez, prevê a produção de um deslocamento estrutural nesse modo de operar, propondo que duas ou mais instâncias sejam as responsáveis diretas por estipular a pauta daquilo que poderá se constituir como um projeto conjunto, institucionalmente respaldado.

Apresentando afinidades com o modus operandi dos movimentos sociais, a maneira colaborativa de conceber a ação coletiva relaciona-se com o diagnóstico de Deutsche, já mencionado aqui, em torno da proliferação de práticas sociopolíticas alavancadas pela perspectiva dos direitos civis. A propósito disso, as ações baseadas nas demandas emergentes dos sujeitos e coletividades desfazem qualquer conotação abstrata do que sejam o direito e a liberdade, visto que se encontram enraizadas na concretude das condições sociais e urgências daqueles que os exigem. Ainda que, segundo Deutsche, tais iniciativas se defrontem com o poder exercido pelos governos e pelas corporações nas democracias liberais, elas procuram se deslocar "dos princípios que têm sustentado os projetos políticos tradicionais da esquerda", vocacionados a "soluções totalizadoras dos problemas sociais". Resistentes à ideia de serem conduzidos por "partidos políticos que se autoproclamam representantes dos interesses essenciais do povo", 
parte significativa dos movimentos sociais se dedica à "construção de identidades políticas dentro da sociedade e pela formação de alianças temporárias com outros grupos", com eles colaborando e praticando o que se tem chamado de micropolítica (DEUTSCHE, 2008, p. 6-7, grifo meu).

Podemos depreender das palavras de Deutsche um paralelo entre os planos político e artístico-institucional. De um lado, percebe-se a descontinuidade produzida pelos movimentos sociais nos discursos de representatividade que caracterizam a forma de atuação dos partidos políticos. De outro, nota-se o deslocamento provocado pelas experiências colaborativas fomentadas por certas vertentes da mediação cultural frente à predominância dos projetos calcados em oportunidades de participação, amplamente ofertados aos públicos nos contextos institucionais de arte.

A diferenciação entre as lógicas colaborativa e participativa favorece a compreensão de um tipo de descentralização testada pela primeira. Operar de modo colaborativo implica a abertura àquilo que não está dado por uma matriz enunciadora e propositora, que geralmente concentra em si as instâncias deliberativas, inclusive no que se refere à definição de pautas e programações, sobretudo quando consideramos a realidade institucional no campo das artes visuais. Logo, exige a disponibilidade ao imprevisível das relações horizontais e suas contingências, a partir das quais se busca chegar a decisões de maneira distribuída, mediante o debate e a confrontação de diferentes subjetividades e perspectivas.

Enquanto o registro participativo promove situações em que os públicos devem tomar parte, agregando-se a núcleos discursivos previamente definidos, a vertente colaborativa propõe que os públicos, entendidos como agentes, tomem posição e cheguem a decisões conjuntamente, instaurando um espaço de intercâmbio até então inexistente, formado temporariamente pela articulação e negociação entre uma gama de intencionalidades. Se a participação inclui os públicos em um lugar discursivo pré-definido, a colaboração lhes possibilita a construção de algo por vir.

Portanto, o registro colaborativo traz consigo o potencial de produção do comum em nível duplo: primeiro, ao favorecer a emergência de interesses e agendas que, cotejadas, podem resultar em novos compromissos a serem defendidos e trabalhados por grupos temporariamente constituídos; e em segundo nível, a depender dos desdobramentos desse trabalho conjunto, quando funciona como ocasião para a produção de marcos comuns junto a outros círculos sociais.

\subsection{UM GUIA PARA A LÓGICA COLABORATIVA}

Uma experiência representativa das práticas colaborativas desenvolvidas no campo da mediação cultural, em interseção com fazeres e vocabulários da arte aplicada, pode ser observada no processo que deu origem ao Guia para permanecer em Zurique ${ }^{7}$. Trata-se de uma publicação elaborada pelos integrantes do Antikul-

7 O material pode ser visto em: <http://www.kultur-vermittlung.ch/zeit-fuer-vermittlung/download/materialpool/MFV0504.pdf>. Acesso em: 30 dez. 2016. 
ti-Atelier ${ }^{8}$, um grupo formado por habitantes da cidade de Zurique - em sua maioria imigrantes - que veio a se constituir a partir de um projeto em rede. Entre os imigrantes envolvidos com o grupo, a maior parte encontrava-se em situação de informalidade quanto ao registro de permanência no país.

A principal motivação do grupo condizia a uma frente ampla comum: a luta pelos direitos de todos aqueles que vivem na Suíça, sem restrição aos segmentos imigrantes. A definição de uma agenda reivindicatória - e as diferentes iniciativas por ela impulsionadas - apontava para um espaço público possível, no sentido de um recorte crítico no panorama social e político do país, sobretudo no que diz respeito à sistemática situação de discriminação e exclusão vivida pelos imigrantes.

Nesse ponto, é importante salientar que na Suíça um dos principais fatores de desigualdade está diretamente associado à dinâmica imigratória. Para exemplificar o racismo arraigado e manifesto por parte significativa dos “cidadãos pátrios”, Landkammer destaca um debate político recentemente pautado no país: "propunha-se que as estatísticas diferenciassem os suíços 'de nascimento' dos suíços 'naturalizados”. Ainda que a proposta não tenha recebido o apoio da maioria da população, ela foi defendida e ventilada por parcelas consideráveis da classe política e da sociedade civil. Esse fato denota que nem o acesso à "cidadania suíça” - algo dificil de obter, diga-se de passagem - seria suficiente para livrar os imigrantes da discriminação e, se considerados aqueles que se encontram em situação informal, do bloqueio mesmo de seus direitos sociais e políticos (LANDKAMMER, 2014, p. 29).

Como forma de se contrapor a uma cultura racista-excludente e enfrentar os obstáculos por ela erigidos, o grupo em questão posteriormente se constituiria como um coletivo, passando a transitar tanto pelo campo da arte como em ambientes autônomos de cunho educacional e ativista. Como integrante do coletivo, Landkammer explica que a expressão Antikulti, presente no nome do grupo, prestava-se a anunciar o compromisso dos seus integrantes com o trabalho de invenção de "uma contracultura", por um lado reagente à xenofobia e à naturalização do quadro de exclusão social e, por outro, produtora de um imaginário cosmopolita de imbricações culturais e de convivência com as diferenças (LANDKAMMER, 2014, p. 29, grifo meu). Ou, para retomar Arendt, de interações sociais a partir daquilo que nos distingue. e abril de 2014 em Zurique. Constituído a partir de um workshop sediado no Museu de Design de Zurique, o grupo desenvolveria uma série de projetos culturais e políticos. Inicialmente vinculado a um projeto institucional em rede, o Antikulti-Atelier posteriormente se definiu como um coletivo independente, trabalhando tanto em ambientes institucionais como em espaços autônomos. Dedicado a práticas colaborativas, o grupo buscaria desafiar, conforme se pode ler em sua apresentação, o sistema racista, classista e sexista produtor de discriminação, desigualdade e exclusão sociais. O blog do coletivo continua no ar em: <http://antikultiatelier.blogspot.com.br>. Acesso em: 30 dez. 2016. 
Landkammer detalha que a constituição do Antikulti-Atelier nasceu de um projeto colaborativo envolvendo organizações de naturezas distintas: o Museu de Design de Zurique, vinculado à Universidade das Artes da mesma cidade, e a Escola Autônoma de Zurique, um programa educacional autogerido e de vocação nômade, instalado temporariamente em diferentes edificios ocupados da cidade. Tal programa, sobretudo seus cursos de língua alemã, era frequentado por alguns dos imigrantes que viriam a integrar o Atelier, após convites circulados durante as aulas. A colaboração entre as organizações e alguns de seus membros e frequentadores foi composta, ainda, por um terceiro organismo: o Instituto de Educação em Arte da Universidade das Artes de Zurique. À época, Landkammer atuava profissionalmente tanto no Instituto, na condição de docente, como no Museu, enquanto educadora (LANDKAMMER, 2014, p. 30).

Cumpre destacar, em acordo com as preocupações da nossa investigação, que a elaboração do Guia para permanecer em Zurique ainda não se encontrava no horizonte do grupo no momento inicial do processo de colaboração nessa ocasião, o grupo tampouco se reconhecia como um coletivo. Na fase inicial do projeto, ainda sob a forma de um workshop, não existia uma proposição concreta a que as pessoas devessem se agregar, ou uma estrutura discursiva da qual passassem a participar. Este é o ponto: a colaboração aqui se processa como ocasião para aproximar, cotejar e articular possíveis intenções que, ao longo do processo, possam ser reconhecidas como agendas comuns. Tais agendas se tornam evidentes, adquirindo corpo, mediante a tomada de posição e mobilização de todos os atores implicados no processo. As discussões e ideias daí surgidas servem de base para a definição do escopo do projeto a ser realizado. Logo, o que se tem é uma inversão do rito participativo, na medida em que, nele, a pauta de uma determinada iniciativa é definida de antemão por um corpo técnico especializado.

O estado de colaboração vivenciado durante o processo que resultou no Guia constituiu uma "dinâmica própria", com autonomia frente ao marco institucional. Além disso, a reunião de atores diversos abriu a oportunidade para que novas posições fossem testadas entre eles, o que permitiu levar em conta não apenas os interesses apresentados de início por cada um, mas "construir juntos novos interesses". Interesses que não se deixam conhecer de antemão, "nem a partir do lugar institucional, nem a partir do lugar da escola autônoma ou do ativismo antirracista” (LANDKAMMER, 2014, p. 31). A própria mediadora se vê afetada pela dinâmica de construção coletiva dos interesses e inciativas do grupo:

Entrei no projeto como educadora do Museu e pesquisadora, com interesses definidos a partir dessa posição. Porém, já não posso falar a partir de tal posição, visto que me tornei integrante de um coletivo cujos interesses eu não apenas compartilho, como também me oferecem a possibilidade de eu desenvolver minhas próprias ideias - por exemplo, sobre o que significa "colaboração”. Por isso, agora devo observar [as coisas] a partir das posições 
que o ateliê Antikulti elaborou acerca do trabalho conjunto, da política e das colaborações com instituições culturais, assim como em relação ao campo da educação em museus. (LANDKAMMER, 2014, p. 31.)

O grupo que daria origem ao coletivo Antikulti-Atelier era formado por dezesseis pessoas 9 . Seu projeto inaugural, justamente o Guia, data de 2010. Sua plataforma inicial de discussão foi a exposição Global Design, em cartaz no Museu de Design. $\mathrm{O}$ foco da mostra recaiu nas relações entre o design e o processo de globalização, em especial em suas incidências nas áreas do comércio, mobilidade, comunicação e controle. A exposição seria usada como ponto de partida para um projeto que, como já dito, ainda não contava com um objeto definido:

As reuniões começaram com um ateliê semanal aberto, com visitas à exposição e introdução aos meios visuais, como a fotografia. O primeiro projeto conjunto do grupo nasceu a partir de conversas sobre as fotografias que todos haviam tirado na cidade. Mostrou-se evidente que entre os temas importantes das conversas estavam as possibilidades de mobilidade ou de comunicação [acessadas por quem se encontrava na condição] de refugiado em Zurique, e como responder ao controle [policial] constante. A partir daí, desenvolvemos a ideia de fazer um livro sobre Zurique, que seguiu em desenvolvimento pelo grupo, resultando em um "guia para permanecer [na cidade]". (LANDKAMMER, 2014, p. 30.)

O Guia seria produzido mediante a reunião de conhecimentos empíricos acumulados pelos integrantes do grupo ao longo de seus diferentes períodos de residência na cidade, acerca dos lugares estratégicos de Zurique ligados aos serviços sociais básicos e, em última instância, à condição cidadã. Entre as seções que integram a publicação, encontram-se referências (endereços, dicas e fotografias ilustrativas) sobre locais onde encontrar asilo, oportunidades educacionais, organizaçôes de luta por direitos, comunicação remota, transporte, equipamentos esportivos, locais de lazer, pontos de alimentação gratuita, centros de compra a baixo custo e, além disso, os locais de controle policial mais acirrado em relação aos imigrantes em situação informal. Isso numa cidade em que, é importante frisar, a obtenção de informações dessa natureza não costuma ser facilitada. $\mathrm{O}$ Guia para permanecer em Zurique passou, portanto, a funcionar como um

9 São elas: Aras Hemn Hassan, Benjamin Jafari, Fabiana Gonzáles, Felipe Polania, Ibrahim Haydari, John Mwangi Njuguna, Karim Khider, Katy Ekator, Marco Weibel, Marguerite Kengmore, Motina, Nareeman Shawkat, Nora Landkammer, Saleban Abdi Askar, Tagharrobi Farzad e Zuher Kara Ahmad. 
compêndio de informações ${ }^{10}$ de interesse e utilidade para o contingente de imigrantes que habitam a cidade, extravasando o núcleo inicial onde foi editado.

No que se refere ao formato da publicação, vale detalhar que, para cada seção do guia, os integrantes do grupo desenharam um pictograma específico, cujo significado aparece descrito em dez idiomas diferentes, justamente aqueles falados por seus autores. Devemos destacar, nesse sentido, que expertises encontradas no Museu de Design, tais como os saberes e repertórios visuais, gráficos e editoriais, foram incorporadas pelo grupo ao produzir um dispositivo útil às necessidades de um segmento social vulnerável e alijado das oportunidades oferecidas pela cidade, dando a ver o valor de uso atribuído a tal conjunto de referências.

Depois de impresso, o guia foi distribuído por seus autores e parceiros em organizações, moradias e pontos de encontro frequentados por imigrantes na cidade. Houve também uma apresentação pública do material no Museu, com o intuito de marcar a posição política do grupo no âmbito institucional e com vistas à obtenção de apoio a uma causa defendida como concernente ao conjunto da sociedade (LANDKAMMER, 2014, p. 31). Logo, além de promover o acesso a informações úteis, o Guia pode ser lido, em sentido mais abrangente, como uma tentativa de produzir um novo marco comum, afirmando-se como um objeto cultural que traduz e condensa em si exigências práticas de pessoas que pleiteiam o reconhecimento de sua condição imigrante e de seus direitos civis, organizando-se e agindo para tal.

No exemplo do Guia e na subsequente formação do coletivo Antikulti-Atelier, nota-se a formação temporária de uma esfera pública ancorada nas problemáticas da imigração e do racismo no contexto suíço. O estado colaborativo instaurado pelas pessoas ligadas, de diferentes modos, ao Museu de Design, à Escola Autônoma e ao Instituto de Educação em Arte da Universidade das Artes de Zurique evidencia o fato de que o processo de trabalho não se restringiu nem à lógica do Museu, nem à da Escola e nem à do Instituto, tampouco ao interesse individual desse ou daquele integrante em particular. O que houve foi a constituição de uma lógica de investigação e construção própria ao grupo, a partir de tomadas de posição alternativas ao marco institucional unívoco ou ao interesse exclusivamente individual. Não se tratou de participar de um projeto formatado a priori e ofertado por alguma das instituições ou por determinado agente. De modo alternativo, foi produzido outro tipo de agenciamento coletivo e colaborativo, que favoreceu a construção de novas relações entre seus atores e ensejou com isso o surgimento de "novos peia, a cidade de Zurique e seus serviços são amplamente esquadrinhados por inumeráveis guias especializados, porém, destinados à população local com potencial de consumo e aos turistas. 
interesses" "11 (LANDKAMMER, 2014, p. 31). Ou seja, interesses, formas de organização e elaborações discursivas que não podiam ser previamente definidos, à revelia das especificidades do grupo. Tais expedientes não seriam concebíveis e praticáveis desde um lugar único, de uma estrutura pré-definida, seja o museu, a escola, o instituto, ou mesmo o ativismo antirracista, e sim a partir da convergência e da negociação entre as intenções dos agentes que falam e se posicionam política e socialmente a partir desses círculos, ao mesmo tempo que os extrapolam.

Entendemos que, nesse caso, os aspectos relativos à vida cotidiana dos imigrantes envolvidos com a produção do Guia, assim como os recursos e repertórios proporcionados pelas instituições envolvidas, funcionaram como elementos favoráveis à deflagração de uma experiência colaborativa e comunicativa, corporificada em um objeto cultural de uso comum, em resposta ao conjunto de urgências vivenciadas por seus membros, seja de maneira direta pelos imigrantes, seja pela cumplicidade dos agentes institucionais que contribuíram para a realização do projeto.

Por outro lado, não podemos deixar de mencionar as limitações institucionais que o projeto tensionou e, ao tensionar, revelou no modo como o Museu compreende seu programa de mediação - que devia se desenvolver, conforme sua política, em função da agenda de exposições, moldando-se de acordo com os temas e períodos de cada mostra. Essa é, diga-se, uma constante na maior parte das instituições de arte, que acabam por enquadrar o trabalho em mediação com públicos no registro da prestação de serviços (por meio de visitas guiadas, oficinas, materiais didáticos, seminários etc.) atrelados àquilo que se encontra em exibição no momento. Porém, essa chave de entendimento mostra-se incompatível com um processo colaborativo como o do Guia, na medida em que este se baseia numa "lógica ativista de construção permanente de uma posição, de um espaço conjunto", cuja duração e formatos não podem ser condicionados a um cronograma e a uma mídia - a exposição - que operam com outros critérios e outra temporalidade ${ }^{12}$ (LANDKAMMER, 2014, p. 32).

Isso torna patente a incompatibilidade da estrutura institucional convencional com propostas que busquem deflagrar formações e processos colaborativos,

11 Durante a elaboração do presente capítulo, tive a oportunidade de me encontrar pessoalmente com Nora Landkammer, por ocasião de um encontro da rede internacional de mediadores Another Roadmap, no contexto da $32^{a}$ Bienal de São Paulo. Nora me relatou que alguns dos imigrantes ex-integrantes do Antikulti-Atelier haviam conseguido ingressar como alunos regulares do curso de graduação em artes visuais da Universidade das Artes de Zurique.

12 Como conta Landkammer, a direção do Museu de Design de Zurique entendia o trabalho de desenvolvimento do Guia como algo diretamente atrelado à exposição Global Design. Tanto é que, quando se encerrou a exposição e a publicação foi concluída, automaticamente o financiamento foi interrompido. Havia a possibilidade de que ele fosse renovado, mas com a condição de que o grupo que havia se constituído se dispusesse a desenvolver novos projetos relacionados às exposições subsequentes, o que se mostrou pouco adequado aos anseios e aos compromissos políticos do grupo, que optou então por se organizar como um coletivo independente, abrindo mão dos subsídios oferecidos de modo condicionado pelo museu. 
predispostos a lidar com questões emergentes, em que os públicos não apenas participem daquilo que as instituições e seu corpo de especialistas têm a oferecer, mas possam trabalhar "a partir de suas próprias ideias, não necessariamente coerentes com o programa de exposições”. Resta pontuar, portanto, que projetos dessa natureza acabam por problematizar a própria efetividade da plataforma de convivência e aprendizagem propiciada pelos museus, tendo em vista as normatizações e restrições que caracterizam suas programações. Destoando desse modelo, o trabalho experimentado pelo Antikulti-Atelier dá a ver "que para que uma colaboração possa ser duradora [e efetiva], a instituição cultural não pode continuar a ser como é” (LANDKAMMER, 2014, p. 33).

Experiências como essa sugerem, em última análise, que a própria relevância social, política e cultural das instituições depende da disposição de seus agentes em alterar sua estrutura e modo de funcionamento, permitindo que se desenvolvam colaborações com outros campos de atividade e atores, alargando e ressignificando permanentemente seu escopo e finalidade. Interessa-nos olhar para casos como o do Antikulti-Atelier e do seu Guia para permanecer em Zurique como exemplares das tentativas de imaginar, estimular e produzir agenciamentos coletivos em novas bases, convocando as instituições artísticas a se abrirem para outro tipo de interação com seus públicos. Tal perspectiva relaciona-se com a aposta de que essas instituições possam funcionar como caixas de ressonância de aspirações e agendas emergentes, enquanto lugares propícios à instauração de esferas públicas que, ao beneficiar-se do aparato material e do capital simbólico institucional, possam repercutir socialmente e pleitear legitimidade e reconhecimento público.

\subsection{O CONCEITO DE ESFERA PÚBLICA}

Como se pode notar no exemplo acima, as práticas colaborativas fomentam a circulação de imaginários políticos e, desse modo, instauram esferas públicas temporárias e parciais formadas por agentes que se propõem a trabalhar a partir de questões que extrapolam o domínio da arte e o escopo convencional de atuação das instituições artísticas. Caberia, agora, refletirmos mais detidamente sobre a origem burguesa do conceito de esfera pública, observando suas especificidades e também algumas críticas a ele direcionadas. Esse exercício servirá para pensarmos os limites, as contradições e as possibilidades de uso dessa noção na contemporaneidade.

Conforme alerta o pesquisador Luiz Repa, devemos reforçar que a noção de esfera pública não se confunde com uma representação de natureza espacial, ainda que, segundo ele, "as discussões públicas precisem geralmente de espaços” para acontecer. Nessa mesma direção, Deutsche pontua que o termo se presta, sobretudo, a "designar um âmbito de interação discursiva acerca dos assuntos políticos" (DEUTSCHE, 2008, p. 22). Logo, a esfera pública não deve ser confundida com o ambiente da rua ou dos edifícios públicos, por exemplo. Tampouco ela teria a ver com a seara do poder público e seu aparato administrativo. Ao contrário, 
essa esfera surge na esteira das revoluções burguesas precisamente em oposição ao poder do Estado, visando consolidar um "Estado de direito que assegurasse, por lei e sanções, a circulação de mercadorias e o trabalho formalmente livre, sem interferências estatais na dinâmica do mercado”. Ela demarca, portanto, uma clara divisão entre os domínios privado e político-estatal, criando entre eles uma terceira instância. Daí a sua vocação liberal (REPA, 2005).

Reunidas em Mudança estrutural da esfera pública, as análises de Habermas acerca da esfera pública burguesa nos colocam a par de que ela representa uma tipologia histórico-social vigente, sobretudo, entre os séculos XVIII e XIX, principalmente em países como Inglaterra, França e Alemanha. É o período em que ganha força a ideia de "opinião pública”, diretamente ligada a sociedades economicamente organizadas de modo privado - onde civis passam a desenvolver seus próprios negócios e a constituir seus patrimônios, concorrendo entre si no âmbito do mercado. Segundo o autor, "dispor da propriedade privada no processo produtivo representava o fundamento de uma autonomia privada”. Essa lógica lastreou, naquele período, a autonomização da sociedade civil em relação ao Estado e à Igreja, de tal modo que os dois últimos deixam de gozar de exclusividade no trato dos assuntos públicos, compreendidos como temas de "interesse universal” (HABERMAS, 2014, p. 53, 73). Nesse sentido, Deutsche comenta que a esfera pública propiciou um "espaço discursivo" onde as pessoas pudessem se colocar para além da sua privacidade e, ao fazê-lo, conseguissem transpor seus interesses individuais, a fim de "comprometer-se com assuntos de interesse público”, sempre através de um tipo de "discussão política racional e crítica” (DEUTSCHE, 2008, p. 22).

Enquanto arena de debate, a esfera pública se constituiria exclusivamente pelo "público leitor", formado por segmentos da sociedade notadamente instruídos, participantes de uma rede crescente de comunicação pública impulsionada pela significativa ampliação da produção e circulação de livros, revistas e jornais. A esfera pública burguesa se consolidou, portanto, no bojo de uma recém-surgida "cultura literária”, que viria a caracterizá-la como uma instância da vida social "definida literariamente por um público de pessoas privadas que discutem mediante razões”. De corte iluminista e liberal, ela se estruturaria com base no pensamento crítico-racional, tendo como suas principais "instituições” os cafés, salões, sociedades de leitura e periódicos (HABERMAS, 2014, p. 91, 141). Tais instituições serviram de plataforma para o desenvolvimento de uma cultura ilustrada, segundo Deutsche alinhada aos preceitos do filósofo Immanuel Kant em torno do "uso da razão no exercício público da crítica” (DEUTSCHE, 2008, p. 22).

Ainda de acordo com Habermas, o cunho literário da esfera pública volta-se, nos seus primórdios, à crítica das linguagens da arte. Mas, com o crescimento da imprensa opinativa e a correlata demanda por liberdade de expressão, ela logo se amplia e passa a adquirir o estatuto de "uma esfera pública politicamente ativa", incorporando às suas pautas temas da ciência, da filosofia, da moral, do direito e da política (HABERMAS, 2014, p. 64). Como detalha Repa, os pressupostos norteadores dessa esfera política 
de debate primavam, em tese, pela "igualdade, liberdade, publicidade e inclusão universais", ainda que essas bandeiras exigissem daqueles que aspiravam participar de suas instituições uma série de condições e atributos paradoxalmente excludentes (REPA, 2005).

Gozando de privilégios sociais e econômicos, os habitués da esfera pública burguesa dedicam-se a discutir assuntos que dizem respeito ao conjunto da sociedade, mediante abordagens e discursos universalistas baseados na argumentação crítico-racional, tendo por horizonte "a transformação da ordem de dominação" tradicionalmente exercida pelo Estado - e também pela Igreja (REPA, 2005). Cumpre pontuar, por outro lado, que, embora a classe burguesa procurasse controlar as ações do Estado, ela o fazia sem a intenção de reclamar para si a administração estatal, haja vista que o seu exercício crítico baseava-se numa rigorosa separação do poder público.

Mas, em que pese a defesa de uma perspectiva crítica objetiva e universalista, transparece na esfera pública burguesa, conforme ressalva Repa, uma lógica autorreferente, ligada ao fato de que seus parâmetros de racionalização política e social provêm - como não poderia deixar de ser - da própria ideologia burguesa, com todos os valores e vieses que lhe subjazem. De acordo com o pesquisador, isso daria a ver "o descompasso entre as ideias universalistas advogadas e a realidade da sociedade de classes" resultante das mesmas revoluções burguesas que possibilitaram o surgimento da esfera pública (REPA, 2005).

Nesse sentido, como a análise de Habermas nos deixa a par, estão excluídos da esfera pública burguesa as mulheres (ainda que segmentos femininos integrassem o público leitor), os trabalhadores e os camponeses, ou seja, a plebe em geral, justamente as "figuras sociais dependentes". Participam dela ativamente, em contrapartida, homens brancos letrados que, enquanto proprietários privados, gozam de "independência social” e, portanto, de autonomia e livre trânsito nas instituições da esfera pública liberal. Hegemônica, tal esfera ofusca, por exemplo, a variante representada pela "esfera pública plebeia", sistematicamente reprimida e invisibilizada no processo histórico (HABERMAS, 2014, p. 91).

Circunscrita pelos fatores citados, a opinião pública incorpora e vocaliza o caráter normativo e totalizante da esfera pública burguesa. Como já dito, ela se afirma como uma instância politicamente ativa, dedicada a criticar e limitar o poder público estatal. Ou seja, opera como um meio para a "possível racionalização do poder em geral”, mediante a qual as questões políticas poderiam ser tratadas, ao menos em tese, de modo estritamente analítico, por meio de um tipo de "julgamento imparcial" orientado para a verdade em relação àquilo que corresponderia ao "interesse universal" - ainda que pautado e abordado por um segmento social privilegiado e restrito (HABERMAS, 2014, p. 64, 73). Daí se depreende as supostas representatividade, objetividade e neutralidade no uso da razão crítica, com vistas à generalização - no sentido de tornar comum a todos - daquilo que resulta do seu exercício.

Entretanto, de acordo com a leitura feita por Repa da análise habermasiana, a esfera pública concebida nesses termos sofreu uma "mudança estrutural” - ou 
mesmo um "declínio", na visão de Deutsche - a partir das últimas décadas do século XIX. Entre outros motivos, ela decorreu das "lutas por direitos de participação democrática e por direitos sociais” das camadas alijadas da esfera pública hegemônica, processo que encontraria respaldo justamente nas instituições do Estado, por meio do "Estado de direito democrático e social", posteriormente desdobrado no Estado de bem-estar social. A isso se conjugaria o exponencial crescimento dos meios de comunicação de massa, que expandem (e banalizam) a rede de difusão da informação numa escala sem precedentes na história (REPA, 2005).

Dessa forma, a esfera pública de matriz liberal tem sua base de sustentação abalada, pois a "separação entre Estado e sociedade, entre público e privado" vai deixando de vigorar na mesma medida em que, de um lado, "estatiza-se a sociedade" e, de outro, "socializa-se o Estado". O que ocorre no segundo caso é a influência de grupos econômicos privados no âmbito do Estado, com vistas à conquista de beneficios junto aos governos. No primeiro caso se dá uma intervenção de ordem estatal no domínio da sociedade, com o objetivo de "garantir o crescimento econômico [dos Estados-nação]" e, também, de "conquistar a lealdade [política] das massas através de compensações sociais” traduzidas nos serviços públicos (nas áreas da saúde, assistência, habitação, transporte, educação, cultura etc.) e, portanto, na proteção estatal destinada à população (REPA, 2005).

Isso desemboca, segundo a perspectiva teórica de Habermas, na ampliação do raio de abrangência da esfera pública e na concomitante perda de sua efetividade crítica e analítica. Tal fenômeno se explica pelo fato de que a sociedade já não poderia mais desfrutar da autonomia e do distanciamento crítico frente ao Estado, pois ambos, sociedade e Estado, passam a nutrir uma relação umbilical de interdependência, a ponto de não poderem empreender suas ações sem que um seja diretamente influenciado pelo outro.

É a partir dessa "mudança estrutural" que o sociólogo alemão constata, de acordo com a explicação de Repa, a transição "de um público burguês restrito que pensa a cultura” para "um público de massa amplo que consome cultura", mais precisamente os "produtos da indústria cultural" (grifos meus). Essa massa não estaria apta a operar com os dispositivos da "publicidade crítica” própria à esfera pública burguesa. Teoricamente incapaz de lidar com os instrumentos da razão crítica e, portanto, de proceder pela via argumentativa, ela se encontra submetida a outro tipo de publicidade, de corte meramente propagandístico e massificante, o que, em tese, a torna um mero "objeto de manipulação tanto dos meios de comunicação de massa como de políticas partidárias e administrativas" (REPA, 2005).

As ressalvas que nos vemos impelidos a fazer ao conceito originário de esfera pública se dão, portanto, em dois níveis: o primeiro refere-se à exclusividade imputada aos expedientes da razão iluminista na abordagem de temas de interesse público, cujo manejo restringe-se a grupos que gozam de prerrogativas sociais, econômicas, de gênero e de formação intelectual. Em relação a tais aspectos, Deutsche chama atenção para a "tendência 
homogeneizadora” da esfera pública burguesa - pouco afeita às diferenças e aos conflitos -, bem como para um tipo de crença na razão que abdica da autocrítica de suas convicções e dispositivos (DEUTSCHE, 2008, p. 23). Atrelado ao primeiro, o segundo nível diz respeito à pressuposição de que a dimensão crítica das iniciativas de grupos sociais frente ao exercício do poder só se tornaria factível na chave liberal, por sujeitos autônomos, "socialmente independentes", capazes de refletir com distanciamento sobre o bem comum, de modo pretensamente isento, desinteressado e racional. Isso significa afirmar que àqueles que não estivessem habilitados a incluir-se nesse registro normativo restaria apenas a condição de passividade diante das injunções dos meios de massa e do aparato estatal.

Contudo, o próprio Habermas, posteriormente, se veria obrigado a relativizar seu diagnóstico - calcado numa perspectiva, a nosso ver, ortodoxa - em relação a grupos sociais que, ao se organizarem politicamente em bases estranhas às da esfera pública burguesa, supostamente se limitariam à condição de massa de manobra das elites econômicas e políticas. Como pontua Repa, as experiências políticas desencadeadas por movimentos sociais minoritários "desmentiram uma total despolitização" dessa nova esfera pública, estruturalmente modificada e povoada por segmentos não burgueses:

\begin{abstract}
A par dos fenômenos de integração relativa do proletariado ao sistema capitalista, constatou-se uma série de movimentos sociais que escaparam até certo ponto à capacidade de controle dos meios de comunicação de massa: o movimento negro por direitos civis nos EUA, o feminista, que inclusive questiona formas patriarcais da esfera pública, $\mathrm{o}$ dos estudantes, que buscou democratizar tanto o sistema educacional ampliado como as estruturas institucionais gerais da cultura e da política, o ecológico que lembra insistentemente os limites naturais da industrialização, o de grupos sexualmente discriminados que reclamam novas formas de identidade etc. (REPA, 2005, grifo meu.)
\end{abstract}

Nota-se que esses movimentos se encontram, cada um deles, ancorados em problemáticas sociopolíticas específicas. Eles teriam condições de deflagrar diferentes espaços discursivos de interesse público, baseados em agendas, linguagens e experiências distintas, fazendo repercutir as variadas postulações do que venha a ser o bem comum. Dessa forma, a ideia hegemônica de uma esfera pública liberal e generalizante, representativa do todo social, é forçada a uma revisão drástica, na medida em que a sociedade civil se pluraliza e se organiza em lutas capazes de produzir contrapontos localizados aos desígnios do mercado e do Estado. É da multifacetada sociedade civil que, segundo Repa, "se originam esferas públicas diversas" (REPA, 2005, grifo meu).

Logo, ao atentar para as mobilizações políticas instauradas pelos diversos segmentos da sociedade civil, somos levados a repensar a própria estrutura 
da esfera pública, compreendendo-a, em consonância com as ideias de Sheikh, como uma plataforma fundamentalmente "fragmentada", constituída por "um número de espaços e/ou formações que às vezes se conectam, às vezes se isolam, e que possuem relações contraditórias e conflituosas umas com as outras" (SHEIKH, 2008, p. 129-130).

No prefácio à edição de 1990 de Mudança estrutural da esfera pública, quando Habermas revisita o seu estudo originalmente publicado no início dos anos 1960, o autor reconhece esse processo de pluralização e fragmentação da esfera pública, declarando que caberia à teoria contemporânea da democracia constatar e se haver com o fato de que "o insuperado pluralismo de interesses concorrentes torna duvidoso que dele possa surgir algum tipo de interesse universal" (HABERMAS, 2014, p. 65, grifo meu). Logo, se o modelo universalista da esfera pública burguesa nos parece inadequado ao enfrentamento das complexidades que caracterizam as sociedades contemporâneas, tampouco a defesa do pluralismo per se apresenta-se como opção suficiente e capaz de enfrentar com os desafios em jogo.

Entre tais desafios, procuramos nos concentrar naquele que se refere à produção de novos "marcos comuns", cujo caráter difere sensivelmente do estatuto categórico dos "interesses universais", uma vez que nos encontramos num ambiente social multifacetado e altamente complexo, esquivo a consensos absolutos e totalizantes. Com outra vocação, tais marcos comuns condizem a balizas voltadas não apenas a condensar os anseios e agendas de grupos emergentes, como também destinadas a torná-los legíveis e reconhecíveis para/entre os diferentes círculos sociais - sem que se possa antecipar e garantir o reconhecimento e a adesão dos variados círculos às causas em pauta. Uma vez mais, estamos falando de traduções culturais. É em relação a essa frente que, a nosso ver, a mediação cultural e as práticas artísticas "no interesse público", assim como a articulação entre elas, assumem hoje um importante papel em termos sociais, culturais e políticos.

Reforçamos que tal preocupação busca responder a um ambiente social onde os parâmetros para o diálogo mostram-se profusamente heterogêneos e, e em muitos casos, mutuamente ininteligíveis. Se, por um lado, o conceito habermasiano de esfera pública (de perfil excludente) não pode dar conta das complexidades da cultura pública contemporânea, por outro, nos vemos diante da necessidade de produzir permanentemente mediações e traduções entre os vocabulários de grupos sociais que se distinguem entre si, conforme a concepção de Arendt. Esse esforço se justifica pela necessidade de não deixarmos que a pluralidade se limite, de acordo com Honorato, à "coexistência indiferente das diferenças", participando, em lugar disso, da construção de um "comum dissensual” (HONORATO; MORAES, 2016). 


\subsection{O CARÁTER TARDIO DA ESFERA PÚBLICA \\ NA AMÉRICA LATINA}

O compromisso com o exercício da mediação e da tradução culturais, sem dúvida, nos cobra um tipo de compreensão contextualizada, que leve em conta os transcursos históricos relativos à implementação e ao desenvolvimento da esfera pública nas diferentes partes do mundo ocidental. Nesse aspecto, o sociólogo Sérgio Costa esclarece que o início e a vigência da esfera pública na América Latina se dão temporal e institucionalmente de maneira distinta da dos países europeus mencionados acima.

Para comentar esse descompasso histórico, ele se vale dos trabalhos de autores como Canclini, Martín-Barbero e José Brunner acerca de "transformações culturais" provocadas pelos processos tardios de urbanização, modernização e estruturação (parcial) da esfera pública no continente latino-americano. Ainda que as investigações dos referidos autores em torno dessas problemáticas apresentem entre si abordagens diversas, elas sugerem como aspecto comum a centralidade dos meios de comunicação, principalmente a televisão, no processo de "constituição dos perfis contemporâneos das sociedades latino-americanas” (COSTA, 2002, p. 20).

De acordo com a lógica de argumentação dos autores, a transição latino-americana para o ciclo da modernidade ressente-se do fato de que os estágios históricos hipoteticamente necessários à ocorrência dessa transição nem sequer chegaram a se dar nas ex-colônias europeias. Conforme elenca Costa, tais estágios apresentam-se condensados na "reforma religiosa, [n]a ideologia liberal-universalista, [n]as revoluções burguesas etc.”. Assim, o processo de modernização nesses países teria se dado de modo retardatário e idiossincrático, mediante hibridizações que conjugam (e hierarquizam) "reminiscências de formas culturais tradicionais" e um abrupto movimento de "urbanização e de fragmentação de identidades preexistentes". Esse empuxo modernizante teria como base de sustentação os "valores do individualismo e do 'desejo de ser moderno' dos públicos educados", sendo os meios de comunicação de massa os principais responsáveis por infundir as premissas modernas em populações tidas menos como comunidades de cidadãos de direitos do que como massas de "receptores-consumidores" (COSTA, 2002, p. 20).

Segundo Costa, o que caracterizaria as sociedades latino-americanas no tocante ao papel que nelas desempenha a esfera pública é a ausência histórica da etapa que, no contexto europeu, pavimentou o surgimento e o desenvolvimento de um "espaço comunicativo" de cunho liberal e racionalizante, supostamente autônomo e apto ao exercício crítico. Portanto, desde os primórdios do processo de urbanização na América Latina, quem ocupa o lugar das instituições da esfera pública burguesa são os meios de comunicação de massa. São eles que assumem a posição mediadora no espaço público discursivo, tornando-se responsáveis, de acordo com as palavras de Canclini, pela "nova diagramação de espaços e intercâmbios urbanos" (CANCLINI apud COSTA, 2002, p. 21).

O vácuo resultante da ausência das instituições e dispositivos da esfera pública crítico-racional teria dado origem a um "espaço público assenhoreado pela 
mídia”. Daí não se poderia esperar, segundo essa linha de raciocínio, uma perspectiva crítica baseada em "argumentos racionais". Teoricamente, isso se deve à proeminência de uma forma de fazer comunicação que prima por um tipo de abordagem refratário às "verdades matizadas" e aos "excursos argumentativos" - característicos dos exercícios analíticos e comunicativos baseados em ponderações pretensamente distanciadas e isentas. Em lugar disso, as mídias de massa operariam mediante a veiculação de "enunciados bombásticos”, pouco (ou nada) permeáveis às relativizações, às suspeições, às contra-argumentações e, em última instância, ao debate de ideias. Para Costa, essa vocação dos grandes meios acaba por provocar uma espécie de rarefação dos conteúdos políticos no âmbito discursivo da esfera pública (COSTA, 2002, p. 21).

É nesse cenário, onde a comunicação pública se encontra aparentemente monopolizada, instrumentalizada e obstruída por poderosos grupos corporativos, que a condição cidadã e sua exigência por direitos são prematuramente desarticuladas em favor da posição predominante do consumidor de produtos e serviços. Canclini afirmará, com um otimismo criticado por Costa, que na falta dos espaços públicos discursivos e das garantias cidadãs o próprio consumidor acabaria arrogando a si a tarefa de "instituir direitos”. Para isso, segundo o antropólogo, ele "organiza-se, protesta, boicota, fazendo valer seus interesses" (CANCLINI apud COSTA, 2002, p, 21). Cético quanto à efetividade de tal manobra, Costa contrapõe que a intensificação do "nível de exigência dos consumidores" corresponderia apenas a um sucedâneo do movimento de ampliação e capilarização crescentes das relações comerciais no capitalismo avançado. De acordo com o sociólogo, a hegemonia econômica e a onipresença do consumo têm como sua contraparte um rol de "efeitos sociais devastadores" (COSTA, 2002, p. 21), que vão desde a exacerbação do individualismo, da competitividade e da meritocracia até o aprofundamento da precarização do trabalho, da desigualdade e da vulnerabilidade.

Destarte, não seria o "cidadão econômico virtuoso" a figura social mais habilitada a instaurar ações e formas de comunicação "revitalizadoras da política e do espaço público" (grifo do autor). Longe disso, essa figura se encontra enredada nas tramas do que Costa chama de "sistema de necessidades", um conjunto de condicionantes que limitariam a sua compreensão da realidade na medida em que entronizam "interesses individuais e conflitantes”. Ao influenciar as populações nessa direção, tal sistema "minaria os laços de solidariedade e cooperação social", tornando seus membros pouco sensíveis às premências coletivas e, em grande medida, alheios a âmbitos sociais diversos daquele onde se desenrola a experiência atomizada proporcionada pelo consumo, calcada em critérios de satisfação pessoal e imediata (COSTA, 2002, p. 22).

Costa defende que as "práticas capazes de restaurar as relações solidárias" se processam alhures, em esferas da vida social alheias à dos circuitos comerciais. Em algumas delas pode-se notar, segundo o autor, a existência de "um leque diversificado de estruturas comunicativas e uma gama correspondente de processos sociais". Estes representam contrapontos ao "espaço público transformado em mercado", haja vista que 
se encontram ancorados no cotidiano e nas premências sociopolíticas dos diferentes atores e comunidades (COSTA, 2002, p. 22). É ao surgimento e à vigência dessas outras esferas de intercâmbio comunicativo que nos ocupamos aqui, acrescentando a preocupação com processos de tradução e mediação entre os diversos círculos sociais e, portanto, entre as problemáticas com as quais estão comprometidas as suas diferentes comunidades.

Vejamos agora, ainda que de modo panorâmico, como se constituem a esfera pública e o seu respectivo debate no Brasil. De acordo com Costa, o tema do espaço público tem sido historicamente tratado no país "a partir de sua inexistência”. Os textos clássicos da sociologia brasileira, com destaque para a obra de Sérgio Buarque de Holanda, postulam, em linhas gerais, que a esfera pública brasileira sempre esteve condicionada pelas injunções provindas da esfera privada, de tal forma que "a lógica das relações pessoais e patrimonialistas seria 'contrabandeada' para o plano público” (COSTA, 2002, p. 29). Disso resultaria uma espécie de colonização do espaço público e, por conseguinte, a obliteração da possibilidade de ele se tornar um ambiente propício à discussão e à construção de compromissos e pactos comuns, concernentes aos diferentes círculos da sociedade. Trata-se da famigerada e tendenciosa confusão entre interesse público e privado.

Assim como as investigações sociológicas, também as pesquisas desenvolvidas no Brasil na área da comunicação social têm compreendido o tipo de esfera pública vigente por aqui como um "mercado de opiniões", cujo controle estaria nas mãos dos "atores mais poderosos da sociedade". Autores como Afonso de Albuquerque, por exemplo, entendem que a apropriação da esfera pública por grupos de poder acabaria por transfigurá-la em um simples "simulacro", onde o processo político seria rebaixado ao "comércio de imagens vazias de conteúdo", segundo as palavras de Costa (2002, p. 30).

Teórico de referência no campo da comunicação social, Muniz Sodré encara essa questão de maneira mais matizada. Conforme ressalva o autor, os meios de comunicação de massa e o tipo de abordagem que desenvolvem junto aos seus públicos não se convertem exatamente em "mecânicas caixas de ressonância das empresas e do Estado", pois suas plataformas abririam margem para negociações simbólicas relacionadas às formas de recepção, ressignificação e uso das mensagens. Ainda assim, como sugere a leitura de Costa, Sodré mantém-se vinculado à vertente teórica que concebe o espaço público brasileiro como uma "encenação política” unilateral. Tal percepção aparece em sua afirmação em torno de uma esfera pública que se forja (no duplo sentido do termo) "seja pela criação de uma realidade social despolitizada, seja pela estimulação de técnicas plebiscitárias de sondagem de opinião pública ou então pela simples conversão das campanhas eleitorais em táticas mercadológicas" (SODRÉ apud COSTA, 2002, p. 30). Tais expedientes terminam por impedir, ao menos em tese, a constituição de uma esfera efetivamente pública, na qual a diversidade dos atores sociais possa de fato pautar questões e, assim, exercer influência no debate político. 
Essa simulação de esfera pública é respaldada, em geral, pela concentração de renda e propriedade e, em particular, pelos "mecanismos historicamente prevalecentes na distribuição das licenças de operação”, que fazem dos meios de comunicação "um instrumento de reprodução das relações de poder dadas e da difusão da 'ideologia dominante”. Costa se refere a tal visão da mídia como "empiricista”, dando a entender que ela deixa de levar em conta as possíveis descontinuidades no circuito onde tradicionalmente se exerce o poder corporativo. Totalizante, essa perspectiva tenderia a achatar uma situação que se mostra mais complexa, postulando que "a mídia brasileira e o espaço público de forma geral conformam mesmo um campo no qual formas tradicionais-populistas de conquista de lealdade política se misturam a novas estratégias de conquista de apoio das massas" (COSTA, 2002, p. 31).

Costa contra-argumenta essa tese dizendo que, embora ela ainda seja influente entre os analistas das áreas da sociologia e da comunicação, tem-se reconhecido, sobretudo a partir do cenário sociopolítico inaugurado nos anos 1980, o surgimento do "processo de construção de um espaço público no Brasil", que passou a vigorar no período da redemocratização política do país, pós-ditadura civil-militar (1964-1985). Desse momento em diante, começa a parecer plausível a afirmação de que o espaço público brasileiro não se limita a um "mero palco de encenação política”. Complexificando esse estatuto histórico, a esfera pública no Brasil teria assumido um perfil ambíguo, conjugando, de um lado, a reprodução das relações de poder e, de outro, o surgimento de "inovações sociais" capazes de exercer influência no debate político. Tais inovações estariam diretamente relacionadas à "emergência de novos atores sociais" imbuídos do questionamento e da redistribuição de pesos entre os interesses público e privado, no sentido de "ampliar as fronteiras da política" (COSTA, 2002, p. 32, grifo meu).

A constatação de tal ambiguidade serve de base à relativização que Costa faz das análises predominantes, que circunscrevem a esfera pública brasileira à condição de mero "mercado de opiniões". Segundo ele, as significativas transformações ensejadas pelo processo de redemocratização no país não nos permitem reiterar uma visão monolítica da esfera pública, enquanto espaço discursivo de perpetuação irrestrita do poder. Para ele, as duas últimas décadas do século XX teriam testemunhado um movimento inverso, correspondente ao "processo não de obliteração mas de construção efetiva de um espaço público no Brasil”. Ele credita isso à "relativa porosidade da mídia" no que diz respeito à incorporação de "temas trazidos pelos atores da sociedade civil” (COSTA, 2002, p. 34).

A ambiguidade destacada pelo sociólogo se manifestaria, portanto, na convivência entre a "configuração oligopólica das relações de propriedade em todos

13 Há, aqui, um paralelo com a nossa proposição acerca da necessidade de reconhecimento e respaldo pelas instituições às demandas de comunidades politicamente emergentes. Enquanto Costa se refere especificamente aos órgãos de mídia, reportamo-nos principalmente às instituições artísticas. 
os campos da mídia brasileira" e a proliferação de iniciativas midiáticas comprometidas com "um estilo investigativo de jornalismo", que contribuiria para a "preservação do espaço de afirmação da autonomia dos que produzem o material divulgado (jornalistas, produtores culturais etc.)". Para Costa, tais características fazem dos meios de comunicação, contrariando as análises por ele aludidas, um dispositivo crucial para a “construção do espaço público no país” (COSTA, 2002, p. 34).

A mola propulsora da reorientação das pautas midiáticas e, por conseguinte, do revigoramento do espaço público discursivo no Brasil proviria, de acordo com a perspectiva de Costa, dos "movimentos sociais e associações voluntárias [da sociedade civil]”. Seriam eles os responsáveis pela "introdução de novos temas e questões na agenda política”, os quais concorreriam para a ampliação e diversificação do escopo de problemáticas repercutidas e enfrentadas no espaço público nacional. Tal escopo envolve, por exemplo, abordagens em torno da discriminação racial, da condição da mulher, do aborto, da homossexualidade, da transexualidade, do acesso à terra e à moradia, da situação indígena etc. (COSTA, 2002, p. 34).

Nessa direção, Costa chama atenção para a natureza distinta de tais atores e de suas reivindicações quando cotejados com o perfil e a operatividade dos grupos corporativos de poder. Isso porque, enquanto esses grupos "defendem interesses particulares" e comumente dissimulados, arvorando-se no controle de que gozam dos meios de comunicação, os movimentos sociais e associações civis reclamam influência política com base na publicização de suas "bandeiras" e apostam num tipo de "respaldo social” fundado no reconhecimento da coerência, da justiça, da urgência e do valor comum de suas demandas (COSTA, 2002, p. 35).

Assim, o espaço público nacional já não se resumiria à condição de "mercado de interesses em disputa” - ainda que essa característica permaneça vigente -, deslocando-se de uma configuração histórica de tendência unificadora. Nesse movimento de pluralização, ele passaria a funcionar como "arena que também medeia os processos de articulação de consensos", processando, em termos discursivos, a redisposição parcial e dinâmica dos valores e agendas que orientam a vida social (COSTA, 2002, p. 35). É nesse terreno tornado poroso e, portanto, permeável às demandas dos diferentes grupos sociais que podemos conceber a esfera pública em chave plural.

Ao mesmo tempo, não devemos perder de vista que a reconfiguração da esfera pública - seja na América Latina seja Europa, e guardadas as diferenças entre elas - deve-se em certa medida à emergência de novos atores e enunciados, caracterizados por posições plurais e, com frequência, antagônicas à cultura dominante e às convenções por ela naturalizadas. Daí que a dimensão dissensual apresente-se como condição fundamental para a ressignificação e o revigoramento do espaço público.

Retomando os aspectos normativos da esfera pública burguesa, podemos observar a seguir um exemplo singular dessa lógica disruptiva. A iniciativa em tela, levada a termo por um grupo alijado da discussão pública, mani- 
festa-se já nos primórdios do desenvolvimento da esfera pública liberal na Europa, tendo como alvo uma de suas principais instituições: o jornal impresso.

\subsection{INSURGÊNCIA DOS CONTRAPÚBLICOS}

No exemplo em questão, interessa-nos observar como se dá a emergência da disposição dissensual. Mobilizada por um grupo social específico, tal disposição produz ruídos sintomáticos num órgão representativo do publicismo crítico-liberal. Manifestações como a que narraremos a seguir irrompem no sentido de forçar não apenas o esgarçamento e a pluralização da esfera pública, visto que também subvertem seus preceitos normativos, calcados no pensamento crítico-racional. Esse aspecto pode ser observado na análise que Warner faz do periódico The Spectator, de circulação diária entre os anos 1711-12 em Londres, com significativa adesão do público leitor ${ }^{14}$.

Combinando diferentes vertentes da crítica cultural e de costumes, o veículo em questão apresentava algumas características inéditas para os jornais da época, sendo a principal delas a busca por envolver os leitores na definição das suas pautas diárias. Grosso modo, o The Spectator almejava representar "a voz da sociedade civil” (WARNER, 2008, p. 60).

Com papel central no processo de elaboração e circulação desse periódico, a seção dedicada às "cartas dos leitores” indica uma opção editorial que buscava conferir protagonismo ao seu público leitor, reconhecendo-o como instância dotada de aptidões críticas e capacidade propositiva:

Pede-se aos leitores que emitam juízo informado e equilibrado sobre questões de moda, de gosto, de conduta, de relações entre gêneros. O procedimento de discussão impessoal dá aos assuntos privados uma nova relevância pública, ao mesmo tempo em que permite aos participantes da discussão aceder a esta classe de generalidades que antes havia sido privilégio do Estado e da Igreja.

(WARNER, 2008, p. 60.)

Com isso, o The Spectator se arroga um tipo de funcionamento concernente a um espaço público discursivo comum e abrangente, supostamente destinado a todos. Desse modo, o jornal procuraria produzir e evidenciar uma espécie de dobra a refletir sua própria recepção, na medida em que constitui sua pauta e conteúdo por meio da participação de seus lei-

14 Editado pelos ensaístas Joseph Addison e sir Richard Steele, o jornal The Spectator iniciou sua circulação em $1^{\circ}$ de março de 1711. Estima-se que cada número tenha sido lido em média por sessenta mil londrinos. A publicação do último número do jornal se deu em 6 de dezembro de 1712. O encerramento de suas atividades esteve ligado a uma nova empreitada jornalística assumida por Addison, que fundaria um novo jornal. Apesar disso, Addison chegou a retomar pontualmente a edição de The Spectator em 1714, publicando oitenta números. 
tores. Daí que "os ensaios publicados façam referência aos ensaios anteriormente veiculados e também à recepção dos mesmos” (WARNER, 2008, p. 61). Nesse ponto, o uso do termo "participação" é elucidativo do tipo de envolvimento do público com a dinâmica de elaboração do jornal, quando consideramos as ponderações de Landkammer sobre as diferenças entre as lógicas participativa e colaborativa. Como poderemos constatar a seguir, tal participação se dá mediante a adesão de um público privilegiado a uma matriz valorativa e discursiva pré-definida e refratária à diferença.

Tal periódico parece, a princípio, apontar para uma dinâmica de amplo engajamento social nas questões de interesse público, ao fomentar debates a partir da aparente distribuição das vozes e ampliar assim o escopo dos formadores de opinião para além do comitê especializado do jornal. Antes de qualquer outro meio impresso de comunicação, o The Spectator incorporou a representação de sua própria circulação e de sua comunidade leitora, propugnando que "o discurso público precisa circular, e que não pode ser emitido em uma única direção", tampouco a partir de uma única fonte (WARNER, 2008, p. 62).

Cumpre observar, no entanto, que seu clã de leitores-participantes era formado majoritariamente por um segmento social hegemônico: masculino, branco, letrado e proprietário. Warner pondera que tal constatação deve ser associada ao fato de que o movimento espontâneo de auto-organização dos públicos não está dissociado de formas de comunicação e de canais de circulação pré-existentes e socialmente delimitados. Ao contrário, embora esses meios possam parecer indistintamente acessíveis a todas as pessoas, eles de saída "selecionam aqueles que podem se apropriar deles, mediante critérios de espaço social compartilhado (não necessariamente espaço territorial), hábitos, interesses comuns, referências e formas de inteligibilidade (incluídos os idioletos ${ }^{15}$ e os gêneros de fala)" (WARNER, 2008, p. 69).

São exatamente esses marcadores de distinção social que, no caso do periódico The Spectator, acabariam privilegiando um setor social específico, em detrimento de tantos outros, alijados do processo de enunciação na cena pública e, portanto, do processo de construção de um imaginário social e de um sistema de valores capazes de produzir efeitos na realidade comum. Ou seja, "a voz da sociedade civil", em beneficio da qual esse jornal busca assumir o papel de um bastião, nada mais é do que a voz de uma parcela privilegiada e hegemônica dessa sociedade.

Entretanto, é no seio de dispositivos comunicacionais como esse que irrompem os seus contrapúblicos. Warner nos traz um exemplo contundente desse tipo de insurgência: no número 217 do jornal, o Senhor Spectator, figura utilizada para subscrever os editoriais, relata o recebimento de uma carta encaminhada por certa Kitty Termagant, na qual ela apresenta

15 De acordo com a definição do Dicionário Houaiss, idioleto diz respeito ao sistema linguístico do indivíduo em determinado período de sua vida, que reflete suas características pessoais, os estímulos a que foi submetido, sua biografia etc. 
detalhes dos modos de convivência de um grupo de mulheres do qual faz parte, e que se reúne frequentemente em ambiente reservado. $\mathrm{O}$ grupo se identifica pela alcunha de Garotas Brincalhonas. Num trecho da carta, Termagant diz:

Assim que nos reunimos todas, nos despojamos de toda a modéstia e de toda essa reserva no trato que todas nós, do sexo feminino, nos vemos obrigadas a adotar nos lugares públicos. Eu não saberia expressar o prazer que desfrutamos desde as dez horas da noite até as quatro da madrugada sendo tão rudes como vocês - homens - podem ser em toda sua vida. Assim que o nosso jogo se anima, a sala se enche de leques quebrados, anáguas rasgadas, restos de toucas, babados, rendas, cintas e aventais de trabalho. (TERMAGANT apud WARNER, 2008, p. 74.)

Como sugere Warner, o clube das Garotas Brincalhonas representaria a imagem invertida da comunidade masculina reunida em torno do esclarecido jornal The Spectator. Ali, elas se liberam de todas as restrições impingidas pelo decoro e por sua posição social enquanto mulheres. Em lugar de conversações pautadas por expedientes racionais exclusivamente argumentativos, opiniões e análises distanciadas de indivíduos bem informados e ilustrados, elas escolhem o contato físico como forma de interação, referindo-se aos trapos e refugos daí resultantes como "homens mortos" (TERMAGANT apud WARNER, 2008, p. 75).

Ao comentar a conduta narrada por Termagant, o Senhor Spectator se refere às Garotas Brincalhonas com um misto de desdém e reprovação. Suas ponderações saem em defesa das "boas maneiras para recordar ao leitor a sociabilidade cortês que inspira confiança em um público composto por desconhecidos”. Desviando-se dos preceitos consagrados pelo periódico, as Brincalhonas não poderiam gozar de tal confiança, a ponto de terem sua condição como público negada pelo Senhor do jornal. Em chave reversa, seu estatuto seria o de um contrapúblico (WARNER, 2008, p. 75). Isso se deve ao fato de que a comunidade formada pelas Garotas Brincalhonas

expressa um estilo de sociabilidade excessivamente encarnado, excessivamente agressivo, excessivamente sexualizado, para ser imaginado como circulação indefinida do discurso entre desconhecidos. Essas mulheres não se contentam em ser "mulheres razoáveis", cujo mais elevado modo de presentificação em público seja "a conversa após a refeição, tomando um bom chá”. Elas querem que a sua apresentação pública [e a carta enviada ao jornal é sinal disso] esteja modelada sobre algo distinto do simples ato de leitura realizado no ambiente privado. [...] Essa negativa a toda norma legitimada de sociabilidade com desconhecidos, mais que a simples feminilidade, é o que faz delas uma contraimagem do público. (WARNER, 2008, p. 76, grifo meu.) 
Como contrapúblico do jornal The Spectator, esse grupo de mulheres coloca em xeque as regras que definem o que seja o espaço público, afrontando-as e introduzindo aí a possibilidade de alterá-las. As Garotas almejam, portanto, a mesma liberdade fisica e social de que gozam os homens, mas para fazer com ela aquilo que bem entendem, e não para reproduzir condutas masculinas normalizadas. Desejam, assim, poder praticar "uma fisicalidade, uma corporeidade pública e semipública”. Porém, segundo os códigos hegemônicos masculinos de sociabilidade pública da época, o tipo de dinâmica interpessoal e coletiva cultivado pelas Brincalhonas não passava de um modo de convivência tipicamente íntimo, apenas deslocado do seu "devido lugar": a esfera privada. Conforme prescrevem esses códigos, tal conduta seria "antipública” por natureza, dado o seu caráter marcadamente corporal e sexual (WARNER, 2008, p. 76).

O desfecho das correspondências se daria, passados já alguns números do periódico, com Termagant solicitando ao Senhor Spectator que abrisse espaço em seu jornal para que as Garotas Brincalhonas pudessem apresentar-se publicamente e pleitear alguma influência na dinâmica de elaboração da sua pauta. Isso incluiria um convite feito por ela em nome das Garotas, sugerindo que o Senhor Spectator lhes visitasse numa das noites, no ambiente onde elas se encontravam habitualmente, na condição de espectador (!). Aí está em jogo, como destaca Warner, o fato de que essas mulheres "aspiram expor a intenção transformadora de suas reuniões ao distanciamento crítico do discurso público” (WARNER, 2008, p. 77).

Mas a resposta do Senhor Spectator ao convite é negativa, justificada de maneira taxativa por uma completa indisposição apresentada em primeira pessoa (portanto, em nome do jornal The Spectator e de seus agentes enunciadores), na qual ele diz: "eu não encontro atualmente, em minha pessoa, a menor inclinação de aventurar-me com suas companheiras, as Brincalhonas..." (SENHOR SPECTATOR apud WARNER, 2008, p. 77, grifo meu).

Sua recusa pode ser lida como sinal do receio da comunidade representada pelo The Spectator frente ao risco de ter o seu edifício ideológico colocado em questão. Desse modo, ao evitar conhecer de perto esse outro tabuleiro de sociabilidades, o Senhor Spectator se sentiria autorizado a seguir se referindo às Garotas Brincalhonas como mera anedota, um tipo de bizarrice indigno de ser levado a sério, inclusive porque esse "Senhor", assumindo-se como arauto da vida pública, toma as suas próprias normas de convivência e de abordagem da realidade como inquestionáveis e universais. Flagra-se, portanto, uma manobra dos representantes-beneficiários da cultura dominante, no sentido de desdenhar, delimitar e, finalmente, rechaçar os desvios e antagonismos praticados no interior dessa mesma cultura, autointitulada pública (WARNER, 2008, p. 78).

Contudo, a obstrução à participação de um grupo de mulheres em tal círculo ilustrado não deveria nos levar a cogitar ou reivindicar a sua simples inclusão no espaço (da pauta) do jornal. Lembremos aqui da afirmação da educadora Gabriele Stöger, que já citamos: “a participação se pensa a partir do lado dos donos, que querem compartilhar, sem ceder o direito de disposição sobre o bem completamente”. Os "donos”, no caso do periódico The Spectator, seriam tanto os quadros do jornal como os 
seus leitores padrão, os quais não abrem mão das normativas epistemológicas e comportamentais que lhes garantem privilégio e hegemonia, seus "bens" maiores.

Nesse sentido, Deutsche se reporta ao crítico e historiador John Barrell para pontuar que à mulher vem sendo historicamente negado "tanto o pertencimento à república do gosto como à república política” (BARRELL apud DEUTSCHE, 2008, p. 45). Isso se explicaria, de acordo com a leitura da crítica, pela suposta incapacidade atribuída à mulher "de generalizar a partir de seus interesses particulares", o que a impediria de "exercer a visão pública”. Deutsche não tem dúvida quanto à urgência de reconhecermos o caráter problemático dessa discriminação e de suas consequências. No entanto, ela também alerta para o fato de que o protesto contra tal discriminação - e, consequentemente, contra a exclusão que ela provoca - pode se reverter no apoio, ainda que não intencional, a um ideário que concebe a plenitude da cultura pública por meio da gradativa inclusão - em suas instituições e normas - "dos grupos anteriormente marginalizados”. Tal movimento significaria manter intacto esse mesmo ideário e sua correlata política sexista (DEUTSCHE, 2008, p. 45). Daí que devamos nos ocupar menos das formas de inclusão e mais da identificação e da produção de precedentes alternativos para a esfera pública, procurando concebê-la em bases outras.

\subsection{O QUE COLOCAR NO LUGAR DA ESFERA PÚBLICA BURGUESA?}

Submetida a idealismos e normativas racionalistas e classistas, a cultura pública aludida acima reflete, antes de tudo, a autocompreensão dos segmentos burgueses. Segundo Sheikh, esse entendimento de si postula "um sujeito racional capaz de falar ao público, na sociedade e sobre a sociedade" (SHEIKH, 2009, p. 77, grifos do autor). Em tese, tal condição franqueia aos participantes da esfera pública uma posição de exceção a partir da qual as problemáticas políticas e sociais são criticadas de maneira supostamente distanciada e isenta.

Agindo assim o cidadão burguês chama para si uma posição de imparcialidade. Para Deutsche, essa postura refletiria um tipo de predisposição não para adentrar o espaço público, mas, ao contrário, para escapar dele, haja vista que esse espaço se caracteriza justamente "por sua abertura, contingência e incompletude, em outras palavras, por sua parcialidade" (DEUTSCHE, 2008, p. 41, grifo meu). A atitude de negar tais atributos do espaço público corresponderia à crença de que é possível situar-se para além de quaisquer interesses ou desejos específicos, guiando-se exclusivamente pela perspectiva universalista da razão. Porém, de acordo com as ponderações da filósofa política Iris Marion Young, mencionadas por Deutsche, esse perfil "absoluto e soberano" revela-se abstrato e pouco crível quando consideramos que sua vigência depende de uma completa separação "do contexto de qualquer pessoa real”, como se esse cidadão, supondo-se imparcial e isento de interesses próprios, não estivesse "comprometido com nenhum objetivo 
particular" e, além disso, como se não possuísse "uma história particular", não sendo "membro de nenhuma comunidade" (YOUNG apud DEUTSCHE, 2008, p. 43).

Adotando "um ponto de vista universal" e, portanto, desenraizado de qualquer contexto em particular, essa figura pública idealizada é postulada "mediante a negação da pluralidade e da diferença”. Para se conservar imparcial, ela precisa "eliminar a alteridade" e suas especificidades, suprimindo a diversidade entre as pessoas e grupos e o caráter contingencial das situações vivenciadas por cada um, além de refutar as pulsões emotivas e desejantes (DEUTSCHE, 2008, p. 42-43). Paradoxalmente, para adotar uma visão imparcial e universal, ela deve rejeitar a própria "condição humana”, se consideramos essa condição pela ótica de Arendt, que identifica como seu traço determinante justamente a pluralidade e a possibilidade de as diferenças aparecerem em público (ARENDT, 2007). Enquanto predicado, a humanidade residiria na possibilidade de nos distinguirmos uns dos outros no espaço público, e não de encenarmos uma pretensa imparcialidade.

Isso significa dizer, ainda de acordo com o ponto de vista de Young, que o cidadão imparcial se afirmaria "mediante a perda de outros: da alteridade no sujeito e dos outros no mundo" (YOUNG apud DEUTSCHE, 2008, p. 43). Na leitura que Deutsche faz desse aspecto, tal modelo de cidadania - emblemático da concepção política moderna - baseia-se numa "oposição estrita entre um âmbito público abstrato e universalista e um âmbito privado de interesses parciais em conflito" (DEUTSCHE, 2008, p. 42-43). Em consequência, reforça-se a ideia de que as particularidades de indivíduos e grupos minoritários devem, segundo essa perspectiva, ser relegadas à sombra do domínio privado.

Tal distinção baseia-se num mecanismo de hierarquização que confere legitimidade e reconhecimento público apenas a um tipo ideal de subjetividade, em detrimento de tantos outros. Nesse sentido, a crítica feminista Nancy Fraser esclarece que os status "privado" e "público" são sistematicamente utilizados "para deslegitimar certos interesses, pontos de vista e temáticas”, para, em contrapartida, "valorizar outros”, com a notória desvantagem associada àquilo que se considera apenas da ordem do privado (FRASER apud DEUTSCHE, p. 27). Essa lógica discriminatória seria responsável por limitar o escopo daquilo que devemos, ou não, anuir como digno de integrar a cena e o debate públicos. Os contrapúblicos, por sua vez, defrontam-se justamente com essa questão, exigindo que anseios e comportamentos hegemonicamente tidos como privados sejam reconhecidos publicamente. Localiza-se aí o caráter disruptivo e político do gesto das Garotas Brincalhonas. Ainda que, como já comentado, a sua simples inclusão na esfera pública hegemônica não seja suficiente para a subversão dos dispositivos normativos que a sustentam.

Essa lógica hierarquizante se assenta em uma ideia absoluta do que sejam a comunidade política e, por conseguinte, a esfera pública em si. Sua vigência depende dos critérios que regem a cidadania burguesa, ligados aos princípios da imparcialidade e da universalidade, sendo que ambos trazem consigo uma visão generalizante do homem, refratária às suas 
singularidades e diferenças. Segundo Étienne Balibar, esses pilares - tipicamente modernos - passaram a ser confrontados pela política "pós-moderna”. O filósofo político nos esclarece que tal confronto nasce das próprias possibilidades abertas pelas revoluções burguesas, responsáveis por inaugurar a democracia moderna e, com ela, a perspectiva dos direitos civis que "abriu a todos os seres humanos o direito à política". Desse modo, o processo democrático teria propiciado, ao menos em tese, que o acesso à condição cidadã e ao debate público fosse aberto a todos, possibilitando, como efeito colateral, que as singularidades e diferenças de grupos minoritários encontrassem brechas para tensionar os ideais abstratos de igualdade e liberdade, emblemáticos do programa democrático moderno. Cabe considerarmos, então, que o espaço público se constitui como uma arena de disputas discursivas, onde o "ideal de imparcialidade", representativo de um tipo de cidadania burguesa e excludente, é transformado em objeto de "litígio" (BALIBAR apud DEUTSCHE, 2008, p. 42).

É Sheikh quem formula a pergunta sobre o que podemos colocar no lugar da esfera pública burguesa. Sua indagação denota que já não faz sentido concebermos a esfera pública como uma formação dada, absoluta e totalizante, à qual as pessoas sejam pouco a pouco incluídas ou simplesmente permaneçam alijadas. Ao contrário, ela deve ser compreendida em termos contingenciais, atrelada às iniciativas e demandas de grupos diversos que nela se posicionam instaurando debates e pleiteando o reconhecimento de agendas distintas, decididamente parciais. Logo, nos parece que o conceito de esfera pública deva ser encarado sob rasura, como algo em permanente tensionamento e disputa. Mesmo porque, de acordo com Sheikh, a tipologia histórico-social expressa pela "esfera pública burguesa", ao representar uma formação genérica e avessa às particularidades, apresenta-se como "uma projeção que não parece útil na nossa sociedade modular, multicultural e hipercapitalista” (SHEIKH, 2008, p. 132).

Enquanto a compreensão burguesa da esfera pública pressupõe a universalidade e a racionalidade, os contrapúblicos reivindicam o oposto, inclusive no que se refere ao uso dos espaços públicos. Conforme apontado por Sheikh, suas condutas "implicam uma subversão dos espaços existentes em outras identidades e práticas" - e aqui podemos pensar tanto nos espaços discursivos como nos ambientes públicos. Um exemplo, além dos que já apontamos até aqui, seria o "uso de parques públicos para encontros furtivos pela cultura gay". Como locais regulados de acordo com determinadas noções de convivência pública, os parques e seus recantos são frequentemente investidos de uma dimensão heterotópica pelos segmentos queer, que produzem desvios nas premissas heterossexuais e nas regras do decoro, em favor do livre curso de outros desejos e de outras formas de estar em (e se fazer um) público (SHEIKH, 2008, p. 130).

Daí que Sheikh, em oposição ao cenário totalizante apresentado por Habermas em sua obra referencial, conceba a esfera pública como algo fundamentalmente fragmentado. Para ele, não seria factível compreendê-la no singular, enquanto plataforma unitária, mas através da noção de "esfera 
pública no plural”, que pressupõe reconhecermos a superposição de "espaços e/ou formações que às vezes se conectam, às vezes se isolam", na medida em que "possuem relações contraditórias e conflituosas umas com as outras”. Desse modo, inumeráveis esferas públicas temporárias e simultâneas se manifestariam a partir de diversos "espaços de experiência", permeados por "diferentes e opositoras subjetividades", onde a argumentação crítico-racional e sua pretensa imparcialidade já não gozam de exclusividade e hegemonia (SHEIKH, 2008, p. 129-132).

Em relação ao caráter contingencial e fragmentado da "esfera pública no plural", Deutsche comenta que ela não se limita a um lugar discursivo preestabelecido, configurando-se, antes, como "um lugar construído discursivamente" (grifo meu). Sua vigência depende, portanto, da constante emergência de enunciados políticos provindos de diferentes agentes e grupos sociais. Diríamos, ainda, que a própria composição da comunidade política está condicionada à formulação e à publicização de tais enunciados, os quais se encontram ancorados, para retomar Sheikh, nos "espaços de experiência”, ou seja, na parcialidade das vivências e relações cotidianas daqueles que surgem em público. Tal processo ensejaria a circulação de agendas igualmente políticas, cabendo aos seus postulantes disputar e convencionar "o que é legítimo e o que é ile gítimo dentro do espaço público” (DEUTSCHE, 2008, p. 24). É nessa defesa pela legitimidade de pautas emergentes que, a nosso ver, reside a possibilidade de se produzir certos marcos comuns reconhecíveis pelos diversos círculos sociais ativos no espaço público.

Importa frisar, ainda, que a dinamização e a complexificação do espaço público discursivo, concebido como formação permeável ao surgimento e à circulação de vozes e subjetividades historicamente invisibilizadas, exigem capacidade imaginativa e empenho "para construir novos modelos, novos formatos de esfera pública” (SHEIKH, 2008, p. 133). Do mesmo modo que essa esfera é constituída pelas discursividades e enunciados que a tornam vigente, também o seu modo de funcionamento é produzido e ressignificado pelos variados experimentos comunicativos encetados pelos diferentes atores políticos.

As artes visuais e a mediação cultural teriam papéis táticos a desempenhar nesse quesito. Retomemos o eixo da investigação a que se propõe o presente capítulo evocando a ideia de aparição pública em Arendt. À nossa abordagem até aqui da "arte no interesse público", Deutsche agrega a constatação de que o debate em torno das problemáticas da esfera pública, ao ser incorporado por segmentos do campo artístico, teria promovido mudanças significativas na compreensão da ideia de arte pública, sendo a principal delas a "exigência de politização da arte". Uma das viradas nessa direção nos interessa em particular. Ela se refere à forma de conceber o estatuto dos públicos das práticas artísticas, que passariam a ser entendidos como agentes engajados em determinada "discussão política ou [mesmo] entrando na luta política”. Essa compreensão faria da arte publicamente comprometida "um instrumento que ou ajuda a produzir um espaço público ou questiona um espaço dominado que foi declarado oficialmente como público” (DEUTSCHE, 2008, p. 23-24). 
Compreendemos as iniciativas artísticas e mediativas imbuídas do estímulo à produção de espaços públicos, ou mesmo do tensionamento de espaços pseudopúblicos (no sentido da reunião de subjetividades homogêneas que ocupam determinado espaço discursivo ou mesmo territorial), na chave de agenciamentos coletivos dedicados à catalisação de situações colaborativas e comunicativas, que reforçam o caráter contingencial e temporário de esferas públicas plurais e parciais mobilizadas junto a públicos específicos e formadas em torno de determinadas problemáticas sociopolíticas.

Sheikh nos ajuda a detalhar esse processo ao designar as artes visuais, sobretudo a sua vertente dedicada ao "interesse público", como uma "caixa de ferramentas comunicacional”. Assim como Deutsche, ele também destaca que os públicos de tais práticas estão longe de serem envolvidos e/ou endereçados como entidades abstratas e genéricas - à revelia de suas identidades políticas. Ao contrário, o crítico e curador comenta que os experimentos desenvolvidos por essa vertente da arte procuram geralmente se relacionar "a um conjunto específico de parâmetros e/ou um público específico, em oposição ao genérico e idealizado”. Isso refletiria um distanciamento deliberado da lógica totalizante e abstrata da esfera pública burguesa, representando, por outro lado, a disposição por lidar com "diferentes fragmentos, campos - e/ou contrapúblicos". Em lugar da validade universal postulada pelas perspectivas moderna e burguesa em relação às obras de arte autônomas e à esfera pública unitária, essa outra concepção operaria com a "questão de para que e para quem se está falando e sob quais premissas" (SHEIKH, 2008, p. 127, 133, grifos meus). Logo, do público universal (imparcial) passa-se aos interlocutores marcados por identidades políticas (parciais).

O "mundo da arte", nesse registro, corresponderia a um nicho específico da "esfera pública no plural”, dentro do qual operaria uma miríade de esferas parciais e temporárias, apoiadas por "plataformas comunicativas" concebidas por artistas e mediadores em colaboração com diferentes públicos. Por meio delas, distintas subjetividades e imaginários se encontrariam, produzindo aglutinações, intercâmbios, embates, segmentações e dispersões. Sheikh identifica o nicho da arte como um terreno de batalhas simbólicas, composto por diferentes posições ideológicas em conflito. Pensando numa interação em nível mais amplo, ele se pergunta como a "esfera pública da arte" poderia se relacionar, produzindo fricções e entrelaçamentos, com esferas públicas emergidas dos demais campos sociais (SHEIKH, 2008, p. 128, 132). Fazendo ecoar a sua pergunta, nos indagamos sobre como novos marcos comuns podem ser derivados das interações conflituosas entre subjetividades e comunidades heterogêneas - seja no interior do "mundo da arte", seja em suas interfaces com outros campos da vida social. 
Tais preocupações denotam um contraponto ao papel histórico assumido pelos museus ${ }^{16}$ no que tange à corporificação institucional da esfera pública burguesa, em complementaridade aos salões, cafés, sociedades de leitura e aos periódicos. Assim como nesses locais, nos museus exercia-se a autorrepresentação da classe burguesa a partir de seus próprios valores (SHEIKH, 2008, p. 134). Repletas de emblemas da cultura a serem fruídos e comentados, suas galerias funcionavam como ambiência propícia para que os segmentos burgueses assumissem a posição do público (em sentido totalizante) que discute a arte e a cultura mediante o uso de expedientes da razão argumentativa, de modo distanciado e isento.

Além de lastrear a esfera pública burguesa, o modelo iluminista serve de base a um programa de instrução e disciplinamento das populações urbanas - visando incluir segmentos apartados do espaço público - a partir do que se convencionou chamar de processo civilizatório. Os museus assumem um papel crucial em tal processo. Aí, os sujeitos são subsumidos à categoria de espectadores com base na crença em um tipo ideal e genérico de cidadão. Desconsidera-se, portanto, que suas condutas e pontos de vista estariam ligados a posições relativas a marcadores de gênero, classe, raça e etnia, credo, orientação política etc. Ou seja, negligencia-se (talvez de maneira deliberada) que as visões, sensibilidades e comportamentos são indissociáveis das experiências e dos repertórios de cada pessoa e grupo social.

Enquanto o modelo iluminista idealiza a figura do espectador em bases universais, a indústria cultural - umas das responsáveis pelo declínio da esfera pública na ótica habermasiana - institui uma lógica comunicativa calcada no fundamento mercadológico, confundindo propositalmente sujeitos com consumidores. Conforme assinala Sheikh, a indústria cultural substitui a ideia de bem público pela noção de mercado, de tal modo que o paradigma crítico-racional dá lugar à dinâmica do entretenimento como equivalente dos processos comunicativos (SHEIKH, 2008, p. 134-135). Logo, o controle social e a produção de subjetividades já não seriam mais pautados pelos expedientes racionais caros à esfera pública burguesa, mas pelas injunções do mercado e suas estratégias de captura do imaginário político.

O que Sheikh defende, portanto, é a constituição de formatos alternativos de esfera pública, que se contraponham tanto à matriz iluminista da razão quanto ao modelo de entretenimento da indústria cultural. Isso envolveria a instauração de processos comunicativos modulados de acordo com diferentes públicos e suas respectivas agendas. Nesse sentido, as práticas artísticas seriam capazes de conceber ferramentas comunicativas adequadas à deflagração de distintos espaços públicos discursivos (SHEIKH, 2008, p. 128). A invenção e o uso desses recursos, sem dúvida, surgimento dos museus públicos na Europa não apenas é contemporâneo ao período de consolidação da esfera pública burguesa, como também figura entre suas principais instituições. 
partem da compreensão de que os contextos e os públicos não são estáveis, tampouco universais. Logo, devem dedicar-se à formação temporária de múltiplas plataformas de intercâmbio simbólico, que mantêm entre si relações contraditórias e conflituosas. Por outro lado, sustentando essa natureza conflitiva e dissensual, tais experimentos ensaiariam processos de tradução e circulação de enunciados parciais, a fim de conferir não apenas visibilidade a grupos minoritários, mas também legibilidade aos seus códigos culturais e às suas demandas por direitos civis.

Por fim, cumpre dizer que tais experimentos comunicativos seriam deflagrados por agenciamentos artísticos e mediativos que operam pela via da "implementação”, buscando produzir “acordos imaginários” - por nós designados como marcos comuns - atrelados a subjetividades e discursividades específicas (SHEIKH, 2008, p. 131). Tais aspectos podem ser notados, a partir de uma abordagem singular, no projeto Studio Butterfly, desenvolvido pela artista Virginia de Medeiros em colaboração com travestis da cidade de Salvador.

\subsection{ESTÚDIO COMO PLATAFORMA COMUNICATIVA}

O exemplo a seguir distingue-se pela invenção de uma "plataforma comunicativa" resultante do encontro entre os anseios da artista e os interesses do público com o qual ela interage e colabora. Desse modo, cria uma situação favorável à interlocução com suas integrantes e, ainda, à circulação de imaginários, desejos e códigos culturais que afrontam padrões heteronormativos. Tal plataforma é deflagrada pela experiência urbana da artista, em particular aquela que possibilita a sua aproximação de um grupo social que tem na rua o seu local de luta pela sobrevivência, por meio da prostituição.

Residente na capital baiana, Medeiros conta que havia se mudado de bairro no início dos anos 2000, passando a morar no centro da cidade. Nas noites em que passava a pé pelas ruas da região ${ }^{17}$, espreitava as travestis com fascínio, nutrindo crescente curiosidade pelas artimanhas de suas vidas levadas "na pista". Isso a impeliu a se achegar, pouco a pouco, de algumas delas. Era atraída, principalmente, pelo modo como as travestis desestabilizam os enquadramentos de gênero e os comportamentos sociais tidos como normais e aceitáveis no âmbito público, rompendo de maneira enfática com seus códigos.

A artista se aproximou, inicialmente, de Machelle. Sempre que cruzava com ela na rua, ainda antes de se conhecerem, fazia questão de lhe perguntar as horas, numa tentativa ainda hesitante de estabelecer contato. Mas a relação inaugural de maior proximidade se daria com Rosana, responsável por introduzi-la no círculo das travestis, e que, antes mesmo da vigência do Studio Butterfly, viria a falecer.

No período imediatamente anterior a tais aproximações, a artista já havia iniciado uma pesquisa em torno do universo visual das travestis, por meio 
de pinturas e desenhos alusivos à iconografia trans. No entanto, seu interesse adquiriu outra dimensão no momento em que passou a se "infiltrar" (a expressão é da artista) nos meios frequentados pelas travestis, estabelecendo com elas relações de proximidade e interlocução (LAGNADO; PEDROSA, 2006, p. 242). Seu trabalho passou, então, a ser balizado pela experiência junto a pessoas desse círculo social, o que nos remete aos "espaços de experiência" mencionados por Sheikh em seu exercício de ressignificação do conceito de esfera pública - que passa a ser postulado como uma pluralidade de formações coletivas calcadas na experiência.

Ao longo das conversas com as travestis, a artista logo constatou o interesse delas pela "foto posada", modalidade propícia à exibição e valorização da autoimagem. Boa parte de suas interlocutoras, inclusive, guardava fotografias de diferentes momentos de suas vidas e, por conseguinte, dos seus processos de transição de gênero, compartilhando tais flashs aos poucos com Medeiros.

Desse interesse das travestis pelo retrato fotográfico surge a proposição da artista sob o formato de um estúdio. O Studio Butterfly ${ }^{18}$ funcionou por aproximadamente um ano e meio, de 2003 a 2005. Foi instalado em uma pequena sala alugada num edificio comercial do centro de Salvador, situado nas proximidades da área onde muitas travestis vivem e trabalham ${ }^{19}$. A ambientação do local fora concebida pela artista em colaboração com as travestis interessadas em se envolver com o projeto, a fim de arranjá-lo como um ponto de encontro com e entre elas. O local se transformou num misto de estúdio fotográfico e sala de estar, onde as travestis contavam suas histórias e, mediante traduções poéticas concebidas pela artista, geravam repertórios simbólicos aptos a transcender as paredes do Studio, circulando em outros contextos e temporalidades.

Seu espaço fisico se compôs por elementos que remetiam ao ambiente doméstico das travestis, mais especificamente aos quartos de pensão que lhes servem de morada ${ }^{20}$. Inclusive, antes de instalar o estúdio, a artista adotara o hábito de frequentar uma dessas pensões, a "Pensão de Rosana" (MEDEIROS, s.d., p. 3). Entre as peças usadas para compor o estúdio destacavam-se as fotografias disponibilizadas pelas próprias travestis, contendo registros passados e recentes de suas vidas. Uma parte dessas imagens foi emoldurada e pendurada nas paredes da sala do conjunto comercial, perfazendo um acervo que refletia fragmentos da vida das pessoas ali envolvidas. Os ensaios fotográficos produzidos no estúdio, por sua vez, eram revelados e organizados pela artista na forma de books, os quais eram entregues

18 Uma instalação artística homônima integrou, entre outras mostras, a $27^{\mathrm{a}}$ Bienal de São Paulo - Como viver junto, em 2006.

19 Chamado Sulacap, o edifício localiza-se no número 62 da avenida Sete de Setembro, na bifurcação com a rua Carlos Gomes.

20 Não nos parece desprezível o fato de que o Studio e sua respectiva instalação artística, com a vocação pública que os define, sejam construídos com base em critérios e elementos provindos do ambiente privado. 
como retribuição às travestis fotografadas, além de integrarem um arquivo utilizado pela artista nas situações de exibição pública do Studio.

Somada às fotografias retiradas dos álbuns pessoais - que também mostravam familiares, amigos e amores das travestis -, a sala recebeu uma peça de mobiliário escolhida especialmente para as conversas que ali se desenrolavam. Tratava-se de um assento confortável, designado pelo nome de "poltrona dos afetos" (LAGNADO; PEDROSA, 2006, p. 242). Ela funcionava como um móvel acolhedor, onde as travestis se aconchegavam e narravam suas histórias de vida para a artista. Não é preciso fazer muito esforço para imaginar que, durante tais conversas, a racionalidade pretensamente distanciada e imparcial, característica dos exercícios críticos levados a cabo na esfera pública liberal, passava longe daquela sala de estar.

Em complemento à "plataforma comunicativa” materializada pelo estúdio e pelos ensaios fotográficos daí resultantes, a artista transpôs os relatos e cenas protagonizadas pelas travestis utilizando diferentes mídias. Além da fotografia, Medeiros elaborou instalações e vídeos pensados para integrar exposições do circuito da arte contemporânea. Ela também produziu um livreto de contos, no qual narra suas experiências com as "monas" (a expressão é das travestis) (MEDEIROS, s.d., p. 5).

Em relação a esse aparato comunicacional manejado pela artista, cabe identificarmos um paralelo entre o Studio Butterfly e as ideias de Deutsche em torno da noção arendtiana de aparição. Tendo em vista que a aparição pública condiz a uma condição imprescindível para a inserção do sujeito na vida política de uma comunidade, o campo das artes visuais aí assume um papel tático. Isso se deve às passagens franqueadas pelas ferramentas e operações comunicativas da arte entre o domínio da visualidade e a esfera pública, no sentido de contribuir com o processo de visibilização de agendas e grupos minoritários e promover a circulação de seus enunciados para além dos círculos de onde provêm. Mais que isso, tais proposições não raro deflagram, elas próprias, esferas públicas parciais e temporárias, funcionando como espaços coletivos de encontro, intercâmbio e, também, de disputa.

Vistas as preocupações da nossa pesquisa em relação ao caráter contingencial e imprevisto das formas de atuação dos públicos frente às práticas artísticas que lhes endereçam ou que com eles procuram colaborar, não devemos nos limitar à descrição do projeto pela face de sua proposição por parte da artista. Cumpre observar também certos índices de sua apropriação por integrantes da comunidade em questão, que se envolveram de diferentes modos com o Studio.

Nesse quesito, nos parece oportuno chamar atenção para uma ocorrência protagonizada por uma travesti que cruza o projeto de modo disruptivo, com alguma violência inclusive. Seu apelido é Baiacu. Ela desafiou Medeiros ao tomar de suas mãos o book contendo o ensaio fotográfico de Patrícia, travesti que teria "roubado" o seu marido. O ocorrido se deu durante uma reunião na Associação de Travestis de Salvador, a Atras, ocasião em que Medeiros topou pela primeira vez com Baiacu. Dias antes, esta havia atacado Patrícia com uma faca, furando-lhe o seio a ponto de provo- 
car o vazamento do silicone. Patrícia, que estava a caminho da referida reunião, foi desaconselhada a tempo pela artista - via telefone celular - de se dirigir à Associação, escapando de um novo confronto. Pega desprevenida, a artista se viu no meio de um "fogo cruzado". A certa altura, Baiacu a interpelou exigindo que Medeiros lhe entregasse imediatamente as fotos de Patrícia, chegando inclusive a tentar agarrar a bolsa da artista. De posse do book, Baiacu diria com ironia: "Ah, mas agora a gay vai pegar as fotos aqui na minha mão, se ela quiser” (MEDEIROS, s.d., p. 15).

É importante notar que, ao lidar com as agruras e os encantos de um grupo social, a artista se expunha a situações imprevisíveis, tornando-se suscetível a toda sorte de reações. Ao mesmo tempo que ela efetiva suas intenções artísticas, convivendo com as travestis e produzindo um trabalho de arte a partir dessa convivência, Baiacu se apropria abruptamente de um dos ensaios integrantes desse trabalho ${ }^{21}$, num gesto impulsivo que expressava raiva pelo abandono do seu amado, que a teria trocado por Patrícia ${ }^{22}$. Propositora do projeto, aqui a artista teria sido surpreendida por uma (re)proposição sub-reptícia e desviante de uma de "suas meninas" (o termo é da artista), que pretendia ter as fotos de seu desafeto como um trunfo em suas mãos, enquanto objeto de chantagem (MEDEIROS, s.d., p. 16).

Essa foi uma das passagens vivenciadas pela artista ao longo do período de convivência mais assídua com as travestis. Em interseção com as ideias de Barros em torno da mediação cultural, que destacam a potência inerente ao "trânsito entre o eu e o outro, o conhecido e o desconhecido, as semelhanças e as diferenças", o que a artista fazia era se posicionar, segundo ela própria, como "mediadora de uma fala que se encontra aprisionada por uma imagem estereotipada [acerca das travestis]". Mais do que isso, enquanto se propunha a tarefa de publicizar aspectos relativos às formas de vida de suas interlocutoras, Medeiros sentia que ela mesma era atravessada por esse outro, por sua disruptiva alteridade, fazendo-a viver experiências e sensações desconhecidas, a ponto de afirmar: "me tornei travesti; com toda a diferença que me cabe" (LAGNADO; PEDROSA, 2006, p. 242).

Ao delinear essa passagem que conecta o submundo das travestis soteropolitanas com os circuitos nacional e internacional das artes visuais, Medeiros transpõe para outros contextos e temporalidades o espaço de intercâmbio e afeto que ela e as travestis haviam formado no ambiente do estúdio em Salvador ${ }^{23}$, o que possibilita a circulação e publicização, junto a outros públicos, dos enunciados surgidos dessa interação. Temporário

21 No final da discussão, depois de Medeiros contemporizar, Baiacu devolveu o book, manifestando inclusive interesse em também ser fotografada.

22 Somava-se a isso o fato de que Patrícia, por ocasião de um período de grande dificuldade, teria sido amparada por Baiacu.

23 As instalações montadas por Medeiros em diferentes mostras do circuito artístico reeditavam o formato arquitetônico interno e a decoração do estúdio de Salvador remetendo o público fruidor à atmosfera do local dos encontros. 
e parcial, podemos dizer que o espaço discursivo proporcionado pelo Studio Butterfly funcionou como uma plataforma favorável a situações de comunicação e afeto que, provindas de um nicho social estigmatizado e marginalizado, afrontaram normatividades comportamentais e sexuais de uma cultura discriminatória enraizada e produtora de exclusão social. Aberta às linhas radicais da alteridade, a artista assumiu uma posição tática no processo de produção de um marco comum a partir de bases heterogêneas e dissensuais.

Por fim, resta frisarmos um aspecto detalhado por Sheikh em referência a proposições representativas da "arte no interesse público". Cruzando suas ponderações em torno da "esfera pública no plural" com os atributos do Studio Butterfly, podemos afirmar que Medeiros teria encetado, em colaboração com as travestis, uma esfera pública parcial e temporária no interior do "mundo da arte". Este, por sua vez, corresponderia a um nicho, entre tantos outros, de uma esfera pública concebida como resultado dinâmico da superposição de distintos e inumeráveis espaços discursivos. Também de acordo com o crítico e curador, o nicho da arte caracteriza-se pela diversidade de posições ideológicas, configurando-se como um terreno povoado por batalhas simbólicas. Ao introduzir nesse terreno um dispositivo de amplificação das vozes das travestis, a artista colaboraria tanto com a enunciação pública de seus anseios e agendas como para a ampliação e complexificação do arco de interesses e compromissos das práticas artísticas e de suas plataformas expositivas. Através do capital simbólico e do poder de difusão das instituições de arte, Medeiros repercutiu, a partir delas, demandas de um grupo socialmente excluído e invisibilizado, fazendo com que suas sensibilidades, pontos de vista e trajetórias de vida pudessem incidir tanto na esfera da arte como em outros círculos sociais.

\subsection{ESFERA PÚBLICA NO PLURAL E SUAS AMBIVALÊNCIAS}

A busca por construir o comum em bases dissensuais implica conceber a noção de esfera pública em chave ambivalente. Se, por um lado, não faz sentido tomá-la como uma formação dada e totalizante, acessada apenas mediante os expedientes da argumentação crítico-racional e de maneira supostamente isenta, por outro, não se deveria confundir a pluralidade das agendas e espaços públicos com a "coexistência indiferente das diferenças" (HONORATO; MORAES, 2016). A contraparte necessária à fragmentação (e ressignificação) da esfera pública burguesa, pulverizada em uma multiplicidade de espaços coletivos e temporários de experiência e comunicação, exige esforços no sentido do reconhecimento mútuo das diferenças e da produção de formas de interação e diálogo entre os agentes portadores dessas diferenças. Isso não deve ser confundido com uma perspectiva apaziguadora das tensões daí surgidas - sob o risco, em caso contrário, do encobrimento de hierarquias e opressões sociais.

A aproximação com o pensamento de Costa nos permite afirmar que a pluralidade de públicos alternativos revigora os processos e a qualidade da comuni- 
cação pública. Segundo o sociólogo, ao mesmo tempo que se nota a penetração da dinâmica pública pelas injunções do poder e do privatismo, percebe-se um processo simultâneo de complexificação do "mundo da vida”"24, alavancada pela constituição e expansão de públicos diversos e de novos lugares de experiência e comunicação. Estes correspondem, muitas vezes, a redes de atuação de segmentos sociais minoritários, por meio de associações voluntárias e movimentos sociais constituídos por membros da sociedade civil. Aí se formariam, de acordo com o sociólogo, espaços alternativos. Ainda que se distingam entre si, os públicos neles implicados se encontram, direta ou indiretamente, inter-relacionados, tendo em vista que suas agendas e iniciativas geram efeitos em contextos socialmente compartilhados (COSTA, 2002, p. 23). Essa inter-relação sugere não apenas a possibilidade, mas a premência de repactuações entre as diversas comunidades da sociedade em torno de marcos comuns que se mostrem hábeis em propiciar, a um só tempo, as necessárias transformações e a incontornável liga ao corpo social.

Entre as ressalvas à concepção habermasiana, Costa também destaca, assim como Deutsche, a crítica de Fraser diante da ideia de que haveria uma esfera pública única e totalizante. Sua problematização do conceito original de esfera pública condiz a uma contraposição à ideologia masculinista branca, liberal e racionalista. Ela visaria, portanto, desbancar sua tendência hegemônica ao apontar para a existência de uma multiplicidade de públicos, problemáticas e contextos, nos quais se verificam formas diversificadas de comunicação e experiência (COSTA, 2002, p. 27). Conforme já comentamos, as discursividades e performatividades aí praticadas pressionam pelo reconhecimento dos diferentes públicos e, também, dos contrapúblicos.

Como detalha Costa, o tipo de crítica desenvolvida por Fraser acerca da esfera pública repercute, a título de exemplo, nas discussões sobre as relações raciais no Brasil. Ao tratar da situação do negro no Brasil, o cientista político norte-americano Michael Hanchard defende a formação de uma "esfera pública negra”, decididamente apartada da esfera dominante. Nessa direção, o autor postula a necessidade de um círculo próprio de atuação e manifestação político-cultural, onde seriam cultivados os valores e a identidade da população afrodescendente. Para ele, essa esfera circunscrita contribuiria para o aumento da sua autoestima e, dessa forma, calçaria o combate ao racismo (COSTA, 2002, p. 33). Entretanto, Costa mostra-se cético quanto ao fracionamento da esfera pública em círculos sociais fechados e autossuficientes, definidos por matrizes identitárias:

24 Para Habermas, duas esferas coexistem na sociedade. Interdependentes, ele as identifica como a) sistema e b) mundo da vida. A primeira refere-se à produção material, guiada por premissas instrumentais e, desse modo, por relações hierárquicas (poder político) e dinâmicas de troca (economia). Já o mundo da vida condiz à esfera da producão simbólica. Efetivada pela linguagem, ela corresponde às redes de comunicação e significação e às visões de mundo, estabelecendo diálogo direto com fatos objetivos, normas sociais e, também, com conteúdos subjetivos. 
As consequências de um tal projeto de construção de esferas públicas particulares para a convivência democrática numa sociedade tão diversa, plural e desigual quanto a brasileira parecem evidentes. Ele pode alimentar não o desejado processo de aceitação e reconhecimento mútuo das diferenças e particularidades de cada grupo sociocultural específico, mas exatamente o autorreferenciamento, a fragmentação social e a intolerância recíproca.

(COSTA, 2002, p. 33.)

Em sentido ambivalente, mostra-se imprescindível que os diferentes grupos e culturas, na medida em que afirmam suas particularidades publicamente, formulem demandas que visem repercutir no conjunto da sociedade e assim tenham a possibilidade de endereçar suas vozes para uma arena púbica compartilhada em sentido amplo - a qual não deve ser confundida com uma esfera pública normativa, ao mesmo tempo genérica e restritiva, baseada num tipo de subjetividade hegemônica e excludente. Isso significa, entre outras coisas, poder contar com as plataformas institucionais e os meios de comunicação, na medida em que gozam de poder de influência e capilaridade sociais.

Inscrevendo-se nesses contextos, em particular nas instituições artísticas, os processos da mediação cultural e da "arte no interesse público" potencializam a sua capacidade de reverberar socialmente. Dada a heterogeneidade dos públicos e de seus códigos culturais e discursivos, assim como da diversidade de suas agendas, torna-se fundamental o engajamento em torno de processos de tradução que tornem tais códigos e agendas reconhecíveis e inteligíveis uns para os outros, inclusive no que eles possam ter de inconciliável entre si.

Quanto ao recorte trabalhado até aqui no presente capítulo, entendemos que tanto o projeto mediativo desdobrado no Guia para permanecer em Zurique como o projeto artístico materializado no Studio Butterfly operam, cada qual a seu modo, traduções culturais aptas a funcionar como referências, entre tantas outras, para essa tarefa. Com base nas ideias de Barros já mencionadas aqui, experiências como essas se mostram hábeis em gerar circuitos de "produção e circulação de sentidos", fazendo com que os atores neles implicados possam endereçar suas questões a círculos que transcendam os seus próprios. Ao "organizar e tornar públicos significados” engendrados a partir de vivências e lugares sociais específicos, tais experiências trazem consigo o potencial de atravessar e afetar "diferentes sistemas culturais” (BARROS, 2013, p. 10-11). Com isso, concorrem para a produção de descontinuidades na realidade, no sentido de esgarçar os critérios do que possa ser entendido como comum - enquanto algo que diga respeito ao conjunto da sociedade e, assim, venha a ser tratado como assunto de responsabilidade compartilhada.

Voltando às contribuições de Costa, cumpre salientar, ainda, que a arena pública corresponde a uma rede de relações difusa onde se processam intercâmbios comunicativos emersos dos mais diversos campos da vida social (COSTA, 2002, p. 12). Conforme temos procurado argumentar, 
tais campos se desdobram em esferas públicas parciais e temporárias, formando um circuito dinâmico e instável, onde se cotejam diferentes públicos e perspectivas. É nas zonas de interseção entre essas esferas, que conformam um circuito amplamente compartilhado, que as vozes e os debates por elas desencadeados podem produzir enunciados políticos capazes de extravasar os espaços discursivos específicos. Logo, é nas áreas de contato, e não em círculos fechados em si mesmos, que os interesses coletivos podem ser repactuados.

Segundo a linha de argumentação de Costa, isso estaria relacionado ao fato de que os segmentos minoritários da sociedade civil, organizados como associações voluntárias e/ou movimentos sociais, introduzem novos temas na “agenda pública” (COSTA, 2002, p. 13). Emergentes, eles seriam responsáveis pela ampliação e complexificação e, portanto, pela reconfiguração permanente da rede de espaços públicos discursivos. Recapitulando, esse multifacetado conjunto de atores reivindica o reconhecimento do caráter público de questões como, por exemplo, o racismo, a misoginia, a obstrução ao próprio corpo, a homofobia, a transfobia, a falta de moradia e de terra e o etnocídio (e genocídio) indígena. Baseados na perspectiva dos direitos, esses atores sociais introduzem no debate político problemáticas tradicionalmente invisibilizadas e exigem o reconhecimento de sua pertinência e urgência pelos demais círculos da sociedade.

As mobilizações comunicativas exercidas por eles, em lugar de apenas participar de uma esfera pública preestabelecida, normativa e genérica, constituem-na como tal, dado que definem não somente suas pautas, mas também suas formas de ação e comunicação. Nessa outra chave, a esfera pública se caracteriza como um contexto plural que demanda o exercício permanente das mediações e traduções. A elas caberia conferir legibilidade às iniciativas, enunciações e disputas imbuídas da construção de novos marcos socialmente reconhecíveis, identificados por nós como marcos comuns. Tais dinâmicas se mostram necessárias para a viabilização de uma convivência social realmente aberta aos processos de transformação.

Desse modo, a esfera pública passaria a ser concebida como instância múltipla, correspondente ao amplo e heterogêneo conjunto de debates ancorados no cotidiano dos atores que neles (e a partir deles) tomam posição, apresentando demandas específicas, porém concernentes ao espectro social em sentido amplo.

\subsection{A DIMENSÃO EXTRAINSTITUCIONAL DE MOBILIZAÇÕES DA SOCIEDADE CIVIL: O MOVIMENTO DOS ESTUDANTES SECUNDARISTAS}

Ainda de acordo com Costa, podemos dizer que os atores da sociedade civil e as respectivas comunidades às quais estão vinculados se encontram "enraizados" em contextos "pré-políticos" do ponto de vista do aparelho institucional do Estado. É justamente daí, do âmbito extrainstitucional, que tendem a "emergir os impulsos mais promissores para a renovação da democracia”. Isso se deve ao fato de que muitas dessas iniciativas não se reduzem ou se confundem com a "encenação da vida pública [exer- 
cida] pelos atores convencionais (grupos de interesses poderosos, partidos e agências públicas)". Tal encenação caracteriza, em larga medida, o cenário macropolítico nas democracias capitalistas (COSTA, 2002, p. 29, 35).

Com "perfis organizativos próprios", os agentes da sociedade civil se distinguem por "uma inserção específica na tessitura social", da ordem da experiência vivencial. Por isso, nenhuma instância institucional estaria mais apta do que as comunidades políticas da sociedade civil para identificar e sinalizar premências, denunciar injustiças e reivindicar mudanças relativas aos diferentes aspectos do cotidiano social, sobretudo no que tange ao reconhecimento das diferenças e à conquista de direitos, inclusive aqueles que ainda não integram o rol respaldado pelos dispositivos legais. Logo, suas demandas e contribuições democratizantes não devem ser lidas apenas pela lente de uma configuração político-institucional dada, haja vista que as postulações provindas dos círculos da sociedade civil não raro extrapolam os arcos dos direitos civis já convencionados e das políticas públicas responsáveis por garanti-los (COSTA, 2002, p. 35).

Um exemplo marcante nessa direção, que comentaremos apenas de passagem, pode ser verificado na reivindicação pela gratuidade no uso do transporte público coletivo. Foi ela que, inclusive, desencadeou as inéditas Jornadas de Junho de 2013, quando milhões de pessoas tomaram as ruas das grandes cidades brasileiras para protestar contra o aumento das tarifas. Organizada pelo Movimento Passe Livre (MPL), a luta em torno dessa pauta tem como princípio basilar o direito à cidade. De abrangência nacional, ela postula que os estados e municípios subsidiem integralmente o valor da tarifa, mediante o uso de recursos assegurados pelos impostos pagos pela população. Esse vislumbre propositivo pressupõe que os mais ricos tenham as tributações de sua renda e patrimônio alteradas pelo Estado em sentido crescente, de modo a viabilizar os fundos necessários à implementação de tal política ${ }^{25}$. Sua pauta prevê, além disso, a redução e a limitação do lucro das empresas de transporte coletivo contratadas pelo poder público. Entre os principais argumentos do MPL, está a constatação de que a mobilidade na cidade e o acesso aos serviços públicos gratuitos (nas áreas da saúde, da educação, da assistência, da cultura e do lazer) dependem de um transporte também gratuito, que garanta a universalização do uso dos demais serviços.

Ainda que formulem e pratiquem "mecanismos próprios de [ação e] comunicação", Costa dirá que as comunidades políticas constituídas no âmbito da sociedade civil "interagem" a todo tempo com as instituições do Estado (COSTA, 2002, p. 36). Resultantes de mobilizações em torno de determinadas problemáticas sociopolíticas - como no caso do passe livre -, essas interações se dão tanto pelo caminho da participação, através de

25 Acrescente-se que a parcela mais rica da população seria a principal beneficiária dos deslocamentos rotineiros dos trabalhadores (e consumidores) pela cidade, cabendo a ela, portanto, uma participação financeira efetiva e proporcional na sustentação dos subsídios para o transporte público. 
conselhos, conferências, audiências públicas e orçamentos participativos, como pela ação direta e interventiva, por meio de manifestações de rua, do bloqueio de grandes avenidas, de ações de "pular a catraca" ou mesmo de ocupações de terminais urbanos e edificios, para citar alguns exemplos.

Dado que tais agentes operam mediante "o enraizamento dos valores democráticos nas [suas] práticas cotidianas”, o que importa é, sobretudo, a conservação do seu caráter autônomo, extrainstitucional (COSTA, 2002, p. 36). É essa posição que possibilita a produção de descontinuidades em relação à série histórica de medidas tomadas ou postergadas pelo aparato político-institucional, cujo desenho corresponde a convenções frequentemente descompassadas e alheias às urgências de grupos sociais que contam com baixa representatividade nos poderes legislativo e executivo, em nível municipal, estadual e federal.

Em contrapartida, como insiste Costa, mesmo os "mecanismos [institucionalmente] construídos para a participação" da sociedade civil nos rumos da vida política não devem submeter os agentes civis à circunstância de "uma institucionalização imobilizadora” ou, ainda, de uma possível "cooptação política". "Delicado e sensível”, o imprescindível "ancoramento social" de que se valem esses agentes não deve ser simplesmente confundido e incorporado ao cabedal institucional, sob o risco da perda da autonomia dos entes civis e, portanto, de sua capacidade de "tradução e transmissão para a órbita política institucional dos anseios difusos gestados nos interstícios do tecido social” (COSTA, 2002, p. 36, grifos meus).

Nesse sentido e para concluir o capítulo, observaremos mais detidamente uma manobra de caráter extrainstitucional praticada por uma comunidade específica da sociedade civil em contraposição a medidas unilaterais anunciadas pelo governo do estado de São Paulo: o movimento de ocupação das escolas estaduais levado a cabo pelos estudantes secundaristas entre os anos 2015 e $2016^{26}$. Em coerência com nossos propósitos investigativos, lidaremos com esse acontecimento a partir de traduções das suas linhas de ação, todas elas ensaiadas por agentes da própria sociedade civil que se colocam numa posição mediadora entre as performatividades e enunciados políticos dos "secundaristas de luta" e a possibilidade de compreensão e cumplicidade pelos demais círculos sociais. Referimo-nos a educadores, intelectuais e artistas que, ao se solidarizarem com as pautas e mobilizações dos jovens estudantes, dedicam-se a desenvolver leituras e léxicos favoráveis ao reconhecimento, pela sociedade civil e também pelo Estado, das dimensões política, inventiva e comum das experimentações e reivindicações colocadas em cena pelos secundaristas. Compreendendo-a como um tipo de tradução textual dos eventos protagonizados pelos estudantes, iniciaremos a narrativa em torno do movimento pela

26 Inspirada na "Revolta dos Pinguins", nome pelo qual ficou conhecido o movimento contestatório dos estudantes chilenos deflagrado em 2006 (e retomado em 2011), a luta dos secundaristas brasileiros lançaria mão da mesma tática inaugurada pelos "Pinguins": a ocupação das escolas. 
abordagem da dupla de educadores Lilian Kelian e Julio Neres, à época vinculados, respectivamente, aos núcleos de Juventude e Educação Integral do Cenpec - Centro de Estudos e Pesquisas em Educação, Cultura e Ação Comunitária ${ }^{27}$. Por meio de artigo publicado pelo periódico digital HuffPost Brasil28, a dupla expõe ao leitor que o movimento dos estudantes se insurgia, num primeiro momento, contra o plano do governo paulista de "reorganização das unidades da rede [estadual] de ensino", cujo foco residia num amplo remanejamento que previa que "cada escola fosse responsável por apenas um nível de ensino". Oficialmente anunciada como uma medida que traria beneficios educacionais à comunidade escolar, a "reorganização" conjugava-se a um plano de redução de investimentos e otimização dos recursos destinados à pasta da Educação ${ }^{29}$. Os autores destacam, em contrapartida, que a natureza da medida vinha sendo criticada por especialistas da área da educação, inclusive porque carecia de "comprovações para seus supostos beneficios [pedagógicos]”. Além disso, sequer havia sido previamente discutida com a comunidade escolar (KELIAN; NERES, 2016).

De acordo com a dupla de educadores, o primeiro momento da mobilização - que remonta a 2015 - buscava "defender o espaço de convivência [dos estudantes] e seus vínculos afetivos na escola". Com a "reorganização escolar”, esse espaço de convivência e vínculo passou a ser diretamente ameaçado, pois a redefinição das faixas etárias atendidas por cada escola - quando não o seu fechamento puro e simples - faria com que uma grande parcela dos estudantes fosse obrigada a mudar de escola. Na leitura da dupla, a resistência dos jovens era uma resposta ao fato de que o governo estaria "ameaçando o espaço cotidiano deles de encontros, trocas, amizade e amor", na medida em que a escola representaria para a vida dos jovens "um espaço imprescindível para as suas relações”. Logo, os percalços provocados pela reorganização governamental não se limitariam à necessidade do deslocamento de irmãos com idades distintas para escolas diferentes e distantes entre si. Mais do que isso, ela eliminaria a possibilidade de "uma interação multietária muito importante e querida pelos estudantes” (KELIAN; NERES, 2016).

A fim de se opor e tentar impedir a consumação dessa decisão unilateral, os secundaristas lançaram mão da ocupação como um “dispositivo” de ação política direta, apropriando-se das escolas "a partir da necessidade de transforsem fins lucrativos, que se apresenta como entidade comprometida com a melhoria do ensino público brasileiro.

28 Pertencente à empresa de mídia TheHuffingtonPost.com, Inc., o periódico é produzido, além do Brasil, em outros dezoito países e regiões do mundo, entre eles: Austrália, Grécia, Mundo Árabe, Canadá, Espanha, Índia, Magrebe, Itália, Japão, África do Sul e Estados Unidos. Sua página no Brasil pode ser acessada em: <http://www.huffpostbrasil.com/>. Acesso em: 26 mar. 2017.

29 Além disso, havia rumores de que, com a "reorganização escolar", o governo paulista pretendia pavimentar o caminho para a transferência da gestão das escolas estaduais para as Organizações Sociais (OS), como já ocorre nas áreas da Saúde e da Cultura, por exemplo. 
mar e criar estratégias de luta”. Ao se instalar no ambiente escolar nesse outro registro - não apenas para frequentar as aulas da grade curricular, mas para habitar temporariamente os seus edificios -, os jovens exigiam que suas vozes, "antes completamente desconsideradas na discussão sobre políticas públicas educacionais”, fossem ouvidas e levadas em conta nos rumos da educação pública (KELIAN; NERES, 2016).

Com mais de duzentas unidades ocupadas, os jovens mobilizados foram percebendo, conforme a permanência nas escolas se estendia no tempo, que "suas reivindicações poderiam ser mais amplas", extrapolando a pauta inicial de barrar a "reorganização escolar". Isso se revelava como desdobramento de um tipo de experiência instauradora, na qual ação e organização eram deflagradas como instâncias correlatas e concomitantes, propícias à descoberta, em tempo real, de oportunidades de reinvenção das próprias dinâmicas escolares. Assim, parte significativa da agenda reivindicatória ia se desenhando simultaneamente a essa outra maneira de estar na escola - deslocada das amarras normativas e burocráticas da rotina escolar. Esse estado de devir teria propiciado que outras perspectivas pedagógicas fossem vislumbradas e testadas pelos secundaristas:

Ao promoverem aulas abertas com pessoas da comunidade e discussões com jovens de outras escolas, novas possibilidades se abriram: aulas mais interessantes, alunos com total acesso à biblioteca, grêmios estudantis livres, e não escolhidos pela diretoria, e sobretudo, mais participação nas decisões que afetam diretamente suas vidas. (KELIAN; NERES, 2016.)

Além disso, os jovens se dedicaram a intervir em aspectos estruturais das escolas por eles ocupadas, em grande medida marcados pela negligência. Desse modo, se incumbiam de limpar suas dependências, carpir seus terrenos, pintar suas paredes e realizar reparos pontuais em seus recintos e equipamentos. Também a alimentação era tratada por eles como uma frente crucial na dinâmica das ocupações. Priorizando os alimentos frescos e orgânicos, os jovens se organizavam e se alternavam no preparo de refeições cujos ingredientes eram doados por apoiadores e simpatizantes da sociedade civil, inclusive seus familiares e amigos.

O exercício de experimentação de uma outra escola ensejou, inclusive, a problematização e a repactuação das relações cotidianas entre os próprios estudantes. Kelian e Neres relatam, com relação a esse quesito, que inicialmente as "questões de gênero foram um problema" nas ocupações. Em contrapartida, o feminismo viria a adquirir centralidade nos debates e no dia a dia dos jovens ocupantes. Ainda que o caráter das ocupações fosse decididamente horizontal, diversas lideranças femininas despontaram durante o período de permanência nas escolas. Esse reposicionamento exigido pelas estudantes pode ser notado numa fala registrada pela dupla de educadores: "No começo, um menino disse que a gente tinha que limpar, que na casa dele era assim". Para depois emendar: "Hoje entrei na cozinha e ele tava [sic] lá, limpando com seu rodinho”. As questões 
relativas aos transgêneros também receberiam atenção dos secundaristas. A título de exemplo, um dos efeitos gerados pelas assembleias entre os estudantes diz respeito ao uso dos sanitários: "em uma das escolas [...] os jovens aboliram a separação dos banheiros feminino e masculino para dar conta de acolher os estudantes trans" (KELIAN; NERES, 2016).

Toda essa mobilização estudantil, que não só interrompeu o período letivo nas escolas ocupadas como também atraiu o apoio de parte da população e o respaldo do Ministério Público, gerou um significativo desgaste para o governo. A ponto de provocar a saída do então secretário de Educação, Herman Voorwald. Tal desgaste junto à opinião pública se acentuava em virtude do "uso brutal de força policial contra os adolescentes", que eram duramente reprimidos em seus atos de rua e também no interior das escolas ocupadas (KELIAN; NERES, 2016). No final de 2015, vendo-se pressionado, o governador Geraldo Alckmin anuncia a suspensão temporária do projeto de reorganização da rede estadual de ensino.

Isso não impediria que, no início do ano seguinte, a "reorganização" fosse retomada de maneira velada pelo governador, à revelia dos estudantes e do Ministério Público. Kelian e Neres registram que "apesar de as escolas estaduais paulistas terem recebido 70 mil matrículas a mais do que em 2015, foram fechadas [em 2016] 2.800 salas em todo o estado", conforme levantamento realizado pela Rede Escola Pública e Universidade, formada por professores e pesquisadores da área de política educacional. Já o levantamento da Apeoesp - Sindicato dos Professores do Ensino Oficial do Estado de São Paulo "estima o fechamento de 1.370 salas" (KELIAN; NERES, 2016).

Essa reorganização dissimulada desencadearia novos protestos por parte dos estudantes em 2016. Como no ano anterior, novas pautas se somaram às precedentes, tornando a luta ainda mais abrangente em seus objetos e propósitos. Desta vez, os secundaristas mobilizavam-se não só pela defesa das escolas de ensino regular, como também pelas escolas técnicas estaduais, as Etecs. Ao ampliar o arco das instituições de ensino sob protesto, os secundaristas traziam à tona a precarização a que essas outras escolas também vinham sendo submetidas, sobretudo em relação à falta de equipamentos imprescindíveis aos cursos técnico-profissionalizantes. Tal precarização incluía, ainda, diversas denúncias (e a posterior abertura de uma CPI) acerca do desvio parlamentar de verbas originalmente destinadas à compra de merenda.

O balanço realizado por Kelian e Neres indica que o rol de questionamentos postulado durante as ocupações de 2015 e 2016 denota que "os alunos estão se apropriando do debate sobre políticas públicas e recursos para a educação”. Desse modo, chamam para si e fazem valer os preceitos da LDB (Lei de Diretrizes e Bases da Educação Brasileira) e da Constituição Federal que referendam "a gestão democrática e a participação estudantil” nos processos de deliberação e controle dos expedientes escolares (KELIAN; NERES, 2016).

Importa-nos destacar que a emergência das ações dos secundaristas se dá pela via dissensual, a partir da instauração de uma luta que afronta o poder público, ao passo que se propõe a "reinventar a política e a escola”. Tal 
disposição dos jovens estudantes baseia-se "no diálogo e na potência da diversidade e do conflito" (grifo meu). De viés extrainstitucional, sua insurgência exerce um tipo de força inventiva e revigorante no estado letárgico da educação pública, fazendo circular outros imaginários e, com eles, "repertórios para se [re]pensar o currículo" e o próprio funcionamento da escola (KELIAN; NERES, 2016). Essa dimensão política é o foco da abordagem de Peter Pál Pelbart, filósofo que também se dedica a refletir e conceber traduções conceituais para o que ele identifica como "linhas de força” inerentes ao movimento dos estudantes secundaristas.

Seu exercício aparece condensado num texto concebido em forma de "carta aberta" ${ }^{\text {". }}$. A opção por esse formato deixa claro que o público a que se dirige a reflexão corresponde, em primeira instância, à própria comunidade formada pelos "secundaristas de luta", como se o autor fizesse questão de contar aos jovens como ele, na condição de filósofo, lê o movimento e seus efeitos. Chama atenção, nesse sentido, que o papel de público cabe ora a Pelbart, que se dedica a ler (e a traduzir conceitualmente) as performatividades e discursividades postas em cena pelos estudantes, e ora aos estudantes, que são endereçados textual e oralmente pelo filósofo para refletirem juntos a respeito da dimensão e da potência políticas dos seus atos.

Em seu texto, o autor lança mão de chaves interpretativas e figuras de linguagem vinculadas ao pensamento pós-estruturalista, no qual as perspectivas do desejo, da subjetividade e da singularidade aparecem como vetores fundamentais. Desse modo, Pelbart inicia sua carta afirmando que o "gesto coletivo" dos secundaristas surge como um dos "mais ousados na história recente do Brasil”. Tal afirmação se conecta a um aspecto destacado por ele no final do documento, quando aponta para uma "subjetividade política e coletiva”, perceptível no perfil de atuação dos secundaristas, de natureza "mais insurreta, mais anônima, mais múltipla, de movimento mais do que de partido, de fluxo mais do que de disciplina, de impulso mais do que de finalidades". Para o autor, a mobilização de tais forças pelos jovens, manifestas em confronto às decisões "a portas fechadas" do governo, "destampou a imaginação política em nosso País” (PELBART, 2016, p. 125, 129).

À metáfora da retirada da tampa (de um caldeirão?) e da consequente ebulição da imaginação política, o autor acrescenta a imagem do "corte": ao desencadear um processo autogestivo e radicalmente democrático, "ao mesmo tempo disruptivo e instituinte", as iniciativas dos secundaristas teriam produzido "um corte abrupto na percepção social sobre o ensino, a escola, a polícia, o Estado, o poder, o desejo”. É desse "corte”

30 A "Carta aberta aos secundaristas" foi lida por seu autor na Escola Estadual Fernão Dias Paes, no dia 28 de abril de 2016, durante um debate sobre Ética organizado por Dalva Garcia, professora da escola e da PUC-SP. Participaram do encontro alunos, pais, professores e funcionários da escola. Conforme conta Pelbart, na madrugada seguinte ao evento, estudantes do Fernão retomaram a ocupação de 2015, em solidariedade às recém-ocupadas unidades de ensino técnico do Centro Paula Souza. 
que resulta, segundo ele, a ruptura com um estado de normalidade e apatia. Seu primeiro efeito forçaria a percepção de que "o que até então era a trivialidade cotidiana, de repente torna-se intolerável”. Aqui, o intolerável diz respeito à naturalidade com que se aceitava um quadro político-institucional no qual as decisões sobre os equipamentos escolares ficavam a cargo, quase que exclusivamente, de gestores públicos "de gabinete". Mais do que isso, como numa comporta que se rompe, para usarmos uma terceira imagem, o movimento secundarista faria afluir a insatisfação represada diante de uma série de outras normativas sociopedagógicas, como: “a mercantilização da educação, as relações de poder vigentes dentro da escola, a disciplina panóptica, os modos desgastados de ensino, aprendizado, avaliação, até mesmo o objetivo da escola” (PELBART, 2016, p. 125-126). Como se vê, as imagens utilizadas buscam favorecer o entendimento da complexidade e da novidade de uma mobilização inesperada e, sobretudo, desejante, cuja leitura exige o exercício da construção de novas categorias. A propósito, a vocação aberta e polissêmica das imagens mostra-se bastante útil nessa tarefa.

A esse respeito, o filósofo comenta que o ato da ruptura traz consigo a dificuldade e o desafio de ter suas manobras e consequências devidamente compreendidas. Podemos dizer que isso se deve às descontinuidades provocadas por certas insurreições coletivas no continuum da história, fenômeno que o autor designa por "corte na continuidade do tempo político". Para ele, o "antagonismo ético" dos secundaristas produziu "um acontecimento no sentido forte da palavra" (grifo meu). Tão forte que "abriu um campo de possíveis", tornando não apenas viável, mas desejável, aquilo que até então sequer aparecia no horizonte de possibilidades dos alunos (PELBART, 2016, p. 125-126), como, por exemplo, o fato de conseguirem

ocupar e gerir os espaços que lhe são destinados, não apenas para reivindicar seus direitos, aprofundá-los, ampliá-los, mas também para experimentar a força de um movimento autogestivo, suas possibilidades inúmeras e inusitadas [inclusive aquelas que eles só puderam intuir e fomentar ao se envolverem corporalmente nas ocupações]. (PELBART, 2016, p. 126.)

A dificuldade de compreender essa ocorrência disruptiva e de lidar com as suas consequências deve-se, segundo o filósofo, ao fato de que ela "não pode ser lida apenas com as categorias disponíveis antes dela, categorias essas que a ruptura justamente está em vias de colocar em xeque" (PELBART, 2016, p. 125). É desse mesmo exercício de leitura crítica e de composição de novos léxicos que se ocupam os agentes comprometidos com as práticas da mediação e da tradução culturais. Suas iniciativas nessa direção condizem a um tipo de cooperação com os protagonistas das lutas sociais, denotando o sentido multidirecional dos processos colaborativos.

Malgrado a impossibilidade de compreendê-las por completo e de prever os seus resultados efetivos, o fascinante é pensar que "experimentações coleti- 
vas" como as deflagradas pelos secundaristas são capazes de produzir efeitos complementares: de um lado, provocar mudanças concretas e localizadas no cotidiano escolar e, de outro, inscrever no imaginário político novos precedentes e instrumentos para a intervenção numa dada realidade. Em outros termos, a insurgência dos secundaristas e suas formas de organização foram hábeis em conceber a realidade (escolar, mas não só ela) em outras bases.

Assim, a tarefa daqueles que se solidarizam com a luta dos secundaristas, buscando compreender, traduzir e fazer circular seus gestos, enunciados e desejos, seria a de seguir criando, junto com esses jovens e a partir de suas táticas, condições para que se possa "alargar o campo da política" e, portanto, forçar o esgarçamento de suas fronteiras no sentido de tornar comum - portanto, do interesse e da responsabilidade da sociedade em geral uma causa assentada na convicção de que "a escola deveria ser o coração de uma sociedade, e não seu apêndice agonizante” (PELBART, 2016, p. 128-129). A essa ideia do alargamento do território político, assim como de suas práticas, já havíamos aludido com base no pensamento de Costa. Para retomar tal passagem, conectando-a com a reflexão sobre o movimento dos estudantes, vale reforçar que esse processo é alavancado pelo aparecimento de "inovações sociais" aptas a pautar o debate político. Essas inovações estão relacionadas, de acordo com o sociólogo, à "emergência de novos atores sociais" dispostos a intervir na distribuição vigente dos pesos entre os interesses público e privado (COSTA, 2002, p. 32).

Sem dúvida, os secundaristas surgem no cenário político como "novos atores sociais”. Em seu caso, a referida redistribuição de pesos tem como trunfo, conforme aponta Pelbart, a invenção de "uma nova coreografia política”, exercida em contraponto "ao teatro esgotado e degradado da representação institucional”. Daí a importância de conservar sua vocação extrainstitucional, autônoma, no sentido de não se deixar fagocitar pelas estruturas político-institucionais vigentes. Essa outra "coreografia” expressa as "formas de vida" testadas e cultivadas pelos estudantes nas ocupações - caracterizadas, sobretudo, pela horizontalidade e pela autogestão compartilhada, num exercício de invenção de uma nova "subjetividade política e coletiva”. Logo, "alargar o campo da política” pressupõe reconhecer a dimensão igualmente política dessas formas emergentes de existir e de estar na escola (PELBART, 2016, p. 125, 128-129).

Um dos aspectos-chave dessa outra forma de vida experimentada pelos secundaristas transparece na disposição de resistir e se distanciar das "formas de vida que se têm imposto brutalmente nas últimas décadas”, com respeito, por exemplo, ao "produtivismo desenfreado aliado a uma precarização generalizada, [à] mobilização da existência em vista de finalidades cujo sentido escapa a todos, [à] capitalização de todas as esferas da existência”. Tais injunções tornaram-se onipresentes na sociedade, afetando diretamente o âmbito educacional, pois aí são preparados aqueles que ingressarão (ou já ingressaram) no mercado de trabalho (PELBART, 2016, p. 128).

A busca dos secundaristas por se distanciar dessas injunções revela-se não apenas em suas reivindicações em torno do incremento da qualidade do ensino, da diversificação dos formatos de aula, da melhoria das condições estrutu- 
rais do espaço escolar, do crescimento da participação do corpo discente nas decisões e da garantia de uma merenda digna e saudável. Conforme propõe a argumentação de Pelbart, ela se mostra também, e talvez principalmente, no "prazer em ocupar coletivamente um espaço antes policiado”. Foi na experiência coletiva e disruptiva propiciada pelas ocupações que se pôde "apreender um 'comum' que tem a ver com as redes, com as redes sociais, com a conexão produtiva entre os circuitos vários, com a inteligência coletiva, com uma sensorialidade ampliada” (PELBART, 2016, p. 128-129). O "apreender", aqui, é da ordem da experiência encarnada, notadamente distante do modelo de ensino-aprendizagem conteudista, burocrático e instrumental que define, em grande parte, a rotina escolar.

$\mathrm{O}$ "comum” a que o filósofo se refere condiz ao bem comum, àquilo que deveria pertencer a todos, indiscriminadamente, como "a água, a terra, a internet, as informações, os códigos, os saberes, a cidade”. Nesse ponto, a insurgência secundarista refletiria a tônica das formas de produção contemporâneas que primam pelo "livre compartilhamento do comum", buscando "tornar cada vez mais comum o que é comum", o que Pelbart chama de "comunismo do desejo". Isso confere, segundo ele, uma natureza "constituinte" ao movimento secundarista, na medida em que, além de lutar pelo bem comum nas escolas e nas ruas, os estudantes foram capazes de "suscitar diálogo e conexão com as diversas forças da sociedade civil”, oferecendo para essa mesma sociedade e para o poder público "uma verdadeira aula de ética e de política". Como público dessa "aula", Pelbart deixa-se afetar pela inteligência coletiva e pelo saber fazer dos jovens, buscando, em contrapartida, identificar e publicizar suas "linhas de força", a fim de "fortalecer aquelas direções que garantam a preservação dessa abertura" propiciada pelo movimento (PELBART, 2016, p. 125, 129).

A cumplicidade e a disposição para fomentar a circulação das perspectivas abertas pelos estudantes secundaristas em outros contextos e temporalidades adquirem corpo substancial num projeto artístico-mediativo do Grupo Contrafilé31, intitulado Espaço-dispositivo para conversar sobre a escola que queremos: se a escola se repensa, o que acontece com os outros espaços?. Desenvolvida por ocasião da exposição Playgrounds 2016, no Masp ${ }^{32}$, a pro-

31 Integram o Grupo Cibele Lucena, Joana Zatz Mussi, Jerusa Messina, Peetssa e Rafael Leona. Formado no ano 2000, em São Paulo, o Contrafilé se apresenta como um grupo transdisciplinar que investiga as relações entre arte, política e educação, com especial interesse pelos modos como tais relações favorecem a produção da cidade e de seus equipamentos em bases alternativas.

32 Em cartaz de 18 de março a 24 de julho de 2016 no Masp, Playgrounds 2016 contou com curadoria de Adriano Pedrosa, Julieta González e Luiza Proença. A exposição apresentou trabalhos inéditos de artistas e coletivos interessados nas distintas formas de engajamento dos públicos. Além do Grupo Contrafilé, participaram da mostra Céline Condorelli (França/Reino Unido), Ernesto Neto (Brasil), O Grupo Inteiro (Brasil), Rasheed Araeen (Paquistão/Reino Unido) e Yto Barrada (Marrocos). A reunião de seus trabaIhos sob esse mote fazia alusão ao espírito de Playgrounds, exposição individual do artista Nelson Leirner realizada no Vão Livre do Masp em 1969, ano em que o Museu foi aberto ao público na avenida Paulista. 
posição resultou na publicação de um livro intitulado $A$ batalha do vivo - termo utilizado pelo Grupo para designar a "rebelião do corpo afetado por uma situação macropolítica autoritária”, neste caso, as ações unilaterais do governo e a correlata repressão policial àqueles que a elas resistem. Trata-se de um compêndio que reúne textos, relatos, atas de encontros, fotografias, desenhos, diagramas e frases de protesto, a maior parte resultante dos esforços de agentes diretamente envolvidos com a proposição sediada no Museu. São eles: estudantes, educadores, artistas, antropólogos, psicanalistas, amigos e outras pessoas que estiveram ligadas às ocupações das escolas entre 2015 e 2016.

Tomaremos como base essa publicação para abordar o que entendemos como estímulo à extensão de uma esfera pública de debate ancorada numa problemática sociopolítica específica: a luta dos secundaristas voltada, em última análise, à construção de outra instituição escolar. Interessa-nos chamar atenção para o fato de que a proposição do Grupo Contrafilé lida com seus interlocutores a partir de critérios colaborativos. Portanto, o público com o qual o Grupo colabora encontra-se numa situação completamente distinta da dos públicos concebidos como entidades abstratas, classificáveis e administráveis pela instituição artística. Interagindo com os propositores do projeto e entre si, o público-colaborador de Espaço-dispositivo... usa a plataforma do Museu em prol de uma luta que ele já vem travando no contexto escolar, no sentido de a ela incorporar novas camadas e aliados.

Outro aspecto que merece ser destacado é que, diferentemente do Guia para permanecer em Zurique e do Studio Butterfly, a proposição Espaço-dispositivo... não inaugura uma articulação político-comunitária. Como vimos, tal articulação já se encontrava em curso desde 2015, tendo sido disparada e sustentada pelos próprios jovens engajados no movimento secundarista. Em vez de deflagrar um agrupamento de indivíduos mais ou menos dispersos frente a urgências que lhe dizem respeito enquanto comunidade, o que o Grupo Contrafilé faz é se aproximar (no sentido de se acoplar) e buscar contribuir para o fortalecimento de uma comunidade política preexistente, constituída temporariamente em torno de premências do campo educacional.

No texto de apresentação do referido livro, o Grupo Contrafilé comenta que, no final do ano 2015, seus integrantes haviam sido "atravessados pelo acontecimento de mais de duzentas escolas estaduais ocupadas por estudantes secundaristas" (grifo meu). A declaração sugere que, antes de tudo, os membros do coletivo sentiram-se afetados pela iniciativa e capacidade de mobilização dos estudantes. Isso nos permite dizer que os integrantes do Contrafilé, assim como Pelbart, se tornaram público das performatividades e enunciados colocados em cena pelos secundaristas.

A respeito da capacidade que os movimentos sociais e as associações voluntárias da sociedade civil têm de ocupar a cena pública, chamando atenção da mídia e do público para os "temas que trazem à luz", Costa se baseia no sociólogo Rüdiger Schmitt-Beck para comentar que o sucesso da empreitada depende "da habilidade das associações e movimentos em manipular os recursos comunicativos de que dispõem”. Tal habilidade se 
manifestaria na capacidade desses movimentos de "produzir, seja pela espetacularização de suas ações, seja através de um trabalho adequado de relações públicas, fatos com conteúdo noticioso" (COSTA, 2002, p. 18-19). No caso dos secundaristas, além do vigoroso ato de ocupar as escolas, é notório o poder simbólico das performances e imagens que os estudantes lograram produzir durante os períodos de ocupação. Dentre aquelas que geraram maior efeito midiático, podemos eleger os atos de rua envolvendo bloqueios praticados pelos secundaristas em grandes avenidas da cidade de São Paulo, para o que eles se valeram de cadeiras escolares e de seus próprios corpos, não raro utilizando este mobiliário como escudo para se defender da repressão policial. Ademais, os estudantes se mostraram hábeis na circulação de informações e denúncias pelas redes sociais e na organização de eventos públicos nas escolas, assim como na veiculação de uma miríade de lemas e palavras de ordem. Nos enunciados a seguir, colhidos nas ocupações, nas redes sociais, nos veículos de imprensa e em conversas com os próprios "estudantes de luta", é possível captar o espírito do movimento e algumas de suas principais exigências:

A escola é nossa; Estudantes pela classe; Escolas de luta; Contra o retrocesso na Educação; Escolas livres; Ocupamos o presente, para não invadirem o futuro; Não mude minha escola, mude seu governo; Não tem arrego; Nossa arma é o nosso conhecimento; Educação não é mercadoria; Enquanto a Educação for mercadoria, os estudantes continuarão em rebeldia; Sem luta não há conquista; Não feche minha escola; Ensino público é direito; Secundaristas contra a terceirização; Hoje a aula é na rua; Ninguém fica para trás, nenhum a menos; $\mathrm{O}$ Estado veio quente, nóis já tá fervendo, quer desafiar, não tô entendendo, mexeu com estudante vocês vão sair perdendo; Tira tesoura da mão, para de roubar merenda e investe em Educação; Não acabou, tem que acabar, eu quero o fim da Polícia Militar; Acabou a paz, isto aqui vai virar o Chile; Pisa ligeiro, pisa ligeiro, quem não pode com a formiga não atiça o formigueiro; Mãe, pai, tô na ocupação, e só pra tu saber eu luto pela Educação; Se jogar bomba, nóis chuta, tira uma foto e arrasa na pista, vem secundarista, vem secundarista; Não deixe a escola tirar a sua vontade de aprender; Minha escola, minha escolha; Alckmin mata aula; A gente ocupa, quem invade é a polícia; Estar vivo é pensar com o corpo.

O conjunto de ações comunicativas operado pelos estudantes fez com que o movimento logo adquirisse grande visibilidade, atraindo apoiadores solidários à sua causa - e também opositores. O Grupo Contrafilé foi e segue sendo um desses apoiadores que, magnetizado pela luta dos secundaristas, com eles veio a colaborar. Cumpre notar, nesse pormenor, que é o grupo de artistas que adere à mobilização da comunidade 
(politicamente ativa) com a qual se dispõe a colaborar, e não o contrário. Conforme relatam os seus integrantes, a insurgência e o modo de atuação dos secundaristas se entrelaçavam com muitos dos interesses que o Grupo vinha cultivando desde a sua formação, em particular a sua predisposição para "repensar o que chamamos socialmente de 'escola”" (GRUPO CONTRAFILÉ, secundaristas de luta e amigos, 2016, p. 9-10). Na condição inicial de público atento às manobras de resistência e invenção dos estudantes, o Grupo nutria-se do imaginário político produzido no contexto das ocupações pelas ações dos secundaristas.

O convite recebido na mesma época para integrar a exposição Playgrounds 2016 representou a oportunidade de o Contrafilé construir, conforme expressão dos seus integrantes, "um trabalho comum" com os secundaristas, no qual a experiência como público das discursividades ativistas formuladas e difundidas pelos estudantes alavancasse uma proposição baseada no diálogo e na construção conjunta. Desse modo, o chamado do Museu se desdobraria num dispositivo favorável não apenas à repercussão da luta dos estudantes, mas também à organização de um fórum vocacionado a discutir, refletir e produzir novos léxicos políticos a partir das "linhas de força" do movimento. Tratava-se, sobretudo, de desenvolver um projeto que funcionasse como um espaço de encontro e trabalho. Daí a opção por promover intercâmbios entre alguns estudantes $^{33}$ e figuras como o antropólogo Pedro Cesarino, a psicanalista Suely Rolnik, os educadores José Cavalhero e André Gravatá e o mestre quilombola TC Silva, além dos mediadores do Masp André Mesquita, Thais Olmos, Pedro Andrada, Lucas Oliveira e Luiza Proença, uma das curadoras da mostra. A exposição Playgrounds 2016 ensejou, portanto, a reunião dessas e de outras pessoas num ambiente concebido pelo Grupo Contrafilé sob o nome de Espaço-dispositivo ${ }^{34}$, uma espécie de "instalação composta por diversos ambientes de trabalho" (GRUPO CONTRAFILÉ, secundaristas de luta e amigos, 2016, p. 10-11).

Montado no mezanino da galeria expositiva situada no subsolo do Museu, o Espaço-dispositivo se tornou, durante o período da exposição, o lugar a partir do qual diferentes situações de elaboração discursiva compartilhada foram disparadas pelos envolvidos no projeto. Além de $A$ batalha do vivo, compreendido pelo Grupo como um "livro-dispositivo", nos parece importante chamar atenção para um mobiliário híbrido que funcionaria como o principal set dos encontros: a "mesalousa".

33 Durante a elaboração deste capítulo, tive oportunidade de conversar com Cibele Lucena, uma das integrantes do Contrafilé, a respeito da quantidade de secundaristas envolvidos diretamente com o projeto. Conforme ela conta, nas atividades sediadas no Masp, o número variou de quatro a doze estudantes, enquanto nos encontros realizados nas ocupações esse número variou de vinte e cinco a cinquenta. Lucena reforça a opção do coletivo, recorrente em seus projetos, por trabalhar com grupos numericamente reduzidos, com vistas a favorecer interlocuções e imersões efetivas.

34 Ao nomear o espaço dessa forma, parece-nos que o Grupo produz um deslocamento semântico na noção convencional de "espaço expositivo". 
Como o nome indica, esse construto combinava dois elementos presentes no ambiente e na rotina escolares: a mesa e a lousa. Ao fundir tais suportes, o Contrafilé propunha que ocorresse não apenas a reunião de pessoas provindas de diferentes contextos, formações, faixas etárias e trajetórias de vida ${ }^{35}$, mas também o registro gráfico e coletivo, em tempo real, dos temas ali abordados. Isso porque todos os presentes nos encontros tinham à disposição o tradicional "giz de lousa" para realizar suas inscrições no tampo da mesa ou, melhor, na superficie da lousa transformada em mesa ${ }^{36}$. Ao mesmo tempo que discutiam questões e práticas relacionadas ao processo educacional e às táticas de luta, os envolvidos contavam com a possibilidade de registrar e socializar anotações, esquemas, desenhos, frases de protesto, citações etc. Parte dessas inscrições foi, inclusive, incorporada ao conteúdo da publicação $A$ batalha do vivo, mediante transposições realizadas pelo uso de câmeras fotográficas e de softwares de tratamento de imagem.

Considerando a natureza inventiva da "mesalousa", e sua correlata funcionalidade favorável a elaborações discursivas compartilhadas, mostra-se oportuno olhar para esse dispositivo sob a luz das ideias de Sheikh, que já mencionamos, acerca de experiências artísticas comprometidas com a produção de esferas públicas temporárias. Referimo-nos, em particular, à passagem em que o crítico e curador alude ao papel-chave das "plataformas comunicativas" constituídas e ativadas durante a vigência de experiências colaborativas com públicos específicos (SHEIKH, 2008, p. 128). Sem dúvida, a "mesalousa" representa um elemento decisivo para o funcionamento da plataforma materializada por Espaço-dispositivo para conversar sobre a escola que queremos: se a escola se repensa, o que acontece com os outros espaços?.

Presente em praticamente todos os encontros do projeto, Cavalhero pontua, em alusão às dinâmicas realizadas a partir da "mesalousa", que "nada ali se ensinou”. De acordo com sua linha de raciocínio, além da predisposição dos envolvidos, a própria interação proporcionada pelo móvel - com as pessoas sentadas à sua volta, no mesmo nível, sem posição de distinção e com giz à disposição - sugeria situações de compartilhamento de saberes e insights (CAVALHERO, 2016, p. 37). A subversão do espaço pedagógico testada pela "mesalousa" era, portanto, dupla: além de dar origem a uma inusitada peça de mobília, que conjugava a reunião de pessoas com o exercício da elaboração gráfico-textual, ela também possibilitava situações educativas horizontais, completamente diversas das que caracterizam, em larga medida, o cotidiano das escolas estaduais paulistas - mas não só delas -, marcadas pela acentuada hierarquização entre a direção, os professores e os alunos.

35 Essa heterogeneidade apresenta-se como condição crucial para a constituição de um espaço efetivamente público.

36 Além da caixa de giz, também ficavam disponíveis sobre a "mesalousa" livros, reproduções fotográficas e textos impressos. 
Mas se, por um lado, "nada ali se ensinou", por outro, todos os presentes "queriam aprender, queriam nutrir corpos e relações para pensar e arquitetar novos modos de se fazer e estar na escola”. No limite, buscava-se desfazer "os rígidos e obsoletos contornos de uma realidade educacional" que, justamente, se pretende reinventar a partir dos precedentes criados pelos próprios secundaristas durante as ocupações. Inclusive porque os esforços voltados à imaginação de outra escola eram ali canalizados por situações pedagógicas experimentais, de aprendizagem mútua, que ensaiavam formatos vocacionados a se desvencilhar dos vícios herdados de uma pedagogia conteudista, instrumental e hierarquizante. Nesse sentido, cada conversa entabulada ao redor da "mesalousa" originou "uma grande escrita-desenho-emenda”, constituída a partir de "um processo de pensamento plural” (CAVALHERO, 2016, p. 37).

Da mesma maneira que procuravam formular critérios e formatos alternativos para as dinâmicas pedagógicas, os colaboradores do projeto dedicavam-se a encontrar palavras e a desenvolver conceitos capazes de traduzir os vetores de ação do movimento secundarista em sua complexidade, a fim de lhes conferir legibilidade. É nessa direção que Rolnik, presente num dos encontros de Espaço-dispositivo..., excepcionalmente realizado na ocupação do Centro Paula Souza, sugere aos estudantes: "Eu gostaria muito de ouvir vocês sobre o que aconteceu com o corpo a partir das ocupações. Vocês sentem mudanças? É possível colocar essas mudanças em palavras?" (grifo meu). Complementando tal indagação, a psicanalista expõe sua compreensão de que "juntos, a gente pode ir encontrando as palavras", ao passo que "quando chegamos na palavra isso nos ajuda a descrever melhor o que está acontecendo” (GRUPO CONTRAFILÉ, secundaristas de luta e amigos, 2016, p. 55).

Algumas das respostas dos estudantes à questão de Rolnik afirmavam: "A partir do momento que vamos para uma ocupação, a gente passa a não estar só na sala de aula, naquele quadrado fazendo sempre as mesmas coisas, sem aprender quase nada [...]". Ou ainda: "Aquela comodidade de ficar só na sala de aula vendo tudo acontecer, ver a escola, o estudo desmoronando [...], e a gente lá sentado sem fazer nada, acho que isso revolta. Agora tenho sede, quero justiça [...]”. Percepções como estas levariam a psicanalista a externar sua "impressão" de que, antes do momento das ocupações, o corpo dos estudantes personificava "um corpo que não esta[va] vivo, como se fosse um morto vivo, um zumbi, inerte, só seguindo o que mandam”. Porém, com a iniciativa das ocupações, "parece que o corpo acorda, tá [sic] vivo e toma a vida nas mãos” (GRUPO CONTRAFILÉ, secundaristas de luta e amigos, 2016, p. 55-56). Diante desse comentário, uma estudante detalha:

Eu queria explicar um pouco por que a gente se enquadrava no "padrão zumbi” e o que fez a gente se mover. [...] Para mim, a palavra que definia os estudantes é submissão. A educação não é de liberdade, de construir pessoas, pensamentos críticos pra que esses possam voar livres. Ela sempre foi dominadora e padronizada. Ela 
produz zumbis em massa, como no videoclipe do Pink Floyd. Somos produzidos em série, o professor é o centro, o medo; diretor, então, coordenador, nem se fala! E, a partir do momento em que no Ensino Médio temos pelo menos um professor bom, de História, de Filosofia, aliás aulas essas que são muito poucas comparadas a Matemática - temos uma aula de Filosofia, uma aula de Sociologia por semana e o material é pouquíssimo -, e este nos instiga a procurar uma educação que liberta, a gente começa a pensar com a própria cabeça, aí esse zumbi se dá conta do tanto de coisa que tá [sic] acontecendo em volta e começamos a nos levantar, um por um [...]. (GRUPO CONTRAFILÉ, secundaristas de luta e amigos, 2016, p. 57.)

A iniciativa do Contrafilé de promover discussões como essa, bem como de buscar garantir a circulação dos enunciados daí resultantes, baseia-se na compreensão do Grupo de que "tornar legiveis" os vislumbres e os anseios dos secundaristas corresponde, em si, a um "ato político" (grifo meu). Partindo dessa convicção, seus integrantes propõem-se a "inventar estratégias para fazer circular a emergência de tempos e espaços da vida e para a vida, inscrevendo na imaginação coletiva aquilo que se passa em um espaço determinado"(GRUPO CONTRAFILÉ, secundaristas de luta e amigos, 2016, p. 100). Esse é um aspecto que interessa sobremaneira à nossa investigação, na medida em que aponta para a produção daquilo que Sheikh chama de "acordos imaginários”, e que nós identificamos como "marcos comuns". Trata-se da busca por estabelecer novos compromissos coletivos através da catalisação de esferas públicas formadas por atores sociais emergentes, que as ancoram em problemáticas e vivências cotidianas específicas. Tal busca deve envolver, também, o exercício da tradução e publicização das discursividades e demandas formuladas nessas esferas.

Como já sugerido por Pelbart, a ruptura provocada pelos estudantes secundaristas num estado de normalidade e apatia - responsável por encobrir as mazelas do sistema educacional - exige-nos a invenção de categorias epistemológicas e léxicos capazes de abarcar, em termos conceituais e comunicacionais, a dimensão disruptiva das ações instauradas e dos desejos manifestos pelos estudantes durante as ocupações. É por isso que, segundo os integrantes do Contrafilé, devemos enxergar alguns "gestos aparentemente banais" praticados pelos estudantes no interior de suas escolas como potentes "atos políticos". O Grupo se refere a afazeres que, no contexto doméstico, apresentam-se como triviais, mas que no ambiente de uma escola pública ganham uma dimensão completamente distinta, com os "alunos limpando (a escola), pintando a parede (da escola), cozinhando (na escola) comidas frescas (tudo porque querem, porque acreditam que isso é importante como gesto)" (GRUPO CONTRAFILÉ, secundaristas de luta e amigos, 2016, p. 100). Deslocados do domínio privado para o âmbito público, tais gestos adquirem o estatuto 
de enunciados políticos representativos de uma agenda estudantil comprometida com a reinvenção tanto da escola como do modo de estar nela. Ao cotejar a insurreição dos estudantes secundaristas com a resistência histórica dos povos indígenas no Brasil, Cesarino frisa a importância de compreender os "léxicos particulares" utilizados pelas comunidades políticas em suas lutas, no sentido de perscrutar a natureza de suas "categorias produtivas”. Logo, o léxico e as respectivas operações mobilizadas pelos estudantes incluem, segundo o antropólogo, "agenciamentos, estratégias, poéticas, alianças, bases, redes, conexões entre distintas capacidades”, apresentando como ponto comum o fato de denotarem "dinâmicas em construção" (CESARINO, 2016, p. 187-188).

Durante um dos encontros realizados ao redor da "mesalousa", Cesarino debate com um estudante as diferenças entre os termos "base" e "rede". O estudante faz uma inflexão a respeito da insuficiência da lógica representativa exercida por partidos políticos e grupos influentes, comentando:

[...] quando esses partidos ou grupos levantam bandeiras, é porque acham que podem fazer a diferença, mas fazer sempre a mesma coisa e esperar resultados diferentes, acho que é a maneira mais tosca de se tocar uma luta. Eu acho que uma forma de luta diferente vem dessa ideia de que é a base que tá [sic] lutando, não é um partido, não é nada desse tipo [...]. (GRUPO CONTRAFILÉ, secundaristas de luta e amigos, 2016, p. 57.)

Diante dessas ponderações, o antropólogo procura problematizar a noção de "base no singular": "Você tá [sic] falando em uma base, não é uma base, são várias bases. E essas bases precisam se conectar" (GRUPO CONTRAFILÉ, secundaristas de luta e amigos, 2016, p. 141). A mesma indagação em torno da pertinência da ideia de base, usada para designar o tipo de movimento empreendido pelos estudantes, leva Cesarino a lançar mão da noção de rede:

[...] A base é uma coisa em cima da qual a gente constrói algo. Então, se você constrói algo é porque tem alguma coisa em cima dessa base. [Já] uma rede, não vai nada em cima [...] a rede não tem algo em cima nem algo em baixo. A rede tem lados e todos os lados são iguais a eles mesmos. Então, o que vocês tão [sic] fazendo não é mais uma base, é uma rede. [...] A maneira pela qual vocês se comportam e vocês ativam [o circuito] não é a da base, é a da rede. E é isso que o MPL [Movimento Passe Livre] fazia e faz ainda e é o que aconteceu em vários outros lugares do mundo. Essa é a tática e essa tática é extremamente poderosa e tem que se multiplicar. O problema da base é de soma, você tem que somar, o da rede é de multiplicação. (GRUPO CONTRAFILÉ, secundaristas de luta e amigos, 2016, p. 141.) 
Além de se coadunar com o caráter horizontalizante, ramificado e extensivo do movimento instaurado pelos estudantes secundaristas ${ }^{37}$, a noção de rede também é usada por Cesarino para constatar que a "escola não é só o que está dentro [dela]”. De acordo com o seu argumento, isso tem a ver com o fato de ela estar implicada numa trama social muito mais ampla e complexa que, necessariamente, afeta e é afetada "pelo que acontece dentro da escola”. Logo, os problemas inerentes ao sistema educacional público devem ser reconhecidos e enfrentados pela sociedade em geral, como "um problema nosso", e não apenas por quem está dentro de suas unidades de ensino, sob o risco, em caso contrário, de que seus problemas estruturais e conceituais sigam se perpetuando (GRUPO CONTRAFILÉ, secundaristas de luta e amigos, 2016, p. 143). Daí que o dissenso secundarista traga, em seu cerne, o desejo de produzir um sentido comum para a causa da educação pública.

Aqueles que se sensibilizam e se cumpliciam com o chamado dos estudantes, como é o caso do Grupo Contrafilé e dos interlocutores presentes em Espaço-dispositivo..., encaram o desafio de tentar assegurar, ainda conforme Cesarino, "que essa vitalidade não se dissipe". Agregando novas camadas semânticas às exigências manifestas pelos estudantes, ao mesmo tempo que fomentam a circulação de seus imaginários políticos, esses e outros agentes contribuem não apenas com a possibilidade de sua insurgência "deixar rastros" na realidade sociopolítica. Eles também apostam que ela seja capaz de lastrear "a produção de um outro modo de existência”, na medida em que aponta para a "produção de uma nova [forma de fazer] política” (CESARINO, 2016, 186).

Baseando-se no pensamento do sociólogo Jean Tible, os integrantes do Grupo Contrafilé associam o tipo de luta travado pelos estudantes à práxis de uma "nova esquerda", tendência que caracterizaria parte expressiva dos movimentos sociais contemporâneos. Antes mesmo dos "secundaristas de luta”, também o Movimento Passe Livre já vinha sendo considerado sob tal ótica ${ }^{38}$. De acordo com o entendimento do Grupo, essa outra forma de fazer política se manifesta pela chave do pragmatismo, por meio de mobilizações nas quais "aquilo que é imaginado está totalmente colado a uma prática", dando origem a "uma nova linguagem, um novo imaginário”. Nesses casos, “é a própria vida, em todas as suas dimensões, que se torna o terreno da política”, cujas fronteiras são permanentemente

37 Em relação ao modo como as ocupações rapidamente se alastraram pelas escolas da rede estadual de ensino de São Paulo, vale pontuar que a cada dia que passava dezenas de novas unidades eram ocupadas, com parte significativa de seus alunos aderindo à luta e à tática de apropriação temporária dos edifícios escolares, sem que para isso houvesse qualquer centro de comando deliberando sobre as etapas do movimento.

38 Em virtude do trabalho de base (ou seria de rede?) desenvolvido pelos integrantes do Movimento Passe Livre nas escolas públicas, muitos estudantes já vinham se envolvendo diretamente com a luta em torno do transporte público e da gratuidade da tarifa. Essa experiência política se refletiria, de diferentes modos, no movimento de ocupação das escolas pelos estudantes. 
forçadas e alargadas. Para tratar dessa imbricação entre o que se imagina e o que se pratica, o Contrafilé contrapõe a tradicional forma-comício, que se prestaria a "falar sobre" certas pautas, à ação direta, em que os gestos instituintes dos membros de uma determinada comunidade política acontecem "no momento mesmo da enunciação" (GRUPO CONTRAFILÉ, secundaristas de luta e amigos, 2016, p. 135, 143). Sem dúvida, o ato de ocupar as escolas ${ }^{39}$ surge como exemplo emblemático dessa diferença nos modos de protestar e, ao mesmo tempo, de produzir efeitos na realidade imediata e, quiçá, vindoura.

Para a nossa investigação, o principal aspecto a ser ressaltado em todo esse processo condiz ao fato de que a emergência de novos atores políticos, neste caso os estudantes secundaristas, teria funcionado como alavanca para uma série de iniciativas imbuídas da compreensão, da tradução e da publicização das exigências pleiteadas, bem como das "categorias produtivas” operadas pela comunidade estudantil mobilizada. No entanto, por outro lado, os próprios secundaristas demonstraram capacidade de se fazer ouvir pelos demais círculos da sociedade civil e pelo governo estadual, prescindindo das instâncias de "mediação representativa", como os partidos políticos e as Uniões dos Estudantes (nacional, brasileira, estadual e municipal). Destarte, em vez de falar pelos estudantes, os integrantes do Contrafilé e os demais agentes reunidos pelo Grupo se predispunham a falar com eles - considerando as diferentes acepções implicadas nesta preposição. Ao se vincularem sob esse registro, eles experimentavam um estado de colaboração no qual enunciação e escuta se alternavam com vistas à construção de um pensamento conjunto em torno das problemáticas escolares e, também, das próprias formas de luta utilizadas para intervir no quadro educacional vigente.

Deve-se reforçar, também, que o trabalho colaborativo ensejado pelo Espaço-dispositivo... se beneficiou do respaldo institucional, uma vez que o Grupo Contrafilé, enquanto coletivo responsável pelo agenciamento do projeto, pôde contar com uma série de recursos providos pelo Masp. Aí se incluem aspectos materiais, como o espaço expositivo (nesse caso, tornado um dispositivo); a produção do mobiliário requerido para os encontros e para a extroversão de alguns de seus desdobramentos; os valores financeiros necessários para viabilizar o envolvimento de todos os interlocutores; a preparação e a impressão do livro $A$ batalha do vivo etc. Aí também se agregam os recursos imateriais, como o capital simbólico do Museu e a legitimidade sociocultural de que goza essa instituição artística ${ }^{40}$, o que tenderia a contribuir em alguma medida para o reconhecimento, por outros círculos sociais, da pertinência e da urgência das demandas postuladas pelos estudantes.

39 Cumpre pontuar que a tática de ocupação de edifícios e terrenos (no caso, desocupados) já vem sendo praticada de forma sistemática, durante as duas últimas décadas, por movimentos sociais de luta pelo direito à moradia no Brasil.

40 Recentemente, após mudanças na direção e no corpo téc nico do Museu, assim como em sua política institucional, o Masp retomou uma posição proeminente no circuito artístico-cultural da cidade e do país. 


\subsection{ASPECTOS COINCIDENTES ENTRE O "GUIA", O "ESTÚDIO" E O "ESPAÇO-DISPOSITIVO"}

Para finalizar, repassemos os aspectos coincidentes revelados pela aproximação entre os projetos abordados ao longo do capítulo: Guia para permanecer em Zurique; Studio Butterfly; e Espaço-dispositivo para conversar sobre a escola que queremos: se a escola se repensa, o que acontece com os outros espaços?.

De saída, apontamos que a escolha desses projetos esteve orientada por um critério anunciado no título do capítulo, a saber: a noção de catálise. Partindo dela, procuramos desenvolver uma investigação centrada em iniciativas mediativas e artísticas que se ocupam, sobretudo, do estímulo à formação e dinamização do que identificamos como esferas públicas temporárias e parciais. Isso se dá, como pudemos ver, por meio da organização e da consequente potencialização de movimentos gerados por agentes (propositores e públicos) que, de maneira colaborativa, mobilizam-se em torno de certas problemáticas sociopolíticas. Tais agenciamentos coletivos teriam nas práticas mediativas e artísticas, portanto, importantes plataformas não apenas para a sua catalisação, mas também para a sua reverberação a partir do marco institucional.

Devemos recapitular, além disso, alguns pontos tratados tanto por Arendt como por Deutsche, inclusive em virtude de sua complementaridade. Em relação à primeira, importa anotar que os três projetos refletem, cada um a seu modo, a premissa de que a "condição humana" passa, necessariamente, pela aparição pública do sujeito. Tal aparição baseia-se (nos contextos democráticos) na exigência por reconhecimento e acesso aos direitos, o que também envolve a declaração e a exigência de novos direitos, ainda não reconhecidos e respaldados. Na esteira dessa constatação, Deutsche dirá que certas vertentes contemporâneas das artes visuais conformam um campo proficuo para a aparição de indivíduos e grupos minoritários, em virtude de procedimentos hábeis em conferir visibilidade e circulação a seus códigos, enunciados e agendas. Os projetos em questão, ao lidar com públicos específicos, lançam mão de linguagens e expedientes artísticos para conferir não só visibilidade, mas também legibilidade às performatividades e discursividades de comunidades envolvidas em pleitos por reconhecimento e, portanto, pela possibilidade de pautar o debate político.

Com essas exigências, as comunidades atuantes nos três projetos afirmam o caráter público de suas lutas, propugnando que as especificidades e demandas que as sustentam esgarcem e, com isso, ressignifiquem as balizas que demarcam os interesses comuns - de responsabilidade da sociedade em geral. Isso não deve ser confundido com a sua mera inclusão num quadro normativo - a esfera pública burguesa, por exemplo - que apenas incorporasse novos elementos até então externos a ele, mantendo-se incólume. Daí a busca por produzir, a partir de gestos oposicionais e da consequente tentativa de alargamento das fronteiras políticas, novos marcos comuns.

Em que pese a variedade de abordagens adotadas pelos projetos aqui coligidos e comentados - ora com ênfase na prática mediativa (Guia...), ora com 
ênfase na prática artística (Studio...), ora equilibrando ambas (Espaço-dispositivo...) -, todas elas operam mediante a lógica colaborativa. Tal opção faz com que os trabalhos se desdobrem no tempo, propiciando a formação (ou a extensão) de esferas públicas ancoradas em problemáticas sociopolíticas localizadas. Sua duração depende, portanto, do engajamento e da disposição de seus membros por mantê-las vigentes. Em sintonia com os pressupostos apresentados por Landkammer para definir os processos de natureza "colaborativa”, nota-se que os exemplares da nossa tríade se deslocam do registro "participativo”, na medida em que as definições em torno de suas dinâmicas e desdobramentos não cabiam exclusivamente aos propositores dos projetos, tampouco foram estipuladas a priori. Em lugar disso, puderam ser arquitetadas durante os períodos de convivência entre propositores e públicos que, ao colaborarem entre si, tomavam posição nas e a partir das plataformas constituídas por cada um dos projetos. Houve, ainda, casos em que as situações foram diretamente inspiradas em práticas que já vinham sendo desenvolvidas pelos públicos do projeto, como no agenciamento do Grupo Contrafilé.

Por fim, cumpre ressaltarmos que os três projetos conformam, como sugerem suas próprias designações como "guia”, “estúdio” e "espaço-dispositivo”, o que Sheikh nomeia como "plataformas comunicativas". Ao publicizar posicionamentos parciais daqueles que, por meio dessas plataformas e de seus dispositivos, endereçam outros círculos sociais, tais projetos distanciam-se de qualquer pretensão de parecerem imparciais ou neutros em suas abordagens e propósitos - lembremos que esse era um dos princípios de funcionamento da esfera pública burguesa. Ao contrário disso, eles procuram evidenciar o lugar de onde falam, assumindo posições claras em prol de comunidades específicas. Assim, comprometem-se com a tradução e a difusão de agendas sociopolíticas compreendidas, em meio a tantas outras, como cruciais para a transformação da realidade. Por esse motivo, concebem a produção do comum em bases dissensuais. 


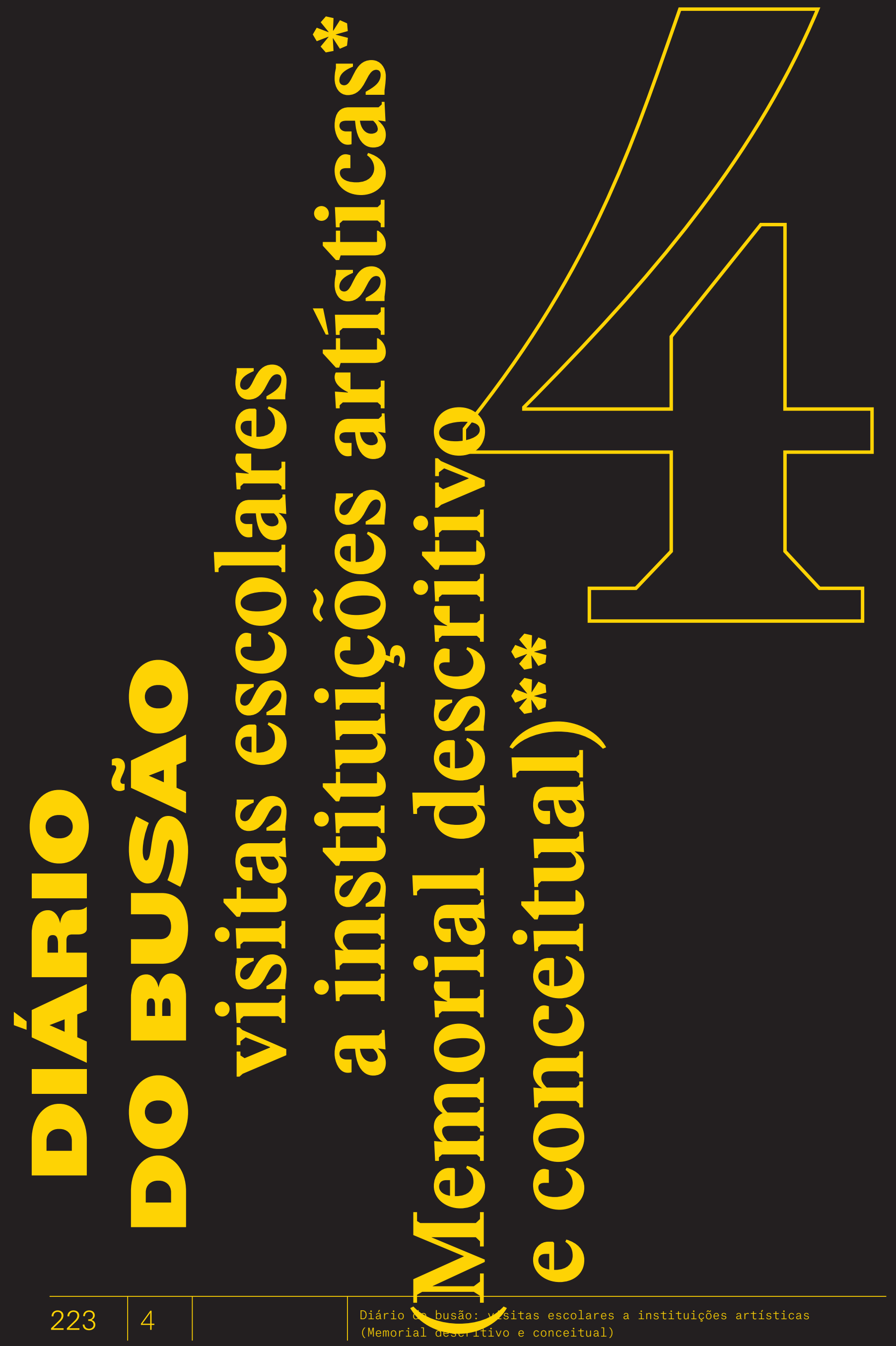


Tangueiros e sambistas transitavam entre os tecidos

sociais, e nesse trânsito traficavam símbolos, gírias,

hábitos e comportamentos [...].

- LIVIO TRAGTENBERG

Seja o aluno do seu estudante.

- PAUL B. PRECIADO

O Diário do busão: visitas escolares a instituições artísticas surge de um projeto mais amplo, envolvendo outros proponentes, intitulado Mediações em trânsito. Elaborado coletivamente por mediadores e artistas à época envolvidos com o grupo de discussão Mediação Extrainstitucional (que segue vigente e com o qual sigo colaborando), tal projeto foi redigido no ano 2013 , tendo em vista sua submissão ao edital Rumos Itaú Cultural 2013-2014, cuja comissão avaliadora acabou não o selecionando. Além de mim, se engajaram em sua estruturação: Cayo Honorato, Viviane Pinto, Alberto Tembo, Stella Ramos, Leandro Ferro e Flavio Aquistapace. Conforme se pode ler em nosso dossiê de inscrição no referido edital, o projeto visava produzir uma publicação, reunindo elaborações diversas, a partir de lugares discursivos como as artes visuais, a cartografia, a crítica da cultura, a literatura e a psicanálise - conforme as trajetórias de seus proponentes colaboradores: os mediadores infiltrados. Tais elaborações ocorrerão a partir das infiltrações de cada um desses mediadores em ônibus que conduzem os grupos de estudantes às instituições culturais para visitas a exposições. Como um desdobramento desse projeto coletivo que, até o momento, não chegou a se efetivar como tal - embora ainda seja possível que o grupo retome a iniciativa de colocá-lo em prática -, o Diário do busão representa a primeira experiência deflagrada a partir do Mediações em trânsito. Ele corresponde, portanto, a um movimento empreendido voluntariamente por mim, na condição de um dos autores do projeto original, mediante a anuência de todos os demais.

** Uma versão parcial deste memorial serviu de base para a comunicação realizada no $26^{\circ}$ Encontro Nacional da Anpap - Memórias e Inventações [sic], na Pontifícia Universidade Católica de Campinas, em setembro de 2017. 
Durante a produção do Diário do busão: visitas escolares a instituições artísticas, quando parte do seu conteúdo já vinha sendo publicizado, uma pessoa interessada e atenta ao trabalho ${ }^{1}$ me procurou para apresentar uma palavra que, embora eu desconhecesse, parecia condensar em si a verve do diário em questão: a palavra-ônibus. Além de mencionar a existência desse substantivo no léxico português, tal pessoa me colocou a par da sua definiÇão: palavra de uso coloquial permeável a uma variedade de significados. Suas acepções são tantas que não chegam a comportar delimitação semântica formal, como podemos conferir em: troço, legal, coisa, chique, chato, caso, aquilo, negócio, fato, absurdo, caos e ato. Ao incorporar a natureza da palavra-ônibus como sua lógica de produção discursiva, é como se o Diário adquirisse o estatuto de um veículo linguístico específico, movido pela possibilidade de, junto aos estudantes e a partir de suas manifestações, esgarçar as delimitações de certas acepções e convenções caras ao campo artístico-institucional, no sentido de desafiar sua frequente unidirecionalidade e, ainda, com vistas a introduzir novos sentidos em seus sistemas simbólicos.

Essa operação semântica se dá a partir de ônibus que se deslocam de diferentes bairros em direção ao centro expandido de São Paulo - onde se concentram os principais equipamentos de arte da cidade -, transportando crianças e jovens em fase escolar para conhecer e interagir com o que têm a oferecer as instituições artísticas. Combinando os sentidos literal e metafórico desse trasladar, compreende-se que os estudantes-passageiros-visitantes atravessam a instituição com seus modos de se comportar, interagir e falar (ao mesmo tempo que são por ela atravessados), provocando o alargamento e a ressignificação de sua plataforma discursiva ${ }^{2}$.

No caso do Diário, as "palavras-ônibus" usadas para verter textualmente os índices desses atravessamentos são ainda desdobradas nos “desenhos-ônibus". É mediante a articulação entre verbo (escrita) e imagem (desenho) que procuro traduzir certos usos, atitudes, falas, gestos, formulações e ações dos estudantes na relação com as ofertas institucionais, com especial atenção àqueles

2 Se tomarmos as visitas escolares pela ótica do atravessamento, torna-se possível concebê-las como intervenções realizadas pelos grupos de estudantes nos contextos expositivos. 
que não se coadunam com os planos colocados em prática por essas mesmas ofertas. Logo, o que está em jogo é a produção de contradiscursos em trânsito e desde o outro, mediante a confrontação de diferentes sensibilidades e parâmetros simbólico-valorativos, tensionando, disputando e ampliando a gama de significados implicados nas visitas mediadas dos estudantes a esses locais.

A opção por acompanhar, além do percurso na exposição, os traslados de ônibus e o embarque e desembarque na escola deve-se ao entendimento de que a visita a um local até então desconhecido para grande parte dos estudantes não se limita ao tempo de permanência nesse ambiente. 0 “antes" e o “depois" do período na instituição artística são cruciais, entre outros motivos, pois é na ida que comumente são verbalizadas as expectativas das crianças e jovens quanto ao que eles encontrarão ${ }^{3}$, enquanto na volta são geralmente expressas suas percepções e opiniões acerca do que acabaram de ver e vivenciar durante a incursão no equipamento recém-visitado ${ }^{4}$. Soma-se a isso o fato de que tais momentos revelam-se propícios à manifestação dos mais diversos comportamentos, assuntos e ações por parte dos estudantes, uma vez que os traslados de ônibus condizem a interregnos abertos entre as dinâmicas e normas da escola e da instituição artística - um "ponto cego" entre elas -, apresentando-se como instantes oportunos para a extroversão daquilo que encontra pouco ou nenhum espaço nesses locais de aprendizagem.

Além disso, ao tratar das ofertas institucionais, e dos bens artístico-culturais que elas procuram tornar acessíveis, através da "lente" do ônibus e dos descolamentos por ele franqueados ${ }^{5}$, criamos uma zona de contágio discursivo. Isso porque, além das referências que os estudantes já trazem consigo, as situações por eles vi-

3 A seguir podemos conferir um exemplo de manifestação no momento da ida por ocasião de uma das visitas ao Instituto Tomie Ohtake: Professora: "Lá no Instituto Tomie Ohtake não vai poder tocar em nada". Aluna: "Nem no chão? E como é que a gente vai andar por lá?"

4 Aqui temos um exemplo de enunciado surgido no momento da volta, por ocasião da visita ao Masp: Já dentro do ônibus, o menino solta: "O museu por dentro foi chato, mas por fora foi legal".

5 Nesse quesito, chamo atenção para um paralelo surgido durante a redação deste memorial: em A cidade é uma só?, filme dirigido por Adirley Queirós, vemos (literalmente) as cidades de Brasília e Ceilândia através da "janela-lente" do velho automóvel dirigido por um corretor de imóveis, que vai e volta inúmeras vezes pelas avenidas expressas da primeira e pelas ruas tortuosas da segunda. O Diário, por sua vez, apresenta (metaforicamente) os ambientes institucionais de arte e as formas de ali estar dos estudantes pela "janela-lente" dos ônibus fretados que os transportam dos bairros à região central da cidade. 
venciadas durante os trajetos percorridos com o ônibus 6 influem de diversas maneiras em suas formas de interagir, perceber e interpretar o ambiente expositivo e seus elementos, produzindo contaminações entre diferentes contextos e regimes simbólicos. Partimos da ideia de que os ônibus e sua vocação itinerante favorecem passagens e influências entre eles.

\subsection{O DIÁRIO EM TERMOS PRÁTICOS}

Objetivamente, o Diário corresponde a um experimento que combina as atividades do artista e do mediador. Tal manobra pressupõe o uso, a modulação e a ressignificação de procedimentos e repertórios que venho trabalhando, ao longo dos últimos doze anos, nas minhas trajetórias simultâneas - aqui imbricadas - nas áreas da criação artística ${ }^{7}$ e da mediação cultural ${ }^{8}$. Entendido como um trabalho em curso9, ele corresponde à “prática artística" - em diálogo com o "exercício teórico" - da minha pesquisa de mestrado na linha de Poéticas Visuais, que apresento sob o título geral de Públicos em emergência: modos de usar ofertas institucionais e práticas artísticas. Sua natureza processual possibilita, entre outras coisas, um tipo

6 Que incluem transições na paisagem, engarrafamentos, ocorrências nas vias, conversas, brincadeiras, músicas, paqueras, algazarra, consumo de alimentos, contemplação, lembranças, segredos, provocações, desentendimentos, broncas etc.

7 Como artista, tenho meu trabalho representado pela Galeria Virgilio desde 2009. Desde que iniciei minha produção, participei de exposições no Centro Cultural São Paulo (em exposição individual no Programa de Exposições 2008 e na coletiva Mano fato mano, em 2014), na Funarte do Rio de Janeiro (onde fui contemplado com o Prêmio Projéteis Funarte de Arte Contemporânea 2006), na Galeria Vermelho (nas mostras coletivas Situ/ação: aspectos do documentário contemporâneo, em 2006, e Verbo, em 2007), no Ateliê397 (em exposição individual intitulada Papeluchos, em 2009), no Paço das Artes (na coletiva Festival dispositivo, com curadoria do coletivo Cine Falcatrua, em 2007) e na Red Bull Station (em exposição individual intitulada Diário do busão, em 2016). Em colaboração com Rafael Campos Rocha, Fábio Tremonte e Marcelo Comparini, realizei a curadoria do projeto expositivo Gabinete, que esteve em cartaz em São Paulo (na Galeria Virgilio, em 2008), Recife (no Museu Murilo La Greca, em 2008) e Florianópolis (no Museu Victor Meirelles, em 2009).

8 A partir do ano 2005, atuei nos programas educativos das seguintes instituições de São Paulo: Museu Lasar Segall (2005-6), Centro Cultural Fiesp (2005), Pinacoteca do Estado (2006), Itaú Cultural (2006-7), Fundação Bienal (2010) e Paço das Artes (2007-8), onde cheguei a coordenar o Núcleo Educativo. Desde 2008, atuo no Sesc São Paulo, num primeiro momento como animador cultural na unidade de Santo André, posteriormente como animador sociocultural na unidade Vila Mariana e, hoje, como assistente técnico na Gerência de Estudos e Desenvolvimento, na Administração Regional do Sesc.

9 A expressão "trabalho em curso" é derivada do conceito de work in progress. Tomo essa derivação de empréstimo aos artistas Jorge Menna Barreto e Ricardo Basbaum, que a têm empregado como uma atualização do conceito original em inglês, com vistas a, por um lado, conservar o caráter contínuo de uma investigação artística e, por outro, evitar o sentido de progresso, que sugeriria um tipo de compromisso (por nós indesejado) com a linearidade e a perspectiva desenvolvimentista do modernismo.

\begin{tabular}{l|l|l}
4 & 4.1
\end{tabular}


de duração favorável à concomitância entre a produção, a circulação e o debate acerca dos enunciados traduzidos e veiculados pelo suporte Diário. Ademais, propicia uma espécie de retroalimentação como efeito direto da recepção pública do trabalho, conforme podemos constatar na incorporação da lógica inerente à palavra-ônibus ao processo de compreensão e constituição do Diário.

Sua elaboração envolve a minha infiltração em ônibus que conduzem turmas de estudantes da rede pública de ensino, ou do terceiro setor ${ }^{10}$, a instituições de arte da cidade. Minha presença inusitada durante esses traslados e roteiros de visitação - posto que eu não exerço a função nem de professor, nem de guia turístico e tampouco de mediador institucional, mas de alguém que "apenas" toma notas num bloco de papel - ocorre por ocasião das visitas agendadas e mediadas às exposições sediadas em tais instituições, assim como aos seus acervos e conjuntos arquitetônicos. O termo “instituição artística" serve-nos, até a presente fase do trabalho, para designar dois museus de arte, um museu da imagem e do som, um instituto com foco em arte contemporânea e moderna, uma bienal de arte contemporânea e uma edificação emblemática da arquitetura moderna. Nominalmente, estamos falando do Masp, da Pinacoteca do Estado de São Paulo, do MIS - Museu da Imagem e do Som, do Instituto Tomie Ohtake, da $32^{\mathrm{a}}$ Bienal de São Paulo e da Casa Modernista ${ }^{11}$.

Cumpre pontuar, também, como se dá a minha entrada no circuito de visitações escolares a tais instituições. Atuando em equipamentos de arte e cultura desde o ano 2005, passei a me envolver a partir de então com uma ampla rede de profissionais vinculados, entre outros, aos seus departamentos educativos. Considero, inclusive, algumas dessas pessoas como interlocutoras diretas do trabalho materializado no Diário, no sentido de entendê-las como pares imprescindíveis a este processo crítico-investigativo que, assumindo um caráter extrainstitucional, busca colocar entre parênteses certos preceitos, crité-

10 O terceiro setor abarca iniciativas privadas originadas no âmbito da sociedade civil, mas com finalidade pública, como ONGs, associações e centros assistenciais. Trata-se de uma expressão utilizada, inicialmente, nos Estados Unidos para designar diferentes organizações sem vínculos diretos com o primeiro setor (público, o Estado) e o segundo setor (privado, o mercado).

11 Inicialmente, vínhamos utilizando a expressão "instituição cultural". Porém, o recorte de equipamentos visitados ao longo do processo revelou-se focado, sobretudo, nas linguagens das artes visuais e da arquitetura, afastando-se do caráter polivalente de instituições como o Centro Cultural São Paulo, as unidades do Sesc São Paulo, o Centro Cultural da Juventude e as Fábricas de Cultura, por exemplo. Daí a opção por adotar o termo "instituição artística". 
rios e metodologias adotados pelos programas educativos institucionais na relação com seus públicos.

Pois bem, é o trânsito por essa rede que me facilita a anuência dos agentes desses departamentos para acessar a agenda de visitas escolares ${ }^{12}$. Tal acesso me possibilita entrar em contato diretamente com as escolas, com o intuito de me apresentar e solicitar autorização para acompanhar as visitas vindouras, expondo o meu objetivo de realizar um tipo de mediação documentária focado nas formas de atuação e nas respostas dos estudantes àquilo que se lhes apresenta e ocorre nos momentos de visitação e também durante os traslados de ônibus.

No que tange à minha interação com os estudantes nos dias em que ocorrem as visitas, não parto de um protocolo preestabelecido de como me apresentar ou me dirigir a eles, deixando que cada ocasião sugira o instante e o modo como isso deva acontecer. Assim, ora os professores me apresentam, ora tomo iniciativa de me apresentar, ora comento o motivo da minha presença isoladamente com alguns alunos ou a minha apresentação é provocada pela curiosidade e interpelação dos próprios estudantes.

Além disso, não faz parte do meu acompanhamento das visitas intervir com qualquer tipo de proposição direcionada ao grupo, tampouco com a realização de entrevistas ou a aplicação de questionários. Em lugar disso, limito-me a estar presente e atento àquilo que se passa durante o transcurso das visitas, abdicando de propostas pedagógicas que pudessem partir de mim em relação aos estudantes ou contar com a minha contribuição direta. Coloco-me, sobretudo, na posição de público das performatividades e discursividades dos estudantes e de seus professores, testando formas de traduzi-las e difundi-las. A essa posição acrescenta-se, ainda, o fato de que eu mesmo acabo participando da visita, a exemplo dos estudantes, como fruidor daquilo que se apresenta ao longo do caminho,

12 Há nessa iniciativa algo que a aproxima das táticas de hackeamento. A Wikipédia nos coloca a par de que, no campo da informática, o hacker corresponde a um agente que se dedica "a conhecer e modificar os aspectos mais internos de dispositivos, programas e redes de computadores". Em virtude dos conhecimentos adquiridos em suas extensas investigações, ele frequentemente logra produzir "soluções e efeitos extraordinários, que extrapolam os limites do funcionamento 'normal' dos sistemas como previstos pelos seus criadores". No caso do Diário, cujo âmbito de atuação refere-se não à informática, mas às instituições de arte, é possivel notar certas preocupações coincidentes às do hacker, na medida em que também nos interessa produzir soluções e efeitos que extrapolem aquilo que se encontra previsto nas políticas e planos institucionais, o que implica, entre outras entradas possíveis, se imiscuir em suas práticas de acolhimento e endereçamento dos públicos, como, por exemplo, as visitas escolares. 
através da janela do ônibus, e durante o percurso pelas obras em exposição, mediante a moldura institucional.

Trata-se de uma opção justificada pelo fato de que o trabalho do Diário concentra-se na minha interposição a uma situação pedagógica e a um formato organizacional não apenas dados, como também consagrados: as visitas mediadas ofertadas pelas instituições artísticas por meio de seus programas educativos, as quais são sistematicamente utilizadas pelas escolas no rol de suas atividades externas.

Assumindo essa posição não interventiva - ao menos junto aos estudantes -, dedico-me a realizar durante as visitas breves anotações e esboços num bloco de papel pouco maior do que a palma da minha mão. Posteriormente, esses mesmos registros gráficos funcionam como referências para um exercício de tradução textual e visual de certas cenas presenciadas e comentários ouvidos por mim. Evidentemente, isso implica na reescrita e no redesenho das passagens anotadas, num processo que combina fato e ficção.

\subsection{O PROCESSO DE TRADUÇÃO}

Entre os momentos de anotação no bloco e da impressão dos desenhos e excertos finalizados no Diário, há etapas que subsidiam e viabilizam o que aqui estamos chamando de tradução. Semanas (ou até meses) depois de ter esboçado os registros presencialmente, retorno ao bloco que contém as anotações referentes a determinada visita. Ao fazê-lo, inicio um levantamento de imagens através da plataforma Google Imagens, tomando por base as "senhas" anotadas nas páginas do bloco. Reúno, então, fotografias, desenhos e demais peças visuais ali disponíveis, selecionando aquelas que possam me auxiliar na reapresentação gráfica, já no âmbito do Diário, das situações protagonizadas pelos estudantes, e também por seus professores, durante a visita em questão.

Escolhidas as imagens correspondentes às cenas que pretendo redesenhar, realizo uma espécie de "decalque modificado" a partir de cada uma delas. Ou seja, me baseio em aspectos-chave de determinada imagem extraída do Google para, ao mesmo tempo, proceder a alterações relativas ao posicionamento e à forma de certos elementos, ao acréscimo ou subtração de itens, à redefinição de cores, entre outras mudanças. Modificado e colorido com aquarela, esse decalque dá origem ao que chamo de "matriz". 
Produzida em papel vegetal, ela é escaneada e enviada ao designer gráfico com quem tenho trabalhado na elaboração do Diário13, para ser vetorizada e, posteriormente, diagramada e combinada aos demais desenhos e excertos textuais de determinada lauda desse compêndio.

Quanto aos excertos apresentados no Diário, eles também são formalizados a partir daquilo que foi anotado no bloco durante o acompanhamento das visitas. Assim como ocorre com os desenhos, as breves anotações textuais passam por um processo de reelaboração, através da edição, da síntese e, em alguns casos, da transcriação das ocorrências e comentários, a fim de lhes conferir legibilidade e expressividade - com sua natureza fragmentária sendo preservada. No caso dos comentários, opto por utilizar aspas, de modo a indicar que o enunciado partiu, por exemplo, dos estudantes. Há, ainda, casos em que as passagens anotadas textualmente dão origem a novos desenhos, ou seja, a desenhos que sequer chegaram a ser esboçados no bloco. Para proceder a tal transição do código textual para o visual, lanço mão de um procedimento similar ao descrito acima, utilizando palavras-chave no Google para encontrar imagens que lhes sejam correspondentes e que me auxiliem nessa tradução.

Com cada uma de suas laudas assumindo o formato de um cartaz A3 ${ }^{14}$, o Diário é impresso por meio da técnica da risografia. De origem japonesa, a máquina Risograph opera por um método de impressão que combina aspectos/efeitos mecânicos e artesanais. Isso se dá em virtude de um tipo de impressão que, embora automático, utiliza recursos análogos aos da serigrafia, o que confere ao conteúdo estampado uma visualidade que, ao invés de disfarçar, evidencia os detalhes reticulares, as imperfeições da aplicação da tinta e os desalinhos (entre as áreas de cor e entre estas e as linhas dos desenhos) gerados no processo de impressão. Tais características mostram- se convergentes à natureza do Diário na medida em que

13 Responsável pela vetorização dos desenhos e diagramação dos conteúdos do Diário, o designer gráfico Guilherme Martinez vem colaborando com a formalização visual do projeto desde o seu início, no começo de 2015.

14 A escolha das folhas em tamanho A3 e, ademais, a opção por não encaderná-las devem-se à variedade de usos imaginados para o Diário. Entre outras formas, inclusive aquelas não previstas aqui, ele poder ter suas laudas funcionando como: a) pranchas espalhadas sobre mesas coletivas de estudo e discussão, b) cartazes exibidos conjuntamente em contextos expositivos, c) folhas avulsas distribuídas em diferentes ambientes e/ou círculos e d) peças isoladas fixadas em paredes ou murais incógnitos. A definição e a abrangência desses usos não se restringem a mim, uma vez que são compartilhadas com pares mediadores, educadores, curadores, gestores e artistas, dependendo inclusive de seus interesses e iniciativas em utilizar o Diário. 
conformam e agregam, de maneira pronunciada, mais uma camada às etapas de tradução das situações presenciadas durante as visitas. Com isso queremos dizer que, ao revelar em seu resultado o processo em si da estampagem, a impressão risográfica acaba por reforçar o fato de que os relatos visuais e textuais do Diário resultam de artifícios narrativos. Reforça, ademais, o fato de que a linguagem não é transparente, tampouco neutra, visto que possui uma espessura própria na qual se encontram sobrepostos pontos de vista, repertórios, escolhas, técnicas e formas de codificar próprias de quem a maneja. Daí que a evidenciação dessas diferentes etapas da tradução mostre-se importante, no sentido de reiterar que se trata de uma versão dos fatos - que inclusive incorpora a dimensão ficcional.

A seguir, apresentamos de maneira decupada um exemplo pontual presente no Diário, a fim de demonstrar como se dá, passo a passo, o processo de tradução verbo-visual das situações que testemunho durante os acompanhamentos das visitas. Usaremos como referência um desenho produzido a partir da minha infiltração em uma visita à $32^{a}$ Bienal de São Paulo, em cuja legenda definitiva pode-se ler: Enquanto aguardamos o mediador aparecer para iniciar a visita, a galera brinca de fazer rizoma no gramado. 


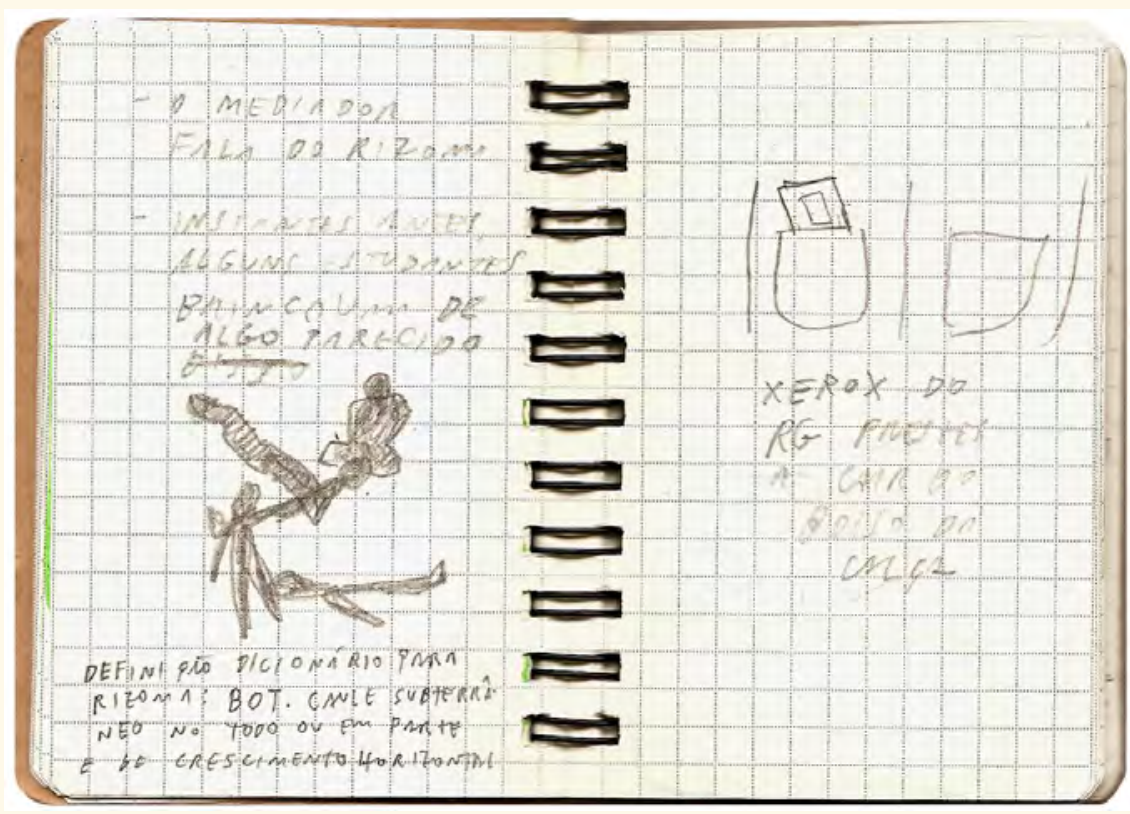

Etapa 1: Anotações e esboços realizados por ocasião do acompanhamento da visita.

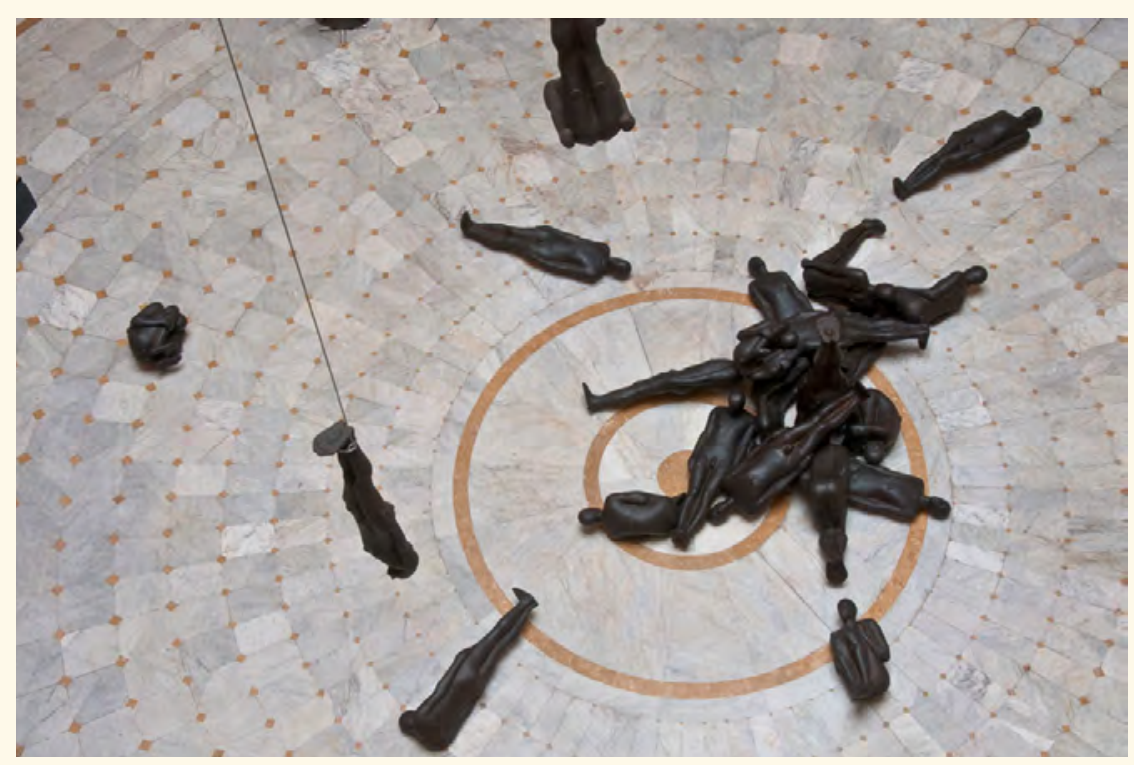

Etapa 2: Uso de registro fotográfico encontrado no Google Imagens, referente à mostra Still Being [Corpos Presentes], do artista Antony Gormley, realizada em 2012 no CCBB do Rio de Janeiro. 

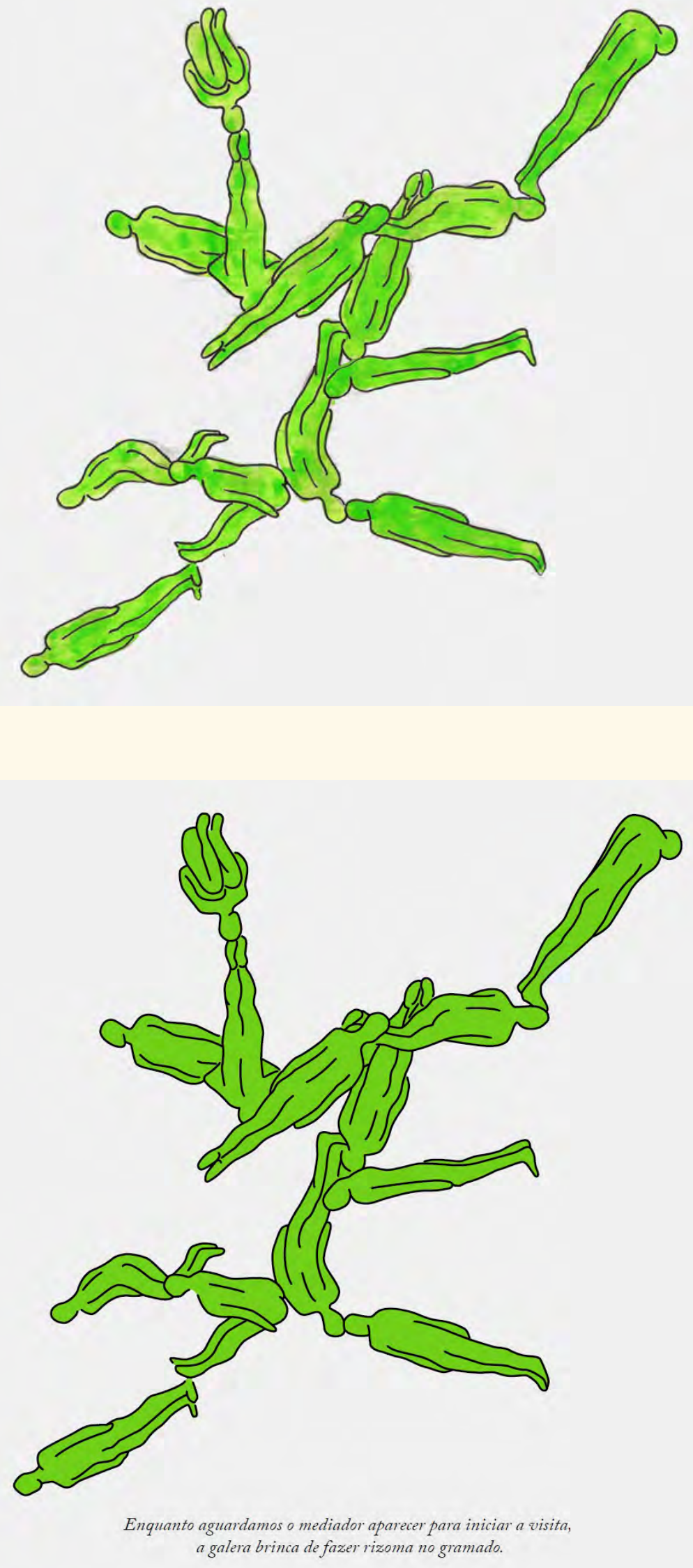

Etapa 3: Elaboração de matriz em papel vegetal, resultante do decalque modificado do registro fotográfico apresentado na página anterior.

Etapa 4: Vetorização do desenho e da respectiva legenda. 


\subsection{POR OUTRA FORMA DE DOCUMENTAR A PRESENÇA DOS ESTU- DANTES NOS CONTEXTOS EXPOSITIVOS}

A opção por acompanhar turmas de alunos da rede pública e do terceiro setor - de unidades situadas, em sua maioria, fora do centro expandido da cidade - deve-se ao fato de que, nas ações e discursos que anunciam o compromisso socioeducativo das instituições de arte, esse público aparece como o seu principal beneficiário. Isso se evidencia, por exemplo, quando consideramos a quantidade exponencial de visitas mediadas realizadas, através do esquema de agendamentos, com grupos escolares das redes estadual e municipal nessas instituições, os quais representam, via de regra, o maior percentual de visitantes atendidos pelos programas educativos ${ }^{15}$. Tal ênfase é justificada pela constatação de que os estudantes das escolas públicas, provenientes em sua maioria de núcleos familiares com menor nível de renda e escolaridade, são pouco ou nada estimulados em seus círculos imediatos de convivência a frequentar os espaços dedicados à exibição da produção artística socialmente legitimada. Daí que tanto a escola como a instituição de arte devam se incumbir de exercer um contrapeso a tal lacuna no processo de formação cultural dessas crianças e jovens, proporcionando-lhes o acesso a esses espaços.

Embora coerente, é comum que essa mesma lógica acabe por "achatar" as complexidades próprias às situações de interação dos estudantes com as ofertas artístico-culturais promovidas pelas instituições. Tal achatamento decorre de uma perspectiva pedagógico-institucional que enquadra esses estudantes na categoria genérica de "carentes culturais", acolhendo-os principalmente com base na identificação daquilo que lhes falta, como a familiaridade com as linguagens da arte e com os códigos de conduta exigidos nos ambientes expositivos. Faltas essas que a instituição, na condição privilegiada de núcleo irradiador de cultura e de local favorável ao exercício da cidadania, se comprometeria a dirimir. Em contrapartida, a ênfase na iniciação do outro, quando não problematizada e rela-

15 Para termos uma noção mais concreta dessa ênfase, tomemos como exemplo a 29a edição da Bienal de São Paulo (2010), que se caracterizou pela retomada, no âmbito dessa instituição, de um programa educativo pujante, orientado para um amplo atendimento de visitantes escolares. Mediante o agendamento de visitas e a correlata mediação realizada pelos educadores da Bienal, foram atendidas um total de 212 mil pessoas. Desse universo, 42\% provinham de escolas estaduais, $36 \%$ de escolas municipais, $13 \%$ de escolas particulares e 9\% de ONGs. Fonte: Relatório de gestão e contribuições à sociedade (2010-2011), Fundação Bienal de São Paulo. Disponível em: <http:// www.bienal.org.br/publicacao.php?i=2107>. Acesso em: 4 abr. 2017. 
tivizada, tende a obstruir a via contrária desse mesmo processo, qual seja, a possibilidade de o outro glosar, afetar, negar ou mesmo desvirtuar os discursos e propósitos postulados pela instância que ocupa a posição de provedora de conhecimento e cidadania.

Participando dessa "equação iniciática" frequentemente à revelia dos seus interesses e, não raro, de modo desavisado ${ }^{16}$, esses estudantes são endereçados por uma gama de abordagens que se, por um lado, buscam lhes proporcionar uma fruição das obras artísticas respaldada por instrumentos educativos, por outro, desaparecem com aquilo que se desvia desse plano, justamente por não coincidir com as pautas pedagógicas e os pretensos benefícios facultados pela instituição. São esses desacordos que procuramos sondar e repercutir com o Diário.

Quando entram em desacordo com as ofertas institucionais e as normativas por elas estipuladas, os estudantes se deslocam para a posição de seus contrapúblicos, o que sugere o caráter iminentemente instável e conflitivo da condição de público. Conforme as análises de Michael Warner, os contrapúblicos despontam no momento em que reagem e, assim, desnaturalizam certas configurações sociocomunicativas e os mecanismos de poder e de reprodução de privilégios que os orientam. Essa disposição opositora se baseia, segundo o crítico, numa "ética do estranhamento", que torna o sujeito propenso a afrontar os discursos instituídos e as discriminações por eles produzidas. Nas palavras de Warner, o contrapúblico geralmente provém de “um grupo dominado [que] aspira a se recriar na condição de público, e ao fazê-lo encontra- se em conflito não só com o grupo social dominante, mas também com as normas que constituem a cultura dominante" (WARNER, 2008, p. 78).

Esse tipo de compreensão ambivalente do que seja a condição de público nos possibilita, entre outras coisas, realizar leituras a contrapelo dos bordões que afirmam o poder (pressuposto) que a arte e a ação institucional que a medeia teriam de transformar o individuo, ou o seu "olhar", no sentido de incrementar seus repertórios, tornando-o mais sensível e crítico não apenas às obras artísticas, mas também aos aspectos que compõem a

16 Ouvem-se com frequência os estudantes dizerem não saber ao certo o destino da excursão da qual participam. Há, portanto, ocasiões em que eles sequer estão cientes da natureza do que irão encontrar nas instituições que visitam. 
sua própria realidade. Afirmações desse gênero são usadas pelas instituições e por seus programas educativos como base de sustentação discursiva de ações voltadas à promoção do acesso, da inclusão, da participação e do desenvolvimento das capacidades dos seus frequentadores, em particular daqueles que ainda não possuem o hábito de usufruir das suas exposições e demais programas.

Sem deixar de reconhecer a pertinência desses expedientes, nos preocupa o fato de que, ao serem afirmadas de maneira peremptória e unilateral, as máximas apologéticas dos benefícios proporcionados ao indivíduo pela arte tendem a provocar o rechaço e a invisibilização dos usos e respostas dos públicos que, porventura, venham a se estranhar, se desviar ou se indispor com essa mesma pressuposição. Interessada naquilo que produz descontinuidades nos discursos afirmativos em torno da arte e da ação institucional, essa leitura ao revés se dá mediante a disponibilidade ao que ocorre no tempo (imprevisível) da visita, de modo contingencial e emergente, para além ou aquém dos planos e protocolos, nos momentos de interação dos públicos com os bens artístico-culturais ofertados pelas instituições.

Compete ao Diário, portanto, funcionar como um compêndio de imagens às avessas dos convencionais registros institucionais em torno da presença dos públicos em seus espaços e atividades - geralmente produzidos em fotografia, vídeo ou texto, e publicados em relatórios, páginas da web, revistas, catálogos, coletâneas audiovisuais, livros etc. Ao retratar de maneira positivada os estudantes em momentos de fruição das obras ou em práticas de ateliê, por exemplo, essas "peças publicitárias" servem principalmente para endossar aquilo que a própria instituição tem a lhes propiciar. Dando visibilidade apenas a essa face da interação, elas obscurecem, por outro lado, aquilo que os estudantes talvez tivessem a comunicar e a propor à instituição a partir de outras bases e desejos, o que tornaria essa relação de mão dupla e potencialmente dissensual. Ao se ater ao registro, edição e propagação de cenas de apelo afirmativo do trabalho institucional, esse tipo de documentação das vivências pedagógicas ofusca o que poderia ser a emergência de outras disposições, interesses, códigos e saberes manifestos pelos destinatários da oferta. De nossa parte, interessa romper com os limites dessa iconografia oficial de caráter publicitário, fazendo com que ela seja alargada e ocupada por outras cenas, outros imaginários. 
Dedicado a refletir as formas de atuação dos estudantes ${ }^{17}$ na relação com as ofertas institucionais, o Diário do busão lança mão de um suporte documental contrainspirado no "diário de classe", ferramenta normativa da rotina escolar. Este último representa um, entre tantos outros, instrumento de controle da conduta do aluno no dia a dia da sala de aula - mediante o registro nominal e individualizado das suas presenças e ausências, das suas notas, do seu desempenho e das ocorrências com as quais esteve envolvido. Já o Diário do busão pretende funcionar como um dispositivo hábil em identificar a potência disruptiva de performatividades e discursividades que surgem da interação desses públicos com as situações e objetos proporcionados pelas instituições artísticas por meio das visitas aos seus espaços, fazendo circular alguns de seus índices através de desenhos e excertos textuais.

Logo, a produção simbólica gerada pelo Diário se faz a partir do interesse pelo que os estudantes e seus professores manifestam nos momentos de interação e como resposta às oportunidades de acesso promovidas pelas instituições através do agendamento de visitas conduzidas por profissionais dos seus departamentos educativos. Minhas infiltrações em tais situações desdobram-se na elaboração de relatórios verbo-visuais alusivos a cada visita ${ }^{18}$. Com seus momentos de observação/escuta, registro, tradução, publicização e debate, o Diário funciona como prática documentária vocacionada a fomentar uma esfera pública específica no contexto artístico-institucional, destinada a trazer à tona, problematizar e discutir as situações vivenciadas por estudantes e professores na relação com ações institucionais representativas das políticas de democratização do acesso aos bens culturais.

17 Ressaltamos que não se trata de refletir sobre tais formas de atuação, de modo distanciado e analítico, mas de refleti-las mediante a sua tradução verbo-visual, praticando com elas operações discursivas direcionadas às instituições artísticas e seus agentes.

18 Os nomes das escolas registrados no Diário do busão são fictícios. Essa opção se relaciona a um distanciamento deliberado que adotamos frente ao modus operandi do "diário de classe", cujo foco reside na identificação das turmas de alunos e de cada um dos seus integrantes, no sentido de esquadrinhar e documentar suas condutas de maneira individualizada, associada à classe e à escola onde estudam. Ao abdicar da identificação dos estudantes e de suas respectivas escolas, o Diário do busão despersonaliza suas manifestações, atendo-se a repercuti-las como formas de atuação anônimas, portanto menos capturáveis pelos mecanismos de repreensão e penalização. 


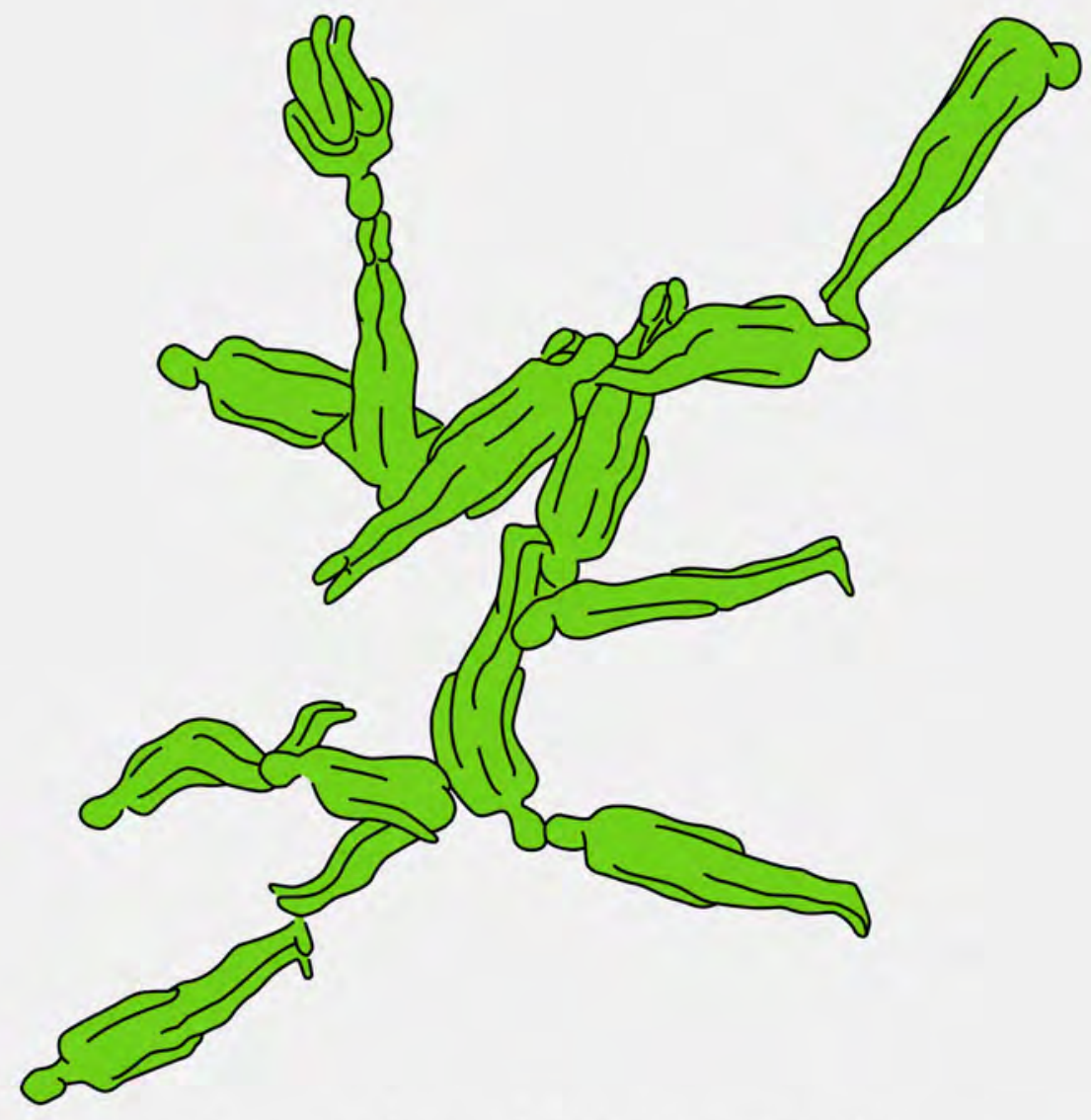

Enquanto aguardamos o mediador aparecer para iniciar a visita, a galera brinca de fazer rizoma no gramado.

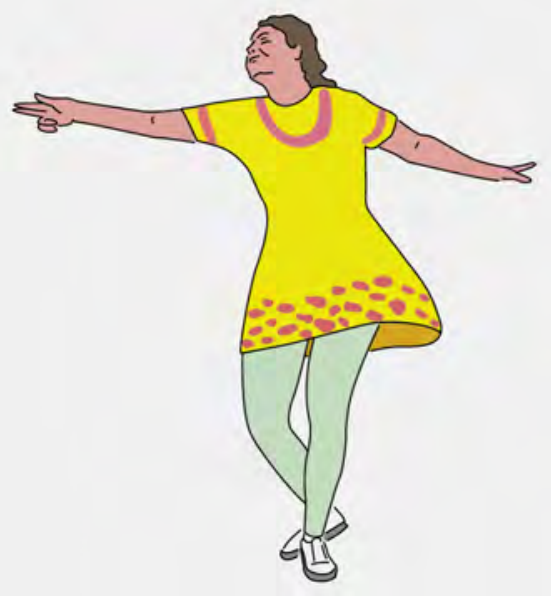

Girando ao vento no Ibirapuera.

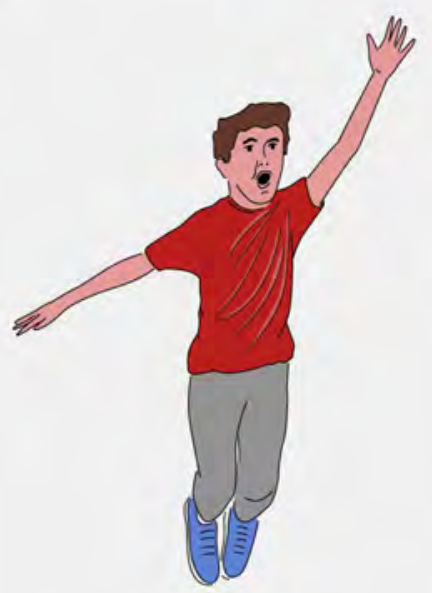

Brincando de fracassar, o garoto tenta tocar o teto do pavilhāo.

Diário do busão: visitas escolares a instituiç̄es artisticas | Relatório 7 | Visita agendada do grupo do $7^{\circ} \mathrm{e} 9^{\circ}$ anos da EMEF Desembargador Alipio Vieira de Albuquerque a $32^{\circ}$ Bienal de São Paulo | 20 de setembro de 2016, $10 \mathrm{~h}$.

Lauda do Relatório 7, referente ao acompanhamento da visita à $32^{\mathrm{a}}$ Bienal de São Paulo.

\begin{tabular}{l|l|l}
\hline & 4.3
\end{tabular}




\subsection{MEDIAÇÃO (DOCUMENTÁRIA) DESOBRIGADA DA GESTÃO DOS PÚBLICOS}

Em lugar de se comprometer com o binômio conexão-inclusão, a modalidade de mediação cultural colocada em jogo pelo Diário funciona como uma prática documentária dedicada à sondagem, tradução e circulação dos índices resultantes dos encontros e desencontros dos públicos escolares com os bens artístico-culturais difundidos pelas instituições, assim como com os discursos e convenções que os medeiam. Busca-se, portanto, produzir um tipo de descontinuidade no fato de que a mediação se encontra, via de regra, a serviço de uma premissa institucional que enquadra os estudantes na posição de aprendizes-beneficiários diante daquilo que é prerrogativa de um corpo técnico e político selecionar, editar e apresentar no ambiente de uma exposição.

0 ponto, então, seria: por que não produzir mediações à revelia das condições estipuladas pelas instituições de arte? Ou mais precisamente, por que não selecionar, editar e apresentar enunciados dos seus públicos de maneira deslocada dos princípios que norteiam a ação institucional? Tal exercício possibilitaria, a nosso ver, a amplificação e a consequente pluralização de temas, códigos e interesses que (inevitavelmente) emergem no momento em que os estudantes visitam uma exposição. Traduzidos e publicizados, seus enunciados passariam a integrar uma esfera pública de debate vocacionada a tensionar a lógica de concentração de decisões, que rege não apenas a definição das pautas e agendas das instituições de arte, mas também prescreve o lugar a ser ocupado pelos públicos. Nesse caso, o escolar.

Aliás, parece-nos que a classificação patente no selo "escolar" responde, antes de tudo, a um tipo de gestão dos públicos praticado pelas instituições que os recebem em situações de visita, no sentido de tentar antecipar e circunscrever a sua posição em relação ao que possa ocorrer durante o tempo em que ali permanecem. As próprias noções de "visita agendada" e "visita mediada" representam, em si mesmas, "contratos" que, de saída, estipulam uma série de condicionantes (cláusulas) para a presença dos estudantes nos ambientes expositivos, como no que diz respeito, por exemplo, ao horário de chegada e saída, ao tempo de permanência, às regras de visitação, ao roteiro a ser percorrido, à forma de fruição das obras, aos formatos de conversa, à necessidade de perma- 
necerem reunidos em grupo e aos códigos utilizados para o diálogo.

Procurando desnaturalizar esse modelo institucional voltado à gestão dos seus visitantes, o Diário aposta numa outra concepção de público e, por conseguinte, em outros modos de como ele possa interagir com as instituições artísticas e seus bens. Referimo-nos a uma compreensão da condição de público baseada em sua natureza contingencial, discursiva e emergente, desdobrada em mais ou menos atenção, entrelaçamentos, recusas, responsividades e negociações simbólicas, praticados por indivíduos e grupos que se autoproduzem como públicos de determinados objetos semânticos (e não de outros) a partir de suas próprias disposições, interesses, repertórios, urgências e agendas.

Característica desse outro tipo de interação, em que a "chave" para tornar-se público de algo não está na mão de ninguém senão na do próprio público, a imprevisibilidade escapa ao planejamento e ao controle meramente administrativo da presença e da conduta das pessoas que adentram o espaço de uma exposição. Vale, portanto, inventarmos práticas e dispositivos que possam conferir consequência e repercussão a essa outra forma de estar nas instituições, gerando precedentes alternativos para as dinâmicas de frequentação e apropriação desses equipamentos e bens por seus públicos.

Nota-se, por outro lado, que o aparelho institucional propositivo mantém-se, no mais das vezes, indiferente ou mesmo refratário às formas de atuação emergentes dos seus públicos, sobretudo àquelas que se desviam dos protocolos e, assim, frustram os discursos e planos praticados pelas instituições. Já as práticas mediativas abertas às contingências da ocasião, como é o caso do Diário, procuram sustentar e lidar com as "coisas estranhas" que surgem das situações de interação, para usarmos uma acepção do antropólogo Bruno Latour referente à natureza da mediação (LATOUR, 2012, p. 92). Essas "coisas estranhas" e as correlatas formas de atuação dos públicos se manifestam na duração temporal, durante a visitação a uma exposição, mas também antes e depois dela. Desse modo, não contam com suportes materiais e espaciais capazes de fazer repercutir os gestos manifestos e os enunciados formulados pelos visitantes durante esses momentos, inclusive porque tais suportes condizem a prerrogativas da instituição e das práticas especiali- 
zadas que dão corpo às suas ações programáticas ${ }^{19}$.

0 desaparecimento das formas singulares e desviantes de atuação dos públicos mostra-se conveniente à retórica cultivada e veiculada pelas instituições artísticas em torno do seu “inquestionável" papel socioeducativo e pretensamente benéfico ao outro - enquanto não iniciado - , exercido com base na sua missão de difundir os exemplares legítimos da cultura e, assim, proporcionar o acesso para muitos daquilo que é produzido por poucos, de acordo com - lema da democratização cultural. O Diário, por sua vez, suspeita dessa perspectiva, nela inscrevendo uma linha de fuga imbuída de apontar noutra direção ${ }^{20}$. Desse modo, ele se compromete com um princípio de distribuição das práticas discursivas e das produções culturais decididamente distinto, sintetizado por Cayo Honorato no lema da "articulação entre muitos do que também é produzido por muitos", em sintonia com as exigências da democracia cultural (HONORATO, 2015a, p. 241, grifos meus).

Cabe, entre outras iniciativas nessa direção, encetar nos contextos expositivos experimentos que funcionem como dispositivos de escuta e amplificação do que sejam as discursividades dissonantes manifestas pelos públicos em meio à orquestração institucional. Tais discursividades se revelam, por exemplo, por meio de gestos oposicionais, desvios semânticos e profanações comportamentais. Entende-se que dessa encruzilhada - aquilo que as instituições difundem versus os usos que os públicos fazem disso - podem advir respostas, saberes e anseios não previstos pelos planos institucionais, capazes de fornecer artefatos simbólicos para um exercício de desconstrução de discursos unidirecionais e hegemônicos. Isso corresponde à tentativa de tornar as instituições mais porosas a demandas apresentadas por seus públicos. Nesse sentido, parece-nos necessário fomentar situações em que as instituições e seus agentes se vejam (re)endereçados pelos públicos, sendo convocados a também aprender com eles em lugar de apenas pretender ensiná-los e incluí-los.

19 No caso de uma exposição, podemos identificar os seguintes recursos como prerrogativas espaciais e suportes para a veiculação dos seus enunciados: espaço expositivo, estrutura arquitetônica, desenho expográfico, comunicação visual, textos de parede, legendas, grid de iluminação, fôlder, catálogo, além da presença das obras em si.

20 Ao traçarem longas e tortuosas linhas no mapa concentrador e altamente desigual da cidade, os itinerários dos ônibus que transportam os estudantes contribuem para essa manobra conceitual. 


\subsection{O PROCESSO DE PUBLICIZAÇÃO DO DIÁRIO}

As ações relacionadas ao Diário tiveram início no começo de 2015, por ocasião do meu primeiro acompanhamento de um grupo de estudantes em visita ao Instituto Tomie Ohtake. De lá até o final de 2016, ocorreram outros seis acompanhamentos de visitas, todos eles traduzidos nos sete relatórios verbo-visuais integrantes da publicação que complementa este volume.

Durante e também após esse período, diversas situações propiciaram a publicização e a discussão em torno dos seus conteúdos, o que denota a vocação assumida pelo Diário de buscar desenhar o seu próprio percurso institucional e, por meio dele, constituir seus públicos para os enunciados e problemáticas que coloca em cena. Em paralelo a essa trajetória, parte significativa dos seus excertos textuais e desenhos foi publicada periodicamente em minha página pessoal do Facebook, bem como em uma conta aberta na plataforma Tumblr ${ }^{21}$, pari passu com as etapas de elaboração do trabalho.

$\mathrm{Na}$ sequência, elencamos aquelas que julgamos serem as principais aparições públicas do Diário, ocorridas desde o início de suas atividades até o momento de finalização da pesquisa de mestrado, em meados de 2017, quando ele é depositado, junto com a dissertação, na Escola de Comunicações e Artes da Universidade de São Paulo. Importa salientar, em relação a tais oportunidades de publicização, que faz parte da manobra implementada pelo dispositivo Diário do busão: visitas escolares a instituições artísticas o delineamento de uma trajetória institucional singular. Singular no sentido de que o Diário se configura como um trabalho em curso que, por articular práticas distintas e trafegar entre diferentes instâncias, requer a invenção de um itinerário próprio de circulação e legitimação, que não se encontra dado nem pelo campo da arte e nem pelo da educação. Isso está ligado, ainda, ao fato de que o Diário opera de modo alternado entre as circunstâncias da infiltração extrainstitucional e da acolhida institucional. É nessa oscilação, nesse percurso em zigue-zague, que procuramos efetivar o seu propósito principal: engendrar uma esfera pública propícia a interlocuções com diferentes agentes institucionais, baseadas na tradução, visibilização e discussão em torno de enun-

21 Os desenhos podem ser visualizados em: <http://diogo82-blog.tumblr.com> Acesso em: 12 mai. 2017. 
ciados que procuram refletir as formas de atuação dos estudantes durante as visitas aos equipamentos de arte.

Abaixo, listamos as ocorrências que denotam, além da publicização do trabalho, o respaldo a ele dispensado por diferentes instituições artísticas, culturais e educacionais:

$\rightarrow$ Publicação do Relatório 1 do Diário (referente à visita ao Instituto Tomie Ohtake) no livro Como (falar sobre) coisas que não existem, elaborado a partir da itinerância da $31^{a}$ Bienal de São Paulo, no Museu Serralves, Porto (2015). Coeditado por Galit Eilat, Charles Esche, Maria Burmester e Ricardo Nicolau；

$\rightarrow$ Utilização do Diário como processo-base para o desenvolvimento do projeto Encontros interestaduais de mediação na arte: a atuação dos públicos, realizado em colaboração com o Fórum Permanente na Universidade de São Paulo/Instituto Tomie Ohtake, Universidade Federal Fluminense/Museu de Arte Contemporânea de Niterói, Universidade Federal do Espírito Santo/Casa Porto das Artes e Universidade de Brasília. Projeto concebido por Martin Grossmann, Diogo de Moraes, Cayo Honorato, Raquel Garbelotti, Yiftah Peled e Diego de Kerchove, contemplado pelo Edital Programa Rede Nacional Funarte Artes Visuais $12^{a}$ Edição (2015-2016) ${ }^{22}$;

$\rightarrow$ Apresentação pública do processo do Diário no colóquio O trânsito nas paisagens culturais: o território, o artista e a educação, organizado por Elaine Fontana, Luciana Nobre e Marina Herling, integrante da $14^{\text {a }}$ Semana Nacional de Museus (Ibram/MinC), no Museu Lasar Segall, em maio de 2016;

$\rightarrow$ Publicação do Relatório 2 do Diário (referente à visita ao Instituto Tomie Ohtake) na revista ERRATA\# - Saber y poder en espacios del arte: pedagogías/curadurías, Bogotá, n. 16 (no prelo). Editada por Carmen Mörsch;

22 A programação completa, os registros em vídeo e os relatos críticos podem ser acessados pelo link: <http://www.forumpermanente.org/event pres/ encontros/encontros-de-mediacao-na-arte-contemporanea-a-atuacao-dos-publicos/encontros-de-mediacao-na-arte-contemporanea-a-atuacao-dos-publicos>. Acesso em: 7 abr. 2017. 
$\rightarrow$ Exposição individual, sob o título (desatualizado) de Diário do busão: visitas escolares a instituições culturais, envolvendo a exibição dos Relatórios 1, 2, 3 e 4 (referente às visitas ao Instituto Tomie Ohtake, Casa Modernista e Masp), com curadoria de Fernando Velázquez, na Red Bull Station, em junho de 2016 23 ;

$\rightarrow$ Comunicação a partir do Diário na mesa “Cultura e participação: a política cultural do Instituto Tomie Ohtake em mediação", organizada por Felipe Arruda, Martin Grossmann e Gilberto Mariotti, no contexto do projeto Encontros interestaduais de mediação na arte: a atuação dos públicos, no Instituto Tomie Ohtake, em setembro de 2016 ${ }^{24}$;

$\rightarrow$ Publicação do Relatório 3 do Diário (referente à visita à Casa Modernista) na revista Concinnitas Arte, educação e sedução, Rio de Janeiro, v. 1, n. 28, do Instituto de Artes da UERJ (2016)25;

$\rightarrow$ Comunicação a partir do Diário no encontro da rede internacional de mediadores Another Roadmap, organizado por Sofía Olascoaga, na 32a Bienal de São Paulo - Incerteza viva, em outubro de 2016;

$\rightarrow$ Comunicação a partir do Diário na mesa "Performance no papel", integrante do seminário Perfor7 [como?], organizado pela Rede de Performance do Estado de São Paulo e Coletivo Sem Título, s.d., na Praça das Artes, em novembro de $2016^{26}$;

$\rightarrow$ Comunicação a partir do Diário na mesa “Públicos e contrapúblicos", no seminário Públicos e mediação cultural, organizado por Cayo Honorato em colaboração com o Fórum Permanente, no contexto do proje-

23 Pelo link a seguir, pode-se acessar matéria elaborada pela área de comunicação da Red Bull Station por ocasião da exposição: <http://www.redbullstation.com.br/em-diarios-do-busao-artista-traz-a-tona-discursos-de-estudantes-em-visitas-culturais>. Acesso em: 7 abr. 2017.

24 No link a seguir, pode-se acessar o registro da comunicação em vídeo: $<$ http://www.forumpermanente.org/event pres/encontros/encontros-de-mediacao-na-arte-contemporanea-a-atuacao-dos-publicos/videos/encontros-de-mediacao-na-arte-contemporanea-a-atuacao-dos-publicos-no-instituto-tomie-ohtake>. Acesso em: 18 abr. 2017.

25 Link para a publicação: <http://www.e-publicacoes.uerj.br/index.php/concinnitas/article/view/25966/18647>. Acesso em: 7 abr. 2017.

26 A página com a programação do evento pode ser acessada pelo link: <http://brasilperformance.blogspot.com.br/2016/10/perfor7-como-14-15-21-e-24-de-novembro.html>. Acesso em: 7 abr. 2017. 
to Encontros interestaduais de mediação na arte: a atuação dos públicos, na Universidade de Brasília, em novembro de $2016^{27}$;

$\rightarrow$ Comunicação a partir do Diário no seminário Pesquisa: no e para o museu, organizado por Pompea Tavares e Andréa de Magalhães Matos (Superintendência de Museus e Artes Visuais do Governo de Minas Gerais), no Museu Mineiro, Belo Horizonte, em dezembro de 2016;

$\rightarrow$ Publicação do Diário como tema do trimestre (abril/ maio/junho) do Boletim Arte na Escola no 80 , do Instituto Arte na Escola (2016) ${ }^{28}$;

$\rightarrow$ Publicação de matéria sobre o Diário no site 0 Beijo - Artes Visuais (2016) ${ }^{29}$;

$\rightarrow$ Aula inaugural a partir do Diário na $5^{\circ}$ edição do Curso de Formação de Mediadores do MAR - Museu de Arte do Rio, organizada por Gleyce Kelly Heitor, em janeiro de 2017;

$\rightarrow$ Mediação documentária com base na experiência do Diário nas Jornadas Hábitos de aprendizaje - Desafíos en común, organizadas por Renata Cervetto, no Malba - Museo de Arte Latinoamericano de Buenos Aires, em março de 201730;

$\rightarrow$ Apresentação pública do processo do Diário no contexto da exposição Corpo de prova - Lais Myrrha, organizada por Valquiria Prates e Fábio Tremonte, no Sesc Bom Retiro, em maio de 2017;

$\rightarrow$ Entrevista "Tres preguntas a Diogo de Moraes", realizada por Renata Cervetto em torno do processo

27 No link a seguir, pode-se acessar o registro da comunicação em vídeo: $<$ http://www.forumpermanente.org/event_pres/encontros/encontros-de-mediacao-na-arte-contemporanea-a-atuacao-dos-publicos/videos/encontro-de-mediacao-na-arte-contemporanea-publicos-e-contra-publicos>. Acesso em: 7 abr. 2017.

28 O Boletim pode ser acessado pelo link: <http://artenaescola.org.br/boletim/ materia.php?id=76633>. Acesso em: 7 abr. 2017.

29 A matéria pode ser acessada pelo link: <http://www.obeijo.com.br/noticias/ diogo-de-moraes-se-inspira-em-excursoes-escolares-por-museus-12772691> Acesso em: 7 abr. 2017.

30 No link a seguir, além da programação das Jornadas, pode-se encontrar um registro em vídeo no qual sumarizo a noção de mediação como prática documentária: <http://www.malba.org.ar/pt/habitos-de-aprendizaje>. Acesso em: 7 abr. 2017. 
de elaboração do Diário, publicada no blog Malba Diario, do Museo de Arte Latinoamericano de Buenos Aires, em maio de 201731;

$\rightarrow$ Aula a partir do Diário no Curso de Formação de Mediadores da segunda edição da Trienal Frestas Entre pós-verdades e acontecimentos, organizada por Fábio Tremonte, no Sesc Sorocaba, em julho de 2017.

\subsection{A ESPECIFICIDADE DA MEDIAÇÃO E SUA POTENCIALIDADE DE (RE)ENDEREÇAR A INSTITUIÇÃO A PARTIR DOS PÚBLICOS}

Cumpre dizer, ainda, que o exercício do Diário concebe a mediação como uma prática cultural específica, que trabalha num espaço epistemológico próprio. Ela não se limita, portanto, a distribuir experiências e sentidos consumados por outras instâncias do circuito da arte, como a gestão institucional, a curadoria, a prática artística e a crítica especializada. Em outros termos, a manobra conceitual e a operação semântica testadas pelo Diário não se incumbem de produzir "pontes" entre o público e a arte, comprometendo-se, em lugar disso, a investigar e conferir visibilidade às formas de atuação dos estudantes, e também às de seus professores, nos momentos de interação com as ofertas institucionais. Ao adotar o ônibus como "lente" para a tradução do que ocorre durante as visitas, abrimos passagem para que diferenças de ordem geográfica, social, cultural, econômica e linguística não só venham à tona, como também ensejem a produção de uma peça gráfica documental passível de retornar às instituições, inscrevendo outros imaginários em seus discursos.

Incorporando expedientes da crítica institucional, o Diário utiliza vocabulários e modos de fazer emprestados da arte, inclusive com vistas a problematizar e redispor um certo estado de questões relativo ao lugar da mediação cultural no âmbito das políticas institucionais. Tal disposição relaciona-se ao entendimento de que as experiências de aprendizagem não devem se restringir à instância dos públicos, na medida em que eles também podem endereçar as instituições e seus agentes (gestores, curadores, educadores, mediadores e artistas) com uma gama de ações, saberes, problemáticas e agendas outras, provocando situações de aprendizagem mútua ou, para usar a expressão do mediador Javier Rodrigo Montero, uma "conversação cultural complexa" (RODRIGO, 2016, p. 8). 
Por fim, devemos frisar que o Diário integra uma investigação mais ampla, que procura analisar teórica e criticamente as modalidades de endereçamento praticadas pela mediação institucional em relação aos seus “públicos-alvo". Nesse quesito, buscamos formular uma chave de compreensão não coincidente à lógica predominante nas instituições de arte, que concebe os públicos, em particular os não iniciados, como entidades abstratas, classificáveis e culturalmente deficitárias, atreladas ao princípio da "objetivação do sujeito", conforme noção emprestada de Foucault (1995, p. 231). O que buscamos com o Diário e com o exercício da escrita teórica é produzir certos deslocamentos nesse modelo atributivo, imaginando os públicos num registro alternativo: como formações emergentes de sujeitos políticos, reativos aos processos de enquadramento e gestão que buscam mobilizá- los e conduzir suas ações e percepções.

Procuramos evidenciar, portanto, as formas de atuação e as respostas dos estudantes em meio a relações de poder e comunicação que, ao identificá-los e endereçá-los, os tornam alvos de proposições pedagógicas. Assim, em vez de conceber esses alunos como "público-alvo" da nossa proposição, o Diário busca fazer com que suas discursividades e performatividades frente àquilo que lhes é ofertado - na medida em que são traduzidas e veiculadas - possam retornar aos próprios agentes do circuito artístico-institucional, numa trajetória similar à de um bumerangue. Ou seja, se a instituição lança proposições em direção aos seus públicos, que ela também se abra e seja afetada pelo movimento contrário, correspondente aos diferentes usos que os públicos possam fazer dessas mesmas proposições.

Com tal (re)endereçamento em vista, o Diário conta com uma tiragem inicial de cinquenta exemplares. Assim como os "materiais educativos" desenvolvidos e distribuídos pelas instituições artísticas às escolas ${ }^{32}$, ele tem suas laudas reproduzidas e acondicionadas em uma caixa-envelope produzida sob medida e devidamente identificada, adquirindo o caráter de um material de uso. Uma vez que ele tem como destinatárias as próprias instituições de arte e seus agentes, estes são provocados no sentido de dedicar

32 Os materiais educativos institucionais geralmente apresentam reproduções fotográficas de obras presentes em determinada exposição ou acervo, sendo complementadas por textos de contextualização e propostas pedagógicas relativas à leitura de imagem e a exercícios investigativos e poéticos que possam ser derivados dessas mesmas obras. 
sua atenção e fazer-se público de índices que refletem modos singulares de interação da comunidade escolar com as ofertas institucionais. Logo, os primeiros a receber (gratuitamente) exemplares do Diário serão os departamentos educativos que, até o presente, colaboraram com o seu processo de constituição. Além deles, o Diário ainda elege como seus destinatários iniciais uma variedade de interlocutores - enquanto membros de uma rede, de uma esfera pública - que atuam em diferentes frentes no circuito da arte, na condição de gestores, curadores, educadores, mediadores, professores e artistas. 
Encerrando a jornada da pesquisa, nos deparamos com a indagação sobre qual seria a sua questão "de fundo". Em outras palavras, vemo-nos convocados a evocar a natureza das inquietações que animaram o nosso processo de investigação, desde os seus primeiros movimentos, passando por suas fases de estruturação e elaboração, até aportarmos aqui, na seção das palavras derradeiras. Este exercício não deve ser confundido com uma tentativa de síntese da dissertação, visto que ele se presta menos a repassar e condensar as diversas problemáticas abordadas ao longo dos capítulos do que a trazer à tona aquilo que teria funcionado como força motriz da nossa "aventura intelectual”, para usar uma expressão de Rancière.

O fato de a nossa investigação ter se assumido, logo de início, como uma atividade pública propiciou que testássemos diferentes tipos de interlocução com os pares, sempre a partir dos enunciados teóricos e artísticos da pesquisa. Ao procurar publicizar suas diferentes facetas de maneira sistemática, através de seminários, congressos, revistas, plataformas digitais e exposições, nos nutrimos de um sem-número de devolutivas, comentários críticos e sugestões de acréscimo ou revisão que puderam ser incorporados, em alguma medida, ao corpo do trabalho. Consideramos que o texto ora concluído já traz consigo algum histórico de recepção e, portanto, camadas de leitura.

A propósito da recepção da dissertação, se você, leitor, chegou até este ponto do texto, podemos depreender que se envolveu como um público da pesquisa. O fato de ter dispensado sua atenção às abordagens aqui desenvolvidas e coligidas - acerca dos públicos das ofertas institucionais e das práticas artísticas por elas difundidas - faz de você membro de uma comunidade de leitores e, quem sabe, de uma esfera de debate vocacionada à reflexão e à discussão em torno da condição de público.

Nesse quesito, a pesquisa dá a ver as dobras que realiza sobre si. Ou seja, ao mesmo tempo que se dedica a questões inerentes ao ato de nos tornarmos público de determinado objeto semântico, experiência artística ou oferta institucional, ela lança mão de procedimentos cientes do seu potencial de produzir os públicos dos enunciados colocados em cena - embora, em última instância, os públicos se (auto)produzam como tal, de acordo com seus interesses e agendas. Provavelmente, o leitor que tenha se dedicado ao nosso texto assim o fez por perceber a possibilidade de entrelaçá-lo às suas próprias inquietações, num processo em que os enunciados em jogo são lidos e apropriados segundo certas preocupações e, ademais, vislumbres de novos desdobramentos discursivos.

Mas haveria, ainda, outro vinco realizado no âmbito da pesquisa. Ele diz respeito à operação por mim experimentada enquanto seu agenciador. Decididamente dupla, essa operação relaciona-se ao delineamento de uma trajetória oscilante entre as minhas atividades como público, de um lado, e como autor, de outro. Com seus expedientes afetando-se mutuamente, essa alternância confere o tom tanto do ensaio artístico-documental como da plataforma teórica da nossa pesquisa, como o leitor deve ter notado.

Entre os agentes que atuam nas estruturas institucionais da arte, o mediador apresenta-se como a figura mais propensa a esse movimento pendular, a par- 
tir do qual testa formas de interação e, quiçá, de colaboração com os públicos. Isso se deve ao fato de ele atuar em zonas intersticiais, onde a atenção e a permeabilidade aos anseios desses públicos devem adquirir importância equivalente à formalização e à enunciação de discursos, o que pode inclusive ocorrer de maneira imbricada e distribuída entre mediadores e públicos.

Contudo, a formação da ampla maioria dos grupos de mediadores (não apenas em termos da constituição dos quadros funcionais, mas também no que tange à definição do seu perfil profissional e das suas atribuições) resulta da iniciativa das próprias instituições artísticas, que desfrutam da vantagem e das condições materiais para arregimentar esses profissionais, ainda que geralmente de forma precarizada, ou mesmo sob o registro do estágio. Como se pode supor desse quadro, a figura do mediador tem sido chamada a atuar em prol das missões e da "boa imagem" desses equipamentos, fazendo com que a presença e a participação dos públicos em seus ambientes e programas sejam condicionadas àquilo que é prerrogativa das instituições proporcionarem, com base em seus saberes especializados e compromissos político-institucionais.

Em suspeição a essa lógica e a partir de uma perspectiva extrainstitucional, caberia imaginarmos maneiras de transformar a mediação tradicionalmente $a$ serviço das instituições numa mediação em função dos públicos, entendidos como sujeitos políticos ligados a comunidades específicas - distante, portanto, da abstração característica do modo como as instituições geralmente classificam e procuram gerir seus públicos. Trata-se de uma rotação no eixo de compreensão das potencialidades inerentes ao escopo de ação do mediador, visto como um agente cultural apto a tensionar e complexificar as dinâmicas institucionais mediante a sua cumplicidade com os públicos, o que pressupõe um estado de abertura às singularidades daquilo que manifestam.

Diríamos que esse aspecto condiz ao substrato do nosso projeto, funcionando como premissa conceitual das nossas abordagens. Referimo-nos à disposição do mediador para conceber a condição de público numa chave experimental, estranha às pressuposições e às convenções a que esse papel social se encontra normalmente submetido. Ao mesmo tempo que pauta o nosso trabalho investigativo, tal premissa nos leva a testar um deslocamento no modus operandi das mediações institucionais. Através desse movimento (político-cultural, no limite), buscamos nos desviar de um tipo de compulsão propositiva que faz do outro, sobretudo o não iniciado, um mero suporte de intenções alheias, em particular daqueles que propõem situações e discursos a partir de lugares reconhecidos em termos epistemológicos e sociais, como é o caso da gestão institucional, da curadoria, da arte-educação e também da prática artística. Nesse terreno loteado por saberes e agentes especializados, é comum que reste aos públicos desempenhar papéis a eles atribuídos por terceiros, apenas ratificando proposições definidas a priori e à sua revelia - ainda que tal expectativa seja renitentemente desviada e frustrada pelos próprios públicos.

O distanciamento adotado frente a essa matriz propositiva abriu espaço para perscrutarmos, no transcurso do mestrado, a potência intrínseca à condição 
de público, sobretudo na imprevisibilidade dos seus modos de recepção, uso e atuação diante daquilo que lhe é ofertado. Nota-se que é na temporalidade dessa relação que surgem códigos, comportamentos e agendas muitas vezes dissonantes, portanto não coincidentes com o que é proposto a esses públicos sob o signo do legítimo. Compete à mediação de viés crítico e inventivo, além de gerar visibilidade para essas discordâncias, tomá-las como precedentes táticos para a constituição de outro regime de interação, calcado não nas agendas institucionais, ou não apenas nelas, mas nas demandas emergentes dos diferentes públicos.

Atuar nessas bases pressupõe traçarmos linhas de fuga que nos permitam escapar dos lugares consagrados de enunciação - a partir dos quais se exerce o poder -, desapegando-nos da comodidade e da autoridade que os distinguem. Justamente por não ter lugar próprio nesse tabuleiro, os públicos "hospedam-se" em discursos que, de saída, não lhes pertencem, praticando com eles usos não previstos por seus criadores e vulgarizadores. Com isso, a posição que lhes corresponde revela-se propícia a manobras de despossessão discursiva, no sentido de afrontar e desafiar a hegemonia dos que gozam do privilégio de enunciar publicamente e de pautar agendas socialmente compartilhadas. Logo, se o nosso compromisso for com a transformação das dinâmicas institucionais vigentes, não podemos desperdiçar as oportunidades instauradas pelos públicos através do dissenso.

Como procuramos evidenciar com a pesquisa, nós mediadores temos muito a aprender com esses públicos, principalmente quando nos deixamos atravessar pelo inesperado das suas respostas às ofertas institucionais e, também, pela idiossincrasia dos seus modos de usar as práticas artísticas e mediativas proporcionadas por tais ofertas. Cumpre-nos buscar traduzi-las e amplificá-las, a fim de promover sua legibilidade em círculos que extrapolem o tempo e o espaço de sua ocorrência. Nesse outro registro, a prática da mediação se daria no sentido reverso do seu estatuto corrente: já não a partir da instituição - com aquilo que ela tem a oferecer - em direção aos seus públicos; mas dos públicos - com aquilo que eles demandam - em direção à instituição, com seus agentes sendo provocados a se deixarem afetar por aqueles que, a princípio, eram apenas os seus "públicos-alvo". Aqui, o mediador se acumplicia com o público, para produzir efeitos e mudanças na instituição.

A formulação de tal programa pode, inclusive, se beneficiar de um enunciado artístico respaldado e difundido institucionalmente. Estamos falando do letreiro criado pelo artista Vitor Cesar, concebido para ser instalado em áreas de grande circulação e visibilidade nos equipamentos de arte, no qual se lê: “artista é público”. Parafraseando-o, anunciamos: mediador é público. 
ALAMBERT, Francisco; CANHÊTE, Polyana Lopes. As bienais de São Paulo: da era do museu à era dos curadores (1951-2001). São Paulo: Boitempo, 2004.

ARANTES, Otília. Os novos museus. In: O lugar da arquitetura depois dos modernos. São Paulo: Edusp, 1993. p. 233-246.

ARENDT, Hannah. A condição humana. Rio de Janeiro: Forense Universitária, 2007.

AUGÉ, Marc. Não-lugares: introdução a uma antropologia da supermodernidade. Campinas: Papirus, 1994.

BARROS, José Márcio. Mediação, formação, educação: duas aproximações e algumas proposições. Observatório Itaú Cultural, São Paulo, n. 15, p. 10-16, dez. 2013/mai. 2014.

BARTHES, Roland. O rumor da língua. São Paulo: Martins Fontes, 2004.

BASBAUM, Ricardo. Além da pureza visual. Porto Alegre: Zouk, 2007.

BAUDELAIRE, Charles. As flores do mal. Rio de Janeiro: Nova Fronteira, 1985.

BENJAMIN, Walter. O flâneur. In: Charles Baudelaire: um lírico no auge do capitalismo (Obras escolhidas v. 3). São Paulo: Brasiliense, 1989. p. 185-236.

. O autor como produtor. In: Magia e técnica, arte e política: ensaios sobre literatura e história da cultura (Obras escolhidas v. 1). São Paulo: Brasiliense, 1994. p. 120-136.

Rua de mão única (Obras escolhidas v. 2). São Paulo: Brasiliense, 1995.

BENNETT, Tony. The exbitionary complex. In: The Birth of the Museum:

History, Theory, Politics. Londres; Nova York: Routledge, 2007. p. 59-88.

BISHOP, Claire. Antagonismo e estética relacional. Tatuí, Recife, n. 12, p. 109-132, 2011. Disponível em: <https://issuu.com/tatui/docs/tatui12/7>. Acesso em: 31 ago. 2016.

BORGES, Jorge Luis. O aleph. Porto Alegre: Globo, 1972.

BOURDIEU, Pierre. A distinção: crítica social do julgamento. Porto Alegre: Zouk, 2013.

BOURRIAUD, Nicolas. Estética relacional. Buenos Aires: Adriana Hidalgo Editora, 2006.

CALVINO, Italo. As cidades invisíveis. São Paulo: Companhia das Letras, 1990. 
CANCLINI, Nestor García. Valorar el arte: entre mercado y política. In: . La sociedad sin relato: antropología y estética de la inminencia. Buenos Aires: Katz, 2011. p. 129-150.

CARERI, Francesco. Walkscapes: Walking as an Aesthetic Practice. Barcelona: Gustavo Gili, 2002.

CAUQUELIN, Anne. Arte contemporânea: uma introdução. São Paulo: Martins, 2005.

CAVALHERO, José. A mesalousa não é a mesma lousa... Será?. In: GRUPO CONTRAFILÉ, secundaristas de luta e amigos. A batalha do vivo.

São Paulo, 2016. p. 32-37.

CERTEAU, Michel de. A invenção do cotidiano - 1. Artes do fazer. Petrópolis: Vozes, 1994.

Espaços e costumes. In: POIRRIER, Philippe; GENEVIÈVE, Gentil. Cultura e estado: a política cultural na França, 1955-2005. São Paulo: Iluminuras; Itaú Cultural, 2012. p. 77-79. Disponível em: $<$ http://d3nv1jy4u7zmsc.cloudfront.net/wpcontent/uploads/2013/04/Cultura-e-estado.pdf $>$. Acesso em: 22 jul. 2016.

CERVANTES, Miguel de. Dom Quixote. São Paulo: Círculo do Livro, s.d.

CESAR, Vitor. Artista é público. 2009. 136 f. Dissertação (Mestrado em Artes Plásticas) - Escola de Comunicações e Artes, Universidade de São Paulo, 2009.

CESAR, Vitor; KUNSCH, Graziela. Apresentação - Projeto Arte e Esfera Pública. In: Arte e esfera pública. São Paulo: Funarte, 2008. p. 2.

CESARINO, Pedro. Aprender com as crianças // Negociar com os homens. In: GRUPO CONTRAFILÉ, secundaristas de luta e amigos. A batalha do vivo. São Paulo, 2016. p. 182-188.

CHIARELLI, Tadeu. Para que Duchamp? Ou: sobre alguns trabalhos de Waltercio Caldas. In: RIBENBOIM, Ricardo (Org.). Por que Duchamp?: Leituras duchampianas por artistas e críticos brasileiros. São Paulo: Itaú Cultural; Paço das Artes, 1999. p. 23-31.

COELHO, Teixeira. Política cultural: uma história comum. In: POIRRIER, Philippe; GENEVIÈVE, Gentil. Cultura e estado: a política cultural na França, 1955-2005. São Paulo: Iluminuras; Itaú Cultural, 2012. p. 11-13. Disponível em: $<$ http:// d3nv1jy4u7zmsc.cloudfront.net/wp-content/uploads/2013/04/Cultura-e-estado. pdf $>$. Acesso em: 22 jul. 2016.

COSTA, Sérgio. As cores de Ercília: esfera pública, democracia, configurações pósnacionais. Belo Horizonte: Editora UFMG, 2002. 
CUNHA, Newton. Dicionário Sesc: a linguagem da cultura. São Paulo: Perspectiva; Sesc São Paulo, 2003.

DEBORD, Guy. A sociedade do espetáculo. Rio de Janeiro: Contraponto, 1997.

DELEUZE, Gilles. Conversações, 1972-1990. São Paulo: Editora 34, 1992.

DEUTSCHE, Rosalyn. Agorafobia. Quaderns portàtils, Barcelona, n. 12. p. 1-61, 2008. Disponível em: <http://www.macba.cat/uploads/20140211/QP_12_Deutsche. pdf $>$. Acesso em: 16 jun. 2017.

A arte de ser testemunha na esfera pública dos tempos de guerra.

Concinnitas, Rio de Janeiro, ano 10, v. 2, n. 15, p. 175-183, dez. 2009.

DINIZ, Clarissa. Partilha da crise: ideologias e idealismos. Tatuí, Recife, n. 12, p. 3344, 2011. Disponível em:<https://issuu.com/tatui/docs/tatui12/7>.

Acesso em: 31 ago. 2016.

DUCHAMP, Marcel. O ato criador. In: BATTCOCK, Gregory (Org.). A nova arte. São Paulo: Perspectiva, 1975. p. 71-74.

DUNCAN, Carol. The Art Museum As Ritual. In: Civilizing Rituals: Inside Public Art Museums. Londres; Nova York: Routledge, 1995. p. 7-20.

FLUSSER, Vilém. Filosofia da caixa preta: ensaios para uma futura filosofia da fotografia. Rio de Janeiro: Relume Dumará, 2002.

FOSTER, Hal. The Artist as Etnographer. In: The Return of the Real: The Avant-Garde at the End of the Century. Cambridge: MIT Press, 1996. p. 171-204.

FOUCAULT, Michel. Isto não é um cachimbo. Rio de Janeiro: Paz e Terra, 1988. O sujeito e o poder In: RABINOW, Paul; DREYFUS, Hubert. Michel

Foucault: uma trajetória filosófica. Para além do estruturalismo e da hermenêutica. São Paulo: Forense Universitária, 1995. p. 231-249.

As palavras e as coisas: uma arqueologia das ciências humanas. São Paulo: Martins Fontes, 2007.

FRASER, Andrea. Museum Highlights: The Writings of Andrea Fraser. Cambridge: MIT Press, 2005.

O que é crítica institucional. Concinnitas, Rio de Janeiro, ano 15, v. 2, n. 24, p. 1-4, dez. 2014. Disponível em: <http://www.e-publicacoes.uerj.br/index.php/ concinnitas/article/view/18731/13645>. Acesso em: 7 ago. 2016. 
FREIRE, Cristina. Além dos mapas: os monumentos no imaginário urbano contemporâneo. São Paulo: Sesc; Annablume, 1997.

. Poéticas do processo: arte conceitual no museu. São Paulo: Iluminuras, 1999.

FREIRE, Paulo. Pedagogia da autonomia: saberes necessários à prática educativa. São Paulo: Paz e Terra, 1996.

GRINSPUM, Denise. Visita monitorada no museu: o que é e para que serve?. In: Educação para o patrimônio: museu de arte e escola - Responsabilidade compartilhada na formação de públicos. 2000. $148 \mathrm{f}$. Tese (Doutorado em Educação) - Faculdade de Educação, Universidade de São Paulo, 2000.

Mediação em museus e em exposições: espaços de aprendizagem sobre arte e seu sistema. Revista do Grupo de Pesquisa em Educação e Arte (GEARTE). Porto Alegre, v. 1, n. 3, p. 272-283, 2014. Disponível em: <http://seer.ufrgs.br/index.php/ gearte/article/view/52606/32622>. Acesso em: 31 ago. 2016.

GROUP MATERIAL. Caution! Alternative Space! (1982). In: STILES, Kristine; SELZ, Peter (Orgs.). Theories and Documents of Contemporary Art: A Sourcebook of Artists'Writings. Berkeley; Los Angeles: University of California Press, 1996a. p. 894-895.

Statement (1985). In: STILES, Kristine; SELZ, Peter (Orgs.). Theories and Documents of Contemporary Art: A Sourcebook of Artists' Writings. Berkeley; Los Angeles: University of California Press, 1996b. p. 895.

GRUPO CONTRAFILÉ, secundaristas de luta e amigos. A batalha do vivo. São Paulo, 2016.

HAACKE, Hans; BOURDIEU, Pierre. Livre-troca: diálogos entre ciência e arte. Rio de Janeiro: Bertrand Brasil, 1995.

HABERMAS, Jürgen. Mudança estrutural da esfera pública: investigações sobre uma categoria da sociedade burguesa. São Paulo: Editora Unesp, 2014.

HEINICH, Nathalie. A arte contemporânea exposta às rejeições: contribuição a uma sociologia dos valores. Observatório Itaú Cultural, São Paulo, n. 12 (Os públicos da cultura: desafios contemporâneos), p. 77-90, 2011. Disponível em: $<$ http://d3nvljy4u7zmsc.cloudfront.net/wp-content/uploads/itau_pdf/001829.pdf $>$. Acesso em: 23 jul. 2016.

HOLANDA, Sérgio Buarque de. Raízes do Brasil. São Paulo: Companhia das Letras, 1995.

HONORATO, Cayo. Mediação na arte contemporânea: posições entre sistemas de valores adversos. Marcelina, São Paulo, ano 3, v. 3, p. 52-68, segundo semestre de 2009. 
Arte para o público: comédia ou tragédia da mediação. In: Encontro Nacional de Pesquisadores em Artes Plásticas, 2011, Rio de Janeiro. Anais., Rio de Janeiro: Associação Nacional de Pesquisadores em Artes Plásticas, 2011, p. 338-351. Disponível em: <http://www.anpap.org.br/anais/2011/pdf/ceav/cayo_honorato. pdf $>$. Acesso em: 22 jul. 2016.

Mediação e democracia cultural, 2013a. Texto comissionado pelo Centro de Pesquisa e Formação do Sesc São Paulo, p. 1-11. Disponível em: $<$ https://issuu. com/centrodepesquisaeformacao/docs/media o_e_democracia_cultural/1>. Acesso em: 16 jul. 2016.

Dos "públicos no plural” a uma pluralidade das concepções de públicos, 2013b, p. 1-17. Disponível em: <http://centrodepesquisaeformacao.sescsp.org.br/ issuu/NjIONjgyOS84MTc1MjUz>. Acesso em: 6 set. 2015.

Notas sobre a mediação extrainstitucional. Urbânia, São Paulo, n. 5 (Educação), 2015a. p. 241-243. Disponível em: <http://www.naocaber.org/wpcontent/uploads/2015/01/urbania5_web_pagsjuntas.pdf >. Acesso em: 20 jul. 2015.

. Unrepentant populism. In: World Biennial Forum, n. 2, p. 124-132, 2015b. Disponível em: <http://cayohonorato.weebly.com/uploads/8/4/7/3/8473020/2015_ makingbiennialsincontemporarytimes_biennialfoundation.pdf $>$. Acesso em: 16 jul. 2016.

Educação perguntadora. In: Encontro Nacional de Pesquisadores em Artes Plásticas, 2015, Santa Maria. Anais..., Santa Maria: Associação Nacional de Pesquisadores em Artes Plásticas, 2015c, p. 684-696. Disponível em: <http://anpap. org.br/anais/2015/comites/ceav/cayo_honorato.pdf>. Acesso em: 31 ago. 2016.

HONORATO, Cayo; MORAES, Diogo de. Editorial. Periódico Permanente, São Paulo, n. 6 (Mediação cultural), 2016. Disponível em: <http://www. forumpermanente.org/revista/revista/numero-6-1>. Acesso em: 12 mar. 2016.

HOOPER-GREENHILL, Eilean. What is a museum?. In: Museums and the Shaping of Knowledge. Londres; Nova York: Routledge, 1992. p. 1-22.

HUYSSEN, Andreas. Escapando da amnésia: o museu como cultura de massa. Revista do Patrimônio Histórico e Artístico Nacional, Brasília, n. 23, p. 35-57, 1994.

IANNI, Octavio. Teorias da globalização. Rio de Janeiro: Civilização Brasileira, 2001.

INTERNACIONAL SITUACIONISTA. Situacionista: teoria e prática da revolução. São Paulo: Conrad, 2002.

JACQUES, Paola Berenstein (Org.). Apologia da deriva: escritos situacionistas sobre a cidade / Internacional Situacionista. Rio de Janeiro: Casa da Palavra, 2003. 
KELIAN, Lilian; NERES, Julio. O que as ocupações dizem sobre a escola (e o mundo) que os jovens querem, 2016. Disponível em: <http://www.brasilpost.com.br/ cenpec/o-que-as-ocupacoes-dizem-_b_10106494.html>. Acesso em: 24 maio 2016.

KUNSCH, Graziela. Projeto Mutirão. 2008. 185 f. Dissertação (Mestrado em Ciência da Comunicação) - Escola de Comunicações e Artes, Universidade de São Paulo, 2008.

LAFUENTE, Pablo. Arte, educação, classe. Urbânia, São Paulo, n. 5 (Educação), p. 274-275, 2015. Disponível em: <http://www.naocaber.org/wp-content/ uploads/2015/01/urbania5_web_pagsjuntas.pdf>. Acesso em: 20 jul. 2015.

LATOUR, Bruno. Reagregando o social. Salvador; Bauru: Edufba; Edusc, 2012.

LAGNADO, Lisette; PEDROSA, Adriano (Eds.). 27ª Bienal de São Paulo: como viver junto. Guia. São Paulo: Fundação Bienal, 2006.

LANDKAMMER, Nora. Educación en museos y centros de arte como práctica colaborativa. In: Fundación Museos de la Ciudad de Quito (Ed.). Contradecirse una misma: museos y mediación educativa crítica. Experiencias y reflexiones desde las educadoras de la Documenta 12. Quito: Fundación Museos de la Ciudad, 2014. p. 22-37.

LARROSA, Jorge. Notas sobre a experiência e o saber de experiência. Revista Brasileira de Educação. Rio de Janeiro, n. 19, p. 20-28, 2002. Disponível em: <http:// www.scielo.br/pdf/rbedu/n19/n19a02.pdf>. Acesso em: 25 jun. 2017.

Tecnologias do eu e educação. In: SILVA, Tomaz Tadeu da (Org.). O sujeito da educação: estudos foucaultianos. Petrópolis: Vozes, 1994. p. 35-85.

LOPEZ, Telê Ancona (Org.). De São Paulo: cinco crônicas de Mário de Andrade, 1920-1921. São Paulo: Senac, 2004.

MAFFESOLI, Michel. Sobre o nomadismo: vagabundagens pós-modernas. Rio de Janeiro: Record, 2001.

MEDEIROS, Virginia de. Fraturar-se para o encontro, 2008-2009. Disponível em: <http://www.pipa.org.br/pag/virginia-de-medeiros/>. Acesso em: 24 fev. 2016.

Contos. São Paulo: Imprensa Oficial, s.d.

MENNA BARRETO, Jorge. Anotações sobre uma certa inclinação (supostamente) educativa de uma trajetória (supostamente) artística. Urbânia, São Paulo, n. 5 (Educação), p. 214-223, 2015. Disponível em: <http://www.naocaber.org/wpcontent/uploads/2015/01/urbania5_web_pagsjuntas.pdf>. Acesso em: 20 set. 2015. 
MESQUITA, André et al. Caso Caroline Pivetta da Mota na $28^{\mathrm{a}}$ Bienal de São Paulo, 2008. Disponível em: <http://www.forumpermanente.org/revista/imprensa/arecepcao-da-28a-bienal-de-sao-paulo/caso-caroline-pivetta-da-mota-na-28a-bienalde-sao-paulo>. Acesso em: 31 ago. 2016.

MESQUITA, Ivo. 28a Bienal de São Paulo, 2008. Disponível em: <http://www. artecapital.net/perspetiva-71-ivo-mesquita-28\%C2\%AA-bienal-de-sao-paulo>. Acesso em: 31 ago. 2016.

MESQUITA, Ivo; COHEN, Ana Paula. Caso Caroline: algumas questões não consideradas, 2008a. Disponível em: <http://www.forumpermanente.org/ imprensa/a-recepcao-da-28a-bienal-de-sao-paulo/caso-caroline-algumas-questoesnao-consideradas $>$. Acesso em: 31 ago. 2016.

28 a Bienal de São Paulo. Guia. São Paulo: Bienal de São Paulo, 2008b.

MORAES, Diogo de. Episódios contrapúblicos. Urbânia, São Paulo, n. 5 (Educação), p. 245-247, 2015. Disponível em: <http://www.naocaber.org/wp-content/ uploads/2015/01/urbania5_web_pagsjuntas.pdf >. Acesso em: 20 set. 2015.

MÖRSCH, Carmen. At a Crossroads of Four Discourses: Documenta 12 Gallery Education in between Affirmation, Reproduction, Desconstruction, and Transformation. In: . Documenta 12 Education, v. 2, Between Critical Practice and Visitor Services Results of a Research Project. Zurique: Diaphanes, 2009. p. 9-31.

O’DOHERTY, Brian. No interior do cubo branco: a ideologia do espaço da arte. São Paulo: Martins Fontes, 2002.

O'NEILL, Paul. Biennial Culture and the Emergence of a Globalized Curatorial Discourse: Curating in the Context of Biennials and Large-Scale Exhibitions Since 1989. In: The Culture of Curating and the Curating of Culture(s). Cambridge: MIT Press, 2012. p. 51-85.

OLIVEIRA, Lúcia Maciel Barbosa de. Que políticas culturais?, 2009. Disponível em: <http://www.forumpermanente.org/revista/edicao-0/textos/que-politicasculturais $>$. Acesso em: 13 jun. 2015.

ORTELLADO, Pablo; LIMA, Luciana Piazzon Barbosa; SOUZA, Valmir de. O que são as políticas culturais? Uma revisão crítica das modalidades de atuação do Estado no campo da cultura. In: Seminário Internacional Políticas Culturais, 4., 2013, Rio de Janeiro. Anais., Rio de Janeiro: Setor de Políticas Culturais da Fundação Casa de Rui Barbosa, 2013, p. 1-17. Disponível em: <http://culturadigital. br/politicaculturalcasaderuibarbosa/files/2013/11/Luciana-Piazzon-Barbosa-Limaet-alii.pdf>. Acesso em: 21 jul. 2016.

PAZ, Octavio. Marcel Duchamp ou o castelo da pureza. São Paulo: Perspectiva, 2002. 
PELBART, Peter Pál. Anota aí: eu sou ninguém. Folha de S.Paulo, São Paulo, 19 jul. 2013, p. A3. Disponível em: <http://www1.folha.uol.com.br/ opiniao/2013/07/1313378-peter-pal-pelbart-anota-ai-eu-sou-ninguem.shtml >. Acesso em: 4 dez. 2016.

Carta aberta aos secundaristas. In: Grupo Contrafilé, secundaristas de luta e amigos. A batalha do vivo. São Paulo, 2016. p. 124-129.

PICON, Gaëtan. A cultura e o estado. In: POIRRIER, Philippe; GENEVIĖVE, Gentil. Cultura e estado: a política cultural na França, 1955-2005. São Paulo: Iluminuras; Itaú Cultural, 2012. p. 51-53. Disponível em: <http://d3nv1jy4u7zmsc.cloudfront.net/ wp-content/uploads/2013/04/Cultura-e-estado.pdf>. Acesso em: 22 jul. 2016.

PLAZA, Julio. Arte e interatividade: autor-obra-recepção. Ars, São Paulo, n. 2, p. 9-29, 2003.

PREZIOSI, Donald. Collecting / Museums. In: Critical Terms for Art History. Chicago: University of Chicago Press, 1996. p. 407-418.

PROUST, Marcel. No caminho de Swann. São Paulo: Abril Cultural, 1979.

RANCIÈRE, Jacques. A partilha do sensível: estética e política. São Paulo: EXO experimental org.; Editora 34, 2005a.

O mestre ignorante. Belo Horizonte: Autêntica, 2005b.

A política da arte e seus paradoxos contemporâneos. In: Encontro

Internacional Situação \#3 Estética e Política, 17 a 19 de abril de 2005c, São Paulo (mimeo.).

O espectador emancipado. São Paulo: WMF Martins Fontes, 2012.

REPA, Luiz Sérgio. Sobre o conceito habermasiano de esfera pública. Número, São Paulo, v. 6, 2005. Disponível em: <http://www.forumpermanente.org/rede/numero/ rev-numero6/seisluizrepa >. Acesso em: 30 mar. 2017.

RIBAS, Cristina. Vocabulário político para processos estéticos. Rio de Janeiro: Aplicação, 2014.

RIO, João do. A alma encantadora das ruas: crônicas. São Paulo: Companhia das Letras, 2008.

RODRIGO, Javier Montero. Experiências de mediação crítica e trabalho em rede nos museus: das políticas de acesso às políticas em rede. Tradução de Lucas Oliveira. Periódico Permanente, São Paulo, n. 6 (Mediação cultural), p. 1-20, 2016. Disponível em: <http://www.forumpermanente.org/revista/revista/numero-6-1>. Acesso em: 11 mai. 2017. 
ROSA, João Guimarães. Grande sertão: veredas. Rio de Janeiro: Nova Fronteira, 2006.

RUBIÃO, Murilo. O pirotécnico Zacarias, e outros contos. São Paulo: Companhia das Letras, 2006.

RUFFATO, Luiz. Eles eram muitos cavalos. Rio de Janeiro: BestBolso, 2010.

SAFATLE, Vladimir. Lebensform: ascensão e ascensão da plasticidade mercantil do corpo. In: O circuito dos afetos. São Paulo: Cosac Naify, 2015. p. 187-226.

SENNET, Richard. O declínio do homem público. Rio de Janeiro: Record, 2014.

SHEIKH, Simon. No lugar da esfera pública? Ou o mundo em fragmentos. Urbânia, São Paulo, n. 3, p. 127-135, 2008.

. "Sobre a produção de públicos ou arte e política em um mundo fragmentado”. In: CAMNITZER, L.; PÉREZ-BARREIRO, G. Arte para a educação / educação para a arte. Porto Alegre: Fundação Bienal do Mercosul, 2009. p. 74-88.

. Política da estética. Entrevista a Ana Letícia Fialho e Graziela Kunsch. Trópico, São Paulo, 2010. Disponível em: <www.revistatropico.com.br/tropico/ $\mathrm{html} / \mathrm{print} / 3217 . \mathrm{htm}>$. Acesso em: 16 jul. 2016.

SHOHAT, Ella; STAM, Robert. Do eurocentrismo ao policentrismo. In: Crítica da imagem eurocêntrica: multiculturalismo e representação. São Paulo: Cosac Naify, 2006. p. 37-88.

TEREPINS, Luis. Bienal 2014. Entrevista ao Canal Arte 1. Disponível em: <http:// arte1.band.uol.com.br/bienal-2014>. Acesso em: 15 jul. 2016.

WARNER, Michael. Públicos y contrapúblicos. Barcelona: Museu d’Art Contemporani de Barcelona; Servei de Publicacions de la Universitat Autònoma de Barcelona, 2008.

WERBER, Niels. O populismo como uma forma de mediação. Tradução de Jorge Menna Barreto e Diogo de Moraes. Periódico Permanente, São Paulo, n. 6 (Mediação cultural), p. 1-19, 2016. Disponível em: <http://www.forumpermanente. org/revista/numero-6-1/sumario >. Acesso em: 16 set. 2016.

WU, Chin-Tao. A absorção da cultura empresarial: instituições artísticas a partir da década de 1980. In: . Privatização da cultura: a intervenção corporativa nas artes desde os anos 80. São Paulo: Boitempo; Sesc São Paulo, 2006. p. 145-179. 
Projeto gráfico: Frederico Floeter

Revisão: Érico Melo

Este volume é composto pelas famílias tipográficas Stanley, Atlas Grotesk e Typewriter. Impresso nos papéis Alta Alvura $120 \mathrm{~g} / \mathrm{m}^{2}$, Color Plus Marfim $120 \mathrm{~g} / \mathrm{m}^{2}$, Rio de Janeiro $180 \mathrm{~g} / \mathrm{m}^{2}$ e Tóquio $240 \mathrm{~g} / \mathrm{m}^{2}$, nas máquinas da Gráfica InPrima, em julho de 2017. 


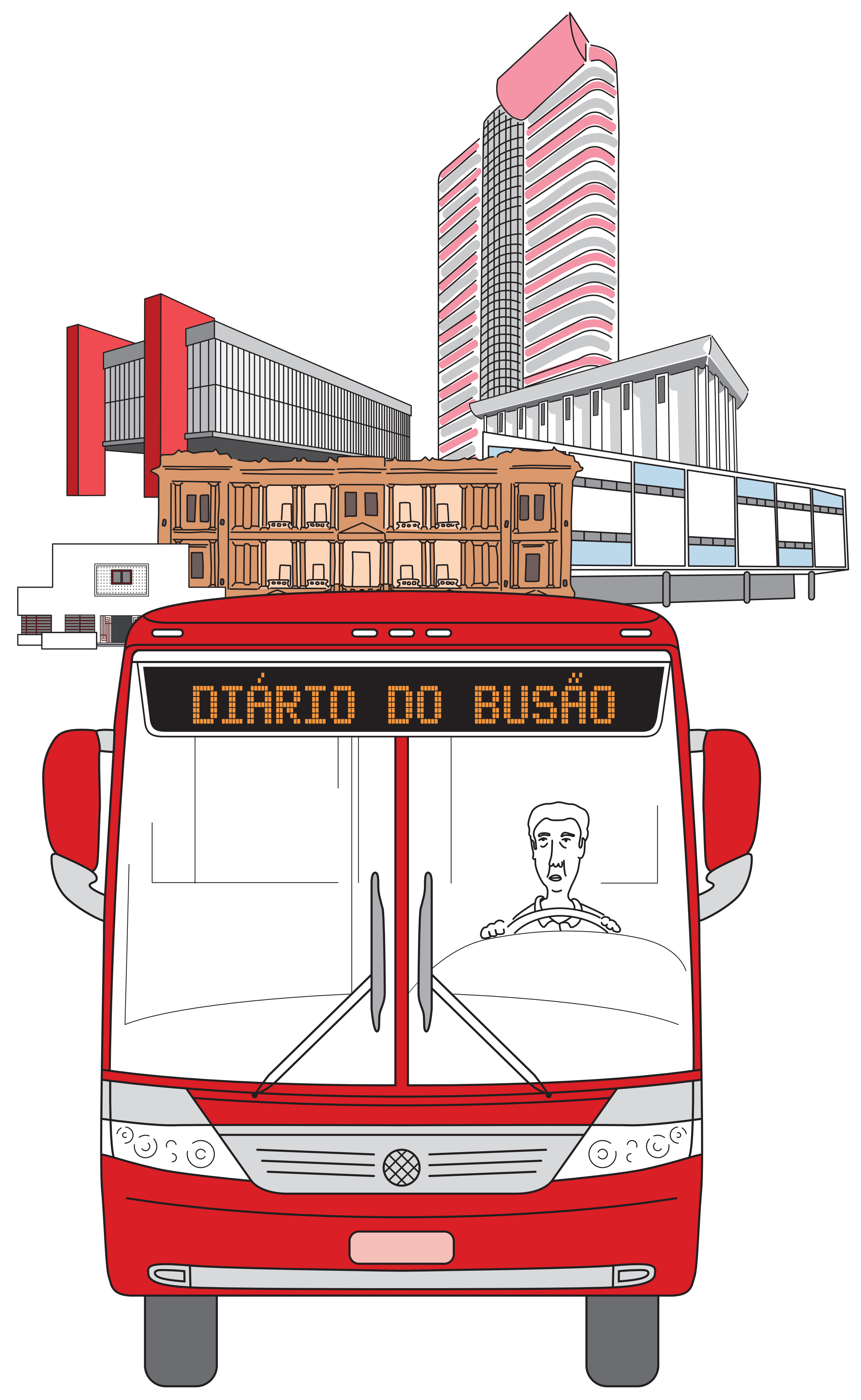


Diogo de Moraes

\section{DIÁRIO
DO BUSÃO \\ visitas escolares a instituições artísticas}


Diário do busão: visitas escolares a instituições artísticas resulta de um experimento que articula as práticas do artista e do mediador. Sua operação pressupõe o uso, a modulação e a ressignificação de procedimentos e repertórios que venho desenvolvendo ao longo das minhas trajetórias simultâneas - aqui imbricadas - nos campos da criação artística e da mediação cultural. A elaboração de seus conteúdos envolve a infiltração em ônibus que conduzem turmas de estudantes da rede pública de ensino, ou de iniciativas do terceiro setor, a instituições de arte concentradas no centro expandido da cidade de São Paulo, por ocasião das visitas mediadas às suas exposições, acervos e conjuntos arquitetônicos. Atento às formas de atuação dos estudantes e de seus professores durante os itinerários pela cidade e as visitas propriamente ditas, lanço mão de um tipo de registro e tradução contrainspirado no modelo do "diário de classe", ferramenta normativa da rotina escolar.

A produção simbólica ensejada e veiculada pelo Diário do busão se faz a partir do interesse por aquilo que os públicos escolares manifestam nos momentos de interação e resposta às oportunidades de acesso promovidas pelas instituições através dos seus departamentos educativos. Minhas infiltrações nessas situações pedagógicas desdobram-se na formulação de relatórios verbo-visuais alusivos a cada visita, delineados com base nas notas e esboços que realizo num pequeno bloco de papel durante $o$ acompanhamento dos grupos. Isso implica a reescrita e o redesenho dessas anotações, num processo que combina fato e ficção.

Em lugar de se comprometer com o binômio conexão-inclusão, a modalidade de mediação cultural colocada em jogo pelo Diário do busão dedica-se à sondagem, tradução e circulação dos índices resultantes dos encontros e desencontros desses públicos com os bens artístico-culturais difundidos pelas instituições, assim como com os discursos e convenções que os medeiam. Desse modo, ele funciona como prática documentária vocacionada a fomentar uma esfera pública específica, propícia à visibilização e problematização das experiências vivenciadas pelos públicos na relação com ações institucionais representativas das políticas de democratização do acesso.
Por outro lado, nota-se que o aparelho institucional propositivo se mantém, no mais das vezes, indiferente ou refratário às reações e respostas dos seus públicos, sobretudo àquelas que se desviam dos planos, discursos e protocolos praticados pelas instituições. Essa responsividade dos públicos se dá na duração temporal, no tempo de visitação às exposições, mas também antes e depois dele. Logo, não conta com prerrogativas espaciais e suportes capazes de fazer repercutir os enunciados engendrados durante tais momentos, inclusive porque tais recursos condizem a privilégios da instituição e das práticas especializadas que lhe dão corpo.

O desaparecimento das formas emergentes, desviantes e, em certos casos, antagonistas de atuação dos públicos mostra-se conveniente a uma retórica cultivada pelas instituições artísticas em torno do seu "inquestionável" papel socioeducativo e pretensamente benéfico ao outro - o não iniciado -, exercido com base na sua missão de difundir os exemplares legítimos da cultura e, assim, buscar garantir o acesso para muitos daquilo que é produzido por poucos, de acordo com o lema da democratização cultural. 0 Diário do busão surge da desnaturalização dessa lógica e, mais ainda, da necessidade de inserir nos contextos expositivos experimentos extrainstitucionais aptos a operar como dispositivos de escuta e amplificação daquilo que seriam as discursividades, performatividades e táticas praticadas pelos públicos em meio à orquestração institucional, através de desvios semânticos, profanaçôes comportamentais e gestos oposicionais.

Entende-se que dessa encruzilhada - aquilo que as instituições difundem versus os usos que os públicos fazem disso - podem advir reações imprevistas, saberes outros e agendas não coincidentes, capazes de fornecer elementos simbólicos para um exercício de desconstrução de discursos unidirecionais e hegemônicos. A atenção a essa contraface da oferta justifica-se pela tentativa de deflagrar situações em que as próprias instituições e seus agentes se vejam reendereçados por seus públicos, sendo convocados a também aprender com eles.

Diogo de Moraes Junho de 2017 
Relatório 1 - Instituto Tomie Ohtake

Relatório 2 - Instituto Tomie Ohtake

Relatório 3 - Casa Modernista

Relatório 4 - Museu de Arte de São Paulo

Relatório 5 - Pinacoteca do Estado de São Paulo

Relatório 6 - Museu da Imagem e do Som

Relatório 7 - 32ª Bienal de São Paulo 


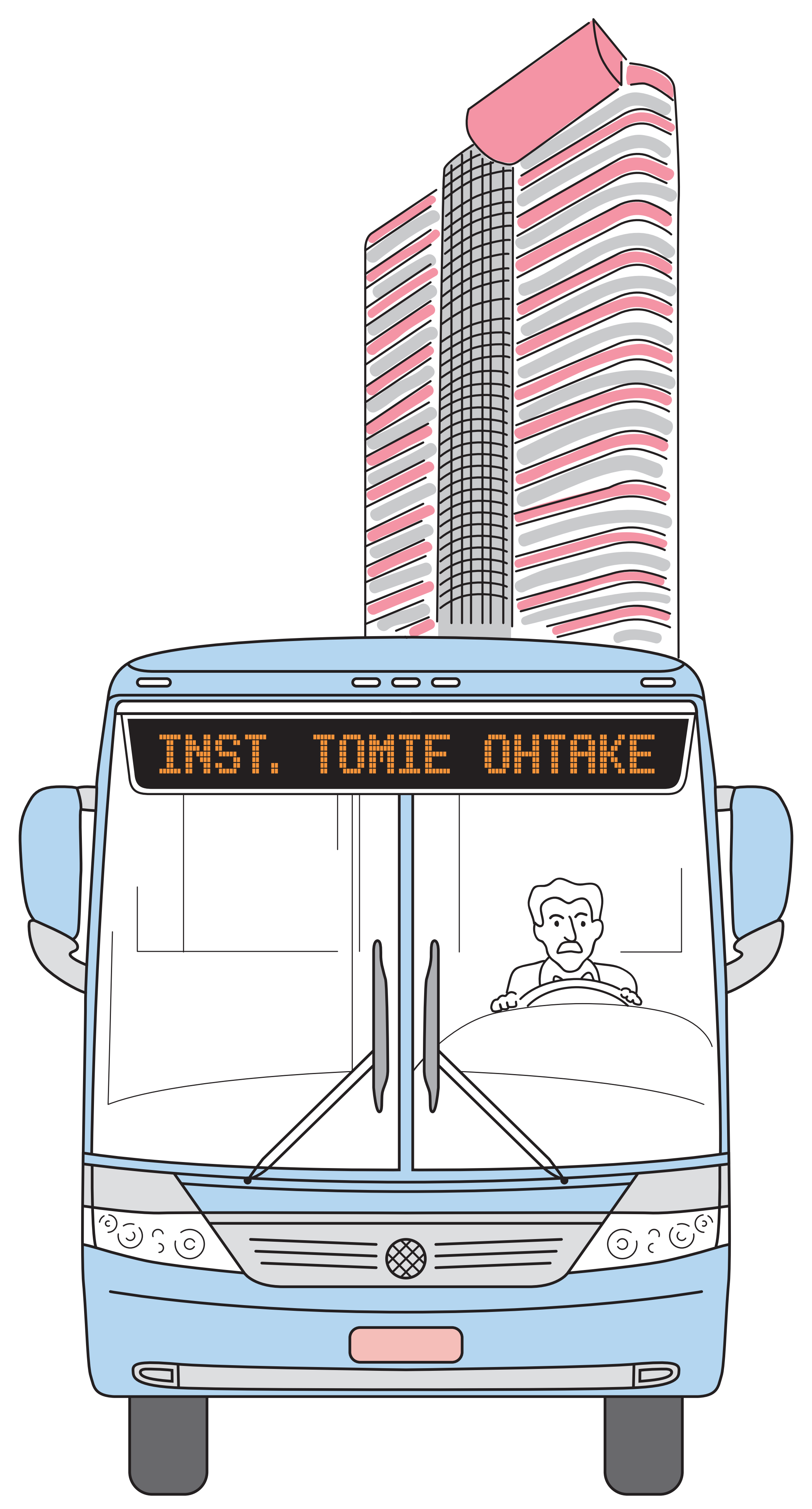




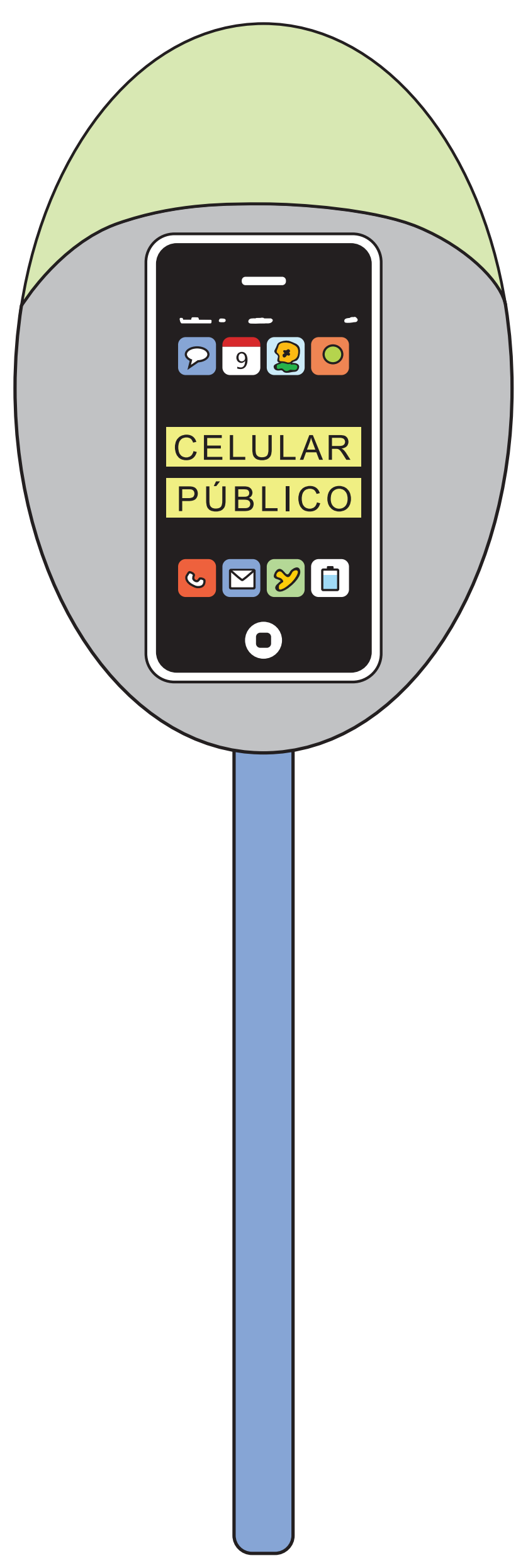

Antes de partir em direção ao Instituto Tomie Ohtake, enquanto o grupo se reúne na recepção da Associação EMP, os jovens usam seus aparelhos celulares para mostrar uns aos outros uma grande quantidade de fotos e mensagens.

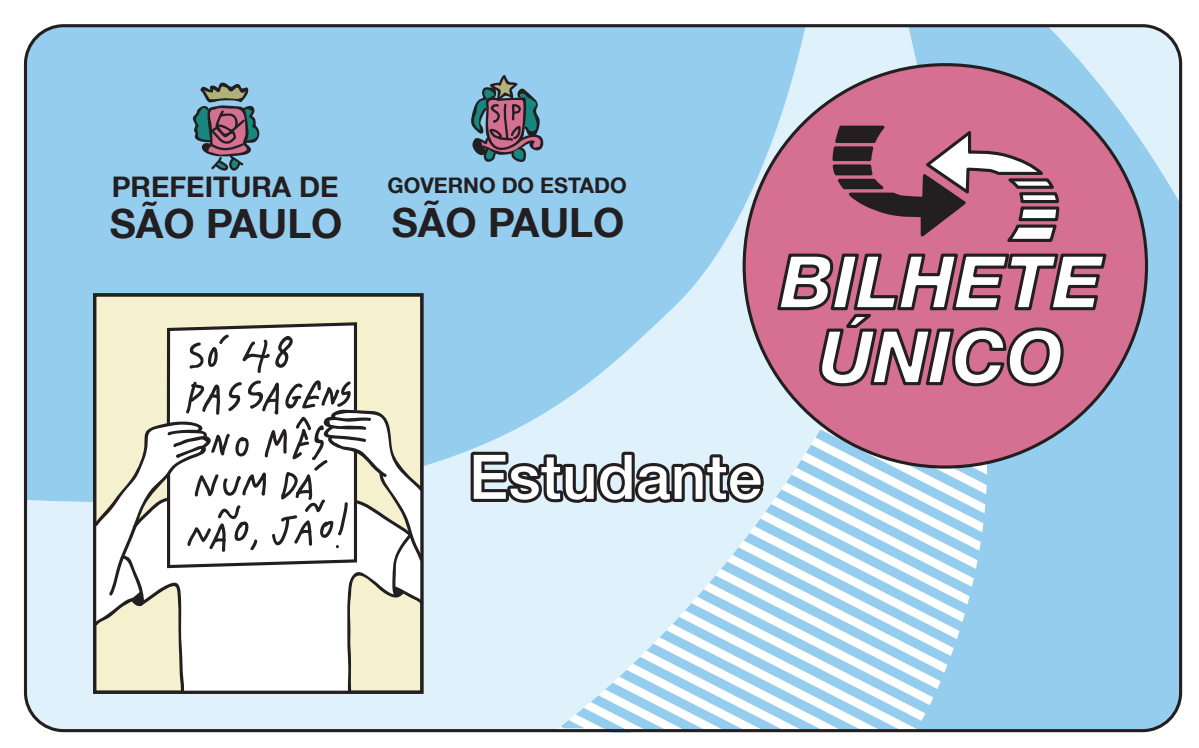

Entre os relatos que se podem escutar, chama atenção os comentários sobre temas como transporte público, shoppings centers, créditos de celular, homossexualidade, procedimentos de controle escolar (ronda policial, horários de aula, fechamento do portão, chamada etc.) e mundo do trabalho. Depois da primeira meia-hora de conversas, ainda na recepção da Associação EMP, um dos jovens cogita, na rodinha da qual participa naquele momento, 0 destino da excursão do dia: "Um museu [sic] de arte".

Basta prestar atenção para notar uma série de comentários que abrangem aspectos importantes da vida social.

Enquanto numa rodinha de jovens começa a surgir um conflito mais acirrado entre dois deles, um terceiro recomenda: "Não vamos brigar, pela conversa a gente resolve tudo".

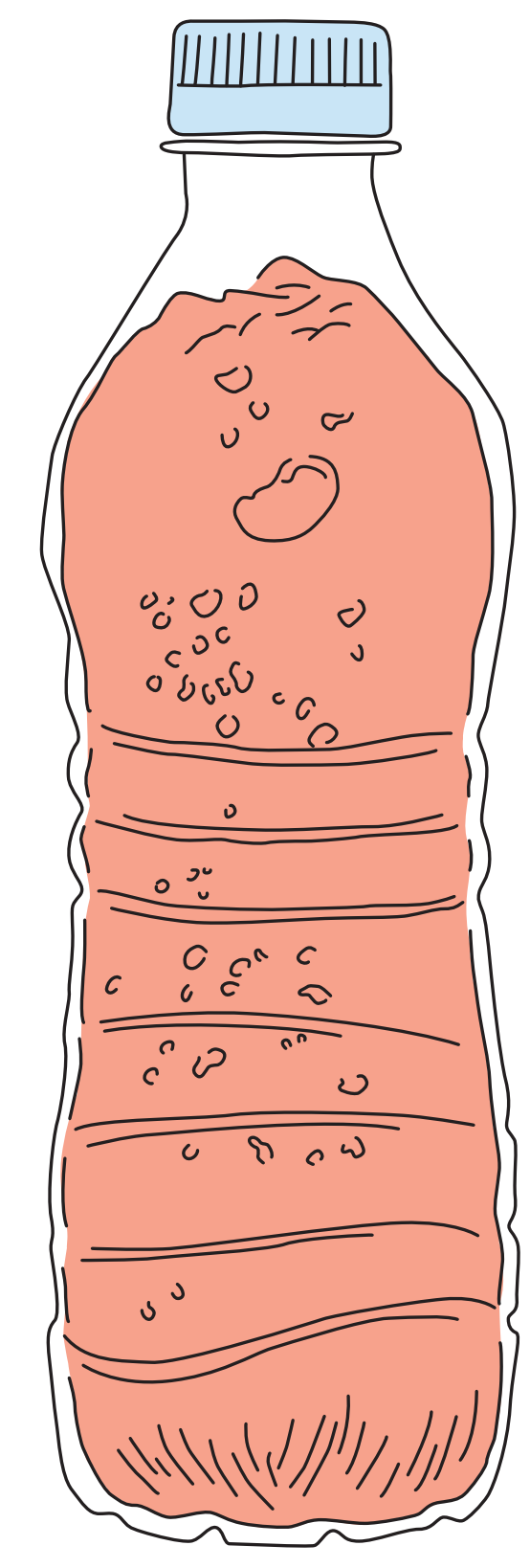

Suco congelado transportado na mochila, para ser bebido fresquinho durante a excursão. 


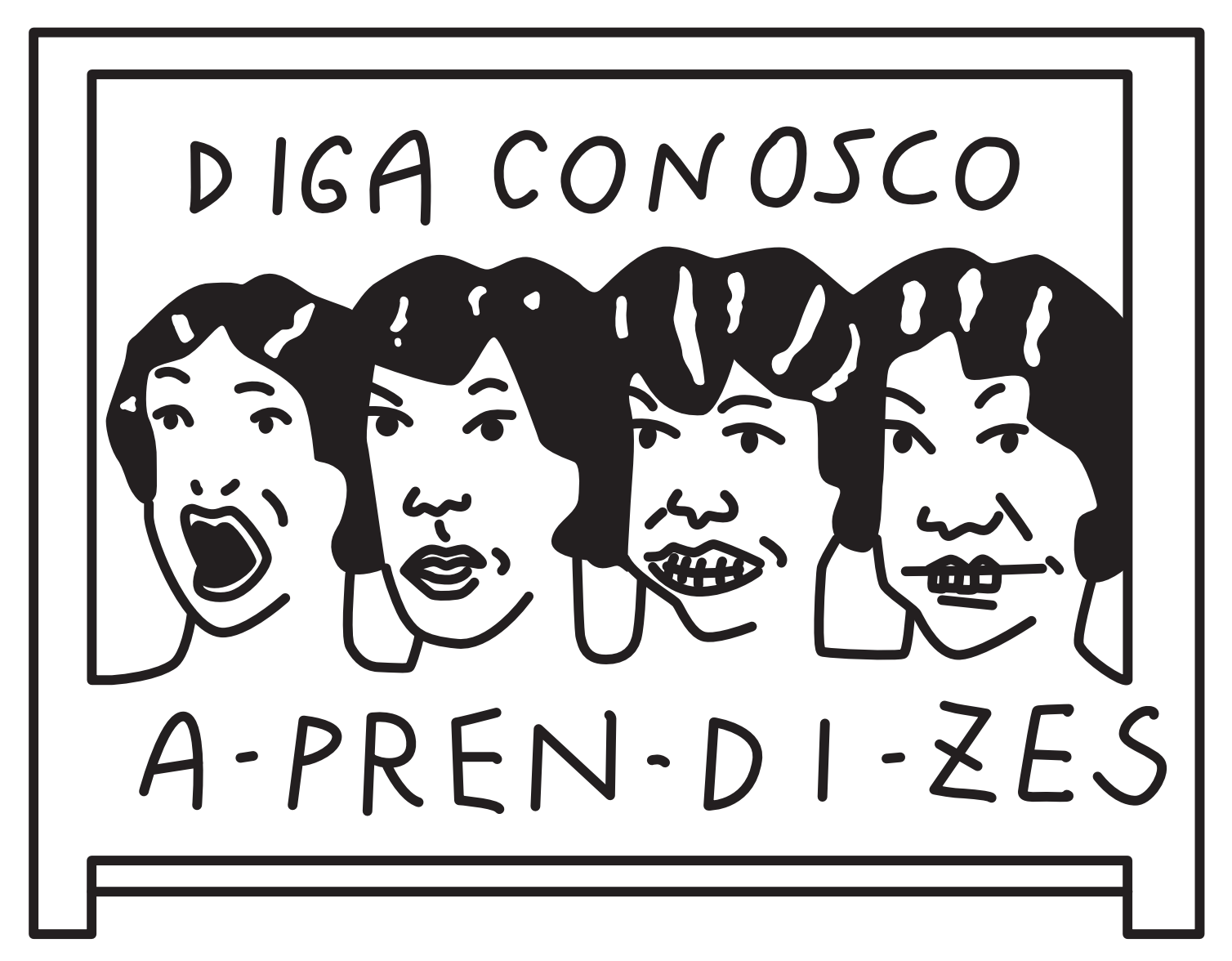

Os jovens da Associação EMP se identificam como "aprendizes".
Um tipo de resposta é recorrente nas conversas e pilhérias entre os jovens: "No teu cú!".

Tem um e outro que não se envolvem nas rodinhas de conversa, permanecendo a sós e calados durante quase todo o tempo.

0 aparecimento repentino da professora na recepção, onde o grupo se reúne, silencia abruptamente as vozes dos jovens.

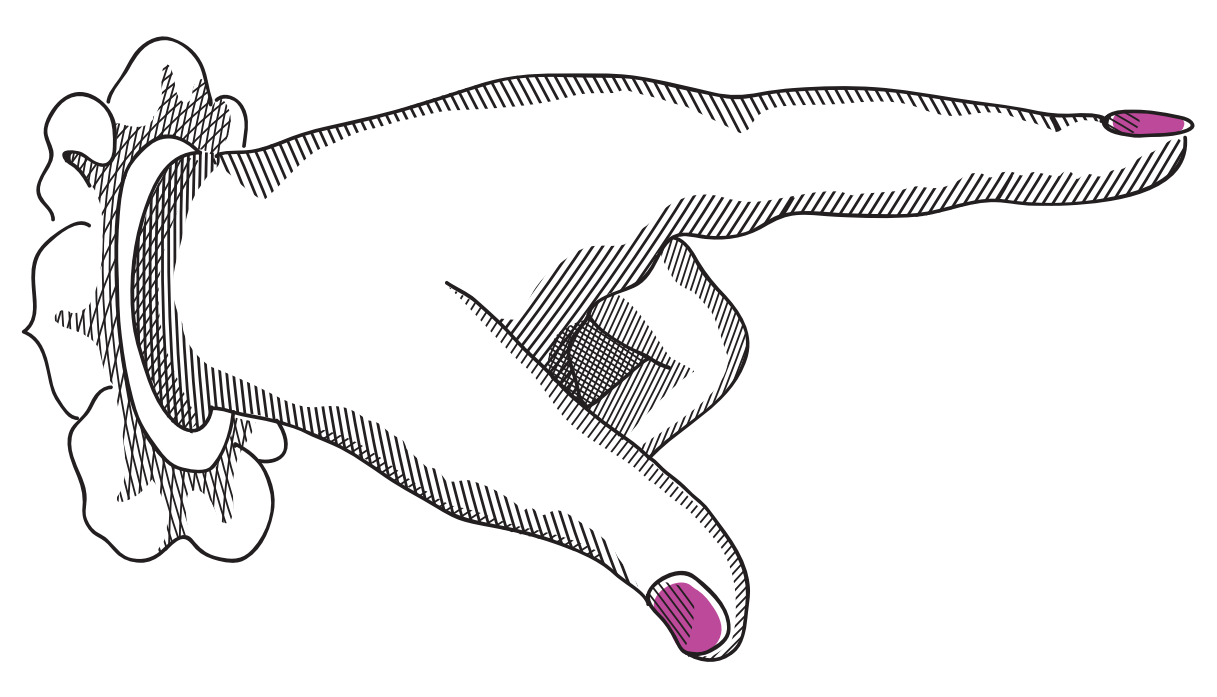

\section{VOC Ê faltou à aula ontem; sua participação na excursão de hoje não está garantida."}

Já na calçada em frente à Associação EMP, enquanto o grupo reunido finalmente se prepara para sair em direção ao Instituto Tomie Ohtake, uma senhora apressada e irritada esbarra em alguns jovens enquanto atravessa a aglomeração sem pedir licença e reclamando da obstrução da calçada pelo grupo. Ao que um dos garotos comenta com seu colega, com certa resignação: "A pessoa quando tem dinheiro é assim...". 


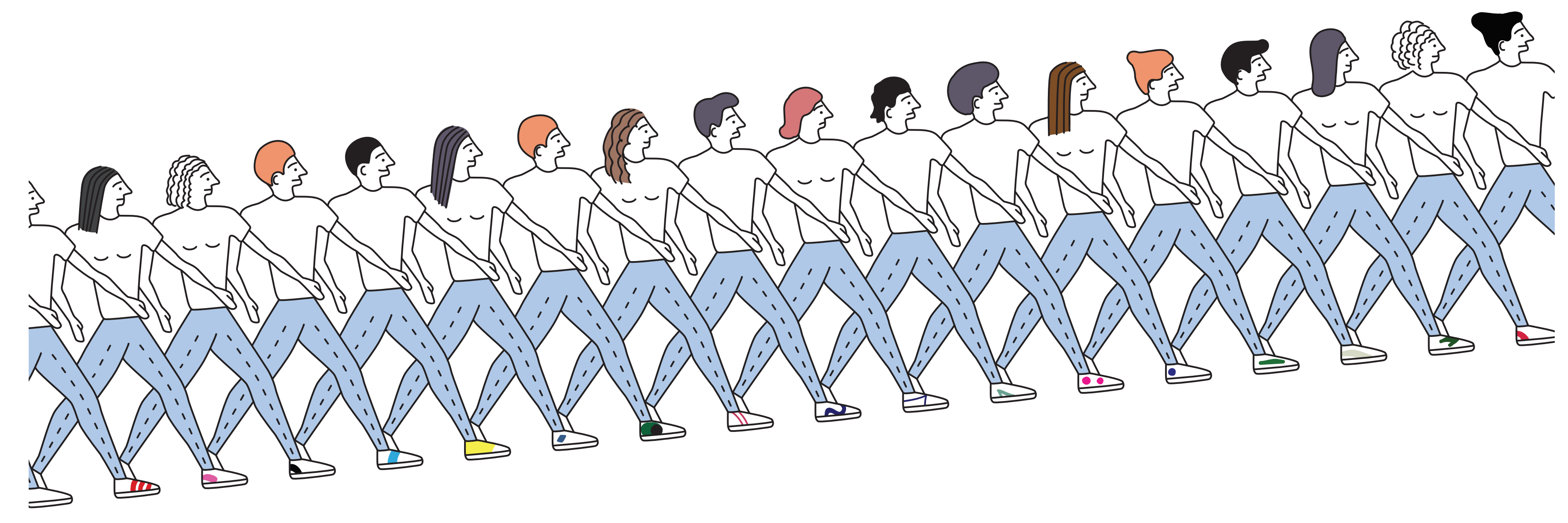

Durante o trecho percorrido a pé, a placa posicionada na vitrine de uma loja chama atenção de uma das jovens, que interrompe seus passos para ler: "ADMITE-SE ESTOQUISTA C/ EXPERIÊNCIA".
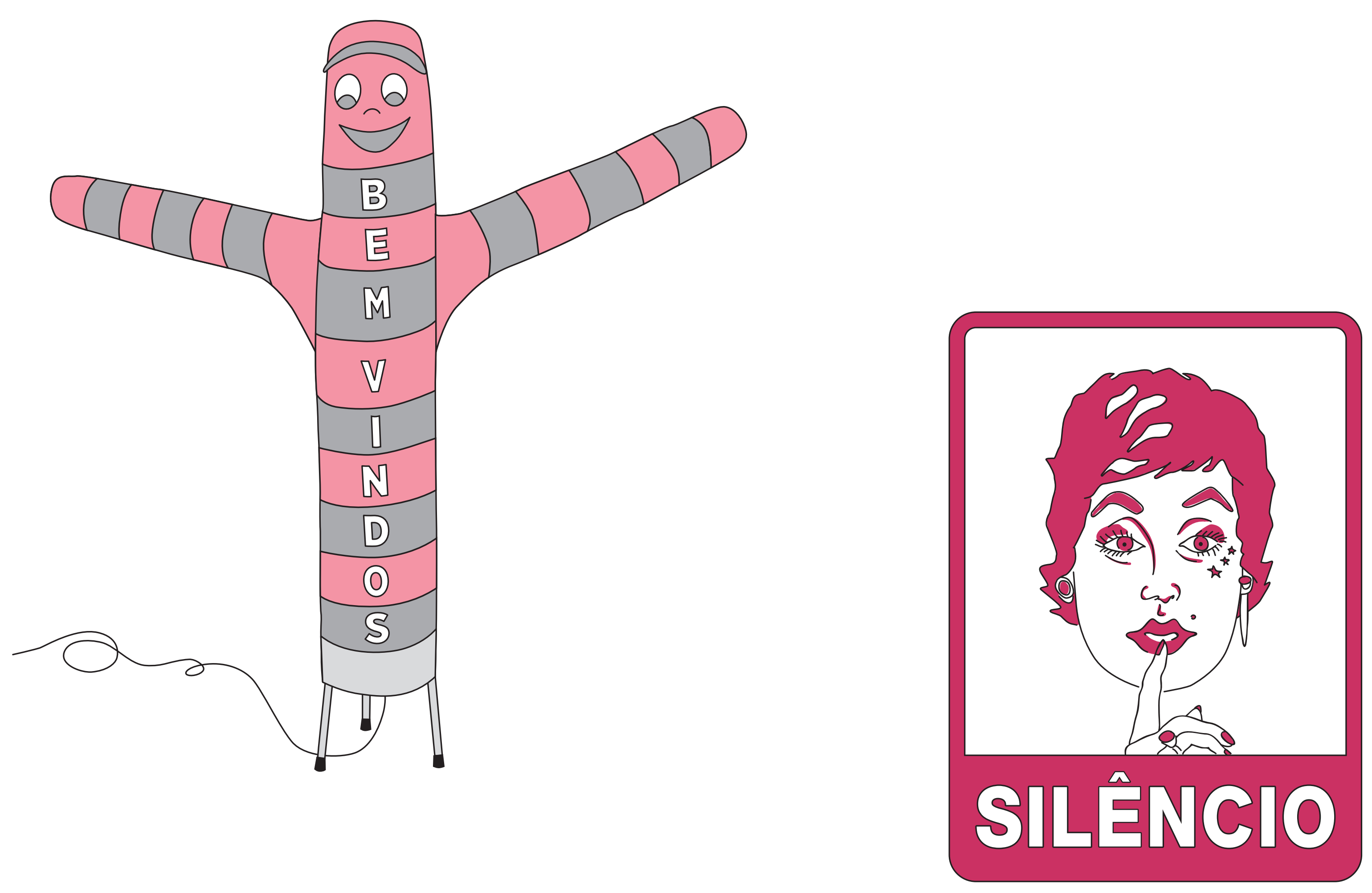

No momento da entrada do grupo no Instituto Tomie Ohtake, sem que tenha havido qualquer orientação expressa por parte dos mediadores ou da professora, os jovens rebaixam suas falas quase por completo, oscilando entre silêncios e sussurros.

Antes de adentrar o espaço expositivo com o grupo de jovens, o mediador diz: "Vou pedir para vocês não tocarem nas obras, pelo amor de Deus". 


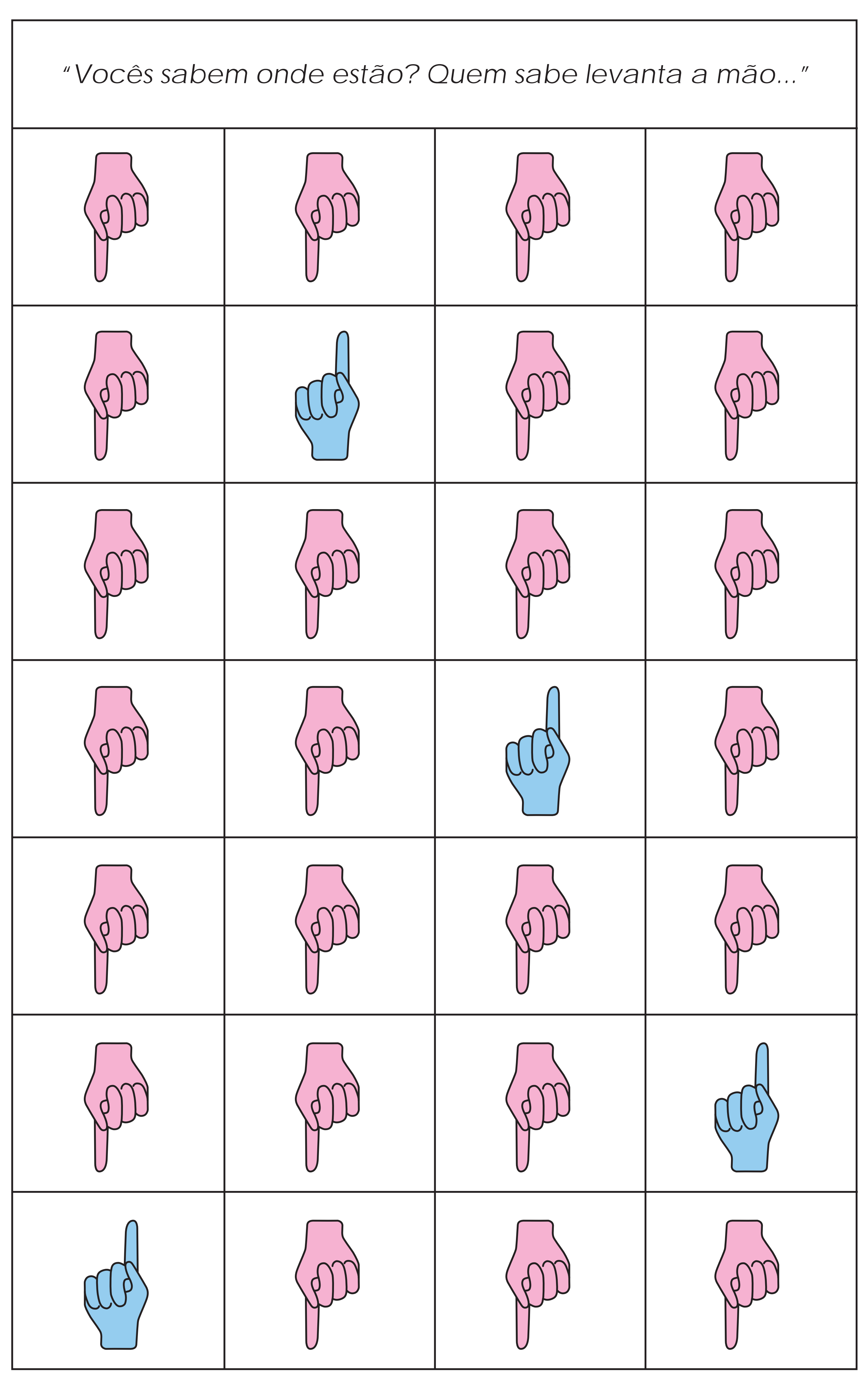


O mediador pergunta ao grupo: "Vocês todos já se conheciam?". Ao que um dos jovens responde: "Sim, menos aquele rapaz ali", apontando para mim. Nesse momento, me apresento ao grupo e detalho o meu propósito ao acompanhá-los: "Observar suas formas de se relacionar com aquilo que surge durante a visita, a fim de poder narrá-las posteriormente".

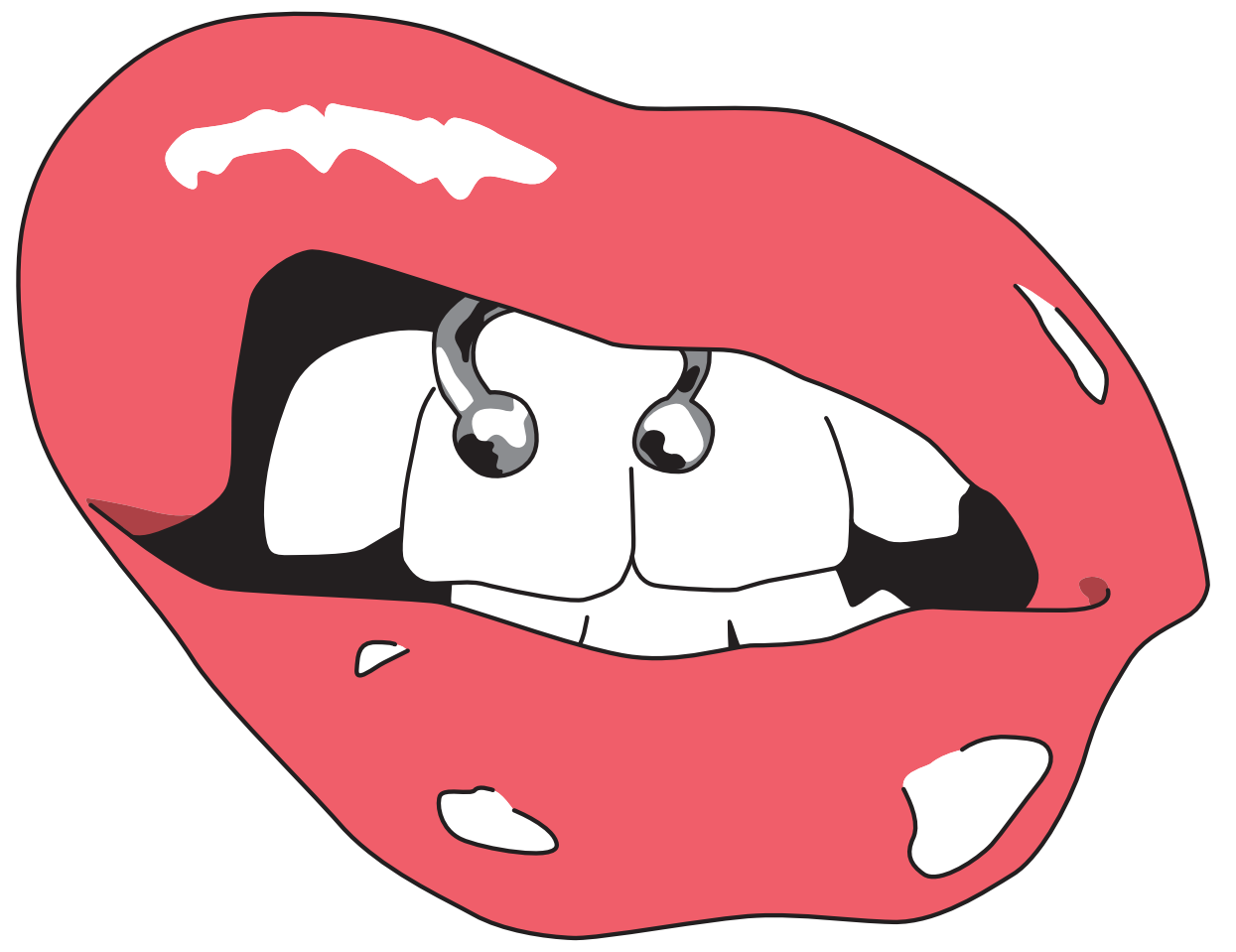

"Você ainda não tirou esse piercing?", diz a professora a uma das alunas.
Chama atenção o uso das roupas no ambiente do Instituto Tomie Ohtake. Tanto os jovens aprendizes e a professora da Associação EMP como os mediadores e vigilantes do Instituto Tomie Ohtake usam uniformes, cada qual indicando sua respectiva posição. Quando surge um integrante do núcleo de curadoria do Instituto, passando próximo ao grupo, salta aos olhos dos jovens o estilo despojado e único do seu traje.

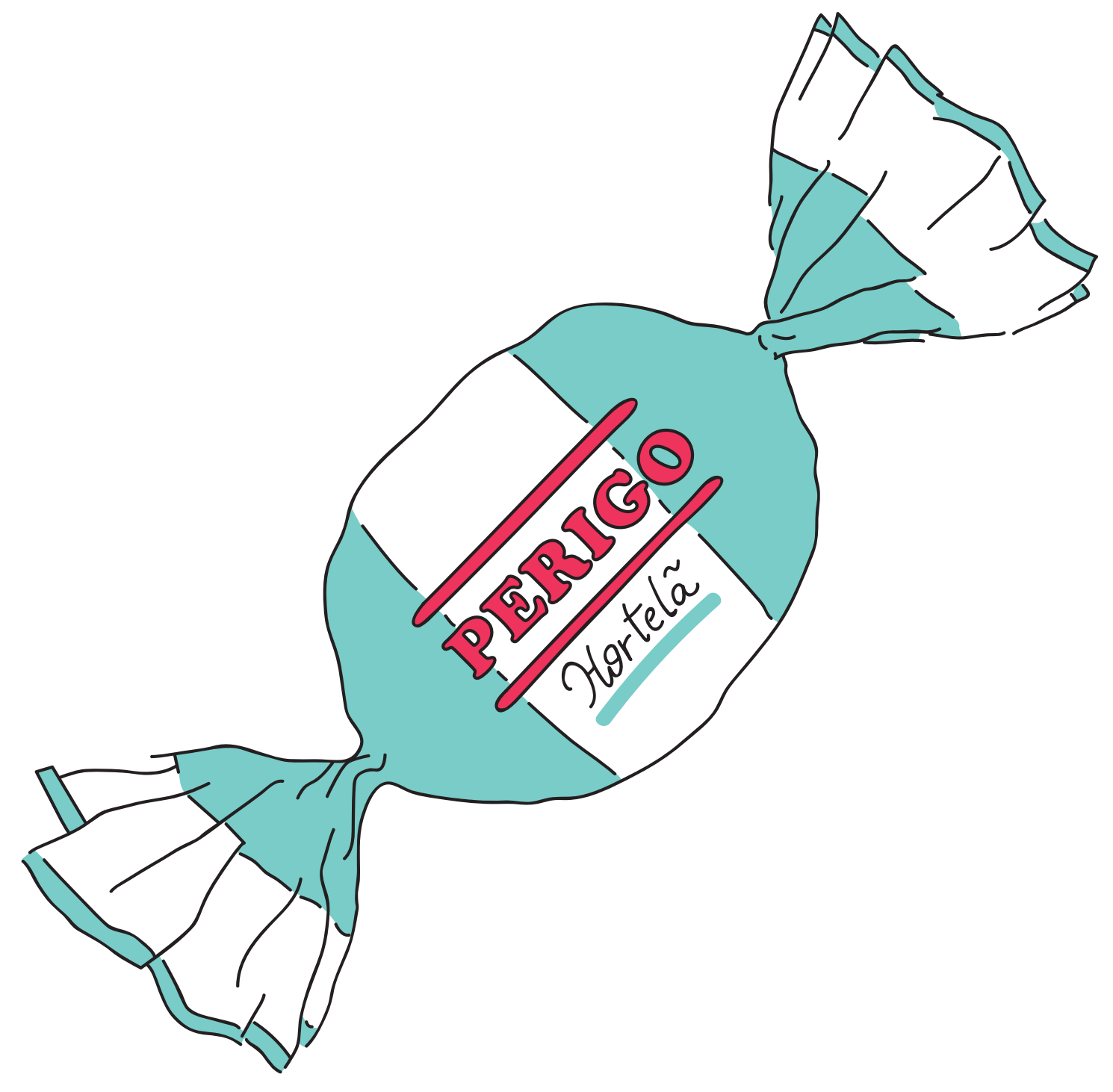

Ao perceber que alguns jovens ficam para trás, o vigilante do Instituto Tomie Ohtake prontamente os orienta: "Não se dispersem do grupo". 


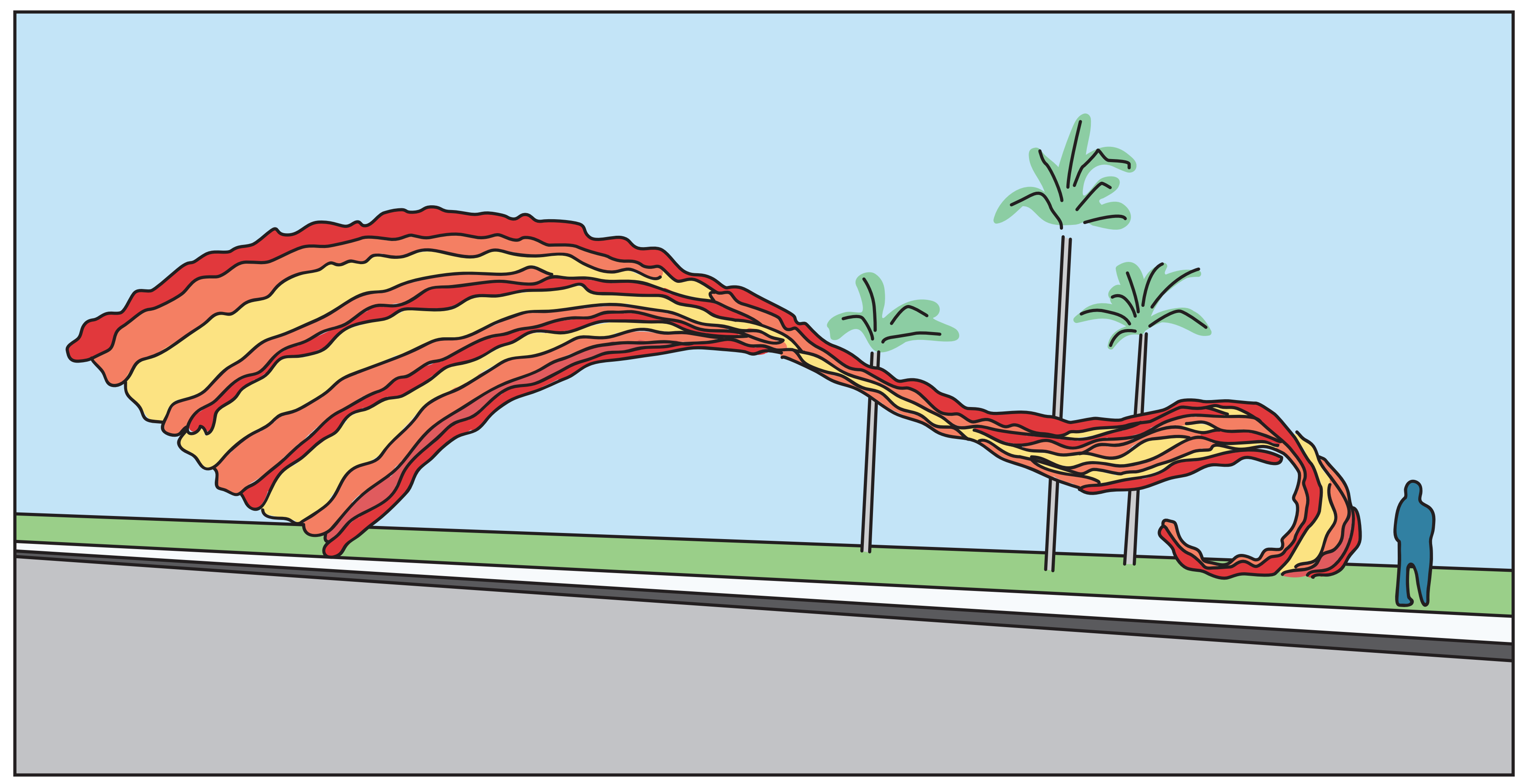

Ao ser perguntado pelo mediador sobre as leituras atribuiveis ao registro fotográfico dessa escultura da artista Tomie Ohtake (Sem titulo, 1999; situada no Parque Industrial da CBMM, em Araxá - MG), o jovem aprendiz responde com uma única palavra: "BACON". 


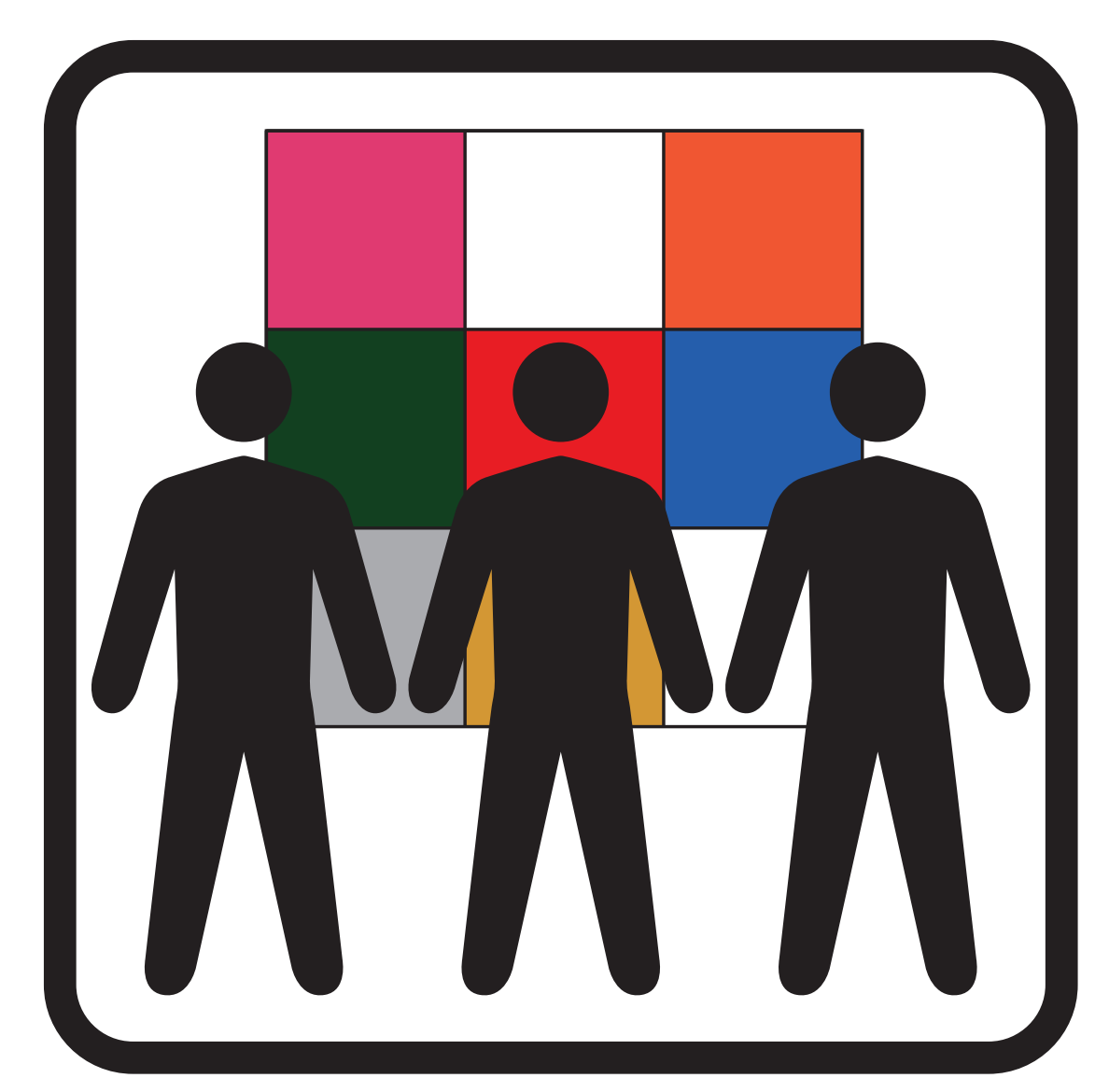

$1^{a}$ pintura

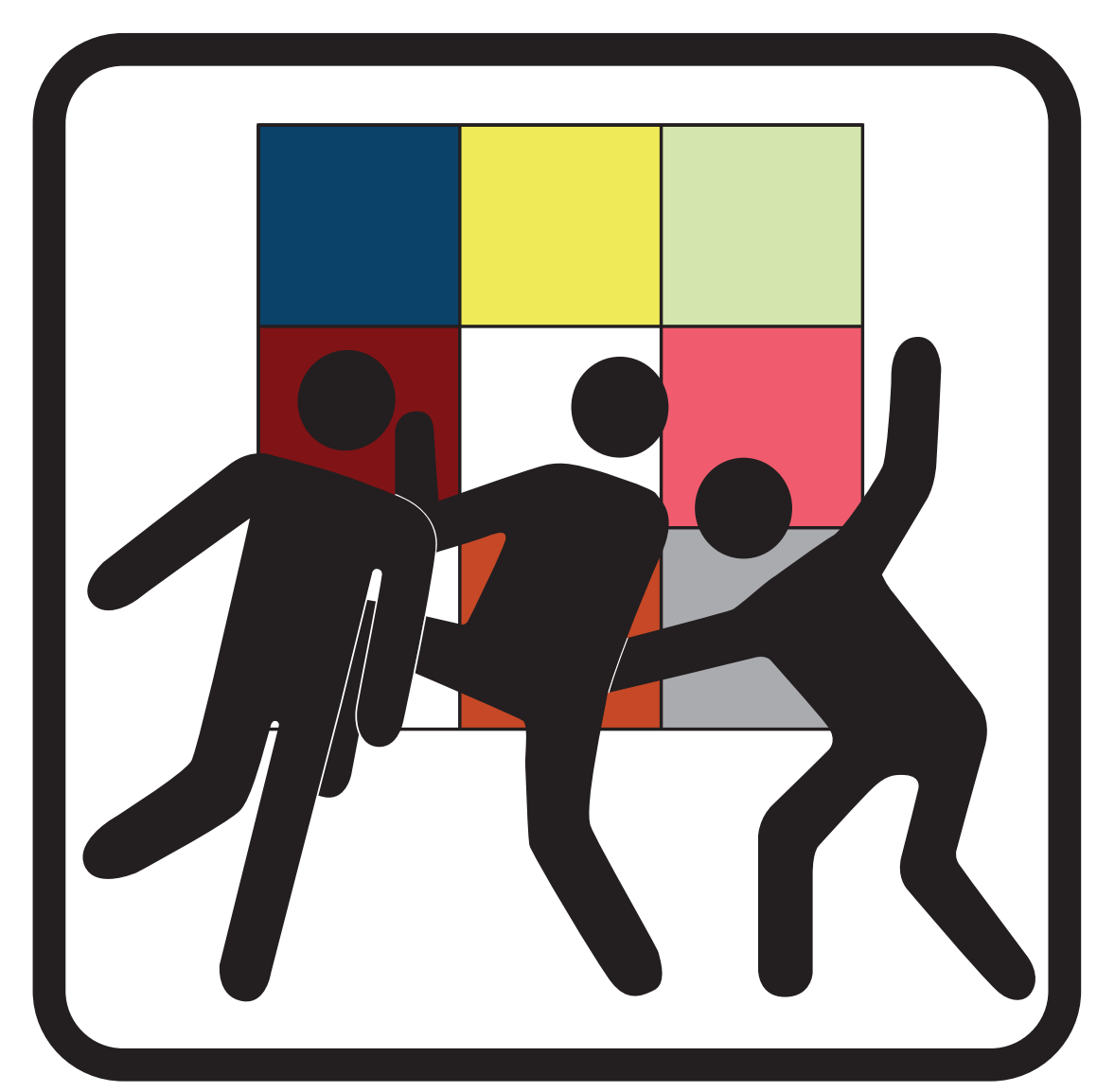

$23^{a}$ pintura

Conforme o grupo avança pela longa série de pinturas, parando em frente a cada uma delas de acordo com a orientação do mediador, alguns jovens mostram-se cada vez mais inquietos.

Um dos jovens, ao notar a aplicação de réguas reais sobre a superfície de uma das pinturas da artista Renata Tassinari, sentencia: "As regras da régua".
Diante do conjunto de pinturas da fase matérica de Tassinari, que evidentemente não poderiam ser tocadas, uma das jovens alisa languidamente com os dedos os cabelos de sua amiga posicionada entre ela e o quadro. 
Quando a conversa passa pelas predileções musicais dos jovens, dois nomes surgem com destaque: Calypso e Ivete Sangalo.

Já no ateliê do Instituto Tomie Ohtake, após a visita à exposição de pinturas, o mediador anuncia de forma convicta: "Agora vocês vão ouvir jazz!".

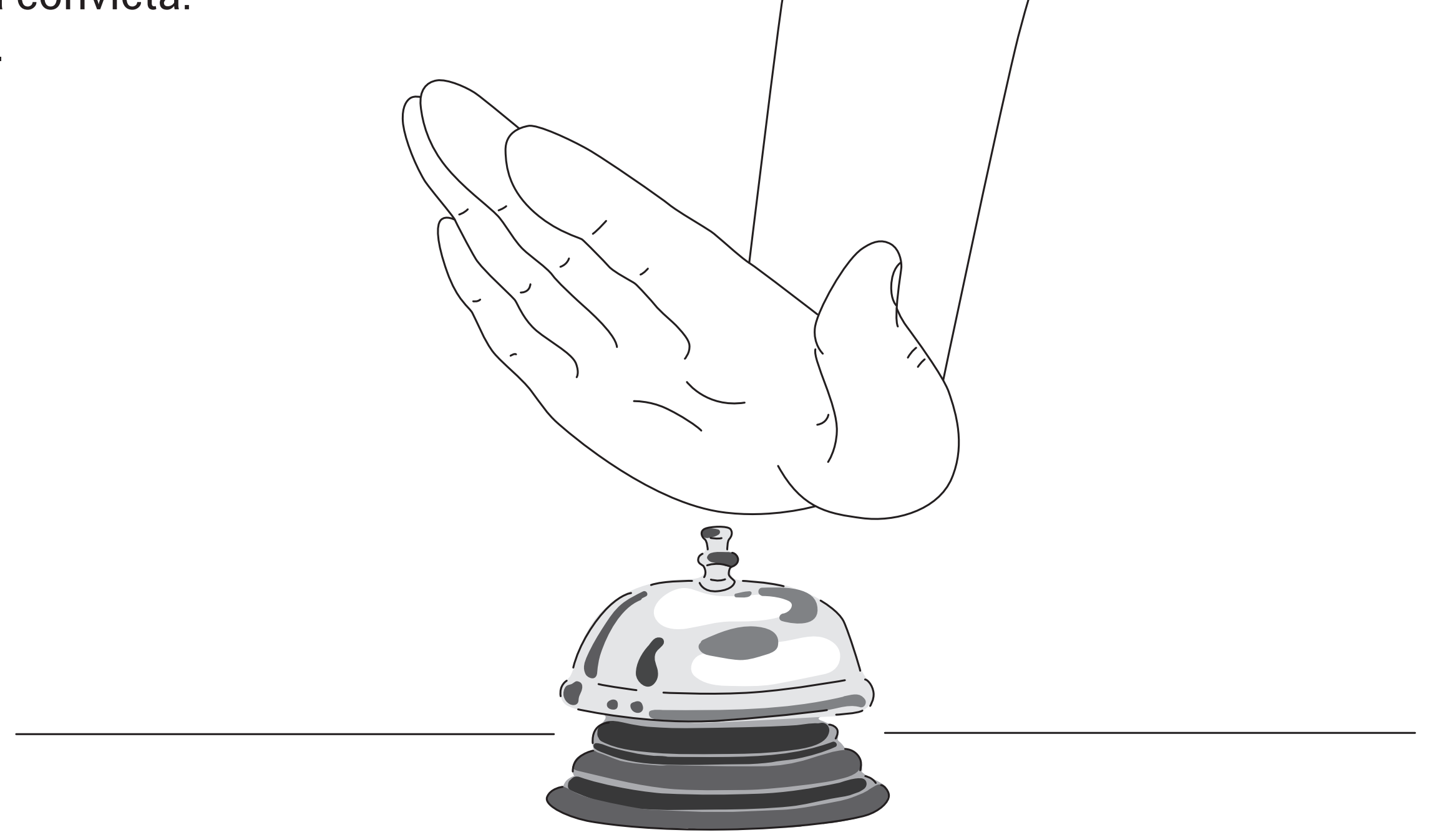

Chega ao fim mais uma visita de escolares.

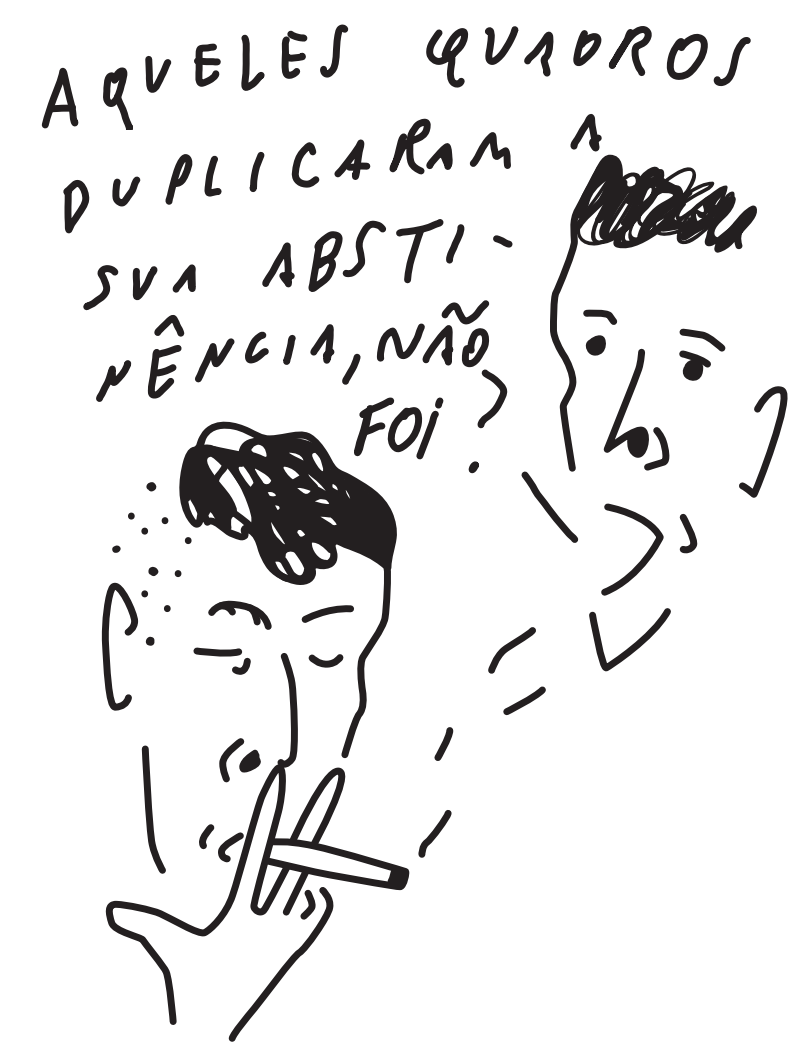

Após a visita, já na calçada, um dos jovens dirige-se em tom de chiste ao seu colega, o qual acabara de acender um cigarro. 


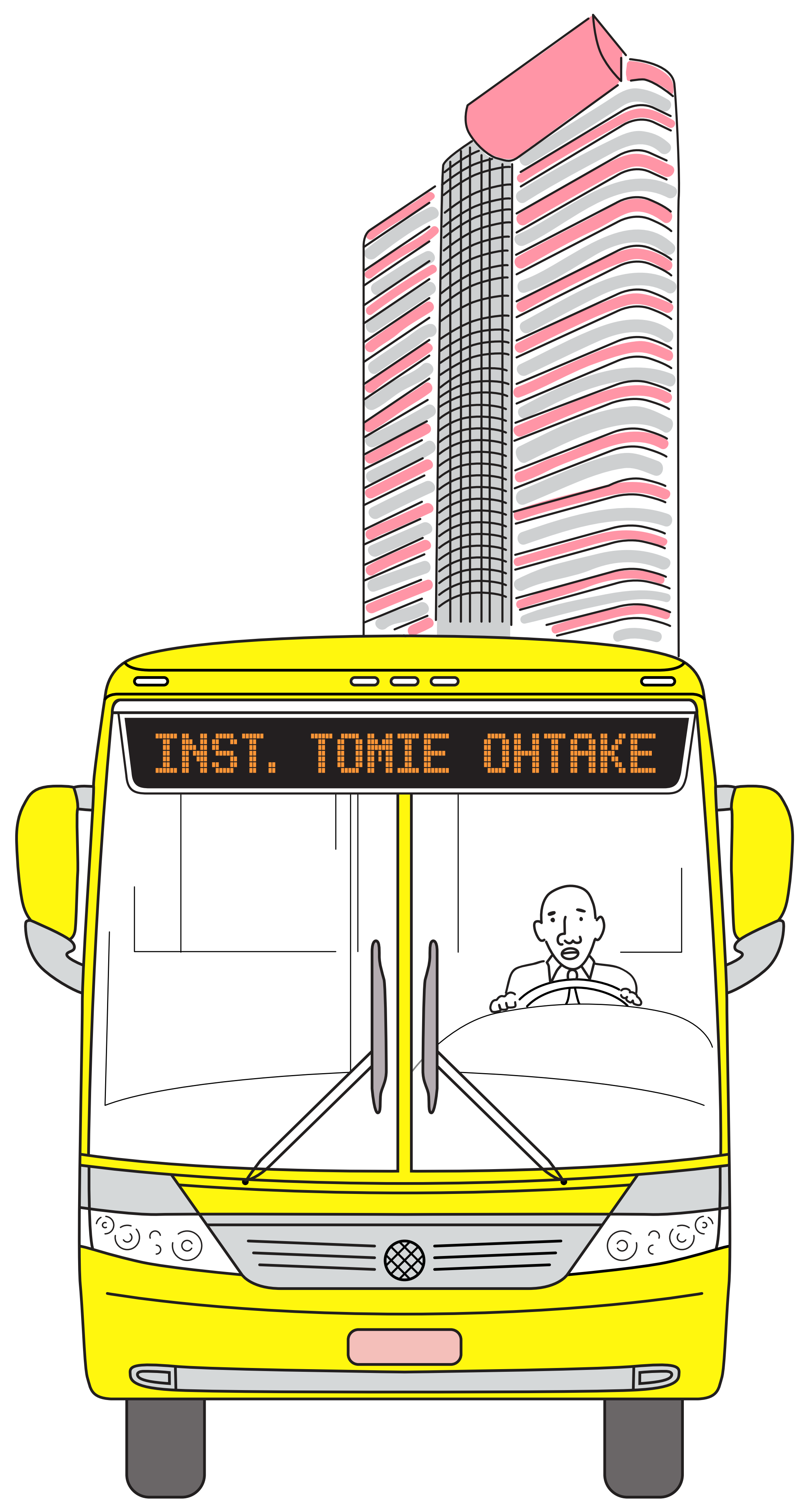




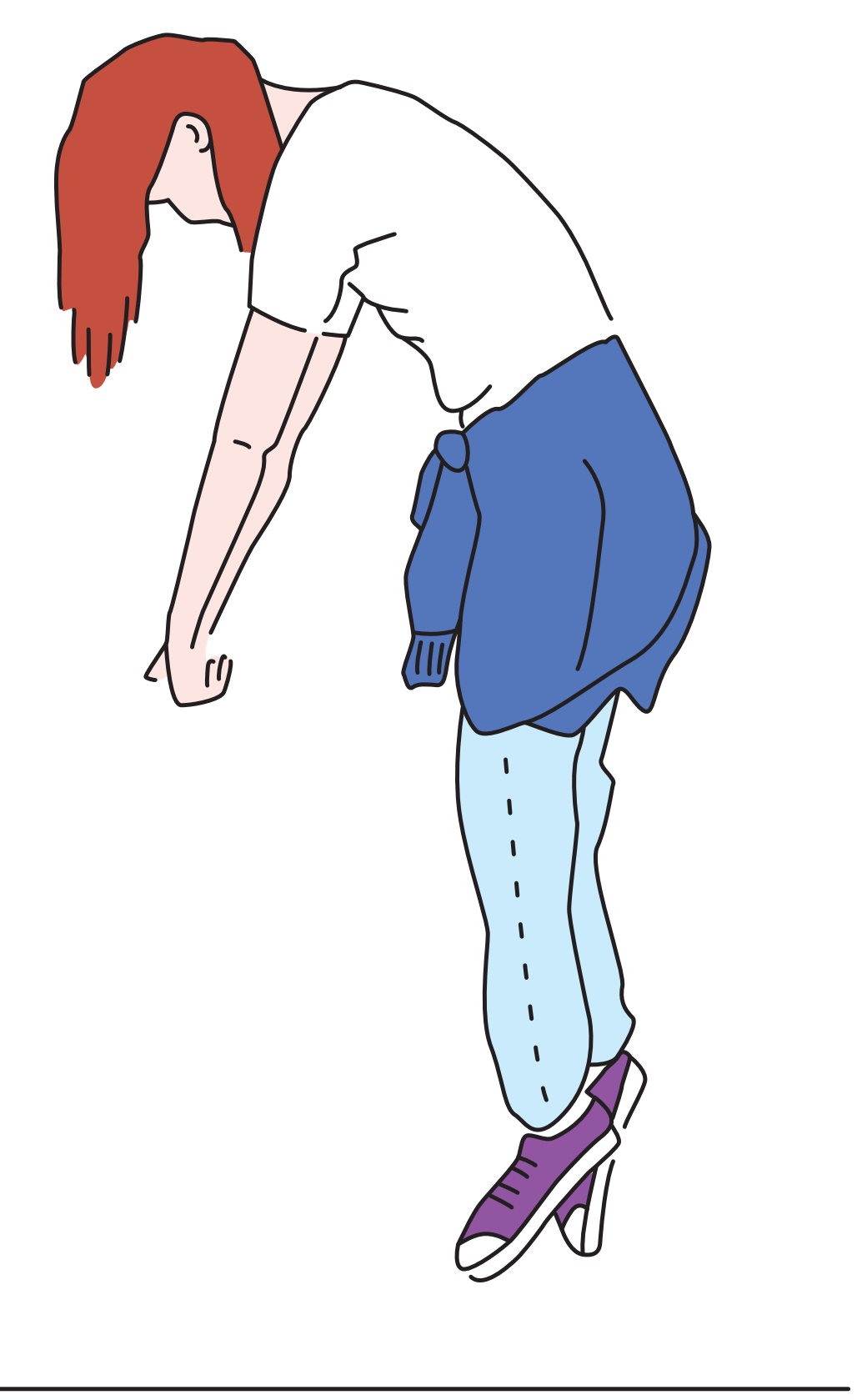

Professora: "Lá no Instituto Tomie Obtake não vai poder tocar em nada". Aluna: "Nem no chão? E como é que a gente vai andar por lá?".

Atrasado, R. é o último aluno da turma a chegar na escola. Está sem o uniforme. Ao vê-lo, a professora relembra que havia avisado, no dia anterior, que todos os alunos deveriam se apresentar de uniforme para a excursão. Ao que $R$. replica de forma displicente: "Era pra ter vindo de uniforme?".

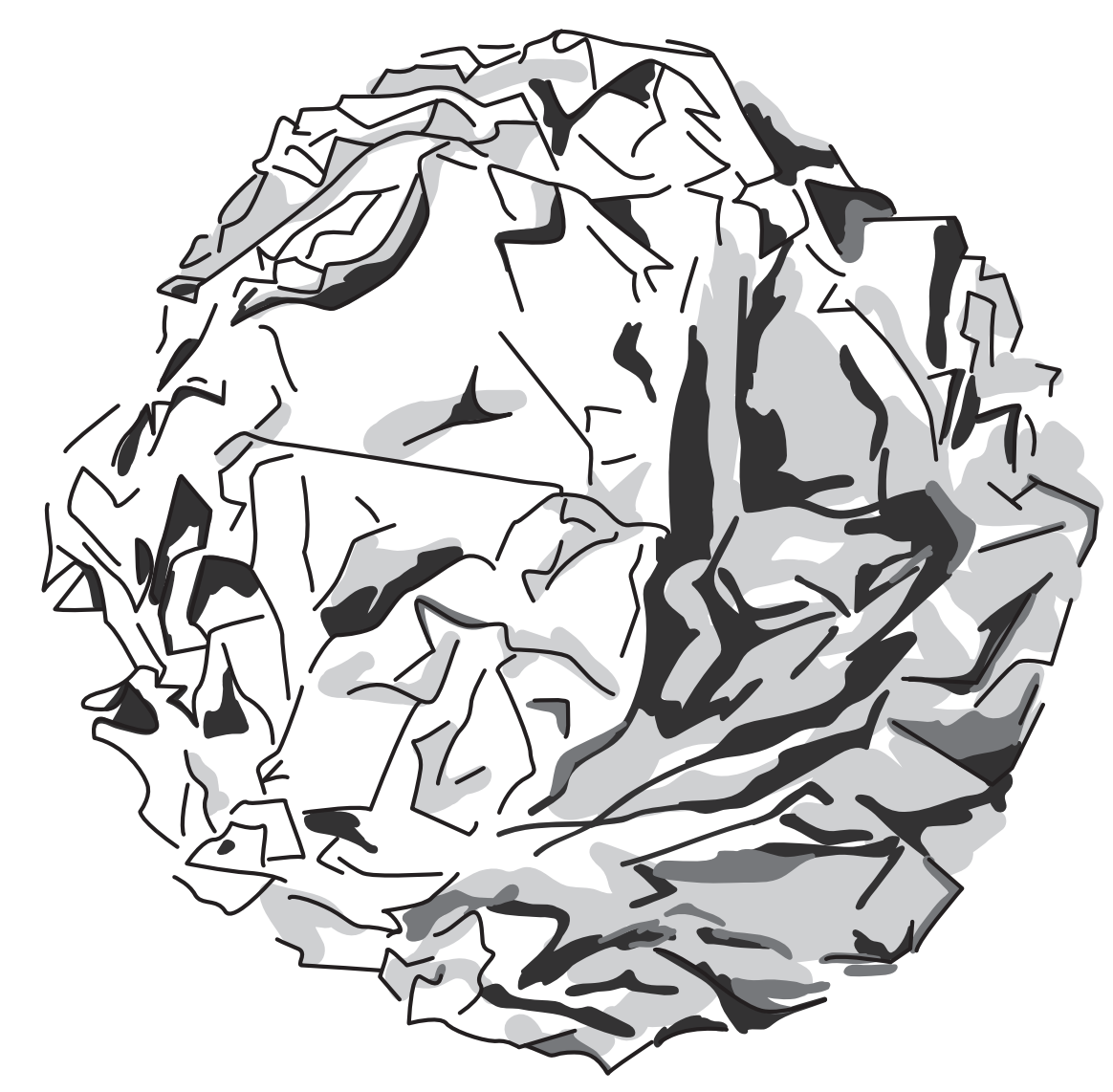

Bolas de papel oscilam entre objeto relacional e arma de guerra nas mãos da "turma do fundão". 


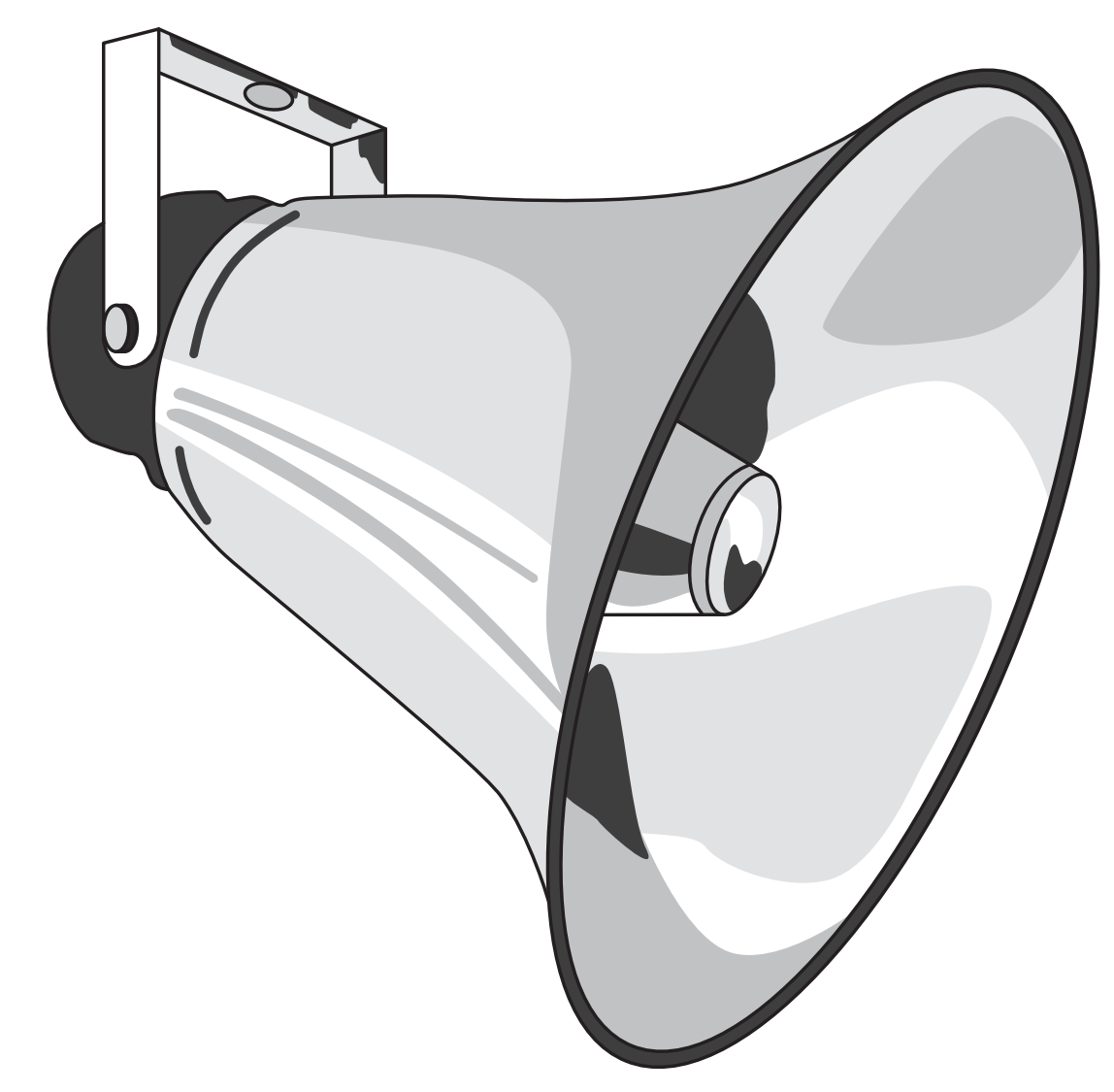

No pátio da escola, enquanto aguardamos o ônibus chegar, a sirene toca. Seu sinal evoca os ambientes da fábrica e da prisão.

A professora relata:

"Eles não têm acesso à cultura. Eles vivem no tráfico de droga". No mesmo instante, começa uma gritaria do outro lado do pátio que acaba embaralhando as palavras do enunciado:

"Eles vivem o tráfico da cultura. Eles não têm a droga do acesso".
Enquanto a turma aguarda a chegada do ônibus, um grupo de meninos aproveita para "bater figurinha" no chão. Ao notar o jogo, a professora prontamente interrompe a partida e confisca as figurinhas.

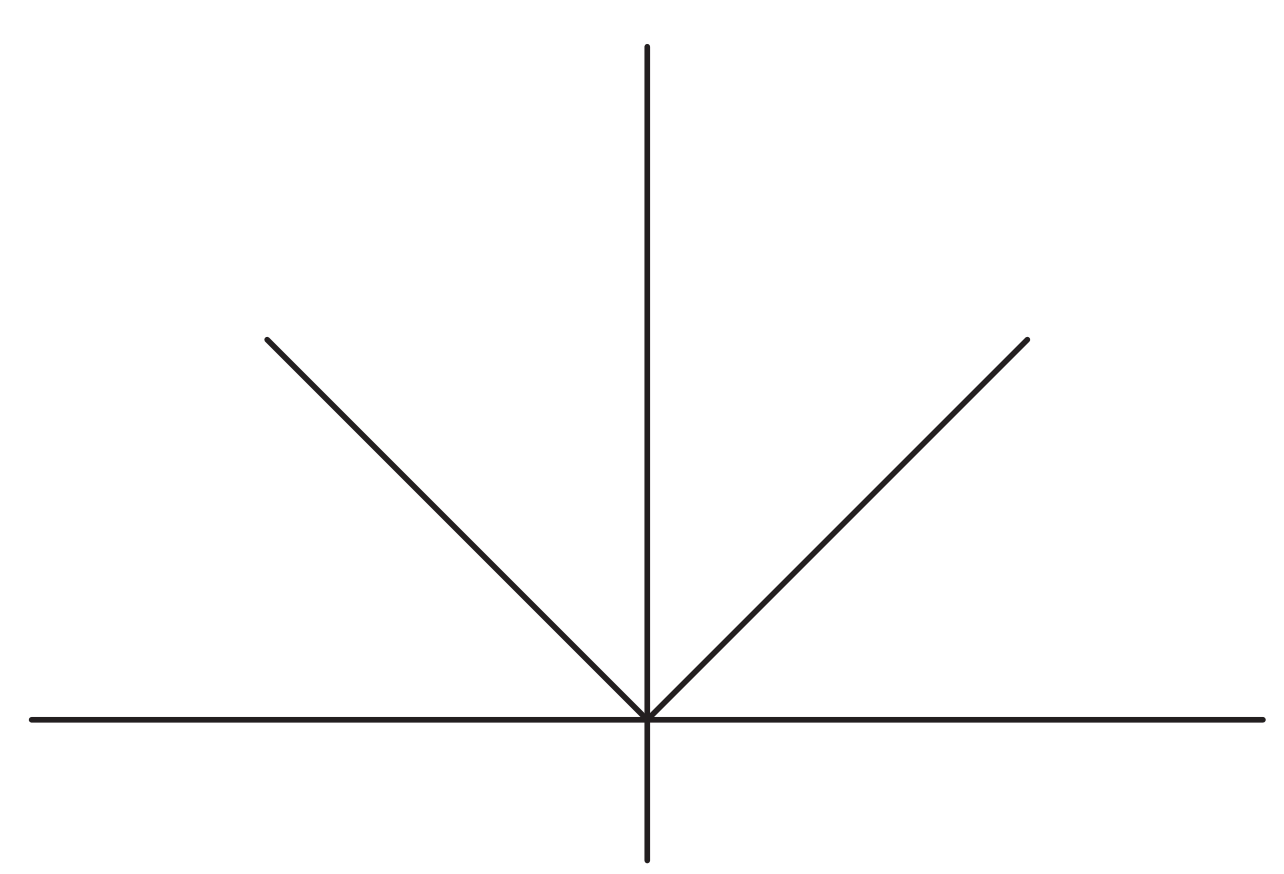

Logo após a partida do ônibus, o garoto diz: "Eu tenho um estilingue". E depois: "Você já desceu aquela rua de bicicleta?". E ainda: "Eu consigo pular esse muro". 
Estamos no ABC Paulista. A professora avisa: "Olhem os caminhões! Aqui fica a fábrica da Mercedes".

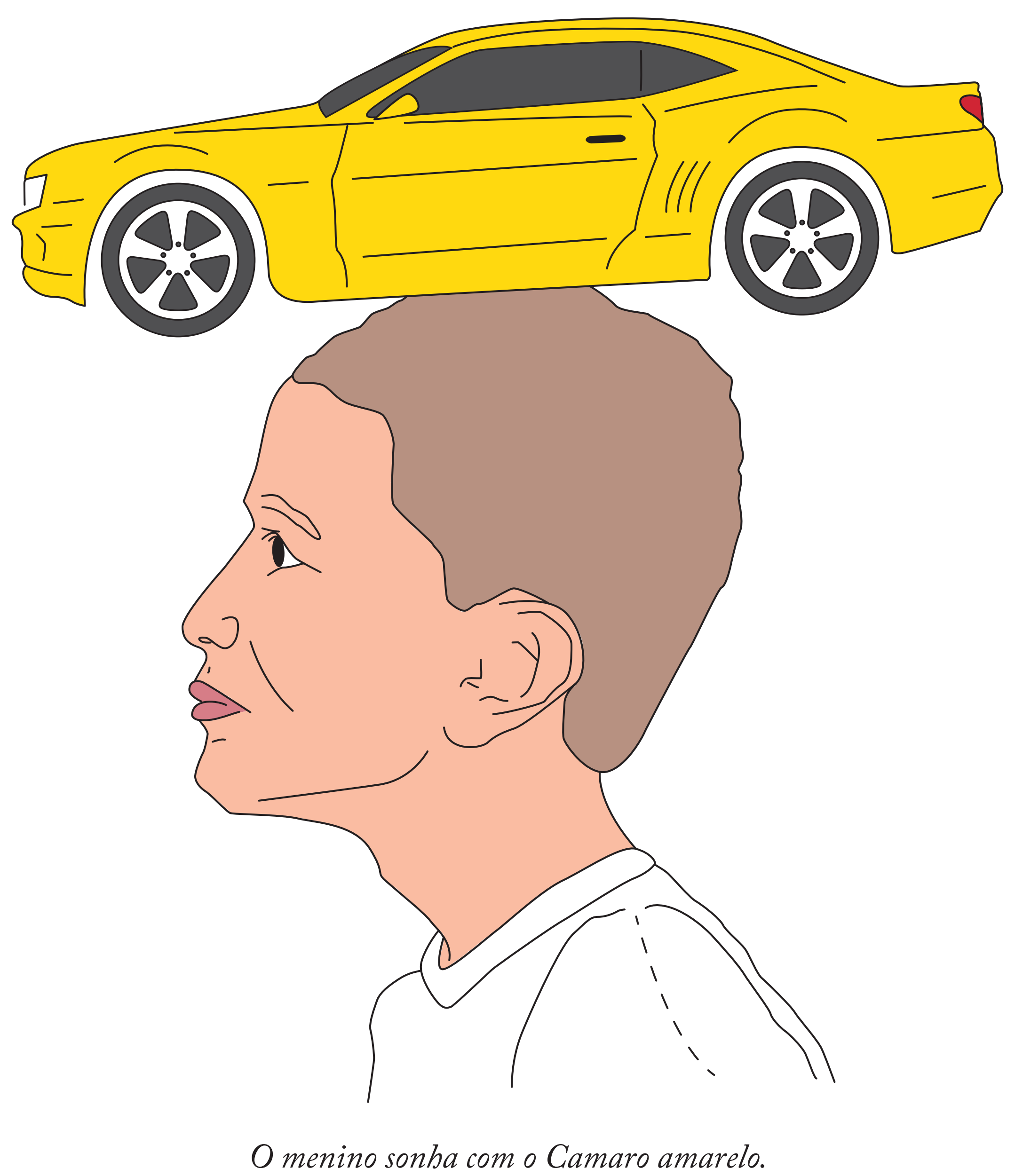

O garoto sentado no banco de trás bisbilhota minhas anotações.

X-BOX é um assunto frequente entre os meninos.

A menina anuncia ter visto o zoológico, fazendo com que praticamente todos os seus colegas no ônibus dirigissem suas atenções para tal atração na paisagem. Após alguns poucos instantes, a professora anuncia solenemente: "Olhem, ali está o zoológico!".

Sentadas no banco próximo ao meu, as meninas cantam músicas e, entre cada uma das canções, perguntam entre si: "Já ouviu essa aqui? Ó...". 
O R. sabe de coisas que as professoras não gostam que ele verbalize. Elas o interrompem quando ele começa a contar histórias de quem já presenciou crimes, prisões, brigas e mortes. Mas não a tempo de calar breves relatos como: "A Rota e a Força Tática invadiram a favela". "O Bozó foi preso". "Se o Beiço sair, ele vai tomar um pau". "A gente não tinha nem nascido quando roubaram aquele policial". "Você já viu um cara morrer?".

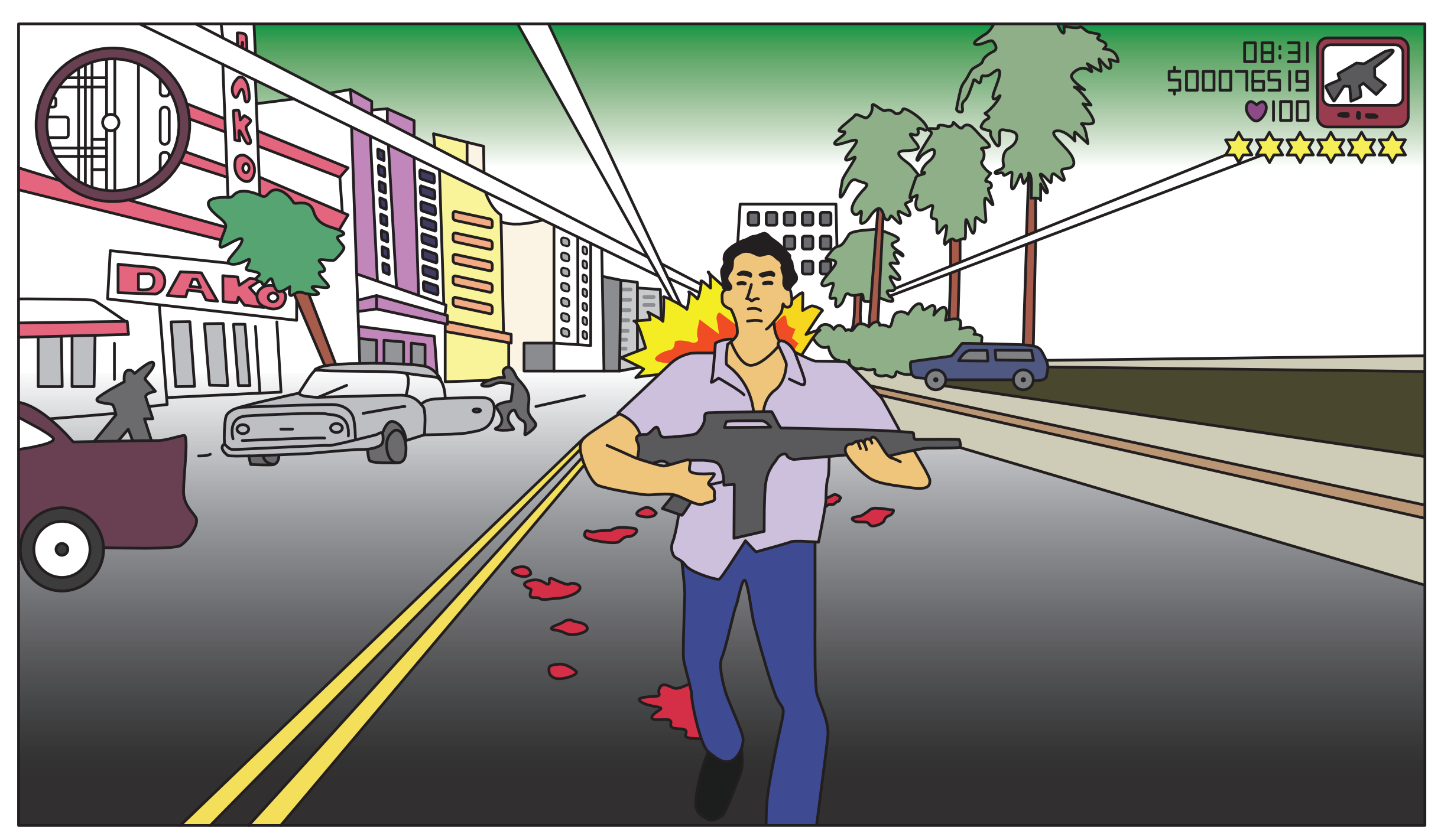

Os meninos sentados no banco de trás sabem tudo de GTA. Em seus comentários, embaralham a cidade observada pela janela do onibus com a cidade virtual do game.

Acompanhando as vitrines das lojas de lancha da avenida dos Bandeirantes, a professora comenta: "No fundo do meu quintal tem uma dessas... só que desenhada".

Ao avistar o aeroporto, um dos garotos comenta: "Eu já voei de avião. Dá muito medo. Lá de cima fica tudo pequenininho".

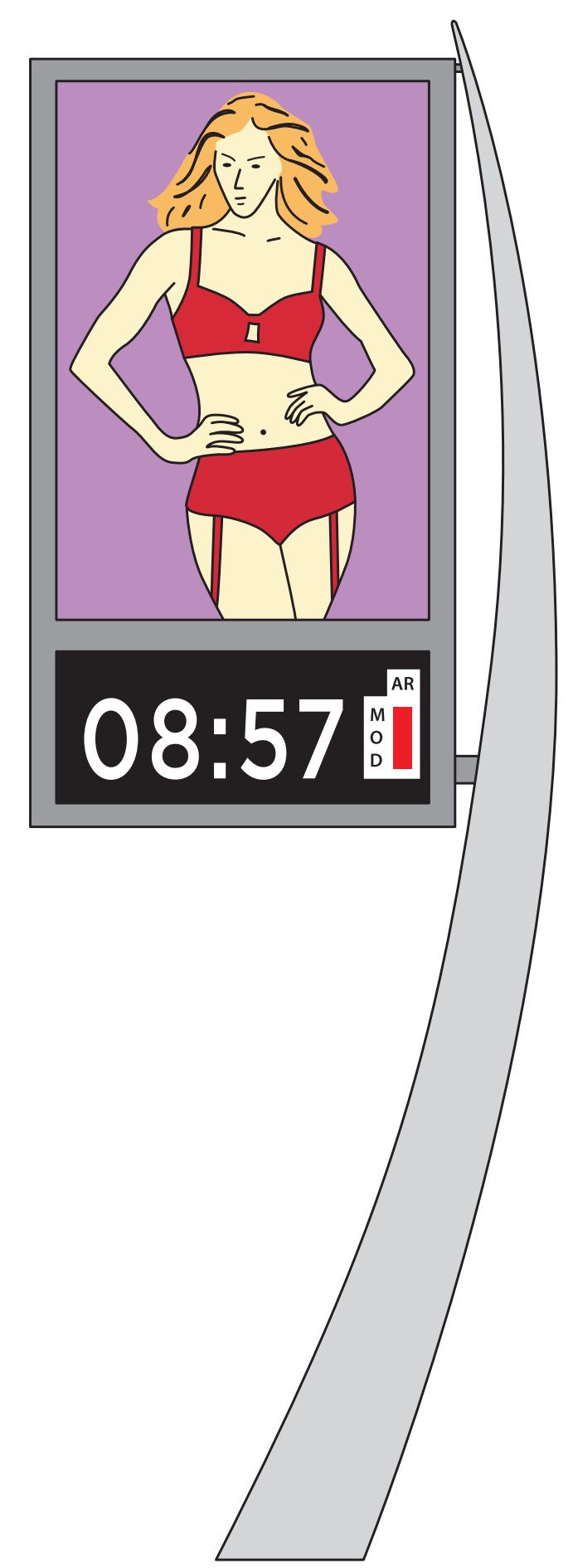

A modelo de lingerie, fotografada seminua e exposta no display publicitário, mexe com a fantasia dos meninos do banco ao lado. Um deles diz baixinho ao outro: "Estou ficando de pinto duro". 


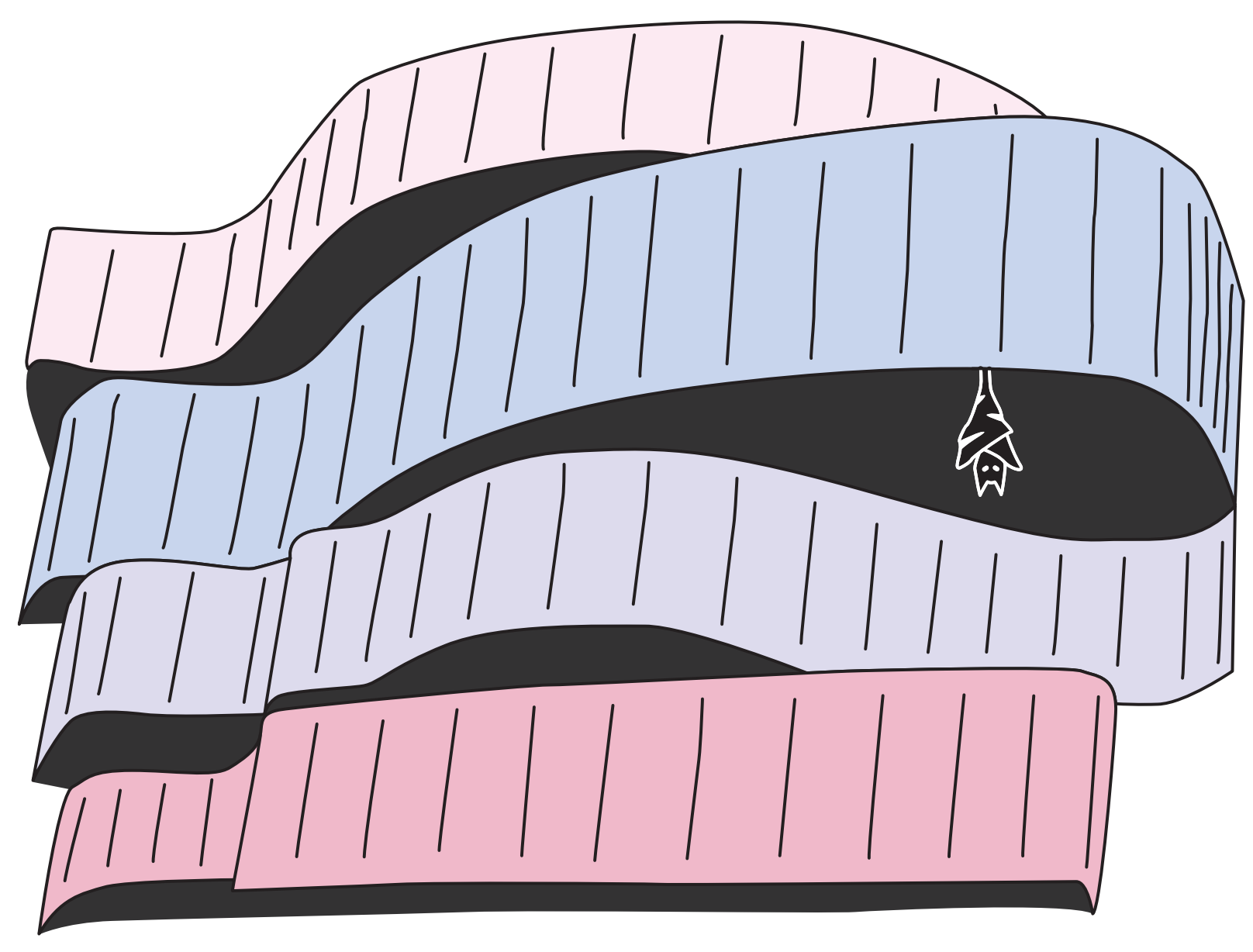

Na chegada ao Instituto Tomie Ohtake, o garoto diz ter avistado um morcego no vão da estrutura metálica que decora a fachada do edifício.

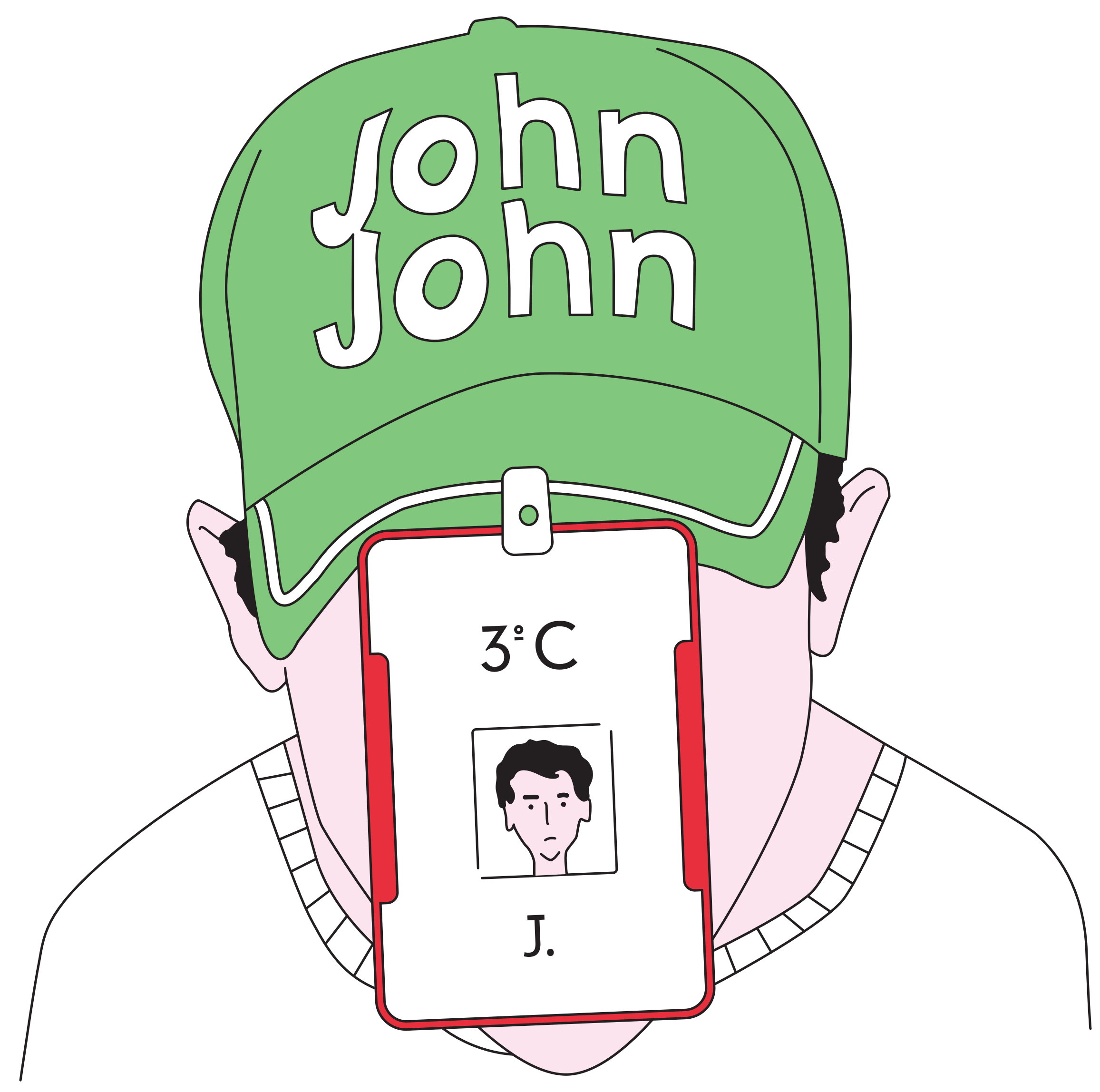

Tentativa de anonimato

Uma garota fotografa o banheiro do Instituto Tomie Ohtake por achá-lo "chique".
O mediador pergunta a uma das garotas: "Você gosta das obras da Tomie Ohtake?". Ao que ela responde: "Eu não sei... mas gosto". 
Ao entrar no ambiente expositivo, a professora ordena ao grupo: "Mãos pra trás!".
O garoto pensa ter visto uma cobra enrolada no pescoço do mediador, que usa cachecol.

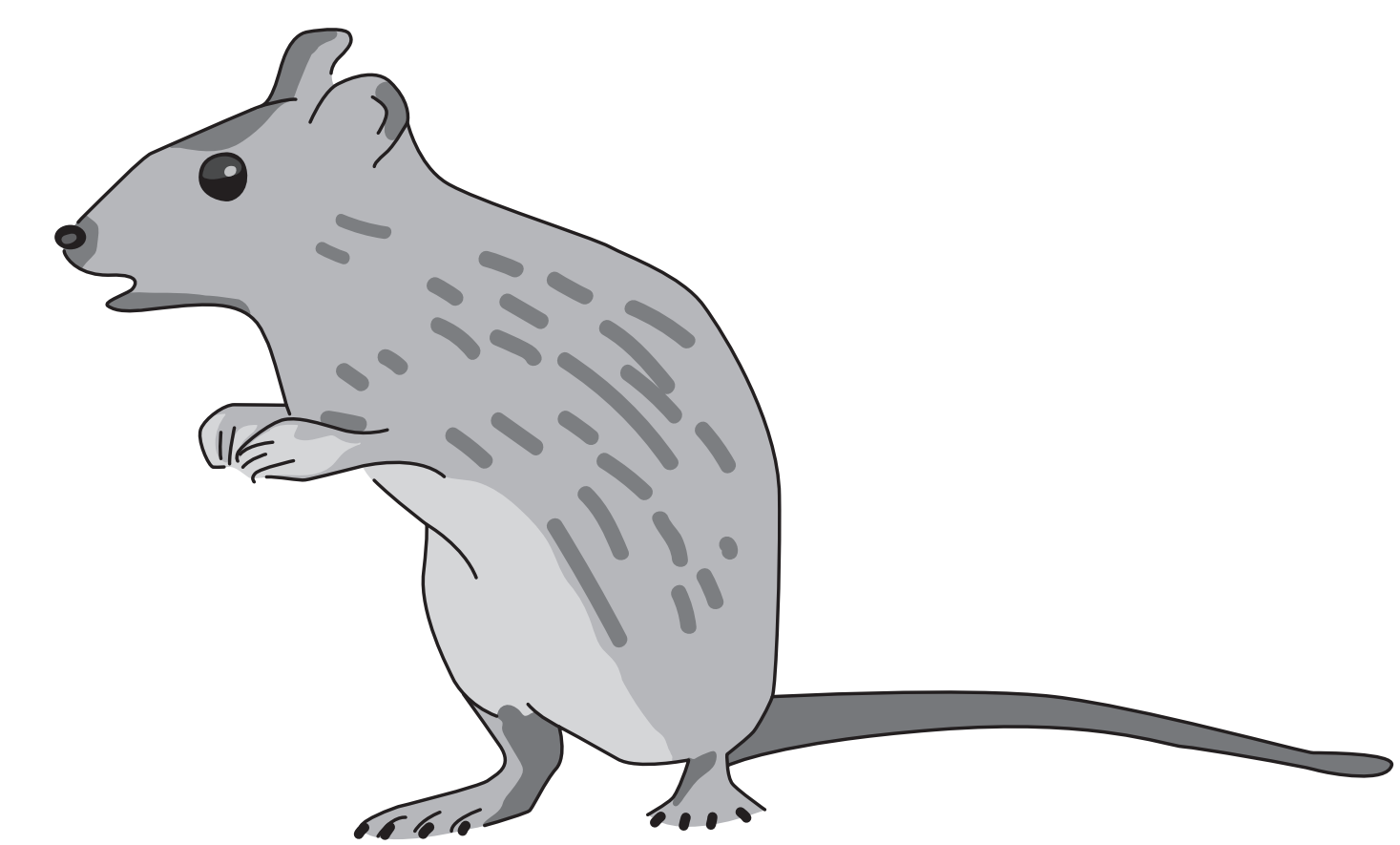

Ao se dirigir ao mediador, o menino fala baixo e de forma truncada.

Um dos colegas o provoca: "Você parece um rato quando fala".

Enquanto fala, o garoto gesticula como um maestro.
O soluço alto de um dos garotos, a cada manifestação, desvia a atenção do grupo.

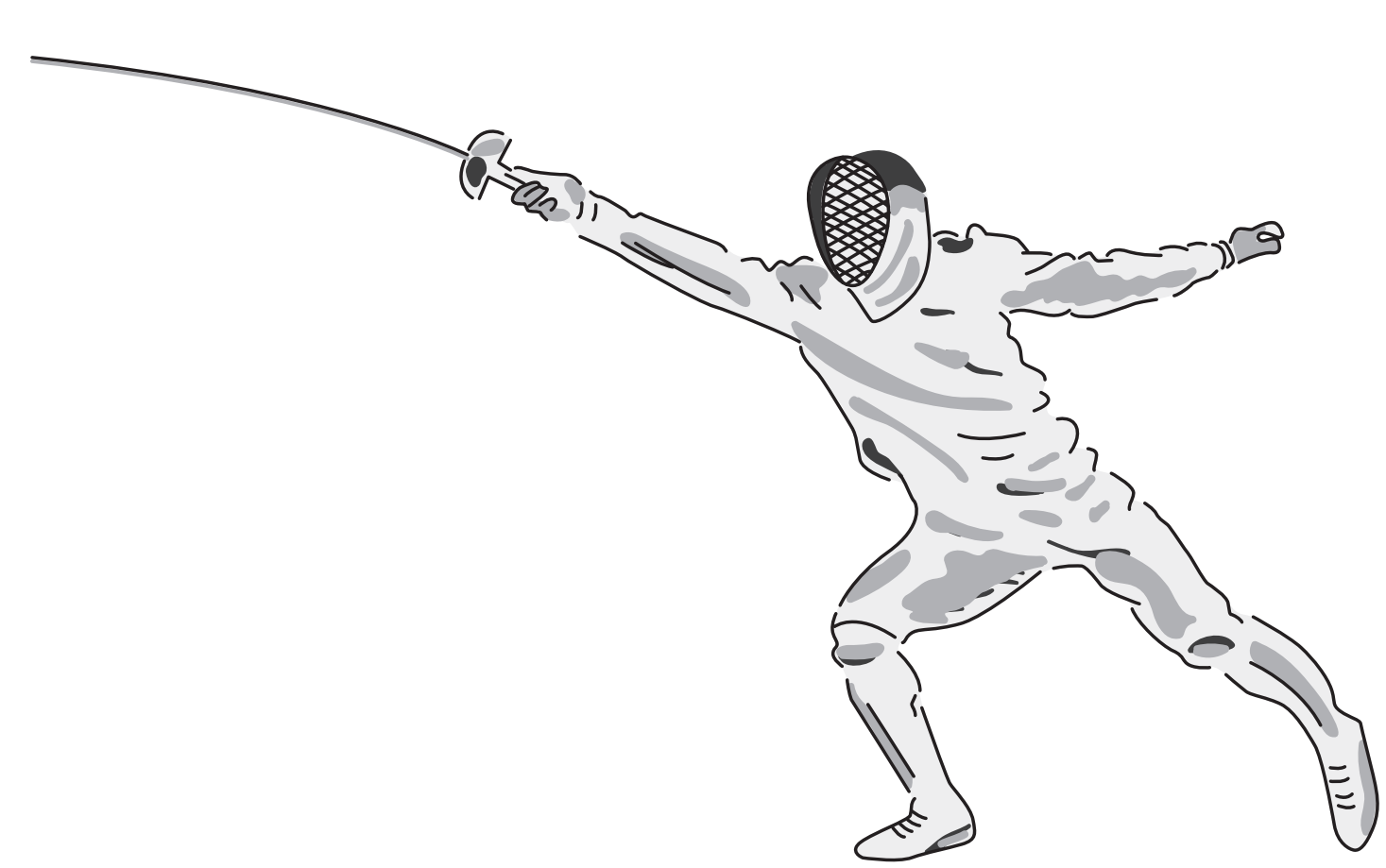

A cada comentário que tece sobre as pinturas de Tomie Obtake, o garoto faz questão de apontar os detalhes na tela, chegando bem perto da superfície com seu dedo indicador. Apesar de não aparecer no desenho, o vigilante está no seu encalço.

As professoras assumem o papel de "cães policiais". Elas "rosnam" a cada projeção das mãos das crianças em direção às pinturas. 
Na sala expositiva, ao fundo, há dois aparelhos de TV cujas telas, em virtude da posição, não podem ser vistas de longe. Ao chegar perto e se deparar com o conteúdo transmitido, o menino diz: "Eu pensei que fosse futebol".

Algo leva a pensar que não faz sentido forjar barreiras entre o (pretensamente) legítimo e o (supostamente) duvidoso. Mais vale multiplicar os percursos de idas e vindas entre eles.

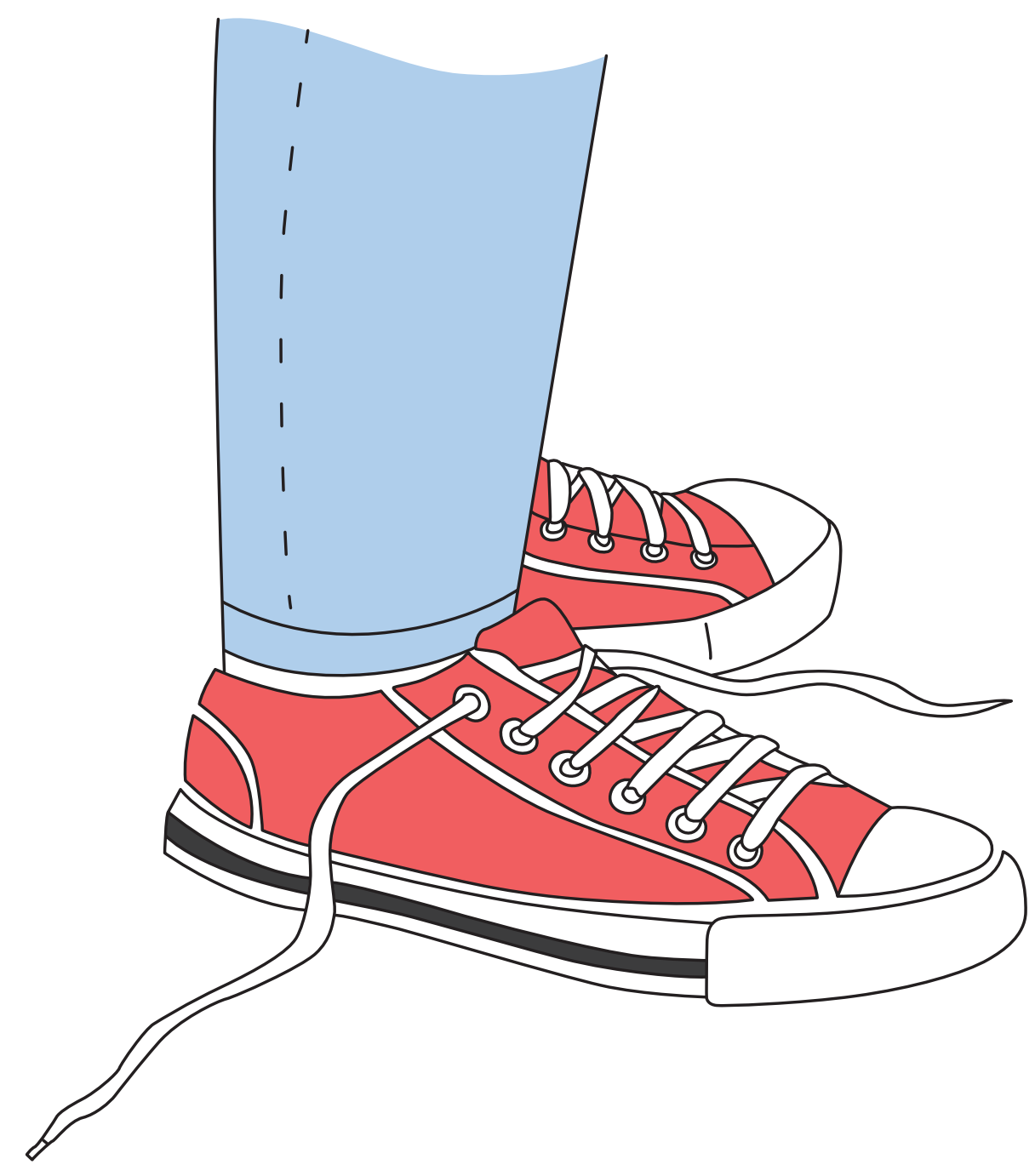

Obras em risco

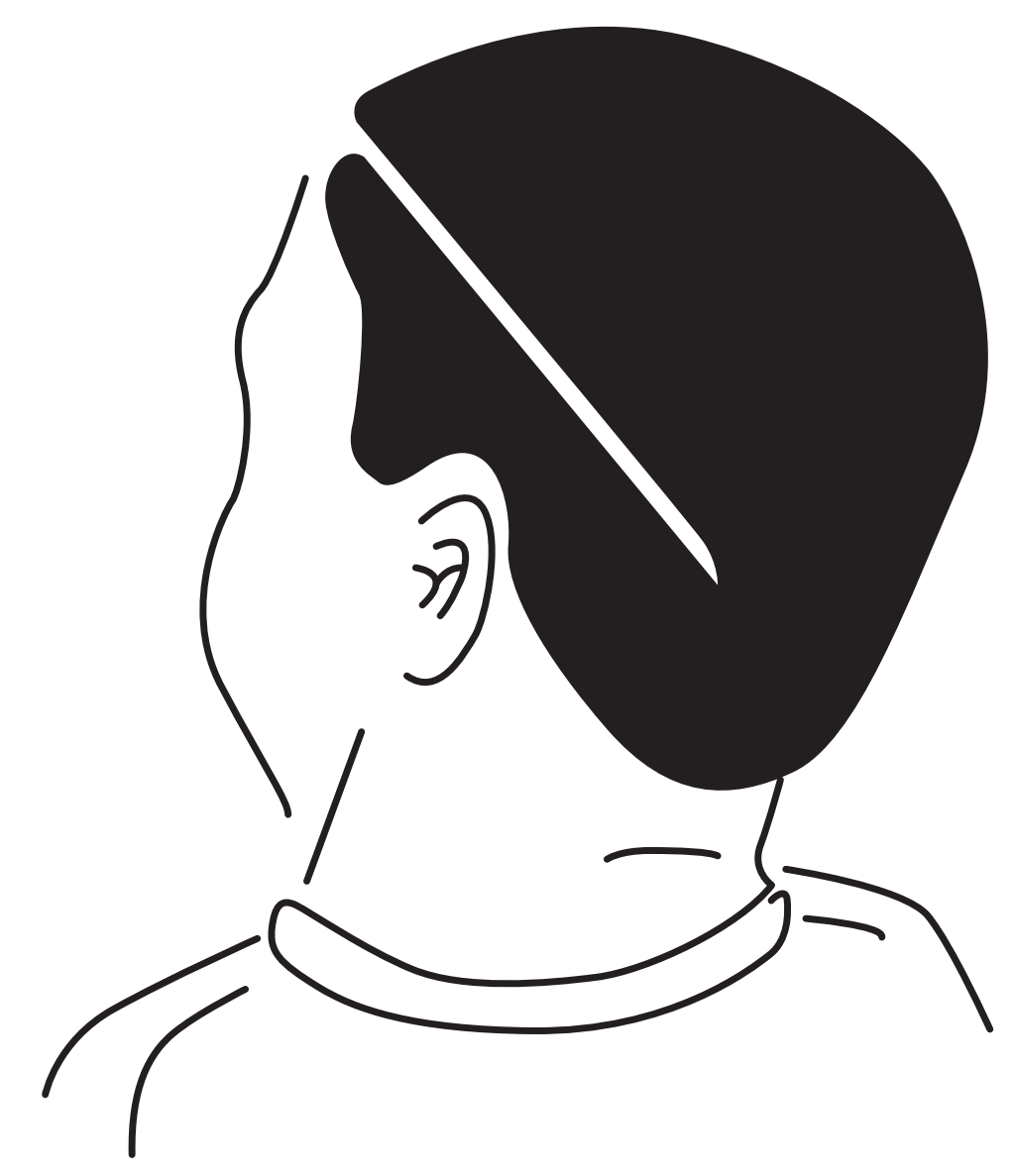

$A$ artista Tomie Obtake produz linhas tênues mediante a sobreposição de camadas de tinta branca sobre a tela. Já o garoto orienta seu cabeleireiro a traçar uma linha diagonal reta, incisiva, em sua cabeça semi-raspada. 


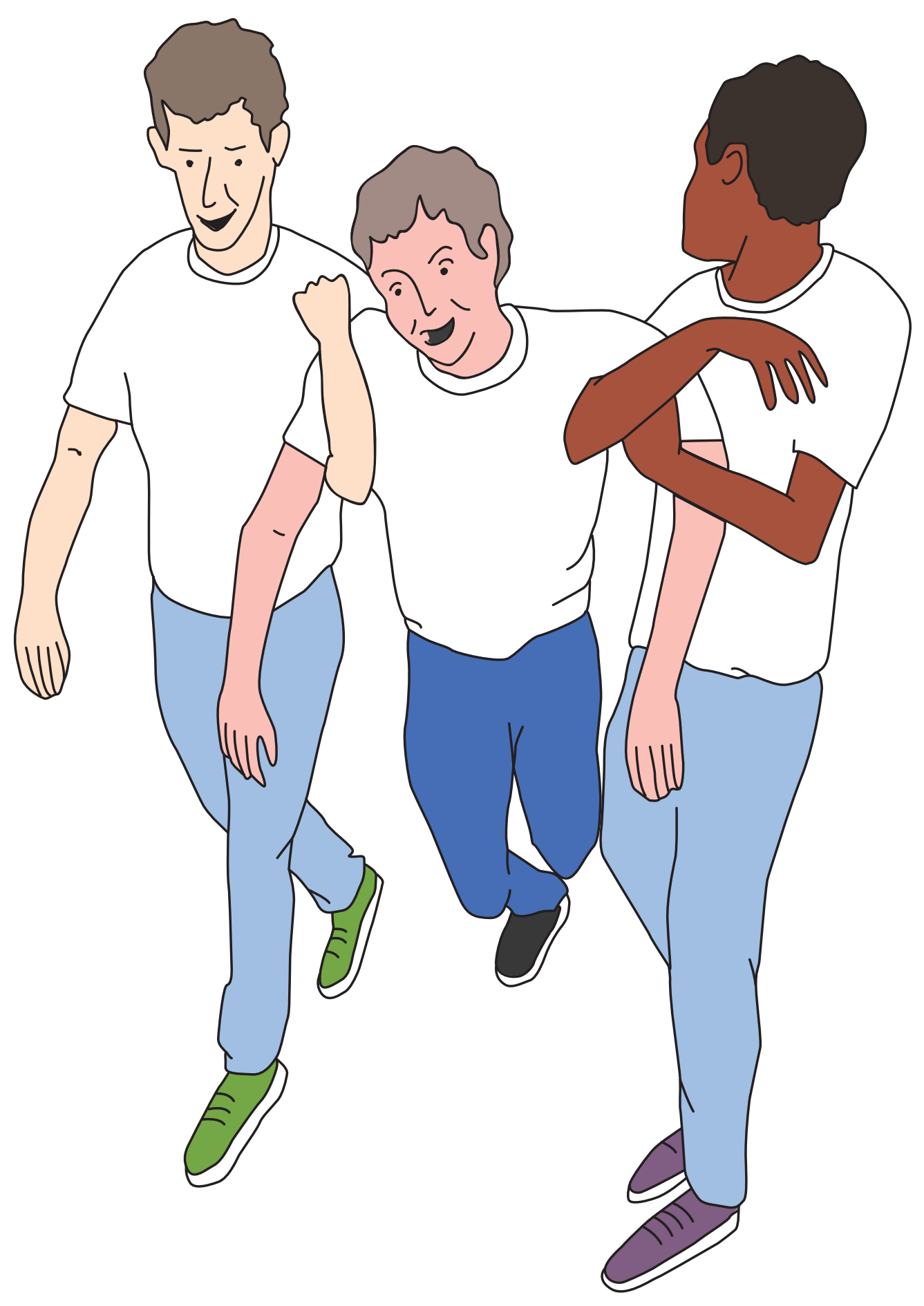

No ateliê, a menina opta por pintar a folha branca com tinta branca. Ao que a professora reage: "Mas você vai usar branco sobre branco? Não vai dar certo". Com um aceno de cabeça, ela diz que "sim", que usará o branco.

O garoto não aguenta mais ver tanta pintura.

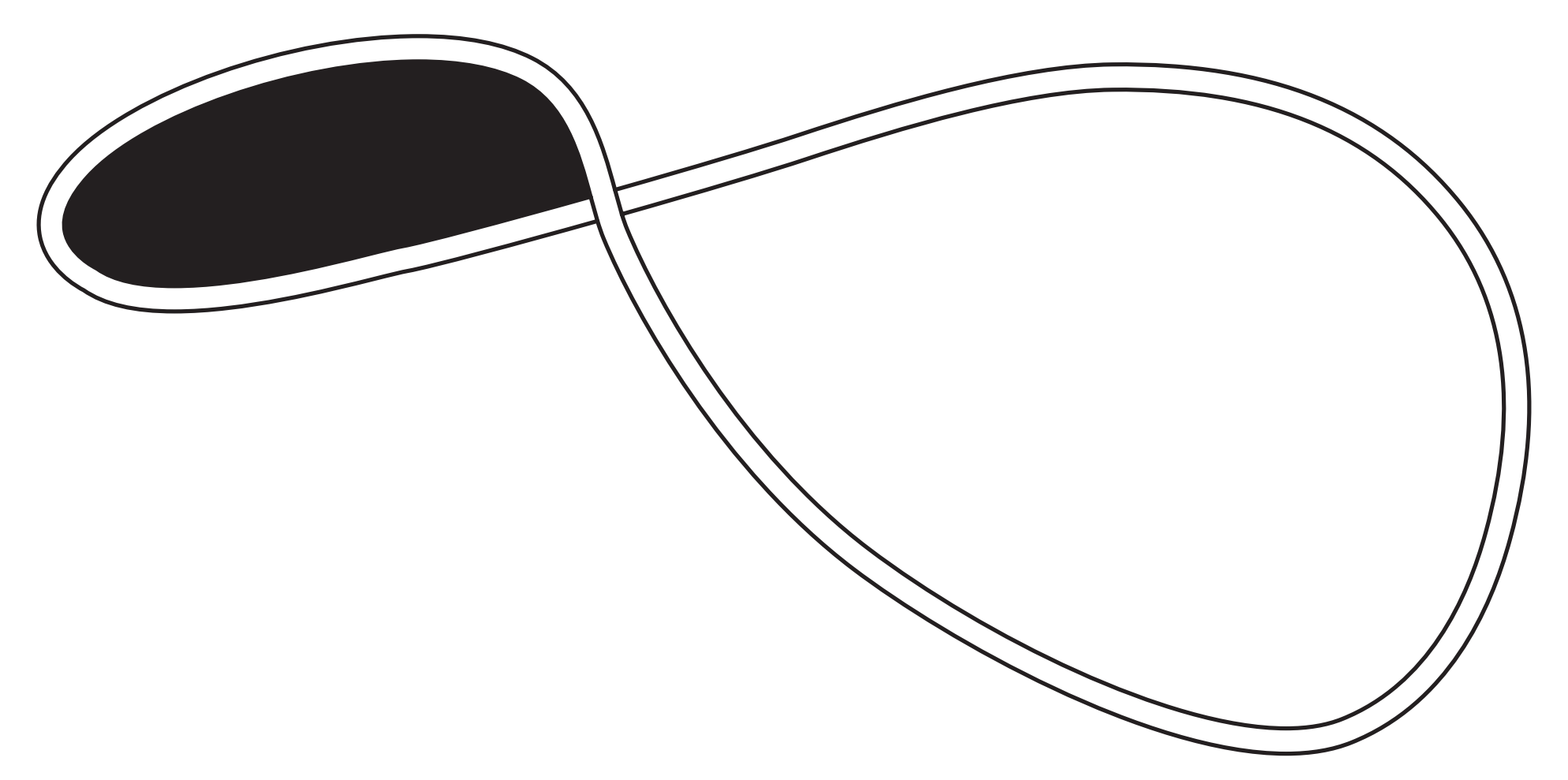

Intuitivamente, a garota sabe que tradução corresponde a traição. Tanto que, ao desenhar uma das esculturas de aço tubular da artista Tomie Obtake (do conjunto exposto no saguão do Instituto), ela realiza ao menos três adulteraçóes: 1) passa do plano tridimensional para o bidimensional; 2) escolhe um ângulo que confere acep̧̧ão simbólica a uma escultura abstrata, denotando o infinito; 3) em seguida, anula este infinito mediante a alusão a um buraco negro. 


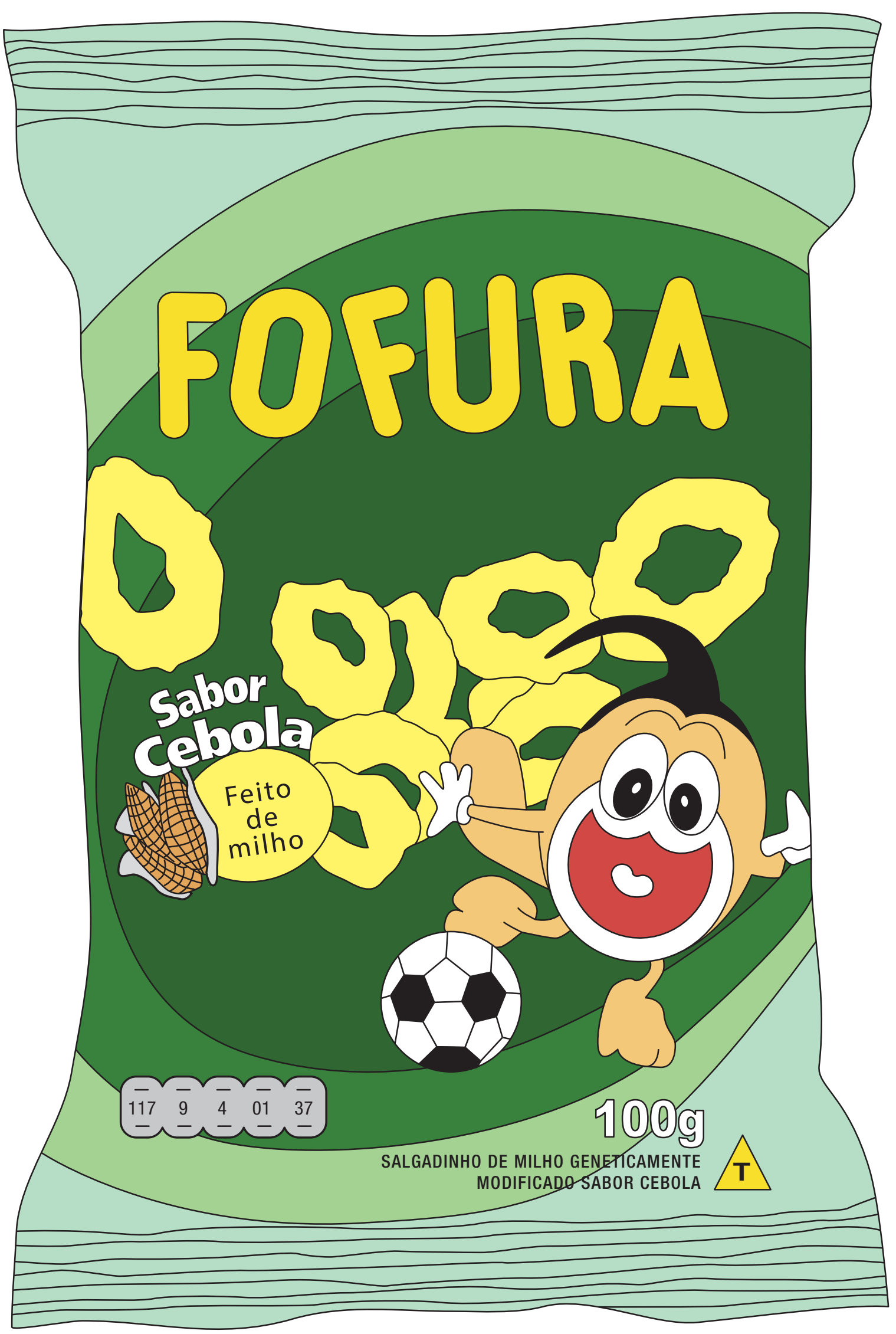

Hora do lanche

Sutilezas da paquera: um garoto e uma garota compartilham os fones de ouvido sentados no mesmo banco do ônibus, durante o retorno à escola.

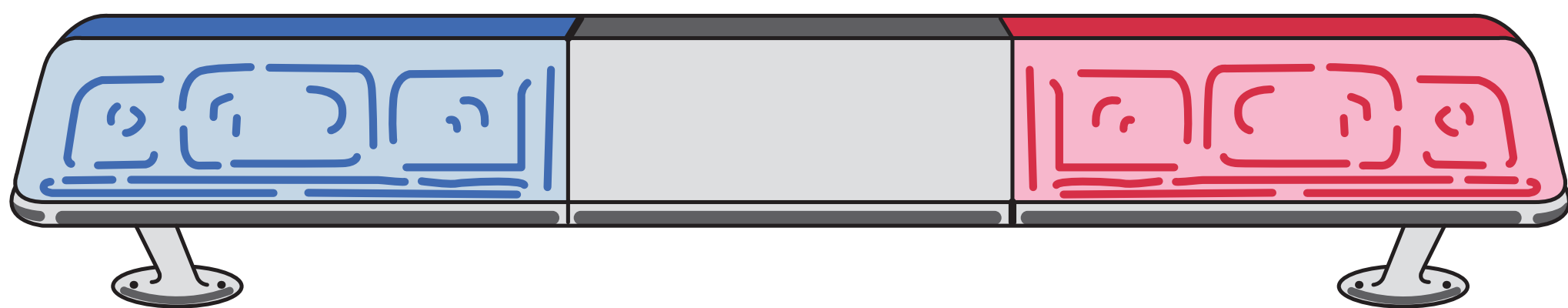

A polícia não passa impune: sempre que as crianças avistam uma viatura pela janela, o fato é por elas alardeado dentro do ônibus.

Elas sabem distinguir entre a Rota, a Força Tática, a Civil e o Garra.

O pai de um dos garotos, conforme ele conta, é vigilante e trabalha de madrugada. 


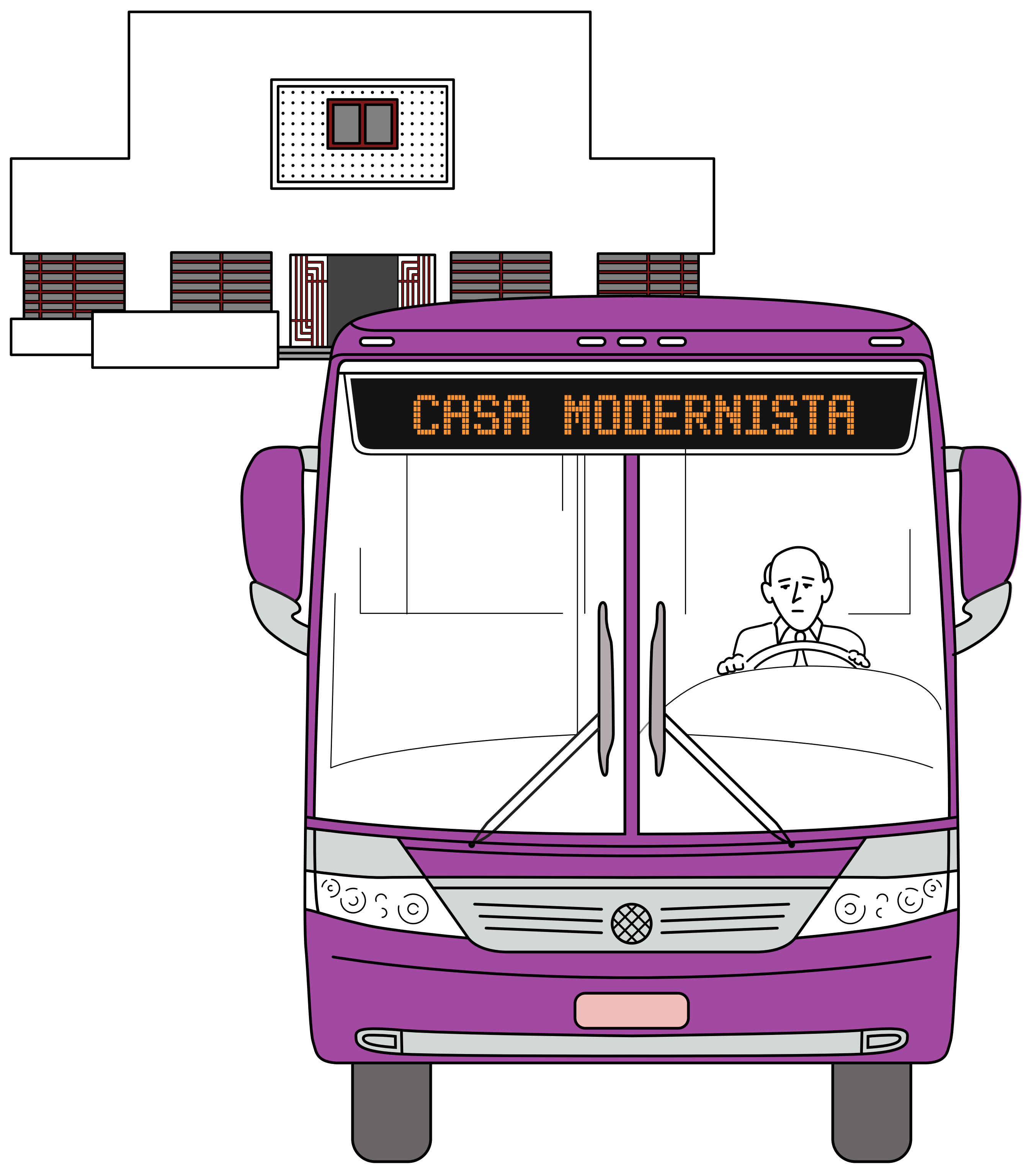




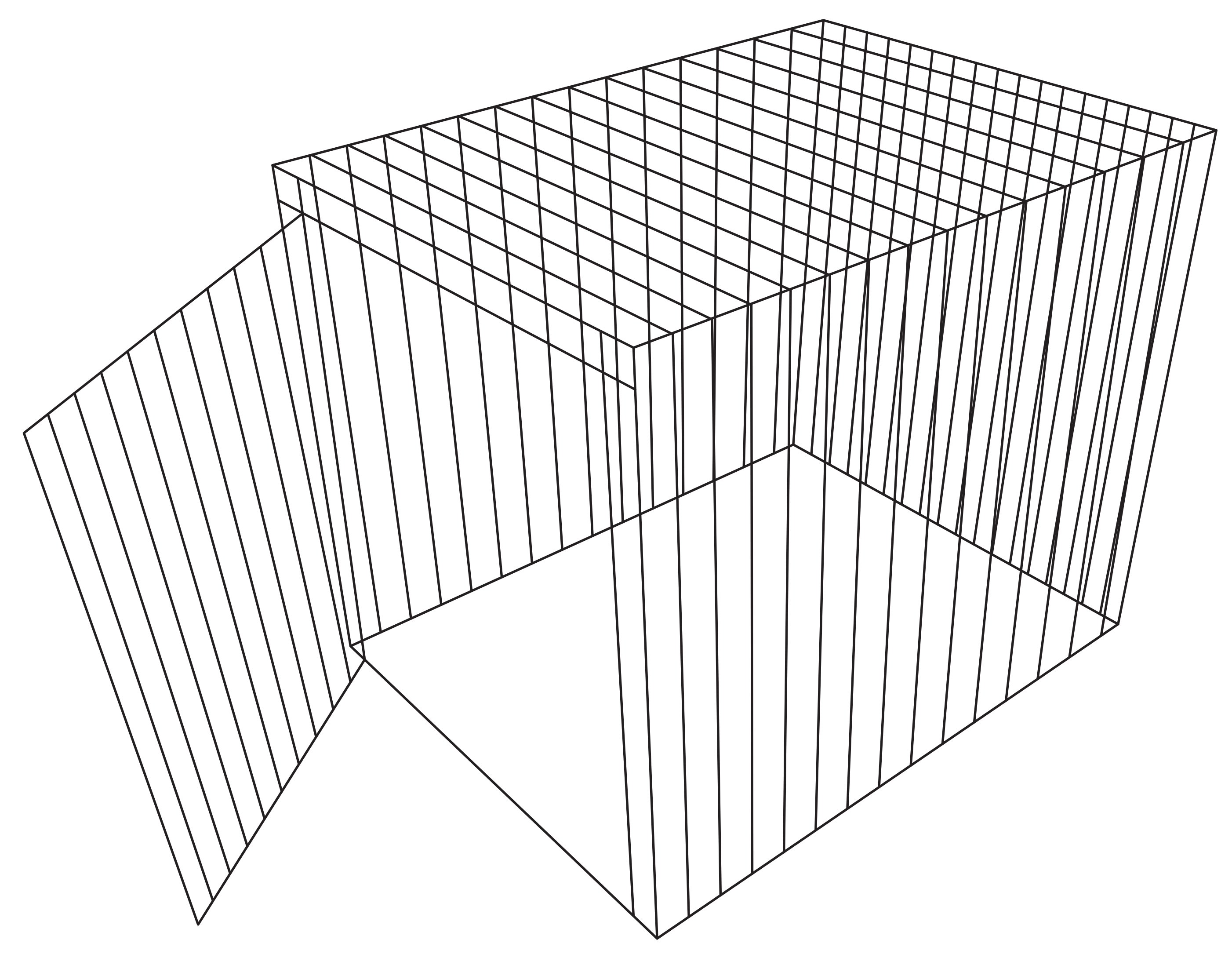

Recep̧̧ão da escola

A professora tem as chaves das portas, grades e portões da escola. O molho fica no bolso do seu jaleco.

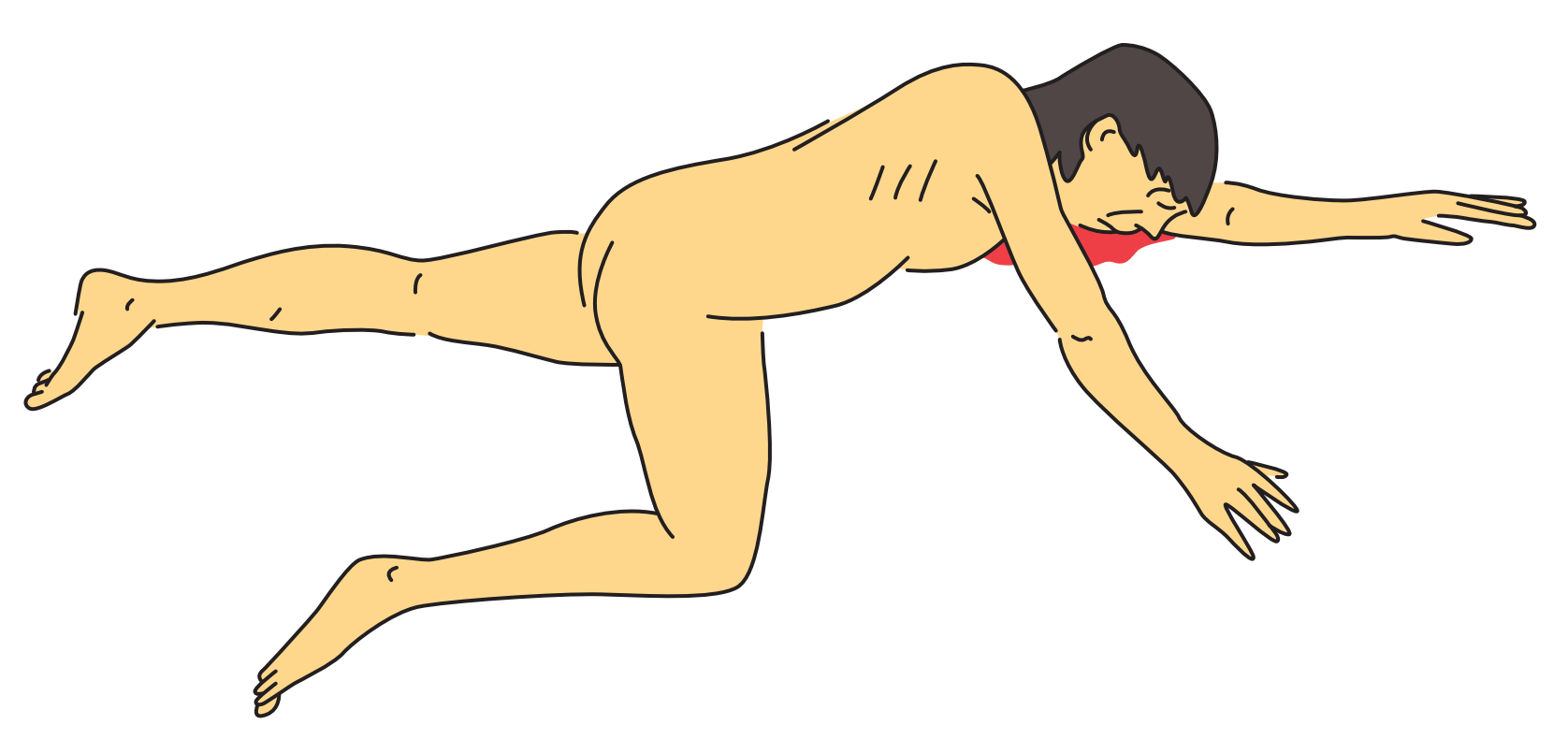

Numa conversa fortuita com a professora sobre assuntos diversos, ela de repente dispara: "Indio é folgado". 

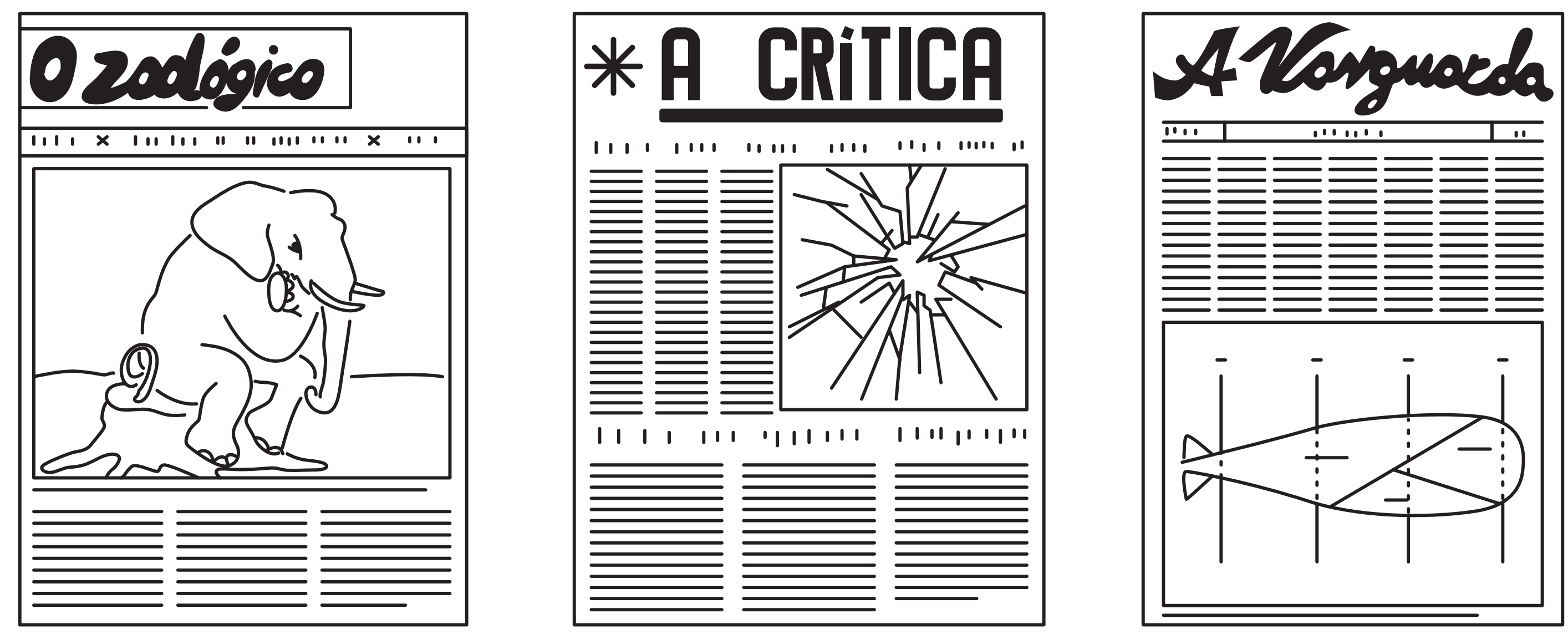

No hall de entrada da EE Ernesto Miranda da Costa, pode-se ver um conjunto emoldurado de fac-similes de jornais publicados nos anos 1950 pelo Grêmio Estudantil.

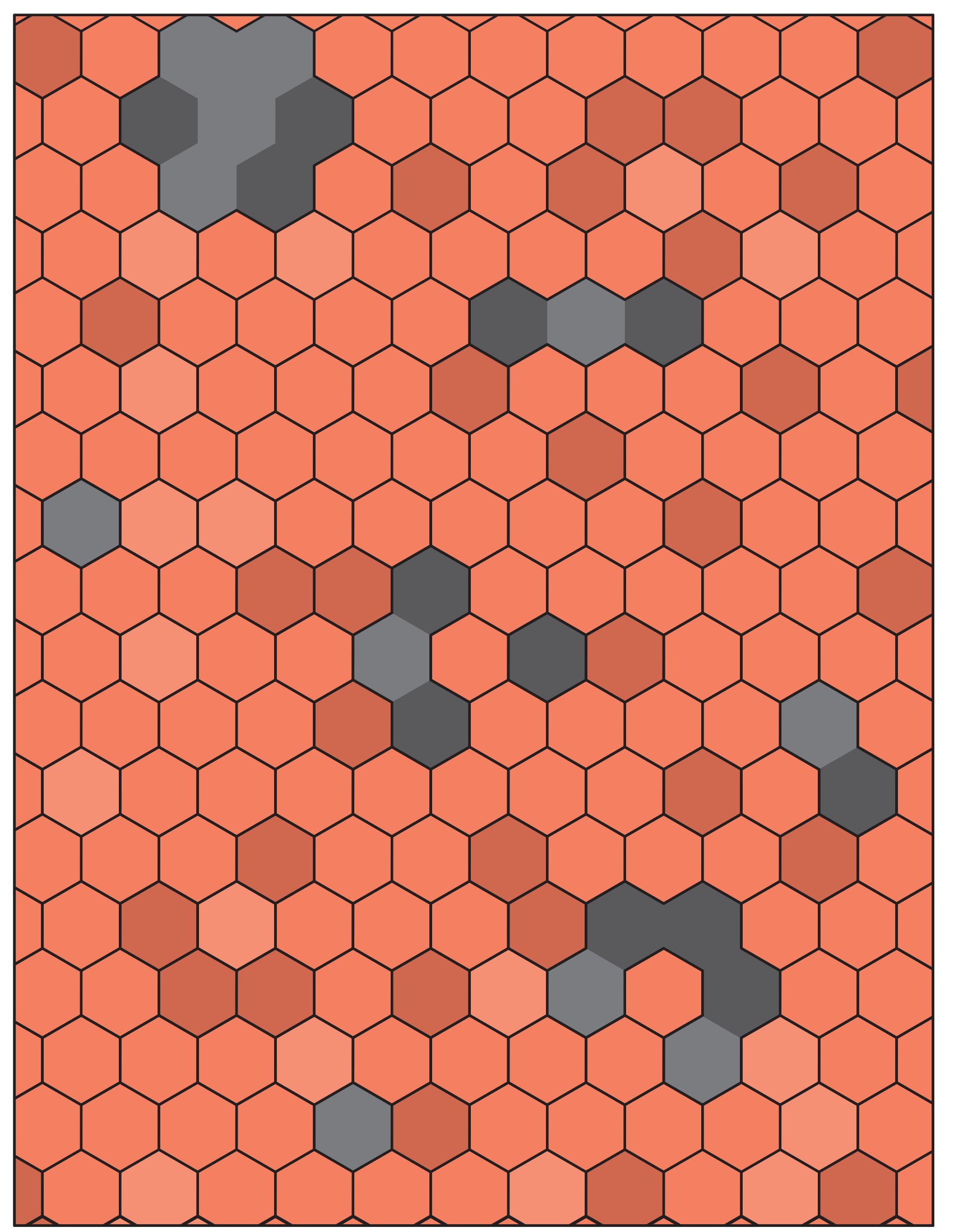

Com suas falhas, o piso de cerâmica do corredor da escola guarda lembranças das rodinhas de amigos, dos trios, duplas, quartetos, dos solitários, dos casais... 


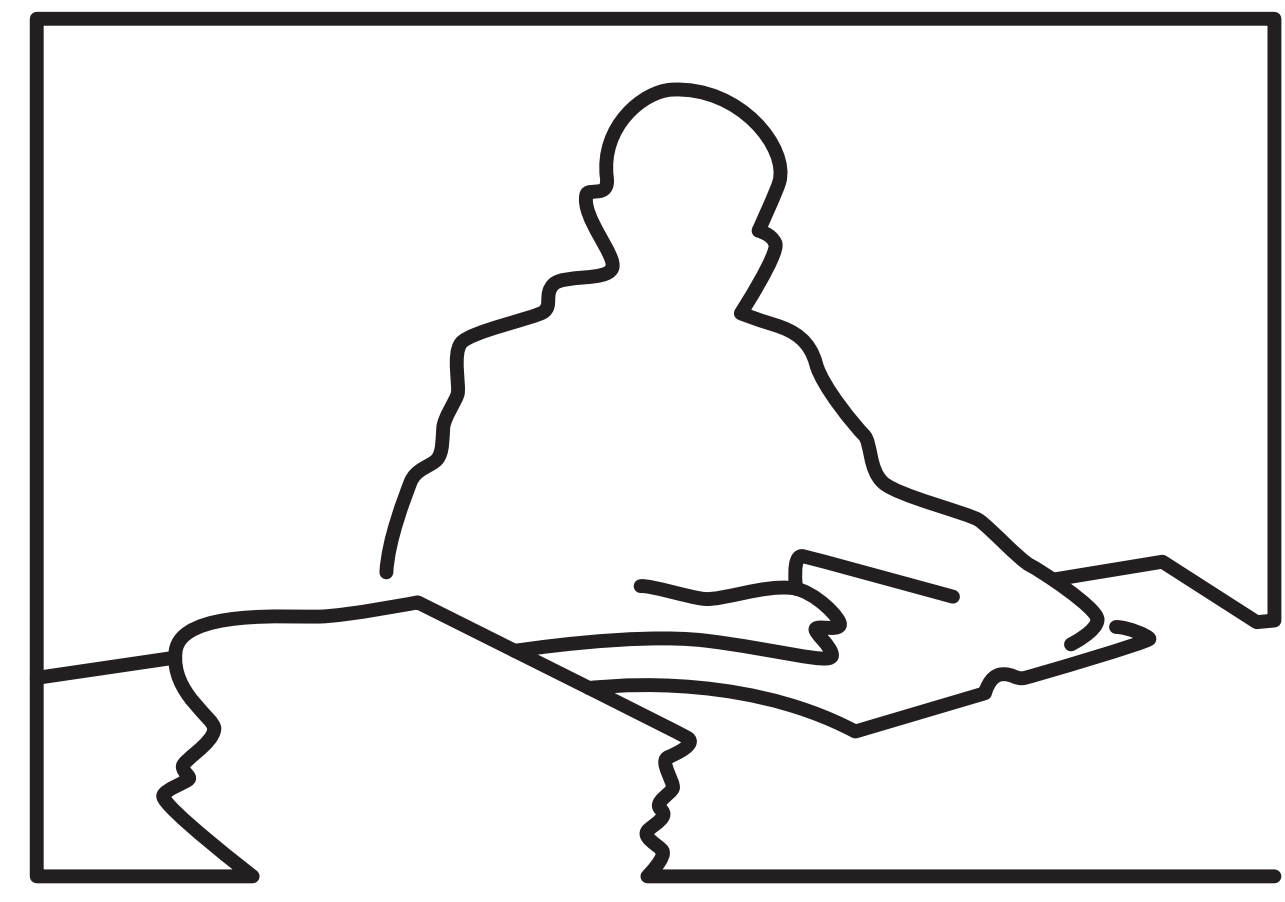

DIRETOR

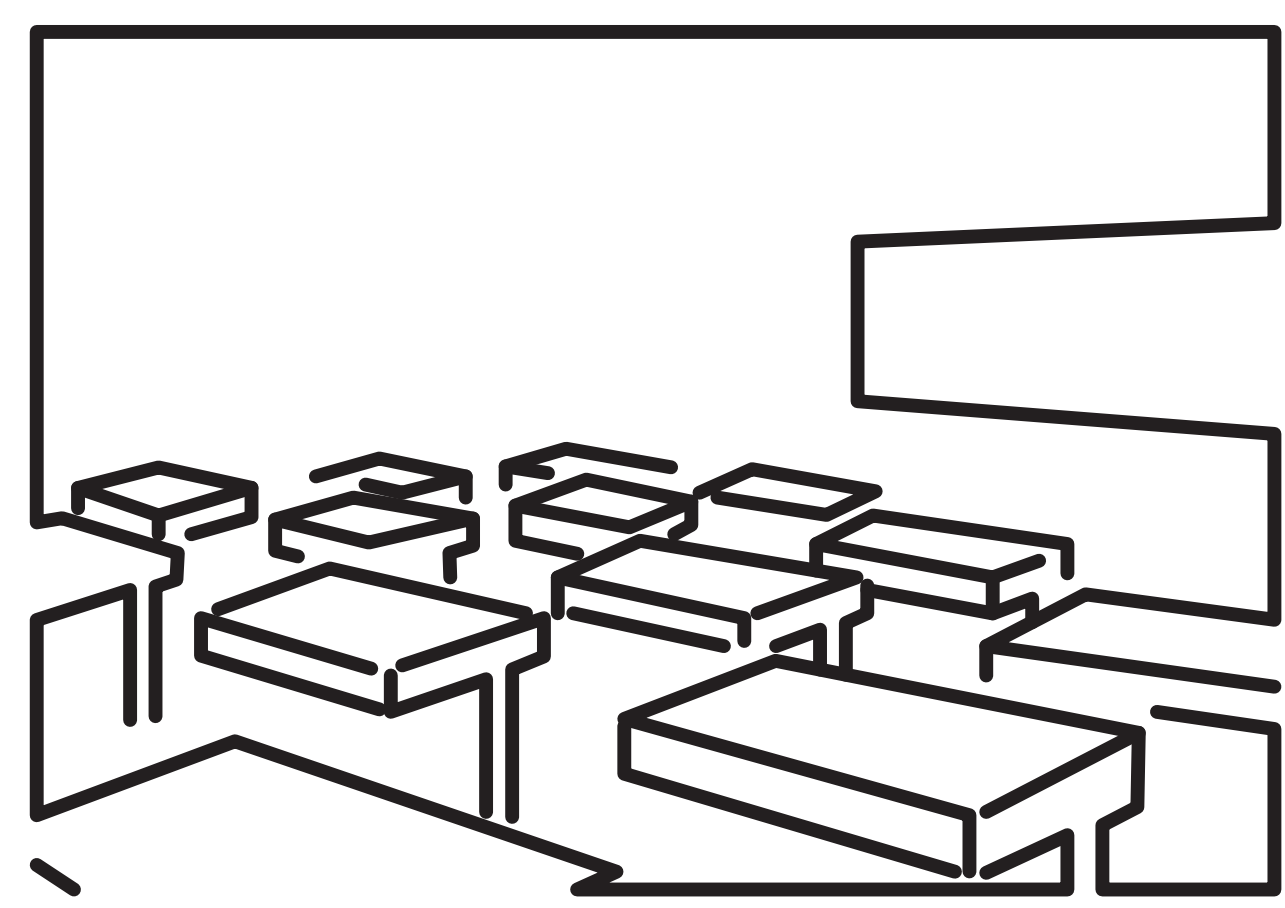

SALA DE AULA

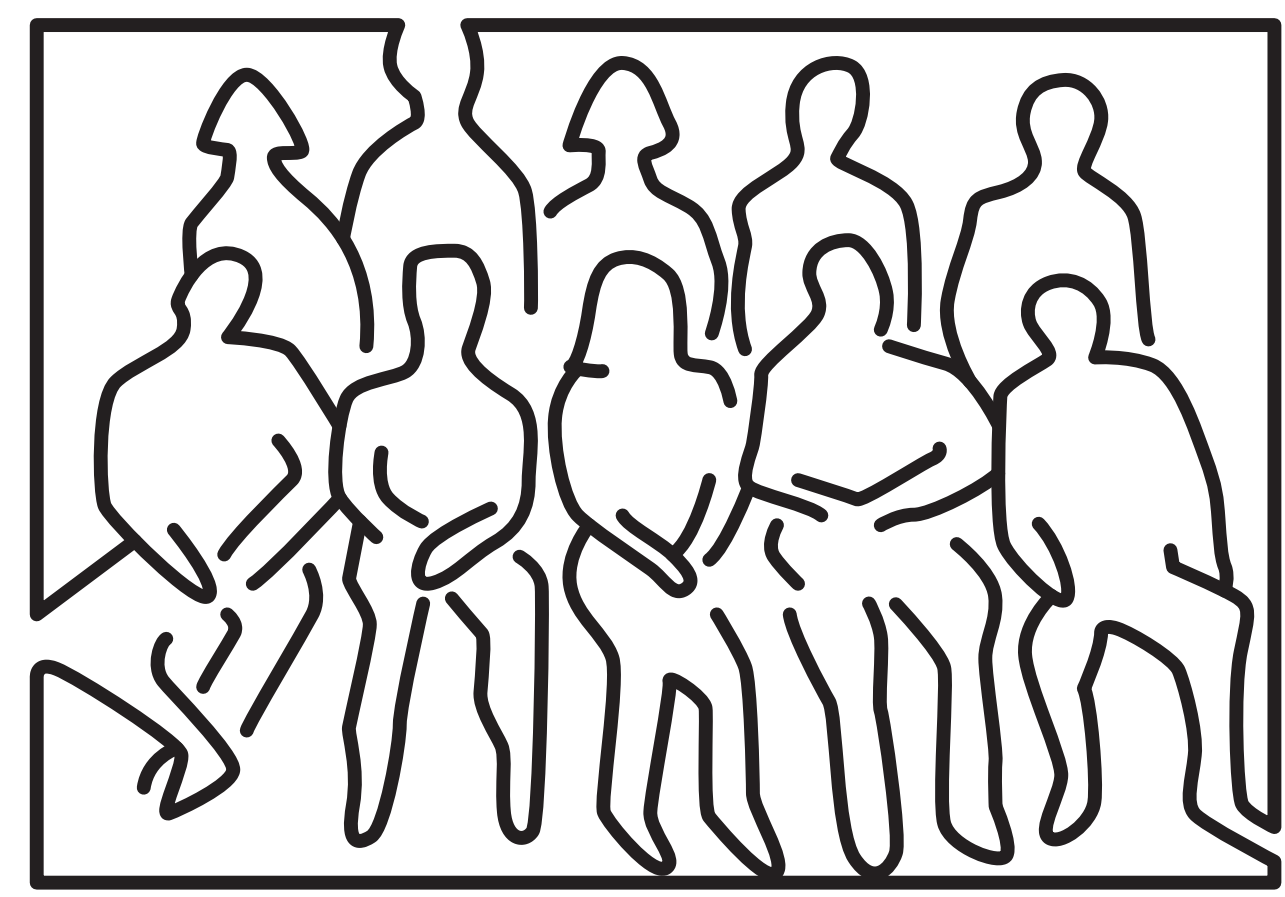

FORMANDOS

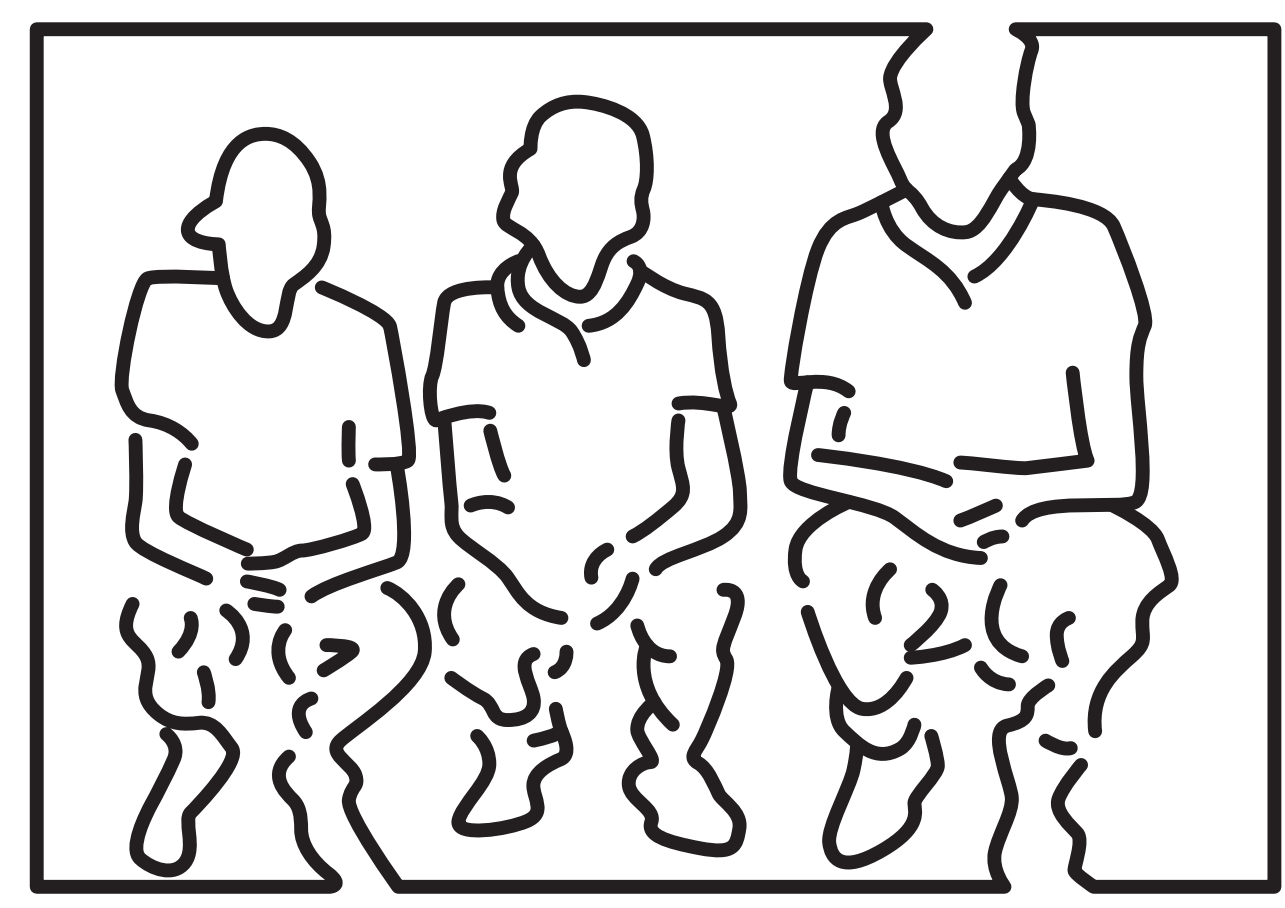

ESPORTE

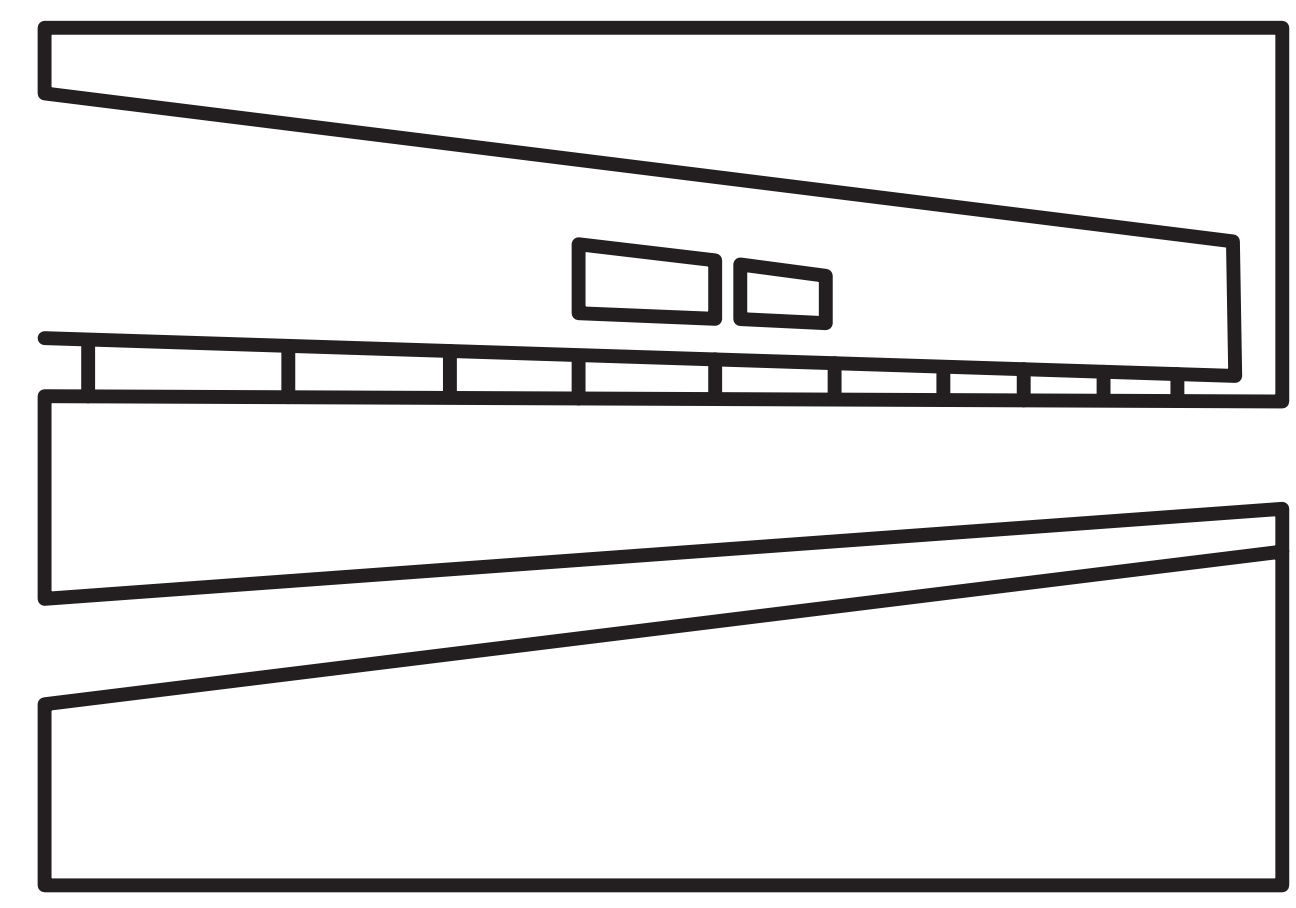

FACHADA

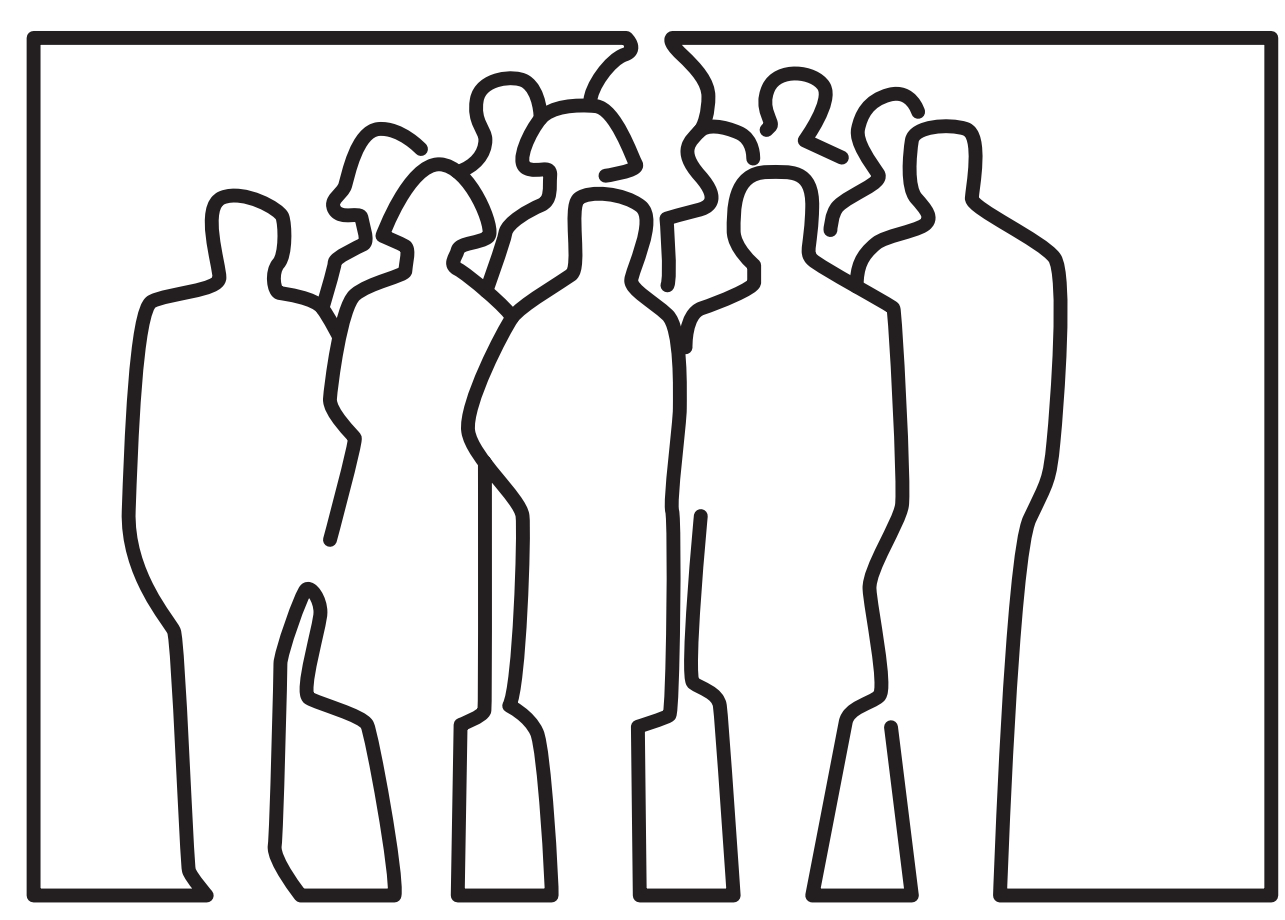

PROFESSORES

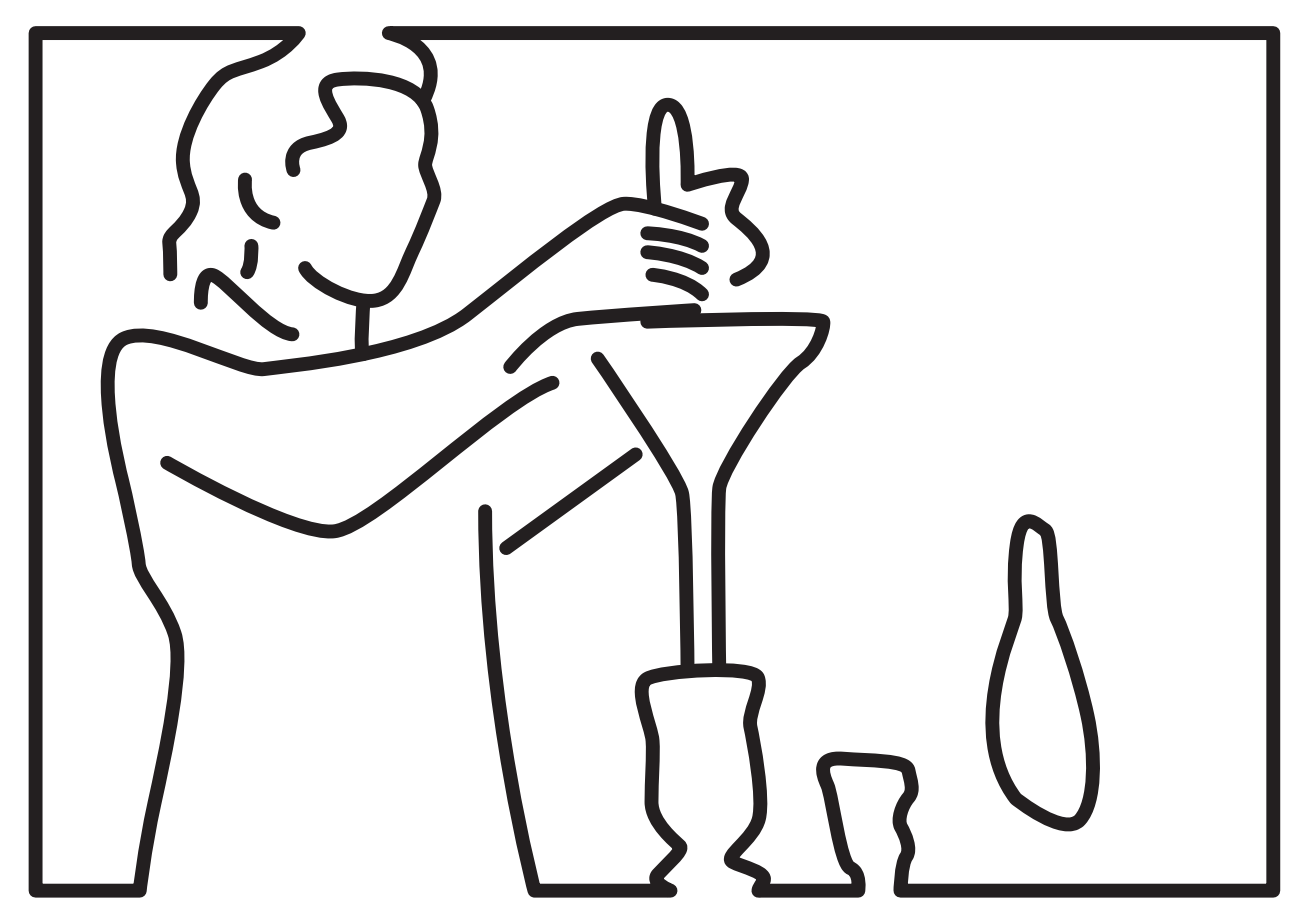

LABORATÓRIO

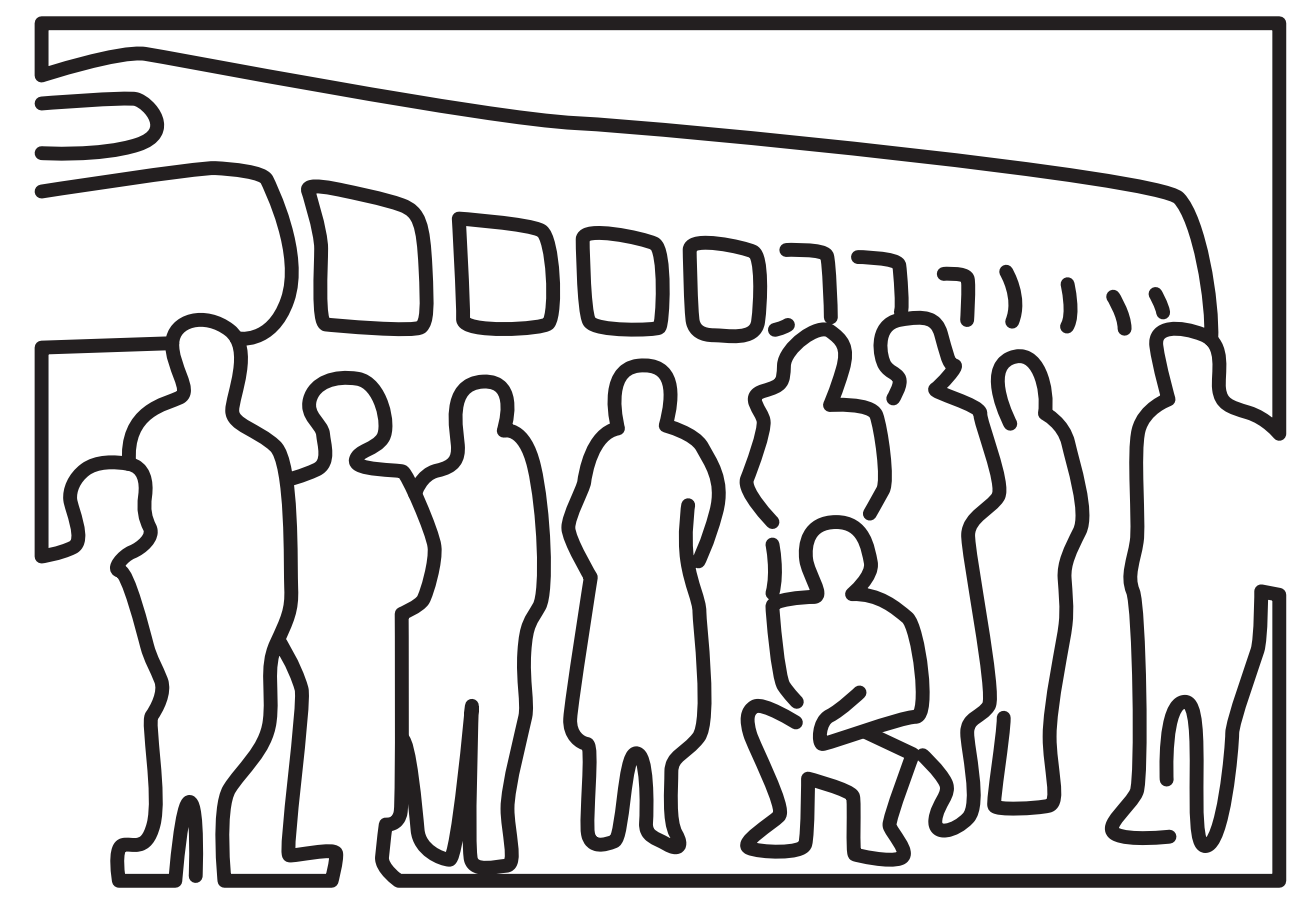

EXCURSÃO 
Ao cruzarmos o portão da escola rumo à Casa

Modernista, a professora diz em tom de brincadeira:

"Eu trouxe um chicote pra ninguém sair do caminho".

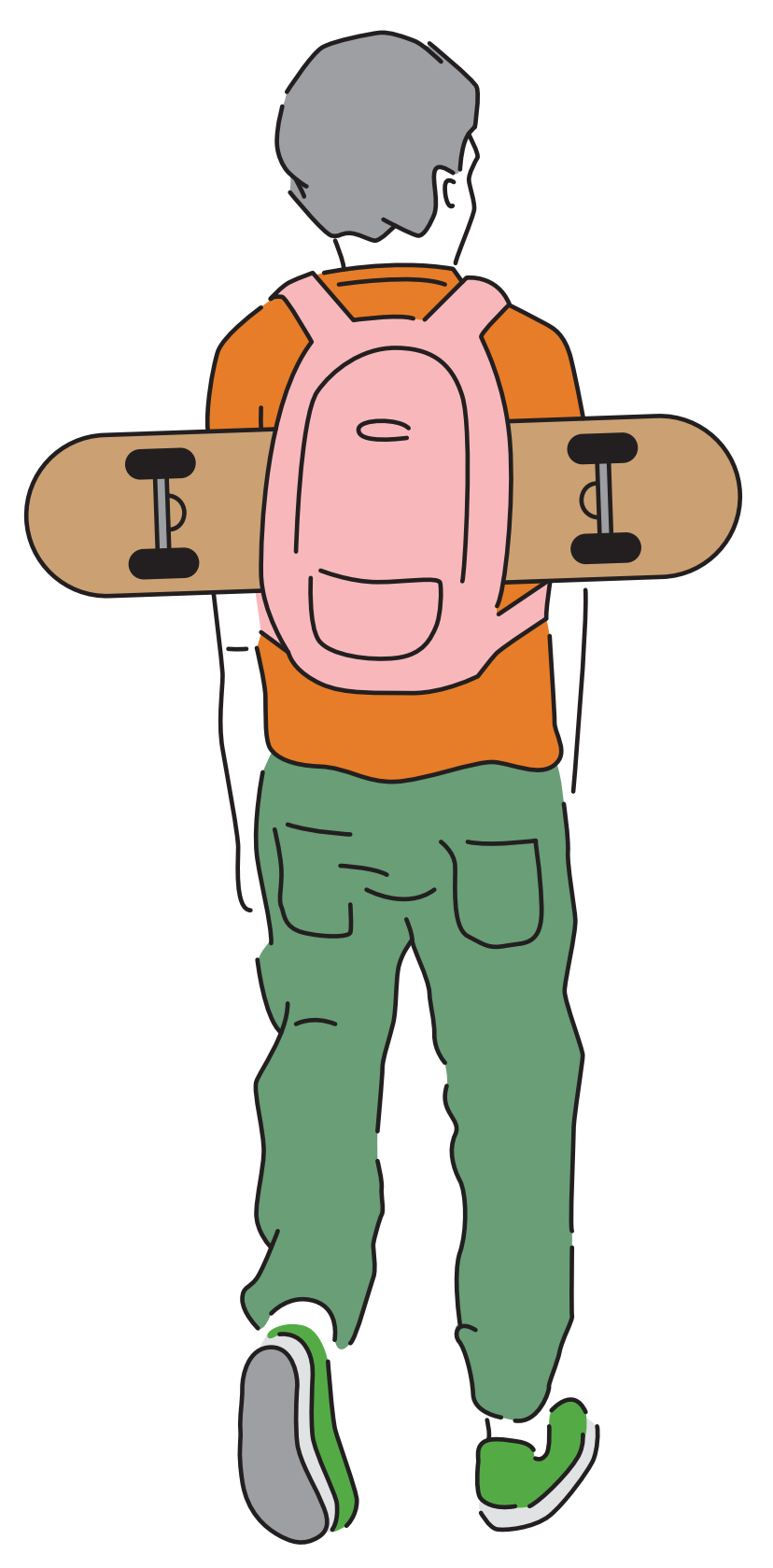

No grupo de alunos há um jovem que toca violino.

"Maconha" é assunto frequente entre eles.

Ao ser avisado sobre a chegada à Casa Modernista, um dos jovens comenta: "Eu já tinha passado aqui na frente, mas achava que era só um terreno com mato".

Na sequência, ele encena estar limpando bem os calçados antes de entrar na Casa. 
$\mathrm{Na}$ introdução da visita mediada, alguns jovens pedem silêncio aos demais. Um deles sussurra delicadamente no ouvido do amigo tagarela: "Cala a boca, caralho".

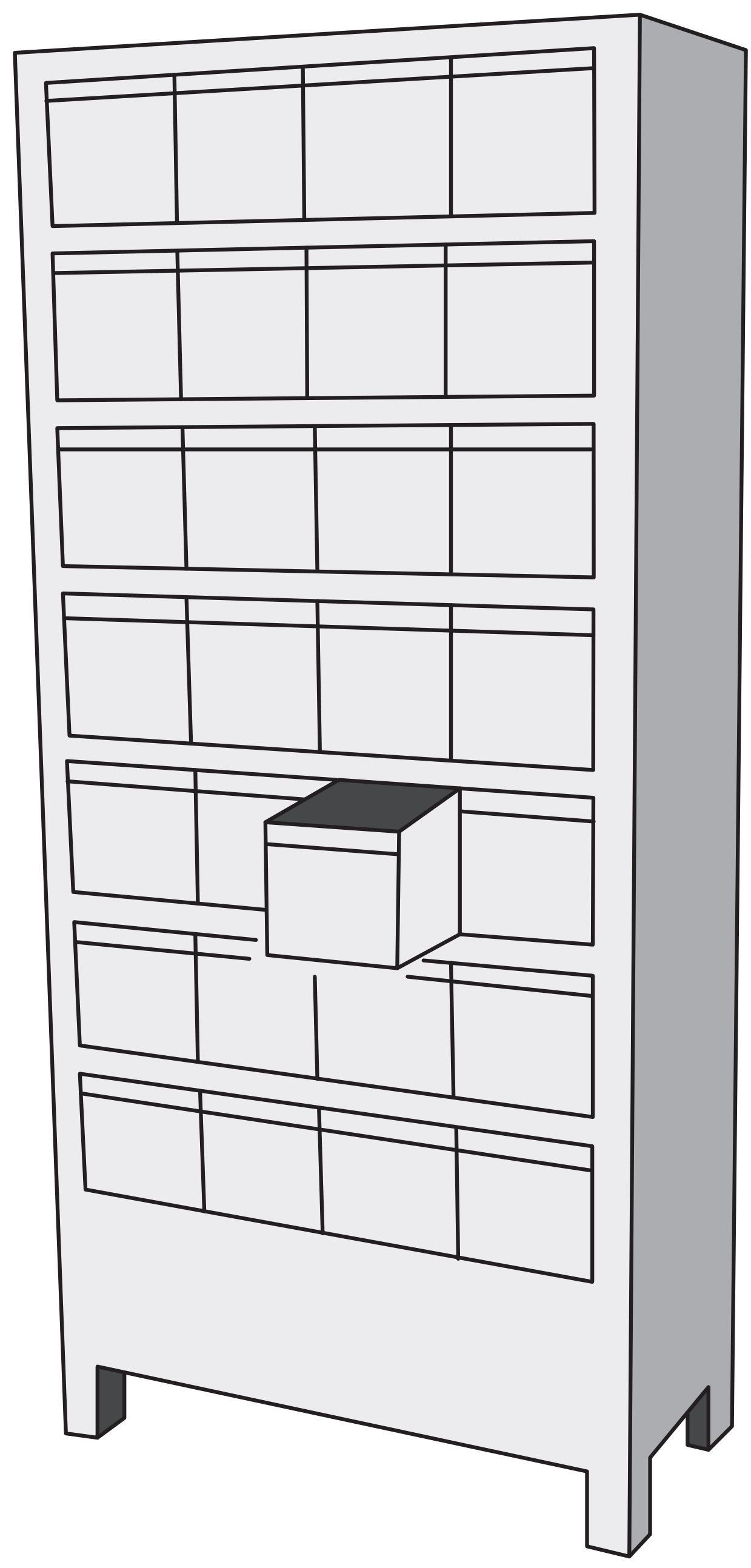

Mediadora: "O que é o Modernismo?". Aluna: "É aquilo que a gente aprende na aula de Educação Artística".

\section{WARCHAVCHIQUE}

Conhecimento é poder e glamour: a mediadora pronuncia o nome do arquiteto Gregori

Warchavchik com afetação. 


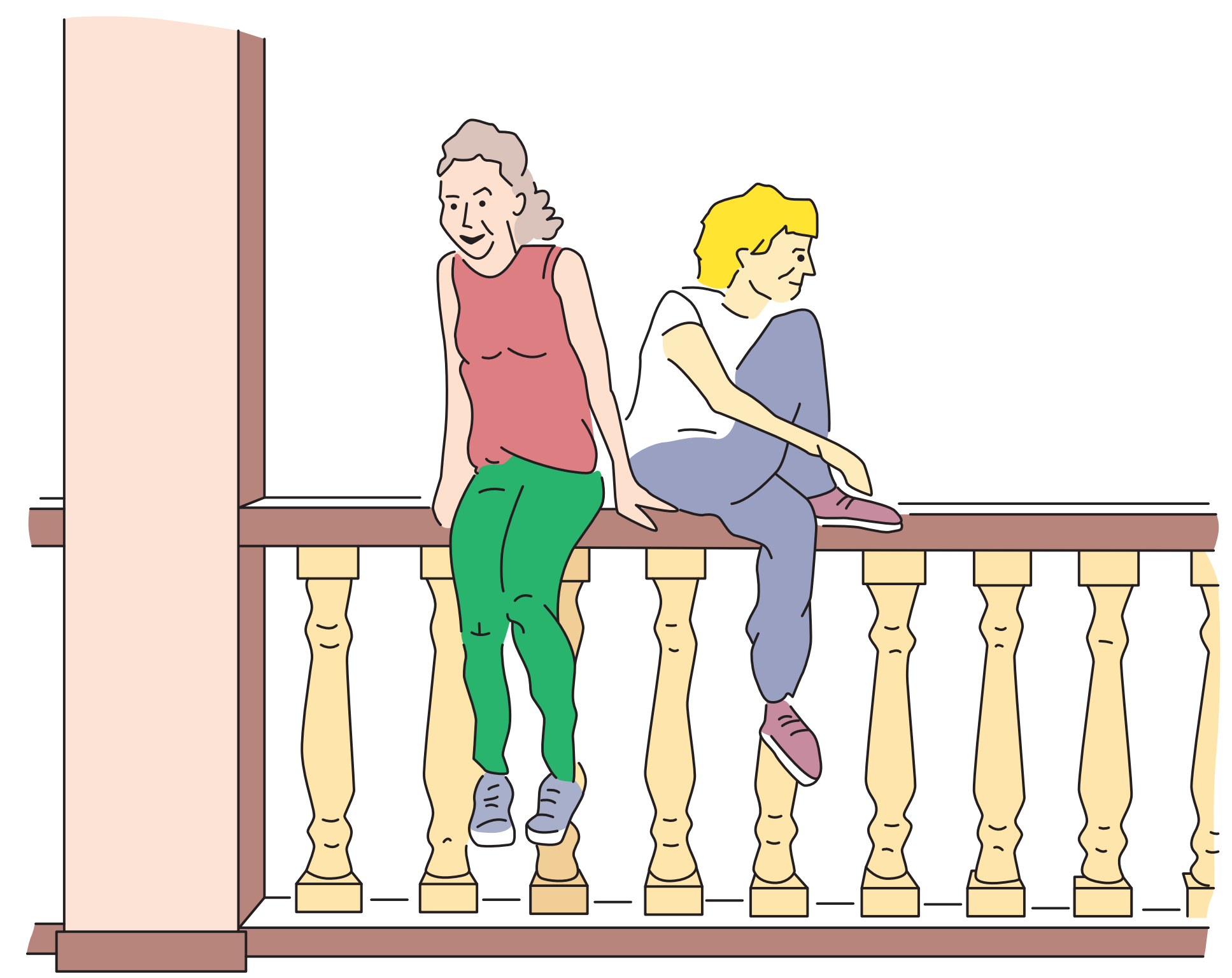

Ao fazer um apanhado geral dos arquitetos influentes no processo de urbanização de São Paulo, a mediadora pergunta: "Vocês conhecem a Casa das Rosas, do arquiteto Ramos de Azevedo?". Ao que a garota responde: "Eu cabulava aula lâ".

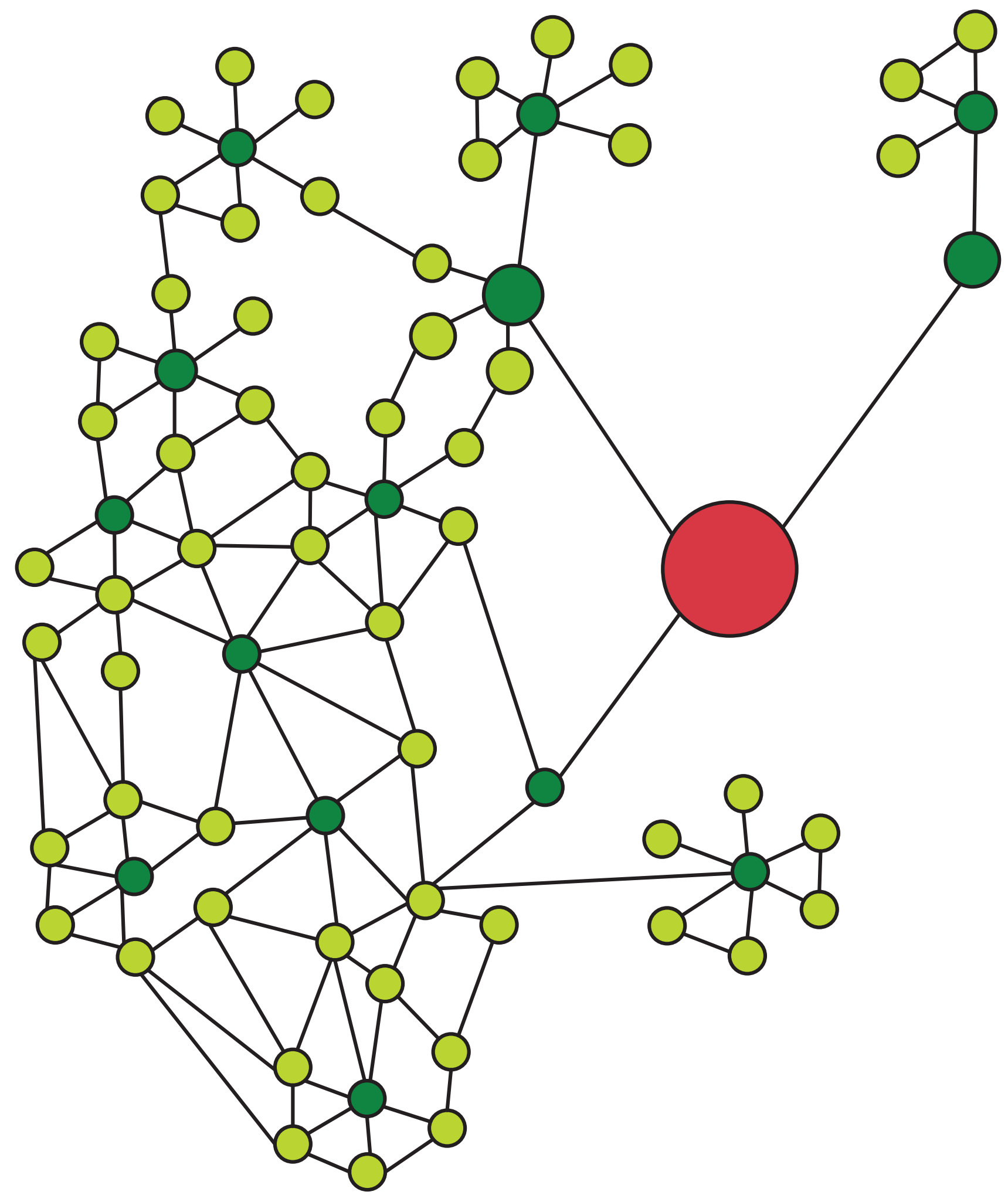

Risadinhas de canto de boca podem ser notadas na expressão de alguns estudantes, do tipo: "Onde é que vai dar todo esse bla bla bla da monitora?".
A mediadora desfla seus conbecimentos em arquitetura. Enquanto isso, conversas paralelas vão sendo tecidas pelos estudantes. 


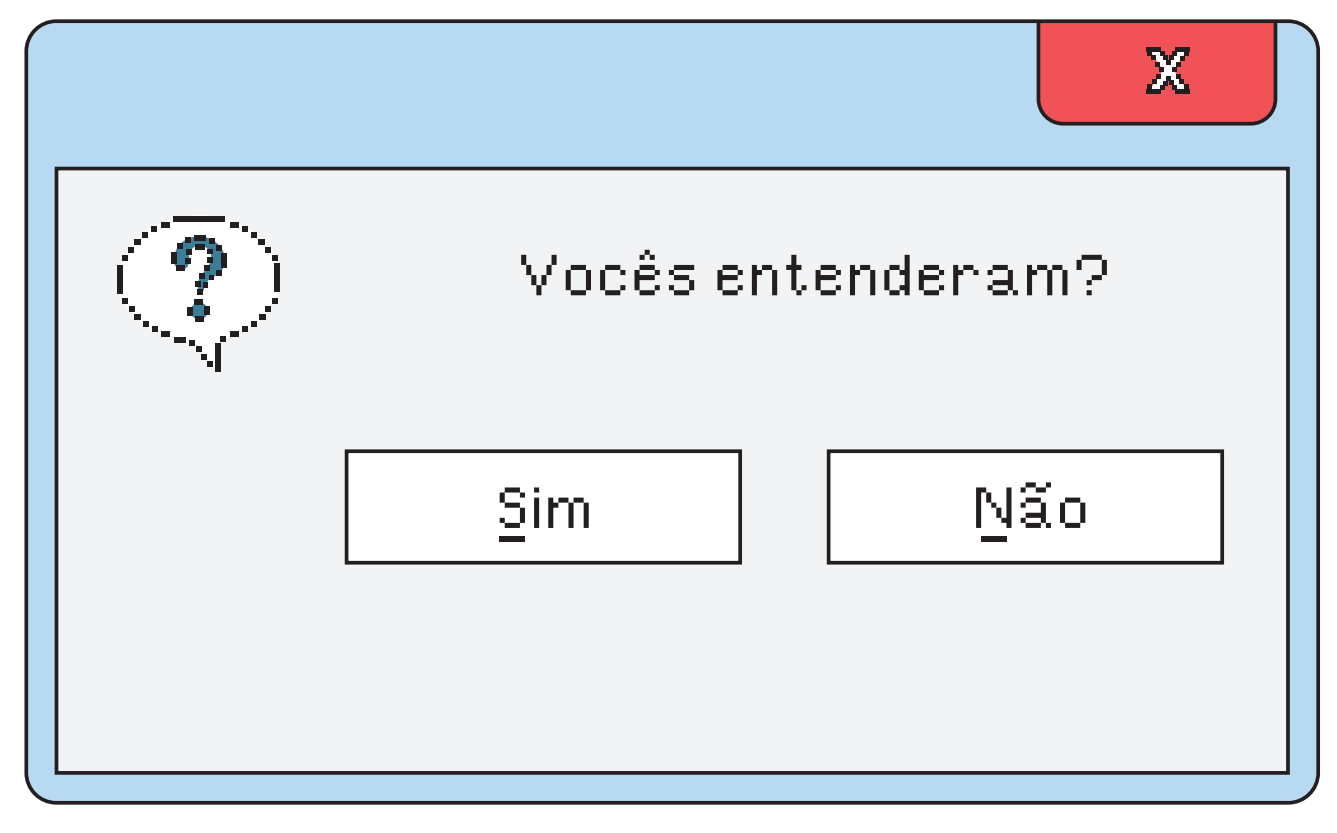

Mediação é diálogo

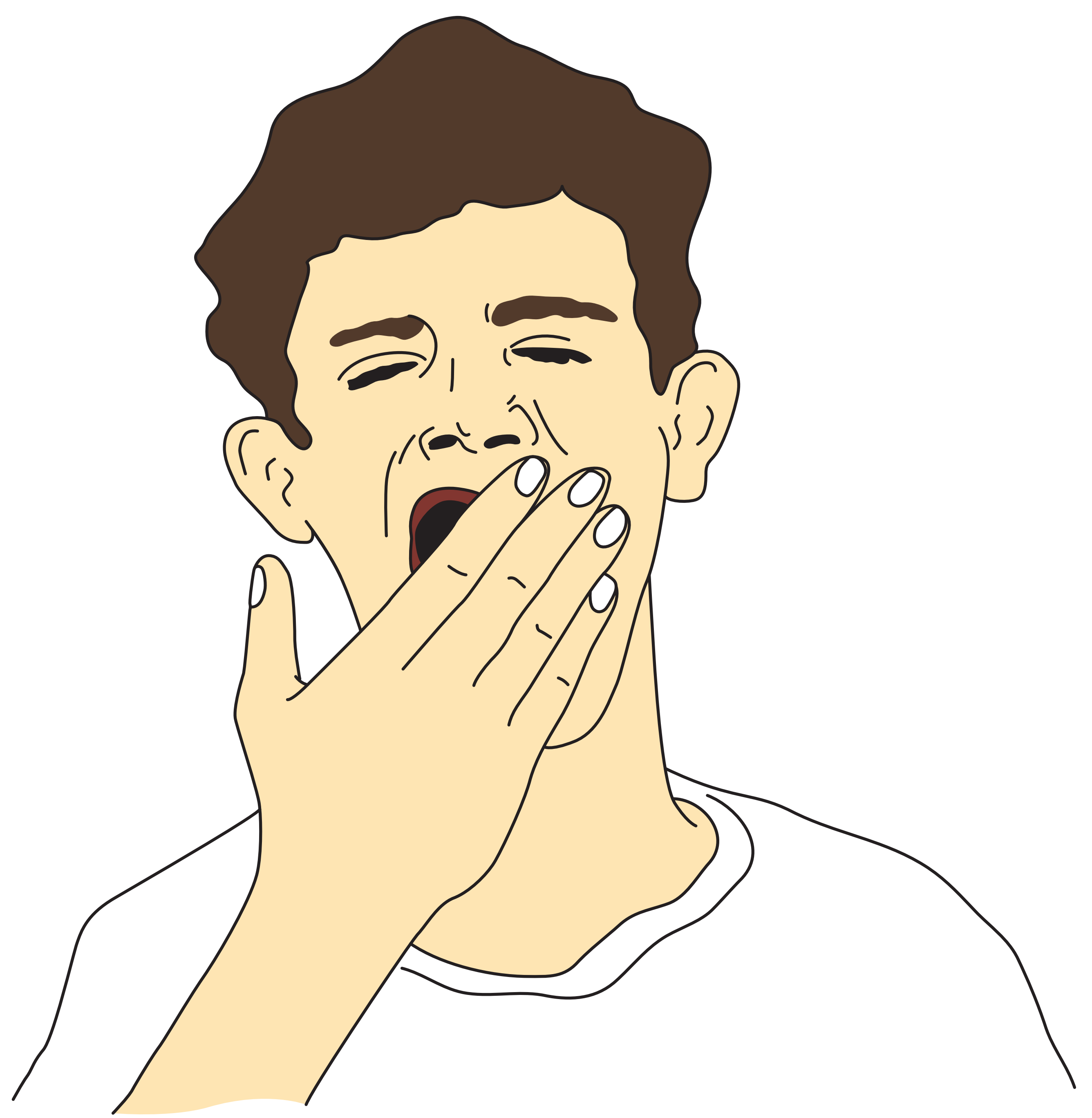

Generosamente, a mediadora anuncia: "Se vocês tiverem qualquer dúvida, perguntem... levantem a mão". 


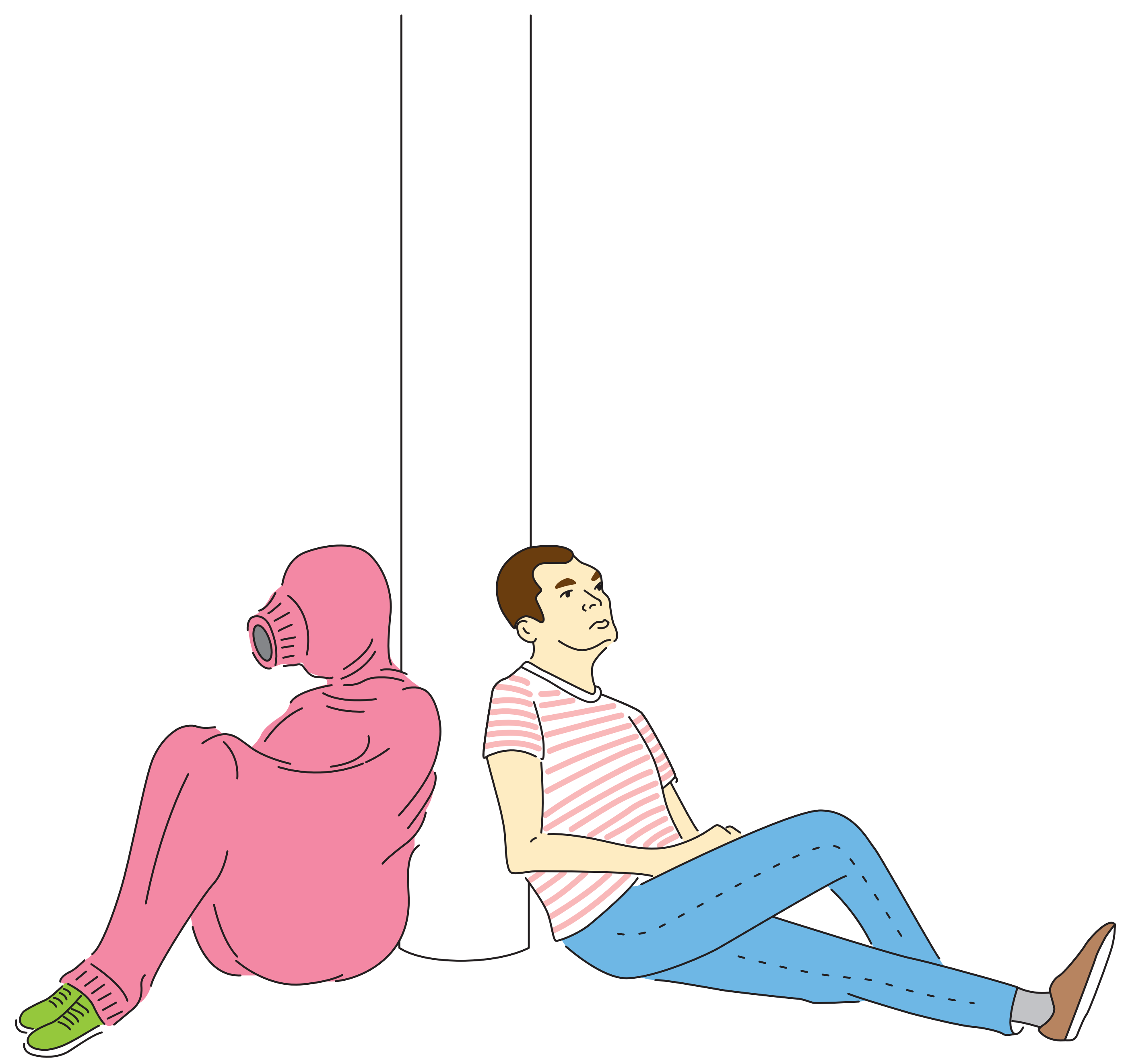

Performatividades em torno do piloti da varanda

A genialidade de Gregori Warchavchik é constantemente reforçada pela mediadora.

Boa parte da visita é dedicada a ratificar uma história familiar de poder e posses: Klabin, criados/empregados, lareiras, propriedades, piscinas, banheiros privativos, closets...

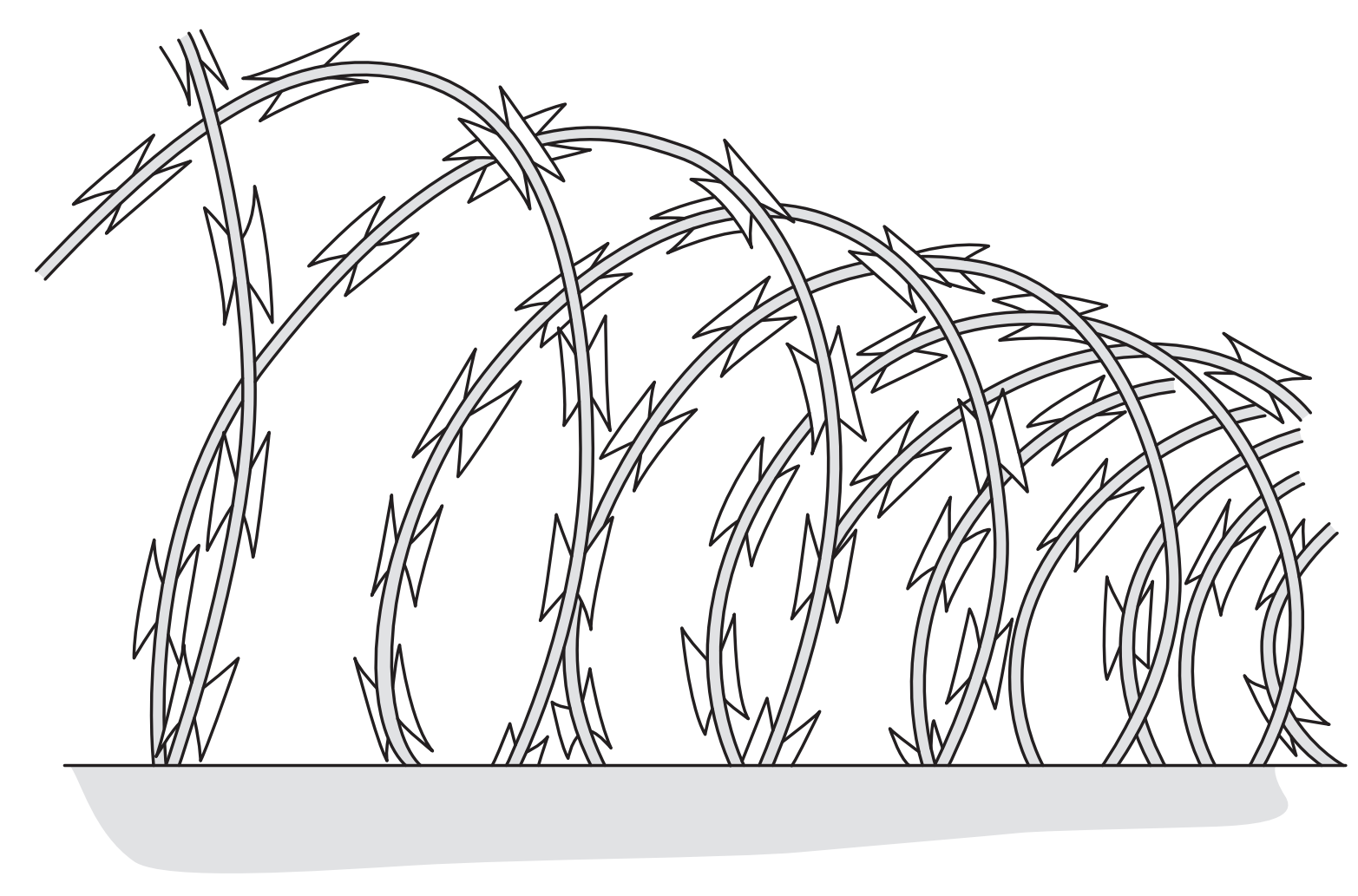

Arquitetura modernista atualizada 


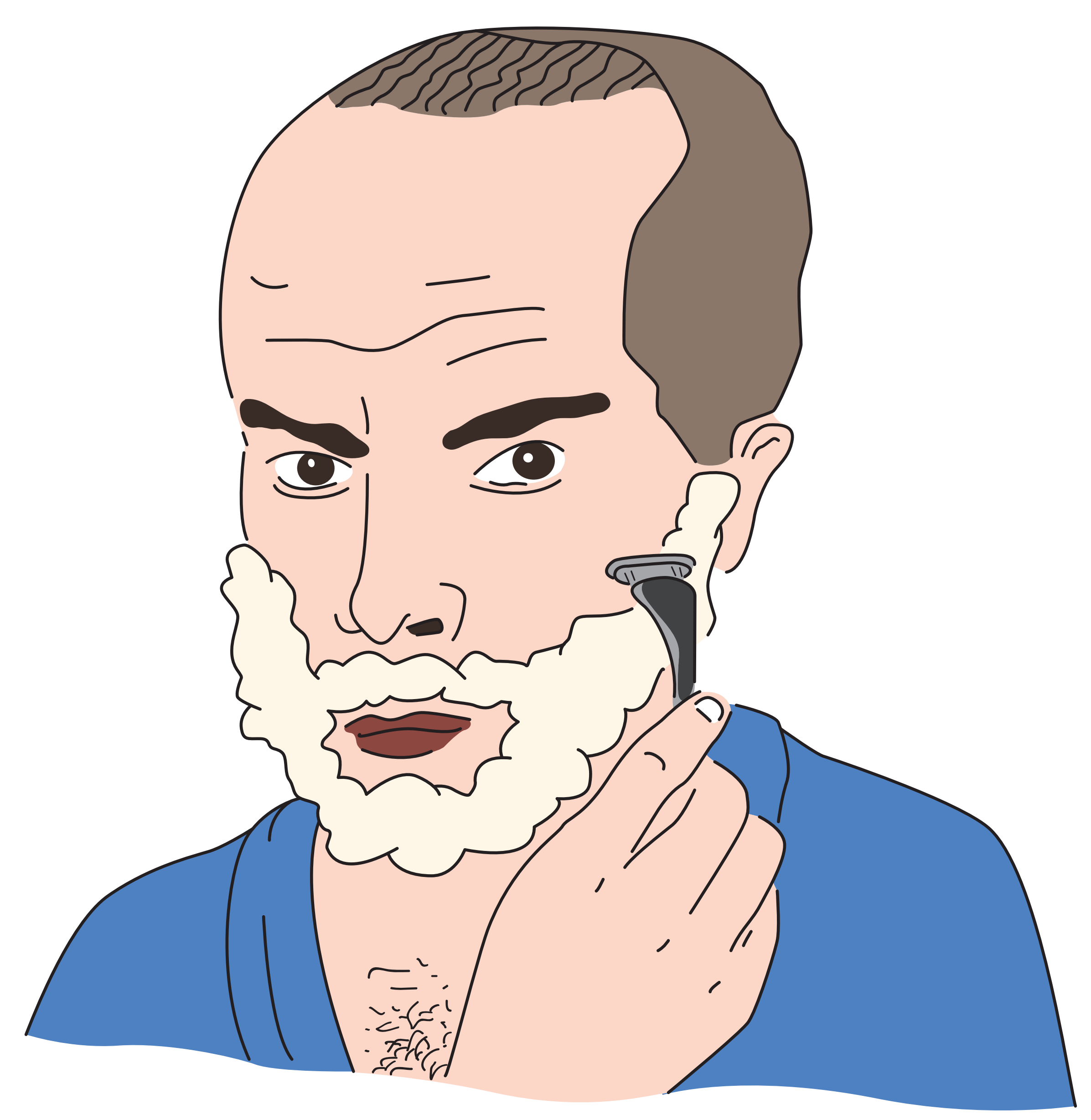

Ao ser informado de que Gregori Warchavchik tinha um banheiro só para si, o garoto ironiza: "Nojento!".

Ao se deparar com um dos banheiros da Casa, o estudante comenta: "Eu moraria dentro desse banheiro".
Tudo indica que a Casa Modernista incorporou algo da Senzala. É a mediadora quem nos conta: "Este era o quarto onde dormia a babá. Ele está situado no segundo piso da Casa porque ela era a única empregada autorizada a frequentar os quartos. Era uma criada bem próxima da família". 


\section{[sic]}

O estagiário problematiza: "Em São Paulo, encontramos alguma casa tombada como patrimônio que não represente as elites dirigentes?". Ao que uma das acompanhantes da visita, cometendo um deslize, responde: "A Casa do Bandeirante".

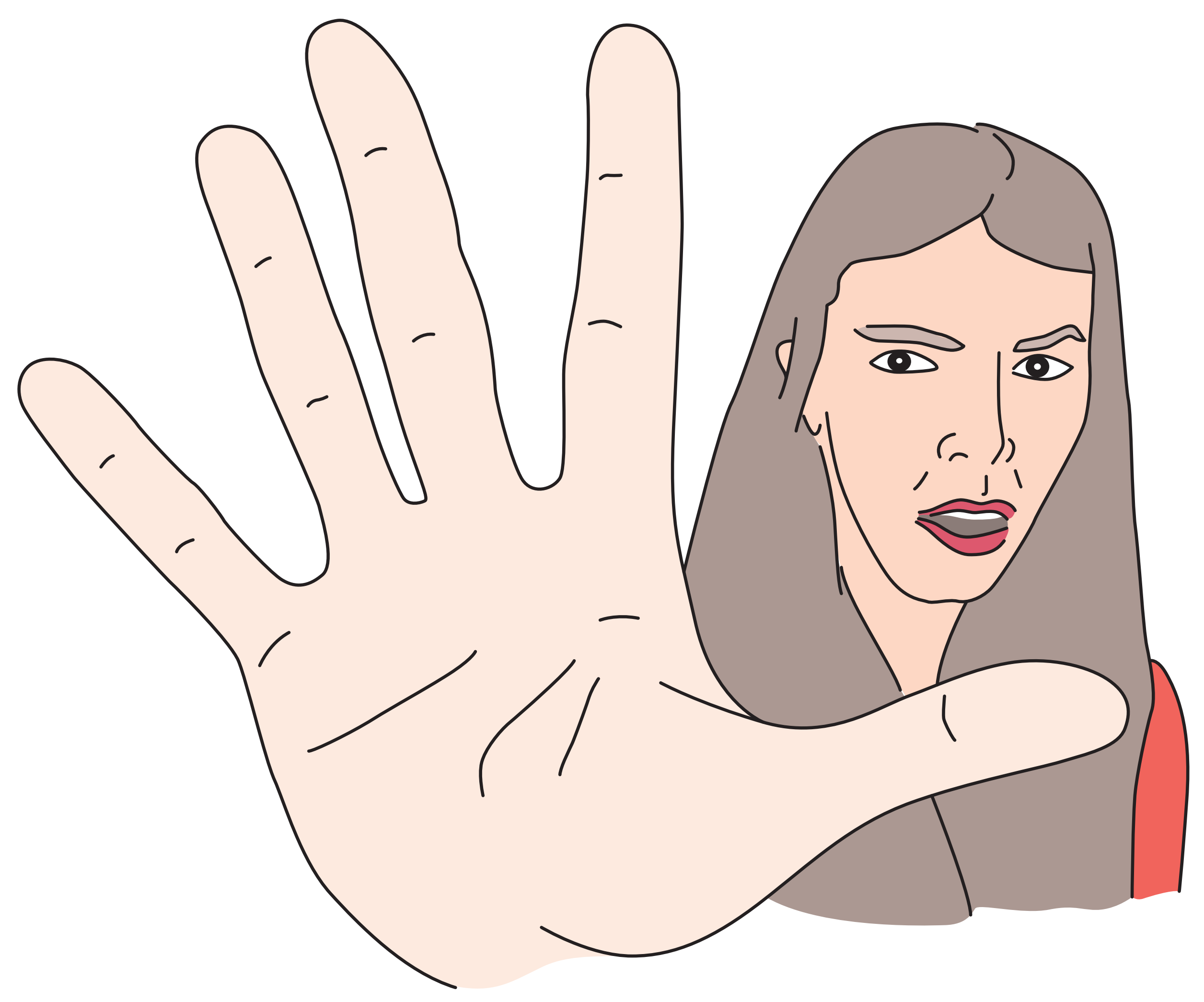

O registro fotográfico institucional não é bem visto por uma das jovens: "Foto não, tia". 


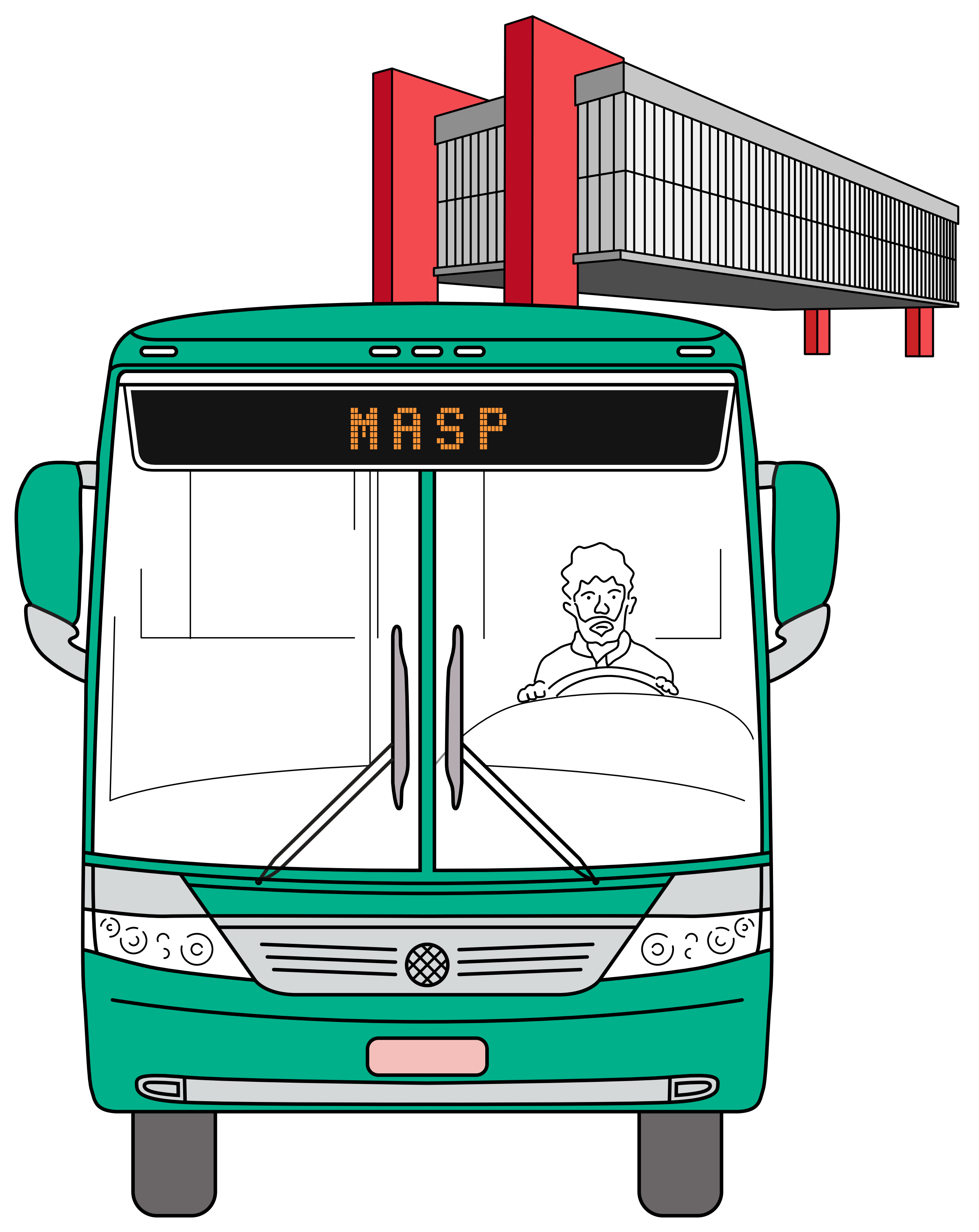




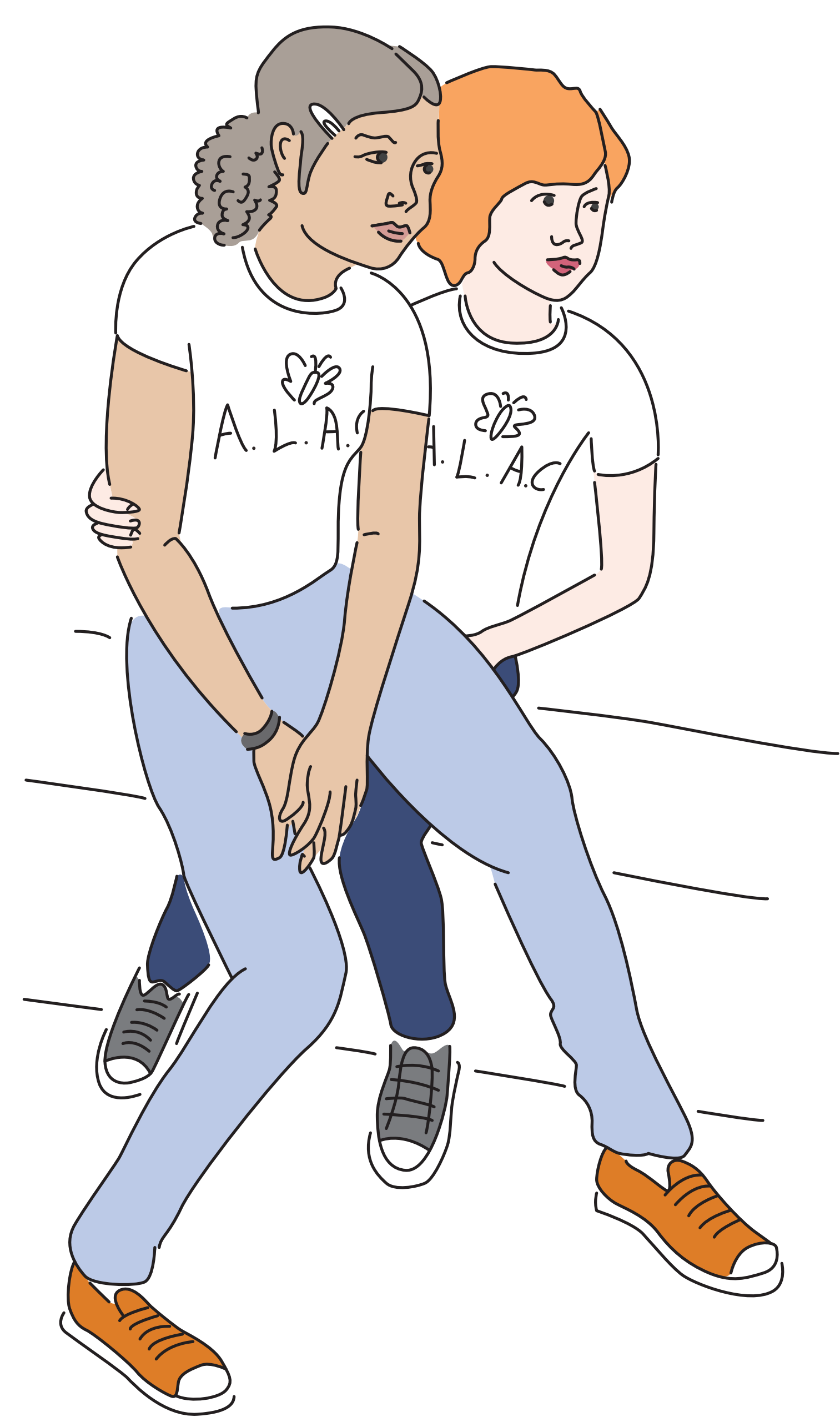

Colo-banco: design do afeto
Ao se despedir do filho, a mãe recomenda: "Ó, respeite as pessoas".

De repente, uma garota gruda no meu braço.

Alguns colegas da turma que visitara o MASP no dia anterior dizem: "Lá é chato, viu?!".

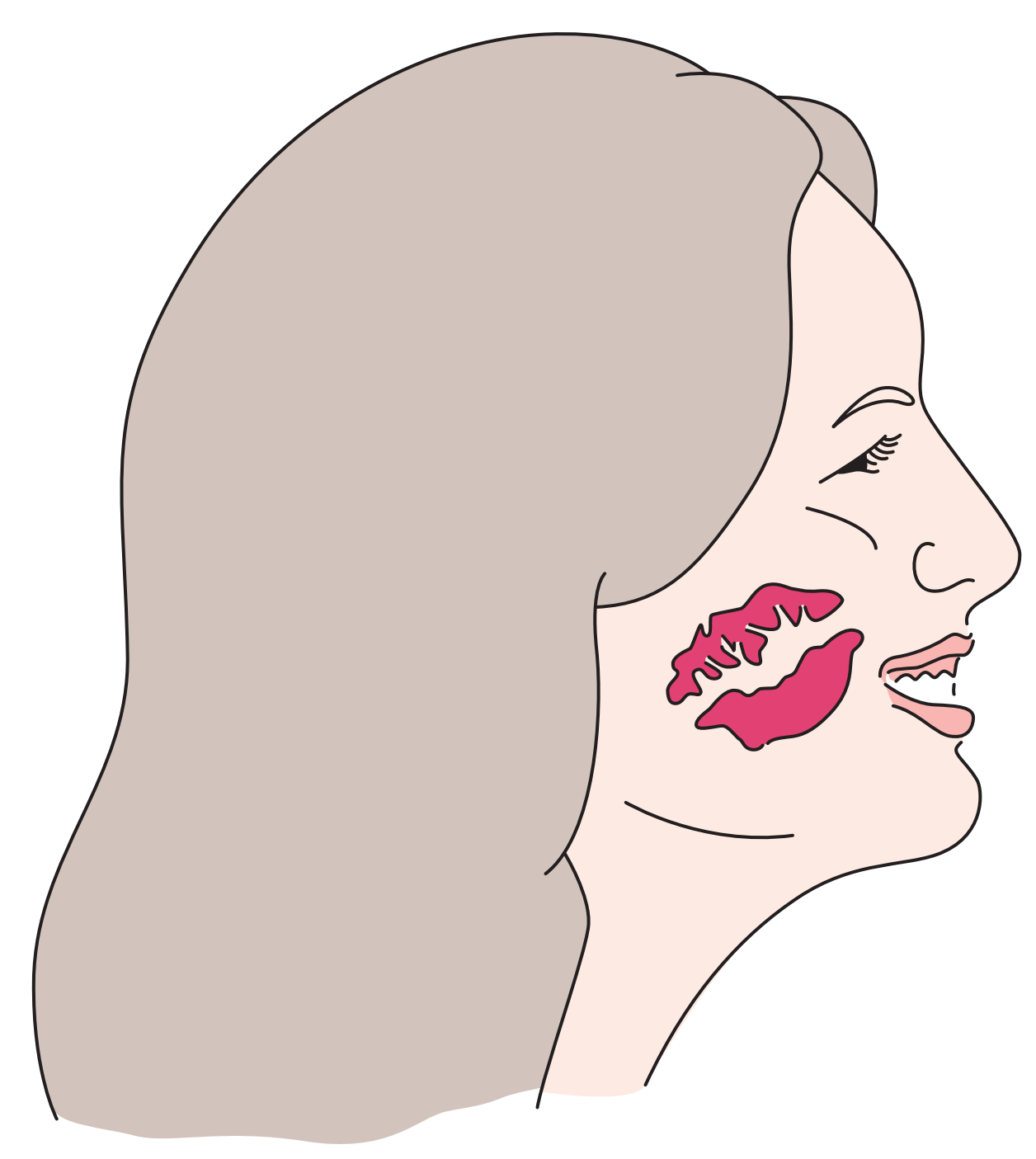

A garota faz questão de deixar o beijo da amiga estampado em seu rosto. 
No portão de saída do Centro Assistencial, a assistente social pede que as crianças formem uma fila por ordem de tamanho. As crianças, por sua vez, não dão a mínima atenção à orientação e partem em direção ao ônibus estacionado no quarteirão seguinte.

Sentadas nos primeiros bancos, algumas meninas brincam de "mandar no motorista", apropriando-se de suas manobras ao volante: "Agora ande!... agora pare!... isso mesmo!". E também: "Vá reto!... vire à esquerda!... agora à direita!...". Suas diretivas misturam-se a muitas risadas.

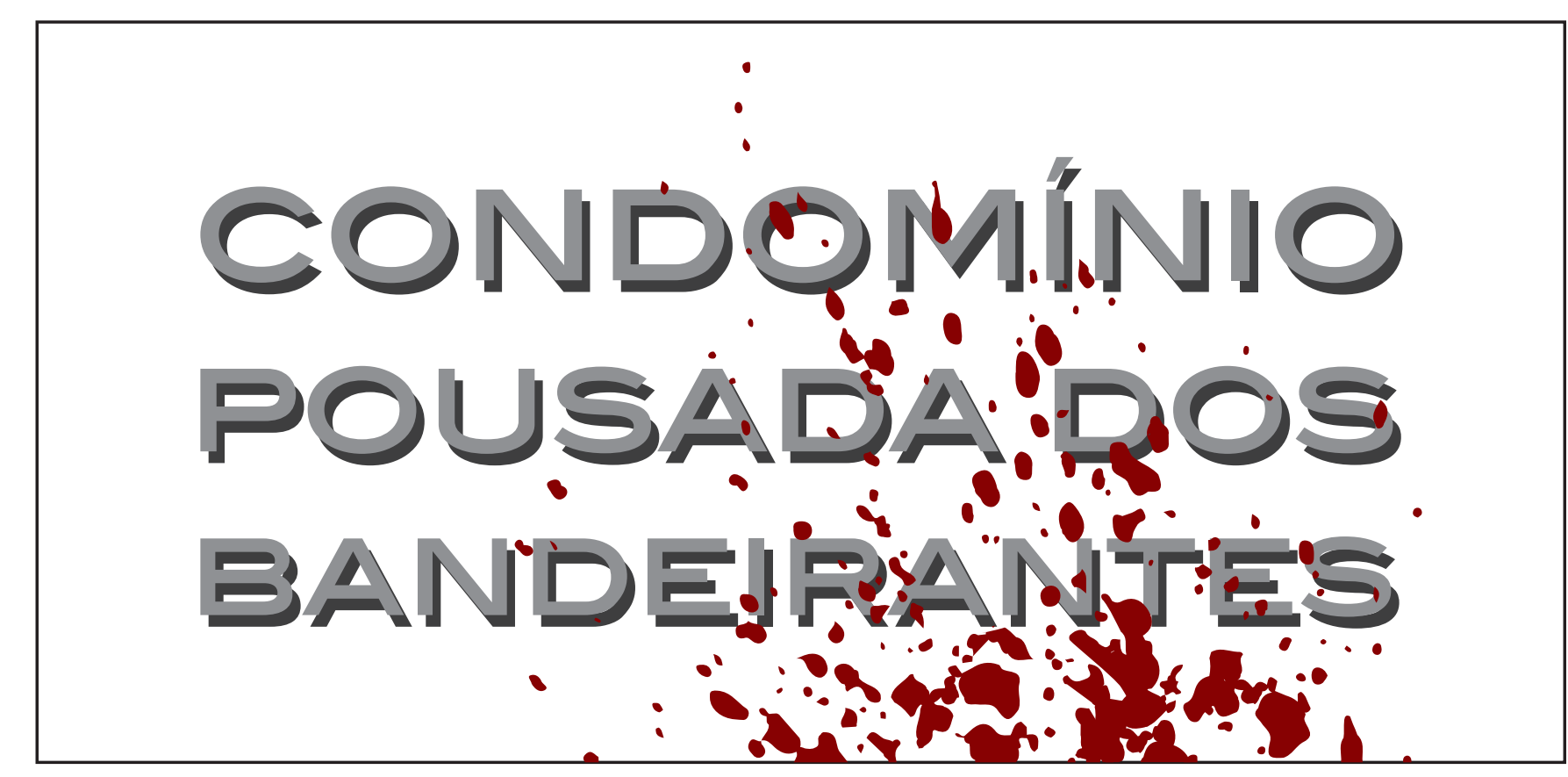

Intervenções pelo caminho

O menino vira abruptamente e diz: "Puts! Olha lá, é a polícia!". Sua colega zomba: "Ai meu Deus! hahaha". A outra emenda com uma sirene onomatopéica: "iió-iió-iió-iió...".

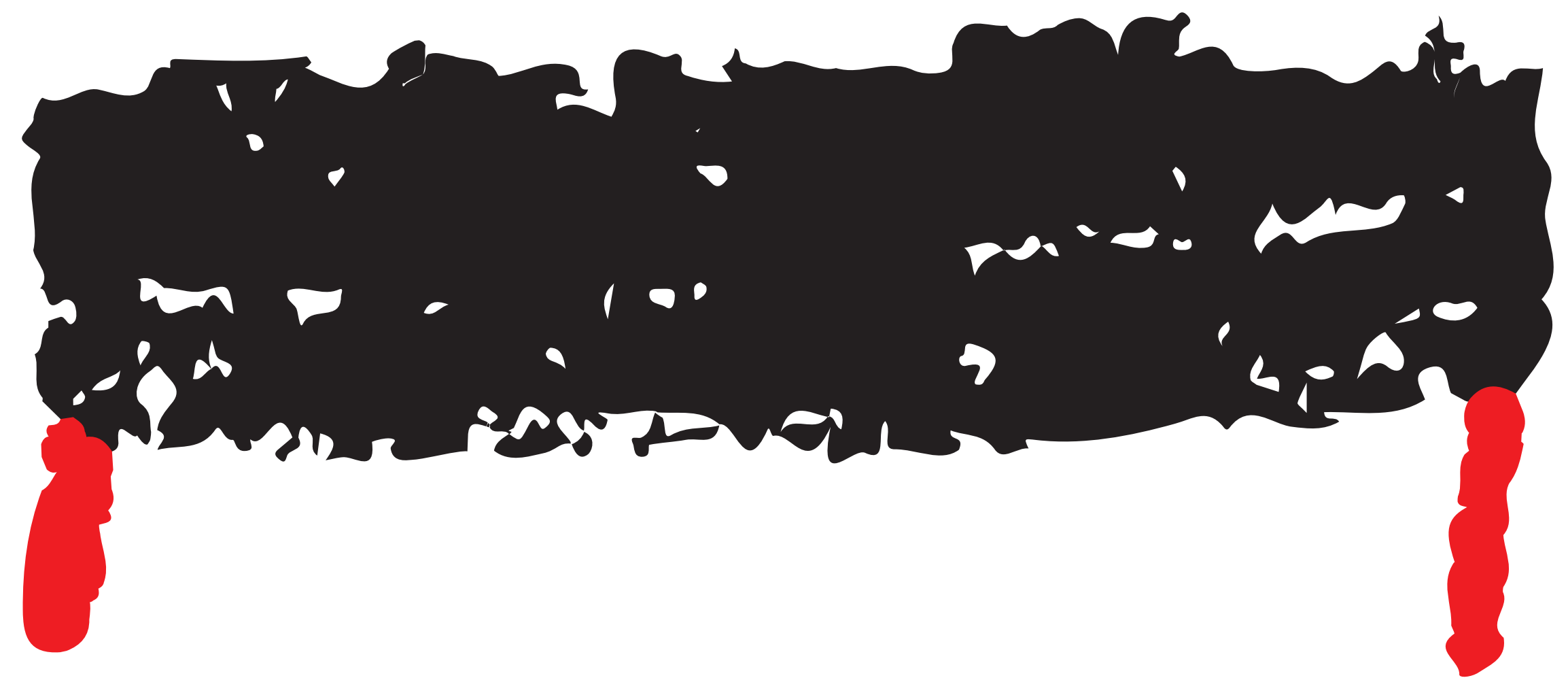

Durante o percurso, o garoto puxa o edifício do MASP pela memória: "Aquele negócio vermelho e preto... as coisas que seguram são vermelhas e em cima é preto". 
A garota traz a bolsa cheia de balas e, além delas, a disposição em dividir os confeitos com a turma. Em tom de escracho, o moleque grita lá do fundo: "Não pega não! Essas balas já foram chupadas... ela pôs na boca e embalou de novo!".
De quinze em quinze minutos, o garoto pergunta: "Falta quanto tempo pra gente chegar?".

A assistente social insiste: "Sentados! Por que vocês estão de pé?".

Ao que a garota responde: "Porque a gente quer, ué!".

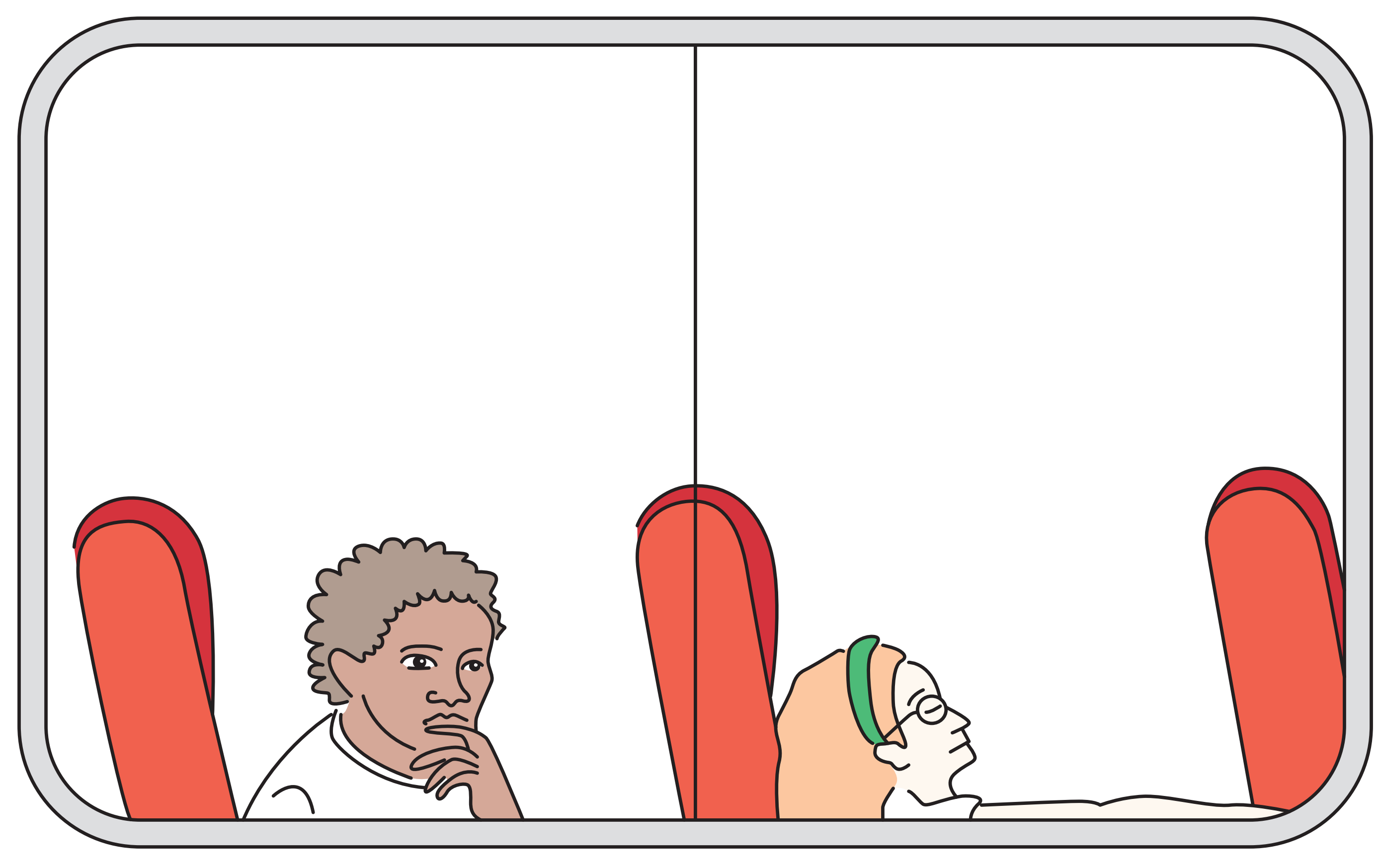

Estado de contemplação na Teodoro Sampaio

O menino observa o que se passa na rua Teodoro Sampaio. No final dela, antes de dobrarmos na avenida Dr. Arnaldo, ele comenta para si, em voz baixa: "Aqui é o Hospital das Clínicas".
Entre a chacota e o sadismo, a assistente social grita para a "turma do fundão": "Vocês vão ficar aqui no Hospital das Clínicas tomando injeção!". 


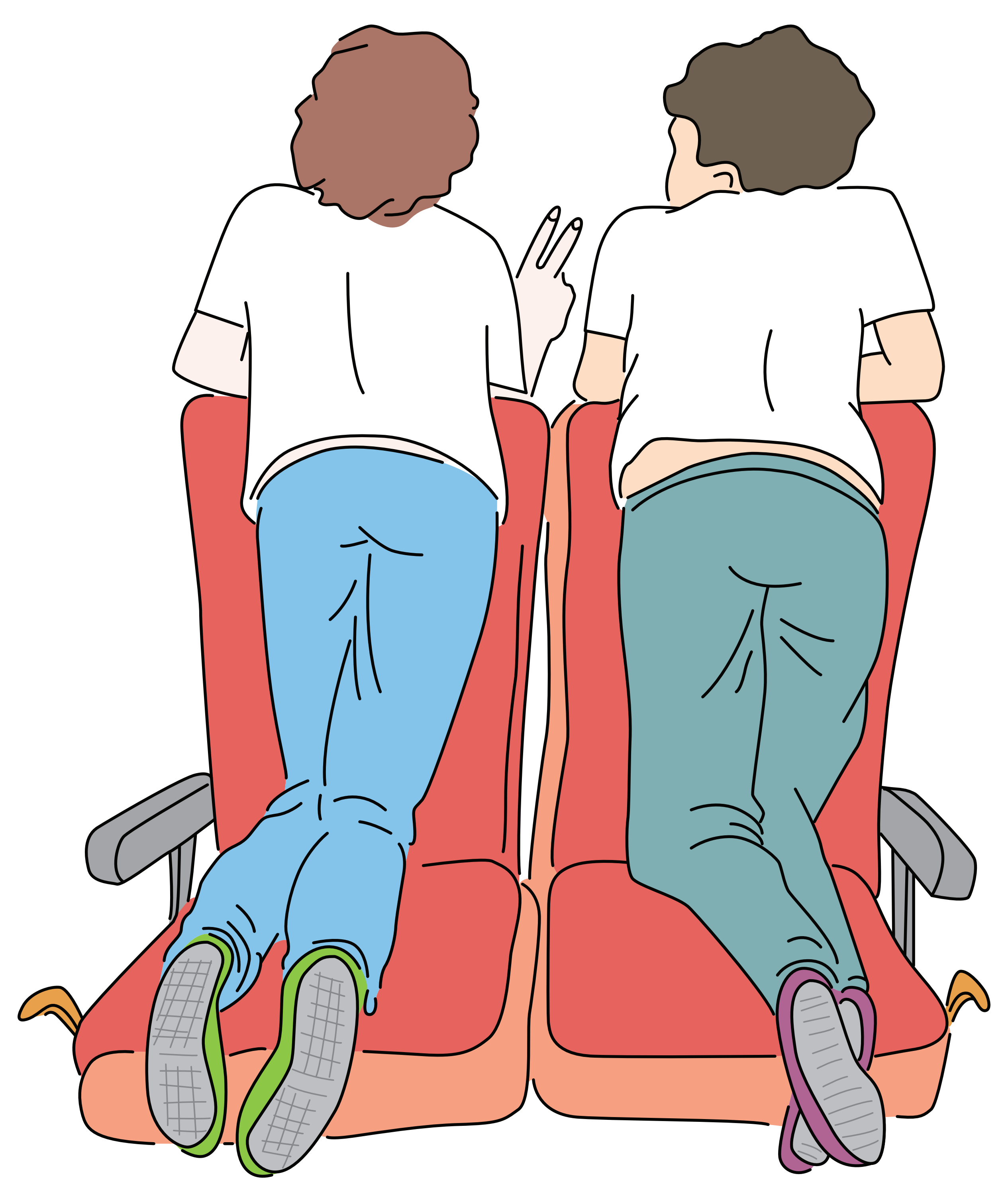




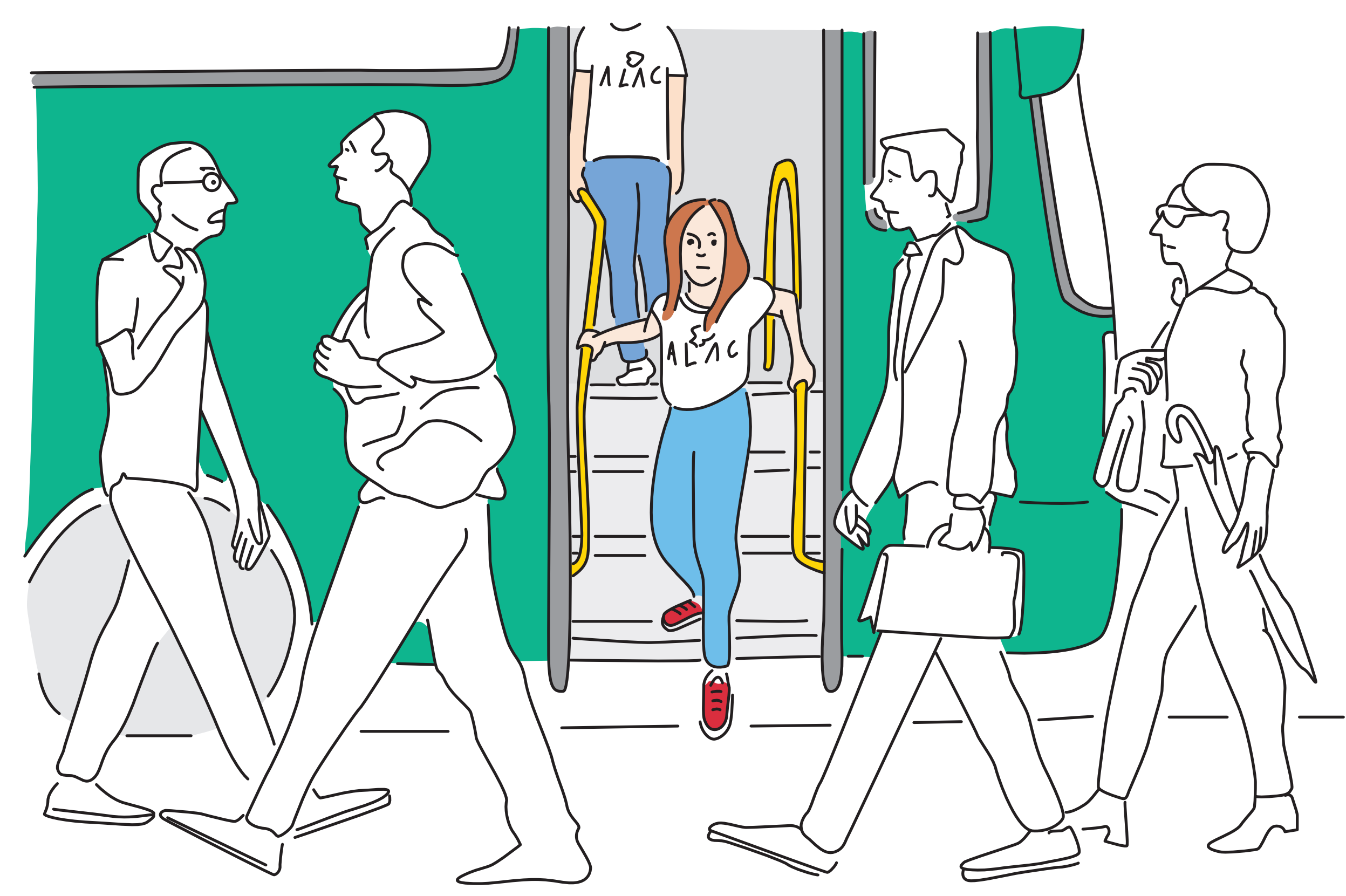

Fluxos cruzados

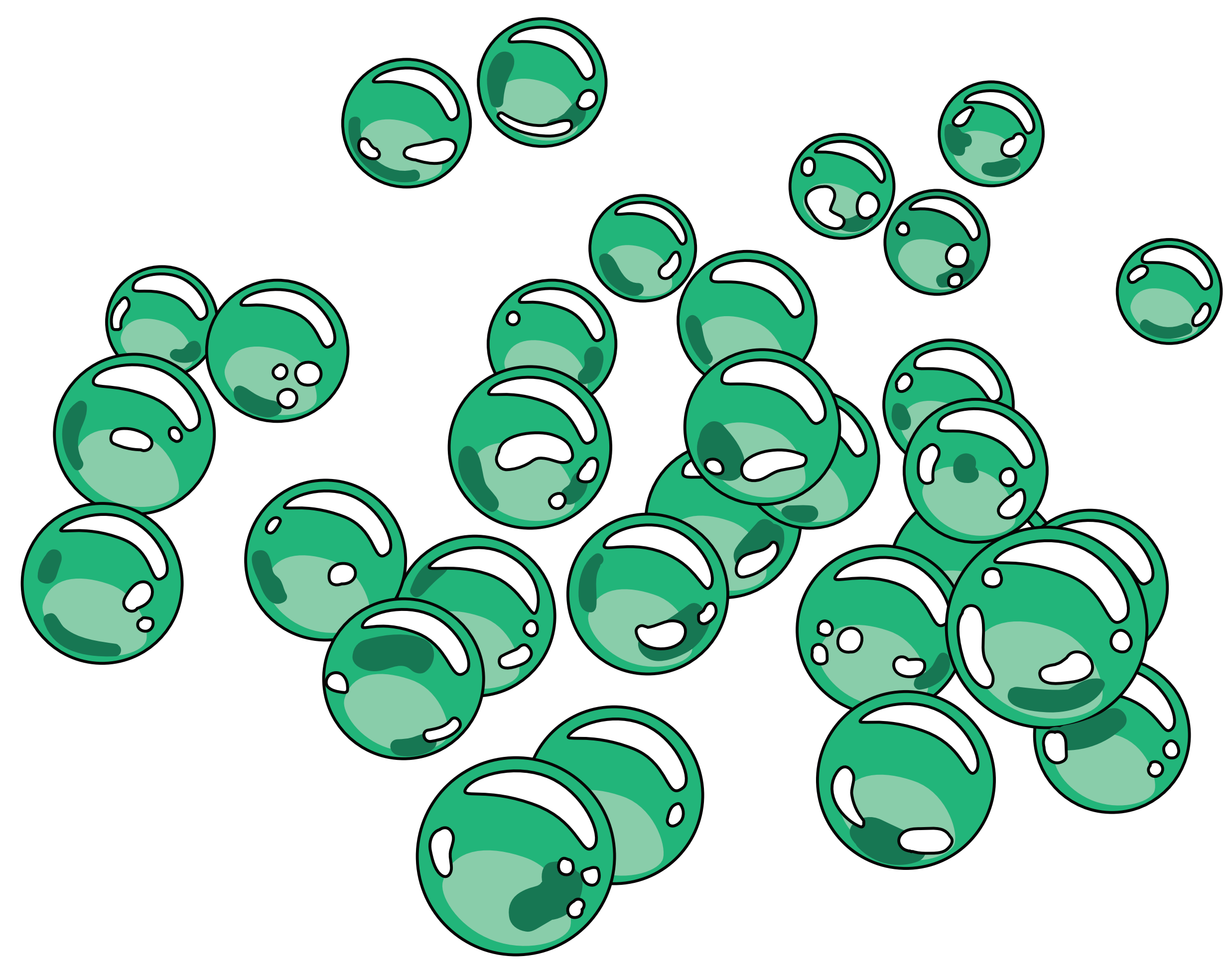

As crianças se espalham pelo vão livre do MASP como bolas de gude. 
No vão livre, algumas crianças improvisam partidas de "futebol de tampinha".
Se esquivando das fotos, a assistente social é interpelada pela menina: "Deixa disso... você é linda".

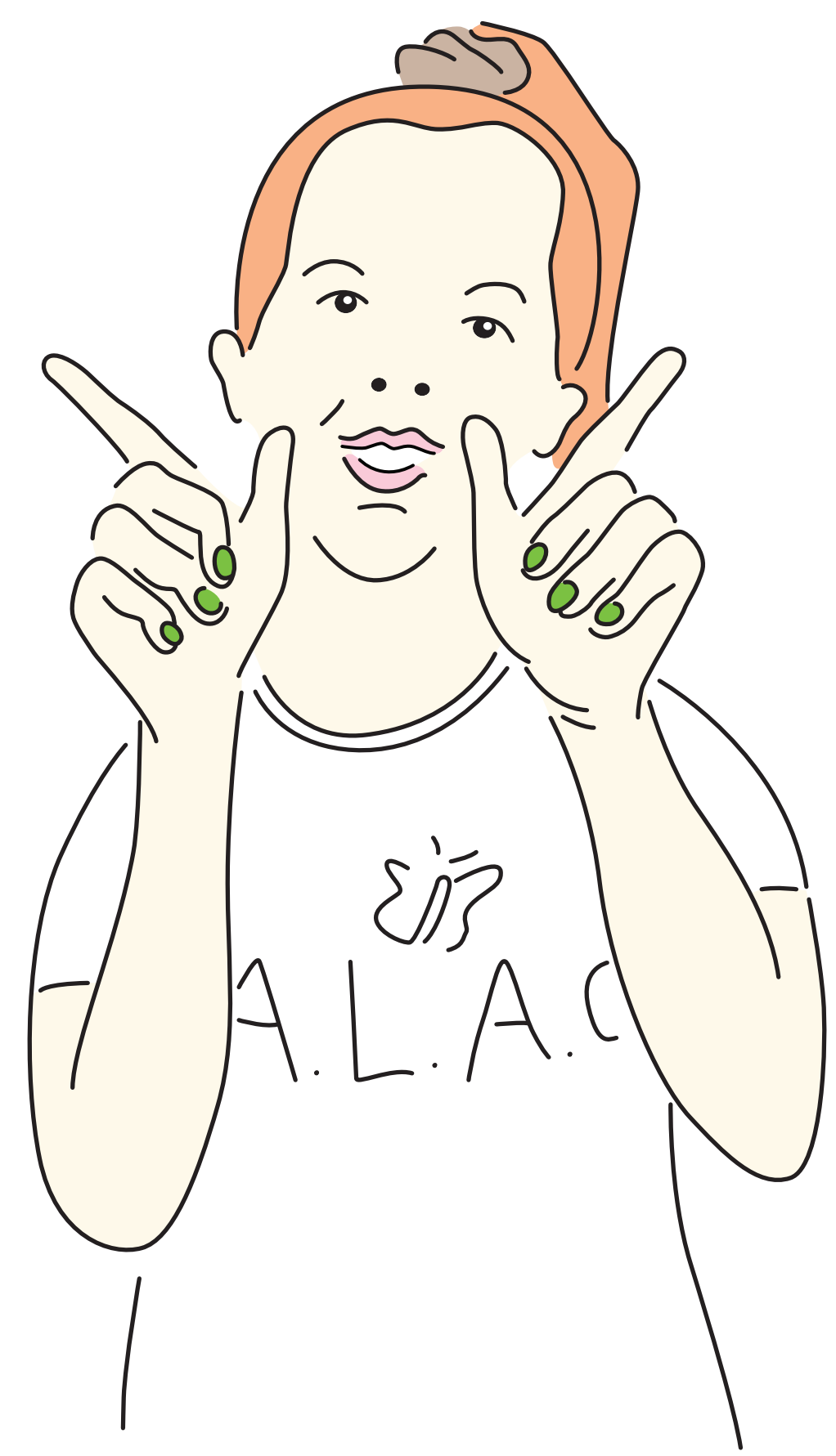

Pose para foto

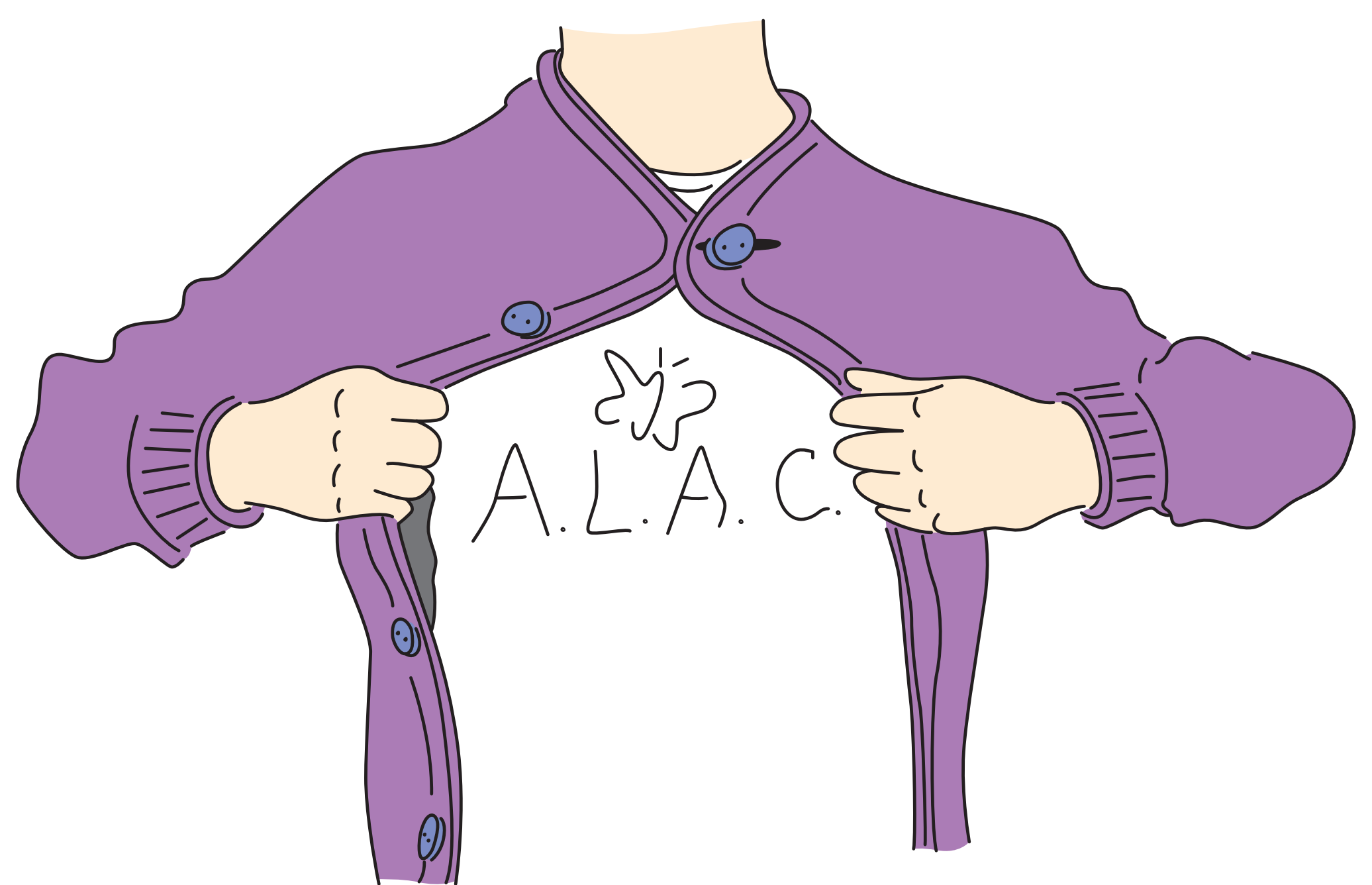

No momento da foto do grupo, a assistente social orienta o menino: "Abra a blusa... a marca do patrocinador tem que aparecer". 


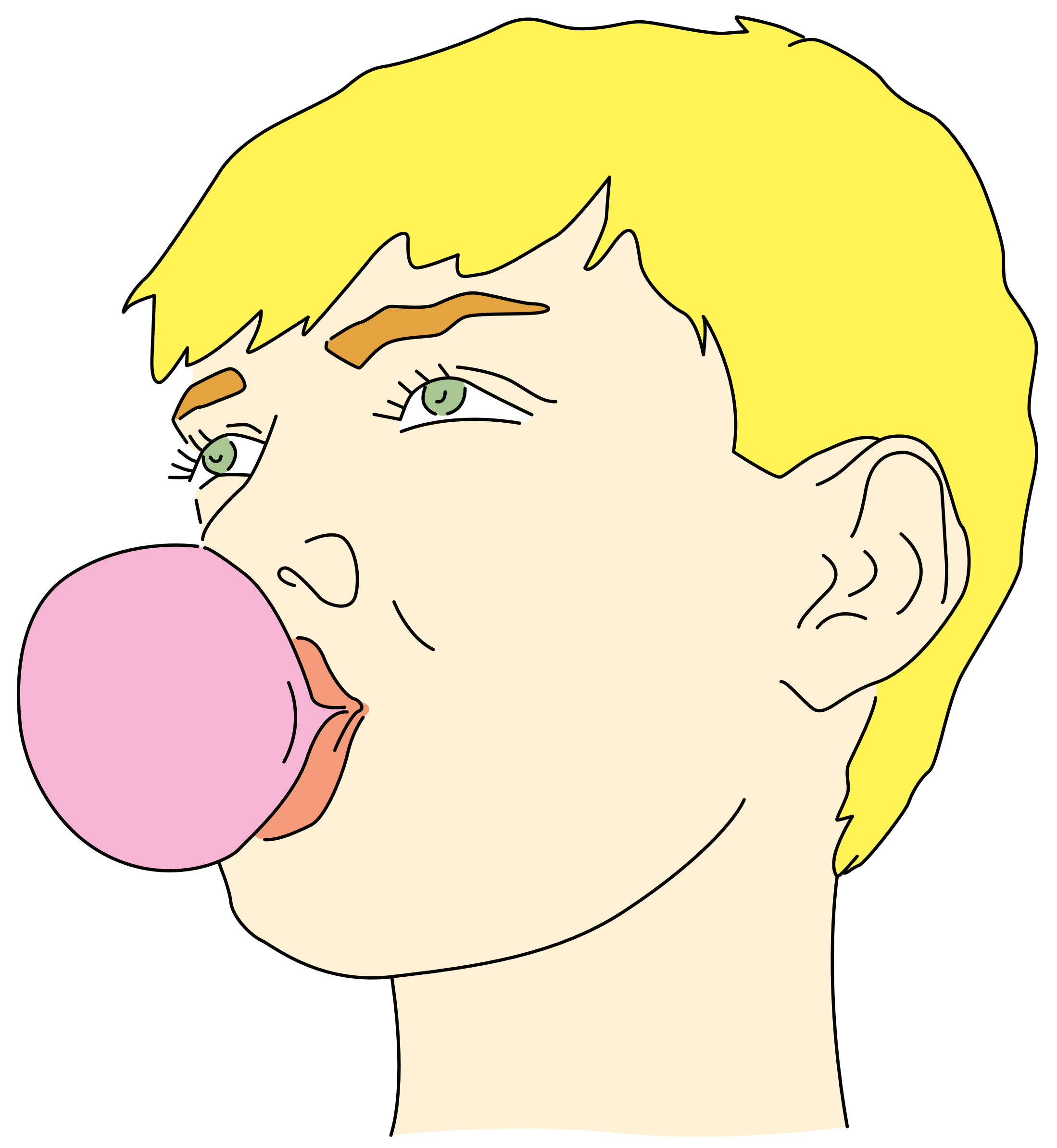

O garoto dá forma ao seu intento.

MAS POR QUÊ??

O menino não se conforma com o fato de que, para entrar no museu, ele deva ser "selado".

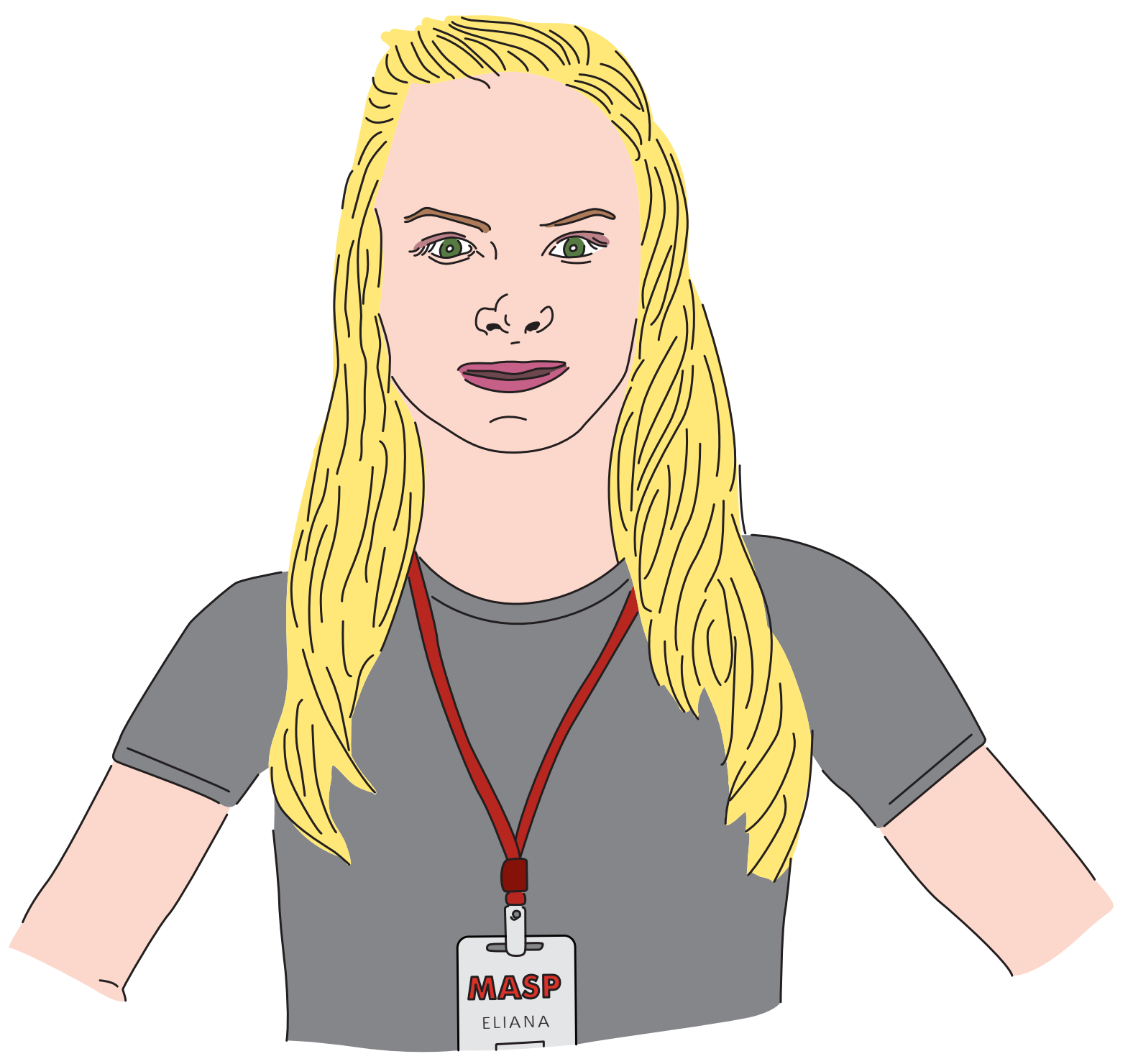

Ao se apresentar ao grupo, a mediadora escuta: "Eliana?... A da TV?".

Durante a conversa de acolhimento com a mediadora, a garota atalha: "A gente só vai ficar falando?". 
"O CHAMADO DA ARTE: O passante negro veio olhar os quadros e ouvir os discursos da grande festa." (Fac-símile de uma página da revista 0 Cruzeiro, com matéria sobre a itinerância de obras do MASP pela Bahia, em 1952, fixado ao lado do quadro O Escolar, de Van Gogh.)

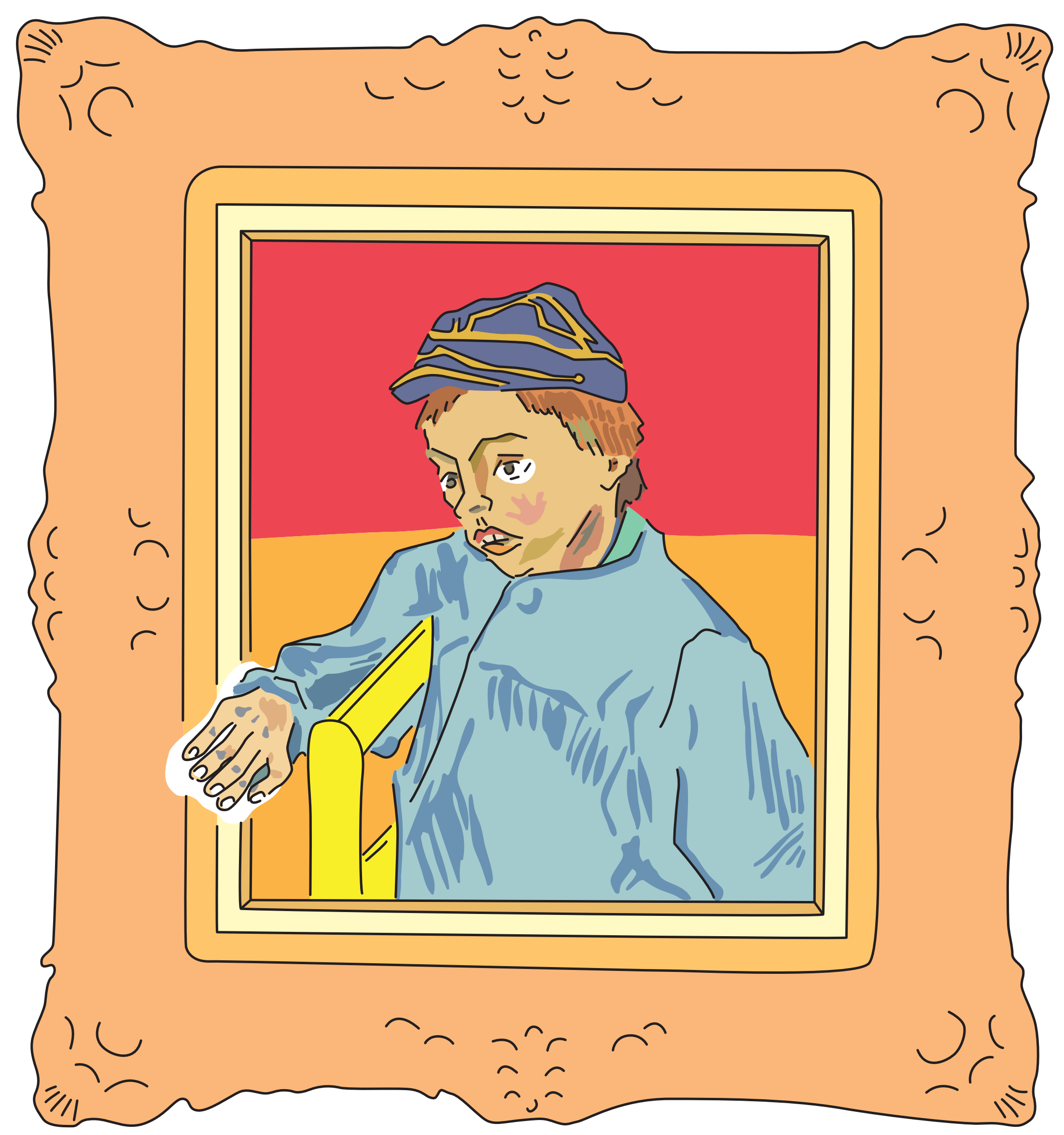

Embora a mediadora reitere a interdição ao toque, tem criança que não se contém.

A garota contra-argumenta as orientações da mediadora sobre os danos provocados nas pinturas pelo toque: "Então por que vocês não colocam vidro para proteger?". 


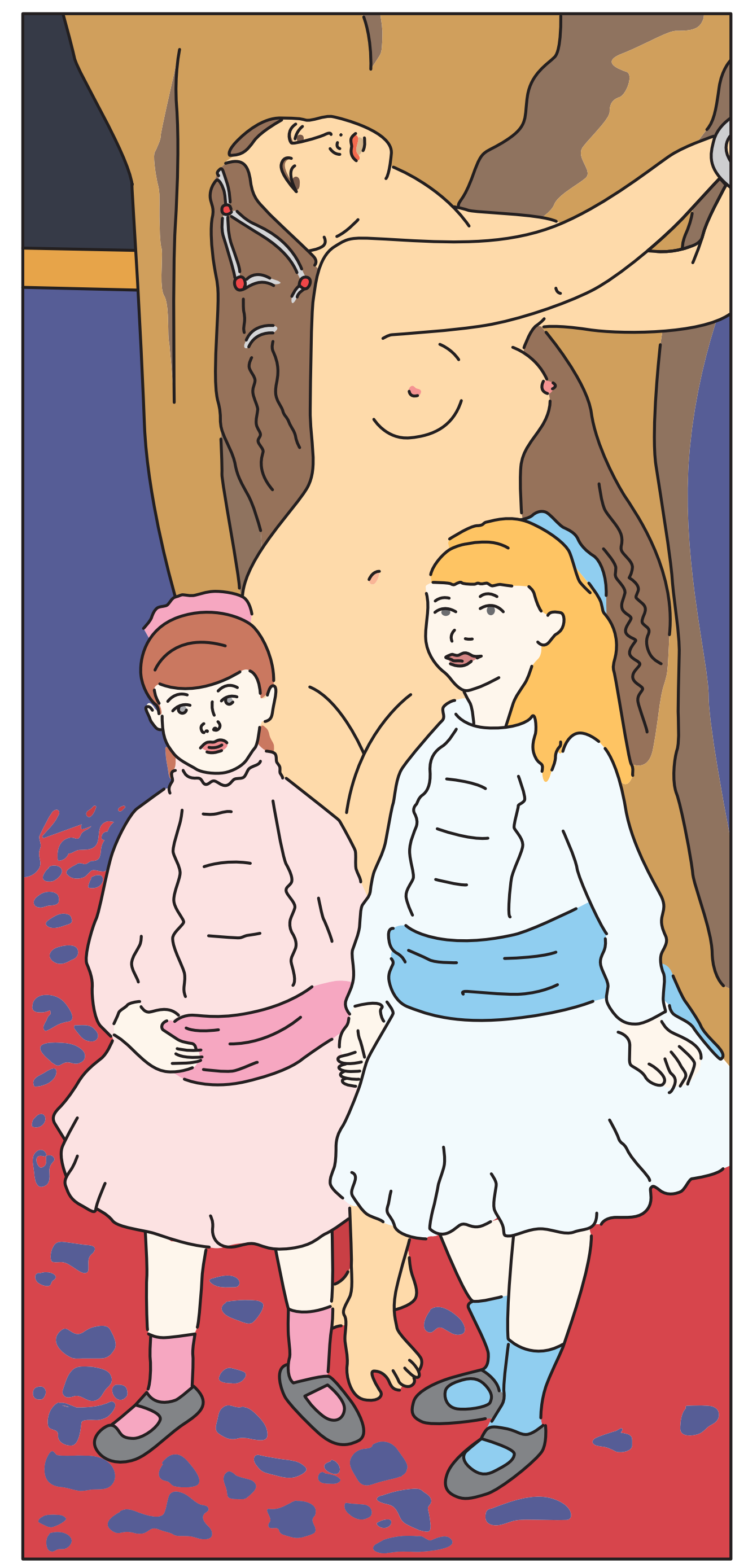

Com o olhar e algumas palavras, a menina funde duas pinturas dispostas no mesmo ambiente.
"Esse pintor é safado!", diz o garoto em referência à pintura $A$ Banhista e o Cão Grifon (Lise à Beira do Sena), de Renoir.

O menino dá três socos no ar, em direção ao Retrato de Elisabeth-Sophie-Constance à Lowendhall, Condessa de Turpin de Crissé, de Fragonard.

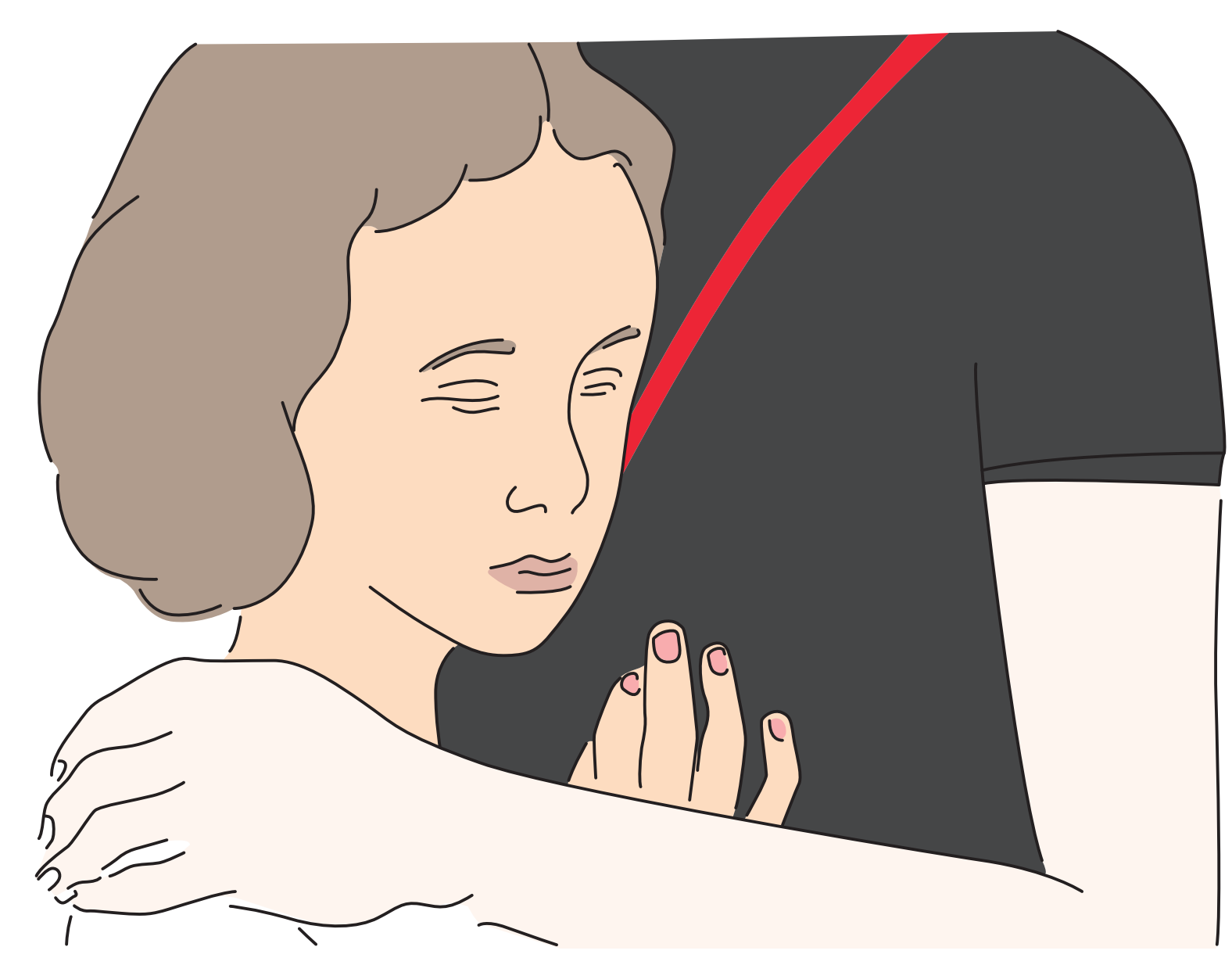

Inesperadamente, a menina se aproxima $d a$ mediadora e se achega ao seu peito. 


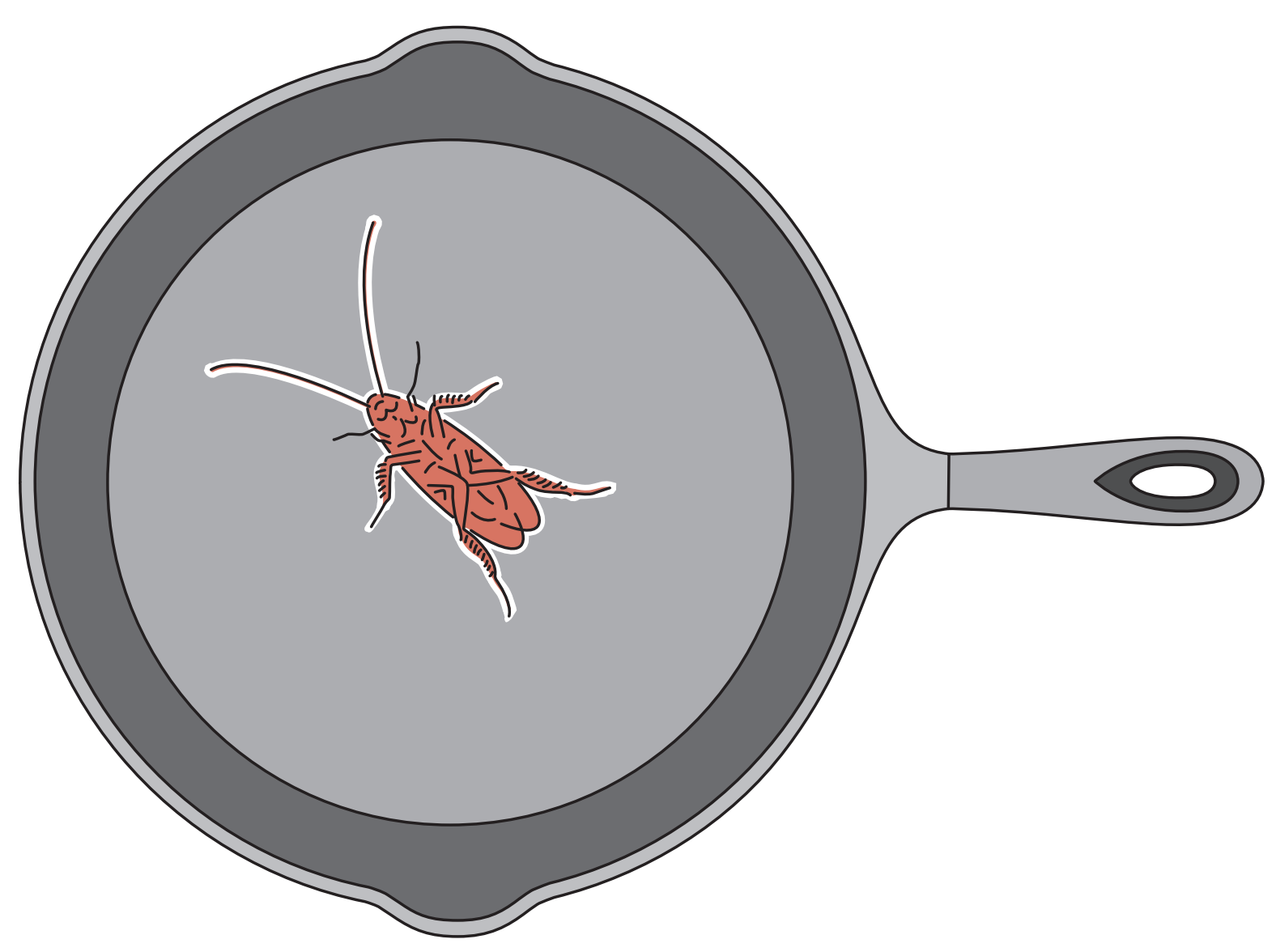

Na saida, surge o assunto da comida preferida. Todos falam ao mesmo tempo sobre seus pratos e quitutes prediletos. $O$ burburinho desvirtua algumas receitas, como é o caso da batata frita.

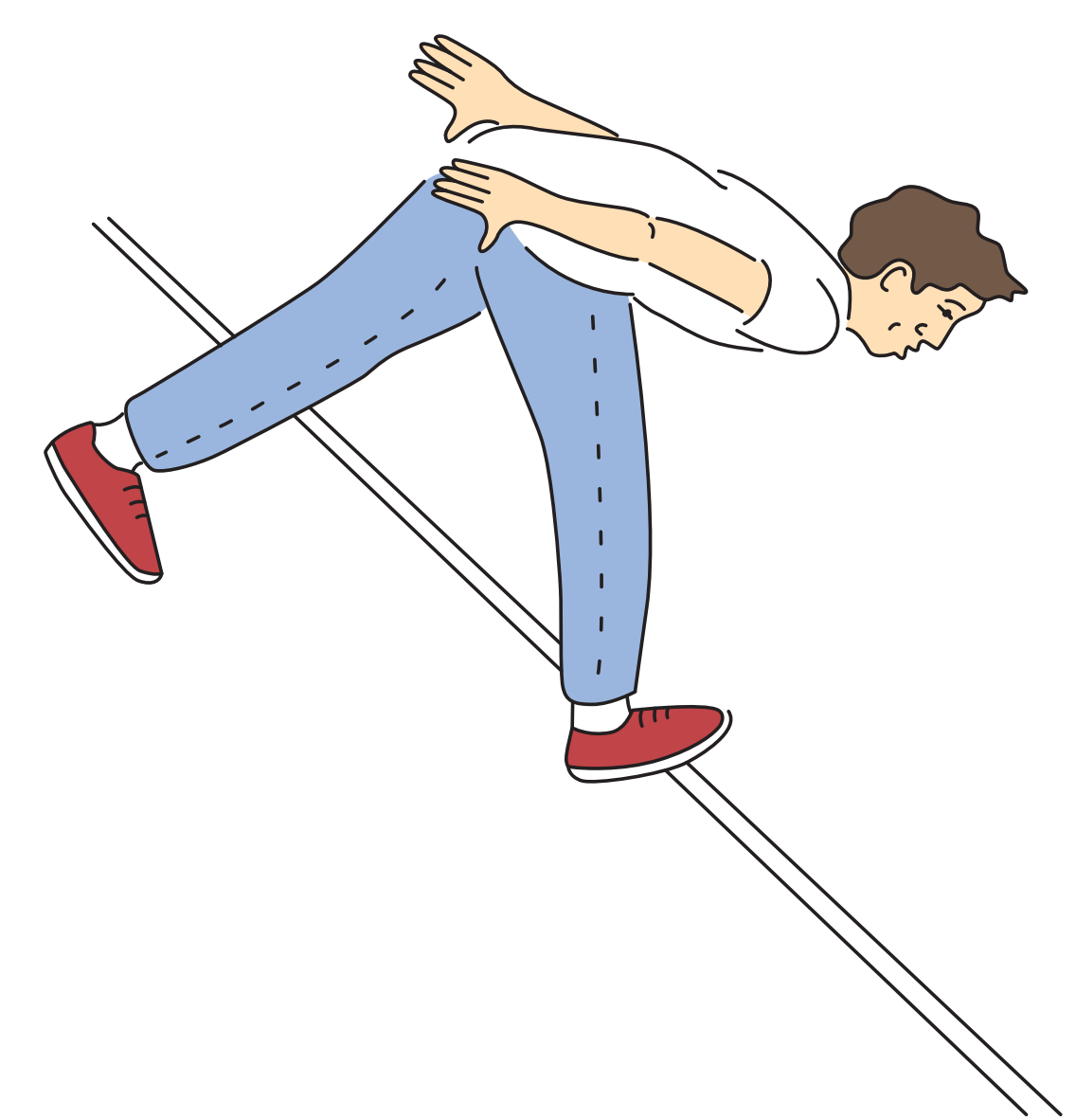

Quando a faixa de segurança se transforma em corda bamba.

No encerramento da visita, a mediadora pergunta ao grupo: "Alguém quer falar mais alguma coisa?". A garota responde: "Sim, tchau!".

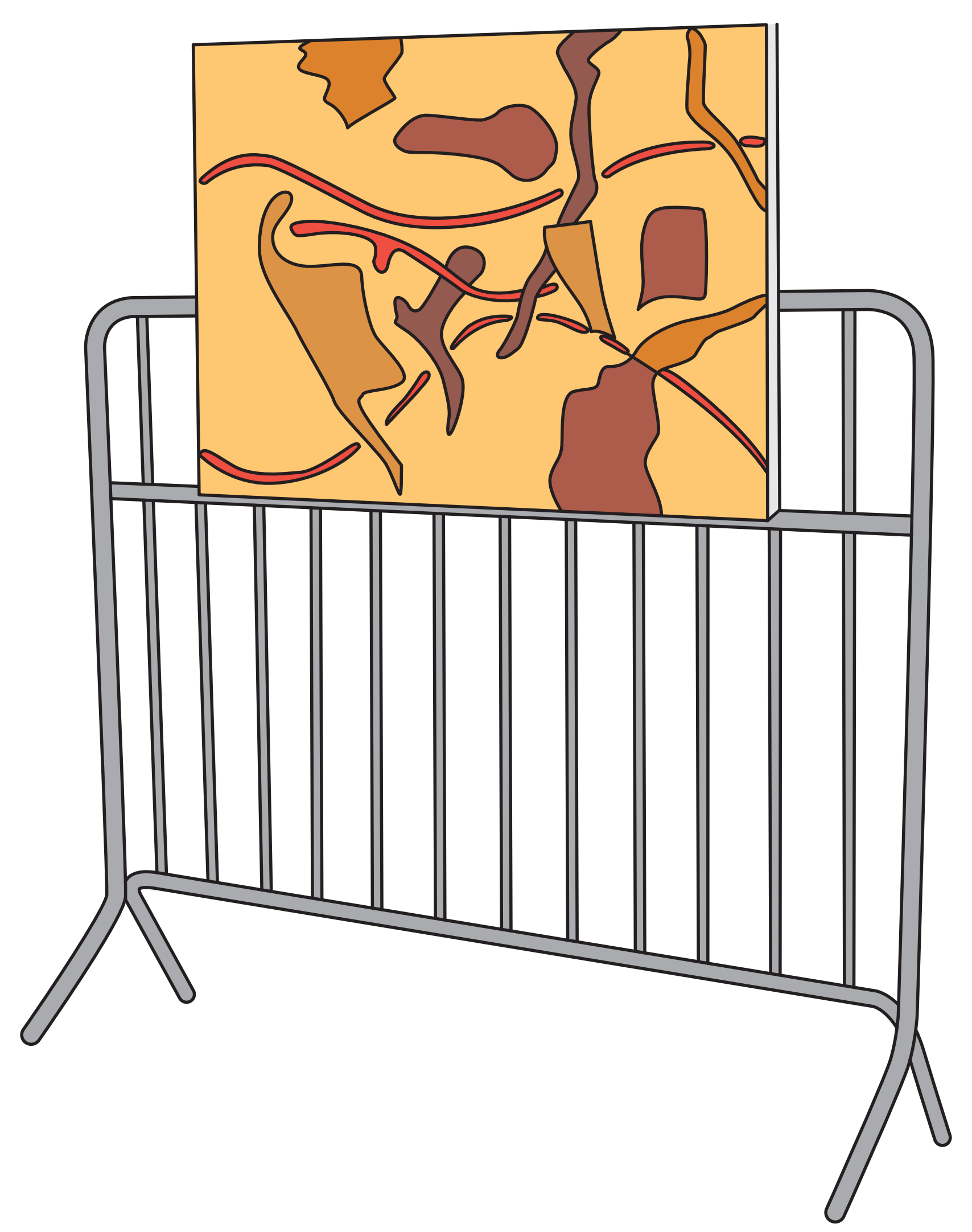

MASP B, no vão livre. 
Enquanto aguardam o ônibus, as crianças brincam e se espalham pelo vão livre. Impaciente, a assistente social assevera: "Vou arrumar um cantinho para sentar vocês... venham todos aqui!".

Já dentro do ônibus, o menino solta: "O museu por dentro foi chato, mas por fora foi legal".

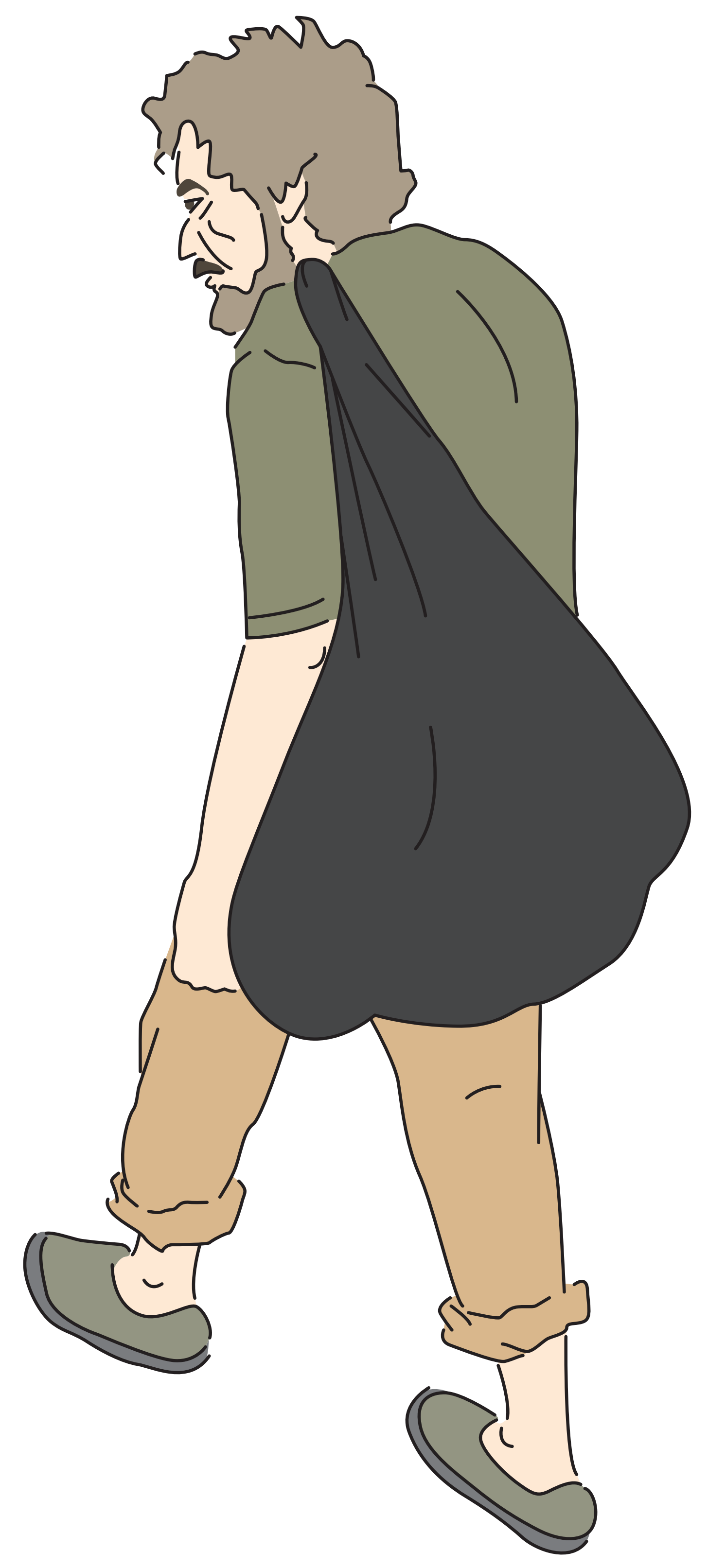

O homem do saco segue vivo no imaginário das crianças.

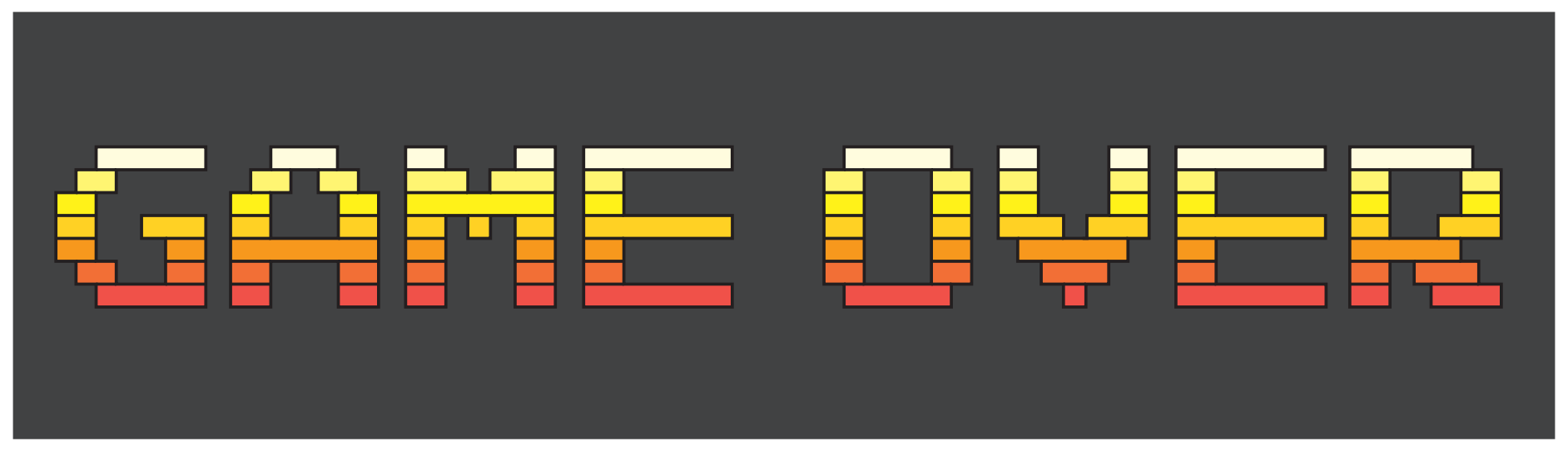

Dirigindo-se ao amigo entretido com o game, o garoto diz: "Depois que você morrer, vai ser a minha vez". 


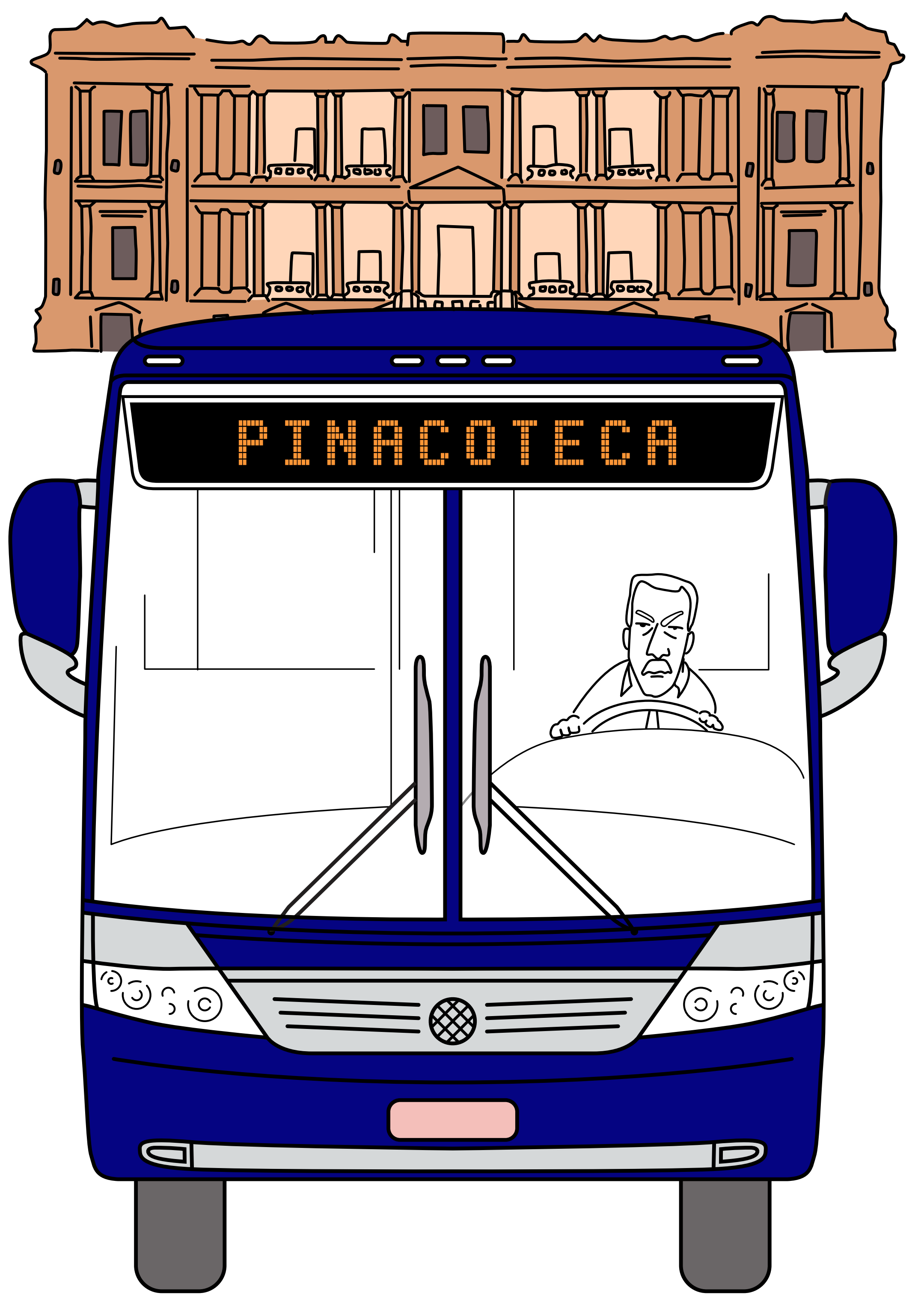



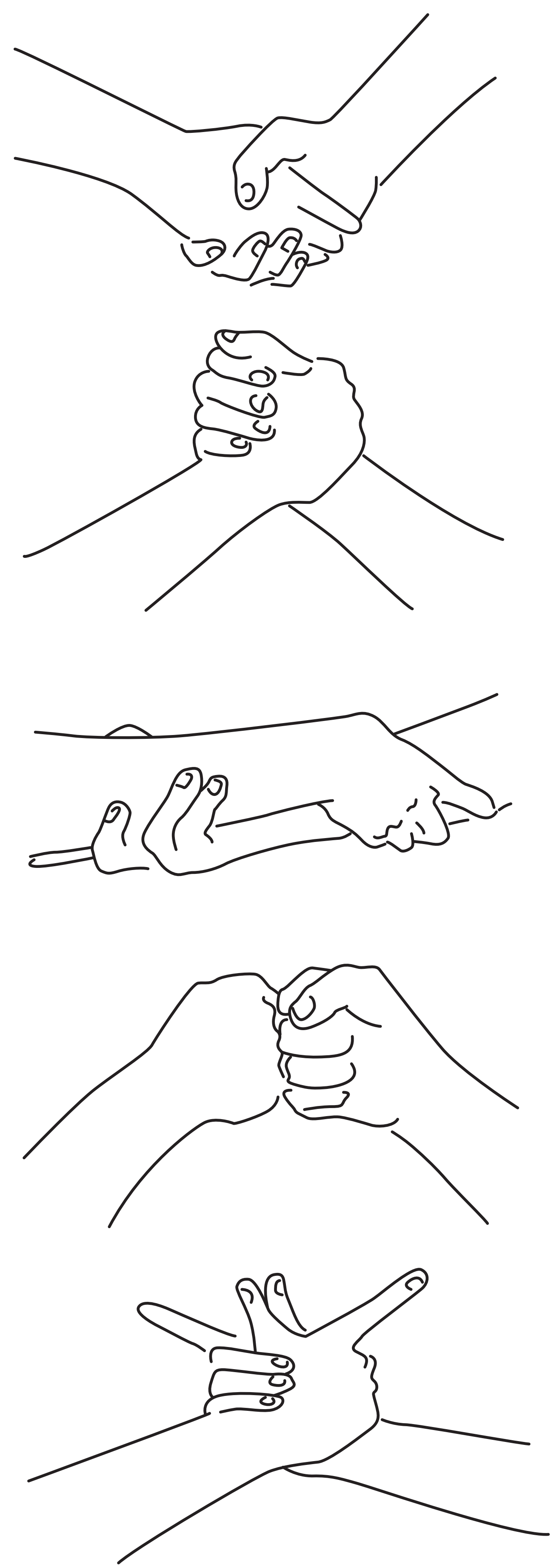

Repertório de toques

Quando alguém faz uma quantidade exagerada de perguntas, denotando demasiada curiosidade pela vida alheia, é chamado de "zé-povinho".
Em lugar do som de sirene, o alto-falante da escola toca música. Dois estudantes afirmam que, caso pudessem escolher o repertório (o que não é o caso), optariam pelo "funk pancadão". 


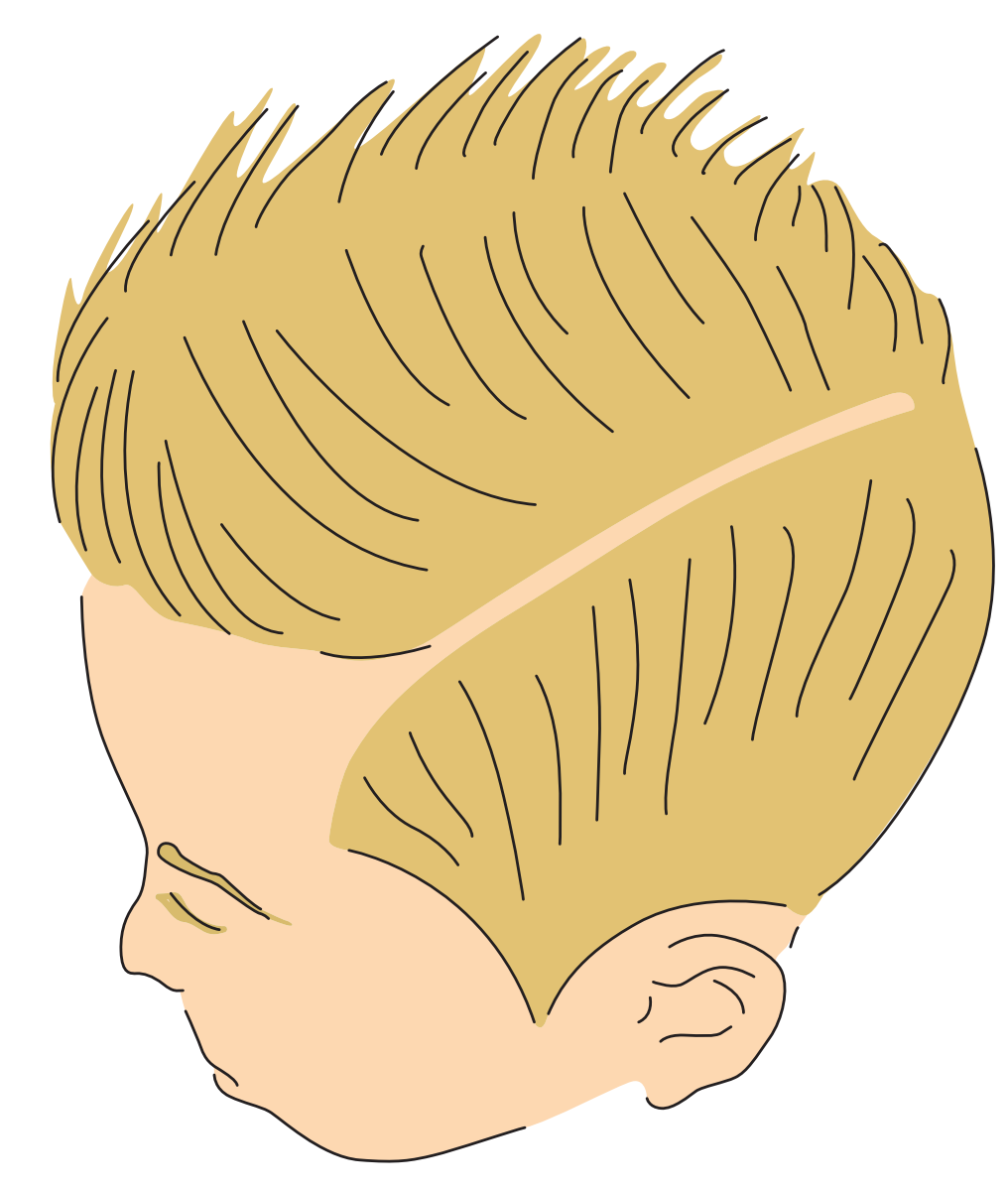

Num misto de carinho e zoação, ao notar o capricho no penteado do colega, o garoto tenta lhe passar a mão na cabeça. Gesto que é prontamente interrompido pela máxima: "Não rela!".

No pátio, ouve-se de passagem o fragmento de uma música cantarolada por um aluno: "Tava mal de bala...".

Ao notar que eu uso um bloco de anotações, o menino comenta: "Ele vai analisar a gente... não pode falar palavrão, hein".

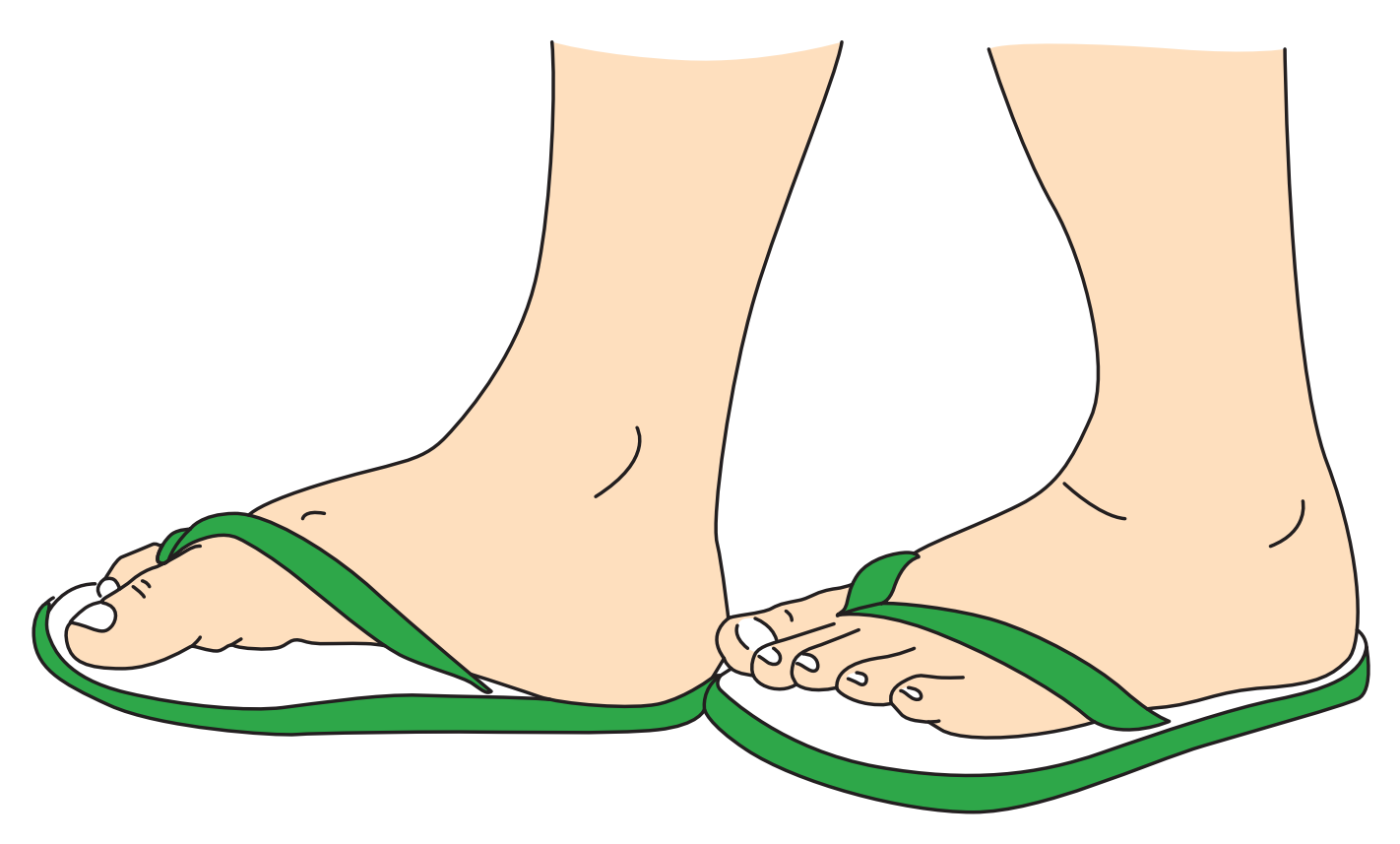

O garoto pergunta: "Pode entrar de chinelo na Pinacoteca?". 
Uma das professoras anuncia: "Quem não

trouxe a autorização preenchida e assinada

pelos responsáveis, não vai para a Pinacoteca".

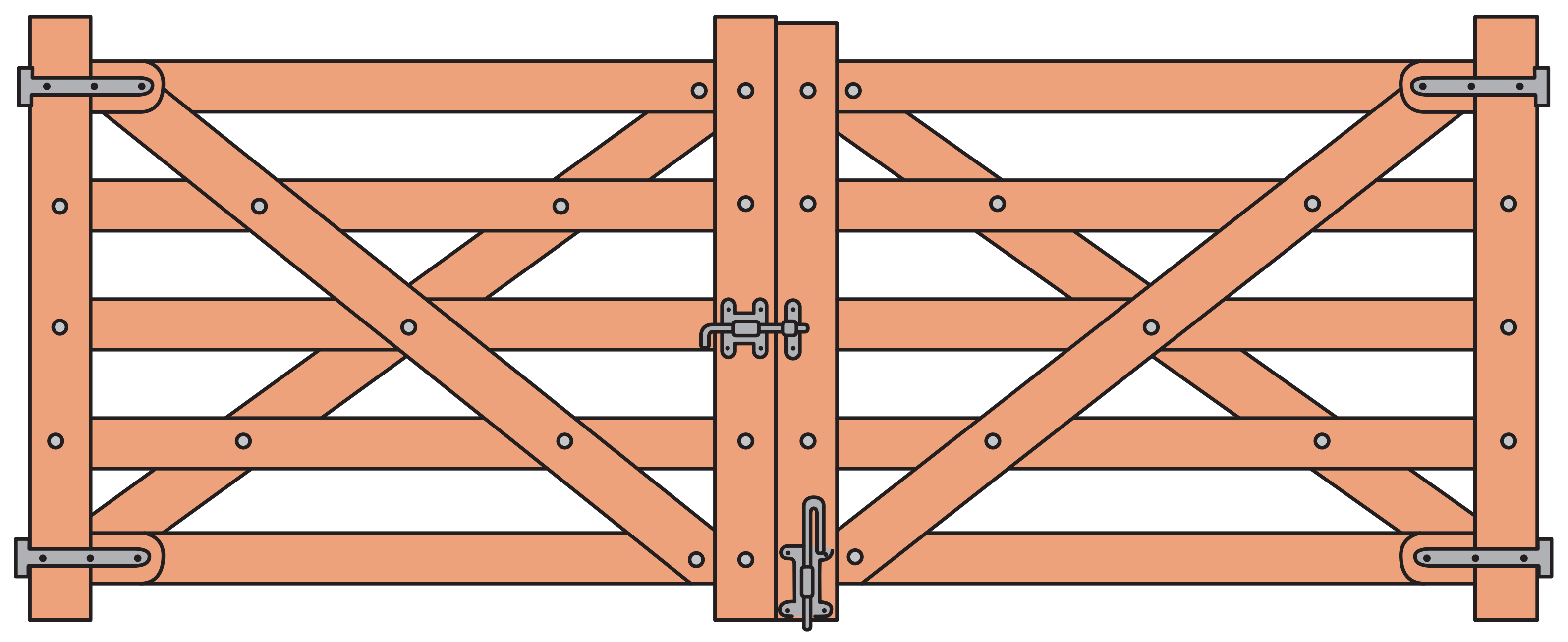

Aglomerados no portão, ainda dentro da escola, os estudantes mostram-se ansiosos para entrar no onibus. Em tom de brincadeira, um deles grita: "Já pode liberar a porteira, professora!".

Um aluno do $7^{\circ}$ ano finge fazer parte da turma do $8^{\circ}$, com o intuito de se infiltrar na excursão. Ao ser identificado pelas professoras, é impedido de embarcar no ônibus.

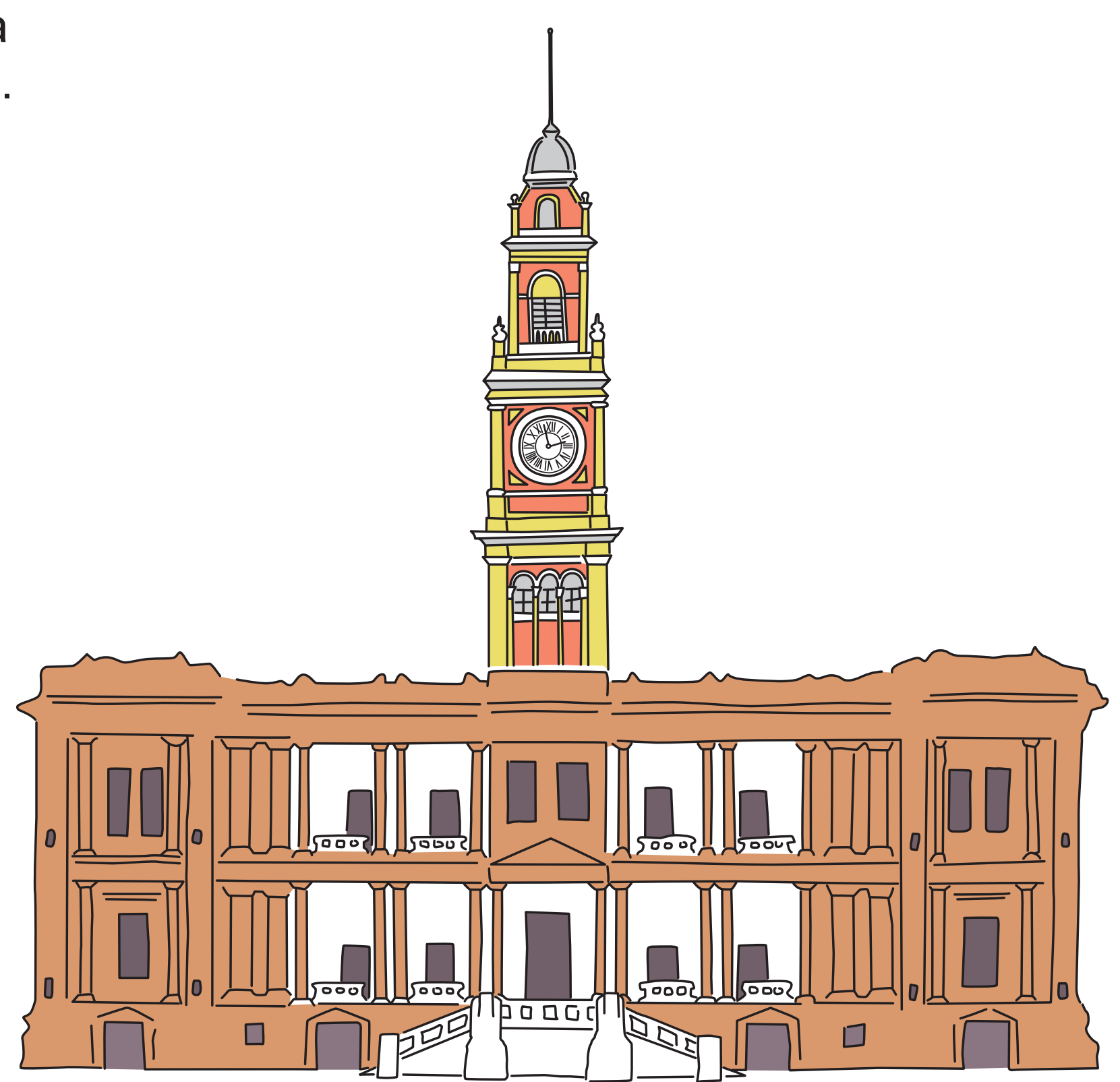

Após nos acomodarmos no ônibus, a garota pergunta para a colega do banco da frente: "Ei, a Pinacoteca é aquele prédio que tem o relógio, né?". 


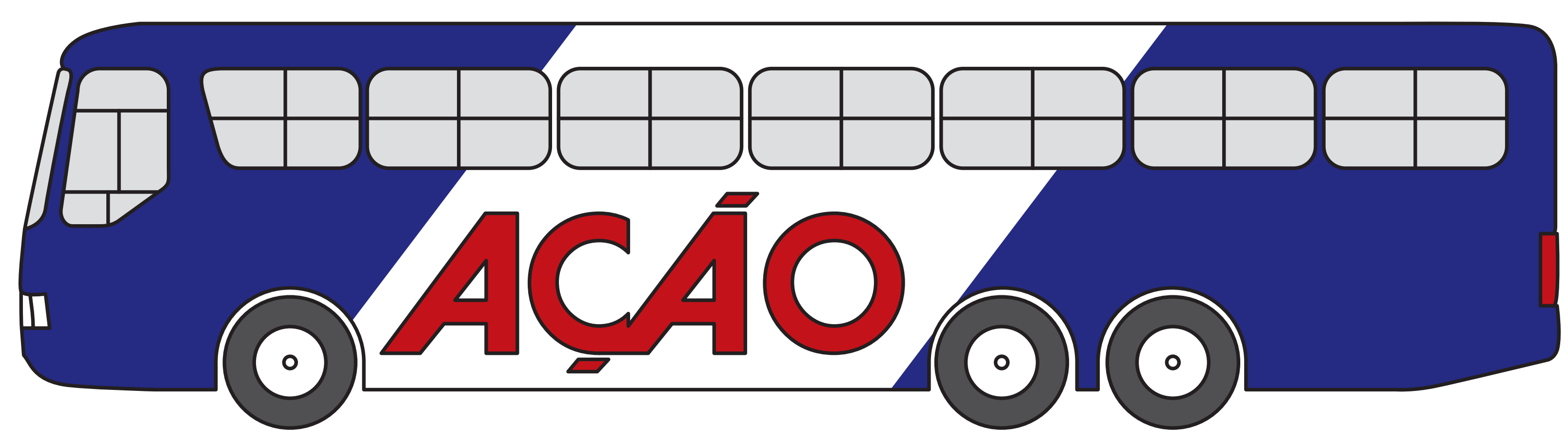

A menina comenta que a bola de vôlei furada, presa na cerca de proteção de uma pequena fábrica avistada pela janela do ônibus, fora lançada ali por sua irmã semanas atrás.

Apontando para o estabelecimento comercial situado nos arredores da escola, o garoto recorda: "Essa loja já pegou fogo".

0 menino indica para o amigo, apontando com o dedo, a rua de acesso que ele geralmente usa para ir à casa de seu pai: "É essa aqui, ó".

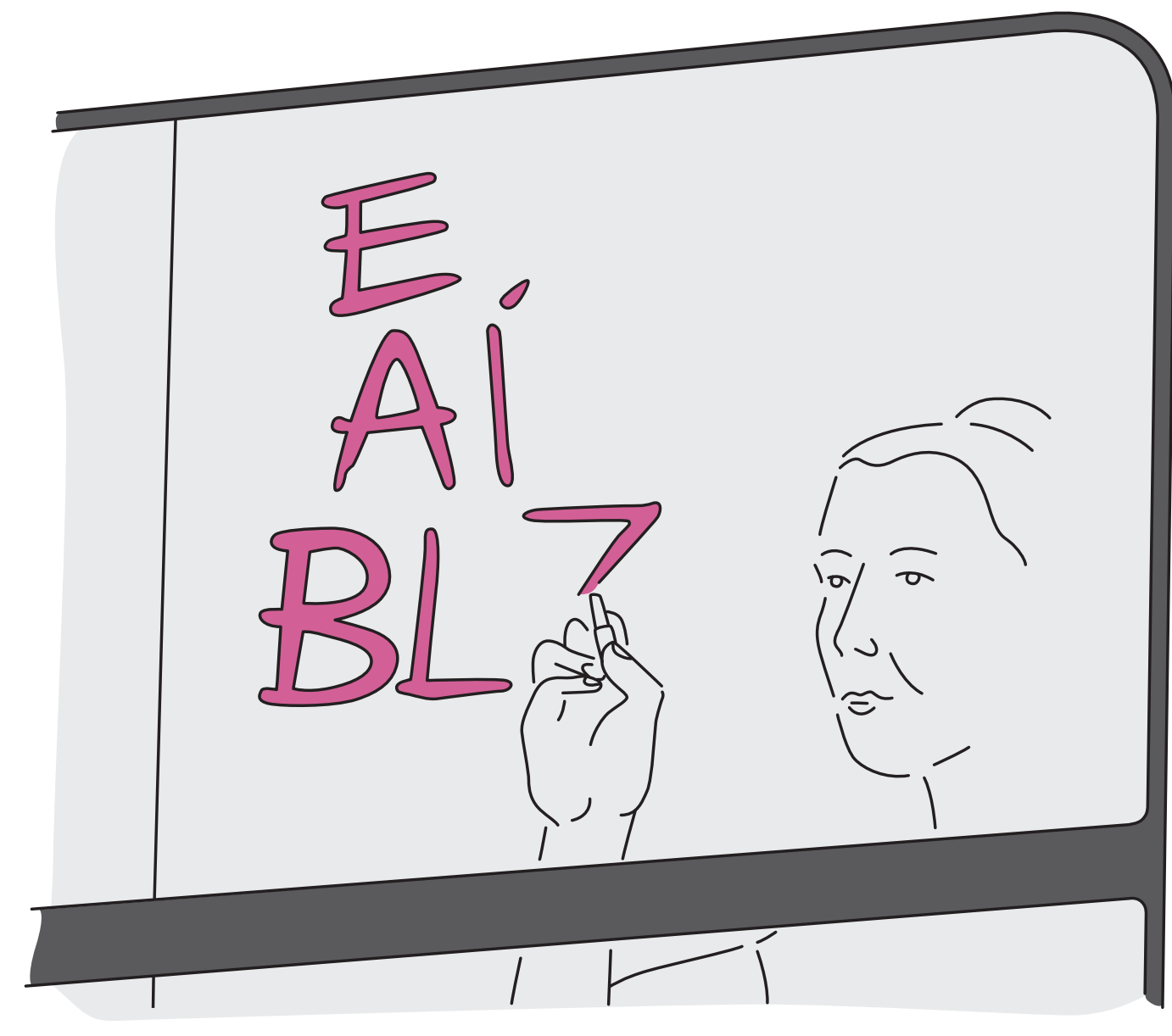

Comunicação com a rua

Paisagens puxam palavras, que puxam outras palavras, que puxam outras paisagens: o quinteto joga com elementos que avistam pela janela do ônibus, selecionando, por exemplo, "árvore", que é emendada por "planta", que é seguida por "verde", que sugere "grama", que vai dar em "campo de futebol".

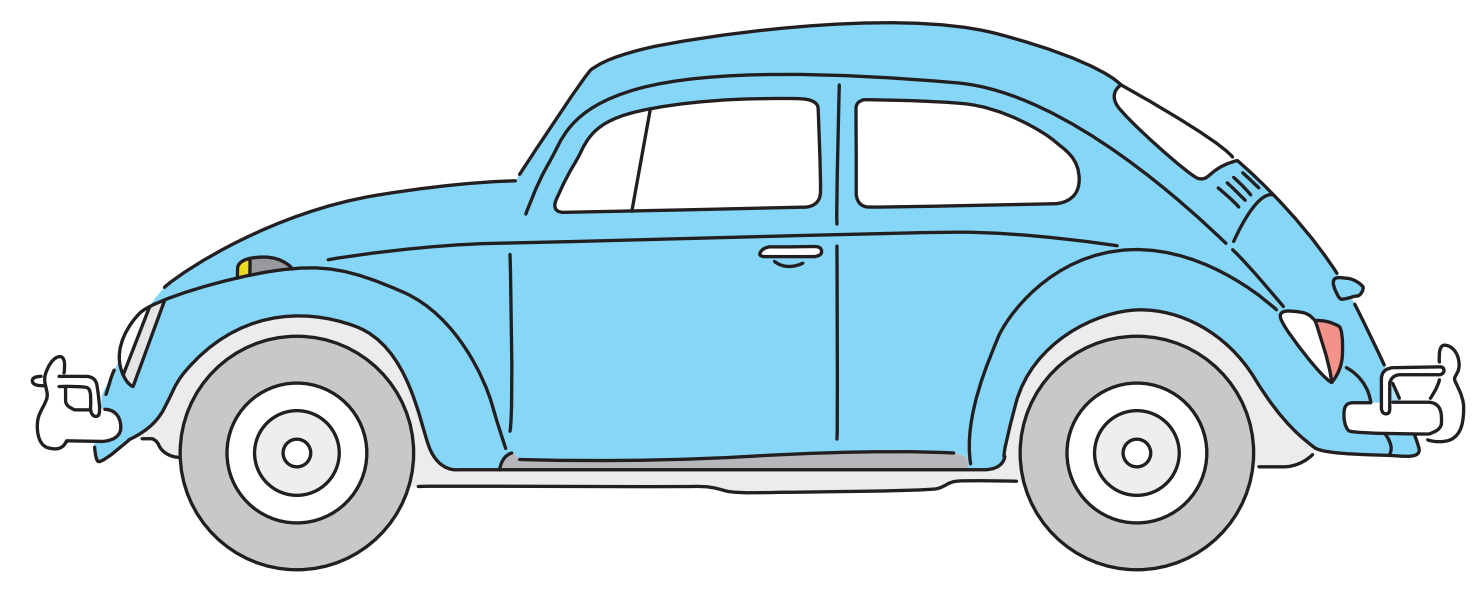

Quem avista o fusca azul primeiro tem o aval para dar um soco no braço do amigo. 


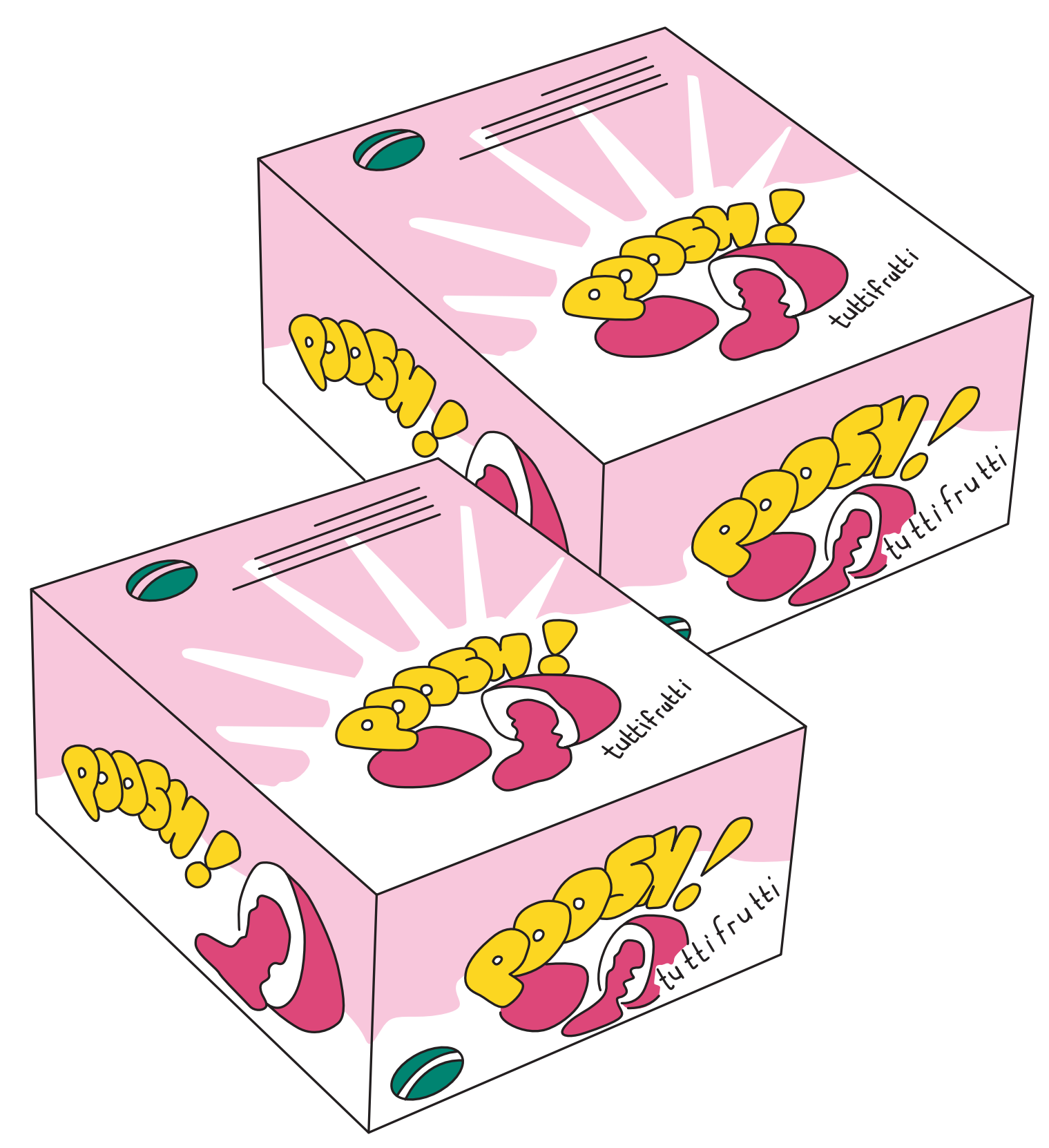

Na véspera, por meio de uma vaquinha, os estudantes compraram duas caixas de chiclete. Ao entrar na Pinacoteca, a primeira coisa que precisam fazer, conforme orientação do mediador, é cuspir tudo no lixo.

O menino tira da mochila um chiclete especial, com licor de morango, dizendo à professora que havia comprado especialmente para ela.

Referindo-se a mim, o garoto comenta: "O professor [sic] fica anotando a gente... dá agonia".

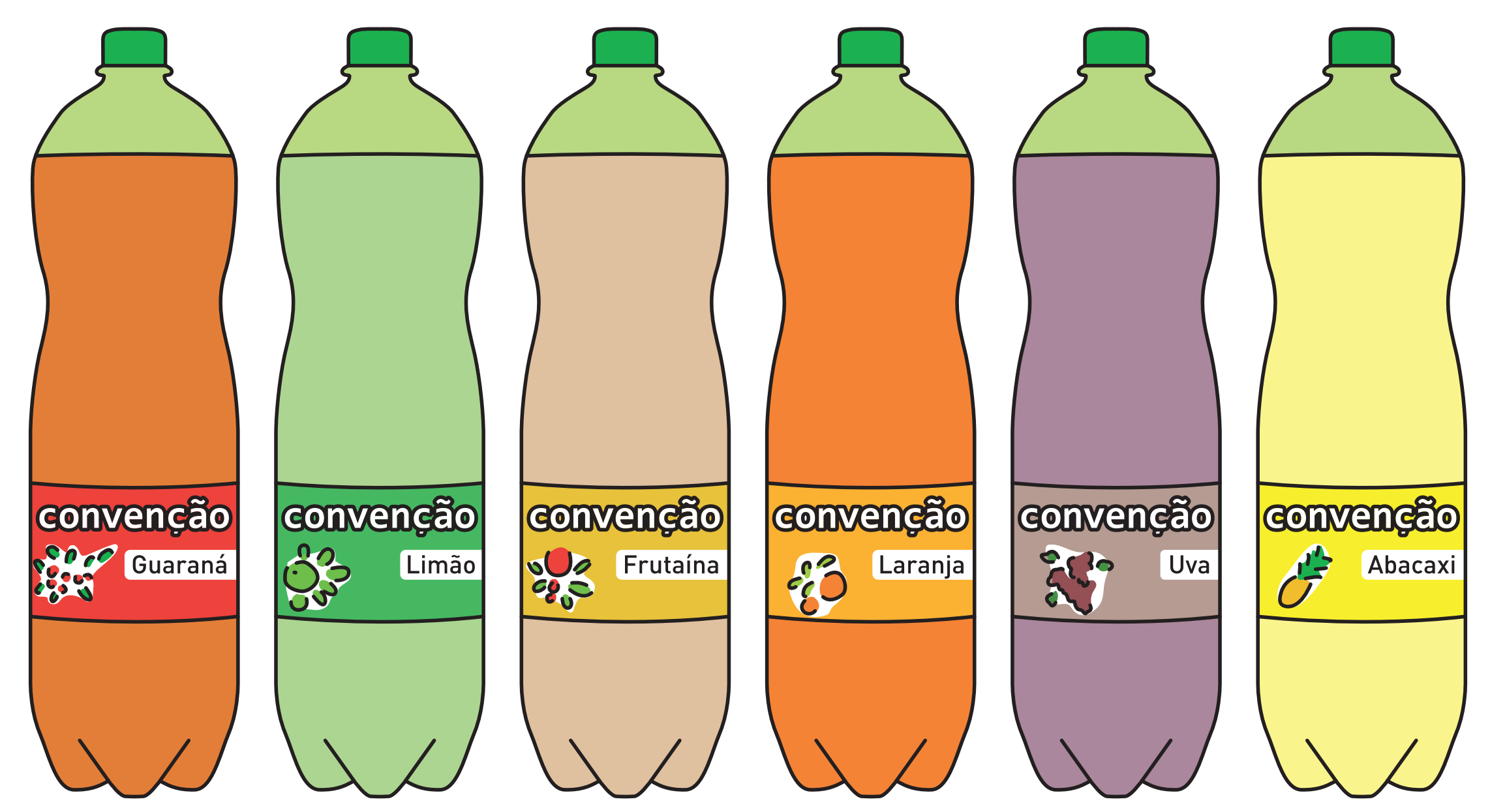

Refripra geral 


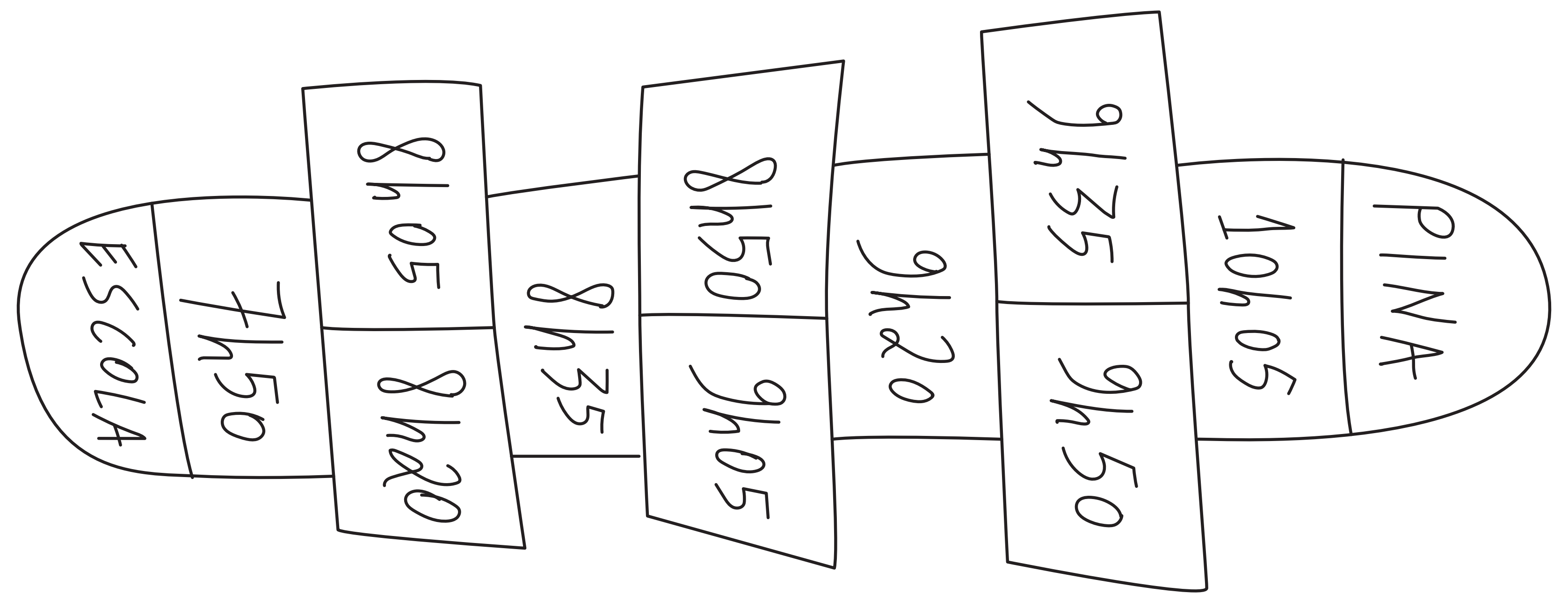

Da Zona Sul ao Centro, 2h15 de deslocamento.

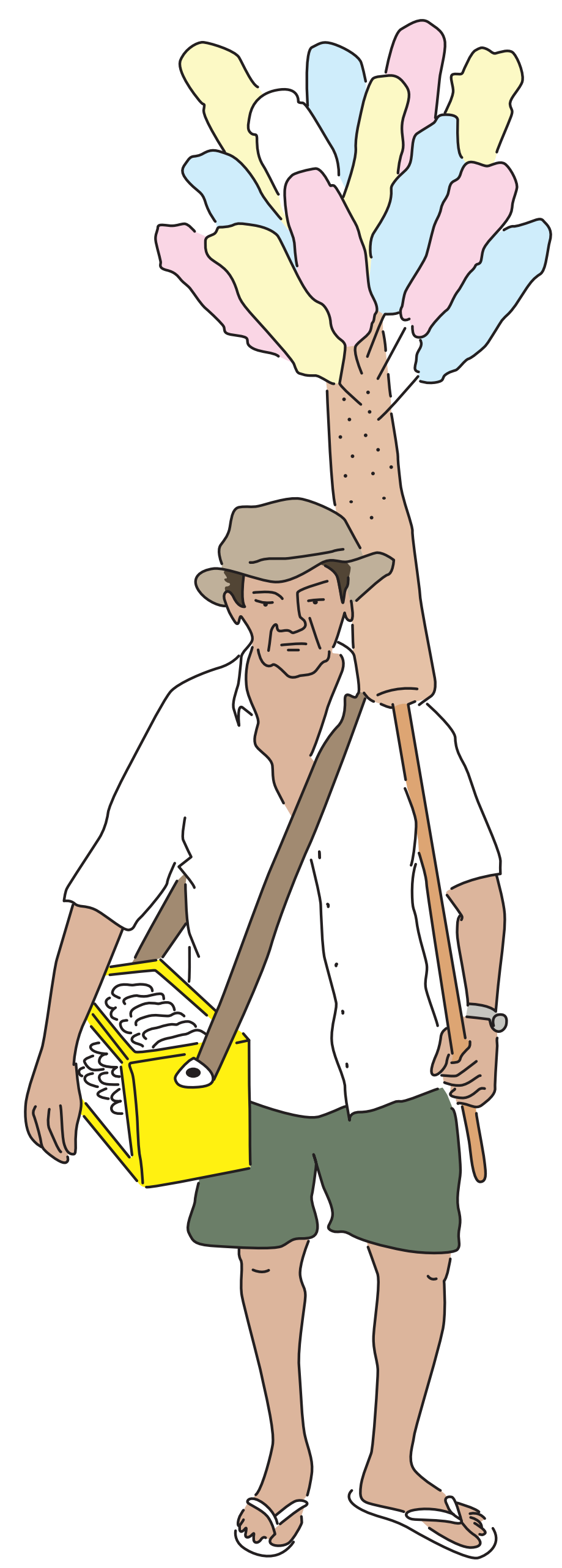

Antes de entrar na Pinacoteca, nos deparamos com uma prévia de como operam os dispositivos de exibição. 

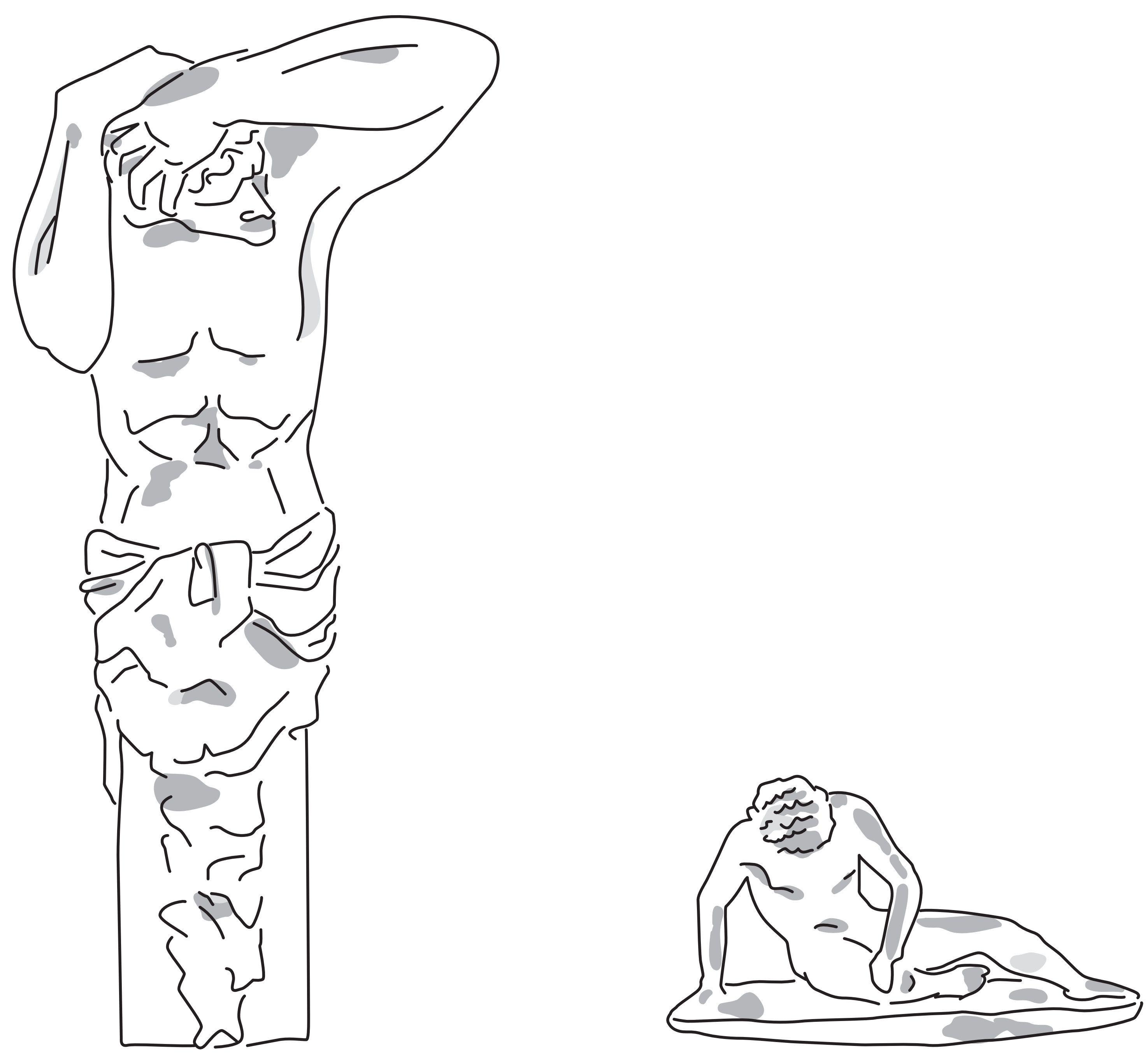

Atlas observa o infante exausto, após longa travessia da periferia ao Centro.

No acolhimento ao grupo, o mediador lança o desafio: "Se discoteca é uma coleção de discos; gibiteca, de gibis; videoteca, de vídeos; e brinquedoteca, de brinquedos... o que seria uma pinacoteca?". Ao que a garota responde de forma convicta: "Coleção de pinos, ué!".

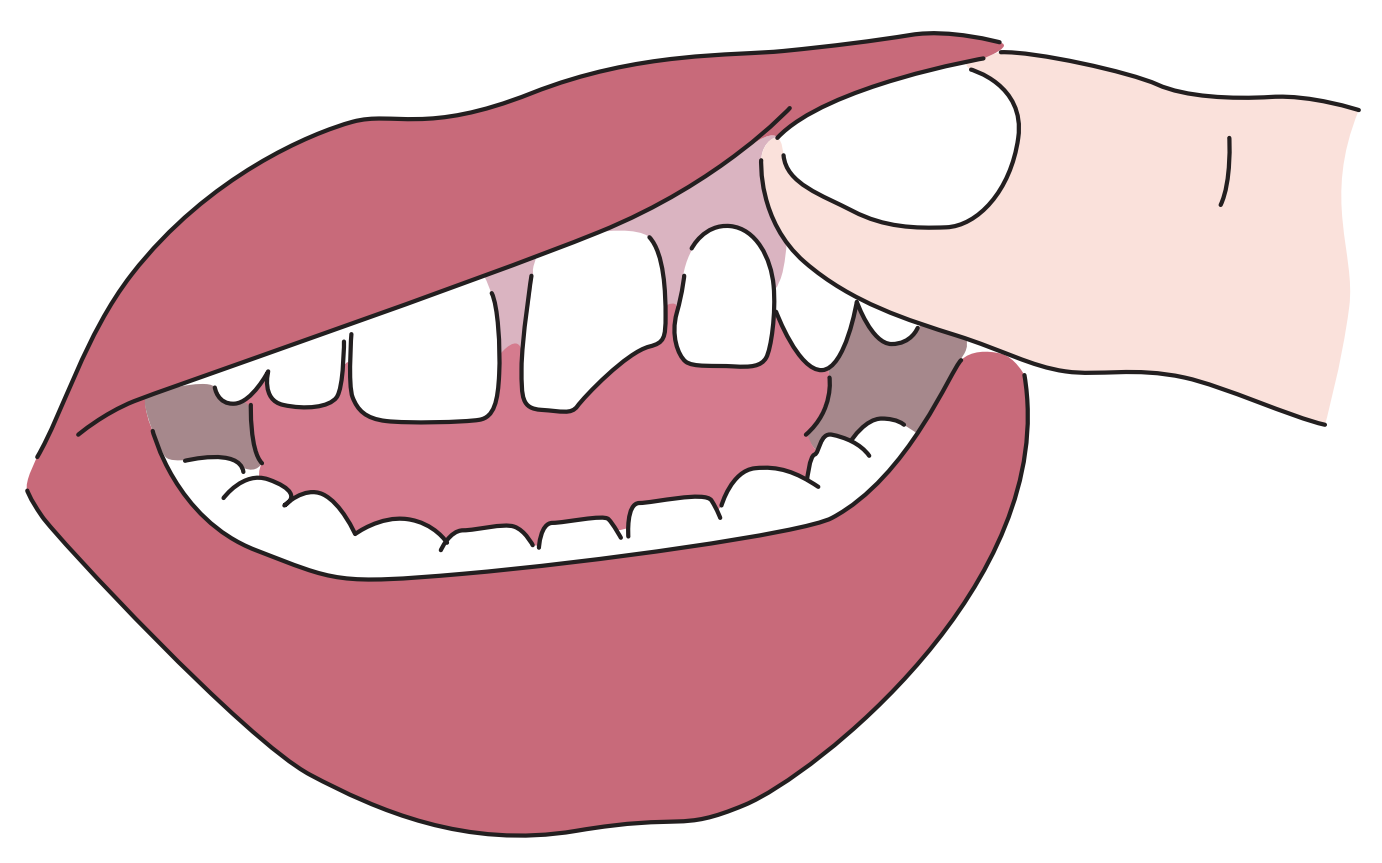

Acervo avariado 


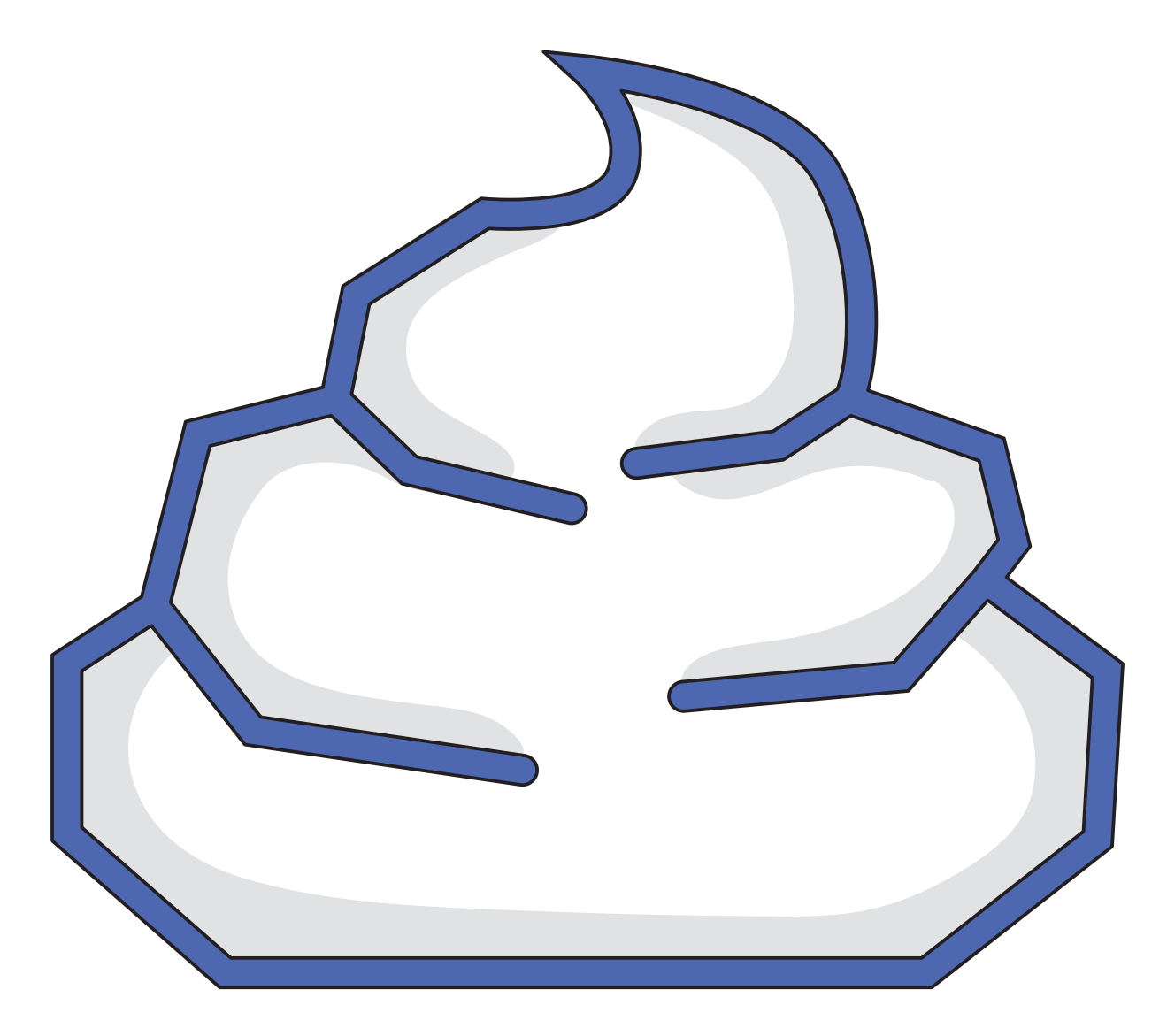

"Eu amo o facebosta", confessa a garota.

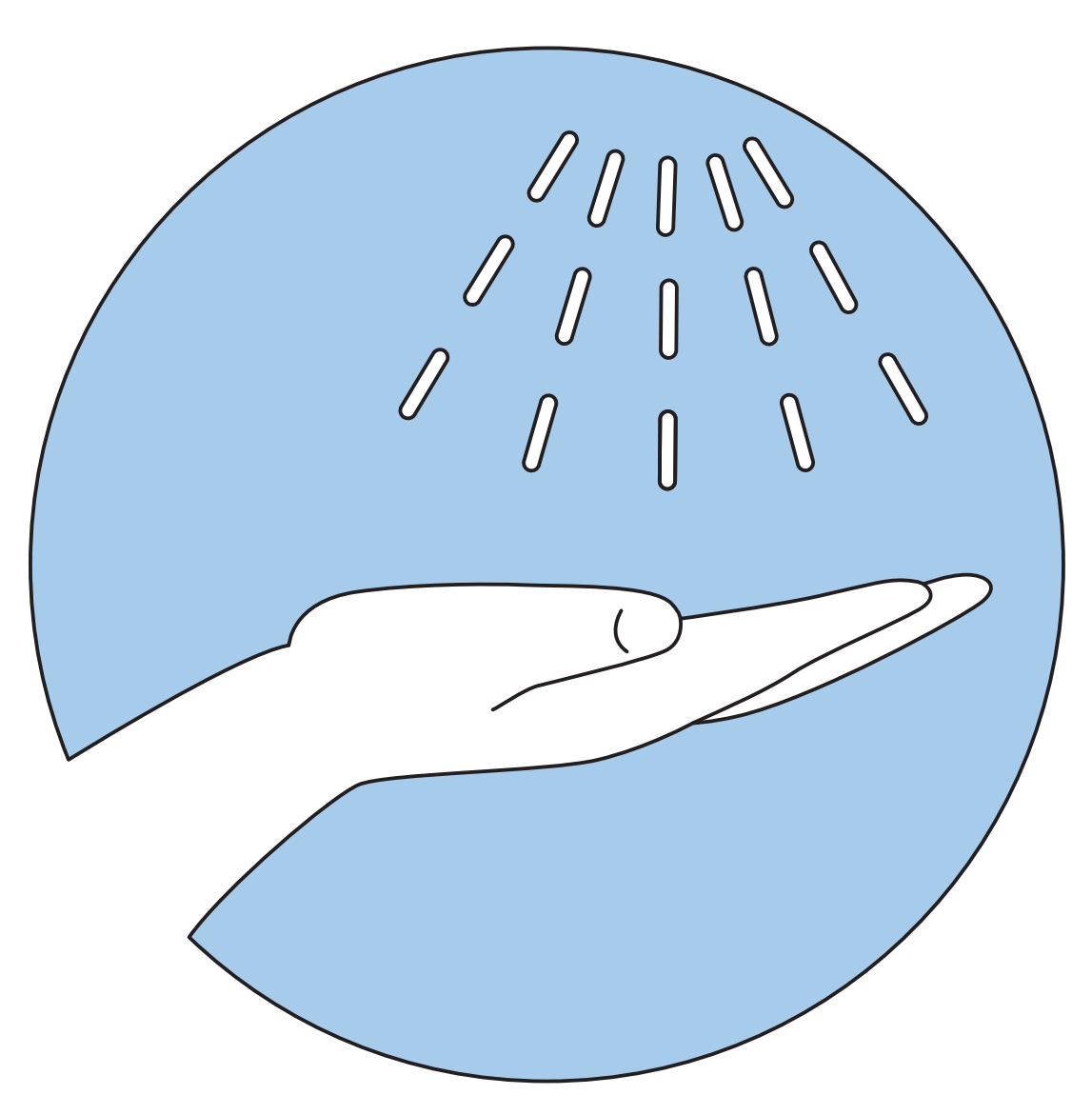

Surpreso com a torneira automática, 0 garoto ironiza: "Lá em casa o que tem é falta d'água automática".

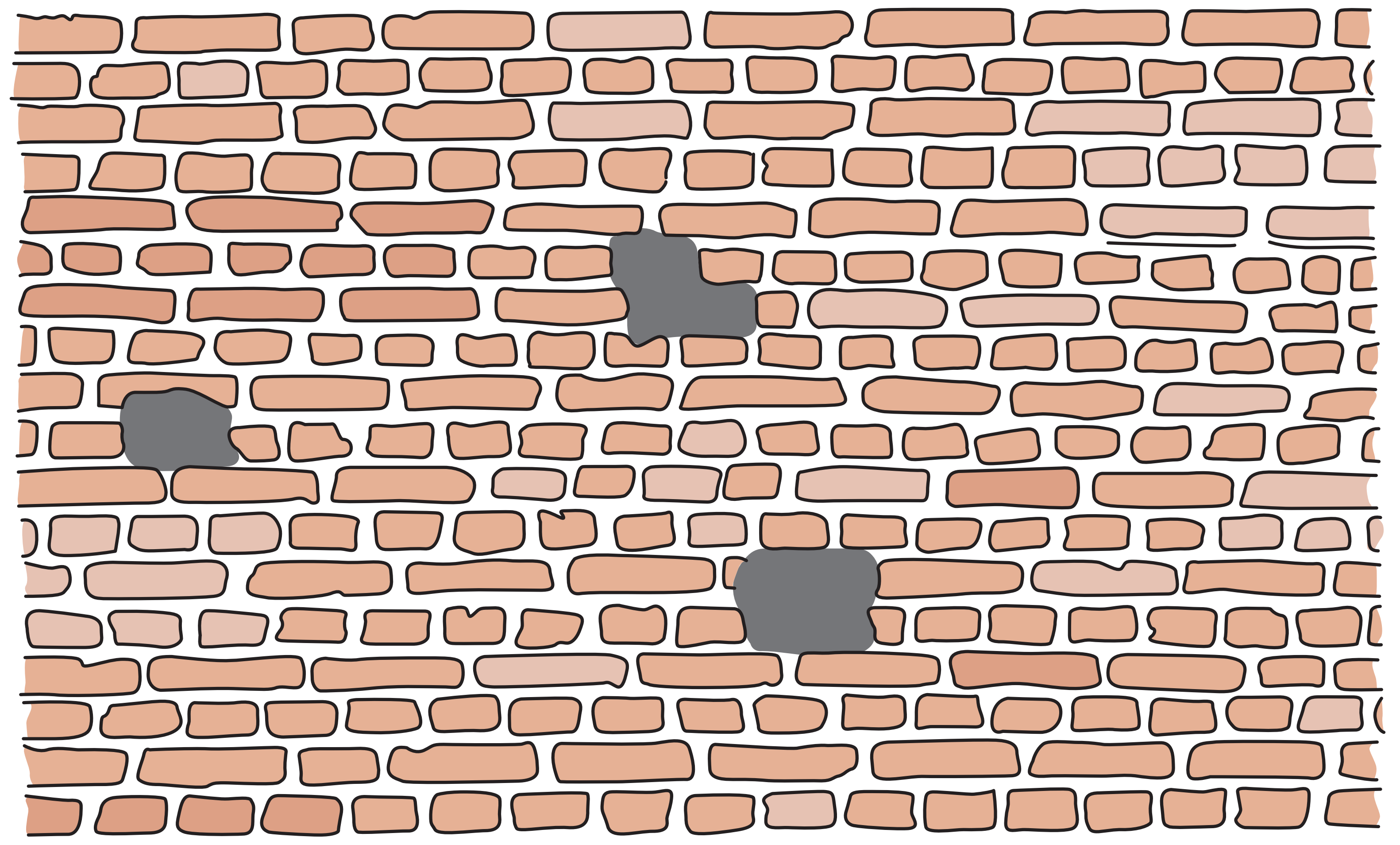

A dupla cogita mandar umas manobras de parkour na parede do pátio interno... 


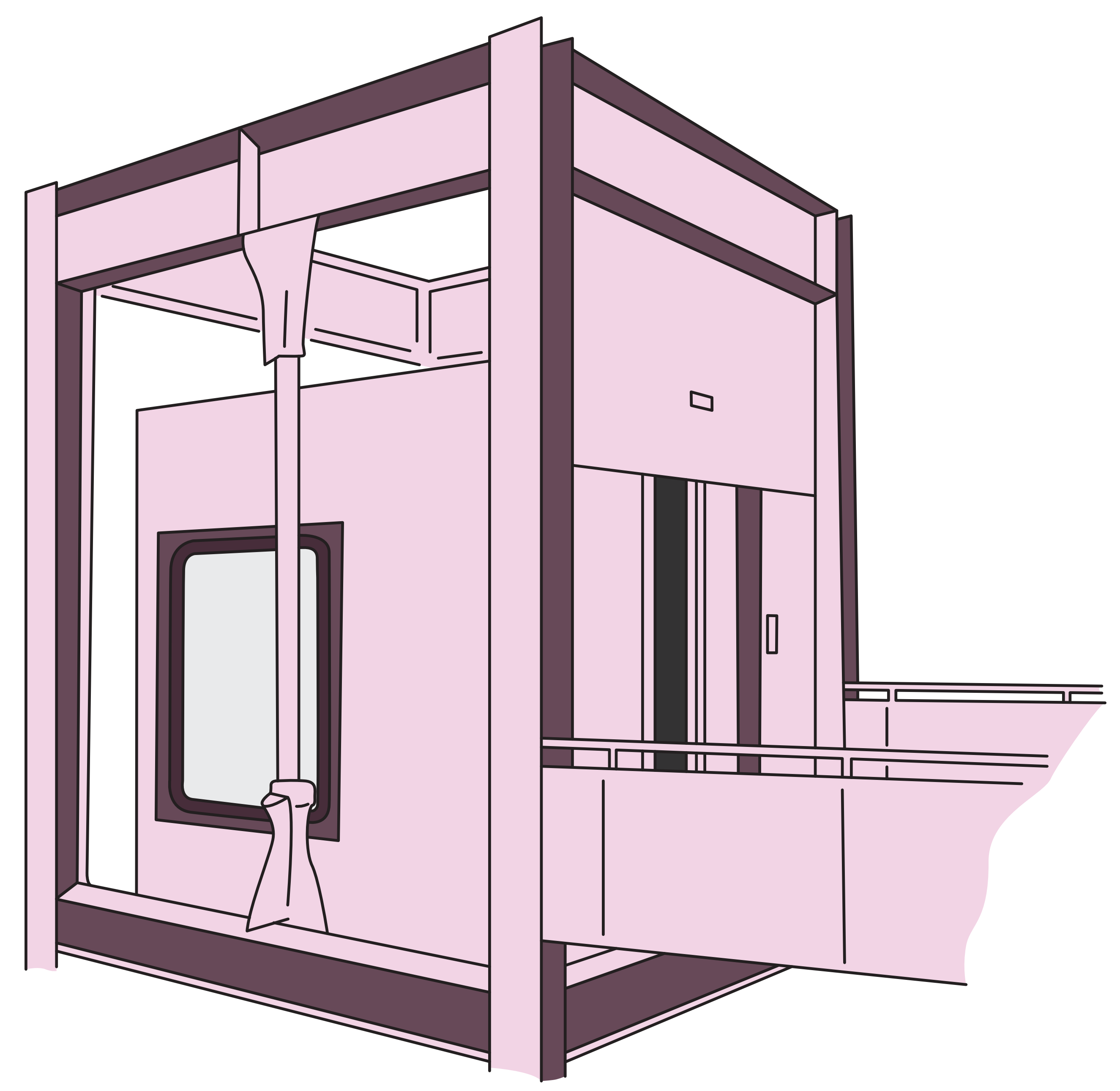

Do corredor, vendo a porta do elevador se fechar, a garota faz uma livre associação: "Puts, perdemos o busão...".

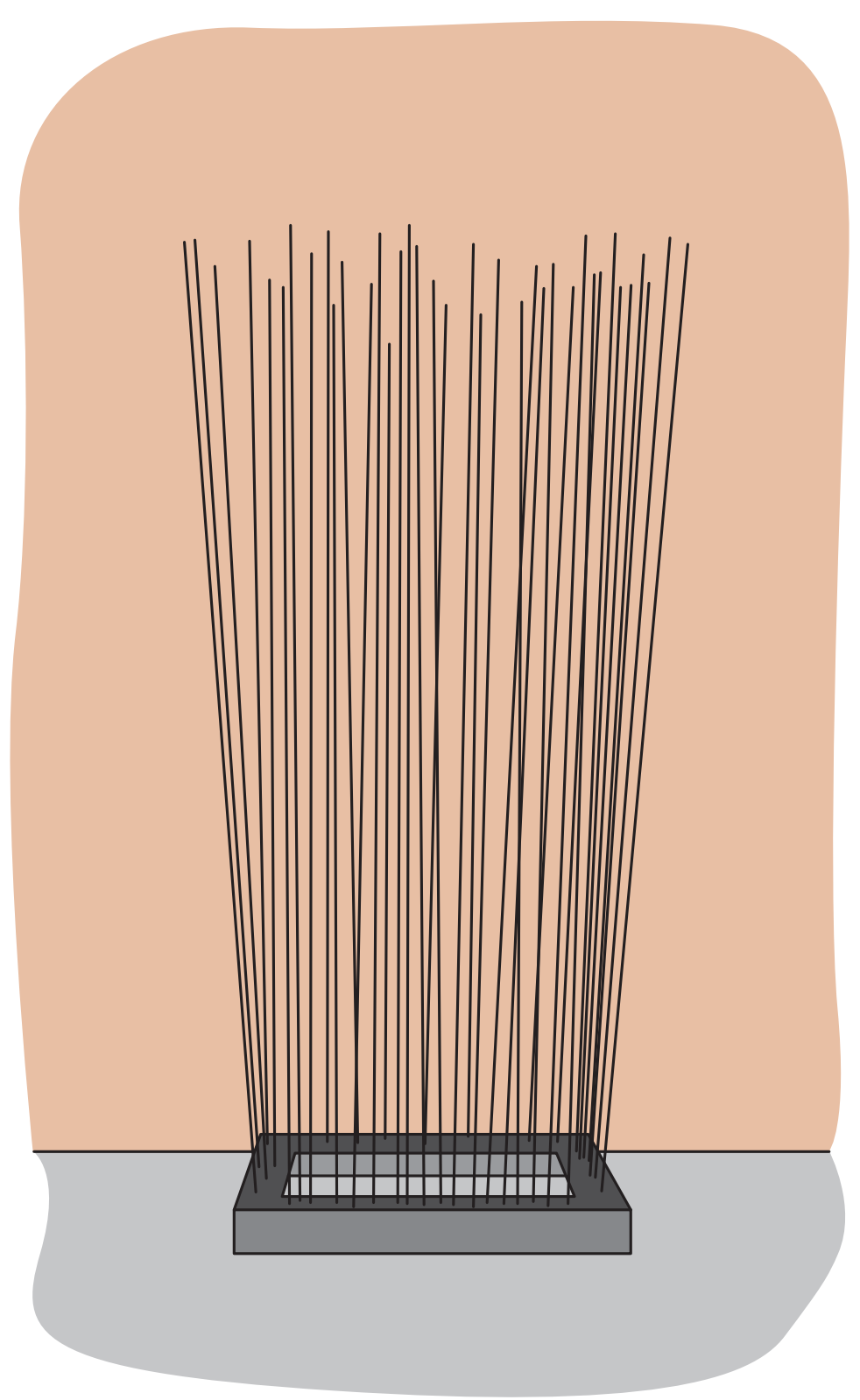

Ao se deparar com a escultura do artista Leon Ferrari, exposta no pátio interno, o garoto observa: "Essa ferragem é pra fazer uma coluna". E emenda dando risada: "Quando será que termina a obra desse prédio?". 

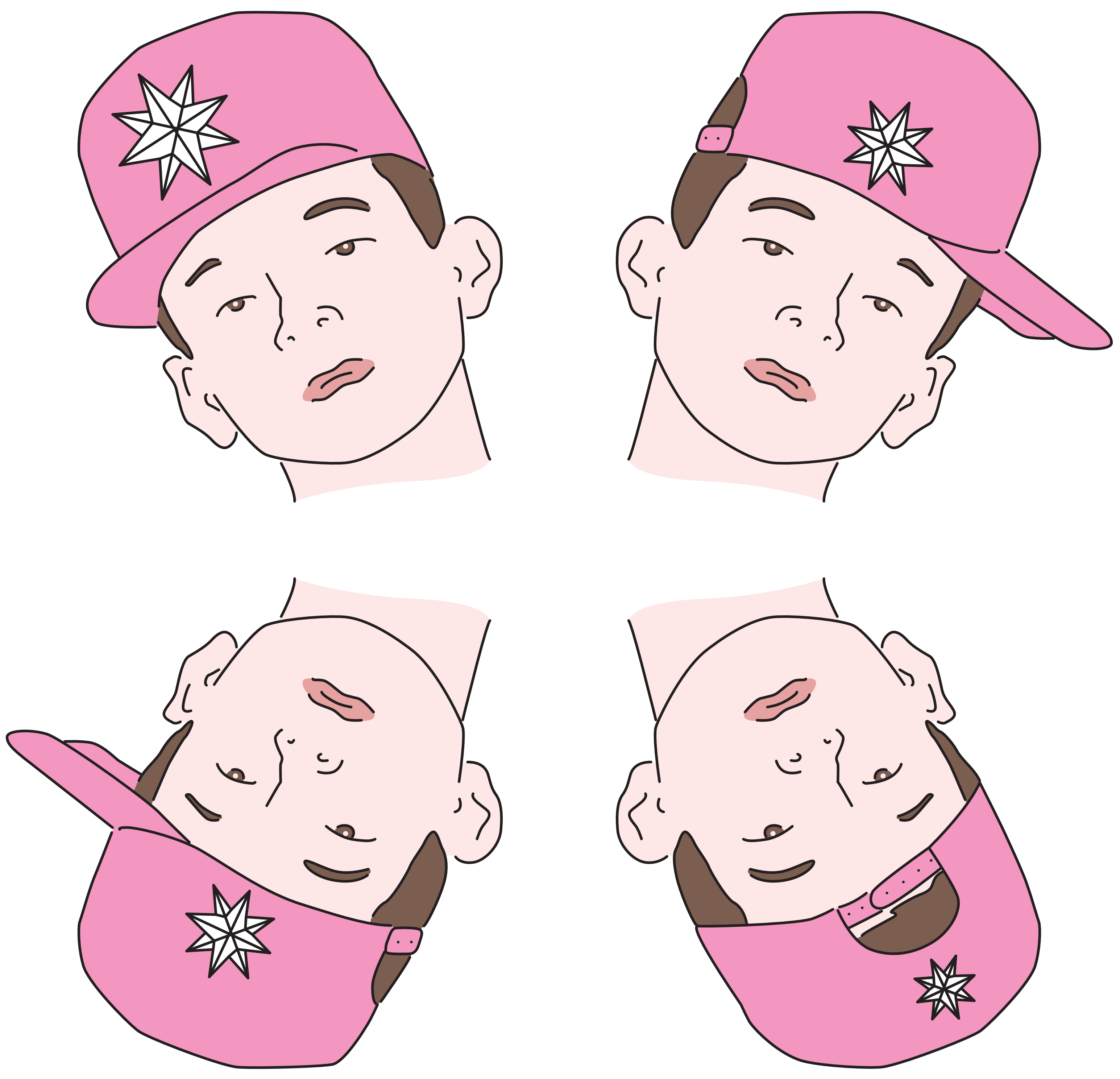

Boné multidirecional 


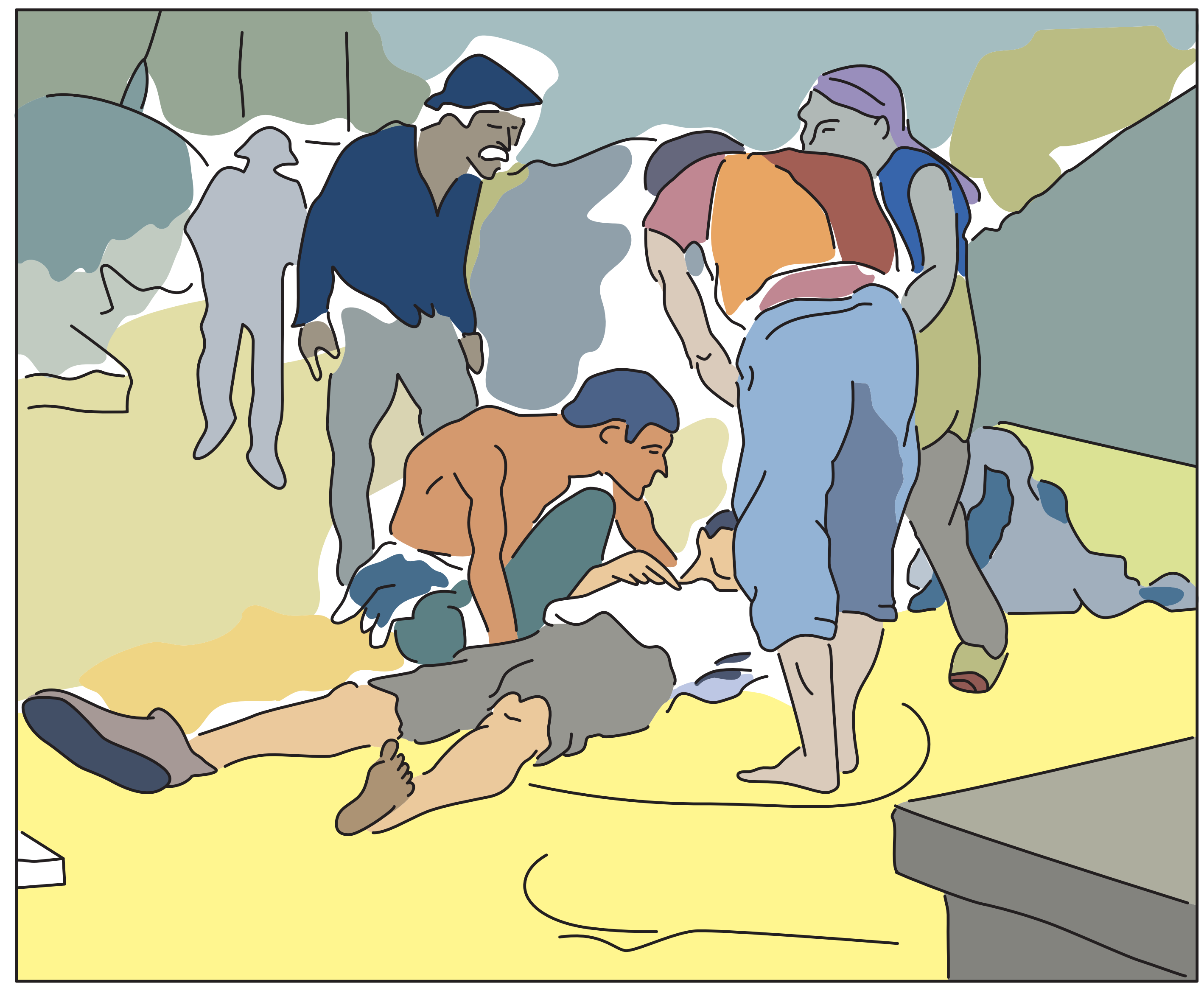

Ao topar com a pintura Os mineiros, de Antonio Rocco, o garoto afirma: "O cara foi espancado".

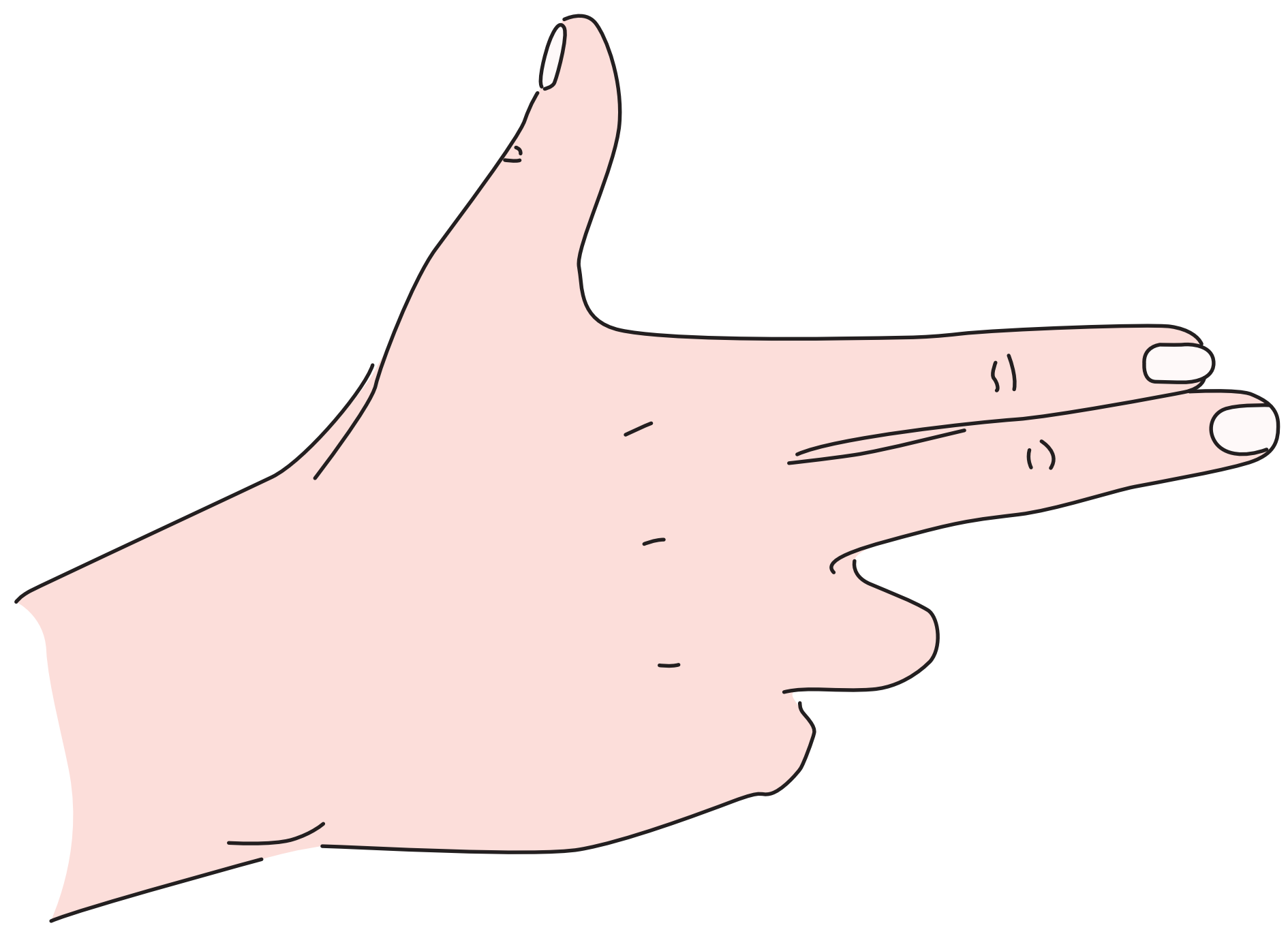

Fim de romance, 1912, Antonio Parreiras
Ao escutar os rangidos produzidos por seus passos no piso da galeria, o menino conjectura: "Esse chão é oco... deve ter dinheiro escondido aqui embaixo". 

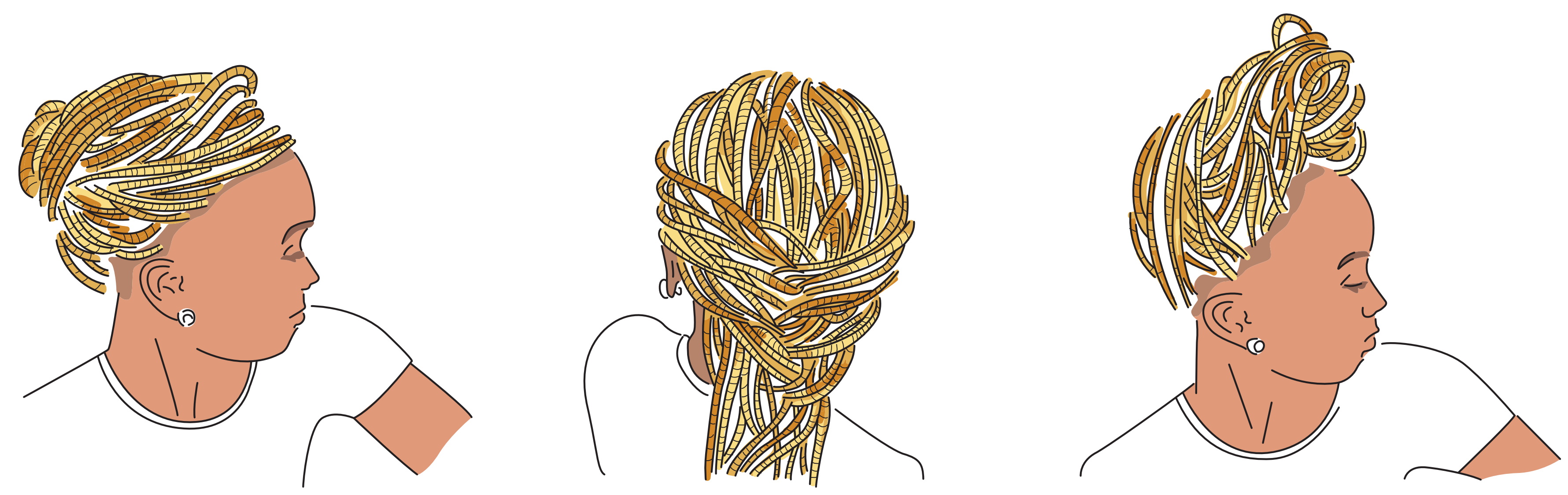

A cada giro um penteado.

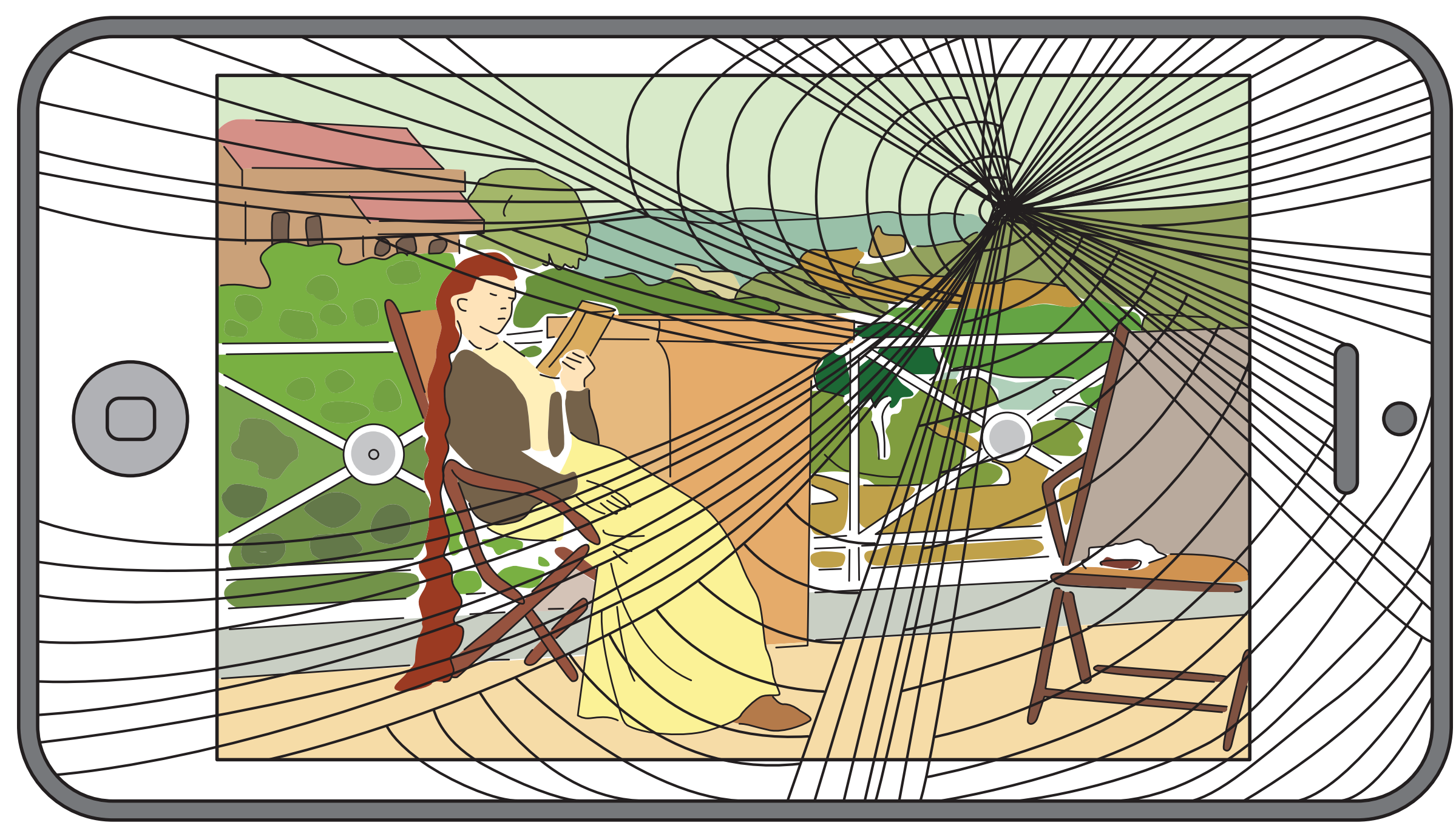

Leitura

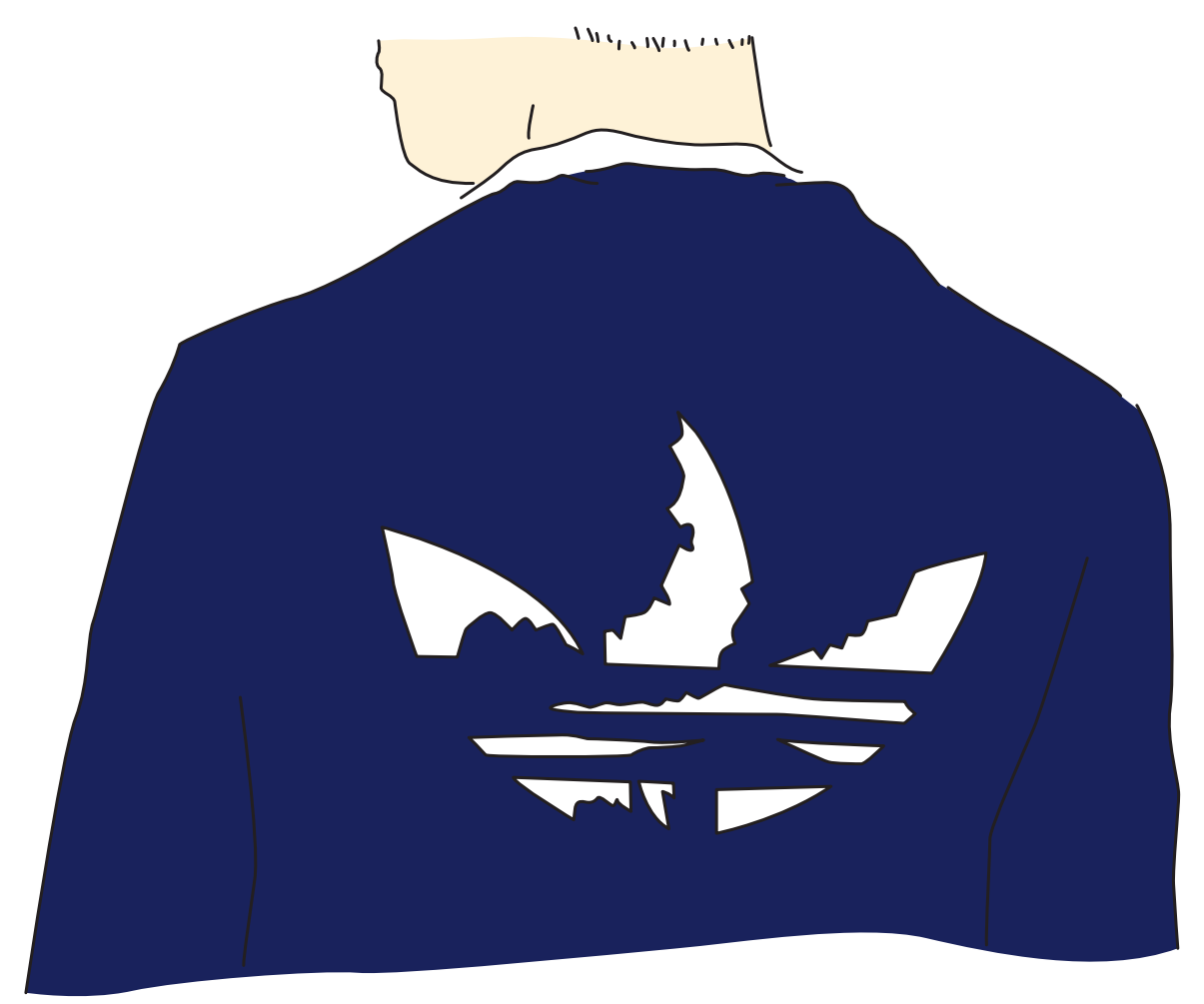

Milianos

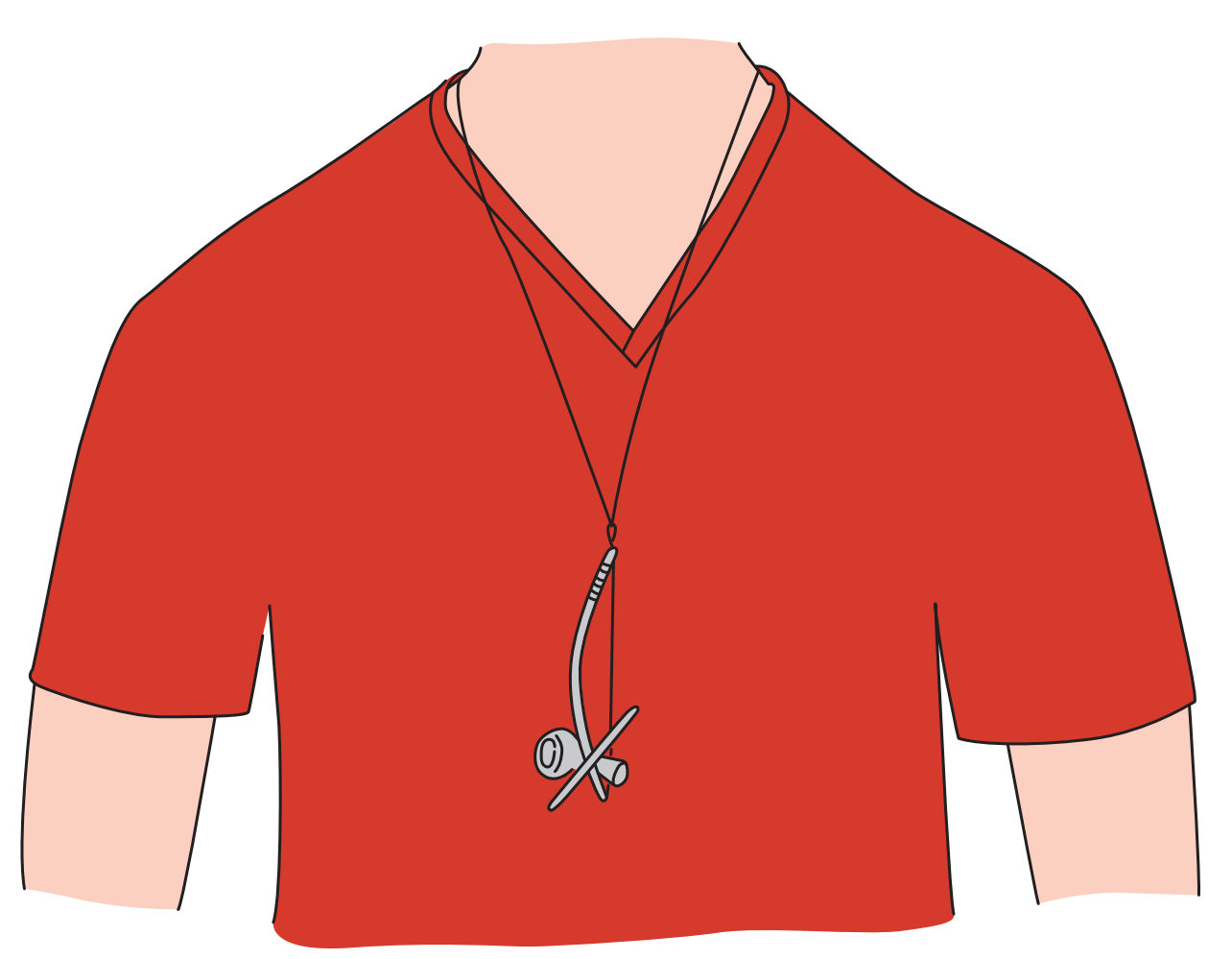

Amuleto 


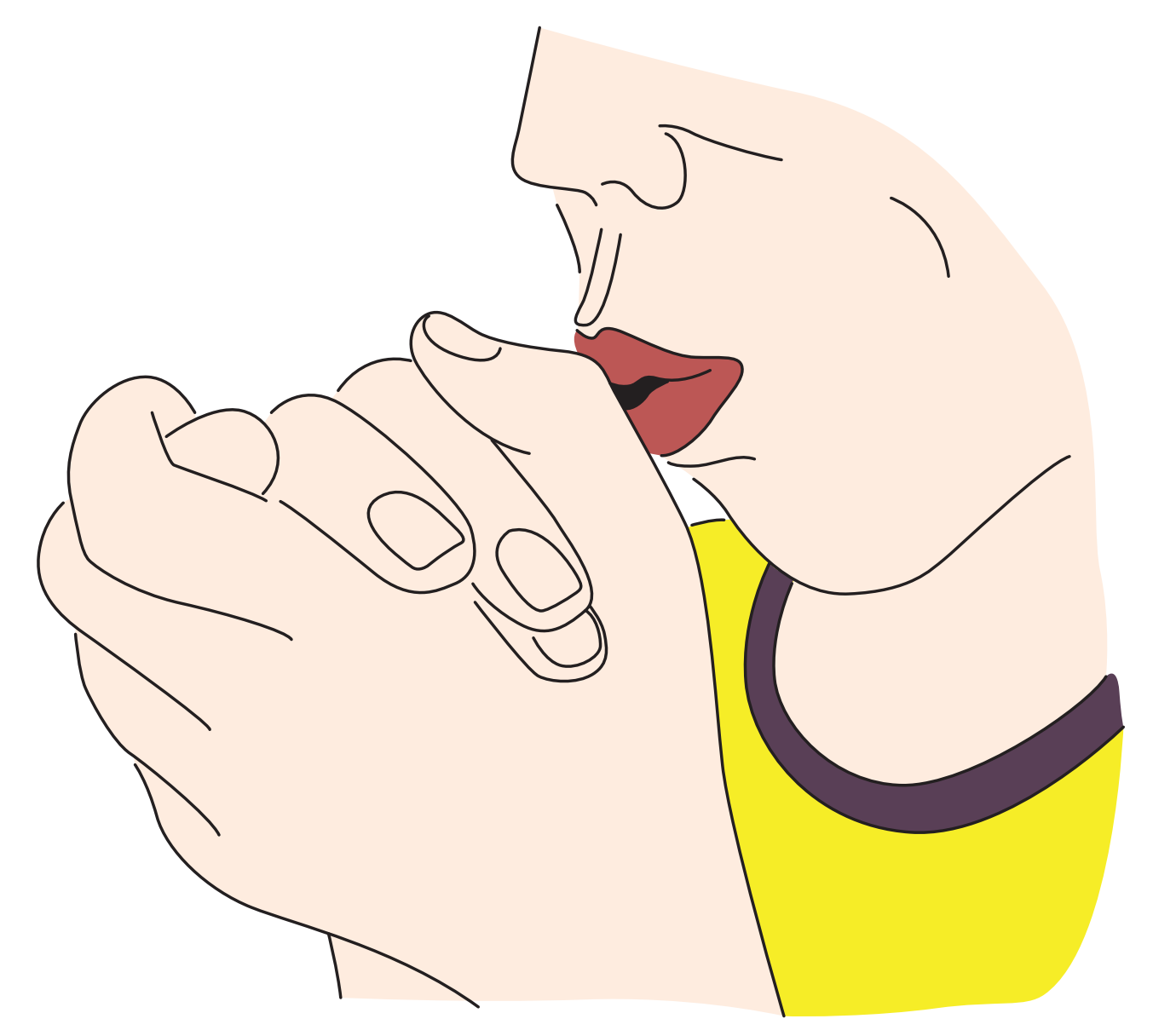

O assobio da garota ecoa pelo octógono central.

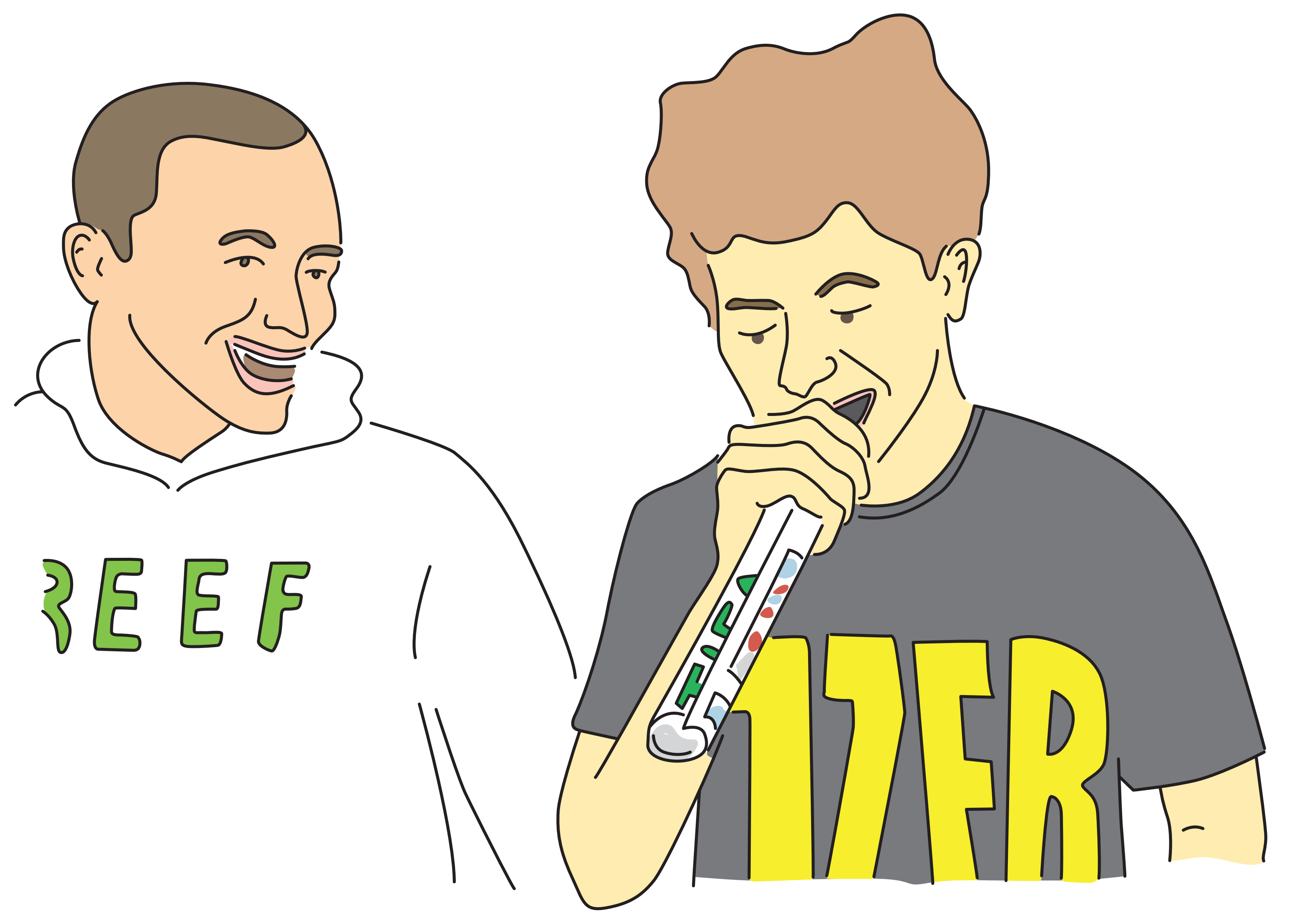

O folder da exposição serve de microfone na batalha improvisada de MCs. 
Já quase chegando de volta na escola, o "famosinho do Campo Limpo" acena pela janela do ônibus para todo mundo na rua.

\section{EM CASO DE EMERGÊNCIA}

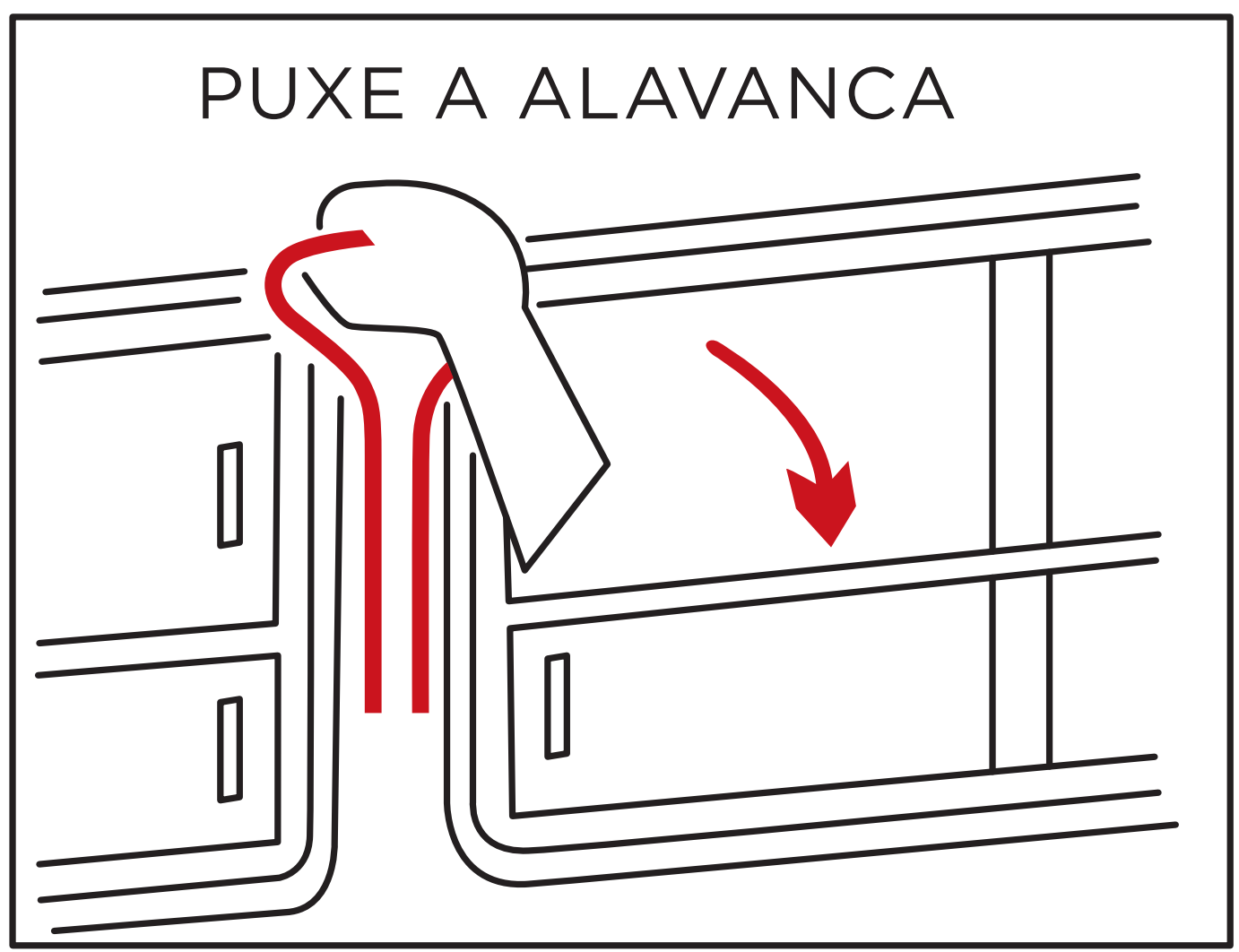

EMPURRE A JANELA COM AS MÃOS

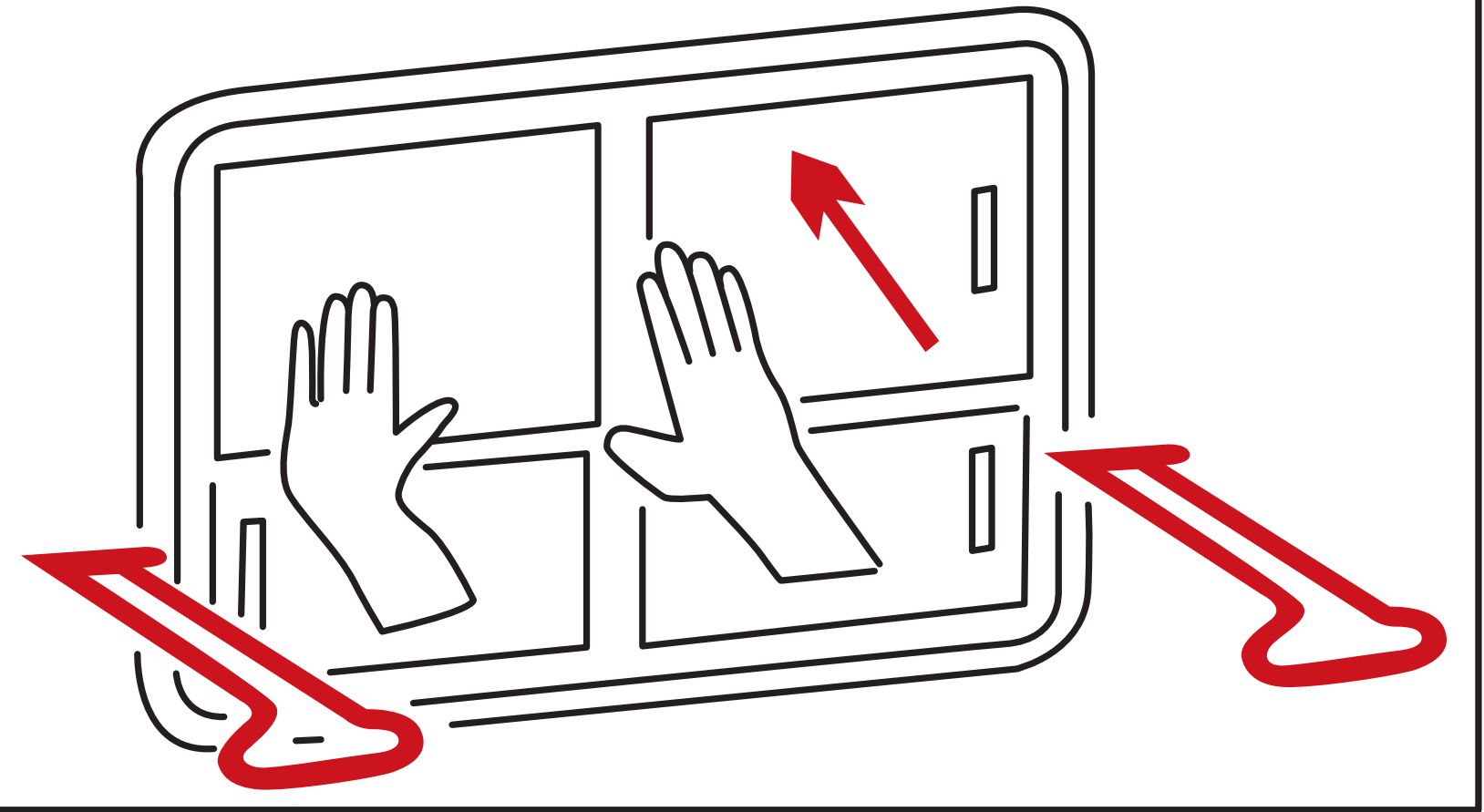

Alguns meninos se agitam, exigindo em vão: "Ei motorista, deixe a gente aqui mesmo... nós queremos jogar bola naquela quadra".

Sobre o tempo gasto na excursão: 4 horas de deslocamento (ida e volta) e 1 h30 de visita na Pinacoteca.
O melhor é deixado para o final: a poucas quadras da escola, o garoto saca da mochila uma caixa fechada de bombons Especialidades. 


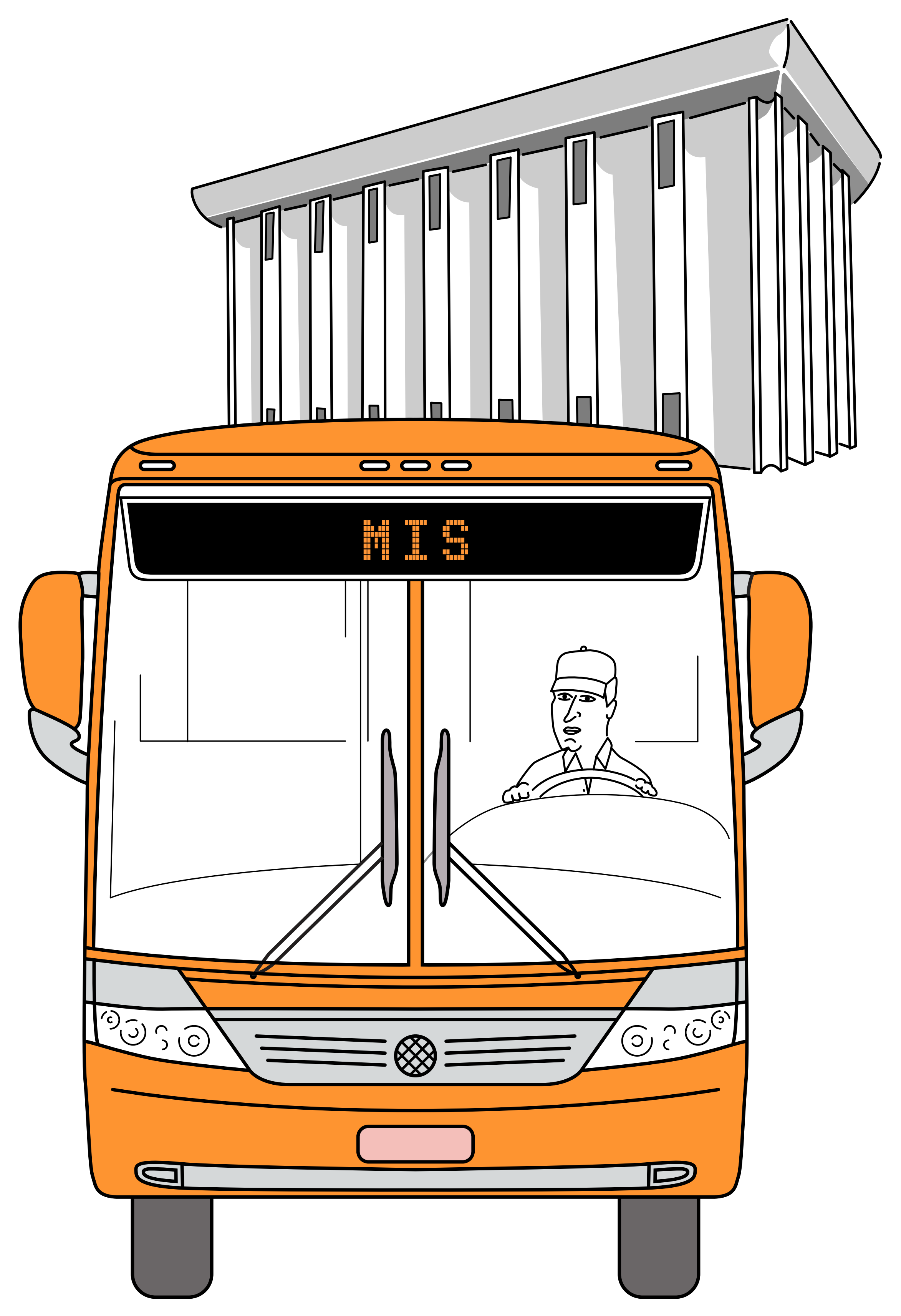


O outro mede sua altura comparando seu corpo com o meu.

Sozinha, uma criança caminha a esmo pelo pátio.

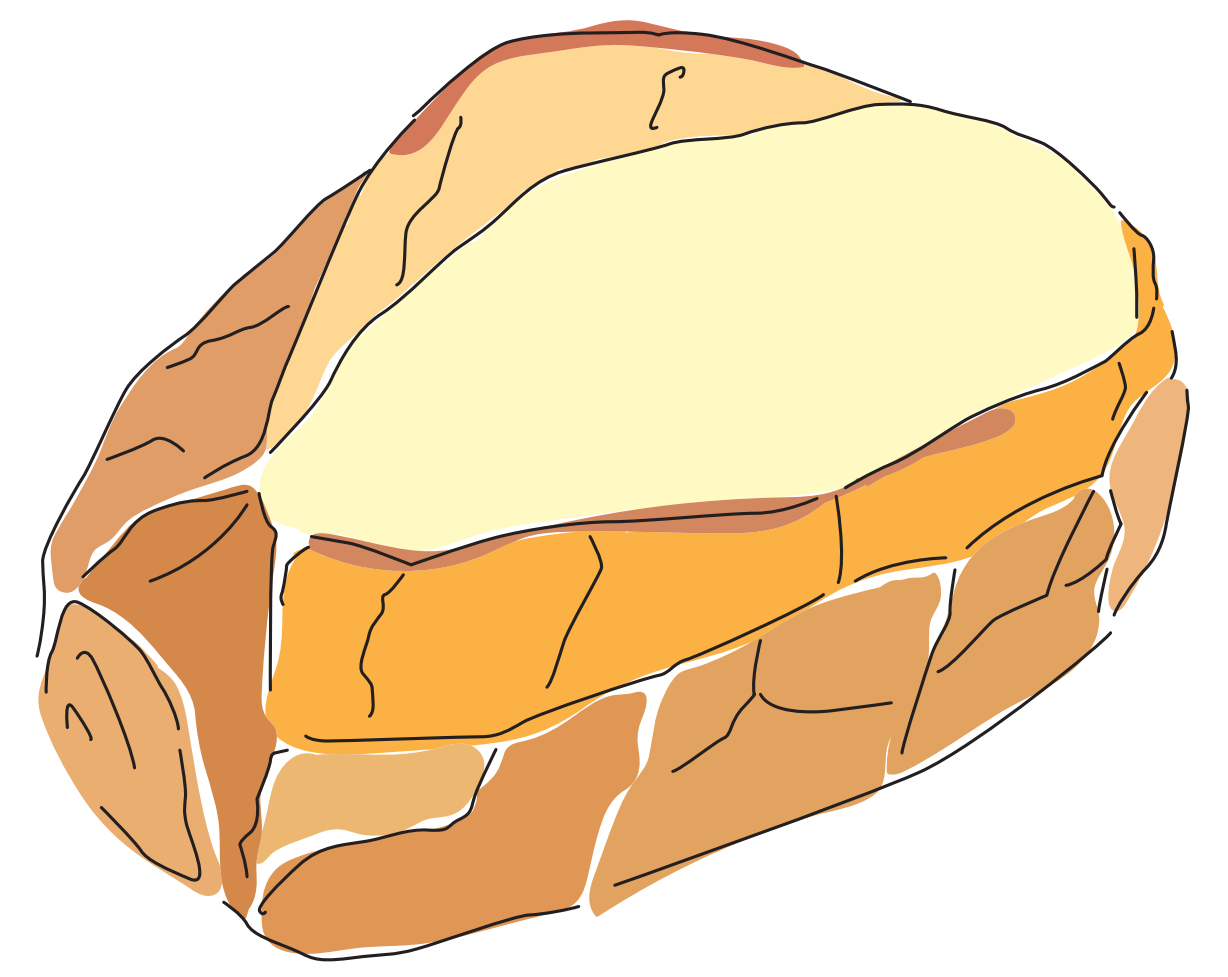

O garoto dirige-se a mim: "Come esse pão aqui, é especial... feito lá no Embü".

A diretora da escola se refere à professora de Artes como a "professora maluquinha".

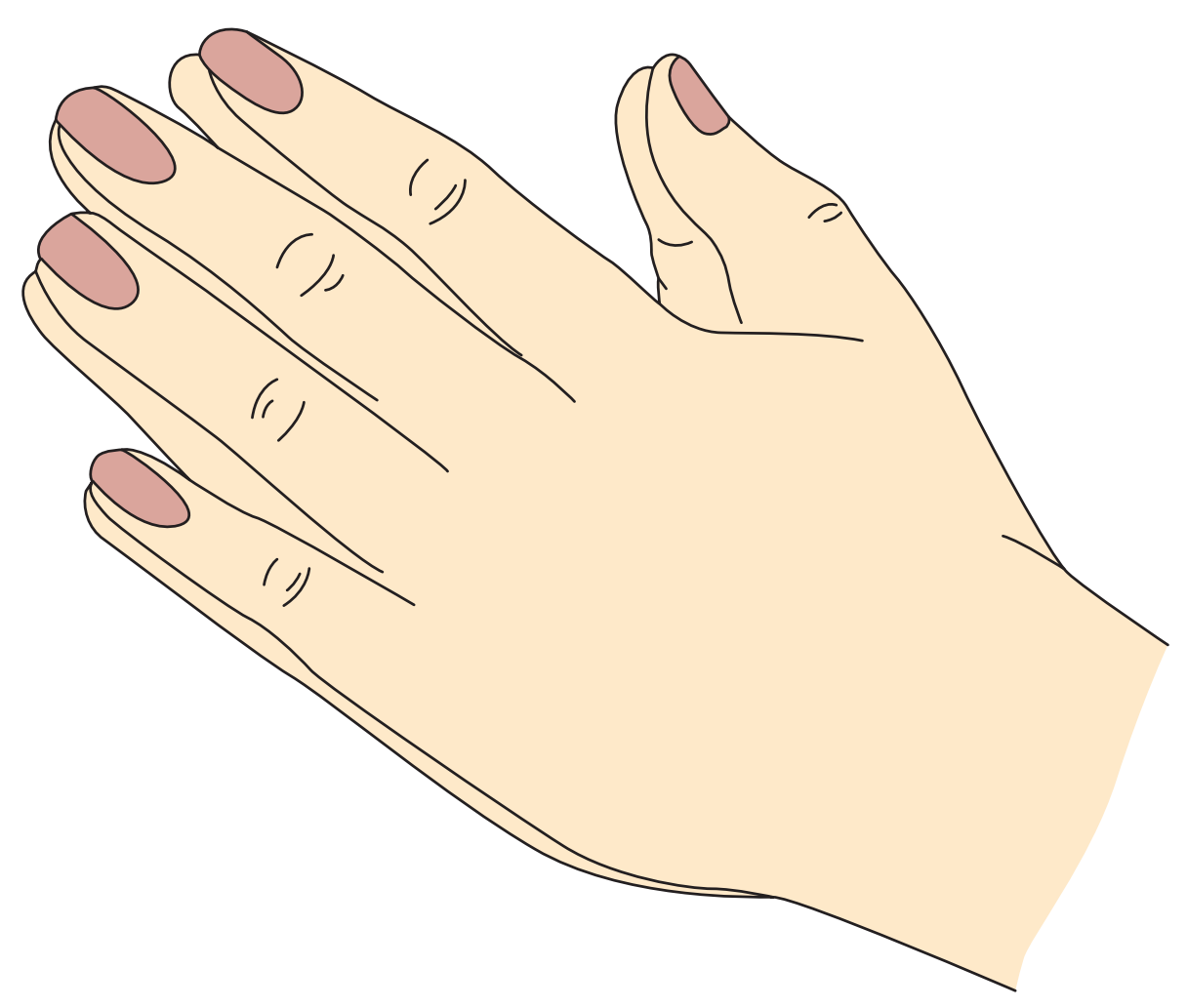

Na conversa inicial de corredor, a diretora da escola me fala da importância da laicidade no contexto escolar. Reforça que cada estudante tem o direito de professar sua fé, sem interferências externas ao meio familiar. Mas qual não é a minha surpresa ao vê-la, minutos depois, puxando a Oração do Pai Nosso em coro com todas as turmas reunidas no pátio.

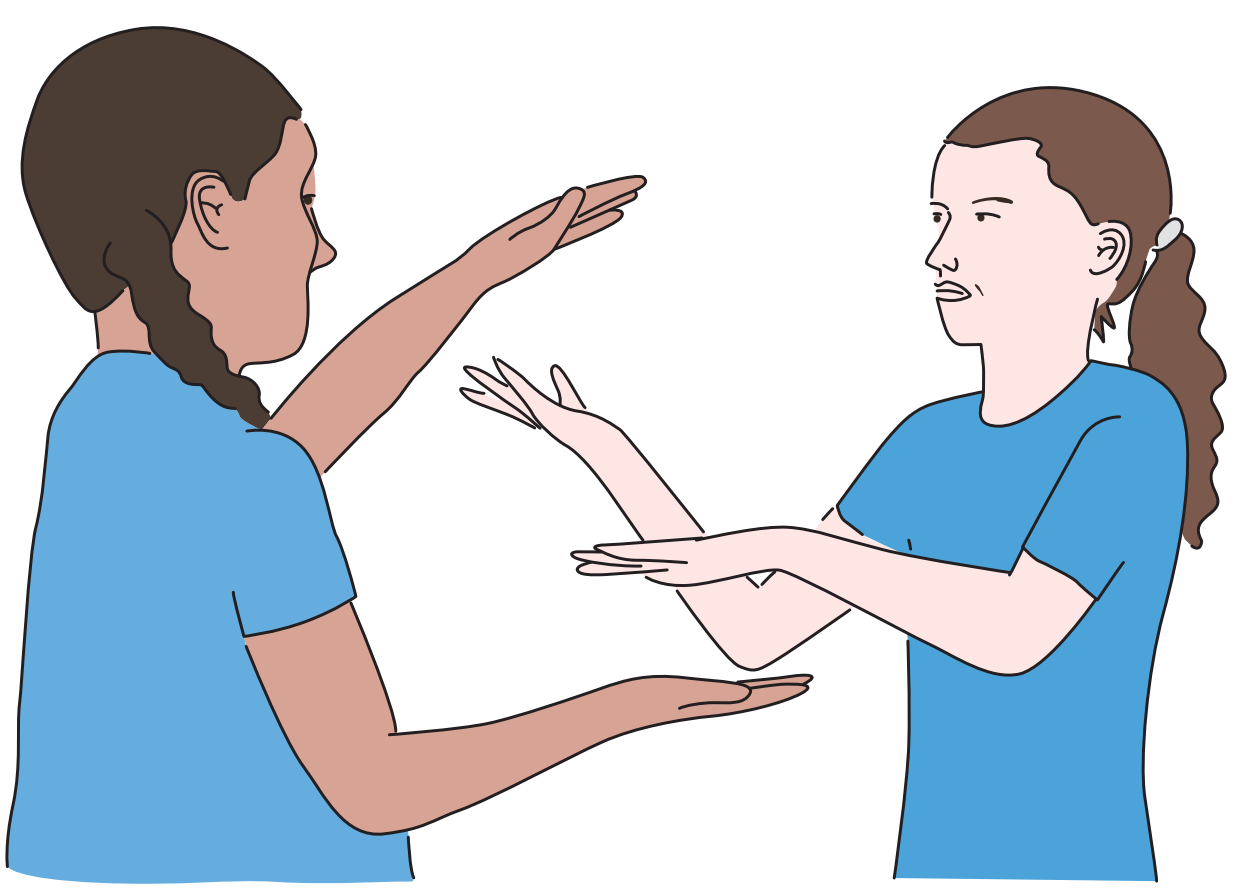




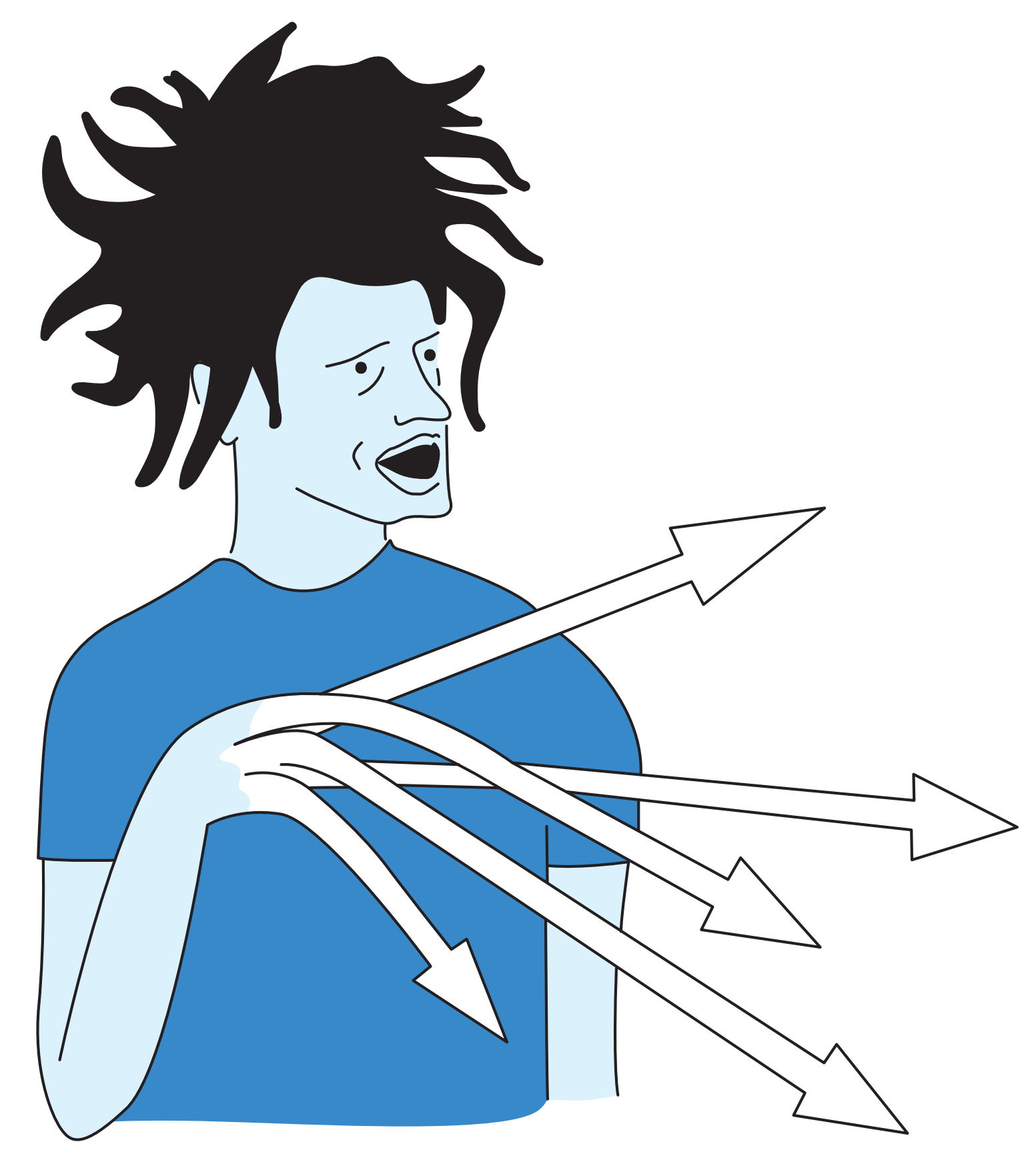

Com a ajuda dos dedos, o garoto narra suas travessias diárias para chegar até a escola.

Da cabeceira do corredor do ônibus, a professora diz para a turma: "Não quero ver ninguém ajoelhado no banco e virado pra trás". Ao que as meninas cochicham entre si: "Ué, então é só ela não virar pra trás que ela não vai ver nada disso".

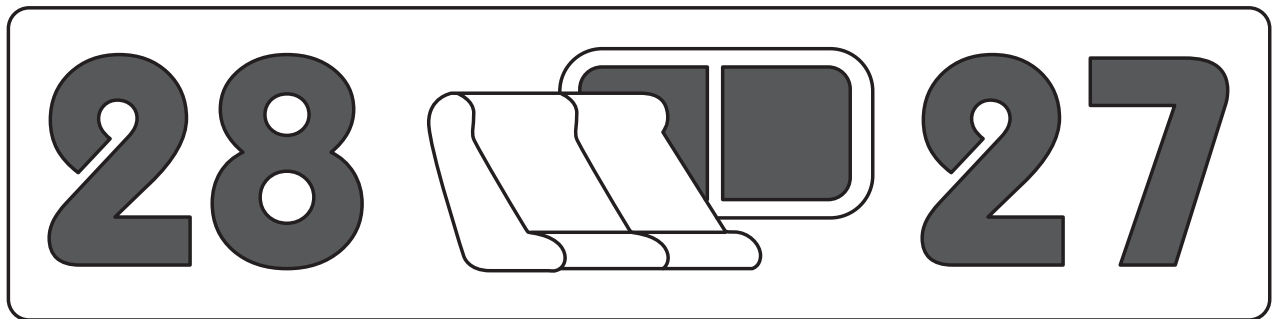

Em pé no corredor, as amigas combinam quem sentará na janela.

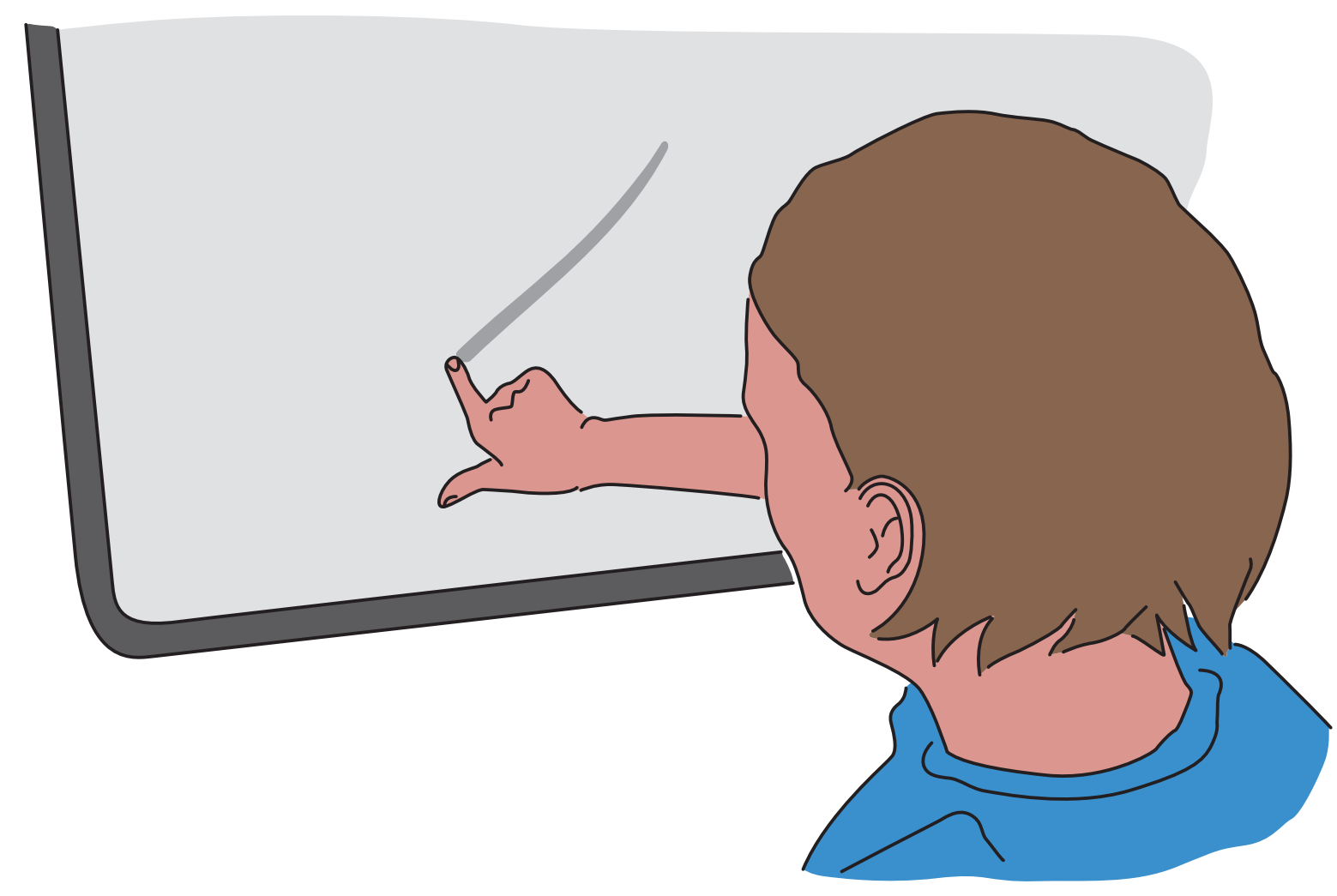

Desenhar com o dedo na janela embaçada do ônibus. 


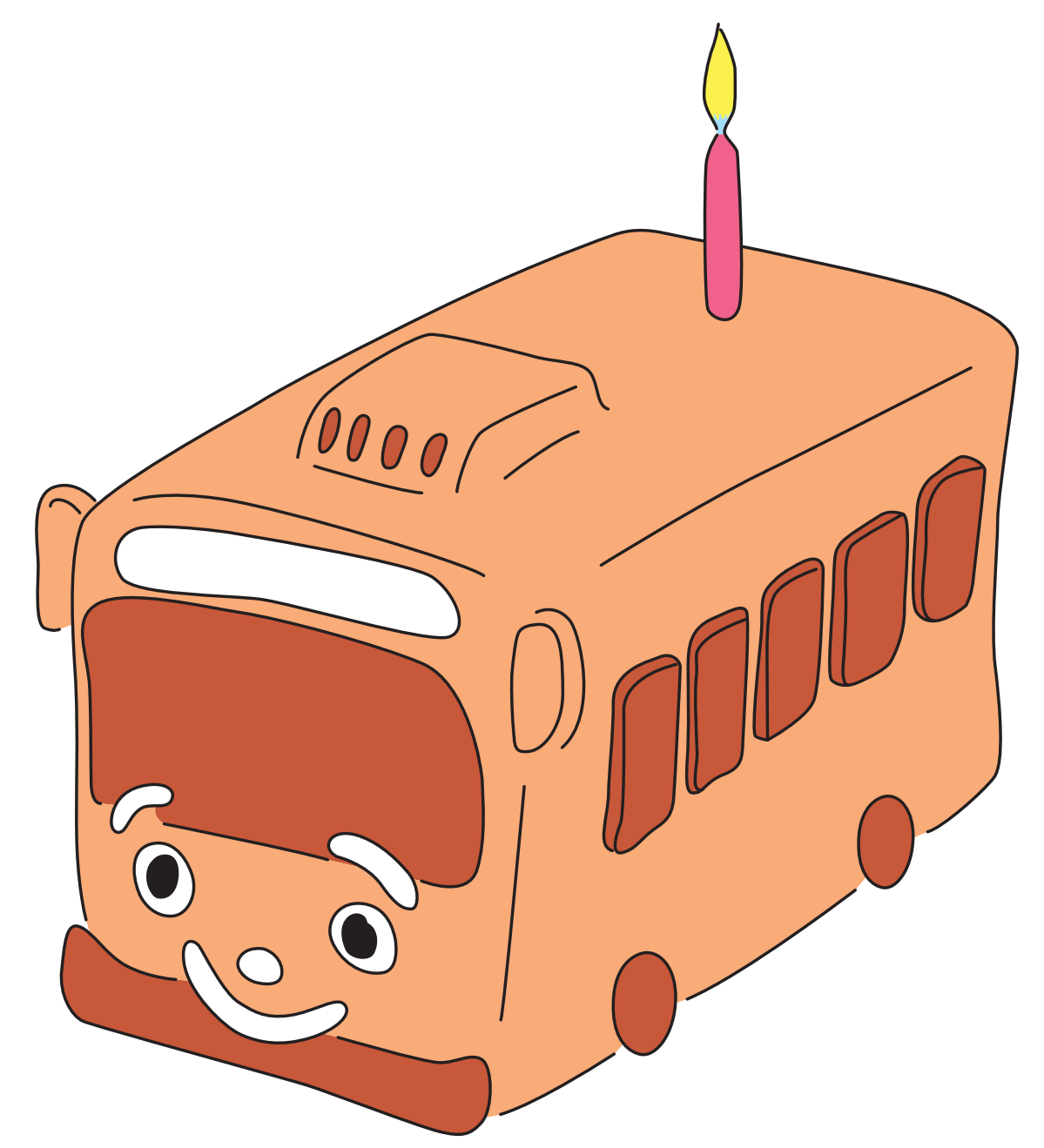

Cantamos parabéns para a aniversariante dentro do ônibus.
A menina comemora o engarrafamento: "Aê! Vai demorar pra gente chegar".

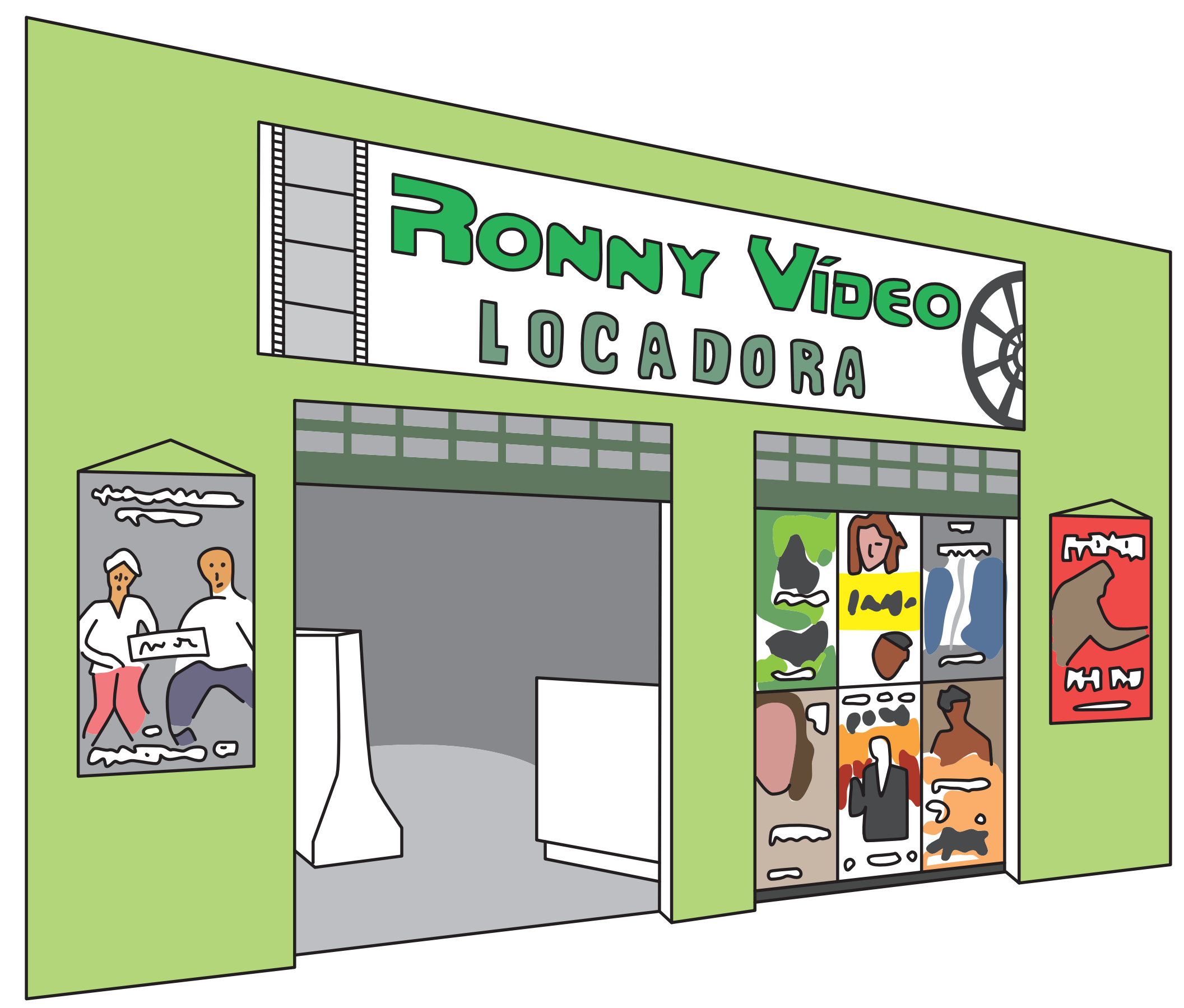

No meio do caminho para o Museu da Imagem e do Som tem uma video-locadora.

Há no grupo uma garota autista. Enquanto me fala de como se dá a integração dela com o restante da turma, a professora comenta que nenhuma das escolas particulares procuradas pela família havia aceito o seu ingresso.

Uma criança vai até a professora: "Prô, tem gente cantando música pesada lá trás".
Ao cantar "Baile de Favela", "Metralhadora" e hits de Wesley Safadão, as crianças transformam a "classificação indicativa" em letra morta. 


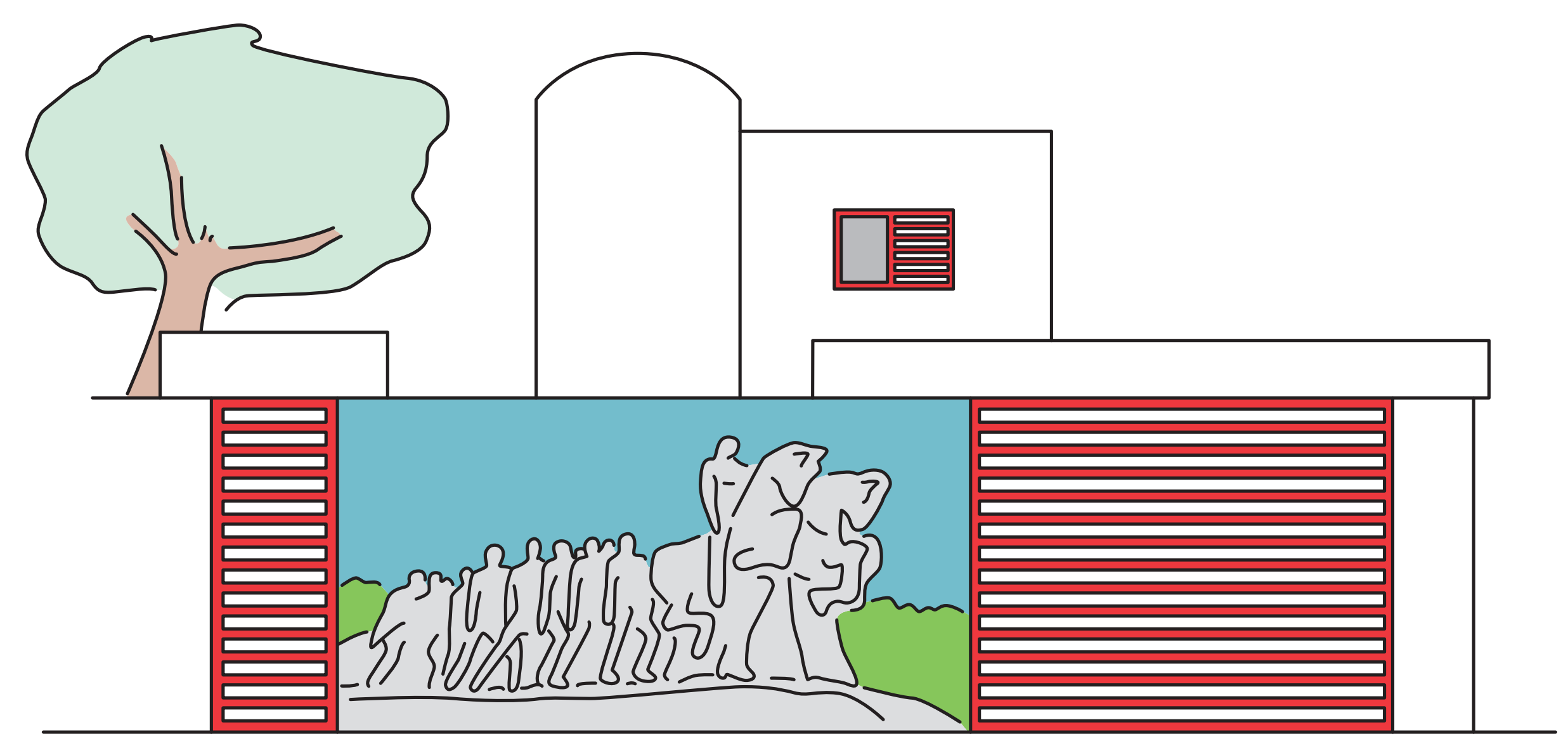

Algumas crianças reconhecem a imagem estampada no grafite feito sob encomenda no muro de um casarão no Jardins.

O menino registra: "Aqui é bairro de rico".

Admirando as mansões pela janela do ônibus, o garoto verbaliza: "Quem me dera ter uma casa assim...". Ao que seu colega recomenda: "Se você trabalhar bastante e ganhar muito dinheiro, aí sim...".
Assim que o ônibus chega ao museu, a professora fica em pé no corredor e pergunta para a turma: "E aí pessoal, que lugar é esse?". Alguém lá do fundo grita: "É o mundo do Tim Burton!".

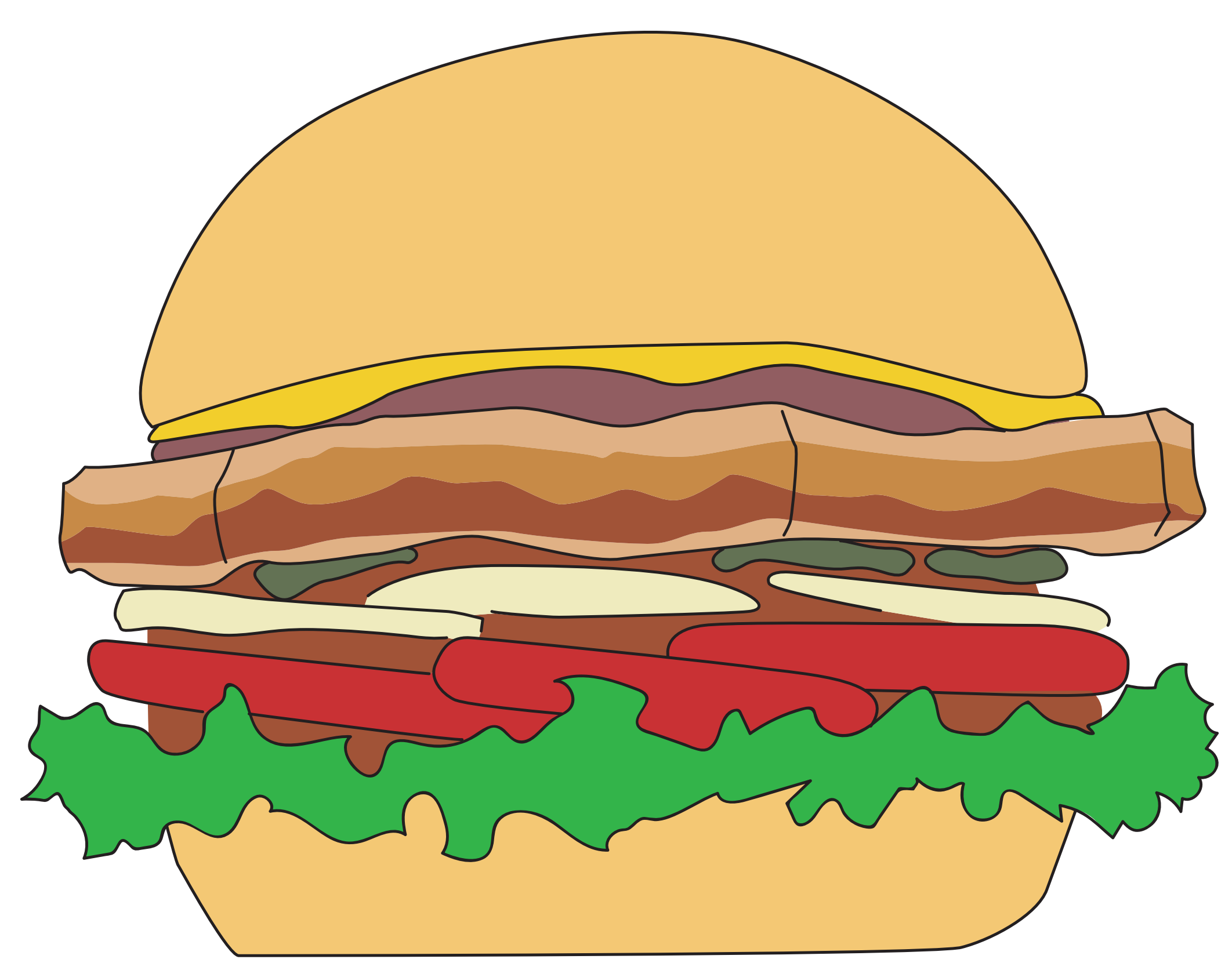

No momento de fazer a foto do grupo, com a fachada do museu ao fundo, o garoto orienta os colegas: "Vai, todo mundo falando ' $X$ ' bisteca!". 
O burburinho do grupo lembra

o zunido de um enxame.

Desde o início, a mediadora é chamada de "prô" por boa parte dos estudantes.

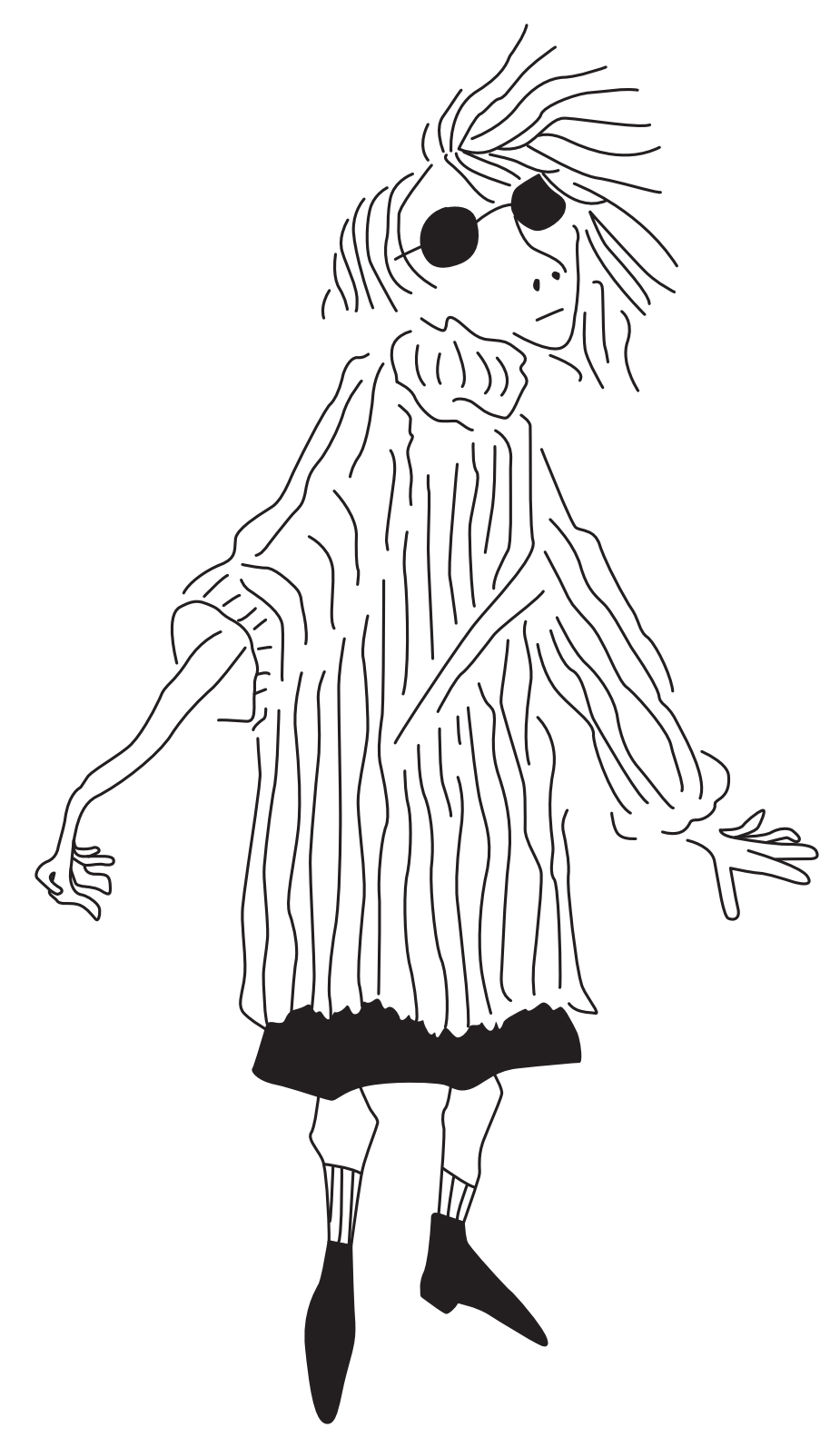

Mediadora personagem

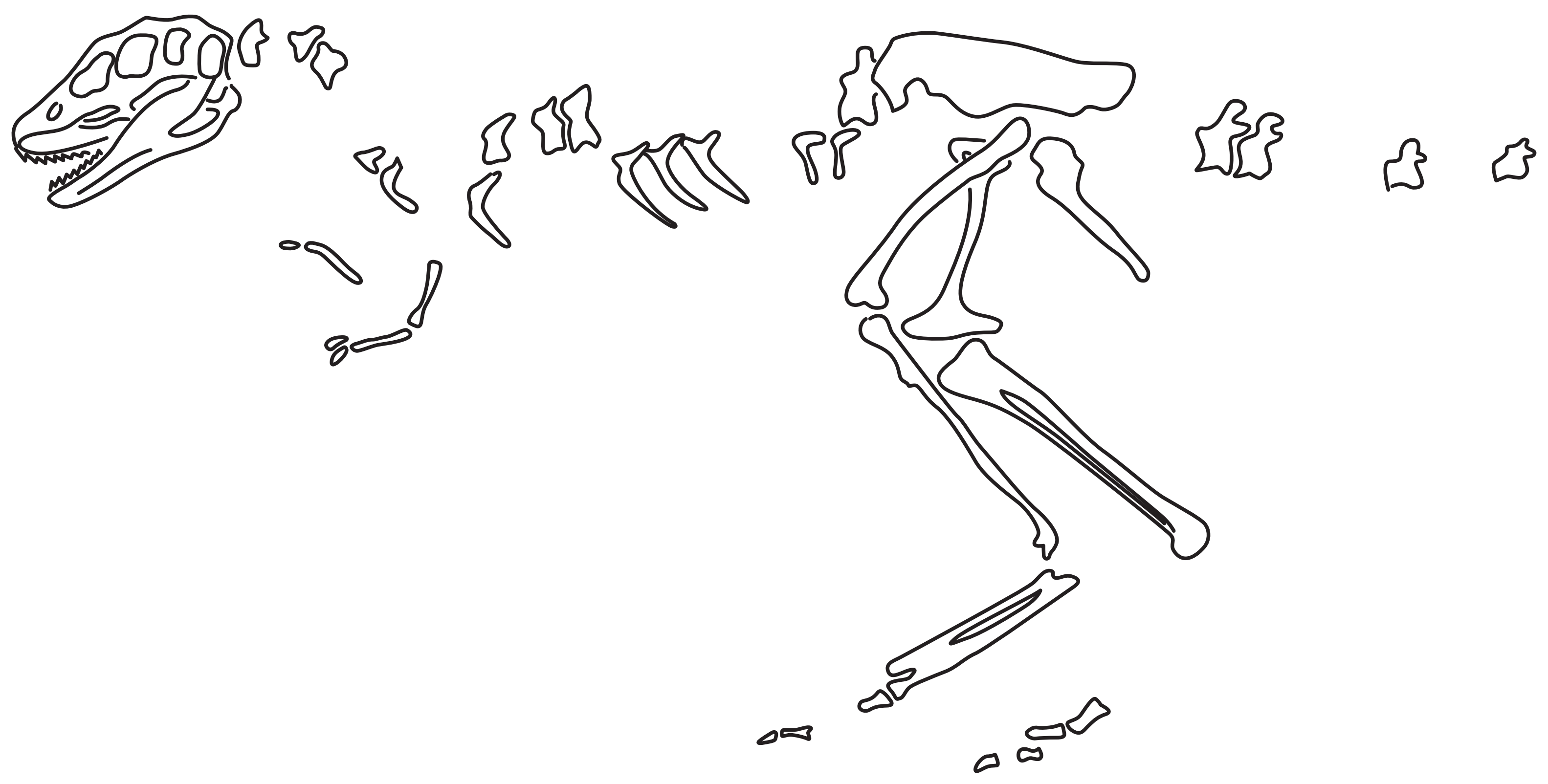

Durante o acolbimento do grupo, a mediadora pergunta: "No que vocês pensam quando escutam a palavra 'museu'?". A primeira resposta é: "Ossos de dinossauro".

O cabelo colorido de uma jovem visitante vira objeto de atenção e comentários do grupo.
Já dentro do museu, o grupo atravessa um espaço onde está acontecendo um coquetel. A responsável pelo evento, ao notar a presença dos estudantes no espaço, fica "de cabelo em pé", cobrando explicações dos funcionários que se encontram em seu campo de visão. 


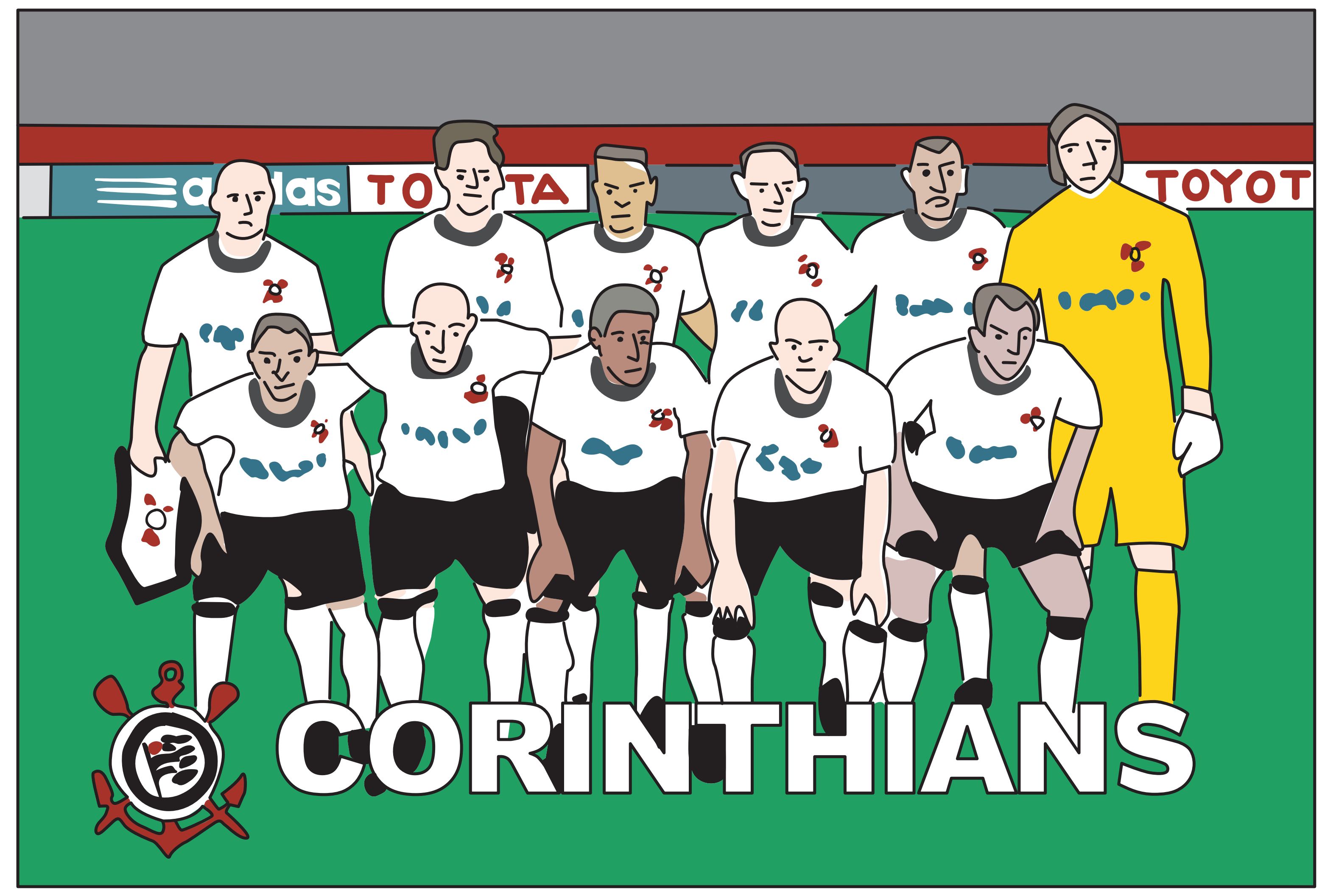

Respondendo à pergunta da mediadora sobre as imagens com as quais nos relacionamos no dia-a-dia, alguém menciona o pôster do time de futebol pregado na parede do quarto.

Logo na primeira sala, ao notar o susto da amiga com a atmosfera e os objetos da exposição, a garota fala baixinho em seu ouvido: "Você achou que seria tudo bonitinho?".
Alguém solta um spoiler: "Lá dentro da exposição tem um escorregador gigante".
A mediadora sugere que os estudantes investiguem as imagens presentes na exposição. Confuso com tal orientação, o menino divide sua incompreensão com o colega: "Investigar imagens? Mas como?". O colega então lhe diz: "É só olhar os detalhes e ver como eles se juntam".
A menina me pergunta: "Você sabe quantas horas são?". 

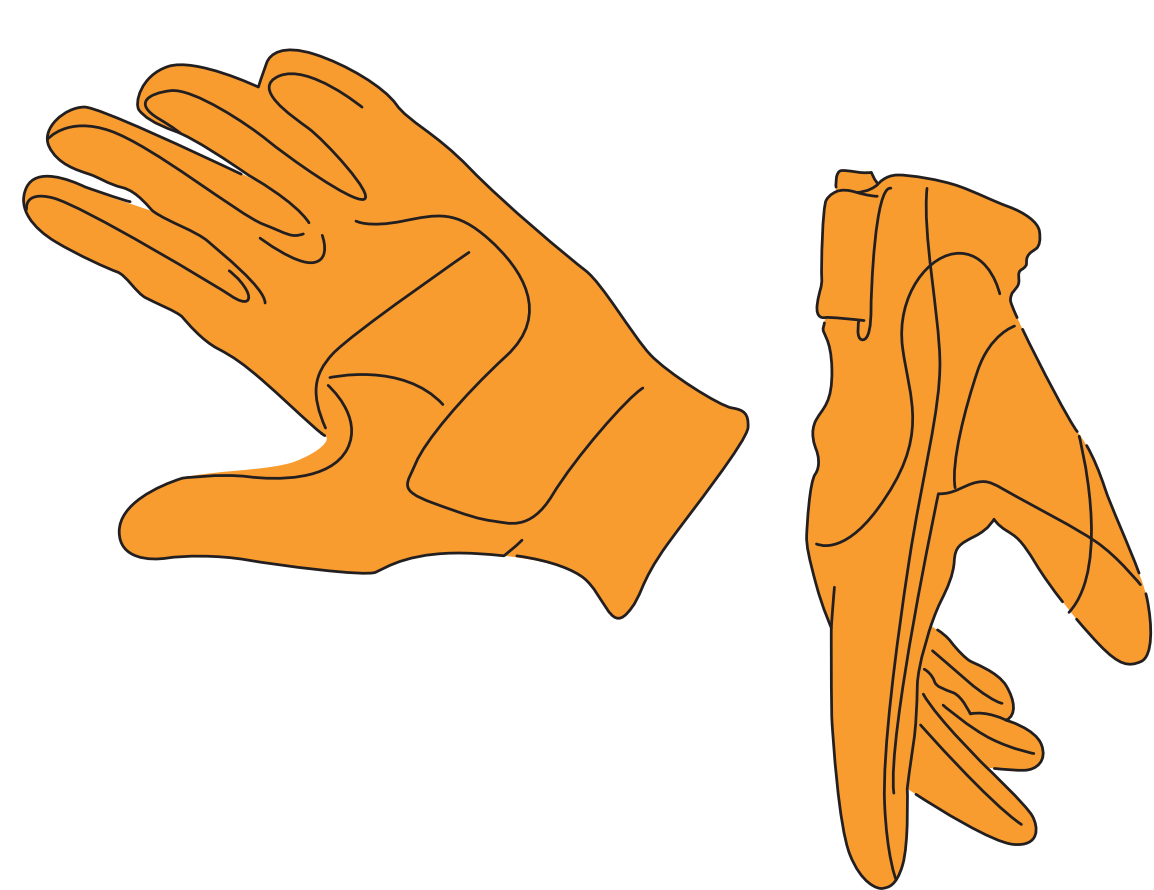

O garoto explica coisas absurdas com suas luvas.

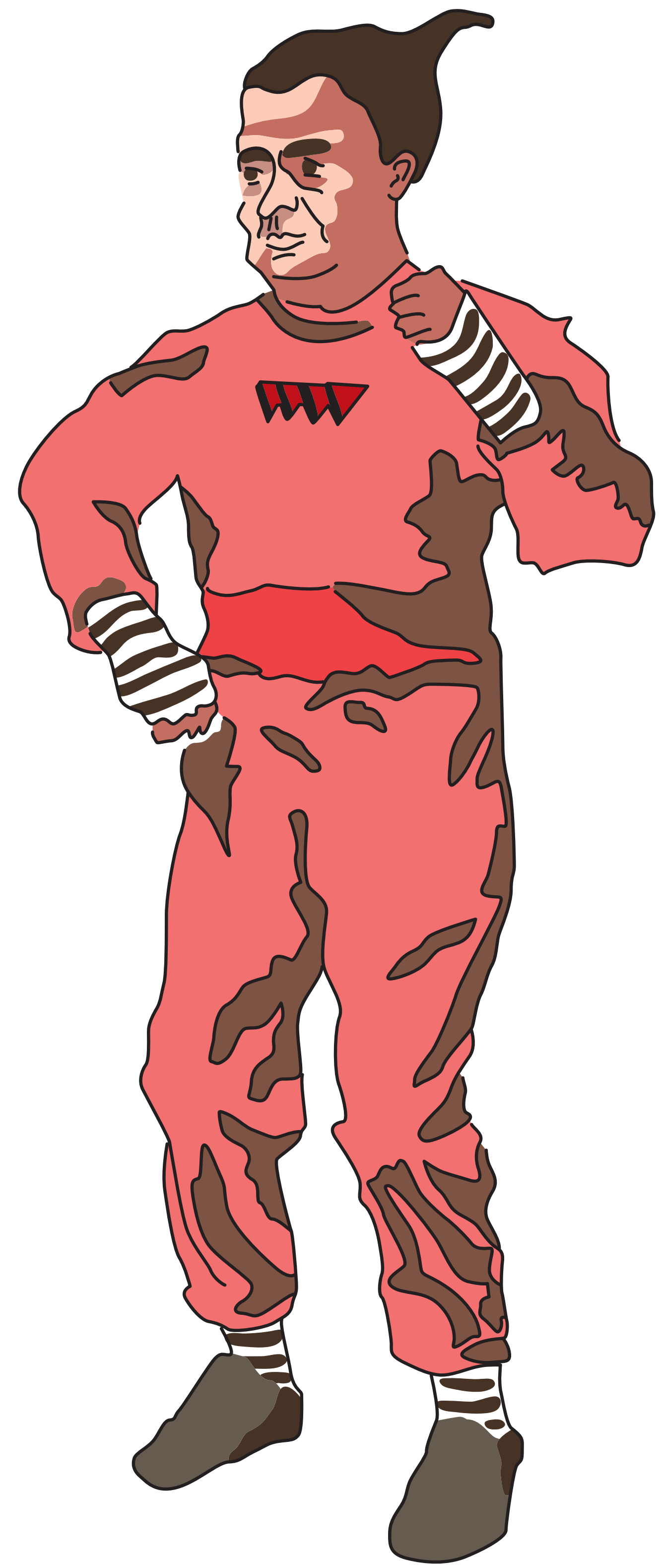

Alguns estudantes tentam entabular conversas com o boneco hiper-realista de Umpa Lumpa.
De repente, alguém toma a iniciativa de me apresentar a um aluno do grupo, de origem cubana, que fala espanhol.
Aqueles que avançam para as próximas salas da exposição antes do restante do grupo retornam com novidades, anunciando o que vem pela frente. 


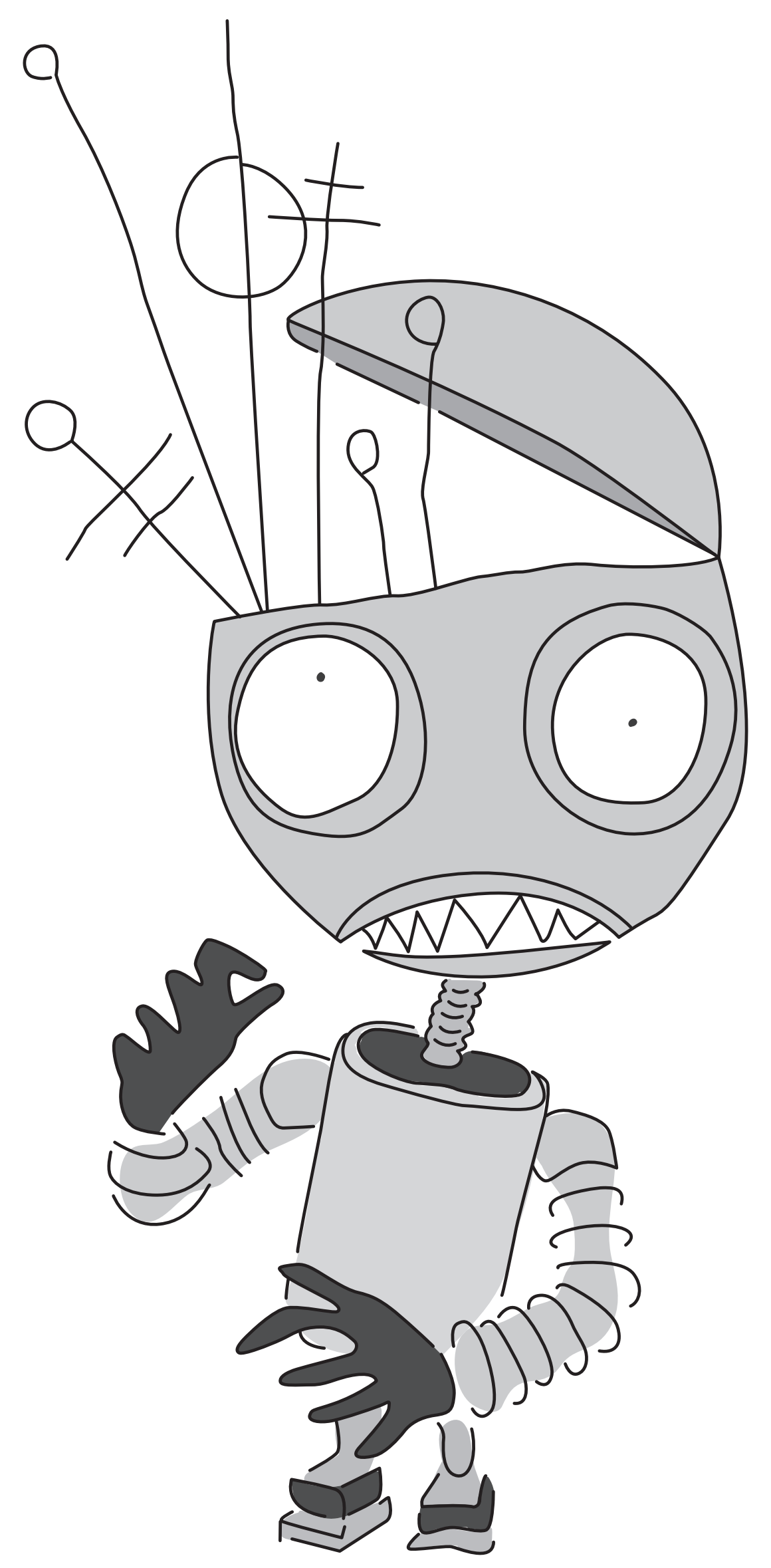

O menino tem inusitadas ideias de arame.

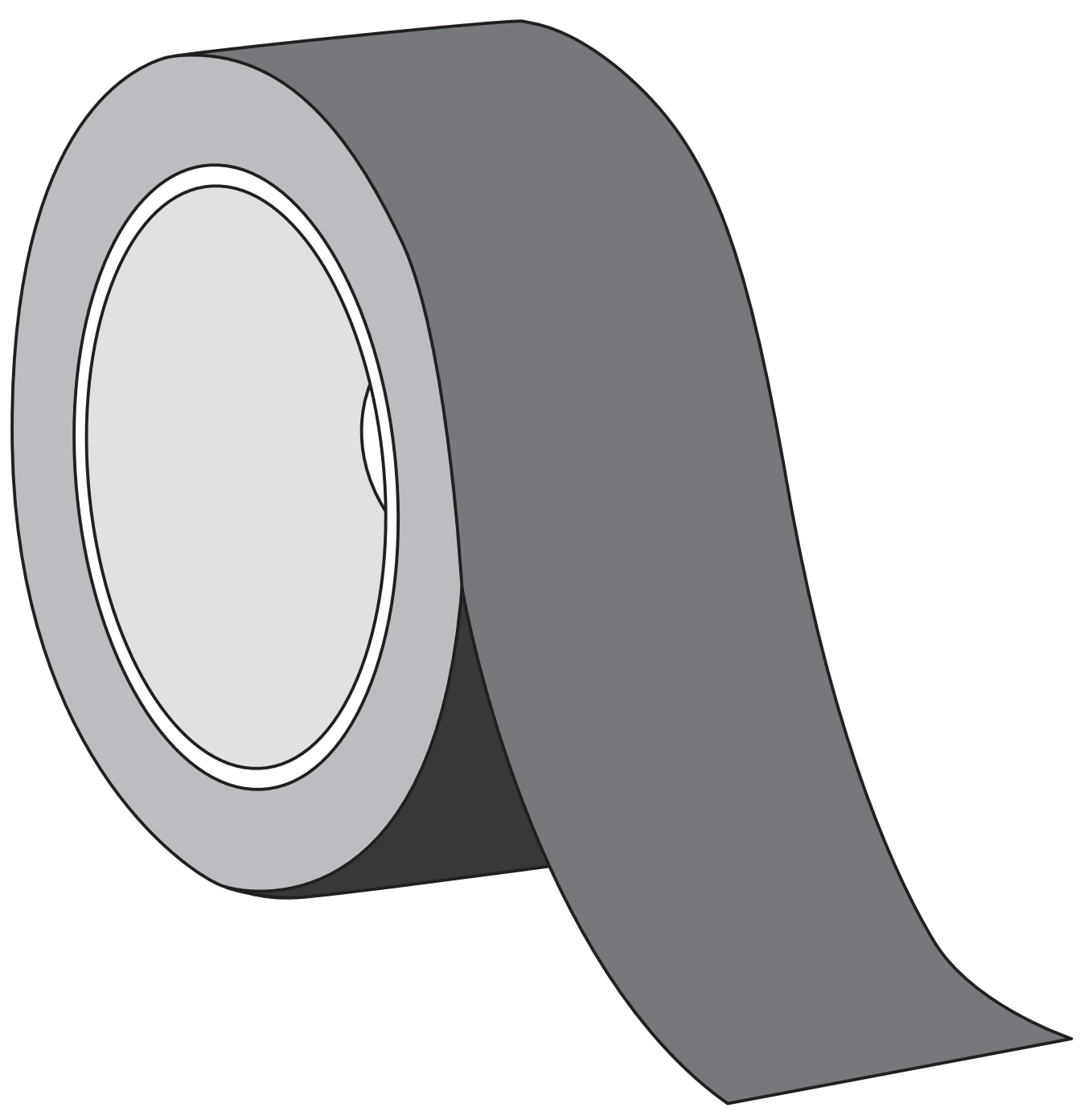

De repente, noto que a cabeça da garota dá um giro de $360^{\circ}$, de modo que seus olhos captam tudo em um só lance de vista. 


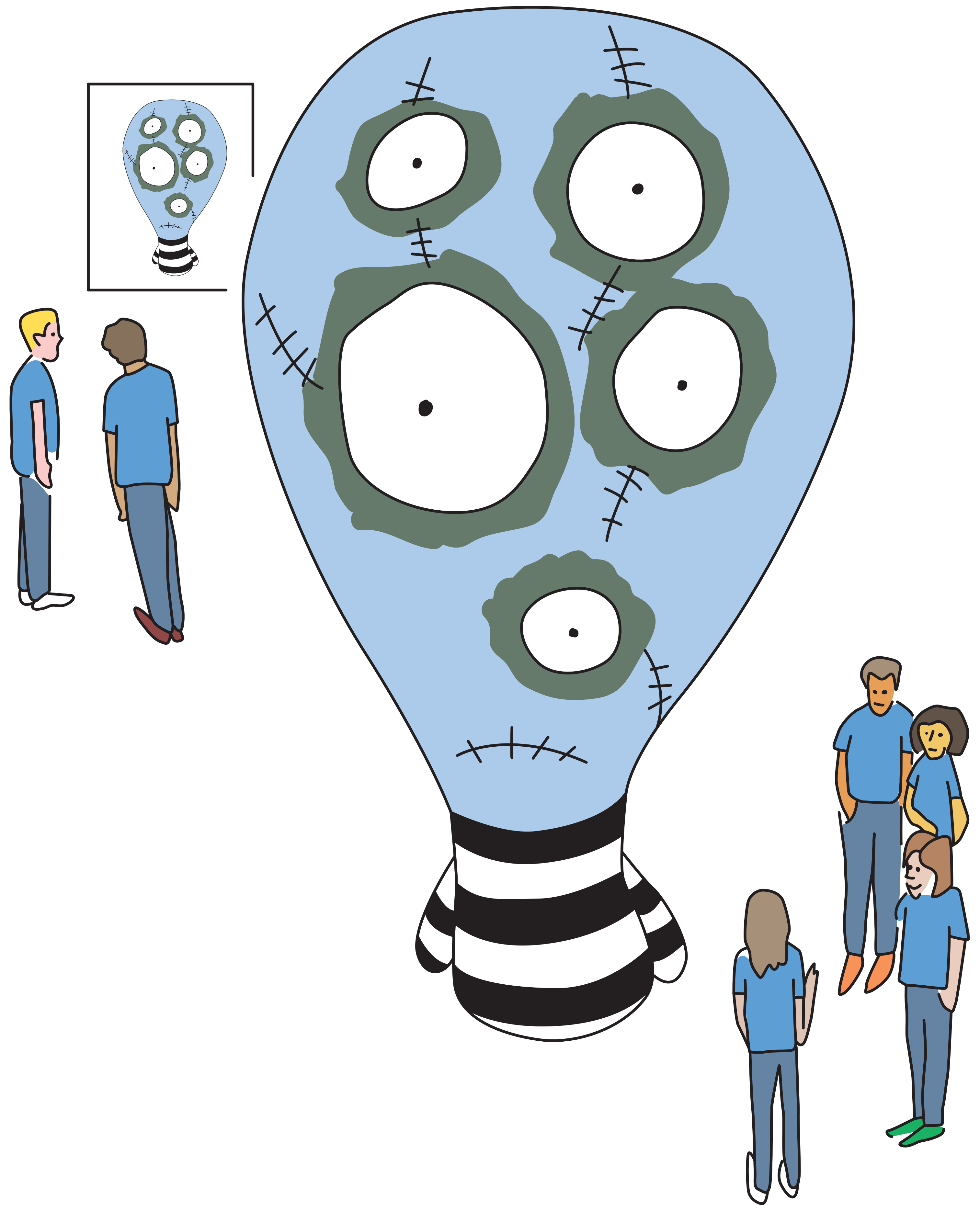

O "antiprojeto": para um dos garotos da dupla, Tim Burton primeiro fez o inflável para depois realizar o respectivo desenho de observação.

Diante da maquete da cidade cenográfica do filme Edward Mãos de Tesoura, o menino anuncia: "Tchau gente, vou me teletransportar para esta cidade". 
Já na conclusão da visita, a mediadora pergunta para o grupo: "Dessas criações todas do Tim Burton, qual foi a que vocês mais gostaram?". A resposta vem em coro: "Do escorregador!". Diante da resposta, a mediadora faz a ressalva: "Mas o escorregador não é obra do Tim Burton. É só um recurso da cenografia da exposição". A reação de alguns a tal observação aparece sob a forma de um lamento cínico: "Ah, que pena".

Ao terminar a visita, um garoto se dirige à professora, indagando-a: "Qual era a surpresa?".

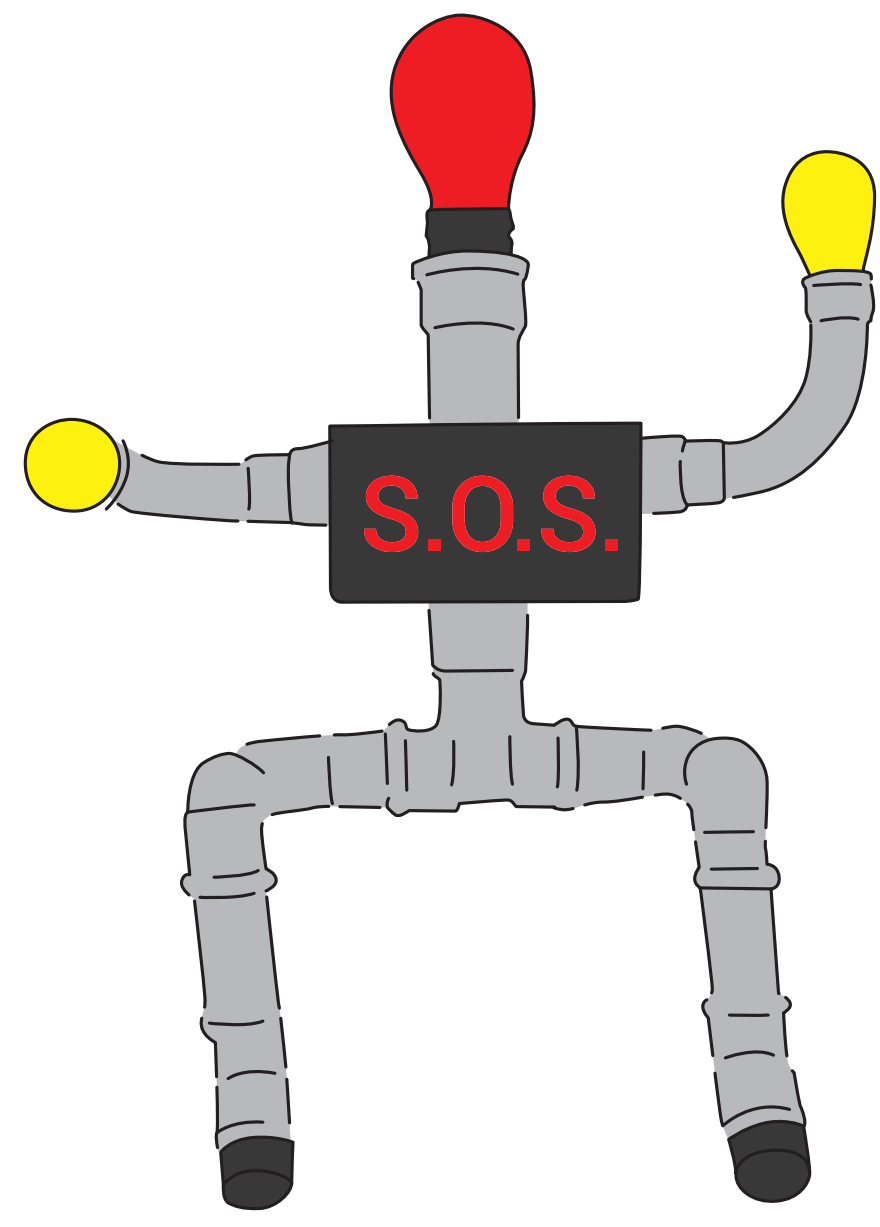

Passando pela porta do almoxarifado de manutenção do museu, vemos um boneco que bem poderia estar numa das vitrines da exposição. Alguém pergunta para a mediadora: "Quem foi que criou aquele boneco?".

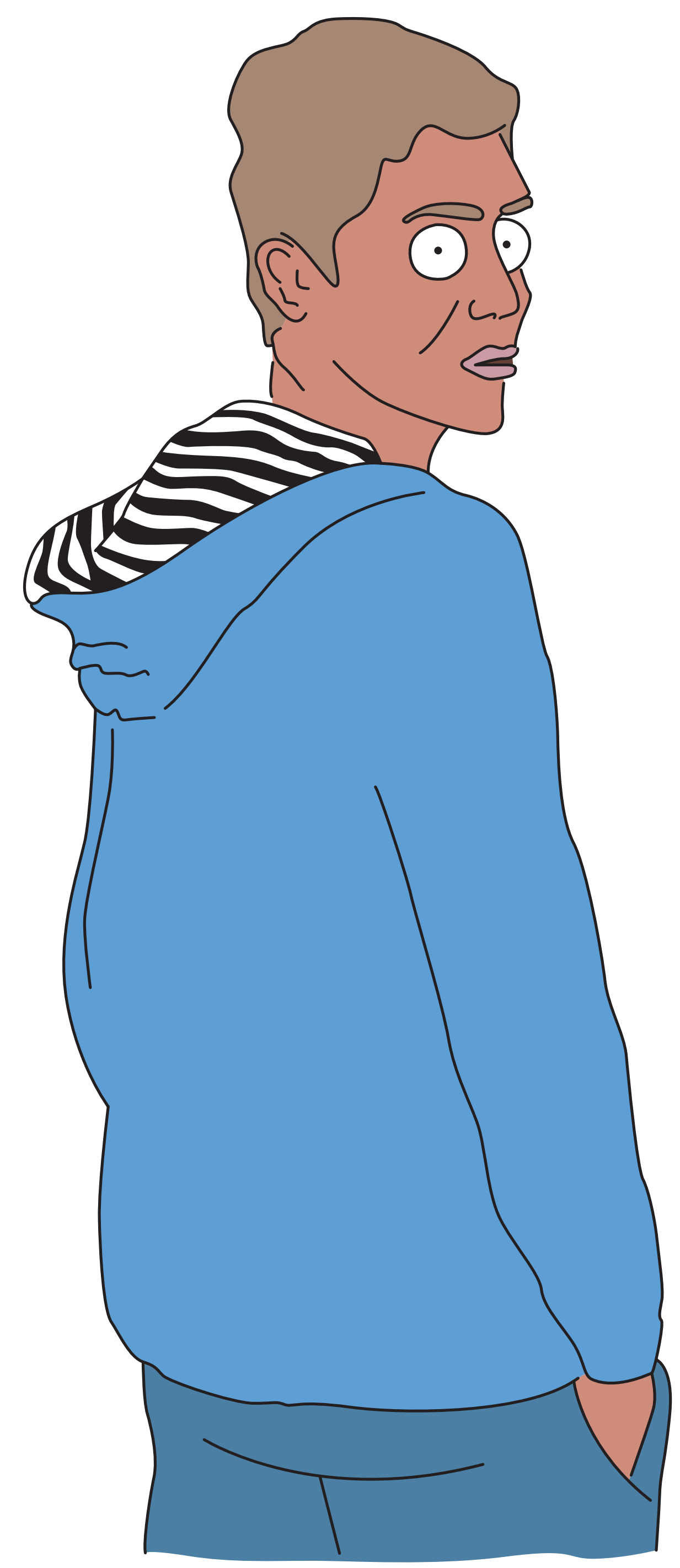

Na saída do museu, alguém comenta: "O estranho é que nenhum personagem principal do Tim Burton é negro". Ao ouvir isso, o moleque "mais figura" da turma dá uma viradinha astuciosa para trás, surpreendendo a todos. 


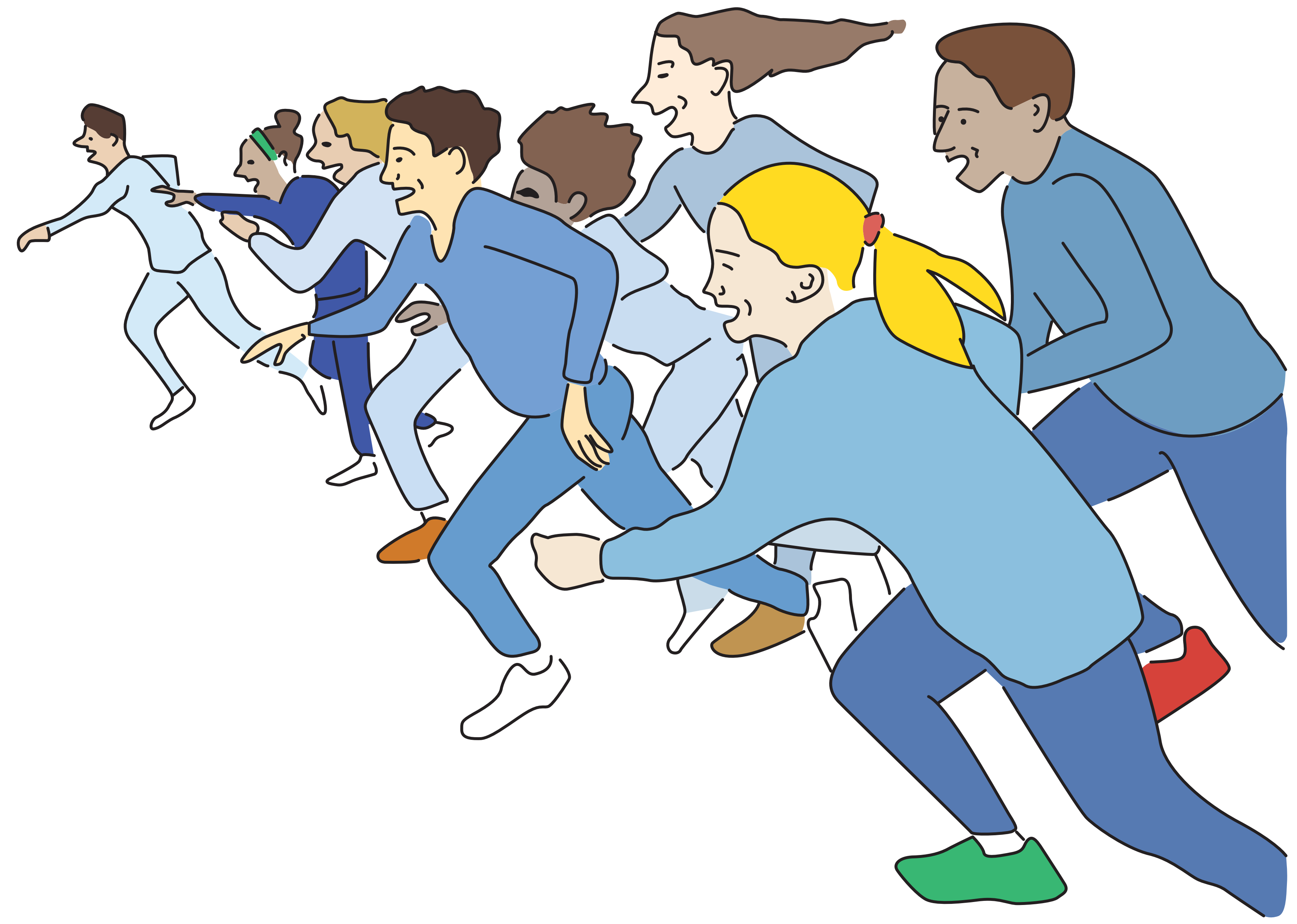

Corrida do portão do museu à porta do ônibus. 


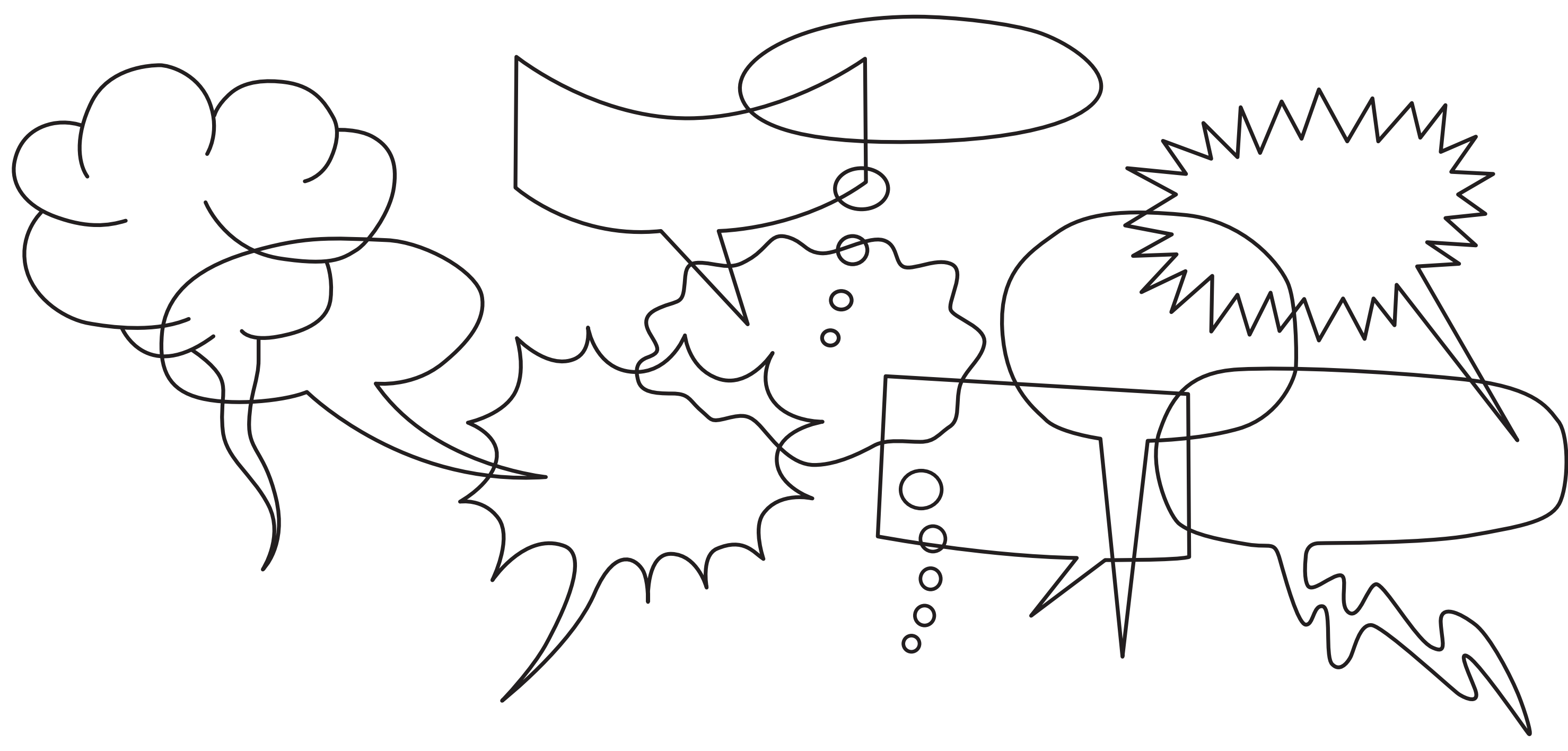

Burburinho no ônibus

A garota lê em voz alta os nomes dos estabelecimentos comerciais que avista pela janela do ônibus: "Letícia Bijoterias, Casa de Carnes Tennessee, Santander, Lavanderia Crispim, Pão de Açucar, Ótica Polux...".

O garoto anuncia em voz alta: "Vou fazer uma mágica...".

Em tom de fofoca, a menina conta para as colegas:

"Minha prima tinha um cabelo enrolado lindo; fez escova, ficou horrível; tentou chapinha, piorou; inventou de fazer progressiva, estragou de vez".

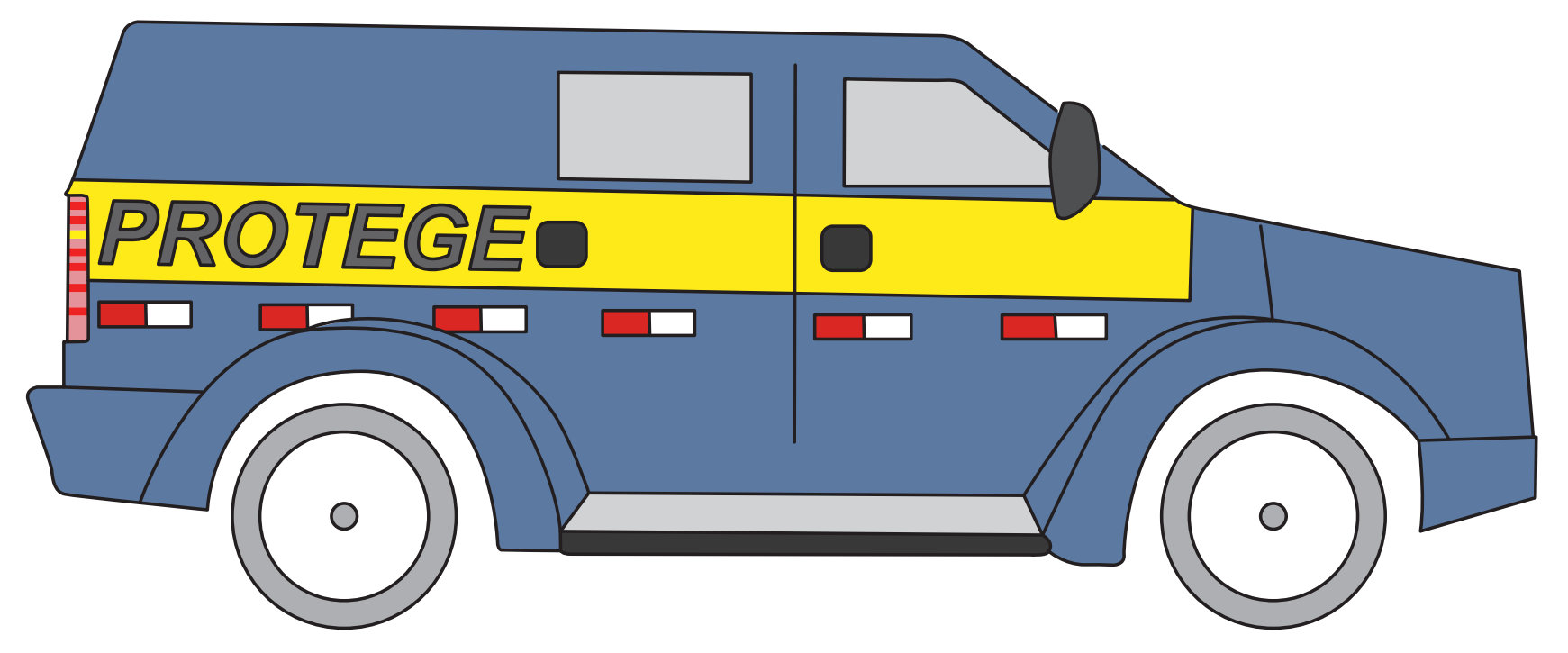

"Olha lá o carro forte... deve ter muita grana lá dentro."

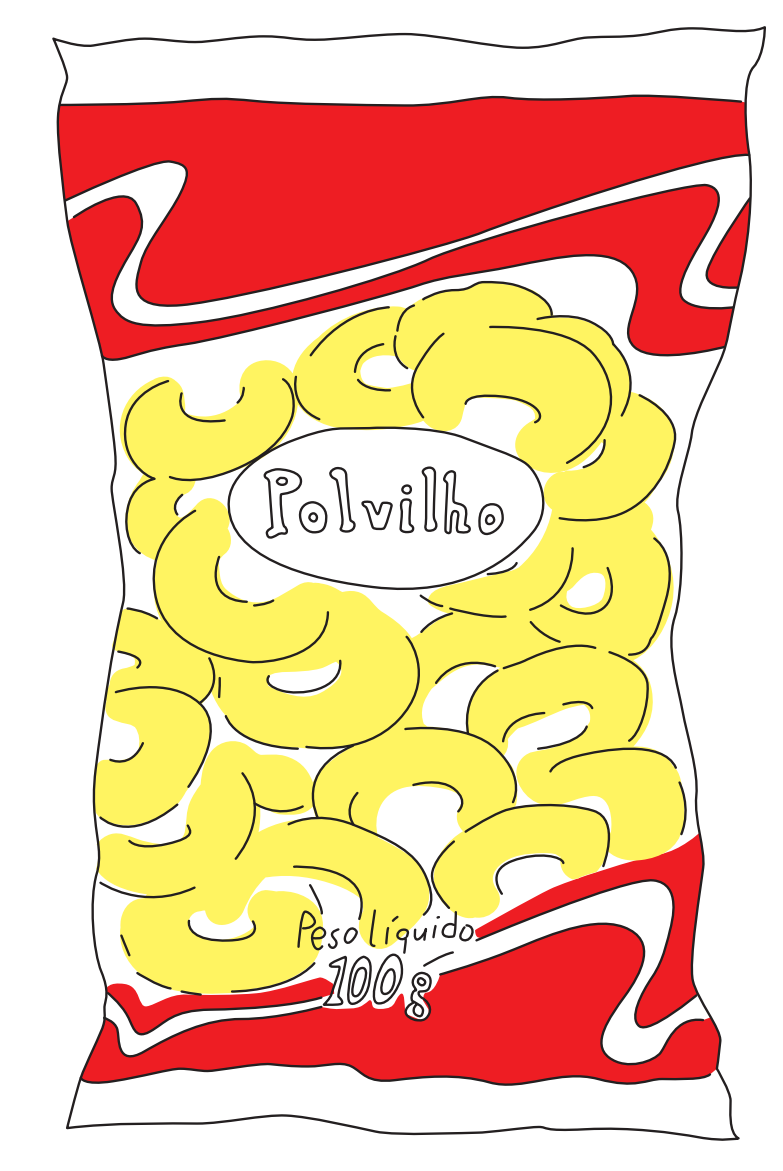

Biscoito de polvilho para segurar a fome do almoço.

O ônibus pode ser uma caixa amplificadora dos resíduos de experiência. 


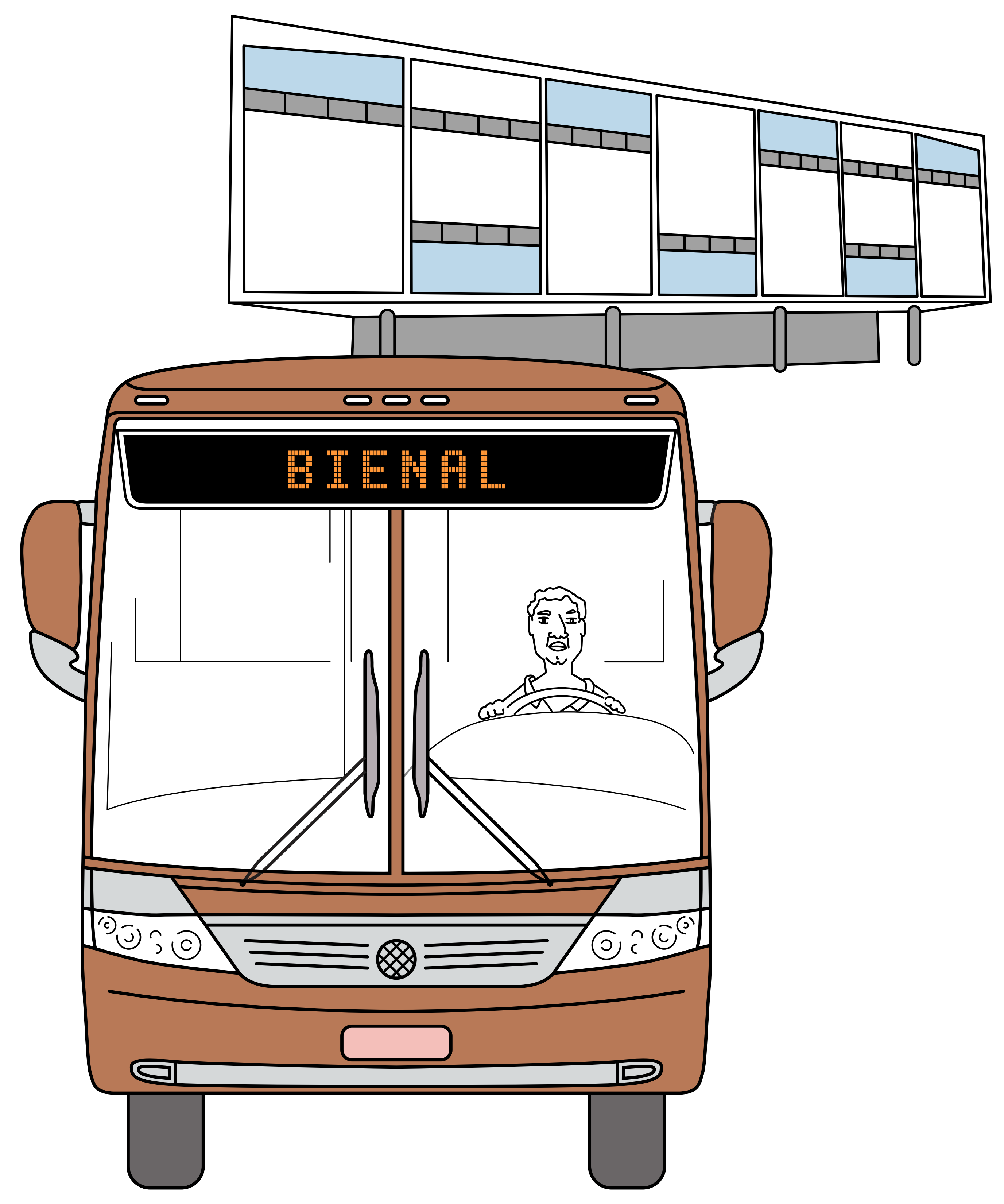


A pichação no muro da escola diz:

"Teu caos ainda é meu cais".

Ao trancar o portão da escola, a inspetora é "repreendida" por um aluno sagaz e brincalhão. Segundo ele, o portão deve permanecer sempre aberto.

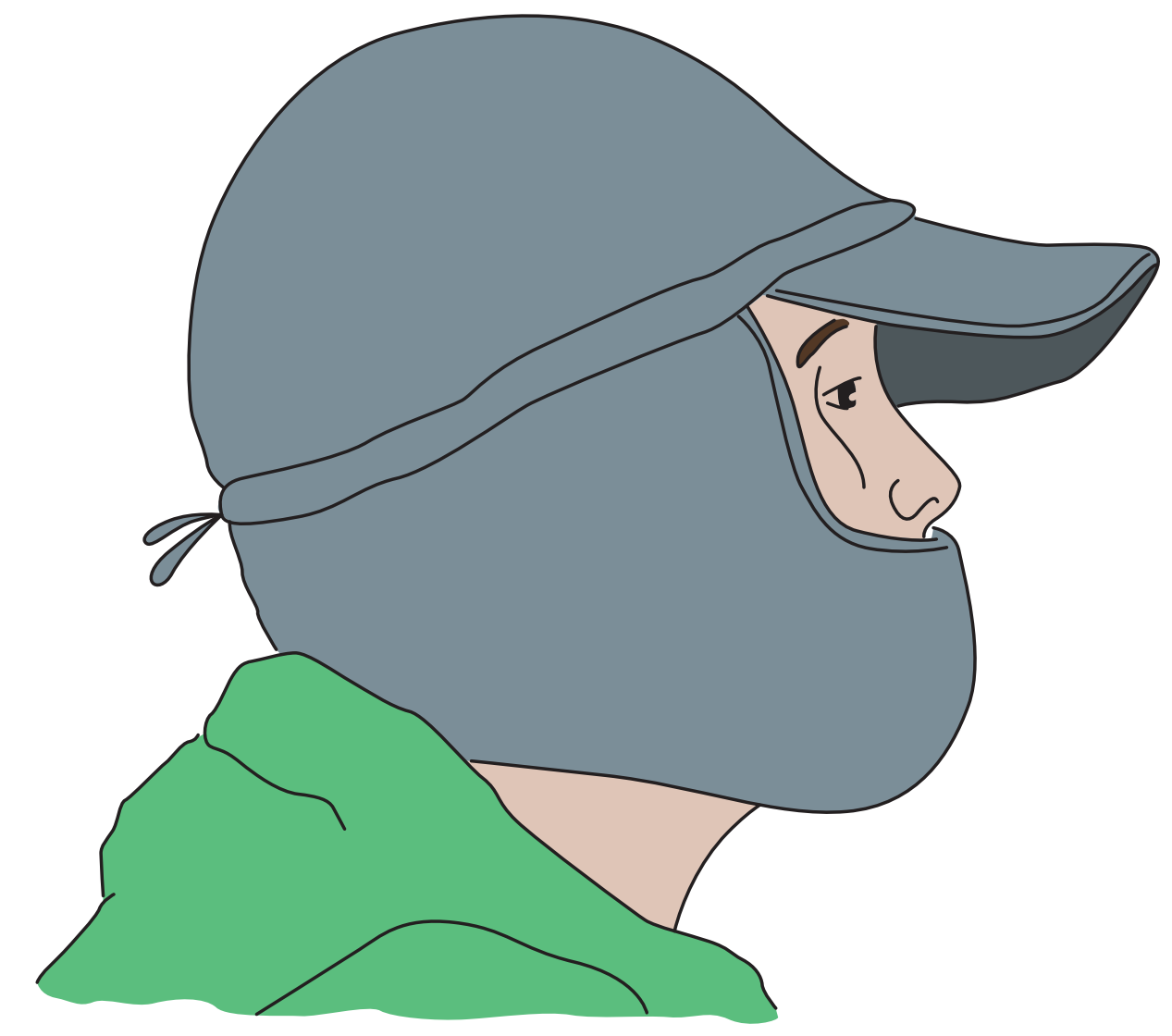

O menino aproveita ofrio da manhã para exercitar o anonimato.

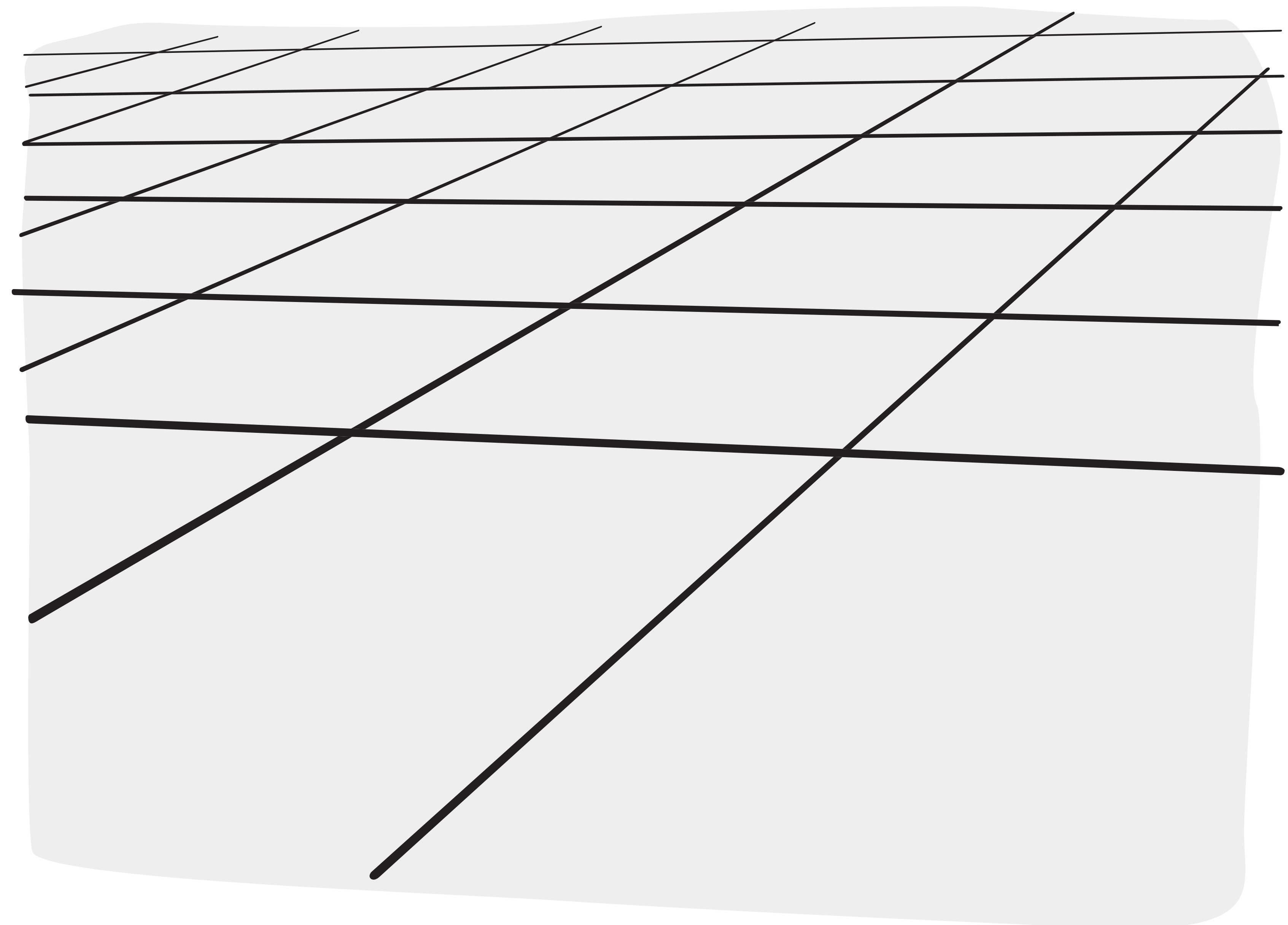

Pátio infinito

No pátio, há crianças correndo, rindo, e adolescentes sentados, conversando. 


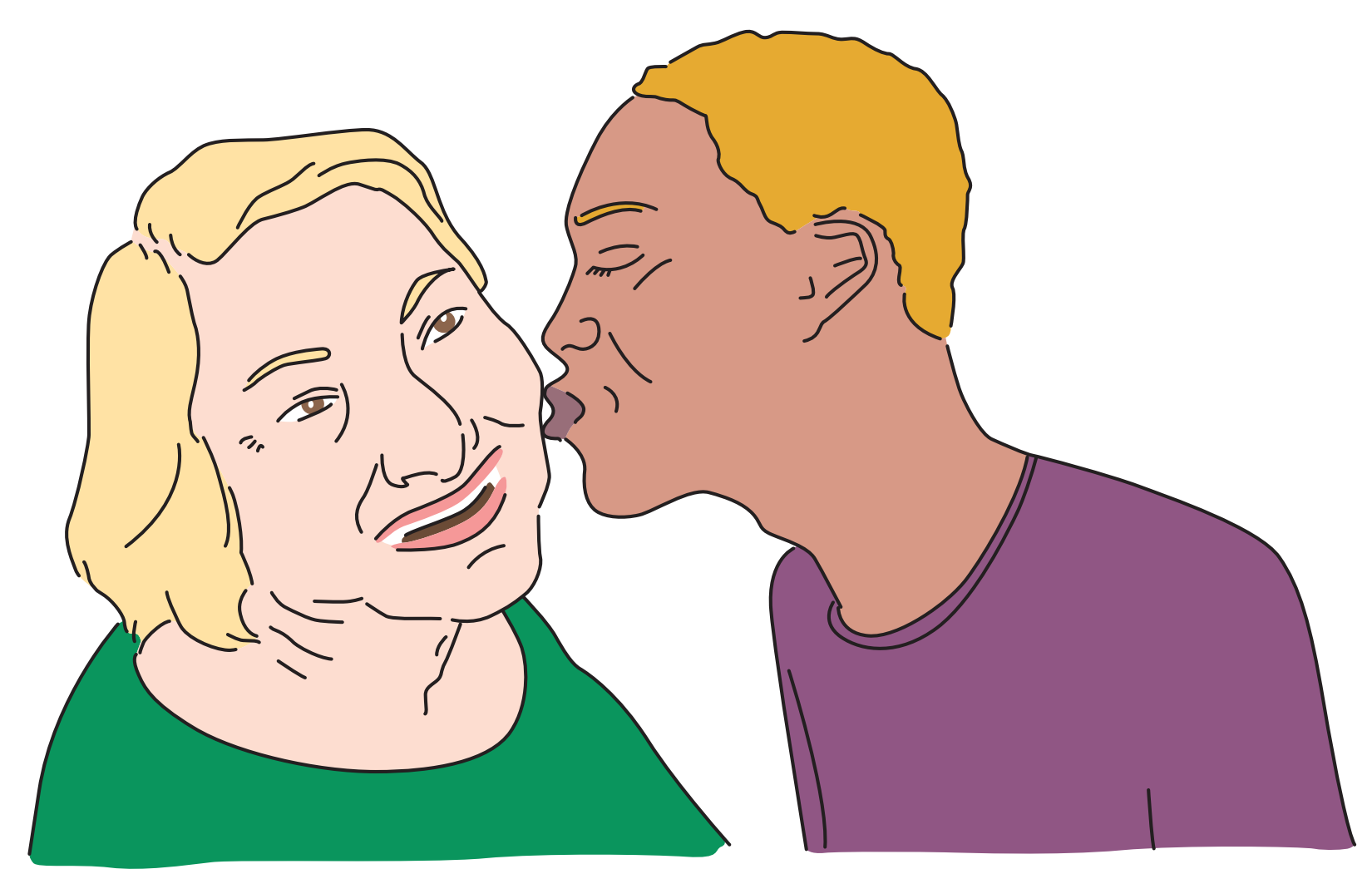

O garoto beija sua professora com gosto.
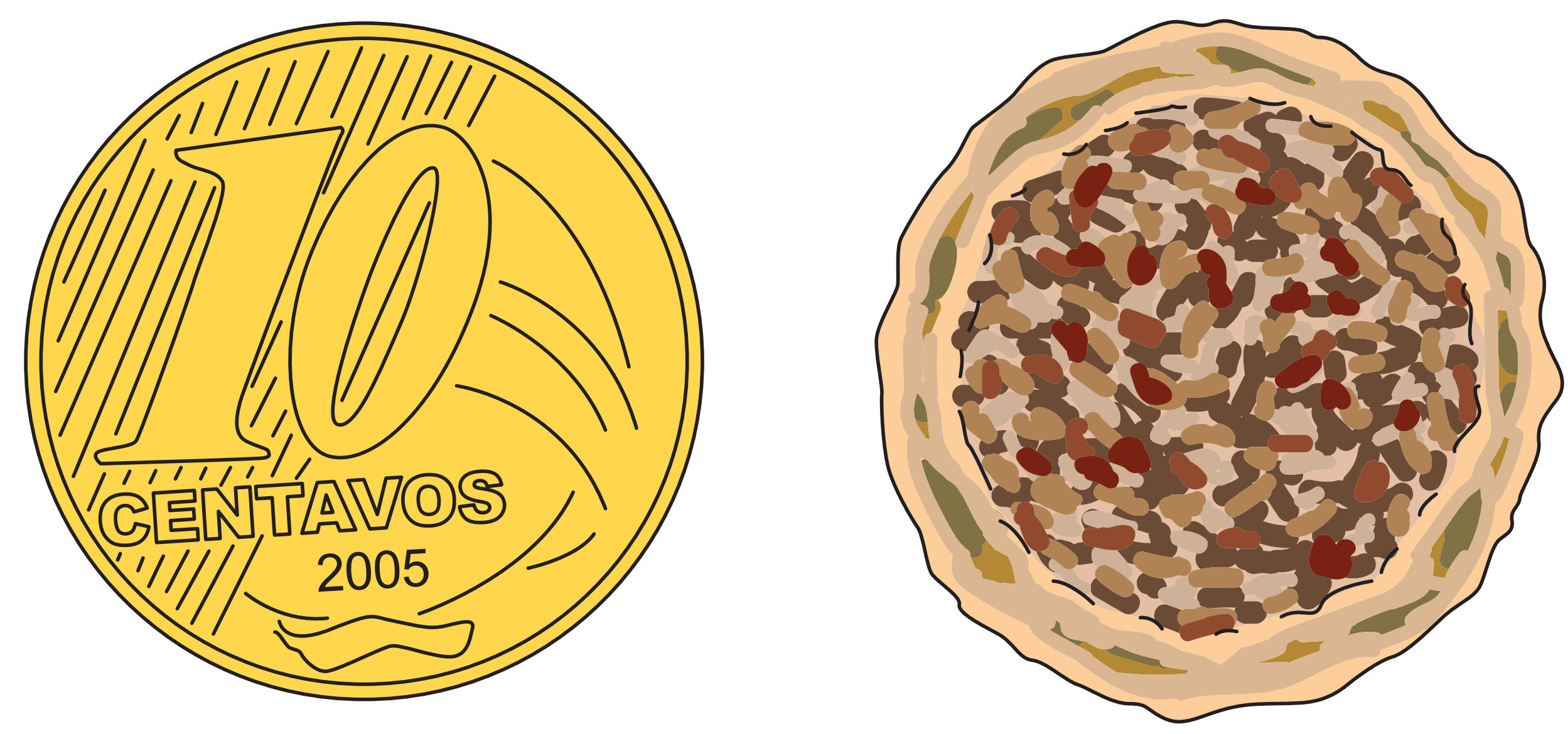

A professora conta que, no ano anterior, havia feito um trato com seus alunos do 8o ano: a cada palavrão que alguém falasse em sala de aula, esse alguém deveria depositar dez centavos num cofrinho, para que no final do ano a turma fosse ao Habib's comer esfirra usando tal poupança.

Ao reproduzir as orientações do motorista do ônibus, a professora comenta com os alunos de maneira bem humorada: "Vejam bem: não pode pôr o corpo pra fora, encher o saco das pessoas na rua e, muito menos, expelir secreções pela janela".
A professora autoriza-se a abrir algumas exceções no esquema de autorizações assinadas pelos pais: como sobraram assentos no ônibus, alguns alunos do $9^{\circ}$ ano são incorporados ao grupo do $7^{\circ}$, à revelia da anuência dos seus responsáveis. 
Assim que o ônibus parte, alguém pergunta: "Como é mesmo o nome da exposição que a gente vai visitar, professora?". Ao que ela responde: "Pelo visto, vocês não fizeram a pesquisa que a gente havia combinado...".

Após revelar que o título da $32^{\mathrm{a}}$ Bienal de São Paulo é "Incerteza Viva", ela provoca os alunos a comentarem o nome da mostra. A garota aceita o desafio e lança de pronto: "A vida é um tabuleiro de incertezas".

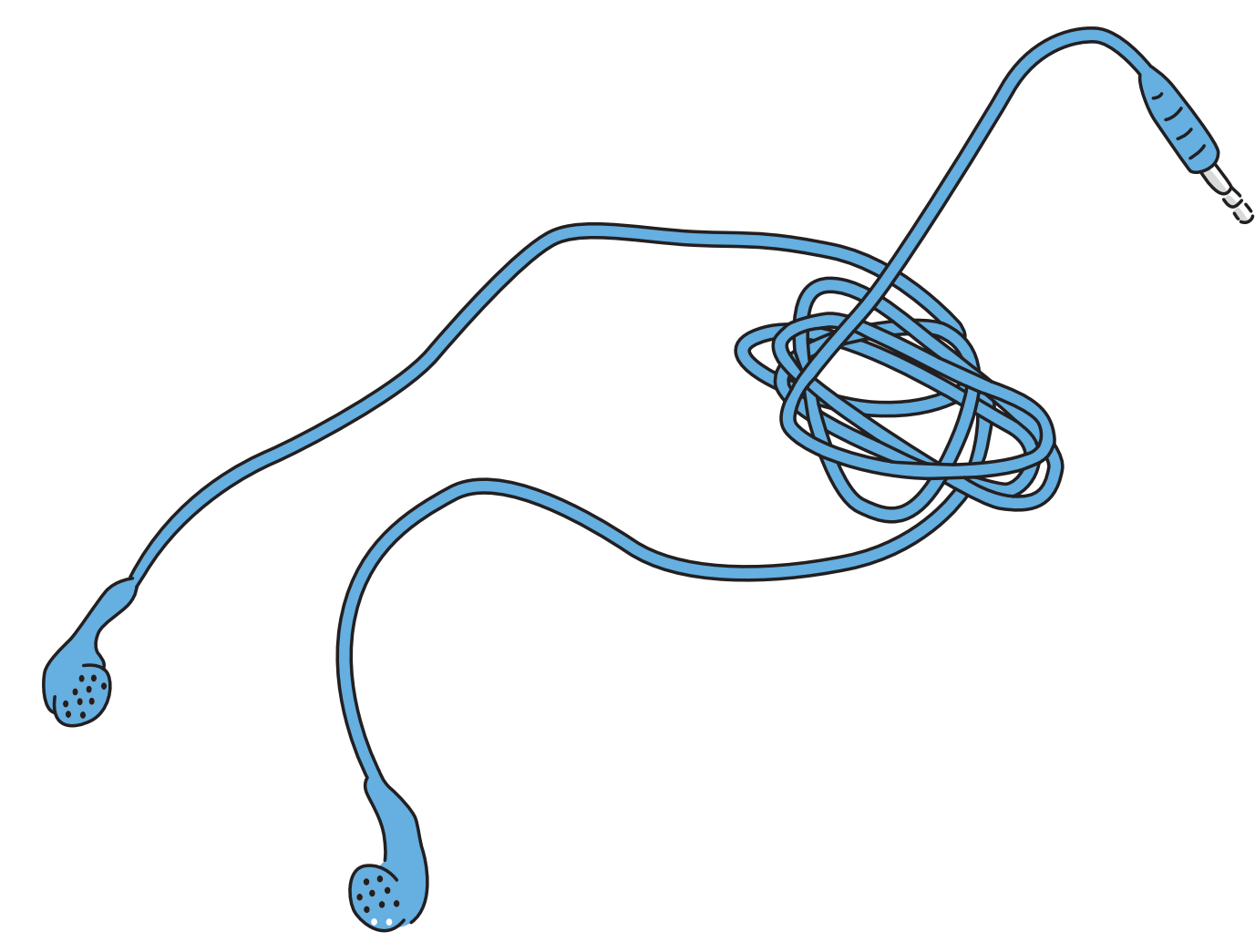

A definição mais pragmática vem de uma garota sentada sozinha: "Certeza que eu fico muito brava quando o fone para de funcionar só de um lado".

Na sequência, outra aluna sentencia:

"Certeza que vou morrer... a incerteza é saber quando e como".

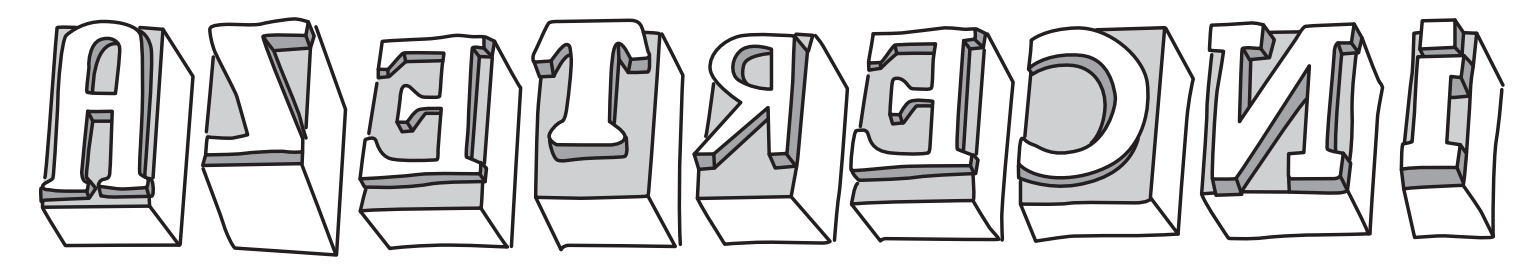

A menina desdenha das incertezas declaradas pelos colegas: "Isso que vocês dizem é tudo clichê".

Para logo completar: "Incerteza mesmo é se eu vou conseguir virar escritora". vocalizada por vários estudantes: "A

incerteza é se eu vou 'passar de ano'".

Das músicas cantadas pelos estudantes no trajeto, o refrão de uma delas se destaca pela crueza:

"Eu vou foder com ela / Muito louco de Selvagem".

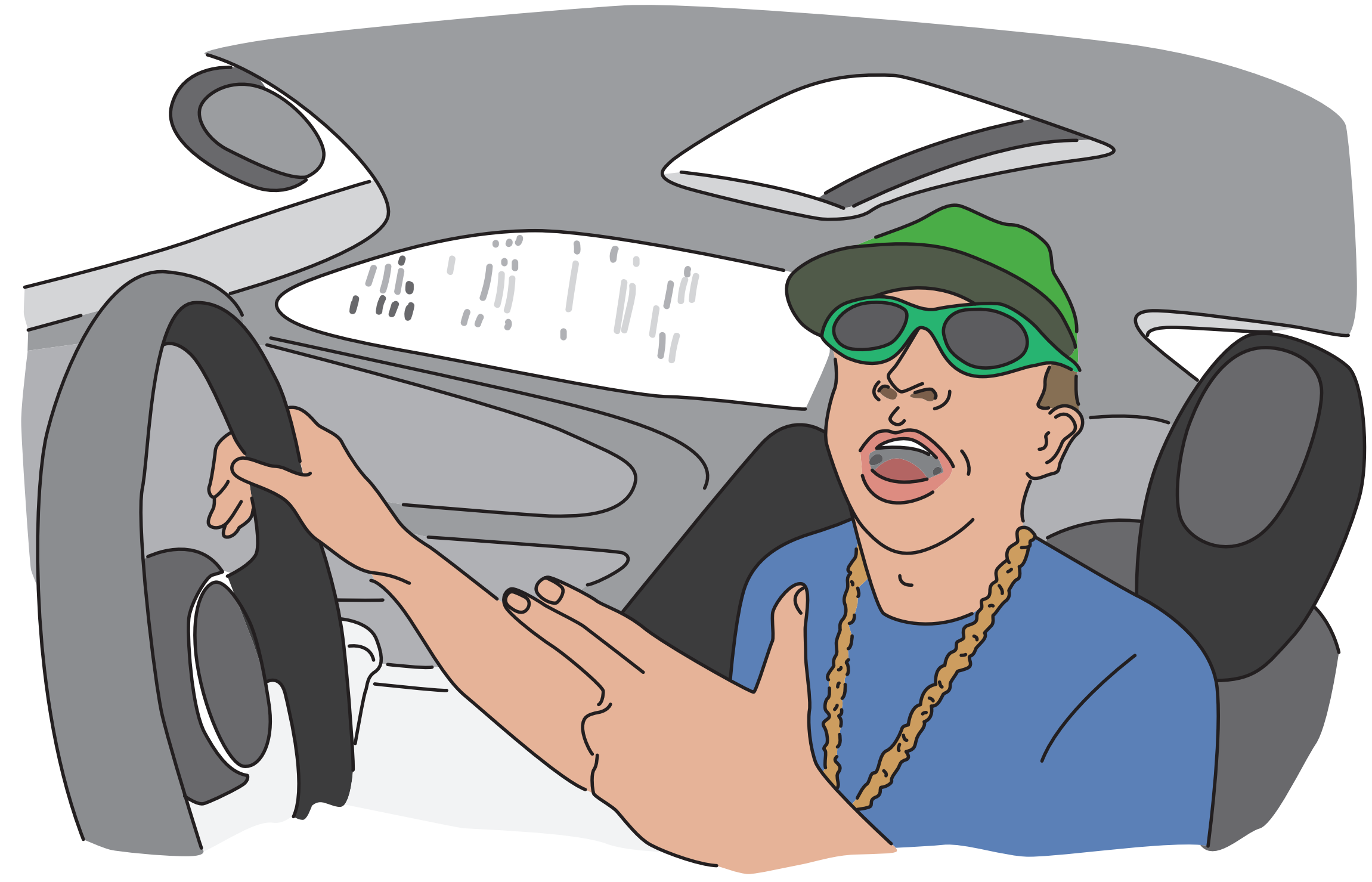

Da poltrona do ônibus, o garoto incorpora a

figura do funkeiro ostentação. 
Assim que o grupo se aproxima do pavilhão, a professora é alertada pelo orientador de público da Bienal: "Procure manter a turma sempre junta".
Há grupos escolares que chegam à

Bienal conduzidos por guias turísticos.
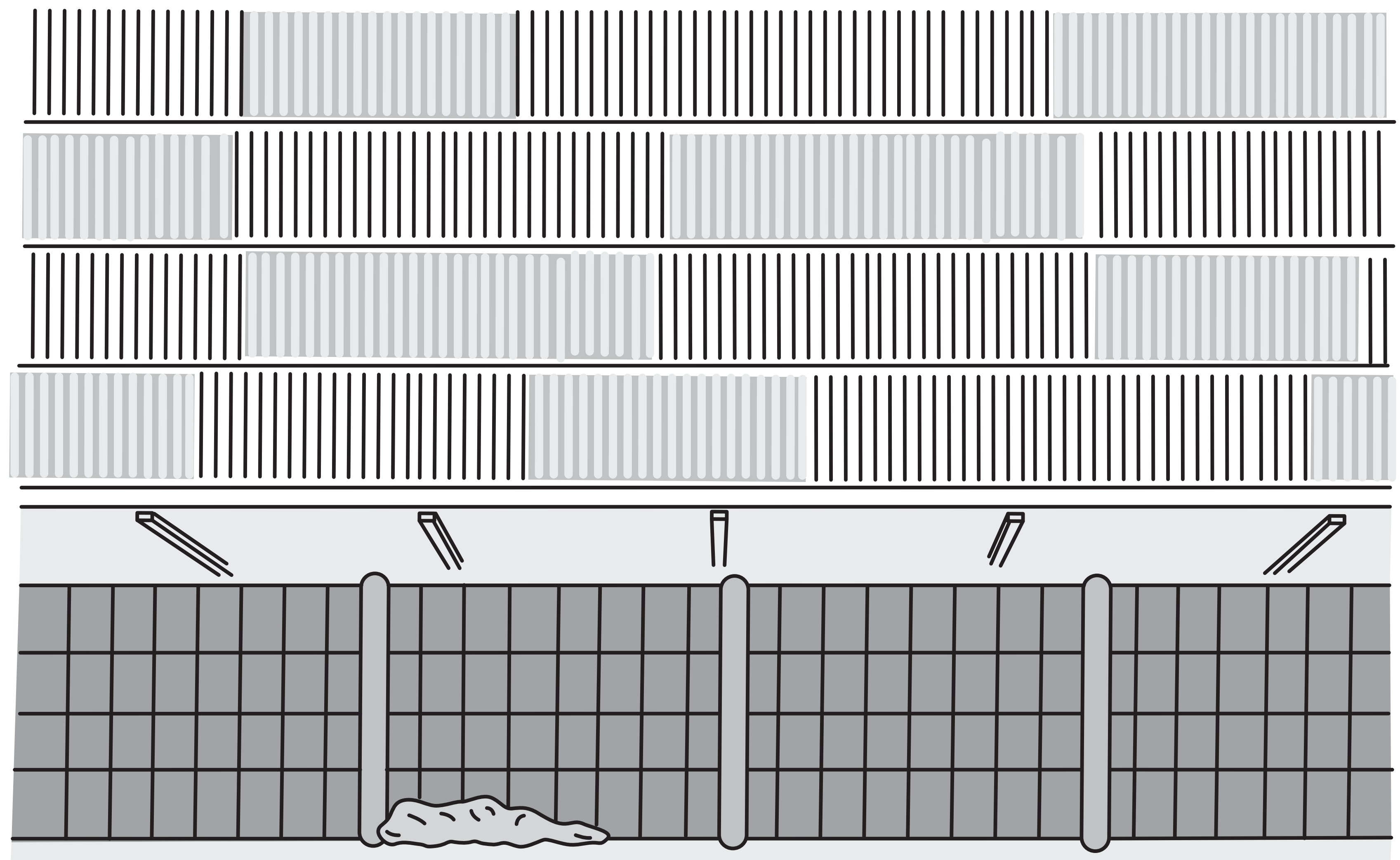

A presença do morador de rua sob a marquise do pavilhão não passa despercebida.

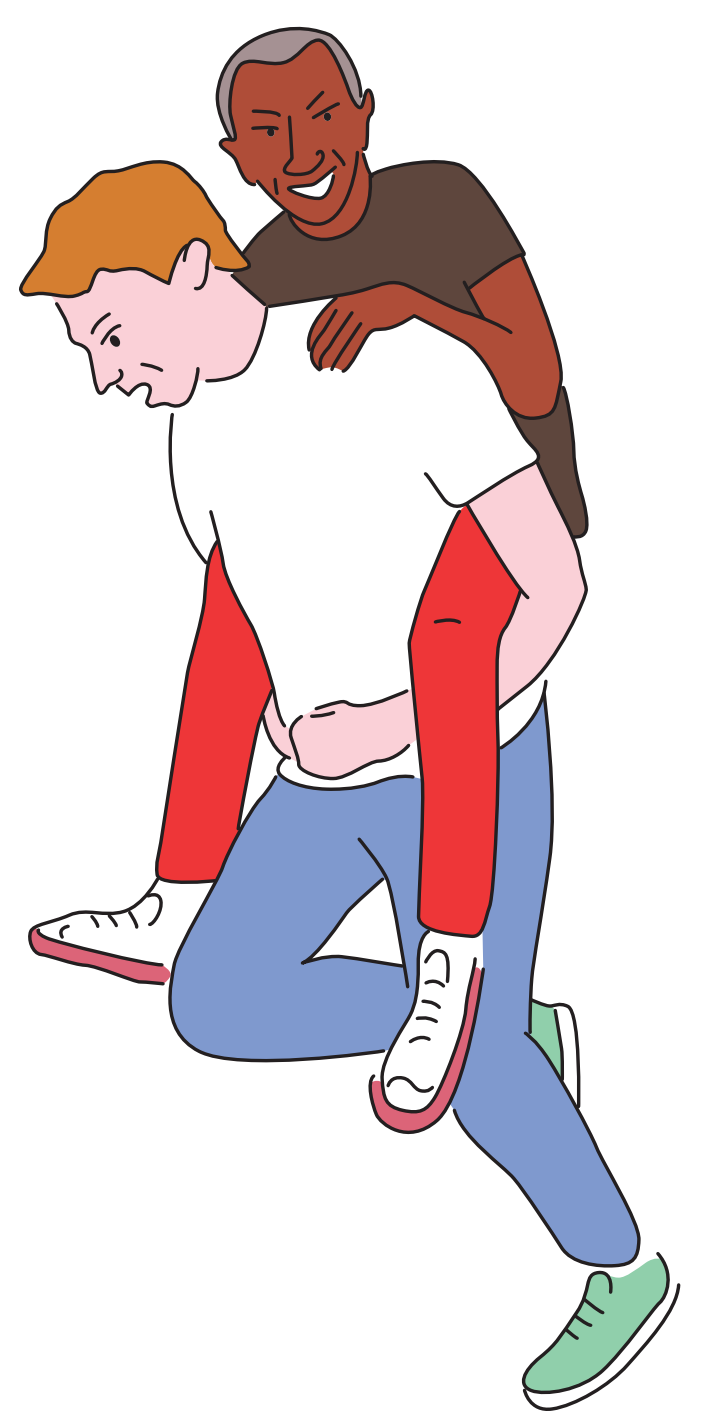

Há dívidas e traumas históricos implicados

no ato de brincar de "cavalinbo". 


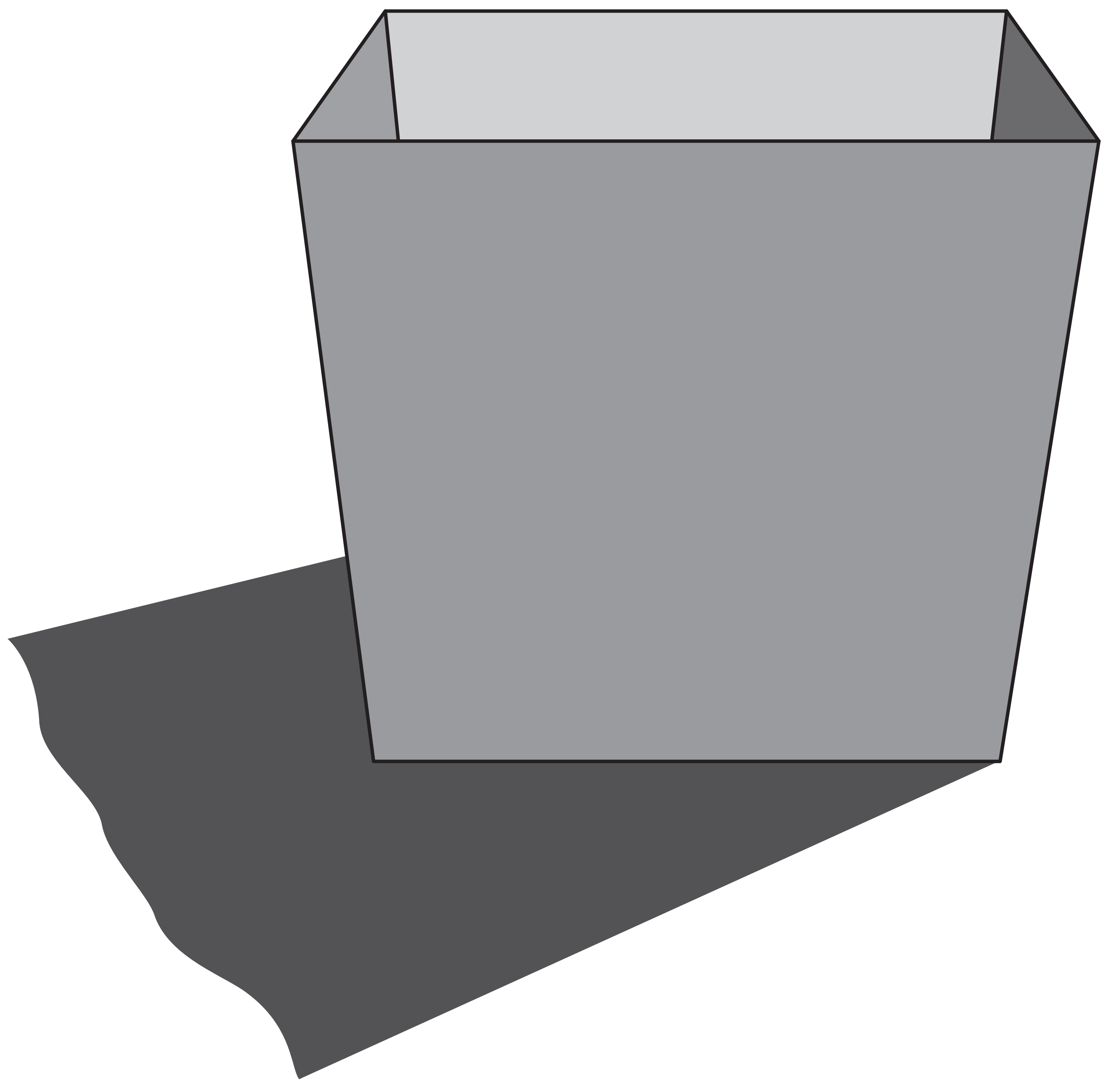

Os estudantes buscam dispensar o lixo gerado pelos biscoitos e bebidas consumidos no ônibus, quando se deparam com um enigma em aço inox na marquise do pavilhão. 


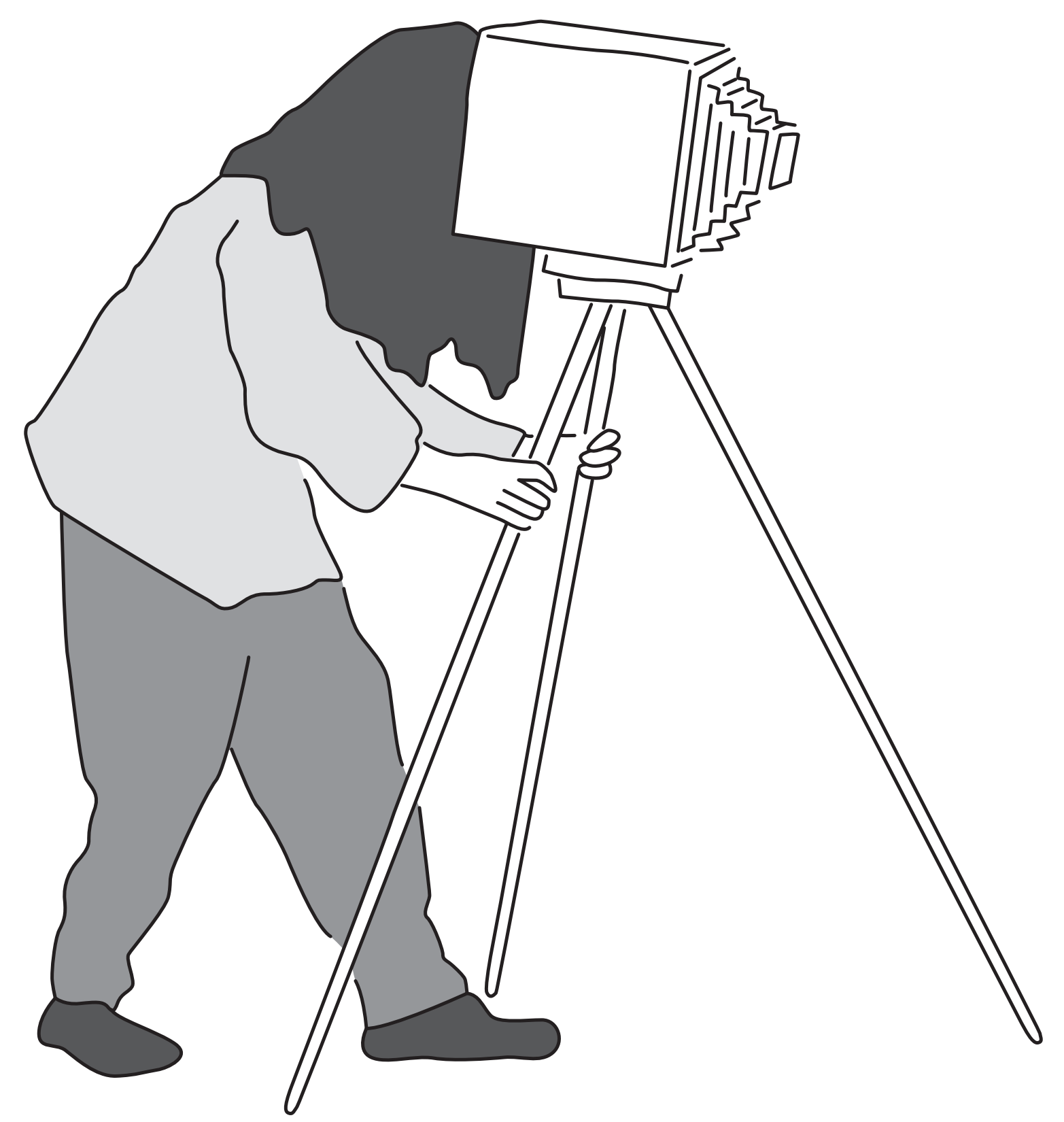

Sou solicitado para tirar uma foto do grupo.

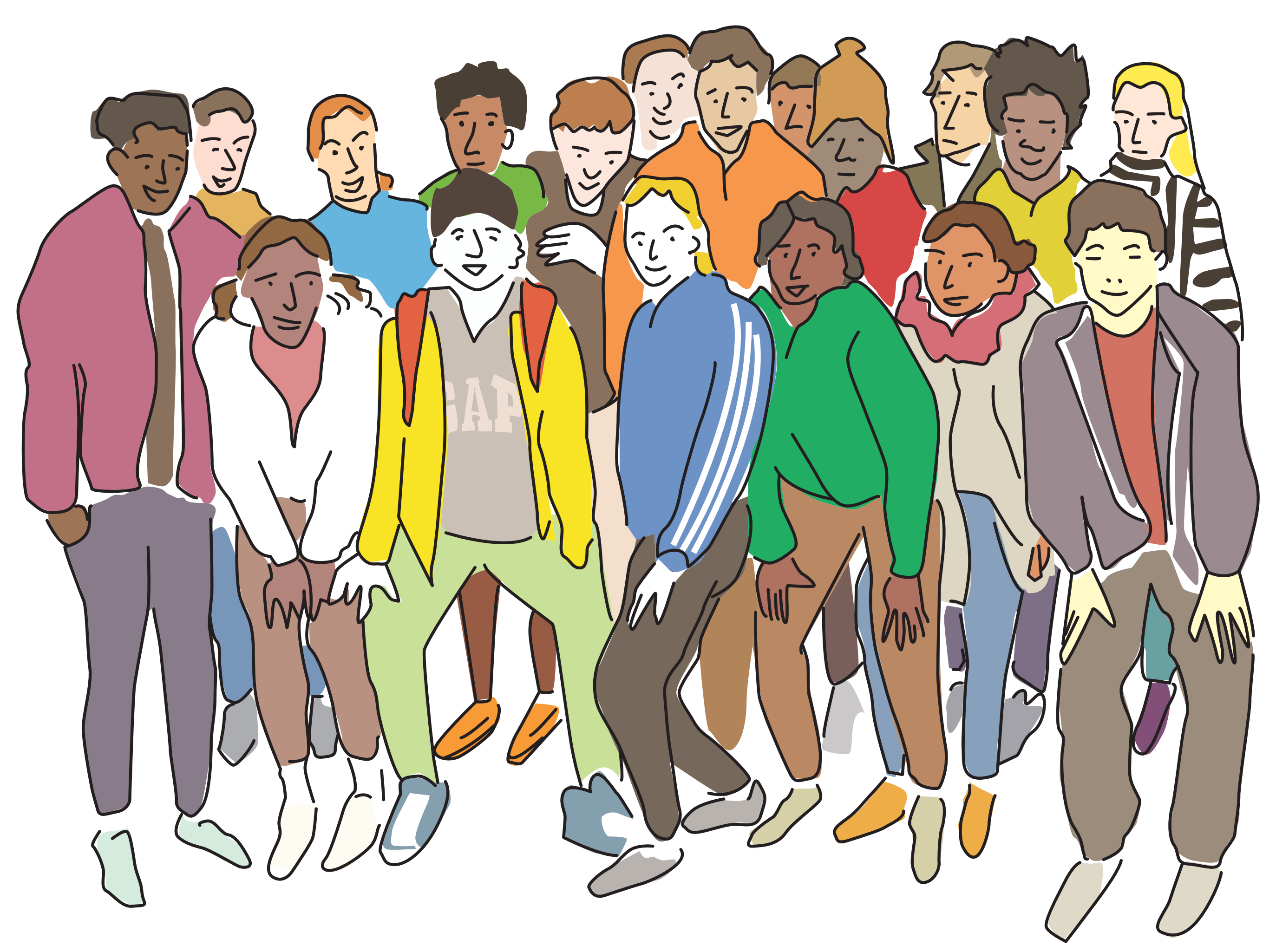




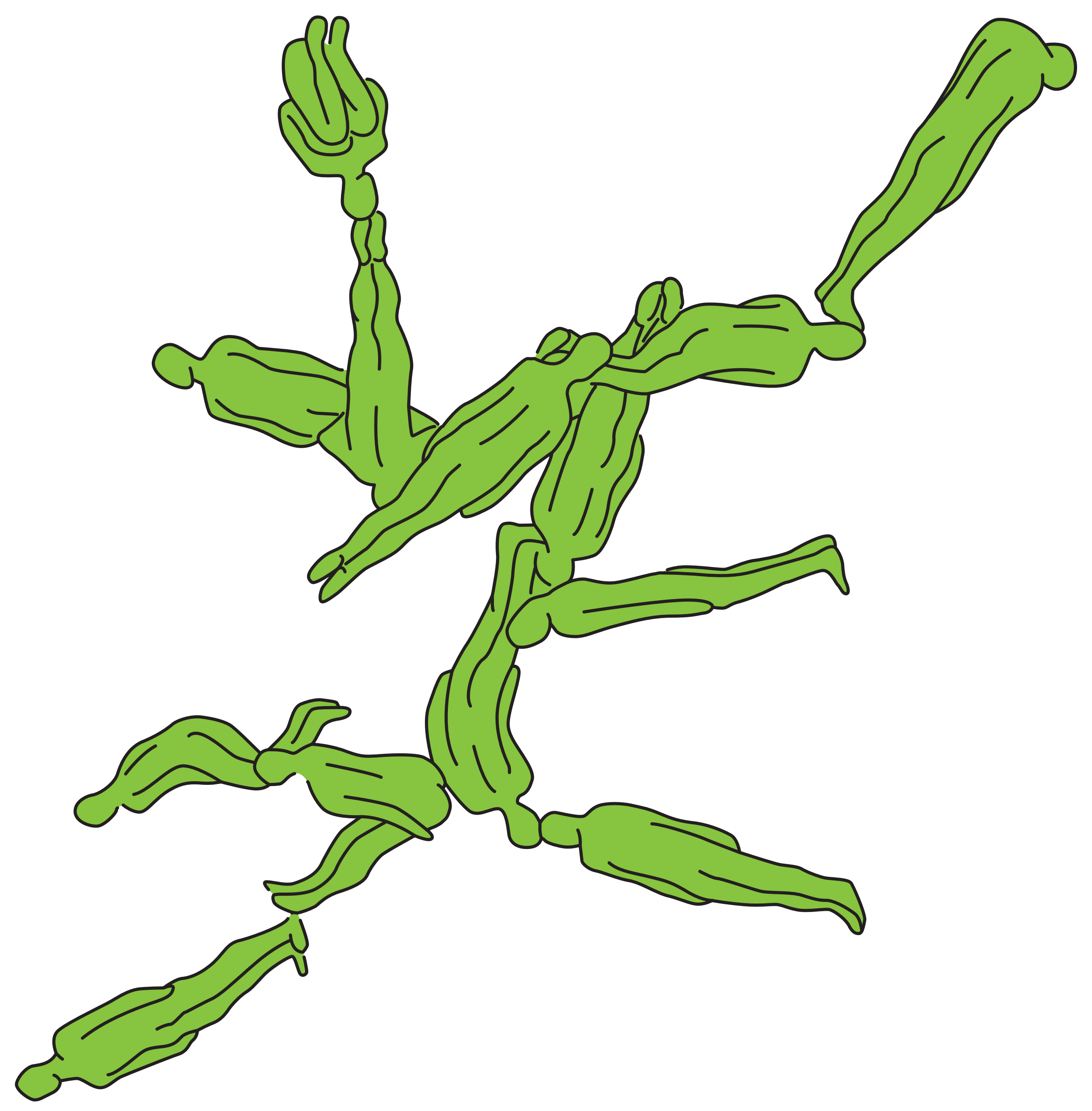

Enquanto aguardamos o mediador aparecer para iniciar a visita, a galera brinca de fazer rizoma no gramado.

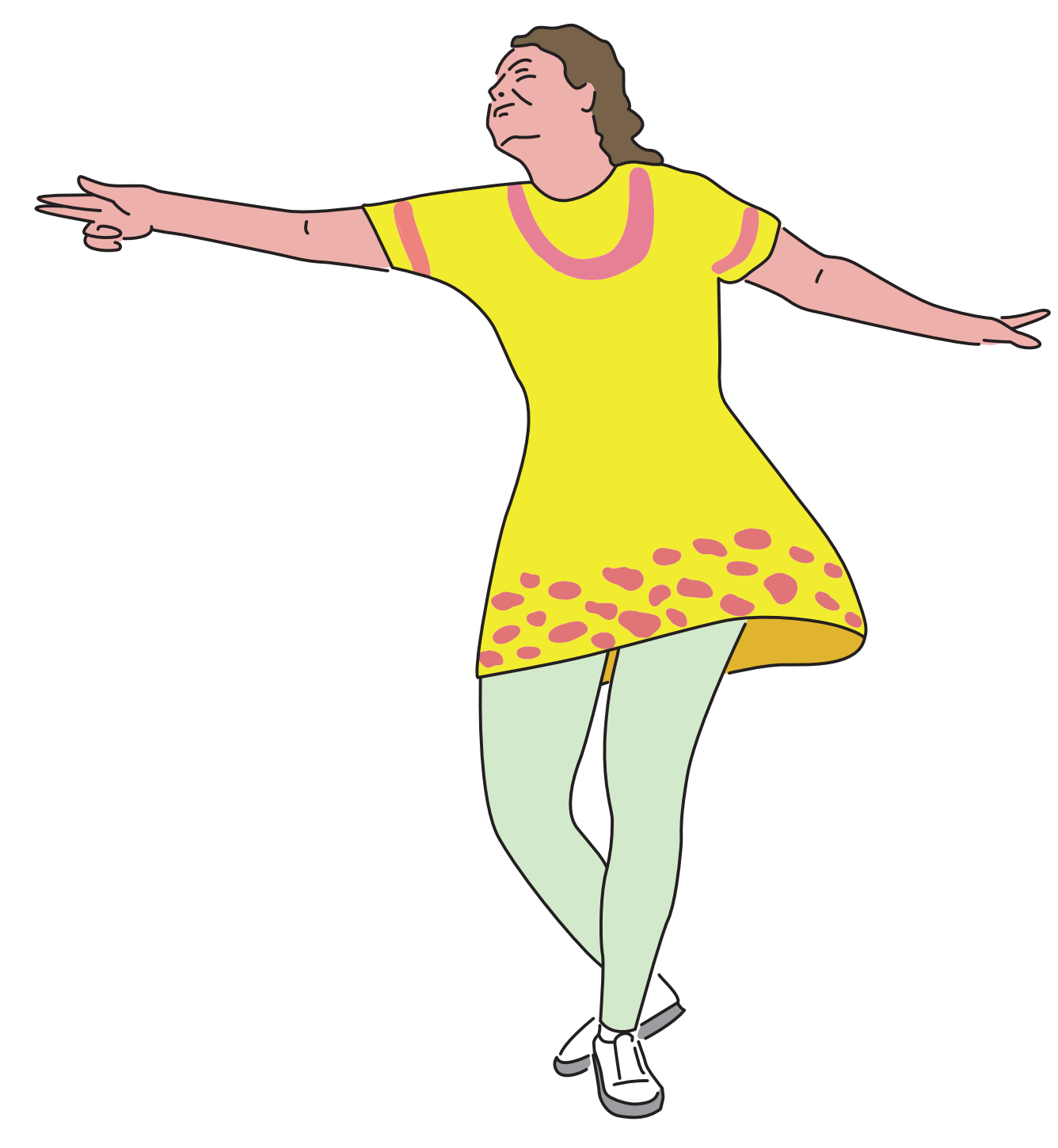

Girando ao vento no Ibirapuera.

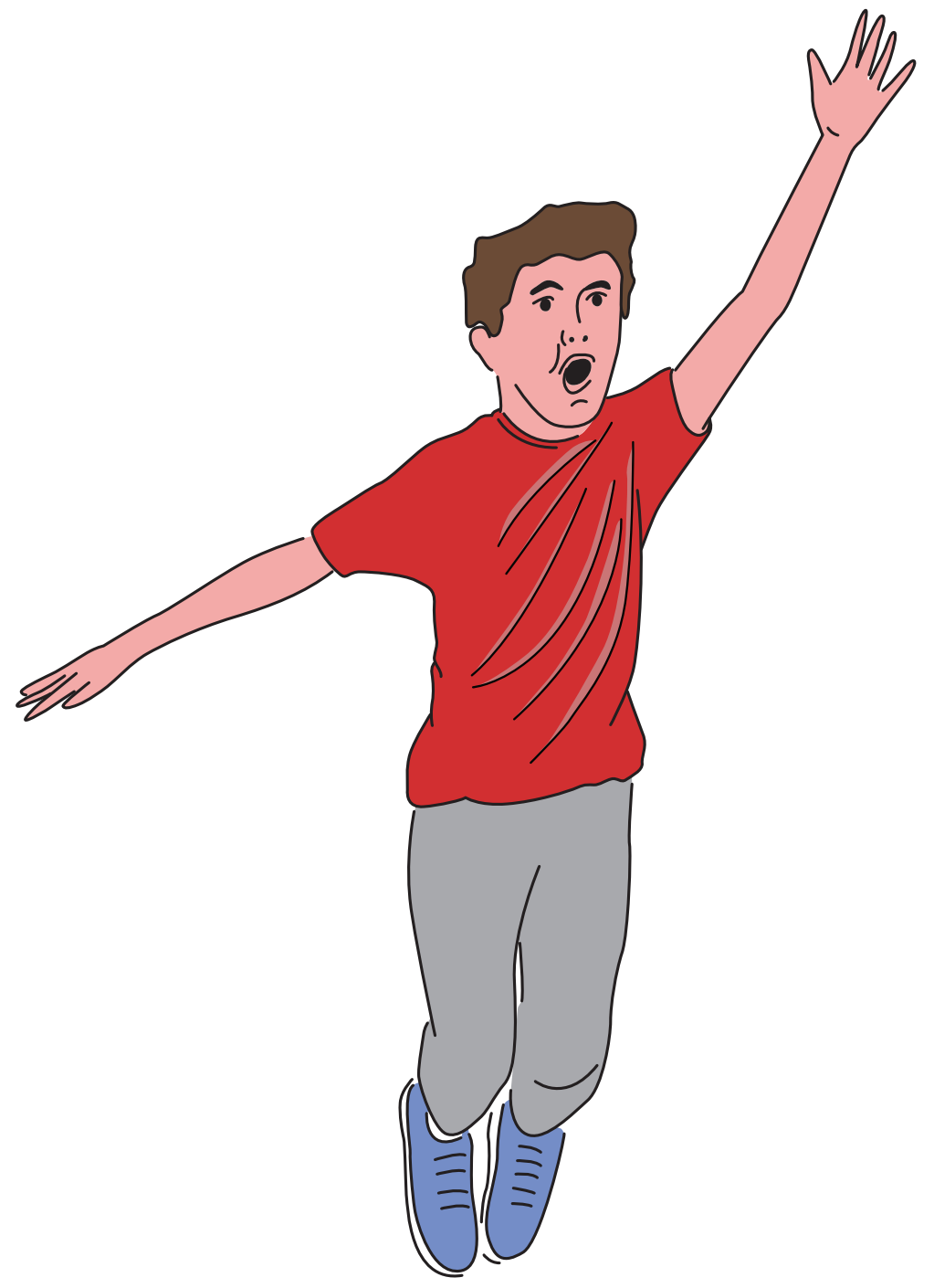

Brincando de fracassar, o garoto tenta tocar o teto do pavilhão. 


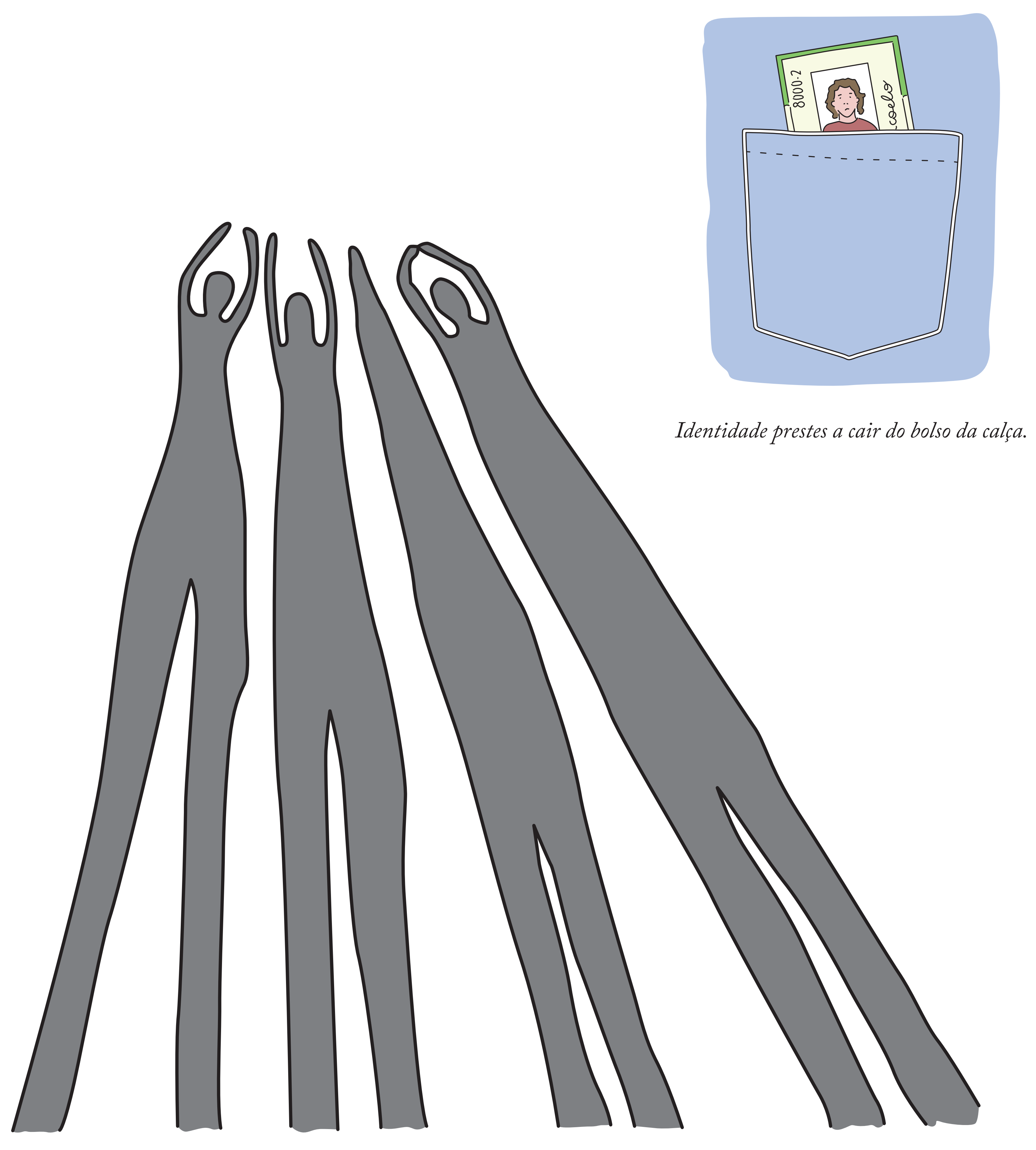

Alguém aproveita a sombra projetada na rampa interna do pavilhão para se desantropomorfizar.

Durante o acolhimento do grupo, o mediador propõe que os estudantes respirem durante um minuto, contando cada segundo mentalmente.
$\mathrm{Na}$ ida ao banheiro, alguns garotos resolvem arruaçar, a ponto de um deles ficar de pé sobre o vaso sanitário.

Prontamente, um funcionário intervém: "Desce daí, mano!". 
O mediador pergunta ao grupo: "Vocês estão acompanhando a situação política do país? Têm visto algo na TV?". Ao que a menina responde de forma ríspida: "TV?! A TV é mentirosa".

Após a observação das peças reunidas na instalação Volta ao campo, de Ruth Ewan, os estudantes são instados pelo mediador a falar sobre suas impressões acerca da obra. A essa solicitação o garoto interpõe outro pedido: "Antes, você poderia falar um pouco mais sobre o trabalho, pra gente entender melhor o contexto dele?".

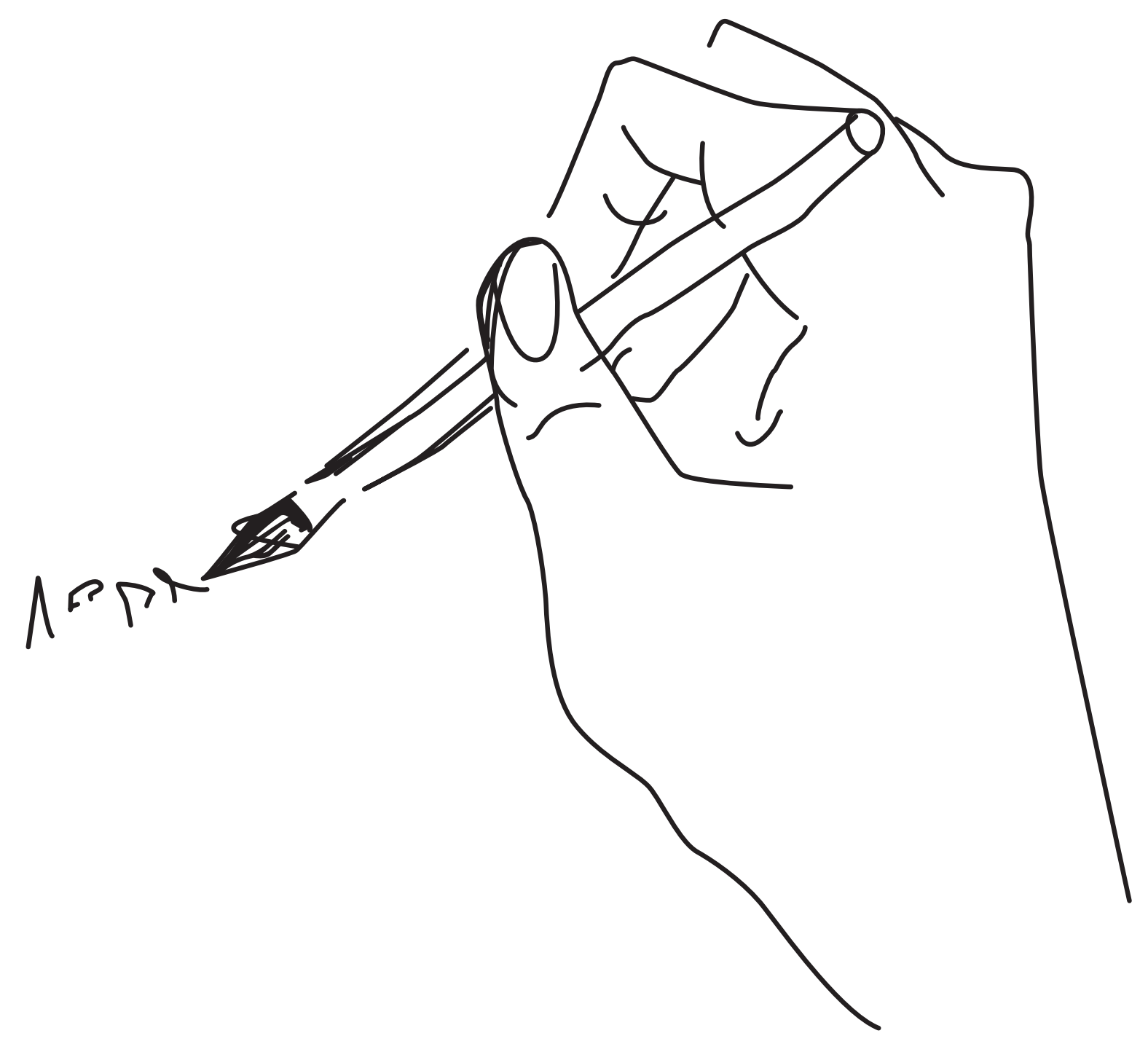

Desenho-espera: como forma de ocupar o tempo necessário para a liberação da concorrida instalação $\mathrm{Na}$ forma de nós mesmos, de Rita Ponce de León, somos convidados pelo mediador a fazer um desenho alusivo a algum tipo de movimento dos membros do nosso corpo.

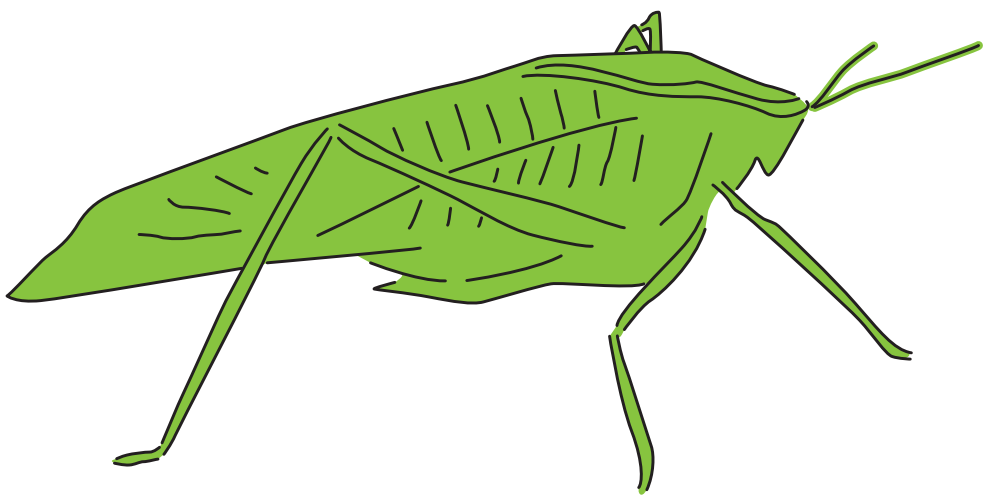

Quando nenhuma resposta vem ao encontro da pergunta, pode-se ouvir o som do grilo ao fundo.

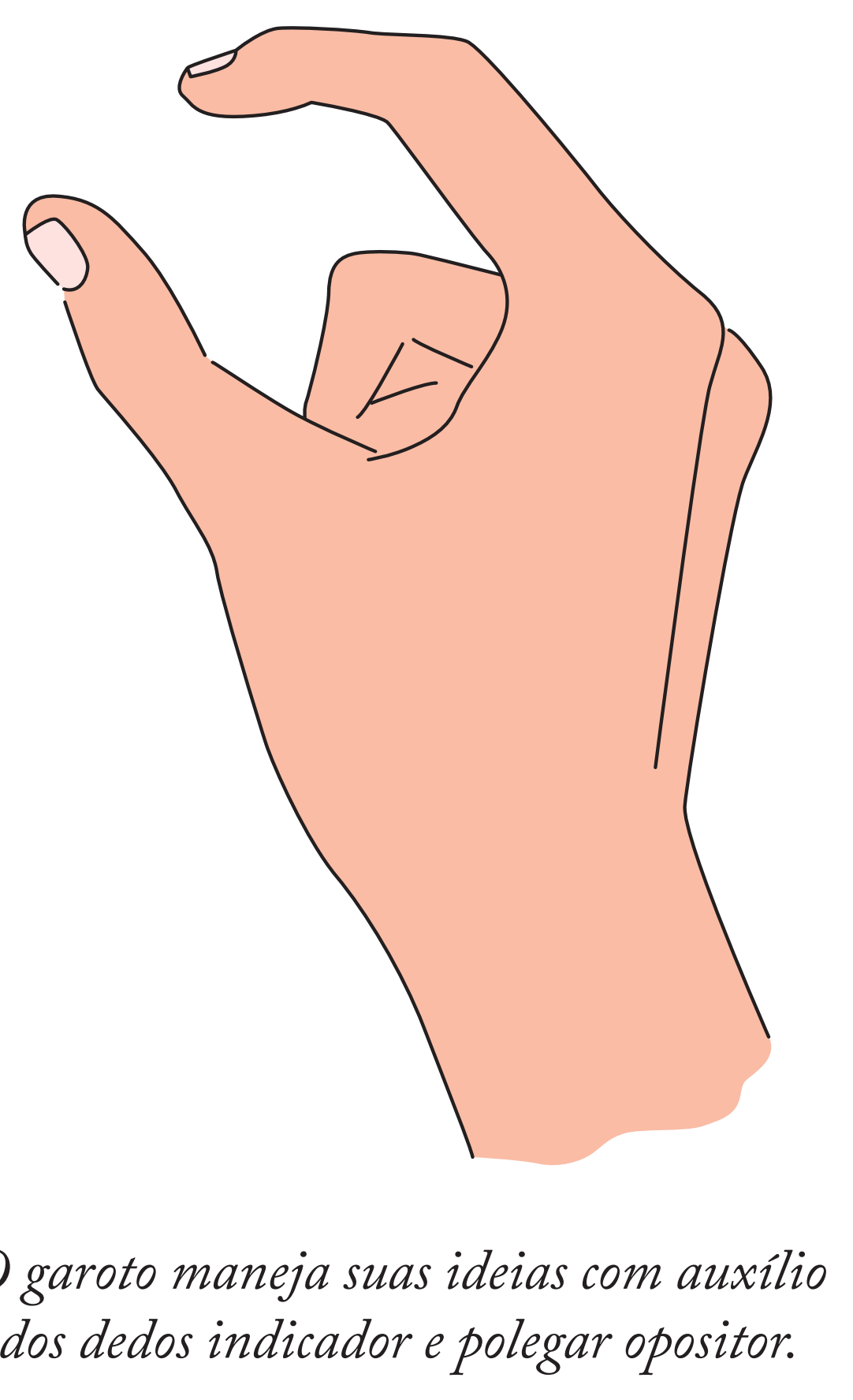

Ao entrar na instalação de León, o garoto parodia: "Essa é uma casa muito engraçada, não tem teto, não tem nada: só barro".

A garota manifesta uma curiosidade prática em relação às obras em exposição: "Como foi que tudo isso chegou até aqui?".

Um visitante se aproxima de mim e pergunta: "Você sabe se a visita guiada é paga?". 
Chegando ao primeiro andar do pavilhão, topamos com um pequeno grupo de jovens imbuídos de um ensaio visual clandestino. Eles utilizam seus celulares e as notas e moedas que trazem em suas carteiras, registrando em vídeo a cascata de dinheiro que fazem cair diante da logomarca do Banco Itaú, distribuída por todo o pavilhão sob a forma de estampa aplicada em "assentos publicitários".

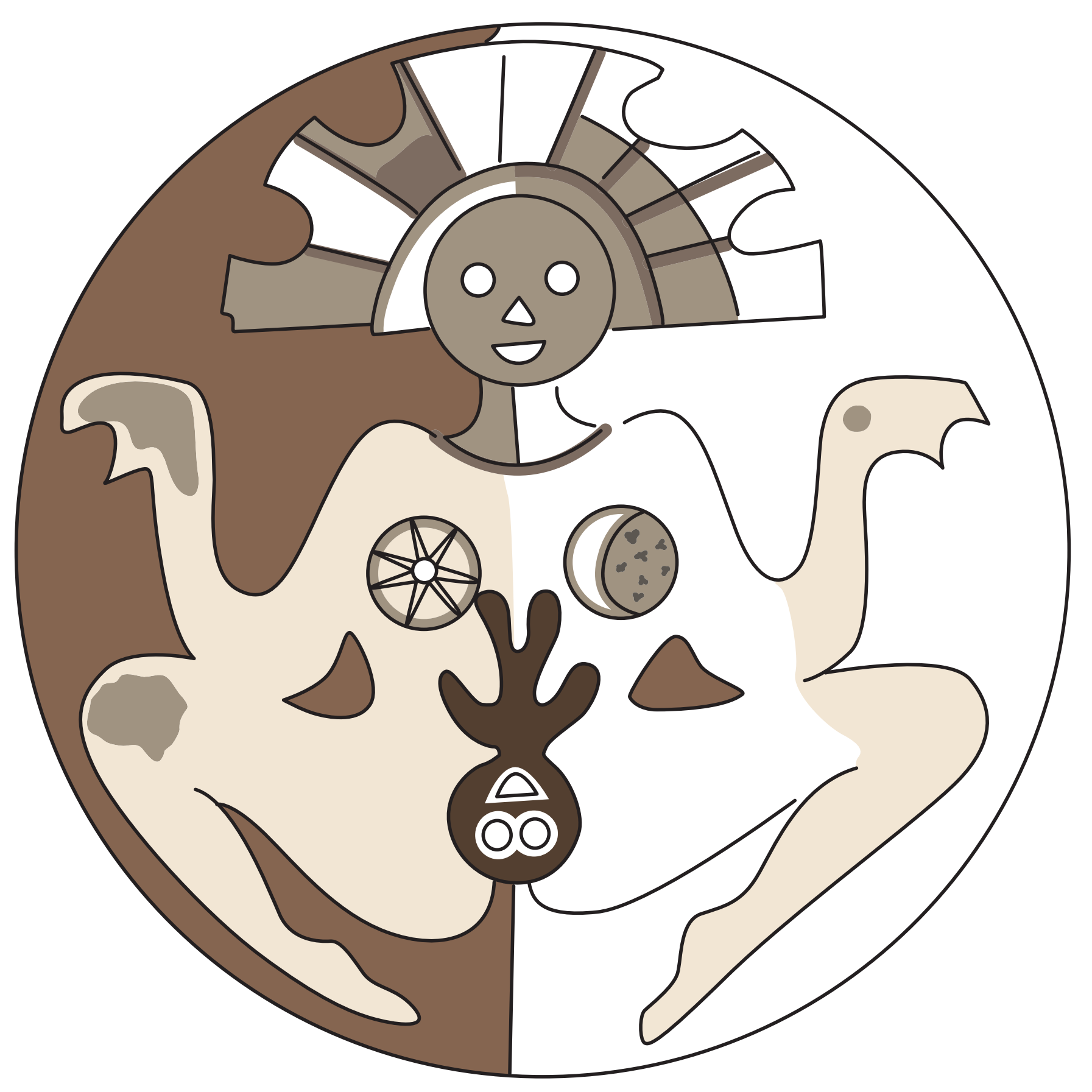

Ao escutar o mediador falando sobre Pachamama, a professora procura se localizar: "Ah, é a Nossa Senhora deles...".
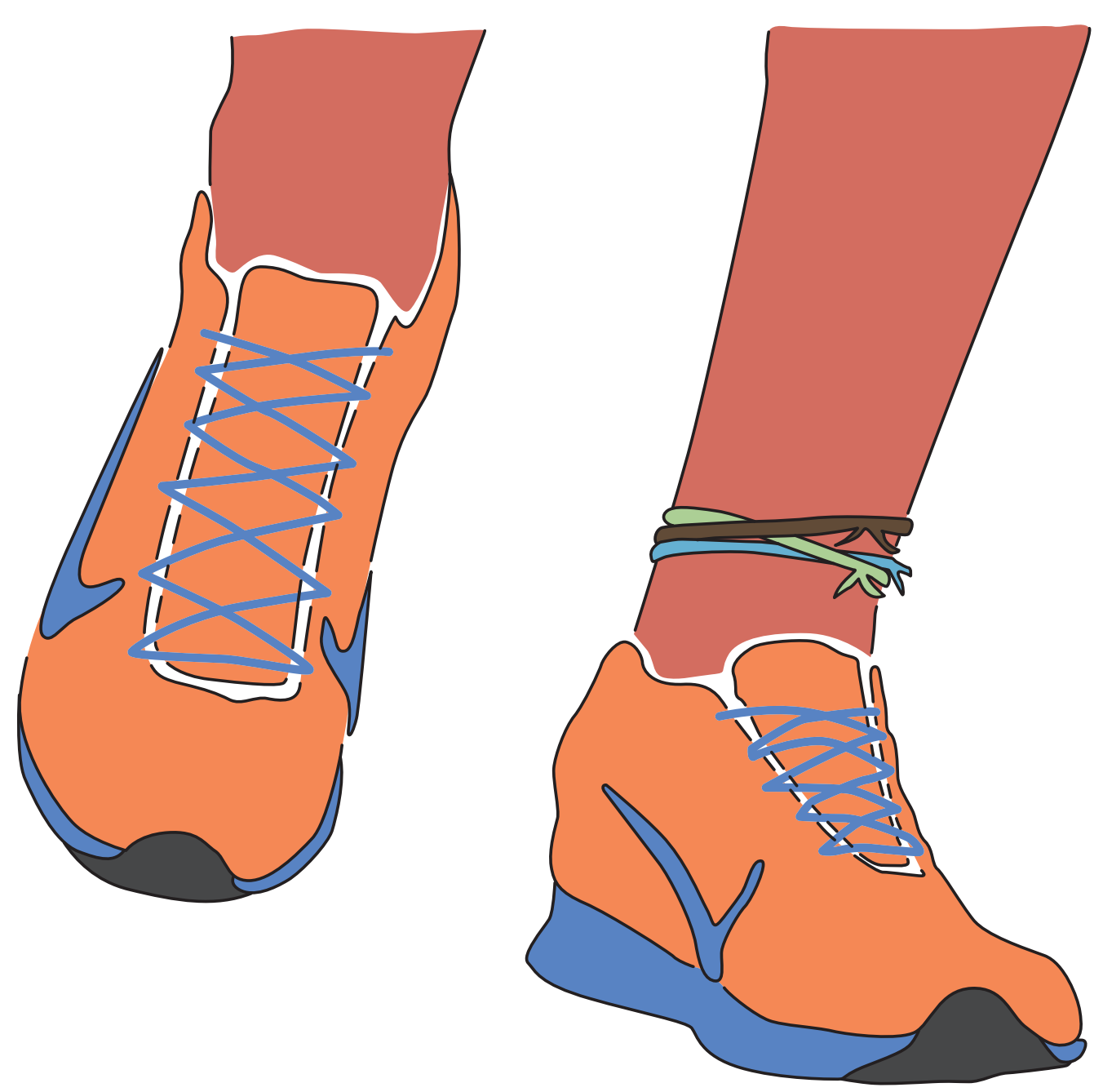

Fetiches

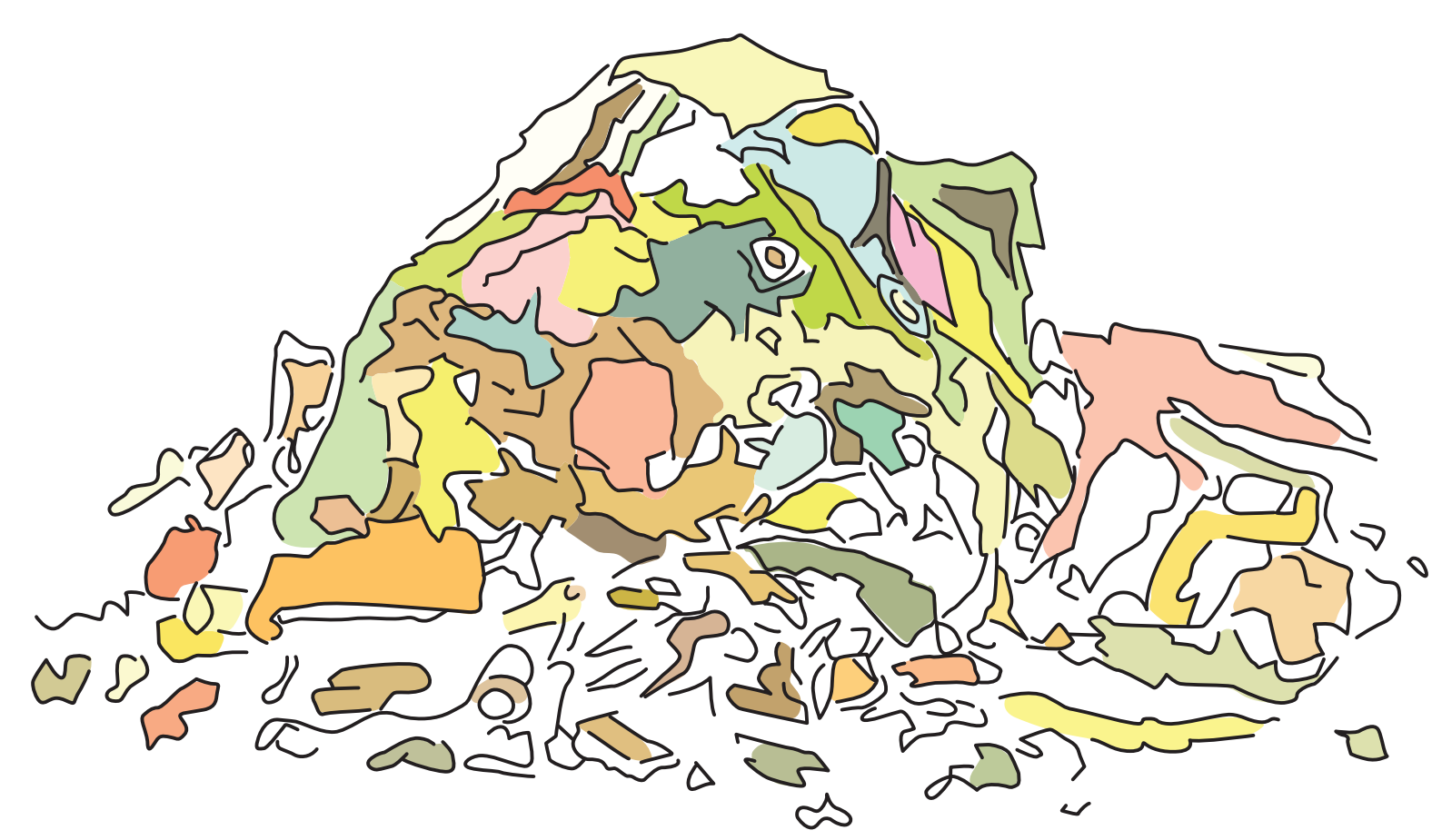

A garota constata: "O ser humano é o único animal que produz lixo". 

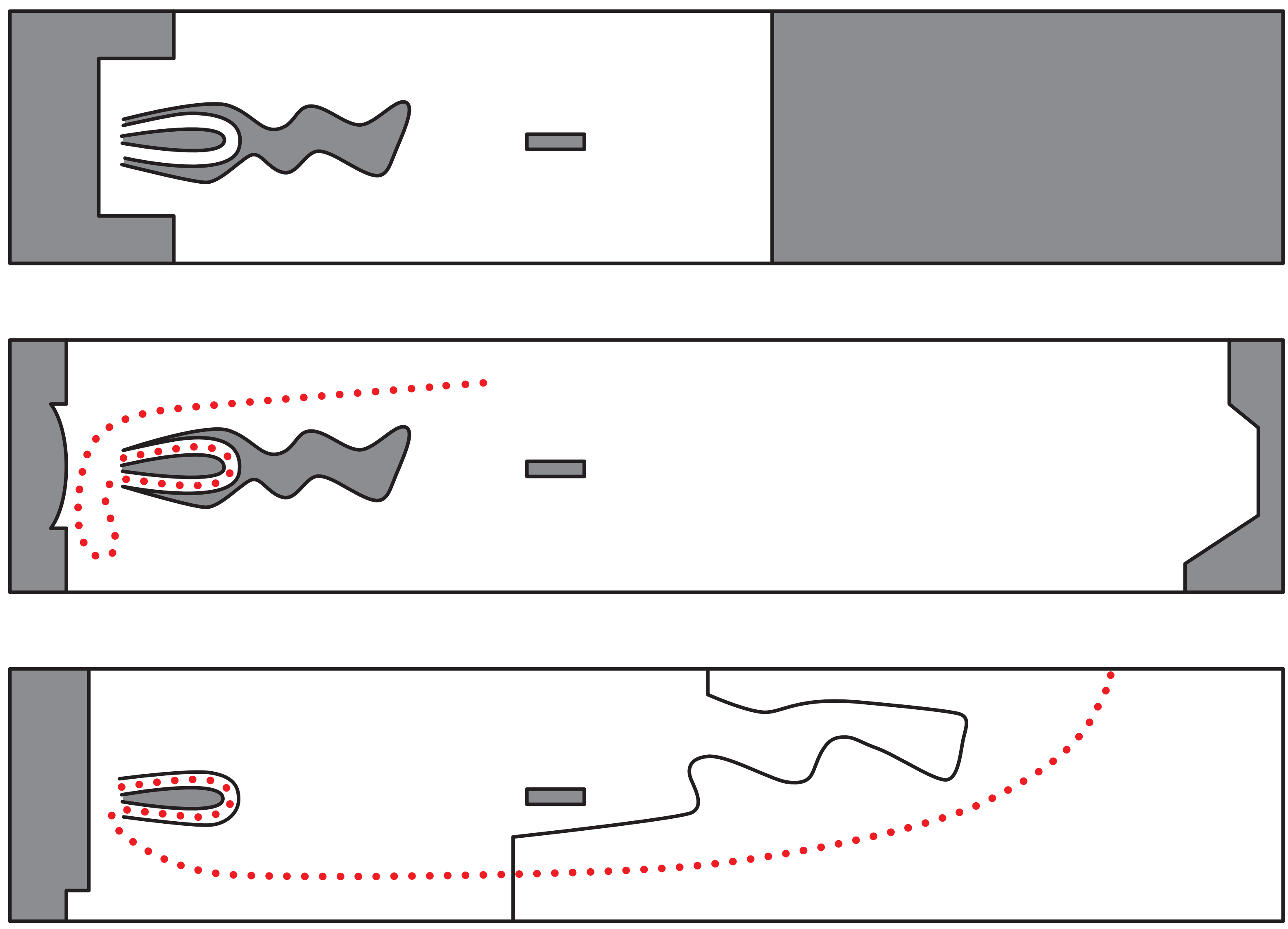

"Visita de médico"

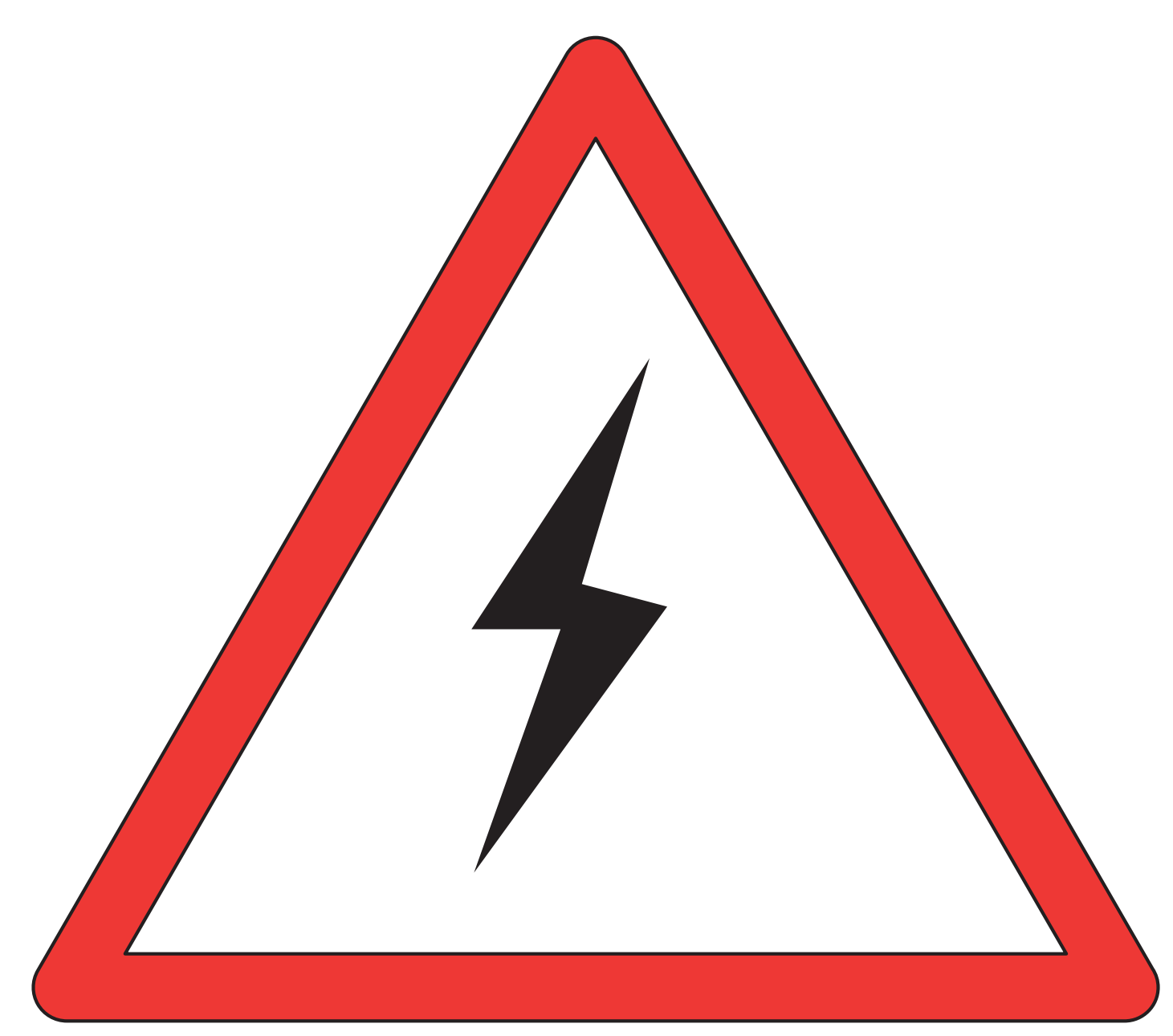

Há sinais de "alta tensão" espalhados pelo pavilhão. Só não vê quem não quer. 
Dentro da instalação escura e estrondosa, a garota encontra uma brecha para grudar no braço da sua pretendente.

Um trio de garotos de outra escola mexe com as meninas do grupo: "Oi, princesas...". Ao que uma delas comenta: "Puts, que cantada zoada".
Também se dirigindo às meninas, outros garotos suplicam: "Ei, deem atenção pra nós...".

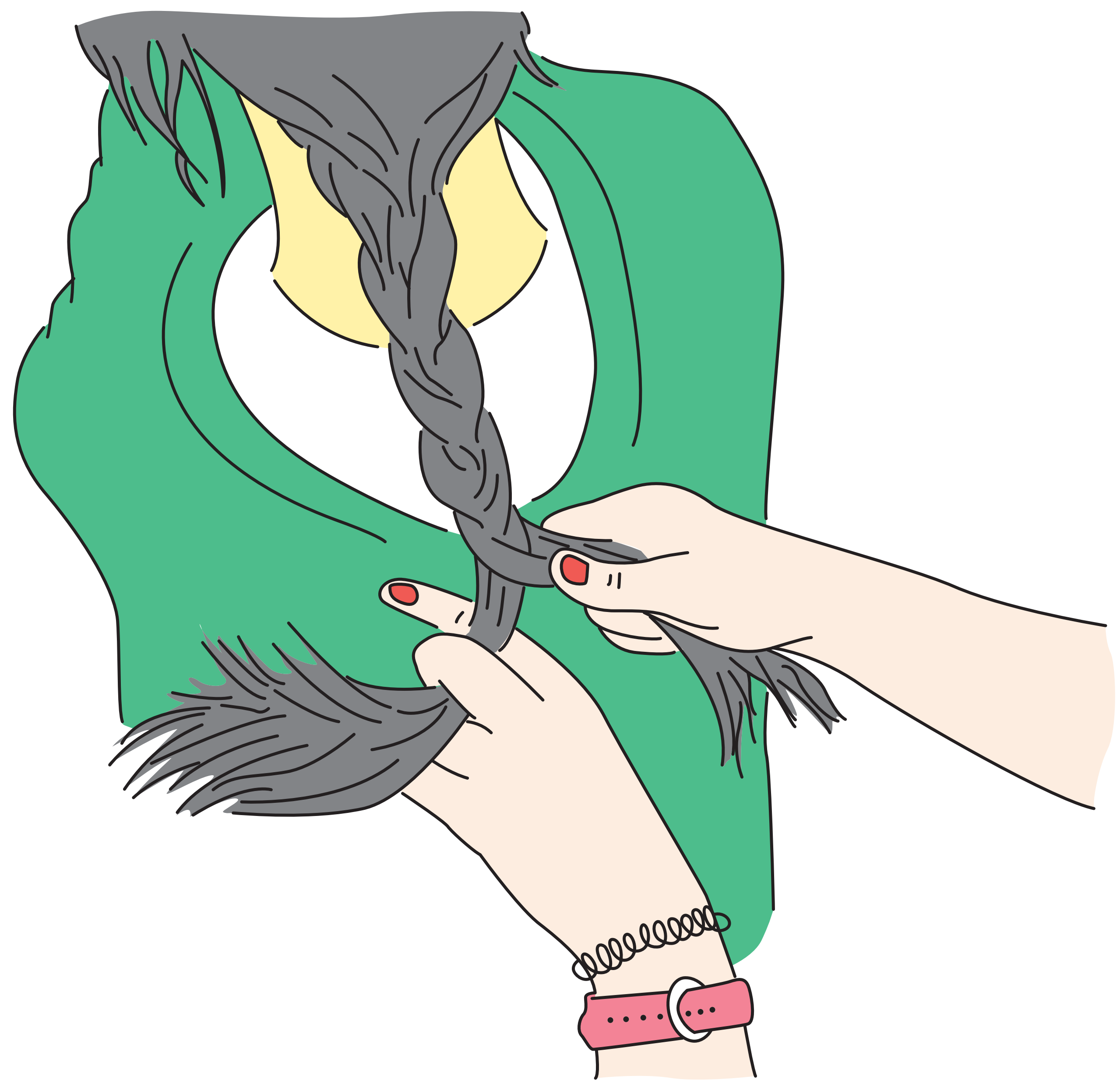

Enquanto se desenrolam as cenas do vídeo, a menina trança os cabelos da sua amiga.

Ao avistar de longe a instalação da artista Ebony G. Patterson, composta por cores vibrantes, adereços festivos e quadros cintilantes, a garota solta um grito: "Uau! Rosa-choque!".
A amiga da garota que acabara de gritar pede para o mediador: "Vamos ver a obra rosa, vamos!". Ao que ele chega a ensaiar um argumento discordante, para logo na sequência aceitar a proposta: "Se formos até lá vamos ter que mudar completamente o rumo da nossa conversa... Mas ok". 
Caminhando em direção ao ônibus, a garota faz uma queixa para o seu amigo, referindo-se à visita: "Nada a ver esse negócio de visitar a Bienal com alguém ensinando arte pra gente. Arte não se ensina".

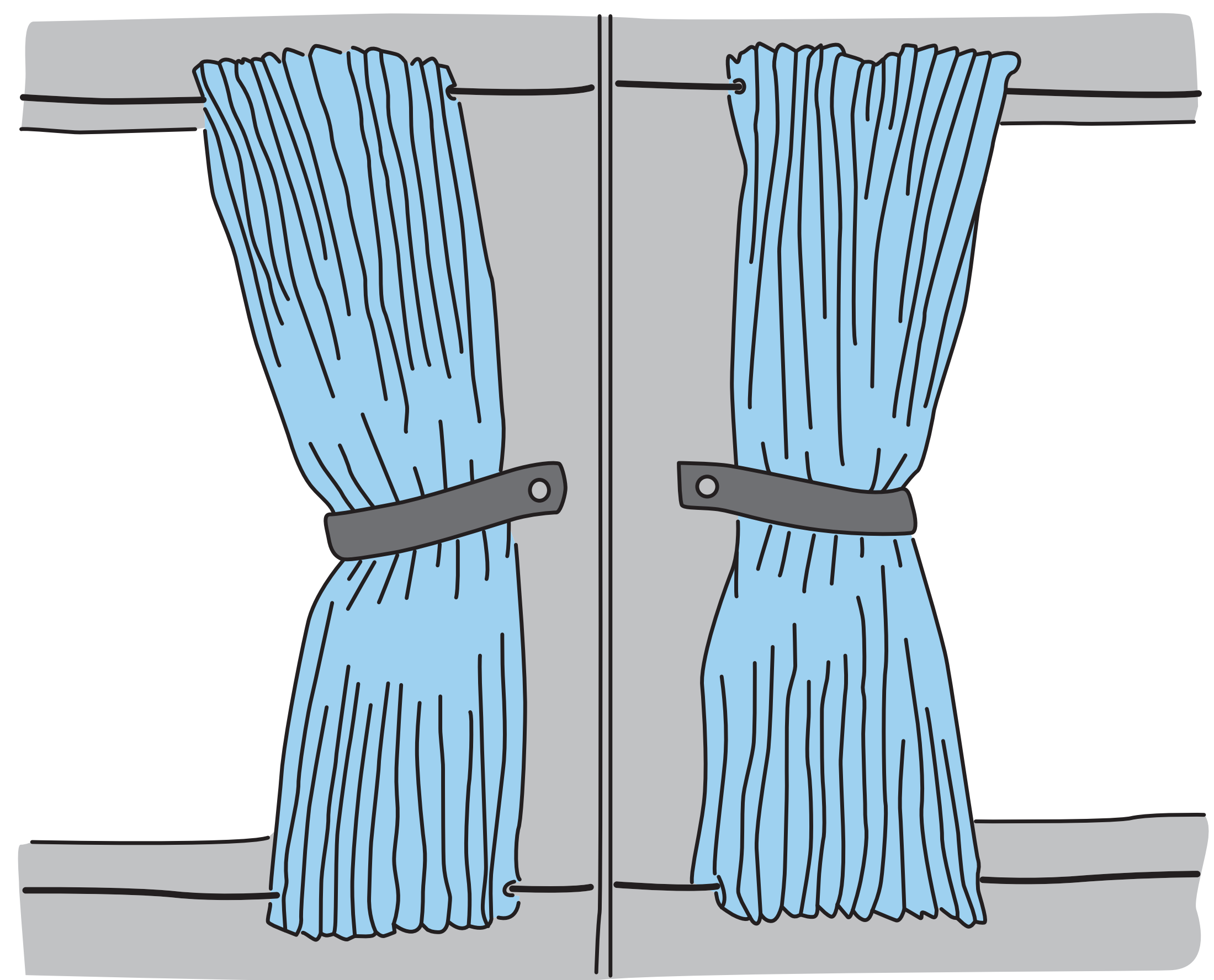

Alguém grita lá do fundo: "Ei, todo mundo fecha as cortinas!".

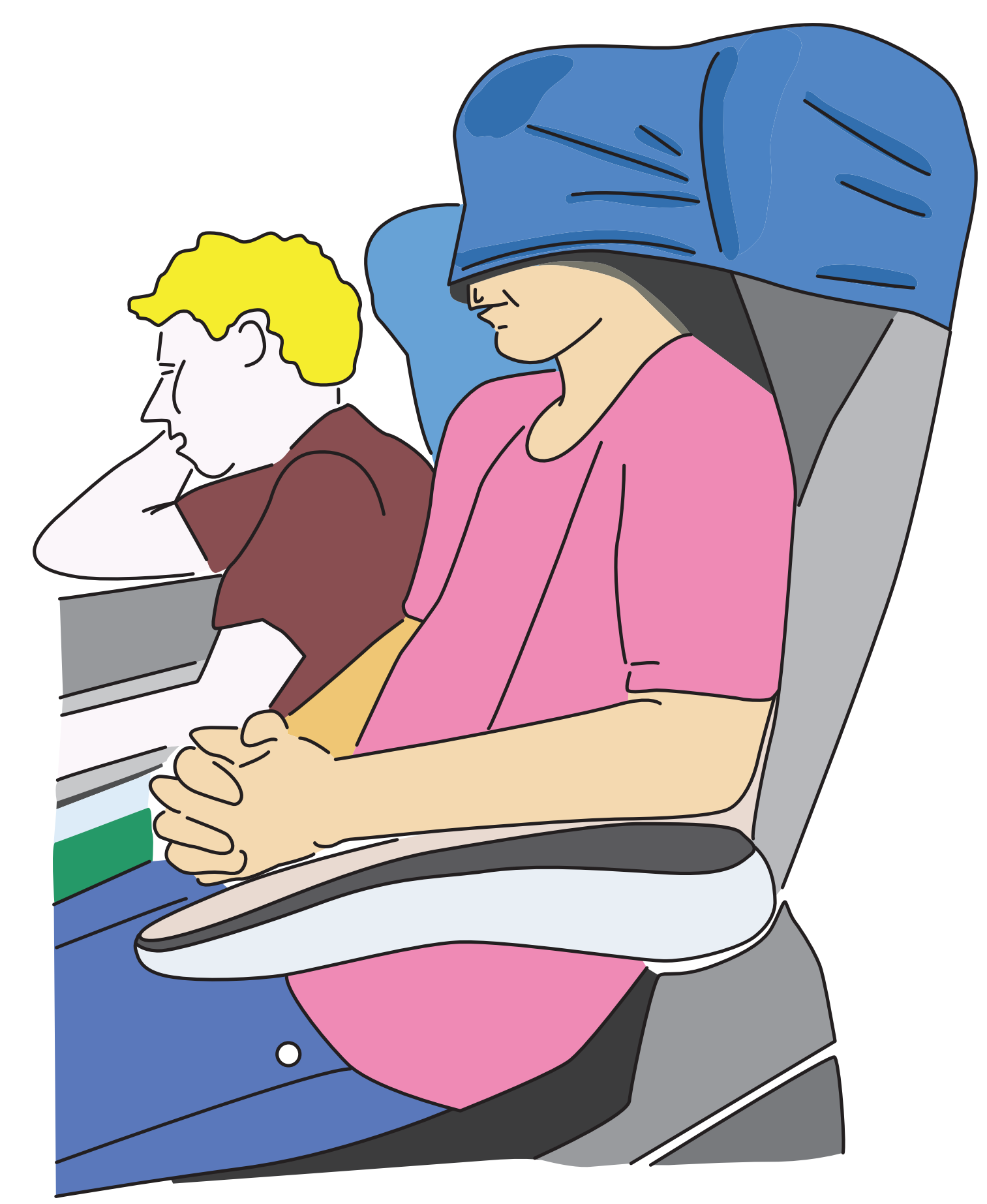

Enquanto a dupla de amigos compartilha suas impressões da Bienal, o garoto sentado no banco de trás solta um forte arroto.

Antes de aceitar o biscoito oferecido por seu colega, a menina pergunta: "Tem leite nesse biscoito?". Seu colega estranha a pergunta e replica: "Sei lá. Por que quer saber?". A resposta: "Porque sou vegana".

Tapa-olho 